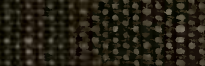

t. 

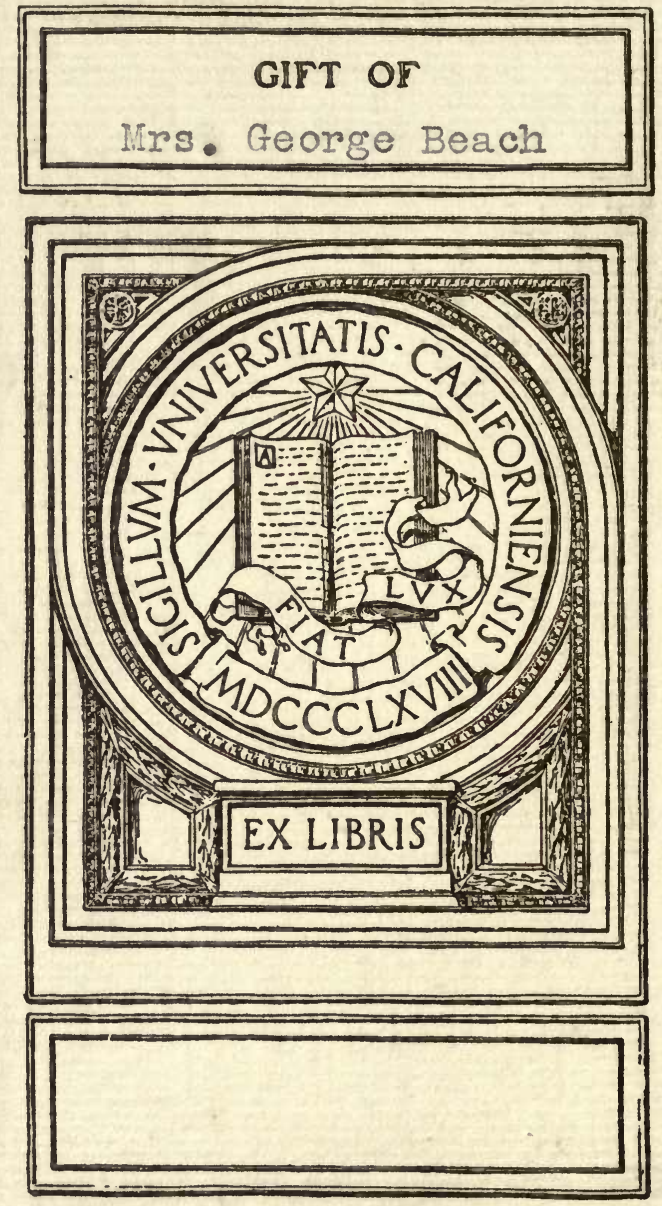


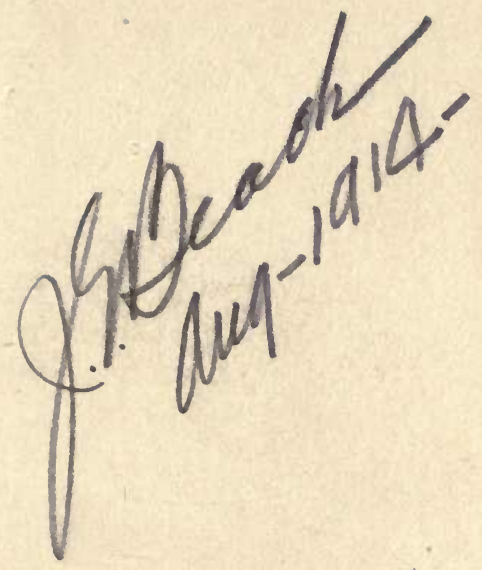


Sitt of Mis. Seo. Bead 


\title{
CITRUS FRUITS
}

AND

\section{THEIR CULTURE}

BY

\author{
H. HAROLD HUME, \\ Professor of Horticulture and Botany in \\ The University of Florida.
}

Horticulturist and Botanist of

The Florida Agricultural Experiment Station.

NEW YORK:

ORANGE JUDD COMPANY. 
$S_{+38}^{336}$

$\because \because \vdots \because \vdots \vdots$

Gift of

Mrs. George Beach

COPYRIGHTED 1904

BY

H. HAROLD HUME.

Printed in U. S. A.

FIFTH EDITION

1913

replacing 265808 
RESPECTFULLY DEDICATED

TO MY FRIEND

George LindLey TABer

WHOSE INSPIRATION HAS MADE THIS VOLUME POSSIBLE 
$2 i, 3: 2: ;: ; \%$, 
The closing decades of the nineteenth century have seen great changes in the principles of citrus fruit culture in America. Twenty years ago the amount of fruit produced was comparatively small, now the industry has attained a place among the large horticultural industries of this country. Then, at most, a few hundred boxes of fruit were produced annually; now the crop is counted not by hundreds but by millions of boxes. The pomelo was scarcey known and the lemon was a fruit imported almost entifely from the Old World. Then, the means of transportation closed many a desirable tract of land through which the railroad now runs and from which large quantities of fruit are now shipped. Then, the methods of combating insects and fungous diseases were less perfectly understood than now. In those days, the fertilizers applied to the soil were mostly made at home, now the nitrogen, phosphorus and potash, deemed so essential for the production of first-class fruit, in many districts, can be obtained as commercial commodities in any market. Numerous devices are now successfully employed in protecting trees and fruit against the effects of frost and freeze, then, nothing of the kind was attempted or in fact deemed necessary. Then, cover crops were not considered in the light in which they now are. Then, the citrus industry in the New World was more or less firmly linked to that of the Old: Ane we have an American industry on the large, broad lines of American progress. 
During these past twenty years no work dealing with the fruits of the genus citrus has been produced. The literature has not kept pace with the growth, the development, and the new phases of the industry. To fill a long-felt want, this volume after many urgent appeals from those interested in and engaged in the industry has been produced in the hope that it may, in some measure at least, supply the lack of reliable, up-to-date information.

In its preparation the author has had the hearty cooperation, assistance and sympathy of many friends. The chapter on Fertilizers and Fertilizing has been reviewed by Prof. H. K. Miller, of the University of Florida, that on Cover Crops, by Prof.. John Craig, of Cornell University: while the chapter on Insects Injurious to Citrus Trees, has been revised and largely re-written from his former publications, by Prof. H. A. Gossard, of the University of Flor. ida. The chapter on Pot Culture of Citrus Fruits, has been revised by Mr. E. N. Reasoner, of Oneco, Fla. Dr. N. L. Britton, Dr. D. T. MacDougal and Miss Anna Murray Vail, of the New York Botanical Garden, have made it possible to examine the older works on citrus fruits, and have rendered much valuable assistance. Prof. A. W. Blair, of the University of Florida, has contributed an analysis of one of the cover crops, heretofore unpublished. All the drawings and some of the photographs used in the illustrations were made by Miss Lucia McCulloch formerly assistant in the Department of Botany and Horticulture in the University of Florida. Prof. Dorsey now of the Mechanics' Institute, Rochester, New York, contrib. uted a number of photographs, while those illustrating California scenes were secured through the kindness of Prof. C. W. Woodworth, of the Eniversity of California, 
Mr. John Isaacs, of the California State Board of Horticulture and Mr. W. J. Allen, of Bonita, Cal.

All photographs reproduced in this book, except where otherwise acknowledged, are from negatives belonging to the Florida Agricultural Experiment Station, for permission to use which, thanks are due to Dr. T. H. Taliaferro, director of the Florida Agricultural Experiment Station. Mr. W. S. Hart, of Hawks Park, Fla.; Mr. E. S. Hubbard, of Federal Point, Fla.; Mr. G. L. Taber, of Glen St. Mary, Fla., and many others, whose names are not here mentioned, have assisted very materially in many ways.

The substance of a number of the bulletins of the Florida Agricultural Experiment Station has been used without denoting the source from which it is derived.

Every effort has been made to eliminate mistakes, but some, doubtless, remain embodied in the work. The author will certainly appreciate it as a favor if any reader noting these will kindly point them out that they may be corrected in future editions.

H. Harold Hume.

University of Florida, Lake City, Fla.

December 1st, 1903. 


\section{PREFACE TO SECOND EDITION.}

The first edition of "Citrus Fruits and Their Culture," published a little over three years ago, being exhausted, a second edition is called for. A number of errors occurring in the first edition have been corrected and by the addition of some new material the volume has for the most part been brought thoroughly up to date. In presenting the second edition the writer begs to acknowledge his indebtedness for many courtesies, particularly from Mr. W. S. Hart, Hawks Park, Fla., and the Rev. C. J. K. Jones, Los Angeles, Cal., and hopes that the edition may meet with the same cordial reception as the first.

H. H. H.

Glen Saint Mary, Fla.

August 6th, $190 \%$.

\section{PREFACE TO THE THIRD EDITION.}

There are more people interested in the cultivation of citrus fruits now than at any previous time, and the demand for information is more insistent than ever before. It is in the belief that this volume will still prove helpful to those engaged in or about to engage in the industry, that the third edition is now given to the public.

H. H. H.

Glen Saint Mary, Fla.

November 20, 1909. 


\title{
CITRUS FRUITS AND THEIR CULTURE
}

\section{CONTENTS.}

\author{
PART I. \\ BOTANY, HISTORY, VARIETIES.
}

\section{CHAPTER I.}

Commercial Status of Citrus Culture................

Distribution of citrus fruits-Fruit as first used in regions where grown-American markets supplied with Mediterranean fruit-Development of the industryRecent developments-Lemons in California-Pomelos in Florida-Output of citrus fruits from Florida and California-Advance in cultural methods-Personal factor in success-Markets not all supplied-The outlook.

CHAPTER II.

Citrus Relationships........................ 7 -10

Family Rutacex-Mostly native of tropical regions-Citrus not indigenous in America-Leaves of plants allied to Citrus-Evolution of citrus leaf-Lemon farthest removed from ancestral type.

CHAPTER III.

Botany of Citrus Fruits.........................

The problem of classification-The latest system-Wild forms mostly extinct-Different forms regarded as species-Native home of citrus-Confusion in naming the lemons and limes-Oil-cells not distinctive-Juice-sacks useful in classification-Family Rutacea-Genus CitrusDescription of species cultivated in America.

CHAPTER IV.

The Trifoliate Orange.......................21-24

Useless commercially except for stocks-Hybrids between trifoliate and sweet oranges-First mention of trifoliate orange in literature-Its nomenclature-Introduction Into America. 
CHAPTER V.

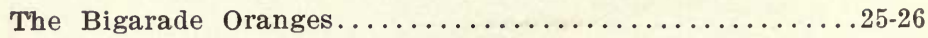

The group name-Confused with the sweet orangesEntitled to specific rank-Brought to America by Spaniards-Important as a stock.

CHAPTER VI.

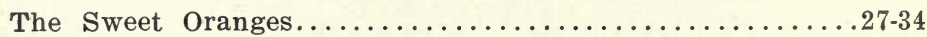

Names used by other writers-Introduction into Europe -Introduction into America-Introduction into California-The most important citrus fruit-Number of varieties-Grouping the sweet oranges-Spanish oranges characterized-Mediterranean oranges described-Blood oranges characterized-Navel oranges characterized-Navel oranges in Florida and California-The navel orange in literature.

CHAPTER VII.

The Mandarin Oranges...........................

Mandarin oranges distinct from sweet oranges-The group name and its significance-Its origin-History of the group-Introduction into America-More important in Florida than in California-Essentially a fancy fruit -Horticultural status of the group.

CHAPTER VIII.

The Pomelos...............................43-50

The name-Origin of the name-The commercial name -Origin of the cognomen, grapefruit-Synonymy-Shaddock a distinct fruit horticulturally-Pomelo the best name-Horticultural status-Spanish introduction-Fruit wasted for years-The judgment of earlier writersFirst marketed between 1880 and 1885- Downward trend of prices-The Florida pomelo-Superior as a breakfast fruit.

\section{CHAPTER IX.}

The Shaddocks...........................51-52

Introduction and origin of name-Not important commercially-Distinct from the pomelo-Characteristics of the fruit-May be used as a stock. 
CHAPTER $\mathrm{X}$.

The Kumquats............................... $53-58$

The common name-Kumquat literature-Introduction into Europe by Mr. Fortune-Introduction into America - Measurements of large kumquat shrubs-A hardy group of fruits-Mr. Fortune's observations-How eaten-A Fancy fruit only.

CHAPTER XI.

The Citrons................................ $59-60$

Only citrus mentioned in ancient literature-Introduction into America-Relative importance of the citronImportations of citron peel-Future of citron culture.

CHAPTER XII

The Lemons...............................61-63

Introduction into Europe-Mentioned by early writers -Introduction into America-Recent introductions-The lemon in Florida-Development of California lemon industry-Lemon culture in the Islands--Uses of the lemon -Lemon susceptible to mal-di-goma.

CHAPTER XIII.

The Limes...............................64-66

Acid limes only grown in America-Confused with the lemons-Introduced into America by the SpaniardsTree very tender-Adapted to poor soils-Variations in Mexican lime-Room for improvement-Uises.

CHAPTER XIV.

Trifoliate Orange Group-Varieties................67-68

Description of Trifoliate orange and its hybrids.

CHAPTER XV.

Bigarade Orange Group-Varieties................69-71 Bigarade oranges described.

CHAPTER XVI.

The Sweet Oranges-Varieties..................... 72-98

Varieties of Sweet oranges described.

CHAPTER XVII.

Mandarin Oranges-Varieties....................99-113

The varieties of Mandarin oranges described. 
CHAPTER XVIII.

Pomelo Group-Varieties.

Varieties of Pomelos described.

CHAPTER XIX.

Shaddock Group-Varieties...

The Shaddocks described.

CHAPTER XX.

Kumquat Group-Varieties.................... 129-131

The Kumquats described.

CHAPTER XXI.

Citron Group-Varieties

The Citrons described.

CHAPTER XXII.

Lemon Group-Varieties $.134-140$

The different varieties of Lemons described.

CHAPTER XXIII.

Lime Group-Varieties. $.141-144$

The varieties of Limes described.

CHAPTER XXIV.

Originating New Varieties. $.145-154$

Bud-Variation-Hybrids-Crosses-The parts of the flower-Cross-pollination-Mode of operation-Emasculation-Pollination.

CHAPTER XXV.

Judging Citrus Fruits.... $.155-164$

Official scale and rules of the Florida State Horticultural Society for judging citrus fruits-California scales and rules-California orange scale-California lemon scale -Proposed pomelo scale.

\section{PART II.}

CULTURAL.

CHAPTER XXVI.

Propagation of Citrus Trees.......................... Advantages of budded over seedling trees-Citrus seeds used in propagation and their care-The nursery and its 
care-Propagation by cuttings-Selecting, cutting and keeping budwood and cions-Materials and tools used in performing the work-Grafting-wax-Budding-knivesShears-Grafting-iron - Shield-budding - Shield-budding with a right-angled incision-Shield-budding with a curved incision-Cleft-grafting - Whip-grafting-Crowngrafting-Sprig-grafting-Inarching.

CHAPTER XXVII.

Stocks for Citrus Trees.......................197-218

Soil adaptations-Mutual influence of stock and cionSour orange stock-Rough lemon stock-Trifoliate orange stock-Mr. Taber's experimental grove-Sweet orange stock-Pomelo stock-Lime stock.

CHAPTER XXVIII.

Citrus Soils...............................219-224

The ideal soil-Florida Soils-High pine land-Flat woods land-High hammock land-Low hammock land Louisiana soils-California soils-Mesas-Foot-hills.

CHAPTER XXIX.

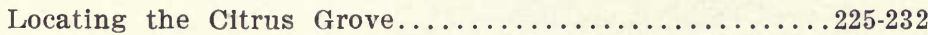

Carrying quality of the fruit-Transportation-FrostsAir drainage-Timber belts-Wind-breaks-IrrigationInsects.

\section{CHAPTER XXX.}

Preparations for Planting......................233-246

Clearing the land-Cultivation previous to plantingGrove plans-Triangular system-Square system-Hexagonal system-Qulncunx system-Number of trees per acre-Hedge plantings-Double plantings-Leveling and smoothing-Distances apart-Laying out before planting-Laying out with the plow-Laying out in rectangles with a wire-Laying out in triangles-Laying out in hexagons-Laying out in quincunx.

CHAPTER XXXI.

Setting the Grove. $.247-262$

Selecting varieties-Adaptation of varieties-Relative members of varieties-Purchasing trees-Buy earlySubstitution-The unaccredited tree peddler-Visit the 
nursery-The best tree-Prices-Best time to plantP.IGE Planting-Root trimming-Planting board-WateringProtecting the trunks-Pruning the tops-The Reed method of transplanting-Labels and maps.

\section{CHAPTER XXXII.}

Cultivation of Citrus Groves...................263-284

Benefits of tillage-Clean culture or no culture-Effects of cultivation-An experiment-Humus and its valueDepth of cultivation in Florida-Depth of cultivation in California and Arizona-Frequency of cultivation-Cultivation in relation to irrigation-"Hard-pan" or "plow sole"-Cultivation in relation to dormancy and frostsThe die-back problem-Implements.

CHAPTER XXXIII.

Cover Crops.............................285-296

Advantages of cover crops-Classes of cover crops-Valuable cover crops-Velvet bean-Nitrogen collected-Baron von Luttichau's experience-Insects and cover cropsBeggarweed-Analysis of beggarweed-Treatment of beggarweed-Sand-spurs and crab-grass-Cover crops in California.

\section{CHAPTER XXXIV.}

Fertilizers and Fertilizing..................... 2978

Analyses of citrus fruits-Amounts of fertilizer removed by the crop-Functions of phosphoric acid-Functions of potash-Functions of nitrogen-Functions of limeSources of plant food-Sources of phosphoric acidSources of potash-Sources of nitrogen-FormulasDifferences in requirements of young and old treesFormulas for young and bearing trees-Amounts of fertilizer-Applying fertilizers.

CHAPTER XXXV.

The Irrigation of Citrus Groves. . . . . . .

The water factor-Amount of water necessary-Precipitation in Florida-Florida artesian area-Pumping water-Applying water-Irrigation in California and Arizona-Amount of water used in California-Furrow irrigation-Check system in California. 


\section{CHAPTER XXXVI.}

Frost Protection...

Warnings - Thermometers - Thermostats - Injurious temperatures-Effects of cold on the leaves-Effects of cold on the twigs-Effects of cold on the trunk-Effects of cold on the fruit-Conditions when most resistantThe insect factor-The food factor-Dormancy as a factor - Fertilizers and cultivation in relation to dormancy-Effects of the stock on the hardiness of the top-Hardy varieties-Banking to save the trunksProtecting the whole tree with earth-Fires-Kindling - The McKinney grove-Coal and oil-California experiments-Walls and fires-Wind-breaks and water protection-Irrigating-MacFarland's tent-Painter's tentSheds-Florida experiences-Results in California.

CHAPTER XXXVII.

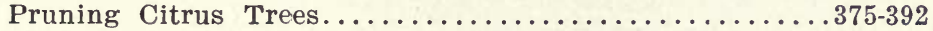

Pruning not always necessary-High vs. low-headed trees-Pruning for insect treatment-Pruning in relation to die-back-Pruning frozen trees-Wiring sprouts from frozen trees-Pruning tools-General remarks-Time for pruning-Baronio system of lemon pruning-Open-center system of lemon pruning-Other systems.

\section{CHAPTER XXXVIII.}

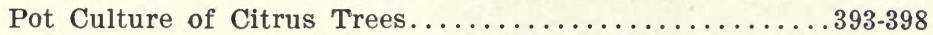

Stocks of potted trees-Soil-Size of pots-Specimens for flowers-Varieties recommended-Fertilizing-Watering-Rest-Insects.

CHAPTER XXXIX.

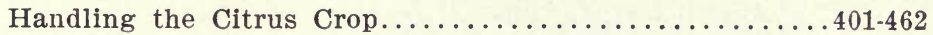

Early experiences-Time of picking-Clippers-Field boxes-Mr. Hart's field box-Picking bags or basketsRattan baskets-Ladders-Field wagons-Pickers and picking-Curing-Washing-Effects and need of curing - Curing lemons - California experience - Lemon packing-houses-Methods of packing lemons-Refrigeration not practicable-Grades of fruit-Grading-Time to grade-Sizers and sizing-Packing-Mr. Bean's experi- 
ence-Citrus fruit packages-Florida and California standard packages-Making packages-Paper-Packing conveniences-Packing-Packing diagrams-Headers or presses-Packing don'ts-Stenciling - Packing-houses -Shipping-The private trade-Commission merchants -Irresponsible firms-Dividing shipments-Spasmodic shipments-Choose a trade-mark-Associations.

\section{PART III.}

\section{DISEASES AND INSECTS.}

\section{CHAPTER XL.}

Fungous and Physiological Diseases.............. 465-492 Fungous diseases: Foot-rot-Scab-Leaf-spot-Ripe-rot -Sooty-mold-Fly-speck fungus - Melanose-LichensPhysiological diseases: Die-back-Blight.

\section{CHAPTER XLI.}

Insects Injurious to Citrus Trees................493-522

Insects classified-Biting insects: Grasshoppers-The orange-dog-Armored scales: The purple scale-Long scale-Red scale of Florida-Red scale of CaliforniaChaff scale-Orange snow scale-Unarmored scales: Turtle-back scale-Black scale-Wax or white scale-Barnacle scale-Cottony-cushion scale-Mealy-bug-Sucking insects other than scales: White-fly-Orange rust-mite and lemon silver-mite-Six-spotted mite-Purple mite or Red spider.

\section{CHAPTER XLII.}

Formulas for Spraying Mixtures................ 523-532

Bordeaux mixture-Ammoniacal solution of copper carbonate-Lime, crude carbolic acid and salt-Crude carbolic acid solution-Sulphurous acid solution-Resin wash-Kerosene emulsion-Good's caustic potash whaleoil soap-Kahle's distillate solution-Soda-sulphur solution-Sulphur-lime solution-Potash whale-oil soap and soda-sulphur solution-Criddle mixture. 


\section{CHAPTER XLIII.}

Spraying and Fumigating.

Spraying: Engines-Number of sprayings-Spraying for rust-mite-Fumigating: Tents and treatmentChemicals and amounts-Dosage.

CHAPTER XLIV.

Fungous and Insect Friends.................. 543-552

Conditions favoring insect control by natural agentsFungous friends: Red fungus-Grey fungus-Black fungus-Brown fungus-Red Aschersonia-Methods of disseminating fungi-Insect friends: Australia ladybug -Two-spotted ladybug.

\section{PART IV. \\ LITERATURE.}

\section{CHAPTER XLV.}

American Citrus Literature...................555-560

Index to American pubications on citrus fruits.

$$
\begin{aligned}
& \text { PART V. } \\
& \text { APPENDIX. }
\end{aligned}
$$

CHAPTER XLVI.

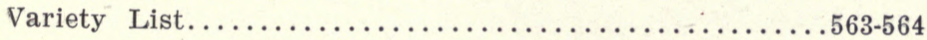

Sweet orange list-Mandarin orange list-Pomelo list

-Kumquat list-Citron list-Lemon list-Lime list. 


\section{ILLUSTRATIONS.}

FIGURES.

FIGURE

1. Leaves of Plants Allied to Citrus............... 8

2. Citrus Leaves.......................... 9

3. Flowers of Sweet Lemon.................. 12

4. Oil Cells in the Rind of Citrus Fruits............. 14

5. Juice Sacks of Citrus Fruits................ 15

6. Trifoliate Orange Tree..................... 21

7. Trifoliate Orange Flowers.................. 23

8. Flowers of Majorca Orange................. 27

9. Pomelo Blossoms....................... 45

10. Kumquat Flowers....................... 53

11. Flowers of Villafranca Lemon................61

12. Flower buds of Mexican Lime...............665

13. Filer Bigarade Orange....................6. 69

14. Sour Orange Fruit.................... 0

15. A Seedling Orange Tree in Florida............. 76

16. Jaffa Oranges........................ 84

17. Everbearing Orange Tree................ 85

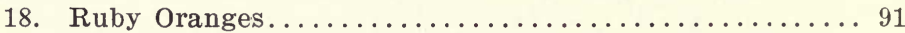

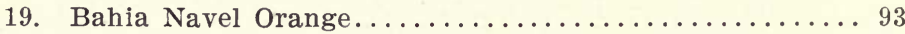

20. King Mandarin Orange Tree................... 99

21. A Grove of Dancy Mandarins..................113

22. The Triumph Pomelo in Fruit...................118

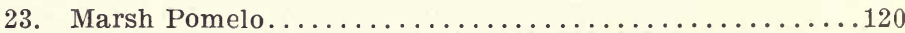

24. Pernambuco Pomelo..................... 123

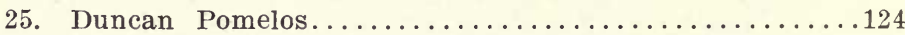

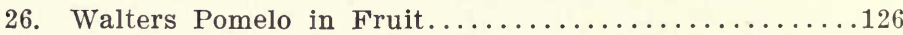

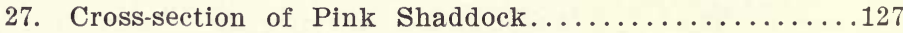

28. Nagami and Marumi Kumquats..................129

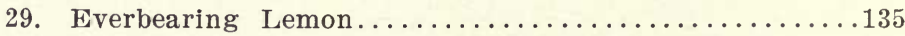

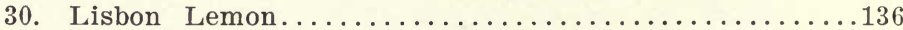

31. Rough Lemon Fruit....................... 138

32. View in a Lemon Grove..................... 140

33. Mexican Lime..........................141 
FIGURE

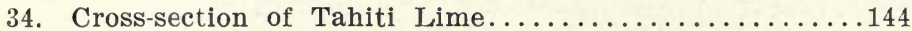

35. Vertical Section Through Citrus Flower...........148

36. Sack Ready for Covering Pollinated Flowers..........150

37. Citrus Flowers-Open-Bud-Emasculated...........151

38. Paper Sack Covering Cross-pollinated Satsuma Flowers...152

39. Triumph Pomelo Fruit in Mosquito-net Sack.........153

40. Seeds of Pomelo,Trifoliate Orange, Sweet Orange,

Rough Lemon and Sour Orange............169

41. Seedling Pomelos Raised in a Flat..............171

42. Germination of Pomelo Seed................172

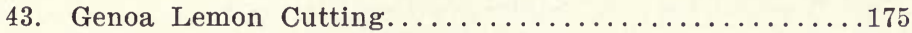

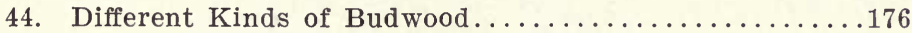

45. Mr. Taber's Budwood Bins..................178

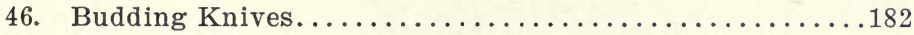

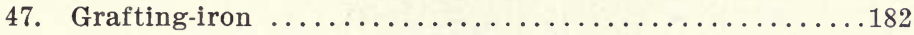

48. Methods of Budding Old Trees...............190

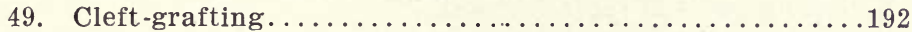

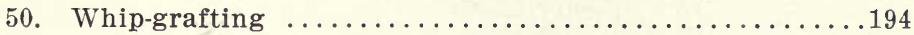

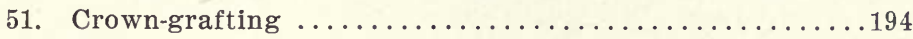

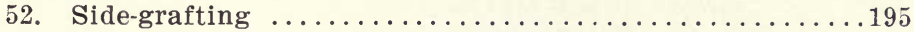

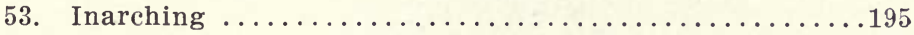

54. Three Sprouts Inarched.......................

55. Triangular System of Planting...............236

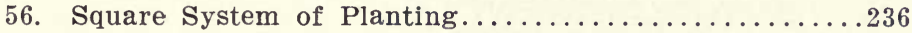

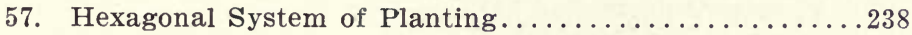

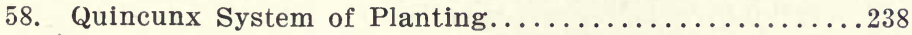

59. Double Planting-Citrus Fruits and Pineapples......240

60. Float for Smoothing Ground.................. 242

61. Branching of Citrus Roots in the Soil after Trimming..254

62. Pruning and Root-trimming of Citrus Trees.........255

63. The Right Way to Plant a Tree...............256

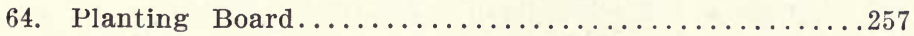

65. Pruning and Root-trimming of Citrus Tree......... 258

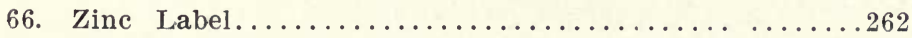

67. Velvet Bean Pods and Nitrogen Nodules.............288

68. Seed Stem and Flowering Stem of Beggarweed......292

69. Nodules on Beggarweed Roots..................294

70. Map of Florida Showing Iake Regions and Artesian-

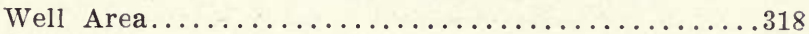


FIGURE

71. Elevations and Depressions in Florida, Between

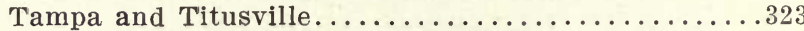

72. Diagram Showing How Artesian Wells are Formed....324

73. Spraying Stands Used in Florida................... 327

74. Artesian Well at Sanford, Florida......................

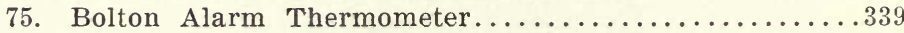

76. Effects of a Slight Frost on Growing Orange Tree.....341

77. Oranges Dropped by the Effects of Cold............ 343

78. Citrus Trees Banked to Protect the Trunks from Frost..349

79. Wood in Place Ready for Firing-North Florida....... . 353

80. Orange Trees on the Kinney Place at Pierson, Fla..... 354

81. Firing a California Grove, Using Crude Petroleum.

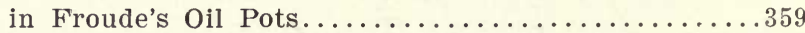

82. The Correct Way to Hold the Shears in Pruning.......375

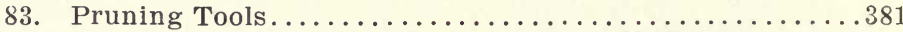

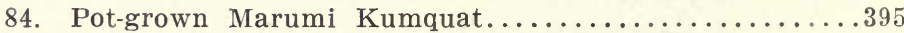

85. Field-box for Handling Fruit................ 407

86. Wickerwork Picking Basket.................408

87. Ladders for Picking Fruit.................... 409

88. Cross-section of a Well Cured Pomelo..............414

89. A Package of Italian Lemons................. 418

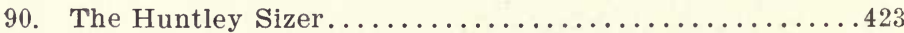

91. Kumquats Packed in Quart Baskets.............433

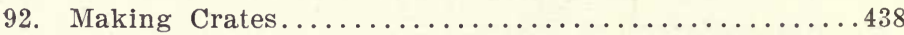

93. Table and Frame for Making Citrus Boxes..........440

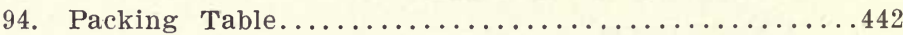

95. Header or Press used by P. J. Bayley, Largo, Fla.......448

96. Press used by Mr. W. S. Hart..................4449

97. Packing-house of P. J. Bayley................. 453

98. Foot-rot on Crown Roots and Trunk of Sweet Orange..467

99. Scab on Young Fruit and Leaves of Satsuma........471

100. Spores and Spore-bearing Parts of Scab Fungus......472

101. Spores and Spore-bearing Parts of Leaf-spot Fungus. . . 474

102. Leaf-spot Fungus on Pomelo Leaves...............475

103. Spores of Ripe-rot Fungus................. 476

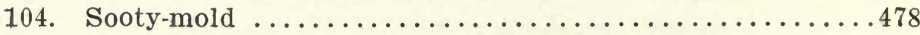

105. Lichens on Trunk of an Orange Tree............... 484

106. Lichen on Leaf of Kumquat...................... 485

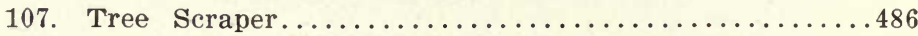


FIGURE

PAGE

108. Orange Tree Showing Effect of Die-back...........486

109. Die-back on Orange Twigs.................. 489

110. Grasshopper Feeding on Orange Leaves.............494

111. Purple Scale on Orange....................500

112. Long Scale on Orange Branch..................501

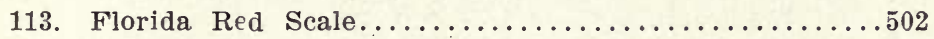

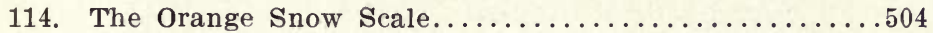

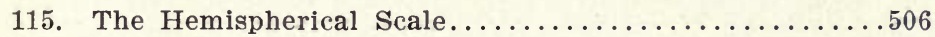

116. Adult Females of the Cottony-cushion Scale.........510

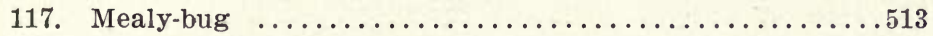

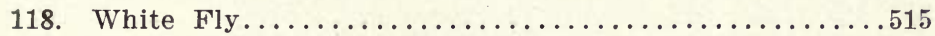

119. Red Fungus of Scale Insects................. 546

120. Spores and Spore-cases of Gray Fungus...........547

121. Spores of Red Aschersonia................548

122. Fungous Enemies of White Fly.............. 549

123. Ladybug Pupæ on Orange Twig.................551

124. Parasitized Plant Lice.................... 552

PLATES.

PLATE

PAGE

1. Picking Scene in a Well-managed Orange Grove...... 2

2. Flowers of Satsuma, a Mandarin Orange........... 36

3. C. Trifoliata, Frult, Leaves and Thorns............. 64

4. Pineapple Oranges as They Hang From the Trees....... 72

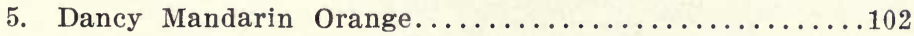

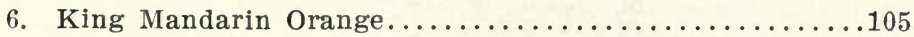

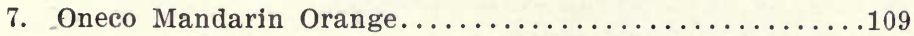

8. Satsuma Mandarin Orange.....................11

9. A Cluster of Hall Pomelos.............................

10. Citron-A Florida Seedling.................... 132

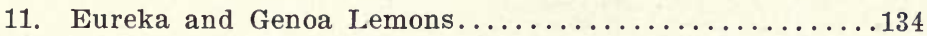

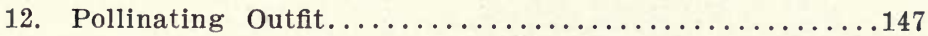

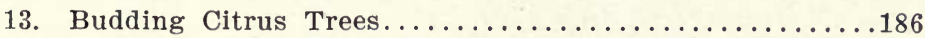

14. Budding Citrus Trees-continued................... 187

15. Seedling Citrus Trees, Stocks....................206

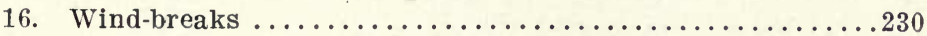

17. Poor and Good Spring Cultivation on High Ground.....272

18. Beggarweed as a Cover Crop in a North Florida

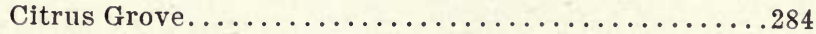


19. A Well-tilled Grove of Seedling Oranges.............306

20. (a) Wind-mill, Pump and Tank in a Citrus Grove......325

(b) A Temporary Steam Pumping Plant on a Lake-

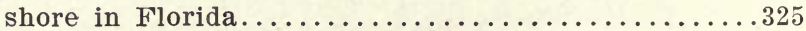

21. (a) Irrigating by Means of Furrows...............330

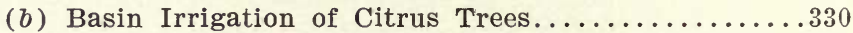

(c) Zigzag Irrigation of Citrus Trees................ 330

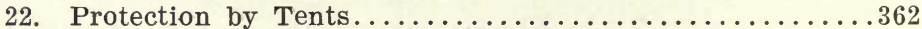

23. Shed Erected by G. L. Taber, Glen St. Mary, Fla.......365

24. Baronio System of Lemon Pruning................ 384

25. Pot-grown Orange Tree in Flower and Fruit.......... 392

26. Picking Parson Brown Oranges in the Grove of Mr.

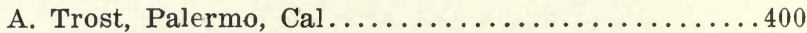

27. Cross-sections of Cured and Uncured Lemons..........416

28. (a) The Ayer Sizer in Operation................426

(b) A Pneumatic Sizer Made by Maull and Jones.......426

29. (a) A Well-packed Box of Sweet Oranges............443

(b) Shelf Paper Used in Packing Oranges.............443

30. A Well-packed Half-strap of 136 Dancy Mandarin

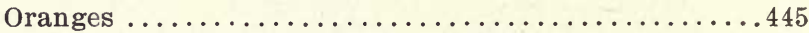

31. Packing-house of W. S. Hart.................. . 455

32. Interior View of Manatee Lemon Company's Pack-

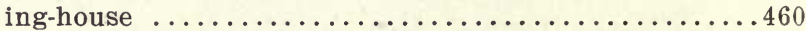

33. Orange Dog (Papilio Cresphontes Cramer)..........496

34. Spraying Orange Trees in a California Grove with

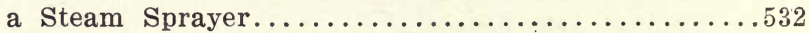

35. Fumigating Citrus Trees in California, Showing Bell Tent in Position and Pole Used in Mov-

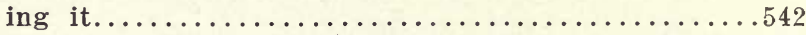






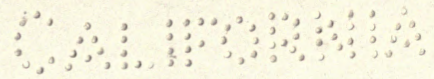

\section{PART I.}

BOTANY-HISTORY-VARITIES. 


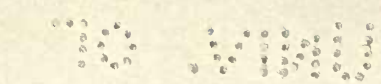

$\therefore 2$ :

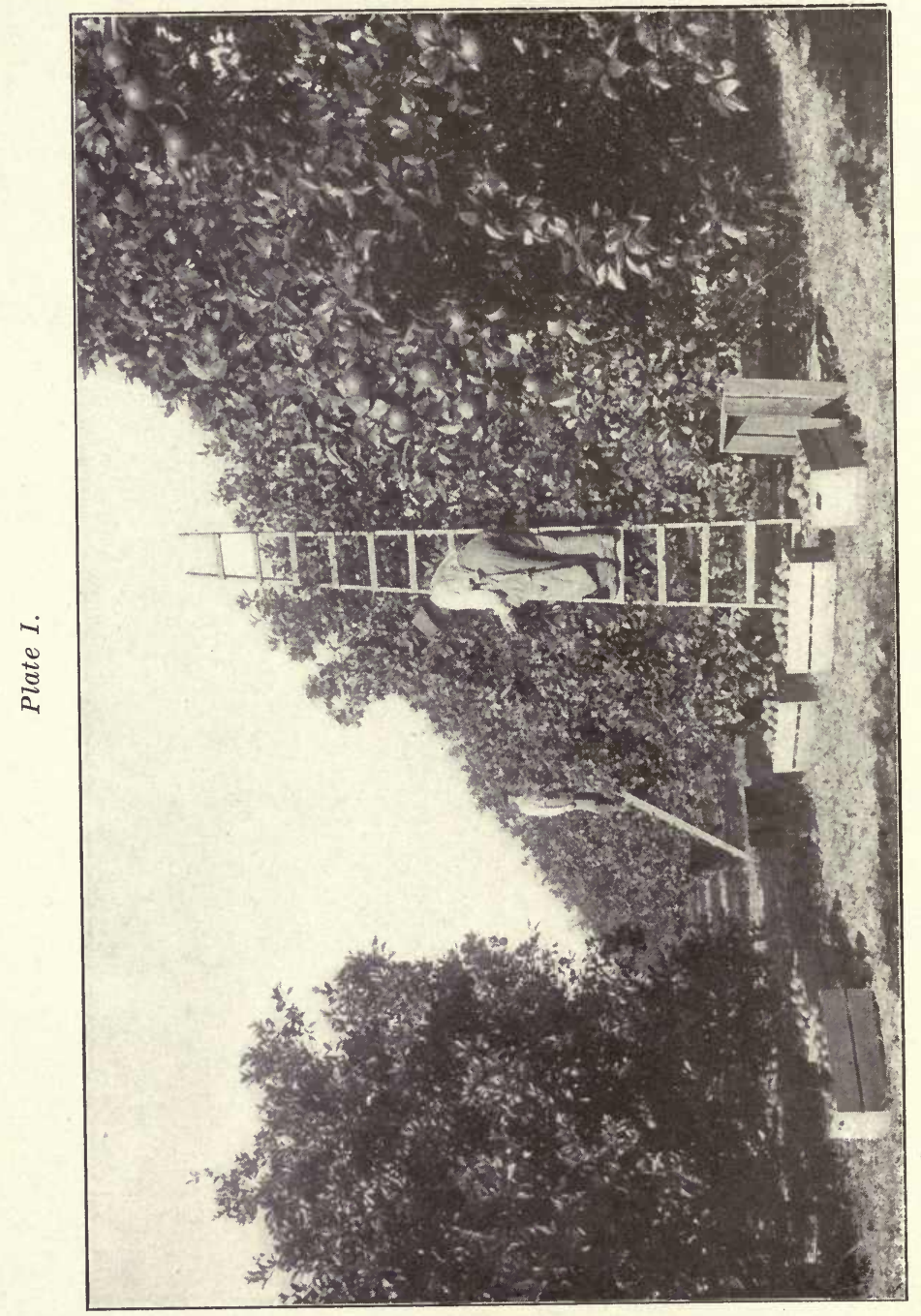

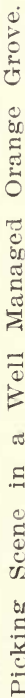

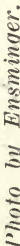




\section{CHAPTER I. \\ I N T R ODUCTION.}

\section{COMMERCIAL STATUS OF CITRUS CULTURE.}

From their home in the Malay Archipelago, where all our cultivated forms of citrus probably had their origin, they have spread throughout the world and are now grown in groves or orchards wherever soil and climatic conditions have been found suitable. Introduced into the Ameri. can continent at an early date, they found in Brazil and other parts of South America, in the West Indies, in Florida and in California, a congenial home where they have maintained their foothold to the present day.

For many years, however, they were grown only in a small way. The means of transportation were so inadequate and the methods of handling the product so crude, that but little of the fruit found its way outside of the immediate regions in which it was produced.

The oranges and lemons used in America in those days were mostly imported from abroad. They came largely from the Mediterranean and even up to within very recent years nearly all our lemons were procured from Italy. Large importations are still made, but they have by no means kept pace with the increase in population. Citrus fruit culture has been gradually extending in America until at the present time the greater portion of these fruits consumed in this country is home grown.

The development of the lemon industry in California has been quite phenomenal and the place secured in the markets by the Florida pomelo, a comparatively new fruit commercially, is equally noteworthy. The successful pro- 
duction, from a commercial standpoint, of these two fruits is among the most important of recent American horticultural achievements.

The following statistics may be interesting, as showing the past and present status of the citrus industry:

OUTPUT OF FLORIDA CITRUS FRUITS.

YEAR

BOXES

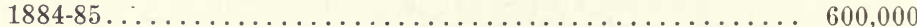

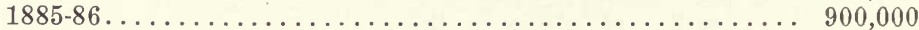

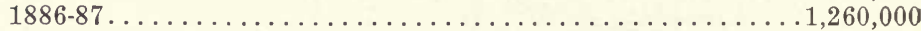

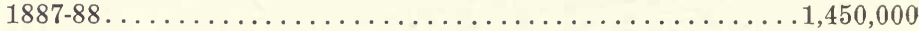

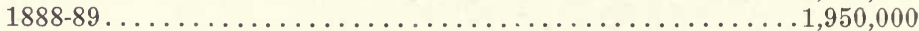

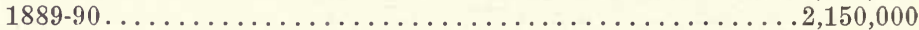

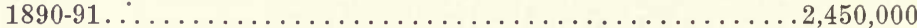

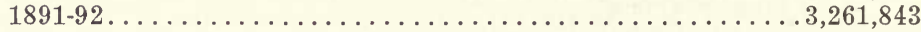

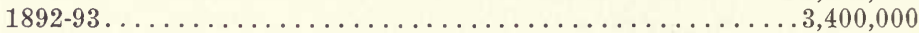

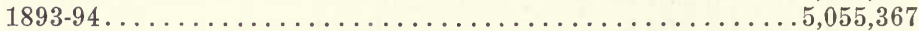

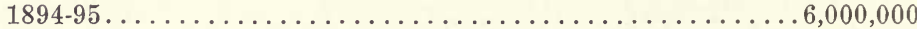

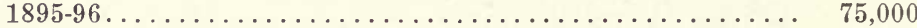

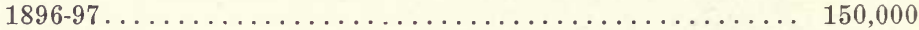

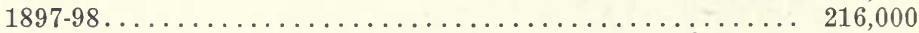

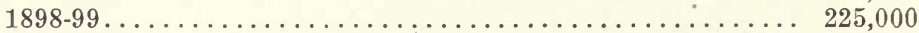

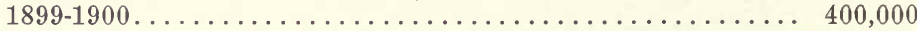

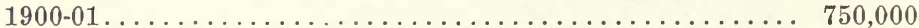

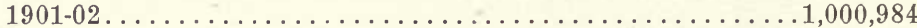

OUTPUT OF CALIFORNIA CITRUS FRUITS.

\begin{tabular}{|c|c|c|c|c|c|c|}
\hline \multirow{2}{*}{ YEAR } & \multicolumn{2}{|c|}{ ORANGES } & \multicolumn{2}{|c|}{ LEMONS } & \multicolumn{2}{|c|}{ Total } \\
\hline & Cars & Boxes & Cars & Boxes & Cars & Boxes \\
\hline 189 & & & & & 4.016 & 134 \\
\hline $1892-3 .$. & & & & . & 4,400 & $1,478,400$ \\
\hline $1893-4 \ldots$ & & & & . & 5,871 & $1,972,656$ \\
\hline 1894-5.. & & & & & 5,022 & $1,687,392$ \\
\hline $1895-6 .$. & & & & & 7,575 & $2,545,200$ \\
\hline 1896-7.. & & & & $\ldots$ & 7,350 & $2,469,000$ \\
\hline 1897-8.. & 13,987 & $5,063,294$ & 1,166 & 363,792 & 15,153 & $5,427,086$ \\
\hline $1898-9$. & 9,448 & $3,420,176$ & 903 & 281,736 & 10,351 & $3,701,912$ \\
\hline 1899-0.. & 16,362 & $5,923,044$ & 1,447 & 451,464 & 17,809 & $6,374,508$ \\
\hline $1900-1 .$. & 21,200 & $7,674,400$ & 2,900 & 904,800 & 24,100 & $8,579,200$ \\
\hline
\end{tabular}


From these it will be seen that the amount of fruit shipped out of Florida and California alone amounted to $10,234,000$ boxes for the season of 1900-1901. The greater quantity of the output eame from California, as in that year the Florida crop was very greatly reduced. Since that time the output has increased considerably.

As the industry has added years to its life, it has reached a higher stage of development along all lines. The methods of combating insects and fungous diseases, of tillage, of fertilizing, of irrigating, of frost protection, of handling and marketing the crops, are far in advance of what they were even ten or fifteen years ago. Much still remains to be learned and never, so long as the fruit is produced, will the last chapter be read, the book closed. But the fact remains that the grower of citrus fruits has now more useful knowledge at his disposal than ever before, and the chances for his success are better. New problems have arisen, but these have been solved in such a way as to lead the student of the situation to believe that any emergency which may arise will be met and dealt with successfully.

In growing citrus fruits as in any other industry in which a man may engage, the individual himself is the most potent factor in the success of the enterprise; the personal factor, the most important element in making the difference between profit and loss. The successful grower must bring to his work a thorough knowledge of every phase of the industry, backed by a fixed determination to succeed in spite of all difficulties.

Even with the enormous output of citrus fruits there appears to be but little or no depreciation in the value of the product. Constantly the cry of "over-supply" is 
dinned into our ears, but that time has not yet arrived and appears still to be in the far distant future.

Not all our American markets have yet been supplied and into many of them the pomelo, for instance, has not yet penetrated. The great northwestern portion of the continent, across the Canadian line, is being populated rapidly and there will be new markets for many days to come, both in the United States and Canada.

The people of the American continent are a fruit consuming people, and have the means at their disposal for satisfying their tastes.

On the whole, the growing of citrus fruits offers as good inducements for honest effort as any branch of horticultural work in which a man may engage. 


\section{CHAPTER II.}

\section{CI'TRUS RELATIONSHIPS.}

The family Rutaceæ, to which the citrus fruits belong, is represented in the United States by the prickly ash (Xanthoxylum), hop-tree (Ptelea), torch-wood (Amyris): and a few other plants. Though comparatively few members of the family are found in the temperate and subtropical regions of North America, this does not mean that there are not many others in different parts of the world.

The representatives of the family are mostly tropical in their distribution, being found in tropical Africa, southeastern Asia and Australia, numbering in all upwards of nine hundred species. Hooker in his Flora of India, 1875, gives twenty-three genera, with at least seventy-eight species native of that country.

Some writers have referred to some of the citrus fruits as being native in Florida, and the fact that lemons, limes and oranges have become thoroughly naturalized and now grow side by side with native trees in the hammocks or forests, lends color to the belief that they are indigenous. But, on the other hand, we know that they are of Spanish introduction, and no citrus trees were growing in the peninsula before the advent of Europeans. This is a matter of history. No species of citrus is native of America, and neither are any members of closely related genera indigenous on the American continent.

In classifying the genera of the family Rutacex, some authors have placed the citrus between Atlantia and $\mathrm{Fe}$ ronia, but the more recent classifications place citrus as 

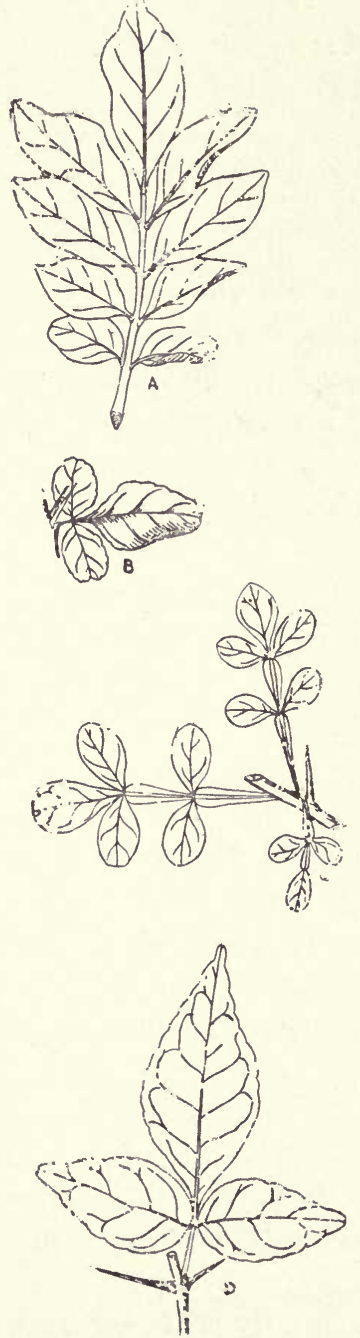

Fig. 1. Leaves of plants allied to Citrus. A, Murraya exotica. B, Triphrasia aurantiola. C, Feronia elephantum D, AEgle marmelos. Two-fifths natural size. the highest type of plant in the whole family. While there may be good grounds for the former arrangement, the latter appears to be better.

The leaves of some of the related genera are shown in Figure 1. A. is that of Murraya exotica Linn., a native Indian plant, the leaves of which are compound with a variable number of leaflets. B. shows the leaf of Triphasia aurantiola Lour., a plant commonly grown in the gardens of India and other parts of the East and planted to some extent as an ornamental shrub in South Florida. The leaves are trifoliate, accompanied at each node by two sharp, straight, slender spines. C. is an illustration of the leaves of Feronia elephantum Correa. they are quite peculiar. The petioles and midribs are winged and in general the three-parted ones bear a striking resemblance to those of Citrus trifoliata, while those with a greater number of leaflets resemble a number of $C$. trifoliata leaves joined together. The leaves are deciduous and the tree is a native of India, where it is also cultivated to some extent. In D. 
we have a representation of the leaves of Egle Marmelos Correa., another native Indian tree. The leaves are deciduous, trifoliate and accompanied by spines.

It is generally believed that all citrus are descended from an original form having a three-parted leaf. Bonavia, however, takes the opposite view, and thinks that they originated from a simple leaved form, because in young plants the first leaves produced are simple and not articulated. In the trifoliate orange the first leaves are mere bracts and not leaves. The author inclines to the former view, that our citrus fruits originated from a primal, three-leaved form, and certain it is, that Citrus trifoliata L., as cultivated in America to-day, is closer to the wild type than any other species or variety known to citrus culturists. Occasionally, on this plant, unifoliate leaves have been noted. One of these is indistinctly shown in the upper right hand side of Figure 7 . On the other hand, trifoliate leaves are sometimes found on other citrus, and the flanges or wings on the side of the petiole of the sour orange, pomelo and other citrus fruits are, in all probability, the remnant of the lateral leaflets, now greatly reduced in size and ses-
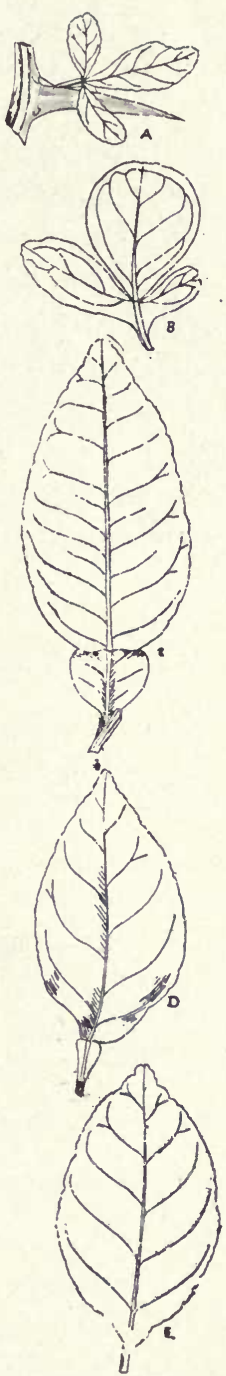

Fig. 2. Citrus leaves. A, Trifoliate orange. B, Sour (Freak). C, Pomelo. D, Sweet orange. E, Lemon. Two-fifths natural size. 
sile. Figure 2. shows some of the different forms of citrus leaves. A. represents the leaf of Citrus trifoliata. B. is from a sketch of a sour orange leaf in which the wings were enormously developed and leaflet-like, in fact, they could well be regarded as leaflets. C. is the leaf of the pomelo, with large wings on the petiole. On the shaddock they are frequently much larger than on the leaves of the pomelo. D. represents the sweet orange leaf, with smaller wings, and $\mathrm{E}$. the lemon, the petiole of which is always wingless, so far as I have ever observed. The citrus with wingless petioles are regarded as being farthest removed from the ancestral type. 


\section{BOTANY OF CITRUS FRUITS.}

No more difficult problem confronts the systematic pomologist than the classification of our citrus fruits. This difficulty lies, not alone in the peculiarities of the plants themselves, and they are surely perplexing enough, but it has been greatly' increased by the innumerable attempts which have been made since the days of Ferrari, and before, to group the various species and varieties of citrus in some sort of orderly arrangement. In truth it may be said that many of these attempts, instead of elucidating the problems connected with the subject, have simply made, or tended to make, them more complicated.

At the bottom of the whole trouble appears to lie the disposition, on the part of many writers on citrus subjects, to take the plants not as they find them growing at the present day, but as they imagine or suppose they must have been several hundreds or thousands of years ago.

No one acquainted with these fruits doubts for a moment but that in ages gone by, or perhaps even in more recent years, though not within historical times, two or more of our present distinct forms were represented by a single one. But what advantage is there, for instance, in throwing the sour orange, sweet orange, pomelo, kumquat and a few other distinctly different trees into one conglomerate species, stretching an imaginative description over the whole bunch and then placing each of the afore-mentioned plants under this species as sub-species and varieties, as was done by Dr. A. Engler, in Engler 
and Prantl's Pflanzenfamilien? Nothing is to be gained by such a disposition of the different forms.

In regard to the citrus fruits it must be borne in mind that in most cases the original wild forms have disappeared, or at least have never been discovered, but aside from the bearing which this may have on the question, there would be just as much sense, for instance, in plac-

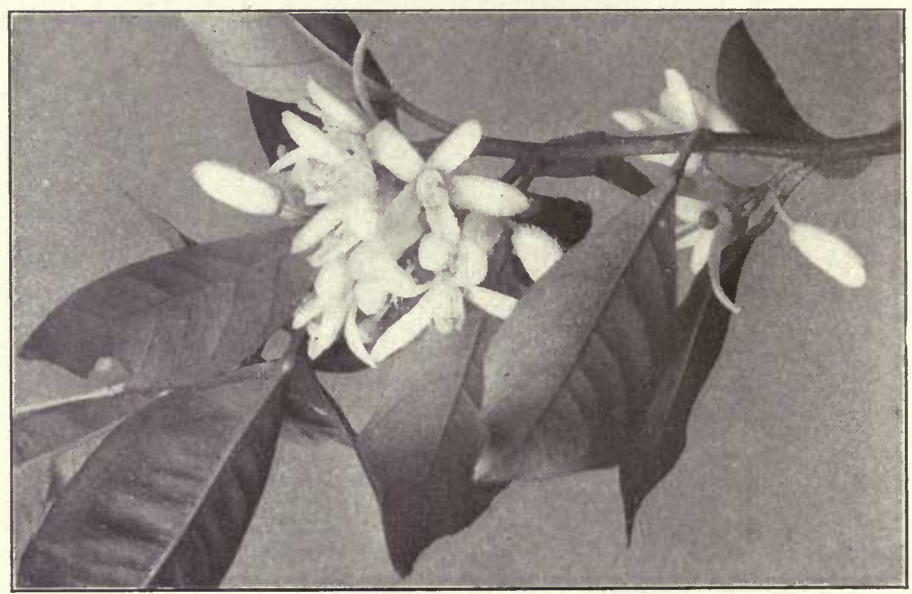

Fig. 3. Flowers of Sweet Lemon. Reduced one-fourth.

ing all the different recognized species of apples or plums in one or two species and then splitting them up into sub-species and varieties. No one would think of doing so.

Hence, following the course that is commonly fol. lowed in regard to other fruits, the writer prefers to designate each of the different forms of citrus as a specie They are sufficiently distinct to be readily separated.

Most members of the genus citrus have had their 
origin in southeastern Asia, though two are native of Australia. From their native regions they have been carried into all countries where the climate is suited to their growth and into many others where artificial heat is necessary for their welfare.

Considerable difficulty has been encountered in straightening out the botanical nomenclature of the species and something still remains to be desired. For instance, in 1813 (Ann. Mus. Par.) Risso described a species of citrus, C. Limetta, which included the sweet limes, Adam's apple, and a few others, but was not apparently intended to include our acid limes. Under $\mathrm{C}$. Limonum, he included the sweet lemons and acid lemons and limes. In 1832, Roxburgh (Flor. Ind.) proposed the species C. Acida to comprehend, as he said, "the sour lemons or limes found in India," but under it he describes (page 392 , vol. 3.) one variety of sweet lime. His species may be considered identical with Risso's C. Limonum. Hooker in his Flora of British India, 1875, described the acid limes, under the name C. Medica, Var. Acida. In the following classification, however, C. Limetta is applied to the acid limes, which may be somewhat stretching the original intent and purpose of Risso, while C. Limonum includes only the acid lemons.

Risso referred to the oil cells in the rind of citrus fruits as being either concave or convex. Just what he meant by this is not clear. It may be he referred to their actual shape, or on the other hand it may be he had in mind the form of the ends of the cells, where they touch the outer plane of the rind.

But in either case the concavity or convexity of the oil cells as a basis of separation of the different species and varieties appears to be worthless. Both kinds have fre- 


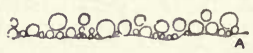

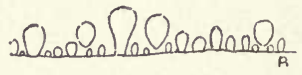

20200000000000000
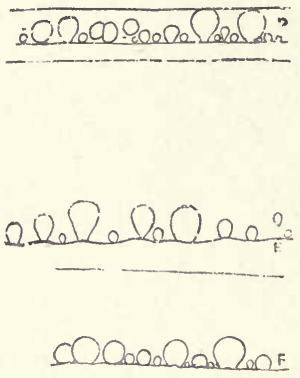

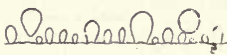

Fig. 4. Oil Cells in the Rind of Citrus Fruits. A, Trifoliate orange. $B$, Sweet orange. C, Sour orange. D, Mandarin orange. E, Pomelo. F, Kumquat. G, Lemon. The distance between the line on which the cells rest, and the next line above represent the thickness of the rind. Enlarged 11/2. times. quently been noted in the same species. Fig. 4 D. shows the usual shape of the oil cells in the rind of the mandarin oranges. The illustration represents those of the China mandarin. Yet in the rind of Beauty, a variety of mandarin closely related to China and truly a member of the group, the oil cells are distinctly oval or double convex. They are scattered through the white fungous portion of the rind and may be readily dissected out.

It is believed that the juice sacks of the pulp, their size, shape and appearance in the cut surface of the fruit, can be used to some extent as a diagnostic feature in classification, a point which seems to have been quite generally overlooked. The juice sacks of a number of the species are shown in Fig. 5 .

Family. Rutaceæ, Juss. Gen., 296, 1789. Trees or shrubs, rarely herbs, with aromatic alternate or opposite, usually compound leaves, dotted with translucent glands containing an essential oil. Flowers generally in axillary or terminal cymes, though sometimes occurring singly. Sepals four to five or lacking. Petals four to five, hypogynous or perigynous. Stamens as many or twice as many as the petals (in Citrus and Egle more), separate or united, inserted on the receptacle; anthers two-celled, opening along the inner face, generally ver- 
satile. Pistils two or five, or one and compound with two to five or more carpels, inserted on the more or less elongated receptacle. Fruit a capsule, berry, drupe or samara. Seeds oblong or kidney-shaped; embryo straight or curved; endosperm fleshy, sometimes lacking; cotyledons fleshy or foliaceous. Plants mostly native of tropical countries.

Genus. Citrus Linn., Gen. Plant., Ed. 5, 341, 1754. Shrubs or trees, usually with spiny branches. Leaves persistent, unifoliate (trifoliate and deciduous in C. trifoliata L.), thick and leathery, dotted with translucent oil glands; petioles generally more or less winged. Flowers axillary, solitary, clustered or in small cymes, white or purplish pink, scented; calyx small, cup-like; sepals three to five; petals four to six, or occasionally eight, linear oblong (in C. trifoliata almost obovate), thick, imbricated; stamens fifteen to sixty, united or separate, inserted round a cupular or annular disk; ovary 5-8 celled, style soon deciduous; ovules several in each cell. Fruit a berry, globose, sub-globose or oblong pointed; rind sweet or bitter, well pro-
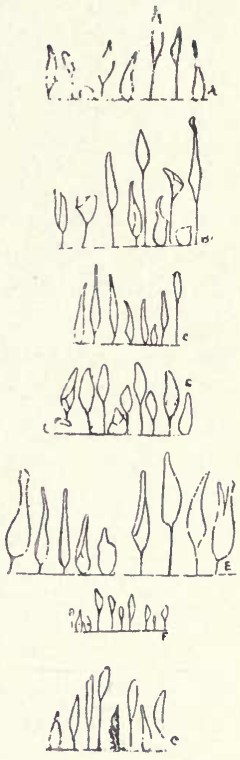

Fig. 5. Juice Sacks of Citrus Fruits. A, Trifoliate orange. B, Sweet orange. $\mathbf{C}$, Sour orange.

D, Mandarin orange. E, Pomelo. F, Kumquat. G, Lemon. Two-fifths vided with oil cells;juice contained in small fusiform sacks or cells; seeds light colored, testa coriaceous or membranous, em. bryos frequently two or more in each seed; cotyledons fleshy, hypogeal in germination. Most members of the genus are supposed to have had their origin in Cochin China and the Malay Archipelago. Several have become domesticated in Florida and the West Indies.

\section{SPECIES OF CITRUS CULTIVATED IN AMERICA.}

Citrus trifoliata L., Sp. Pl. Ed. II, 1101, 1763. A small low branching tree, of strict, upright habit, twelve to fifteen feet in height; young branches angled, older ones rounded, thorny, 
stiff; thorns alternate, 1 to 1 1-2 inches long, flattened at the base, stout, stiff, sharp; leaves deciduous, trifoliate, leaflets more or less elliptical, crenate or dentate, thin; flower buds enclosed in scales; flowers produced singly or in pairs, axillary, generally appearing before the leaves, but occasionally with (fig. 7) or after them; sepals five, light greenish yellow, small, oval, pointed, about 1-4 inch long; corolla large, white, 1 1-2 to $13-4$ inches across when expanded; petals obovate, thin, striated, polypetalous; stamens twenty-one to twenty-three, filaments separate, anthers adnate, oval two-celled; pistil oblong, club-shaped, hairy, style short; ovary six-loculed; fruit light orange, rough, covered with short hair; oil of the rind aromatic, sticky; pulp rather sparse, acid; juice sacks slender, pointed; seeds numerous, distinct from other citrus, oval, rounded at the ends, plump, embryo one; time of flowering variable, extending in the citrus districts from the first of March to the middle of April; fruit ripening in September and October; tree very hardy, native of China and Japan.

Citrus vulgaris Risso, Ann. Mus., Paris, XX:190, 1813. Seville orange, Bigarade orange, Sour orange. A small tree, twenty to thirty feet in height, with a dense, compact head; young shoots light green, thorny; thorns alternate, small, sharp pointed; on older wood larger, strong, stiff; leaves unifoliate, evergreen, alternate, ovate, pointed, strongly and peculiarly scented; petiole 1-2 to $3-4$ inch long, broadly winged; flowers in small axillary cymes, white, strongly sweet scented, somewhat larger than those of Citrus aurantium; calyx cupped, segments four to five, blunt; petals linear oblong, conspicuously dotted with oil cells; stamens twenty to twenty-four, filaments united in groups; pistil club-shaped, smooth, ovary six to fourteen loculed; fruit orange colored or frequently reddish when well matured, inclined to be rough; rind strongly aromatic, bitter; pulp acid, juice sacks spindle-shaped, rather small; seeds flattened and wedged toward the micropylar end, marked with ridged lines. Native of southeastern Asia, probably in Cochin China. Hardier than the sweet orange. Introduced into Florida at an early date and now naturalized in many of the forests.

Citrus Aurantium L., Sp. Pl. 2:782, 1753. Sweet orange. A tree twenty-five to forty feet in height with a compact, conical 
head; bark greyish brown; thorns generally present, 1-2 to 2 inches long, sharp, stout; leaves oval or ovate oblong, 3 to 4 inches long, smooth, shining, somewhat lighter below than above, margins entire, or very slightly serrate; petiole $1 / 2$ to 1 inch long, slightly winged (occasionally with quite a broad wing); flowers axillary in clusters of one to six, white, sweet-scented, smaller than those of $C$. vulgaris; calyx cupped; sepals four to five, awlshaped, thick, greenish, persistent; petals usually five, oblong, 1 to 1-4 inches long, thick, fleshy, recurved; stamens twenty to: twenty-five, hypogynous, filaments flattened, united in groups, shorter than the petals; pistil distinctly divided into stigma, style and ovary; stigma knob-like, style long and slender, ovary rounded, ten to fourteen loculed; fruit globose or oblate, light orange to reddish, rind smooth; pulp juicy, sub-acid; juice sacks spindle-shaped, sometimes larger than those of $C$. vulgaris; seeds few or many, oblong ovoid, plano-convex, generally broad, wedged or pointed at the micropylar end, marked with oblique ridges surrounding one or two plain areas. Native of China or Cochin China.

Citrus nobilis Lour., Flor. Coch., 2:466, 1790. The mandarin orange. A small tree, twelve to twenty feet in height, with a dense head of upright or willowy drooping branches; bark dark brownish or streaked with gray; branchlets light green or dark in color, small, slender, round or angled, thornless or provided with small sharp spines; leaves small, lanceolate to oval, slightly crenate; petioles short, wingless or with very small wings; flowers terminating the branchlets or axillary, sometimes clustered, 3-4 to 1 inch across, sweet-scented; calyx small, shallow, cupped, the petals small; petals white, fleshy, recurved; stamens eighteen to twenty-three in number, shorter than the petals; pistil small, resembling that of $C$. Aurantium; ovary nine to fifteen loculed; fruit distinctly oblate, orange to reddish in color, pulp sweet or sub-acid; juice sacks broad and blunt; seeds top-shaped, beaked, cotyledons pistache green; embryos one or more; sections separating readily from each other and from the rind; rind thin, oil cells somewhat balloon-shaped or oval. Native of Cochin China. Generally admitted to be somewhat hardier than the sweet orange.

Citrus decumana L., Syst. Nat. Ed. 12, 2:508, 1767. Pomelo 
and Shaddock. A tree twenty to forty feet in height, with a rounded or conical head and a trunk upwards of eighteen inches in diameter; bark smooth, grayish brown; young leaves and shoots sparsely pubescent, light green; leaves ovate, blunt, pointed or rounded, emarginate, smooth, dark glossy green, leathery, margin crenate; petioles articulated, broadly winged; flowers produced singly or in cymose clusters of two to twenty, sweet-scented, calyx cupped, large; sepals four to five, pointed; corolla white, 1 1-2 to $13-4$ inches across; petals four to five, slightly reflexed, fleshy, oblong; stamens twenty to twenty-five, anthers large, abundantly supplied with pollen, proterandrous; pistil stout, stigma when ripe covered with a sticky, milky fluid; ovary eleven to fourteen loculed; fruit large, oblate, globose or pyriform, light lemon or orange colored; flesh grayish or pink; juice sacks large, spindle-shaped; flavor a mingling of acid, bitterness and sweetness or sub-acid; seeds large, light colored, wedge-shaped or irregular, ridged with prominent ridges sur. rounding broad, flat areas. Native of Polynesian and Malayan Archipelagoes.

Citrus Japonica Thunb., Fl. Jap., 292, 1784. Kumquat. A shrub from eight to twelve feet high, much branched, the head rather close and compact; branches when young, light green, somewhat angled, becoming rounder with age, thornless or with small, sharp thorns, 1-2 inch long; leaves $3-8 \times 1$ 1-4 inches to 15-8 x 3 3-8 inches, lanceolate; apex obtuse; base acute or obtuse, margin very slightly crenate down about half way from' the apex, upper surface dark green, glossy, lower lighter; flowers pure white, axillary, single or in pairs, occasionally in clusters of as many as four borne on new or on one-year-old wood; peduncle bracted with one or two minute bracts; calyx small, greenish; corolla 5-8 inch across when expanded; petals four to five, oblong, lanceolate, fleshy; stamens unequal, short, united in a ring or in two or three groups, fifteen to twenty-two in number; pistil small, the ovary five to six loculed; fruit round or oblong, 1 to $11-4$ inches in diameter; oil cells of the rind large and conspicuous, the inner lining of the rind sweet; pulp acid, juice sacks small; seeds few, small, blunt pointed; cotyledons green or greenish. Presumably a native of Cochin China.

Citrus Medica L., Sp. Pl., 2:782, 1753. Citron. A shrub or 
small tree, about ten feet high with a short, indistinct trunk and short, thick irregular, straggling, thorny branches; bark light gray; thorns short, sharp, rather stout; young shoots smooth, violet colored or purplish, stiff; leaves large, four to six inches long, oval oblong, serrate or somewhat crenate, dark green above, lighter beneath; flowers small, axillary in compact clusters of three to ten, often unisexual; calyx small, cupped; corolla white within, tinged with purple on the outside; petals oblong, the tips incurved; stamens short, irregular in length, forty to fortyfive in number; pistil small, ovary nine to twelve loculed, or occasionally more; fruit lemon yellow, large, 6 to 9 inches long, oblong, rough or warty; sometimes ridged, apex blunt pointed, rind thick, white except for the outer colored rim; pulp sparse, juice scant, acid and somewhat bitter, or sweetish; juice sacks small, slender, seeds oval, plump, light colored, smooth. Probably native of India, or it may have been introduced there from farther east, China or Cochin China. Extremely sensitive to cold.

Citrus Limonum, Risso, Ann. Mus. Paris, XX:201, 1813. Lemon. A small tree, ten to twenty feet in height, with rather open head of short, round or angular branches, thorny; bark grayish; young shoots purplish, smooth; leaves evergreen, alternate, two to three inches in length, ovate-oval, sharp pointed, light green, margin serrate; petioles entirely wingless; flowers solitary occasionally in pairs, axillary, on distinct peduncles; calyx persistent, segments four to five; corolla large, 1 1-2 to 2 inches across, white inside, purplish outside, petals oblong spreading, strongly reflexed; stamens twenty to twenty-six, separate, or more or less united in small groups; ovary considerably elevated on a prominent disk, seven to ten loculed; fruit ripening at all seasons, ovoid or oblong and pointed at both base and apex, about 3 inches long, smooth or rough, light yellow in color, rind thin; flesh light colored, pulp acid, juice sacks long and pointed; seeds oval, pointed at the micropylar end, quite smooth. Native of the same regions as the citron.

Citrus Limetta Risso, Ann. Mus. Paris, XX:195, 1813. a shrub or small tree of straggling habit, with small, stiff, interlocking or drooping thorny branches, the thorns small, sharp, numerous; bark grayish brown; young branchlets light green, 
becoming darker with age; leaves elliptic-oval, glossy green in color, margin slightly indented; petioles margined; flowers small, produced in axillary clusters of three to ten; calyx small, four to five pointed; corolla white on both inner and outer surfaces, petals four to five, oblong, fleshy; stamens small, twenty to twenty-five, united in a number of groups; ovary about ten loculed; fruit rounded oblong or oblong, frequently mammilate, light yellow, rind thin, pulp greenish, acid; juice sacks small, slender, pointed; seeds small, oval, pointed. Native of India and southeastern Asia. 


\section{CHAPTER IV.}

\section{THE TRIFOLIATE ORANGE.}

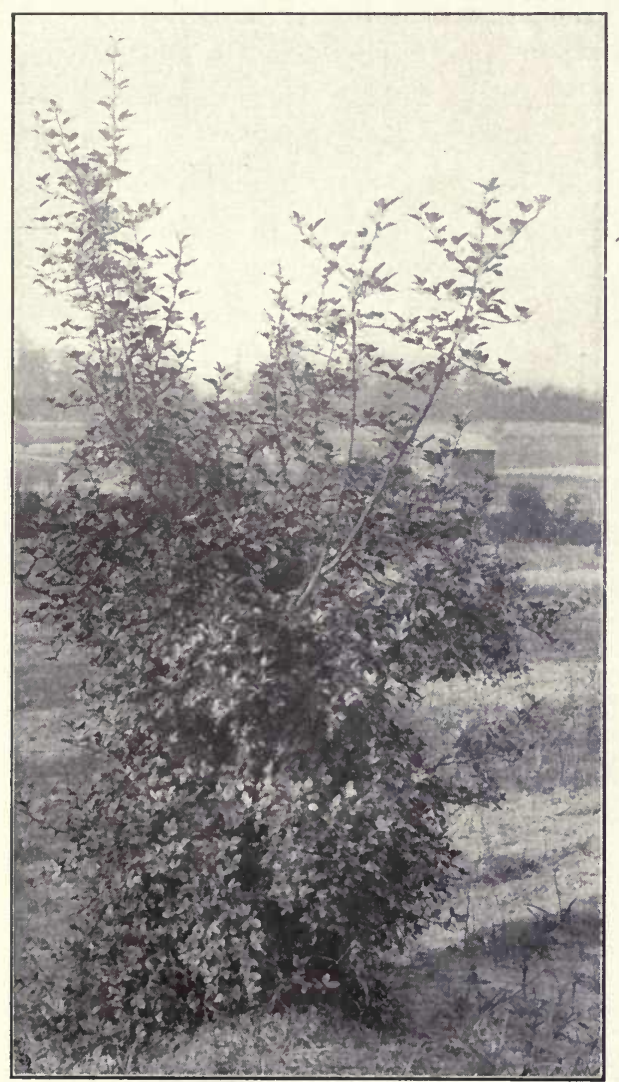

Fig. 6. Trifoliate Orange Tree.

As a commercial variety, the trifoliate orange is worthless. It is, however, val. uable as a hedge plant, and as a stock on which to work othel varieties of citrus. Large quantities of seed are annual. ly produced in Florida a n d Louisiana, but so great is the demand, that a great deal is imported from Japan as well. Hybrids have been produced between the trifoliate and sweet oranges by Dr. H. J.

Webber and others, in the hope of securing a palatable variety more resistant to the effects of frost than the sweet 
orange. What the outcome will eventually be it is diffcult to say, but it may be that from this fruit may spring a race of hardy citrus with which the citrus industry will be extended northward far beyond its present limits.

What seems to be the first mention of the trifoliate orange in citrus literature is that made by Kaempfer in his Amoenitatum Exoticarum in 1712. An illustration (page 802 ), accompanying his brief description, leaves no room to doubt the identity of his Si, vulgo Karatats banna with the trifoliate orange. In 1763 Linnaeus described the trifoliate orange in the second edition of his Species Plantarum and the name applied by him, Citrus trifoliata, is now the accepted one. Thunberg, in his Flora Japonica, 1784, gave the name Citrus trifolia. A. P. DeCandolle, in his Prodromus Systematis Naturalis, 1824, placed the trifoliate orange in the genus Agle, naming it Agle separia. There is doubtless some reason for this disposition of the plant, for in many respects it is not a true citrus. Again in 1829, Desfontaines renamed it Citrus triptera. Engler, in his classification of citrus-Engler and Prantl, Pflanzenfamilien, 1896, has placed Citrus trifoliata in the section Pseudogle of the genus citrus, which, all things considered, is a satisfactory disposition of the species.

The trifoliate orange is said to have been first introduced into America in 1869 by the late Wm. Saunders, of the United States Department of Agriculture.

For many years, it has been the hope of citrus fruit growers that varieties might be secured which would resist many degrees of frost. The production of hybrid varieties with this object in view was undertaken, in Florida, in 1892-93 by Dr. H. J. Webber, and Mr. Walter T. Swingle of the United States Department of Agriculture. Most of the early results were lost, but the work 
was again taken up in 1896-97 and vigorously pushed. Their work resulted in the production of upwards of two thousand hybrids and a number of these have proved to possess the desired hardiness.

Many of the varieties have been fruited for the Department of Agriculture by the Glen Saint Mary Nurseries in northern Florida and by different Experiment Stations in the Southern States. It has been clearly demonstrated that the hardy varieties will stand, uninjured, temperatures which would prove fatal to ordinary oranges. The work has now progressed so far that something definite can be said concerning the quality of the fruit and some estimation can be placed on the work from the standpoint of future and further developments.

Everything pointed to Citrus trifoliata as the parent which would impart the desired hardiness. With this as the female parent (in most cases) the work was undertaken. Crossing was not as easily performed as might be expected. Only about two per cent. of the fruit set and many of these produced a considerable amount of defective seed. A large number of the plants produced cannot be distinguished from the trifoliate orange, others are exactly like sweet orange seedlings, while

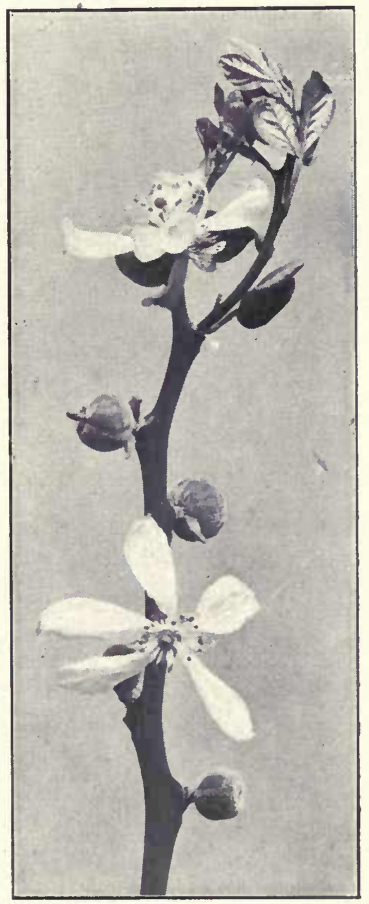

Fig. 7.

Trifoliate Orange Flowers. (Four-sevenths natural size.) 
still others combine the characters of both parents. Many proved to be evergreen like the orange but with trifoliate leaves like those of Citrus trifoliata. The proportion of those showing intermediate characters was probably less than twenty-five per cent. For instance, out of forty plants, raised from seed of a single fruit, twenty-nine closely resembled the trifoliate orange, the remaining eleven being intermediate in character.

The hybrids have proved to be vigorous growers and far surpass, in size, seedling Citrus trifoliata trees of the same age. Those varieties which have fruited have proved to be prolific. The flowers are quite different from those of either of the parents, but for the most part sweet scented like those of the orange.

The fruit varies considerably in size, that produced by some varieties is but little larger than Citrus trifoliata fruit. Others bear fruit equal in size to that of the common orange and one variety at least bears fruit so closely resembling that of the sweet orange that in appearance it cannot be readily distinguished from it.

In quality, the fruits are not so good as the sweet oranges. They are intermediate in character and retain some of the flavor of the Citrus trifoliata fruit. For the most part they are quite sour. They can be used for making a very fine quality of ade and may also be used for many culinary purposes. In fact, some of them may be substituted for lemons as commonly used. As ornamental trees they are decidedly valuable. In foliage, flower and fruit, they are quite ornamental and make very handsome lawn specimens.

Up to the present time five noteworthy varieties of citranges, as they are called, Rusk, Morton, Colman, Savage and Rustic, have been named and described by Dr. Webber. 


\section{CHAPTER V.}

\section{THE BIGARADE ORANGES.}

In America the oranges of this group are commonly referred to as sour oranges, but for some reasons it has been deemed best not to adopt this name, although the sour orange is the most important variety in the group. They have also been called Seville oranges, but this cognomen has also been given to some of the sweet oranges. It, too, has been discarded as a group name in favor of the French "Bigarade."

The sweet and bigarade oranges have been placed under one species, $C$. A urantium L., by many writers. One of the principal reasons advanced for so doing is the statement made by Macfayden and others that sweet orange seed frequently produced trees bearing bigarade oranges.

In view of evidence to the contrary, there appears to be no reason for believing that Macfayden's observations were accurate. In Porto Rico orange trees have been used to a considerable extent for affording shade in the coffee plantations. The plantings are invariably mixed, here a sweet orange, there a bigarade. The planting was done indiscriminately, no notice being taken as to the kind of tree from which the seed was procured. Moreover the work was done by ignorant laborers and any conclusions which might be drawn from it are worthless. In Jamaica, where Macfayden made his observations, practically the same conditions prevail, and the laboring class is the same. The natives were probably the first to aver that sweet orange seed produced trees bearing bigarade fruit and this myth, like many another, found its way into and ob- 
tained an abiding place in botanical and horticultura! literature.

If the bigarade orange has remained specifically distinct, even though the distinctions between it and the sweet orange be slight, through a period of about eight centuries, reproducing itself true to seed without the interference of man throughout that period, it certainly is entitled to specific rank. 'The history of the group shows that it has done so.

The Spaniards brought the first bigarade oranges to America. Fruit was obtained by the Indians and they carried it about on their journeys. The seeds were dropped where the fruit was eaten and finding in Florida and other regions a soil and climate adapted to their growth, grew up where they had been deposited. As a result, wild groves were formed on the shores of lakes and rivers. Natural groves, where four or five hundred trees grew on an acre, were not uncommon at one time in many parts of Florida, and even to this day, the sour orange grows wild in many of the hammocks. By top-working these natural groves, many of the early sweet orange groves were established.

In America the bigarade oranges are unimportant from a commercial standpoint. The greatest use to which the sour orange, the most important variety of the group, is put is for stocks upon which to work other citrus fruits. For the production of stocks, sour orange seed is in considerable demand at a fair price. Orange marmalade of the finest quality may be manufactured from the fruit, while a refreshing drink, "orangeade," may be made from the juice. 


\section{CHAPTER VI.}

\section{THE SIVEET ORANGES.}

This group of citrus fruits has been known by a number of names, names generally derived from the localities from which they were secured. They have been referred to as Portugal oranges, Malta oranges, etc., but the name used above is now generally accepted. It can scarcely be cons i d e r ed descriptive, however. The taste of a good fruit of this group is not sweet. Sweetness should preponderate, but-it should be modified by and blended with acid. Nevertheless, usage has established the name and everywhere it is and has been used for hundreds of years. These fruits were known to

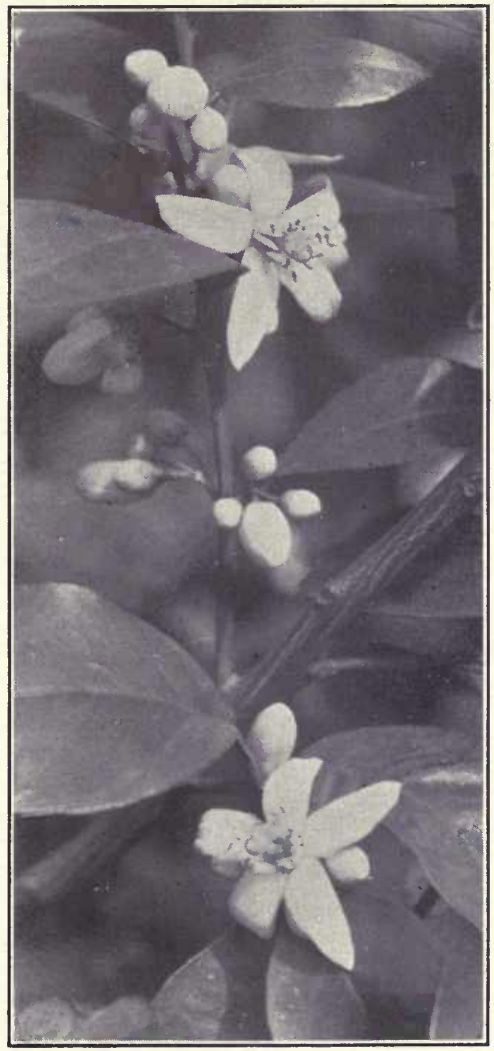

Fig. 8. Flowers of Majorca Orange (Reduced about one-third.) Ferrari as Aurantium vulgare medulla dulci while Volekamer in 1713 called them Aurantium fructu dulci. 
The researches of Gallesio go to prove that the sweet oranges were not known in Europe until early in the fifteenth century. They were, however, rapidly disseminated after their introduction and in a comparatively short time cultivated in all parts of southern Europe, suited to their growth. Later their culture was still further extended, the fruit being grown in houses, of which both Ferrari and Volckamer give illustrations, so that by the end of the seventeenth century they were grown under cover in many parts of Europe, where their culture conld not be successfully accomplished in the open air.

The date of their introduction into America is, as it is with nearly all the early introductions of citrus, merely a matter of conjecture. The Spaniards were undoubtedly responsible for its being brought into many parts of the New World. On the authority of Acosta and Piso, who wrote concerning their travels in the West Indies and Brazil respectively, we must conclude that cranges of some sort were well established in those parts of America, which they visited, prior to the years 1600 and 1648. In Florida the early settlers found sweet orange trees growing in the hammocks in some places. That whole strain of oranges now largely grown on the Indian River had their origin in one of these wild groves. But the fact remains that the sweet orange was not so widely distributed throughout Florida as the bigarade orange, at least, it was not found so abundantly in the native woods. This may be accounted for by the fact that the sweet orange, being less hardy, was not as capable of making a place for itself among the native trees as the bigarade. It is not improbable the sweet orange was introduced at a somewhat later date than the sour bigarade, which might also, in a measure, account for its not being so 
common. But groves were established and in a thorough state of cultivation early in the nineteenth century, and even before that time considerable attention was given to citrus culture.

The introduction of the orange into California is thus told by Mr. B. M. Lelong:

"In 1767 the Jesuits were expelled from the missions in Lower California, their possessions were turned over to the Franciscans, and Junipero Serra was selected as President of the Missions. A dispute arose between the Franciscans and Dominicans over the division of the property. The latter claimed an interest in the mission work. In consequence of this a division was made, and in 1769 the Franciscans started northward, entering and occupying what is now the State of California. * * *

"Jose del Galvez, 'visitor-general' and secular head, with Father Serra, made arrangements for the establishment of settlements. Twenty-one missions were established, all but three of which had gardens and orchards. The mission orchards were very small, and some consisted of but few trees, but those trees played an important part in the horticultural advancement of the State, for they showed the possibilities in fruit culture, and furnished seeds, stocks and scions for many orchards. * * * The chief fruits brought by the Fathers were oranges, figs, grapes and olives. ** *

Of all the citrus fruits cultivated in America at the present time, the sweet orange is the most important. Its cultivation represents more capital than all the others together, and it is likely to maintain its present position so long as fruits of this genus are grown.

It is used as a dessert fruit only and for the most part all sweet oranges are consumed without cooking. In 
fact, cooking spoils the sweet orange; it parts with its flavor and becomes insipid. But as a raw fruit it is unsurpassed.

The number of varieties of sweet oranges which have been brought before the public is considerably over one hundred. Unfortunately, descriptions of them such as may be found for apples, pears and other fruits, are comparatively few. Again, the origin of many of them is lost in obscurity, from which it is almost impossible to bring them. As a result, many varieties have received a number of names. Unfortunately it has not been possible to secure specimens of all the varieties, but a goodly number have been obtained and are described in the section on varieties.

Great difficulty has been encountered in grouping the sweet oranges. But it has finally been decided to group them as Spanish oranges, Mediterranean oranges, Blood oranges and Navel oranges. This classification is in some respects unsatisfactory and further study of the group may produce something better. For the present, however, this is the best that can be given.

\section{SPANISH ORANGES.}

Tree large and of strong, vigorous growth, well foliaged, the leaves oval, pointed, frequently strongly winged; fruit of rather coarse grain, but of good quality, large; ripening for the most part in mid-season; seeds large, wedged and flanged.

Most of the Spanish oranges have originated as seed. lings in America, the majority of the varieties having come from the seedling groves of Florida. Generally they produce fruit in abundance and the greater portion of the fruit at present shipped from Florida, Cuba and Porto 
Rico is of this class. In California they have not proved desirable in most cases. The name has been given because the oranges of this group have come from the Spanish introductions of two or three centuries ago.

\section{MEDITERRANEAN ORANGES.}

Tree standard or half dwarf, generally distinct in habit of growth, many of them not distinguishable from blood oranges; foliage abundant, leaves small, closely set, or larger and resembling those of the Spanish oranges; fruit heavy, rich, vinous, of excellent quality, fine grained, round oblate or somewhat oval, ripening in mid-season or later; seeds oval, plump, pointed.

The fruit of this group is of the same general nature as the blood oranges, lacking the blood color. The size is larger and many of them are more prolific, though in these respects many are similar to the bloods.

Most varieties of this group have been introduced from the Mediterranean region. Some have come from the Azores and some from Palestine. Some have originated in Florida and other parts of America.

They are here called the Mediterranean oranges because they have come either directly or indirectly from the citrus districts of southern Europe. Some have been imported direct, some have come by way of the Azores. It is probable that it would be more satisfactory to subdivide this group, as there are some divergences from the main type, of which Jaffa and Majorca may be said to be representative.

\section{BLOOD. ORANGES.}

Tree dwarfish, compact, distinct in habit of growth; foliage abundant, the leaves small, oval, rounded, generally almost without wings; fruit when fully matured hav- 
ing ruby-red pulp or pulp streaked with red, of superior quality, edible earlier in the season, but not showing blood markings until late, generally small or medium-sized; rind assuming a reddish blush at maturity. The fruit of trees worked on trifoliate orange stock show blood markings earlier in the season than when other stocks are used.

This sub-group contains the best oranges known, the quality of the fruit being equalled by few other varieties and certainly surpassed by none. Seeds are generally quite few in number, small and plump. The small size of the fruit of some varieties is objectionable. The general characteristics of the group, except for the differences in the fruit are almost the same as those of the Mediterran. ean oranges. Most of the varieties now grown in America came originally from the Mediterranean citrus districts, the late General Sanford and Mr. Charles Armory being responsible for their introduction.

Gallesio, in his "Traite du Citrus," Paris, 1811, mentions the blood orange as one of the varieties cultivated extensively in his day in Malta and Provence and by amateurs and seedsmen in Liguria.

\section{NAVEL ORANGES.}

Tree rather dwarf, with well rounded top and glossy green foliage, generally almost thornless; flowers entirely lacking in pollen or only poorly supplied, pistils prolif. erous, giving rise to an umbilical mark of greater or less extent on the apex of the fruit; fruit of superior quality, but perhaps not quite equal to the best of the Mediter. ranean and blood types. A few varieties not included with those of the navel type are sometimes navel marked. Among these may be mentioned Ruby, Boone, St. Michael Blood and the Cleopatra mandarin. 
In Florida the navel oranges have not been a success, owing to the small crops usually produced. The late E. H. Hart, ${ }^{*}$ however, called attention to one variety, a cross between Sustain and Botelha which is quite prolific in the above mentioned district. This tendency toward shy bearing can in part be overcome in Florida by a judicious selection of stocks. The Bahia navel orange is the variety par excellence of the California districts and there seems at present to be no good reason why any other variety of its season should be planted. All things considered, this variety is the most noteworthy of the whole group of navel oranges.

More recently a variety of navel orange known as Surprise has been brought forward by Mr. E. S. Hubbard, of Federal Point, Fla. This variety fruits well on sour orange stock and bids fair to take the place in Florida, which the Bahia now occupies in California.

Regarding the first mention of the navel orange in citrus literature, B. M. Lelong, in his work, "Culture of the Citrus in California," 1902, pages 52 to 53, makes the following remarks: "The first illustration of the Navel orange appears in a volume, 'Table xvi.-Historiæ Naturalis de Arboribus et Fructibus, Libri Decém. Johannis Johnstoni, Medicinæ Doctoris. Francofurti, o-m., MDCLXII.' ('The Natural History of Trees and Fruits. Ten Books. By John Johnson. Doctor of Medicine. Frankfort on Main, 1662'), referred to as Aurantium foetiferum * * * Altheugh no description of the navel orange appears in the text, this is the earliest reference known."

In 1646 Baptiste Ferrari, a monk of the Society of Jesus, published at Rome his famous work, "Hesperides sive de Malorum aureorum cultura et usu, Libri Quatuor." On page 403 he describes and on page 405 illus- 
trates a variety of orange, "Aurantium foemima sive foetiferum." Of it Ferrari says; "This Aurantium imitates to some extent the fertility of the tree which bears it in that it struggles, though unsuccessfully, to produce the fruit upon itself. * * * On the end of the fruit is another, sometimes with a thin rind investing it, but more, frequently naked, so far at least as the pulp (of the larger part) is concerned; this (second fruit) is composed of an inner medulla of about four spikes: the young brood, as it were, of fruits half seen pushing out through the gaping umbilicus, which is sometimes more and sometimes less closely compressed." This is a navel orange both by description and illustration.

There is such a striking resemblance between the illustration given by Ferrari and that reproduced by $\mathrm{Mr}$. Lelong from Johnson's work that the writer is compelled to believe that Johnson copied his illustration directly from Ferrari's Hesperides.

Many writers since the days of Ferrari have referred to the navel orange, notable among whom may be mentioned Volckamer, who in his Hesperidium Norimbergensium, 1713, referred to two varieties of navel oranges, "Aranzo de fior doppio," and Aranzo di fiore Scorza doppio," which he described on pages 201-202 and illustrated on pages $202 \mathrm{~b}$ and $202 \mathrm{c}$.

A closer study of citrus literature may bring to light still earlier references to this interesting type of fruits.

* Am. Gard. Vol. 23. No. 417, Dec. 20, 1902. 



\section{THE MANDARIN ORANGES.}

Many writers on citrus fruits have placed the mandarin oranges under the species, Citrus Aurantium Linn. Others have considered it a variety of that species while some, believing it possesses distinctive, specific characteristics, have followed Lourerio and have referred it to his species Citrus nobilis. In this latter view the writer concurs, and after carefully studying the characteristics of both the mandarin and sweet orange groups, believes it best to place the former under a species separate from the latter.

The group as represented in America is distinct in habit of growth and in fruit from C. Aurantium. The leaves of the mandarin oranges are generally quite small and pointed, while the skin is easily separated from the pulp of the fruit and the sections of the pulp from one another. One noteworthy point, and one which needs to be explained away by those who desire to throw the two groups together, is that the cotyledons of the seeds of the mandarin oranges are pistache green or greenish in color, while those of the sweet oranges are white. Of course it must be granted that one species may shade off into the other, but where such is the case any variety in question should be relegated to the group of which it possesses the greatest number of narked characteristics.

The reasons for adopting the group-name Mandarin are, that it has been longer in use and is probably more widely known than any other. Many have referred to the Tangierines as a group, or sub-group, distinct and separate 
from the Mandarins. There may be reasons of greater or less weight for this division, but in this publication the name Tangierine has been discarded in favor of the older name. No distinction can be made between the Mandarin and the Tangierine oranges so-called, more than can be made between any two distinct varieties of fruits in recognized pomological groups. Moreover, the fact must not be overlooked that in some of the world's citrus growing districts the two names are used interchangeably.

Two explanations have been given for the name Mandarin as applied to this group of oranges. It was given either because the fruit was regarded as the best of the citrus family, just as the Chinese Mandarin or grandee stood in social rank above his fellowmen, or because this orange was the fruit of the rich and therefore only within the reach of the nobility. The fact that the fruit is extensively cultivated in China and Japan and that it is there held in such high esteem leads to the belief that the first explanation is the more correct one.

One other name, "kid-glove oranges," has been applied to the group. In explanation of the origin of this name the remarks of the late $\mathrm{E}$. H. Hart before the twenty-second meeting of the American Pomological Society at Ocala, Fla., in 1889, are self-explanatory. "The term 'kid-glove' orange, as applied to Citrus nobilis, originally a joke of our facetious countryman, Colonel Dancy, of Orange Mills, was gravely accepted as a synonym by our first nomenclature committee, and like many another whimsical whatdo-you-call-him, it struck, where one more dignified would have glanced off."

The investigations of De Candolle and others show that we are safe in concluding that the mandarin oranges 
had their origin in Cochin China. From that center they have been carried into many portions of the world.

Several gaps occur in the history of these oranges, and yet it has been possible to trace it with a fair degree of accuracy. The first mention of an orange which is believed to belong to this group is in Steerbeck's Citricultura, where it is mentioned as the "Muscat apple." It is well within the limits of probability that some member or members of the group were known to Rumphius and indeed Lourerio, in his original description of Citrus nobilis in 1790, refers to this possibility. Referring to the same dates and cuts, Bonavia comes to the conclusion that the Aurantium sinense of Rumphius must be grouped with the suntara oranges of India. Having carefully read the description written by Rumphius, both in the original and as translated by Bonavia, and after comparing it with specimens of the Rangpur lime, grown by Reasoner Bros., by Bonavia said to be a suntara orange, I must say that any attempt to decide this question places one on exceedingly debatable ground.

In 1805 two varieties of mandarin oranges were introduced into England from Canton by Sir Abraham Hume and fruit produced from these trees was illustrated in 1817 (1) and 1824 (2). According to du Breuil (3), the mandarin orange was introduced into Europe (continental) about 1828. In the vicinity of Parma it was cultivated on a large scale as early as 1842 and its culture in the county of Niza and the region surrounding Genoa dates back to 1849 or 1850. The conclusions reached by du Breuil are further substantiated by the fact that Gallesio appears not

\footnotetext{
* Steerbeck, F. Van. Citricultura. 27. 1682.

(1.) Bot. Reg., 3:211. 1817.

(2.) Bot. Reposit., 9:608. 1824

(3.) Hist. Cult. Örang., Risso \& Poiteau. 49. 1872.
} 
to have known this tree, and Risso and Poiteau make no mention of its culture in Europe in the first edition of their work. Du Breuil states that in commerce a distinction was made between the mandarins of Parma and those of Spain, Algeria, Niza and the coast of Italy.

Bonavia says that the mandarin orange was probably introduced into India from Egypt with a collection of orange trees in 1847 (4) and that a second introduction: was made by himself in 1863 (5). It is not improbable that the mandarin oranges found their way into Egypt from some one of the countries of southern Europe.

The China mandarin, according to the best information which can be secured, was brought to Louisiana by the Italian Consul at New Orleans some time between 1840 and 1850. The first trees were planted on the grounds of the consulate at Algiers, across the river from New Orleans. It has been impossible to obtain the name of the consul or the exact date. Shortly after, or about 1850 , some one of the mandarin oranges was known to northern nurserymen, for Buist (6) in 1854, refers to one of them as a recent introduction, valuable for pot culture.

The introduction of the China mandarin from Louisiana into Florida is credited to Major Atway by the committee of the Florida Fruit Growers' Assuciation, and at the time their report was made the original tree was growing in the grove of Dr. Moragne at Palatka. The accidental substitution of one word for another, a typographical error, in Stubbs and Morgan's bulletin, "The Orange. and Other Citrus Fruits," has twisted the phraseology as quoted by Moore, Reasoner and others to read, "Tree of original variety introduced by Major Atway, of Bayou

(4-5.) The Cultivated Orange of India and Ceylon. 56 and 231. 1888

(6.) Buist, R. American Flower-Garden Directory. 224.1824. 
Sara, La." Since their bulletin was written in Louisiana, this reading conveys an erroneous idea.

It has not been possible to fix the date of introduction of the mandarin oranges into Florida, but if the report of the Fruit Growers' Association is correct, it was, of course, subsequent to the Louisiana introduction and presumably some time after it. The origin and introduction of each of the mandarin oranges is given in the section on varieties.

At the present time it may be said that the sweet oranges, lemons, pomelos and mandarin oranges are the four important groups cultivated in America.

Of these four important groups, the sweet oranges occupy the first place and are destined to do so throughout the whole future of citrus culture. The sweet orange is a staple fruit, just as the apple is a staple fruit. It is always in demand, and it is the dessert fruit of America, par excellence.

Considerably more attention has been given to the culture of mandarin oranges in Florida than in California. It must be borne in mind, lowever, that the mandarin orange is essentially a fancy fruit and as such, commands a fancy price in its season, but it would be useless to attempt to place it on the same plane with the sweet orange as a staple fruit. The fruit, generally speaking, is smaller than the sweet orange. The bearing capacity of the tree seldom reaches and rarely exceeds twelve straps, and all the members of the group require careful cultivation and fertilization to secure the best quality. Of course, this may be said of sweet oranges or any other citrus fruit, but it is peculiarly true of oranges of the mandarin group.

Mandarin orange culture is on a staple basis in America at the present time, and the number of trees may be 
conservatively increased. Plantings should not be made out of all proportion to the plantings of other citrus trees, and the object of every grower should be, not so much to increase the output, as to produce a fruit of high quality, else there is no room for the fruit on the market. A good mandarin orange is an excellent fruit, a poor one is worthless. It should be in all respects a fancy fruit.

There is another matter which must not be overlooked in considering the horticultural status of this group. At present it contains the hardiest known, large fruited, edible variety of citrus, the Satsuma. This variety extends the culture of citrus fruits on a safe basis far into the more exposed sections of the country. In northern Florida and California it withstands frost well and a considerable amount of this fruit (four or five hundred straps) was shipped from the extreme northern portion of Florida during the season of 1902 , the price realized being from $\$ 4.00$ to $\$ 5.00$ per strap. The tree is hardy, the fruit matures early and is very desirable for shipment during the months of October and November.

Along the coast of Alabama, Mississippi, Louisiana and Texas and in southeastern Texas, the Satsuma on Citrus trifoliata stock has been planted to a considerable extent. In Texas particularly, a large share of attention is being given to its culture and the industry gives promise of assuming large proportions. If the trees are banked each winter while young (young trees are more likely to be injured by cold) and allowed to branch low, they will, when they have increased in age and size sufficiently, stand a great deal of cold. For a number of years, this orange was known in the markets under the names Mandarin and Tangierine. Recently, however, it has been quoted in market reports under its own name-Satsuma. 


\section{CHAPTER VIII.}

\section{THE POMELOS.}

The name pomelo ( $p l$. pomelos), as applied to the fruit under consideration, is the one now recognized by all horticultural writers and has been adopted by the United States Department of Agriculture, the American Pomological Society, the Florida State Horticultural Society and the California State Board of Horticulture. The word has been variously spelled pummelo, pumalo, pumelo, pumelow, etc., but the name and spelling as adopted in this volume are in accordance with the present usage of American horticulturists.

In 1713, in his Hesperidium Norimbergensium, pages 181 and 189, Volckamer uses the names pompelmoes and pompelmus and on page $189 a$, gives a very good illustration of the pomelo as we know it. This is one of the earliest references to the fruit under this name, although Ferrari apparently referred to the same fruit, or a closely related one, as Aurantium Maximum (Hesperides, 437; pls. 439 and 441, 1646). From the Dutch pompelmoes has come our modern name pomelo. The explanation offered by Bonavia (1) of the derivation of the Dutch name is that they probably first found the fruit at the village of Pompelmousses in the Mauritius and gave the name of the village to it. Harris (2) offers the explanation that pomelo is derived from pomum melo, the melon-apple. Which of these is correct would be difficult to say. 
Commercially this fruit is known as grapefruit, and in market quotations reference is nearly always made to it under this name. This appellation was given because the fruit is so frequently borne in grape-like clusters of from three or four to a dozen and a half. A glance at plate No. IX, which represents a cluster of twelve, of which eleven are visible, proves that the name is not altogether inapplicable. Not only is the fruit known in the market as grapefruit, but it is the name generally applied throughout the citrus districts of the United States, and many people know it by none other. Whether the termgrapefruit-will ever be superseded in common use by the correct horticultural name-pomelo-is extremely doubtful.

When and where this cognomen was first used it would be difficult to say, but John Lunan, in his Hortus Jamaicensis, Vol. 2, page 171, 1814, speaking of the shaddock, says. "There is a variety known by the name of grapefruit on account of its resemblance in flavor to the grape." The Chevalier de Tussac, in his Flora Antillarum (Vol. III, page 74,1824 , calls attention to the fruit in these words: "J'ai eu occasion d'observer a la Jamaique, dans le jardin botanique d'East, une espece de chadec dont les fruits, qui n'excedent pas en grosseur une belle orange sont disposes en grappes; les Anglaise de la Jamaique donnent a ce fruit le non de forbidden fruit, fruit defendu, ou smaller shaddoc, petit chadec."

From this we must conclude that the name grapefruit originated in the West Indies, for I have not found the name in any other of the older works, except where the authors mentioned above are referred to or quoted.

The pomelo is sometimes referred to as the shaddock, variously spelled "shaddock." "chaddock" and "chadec." 
Bonavia, in his work on the oranges and lemons of India and Ceylon makes the name shaddock synonymous with pomelo. In the section of Thomas' Fruit Culture on Subtropical Fruits, written by the late E. H. Hart, of Federal Point, Florida (1897), the name shaddock is used, while pomelo, spelled pummelo in his article, is made synonymous.

However, we have no better name for this fruit than

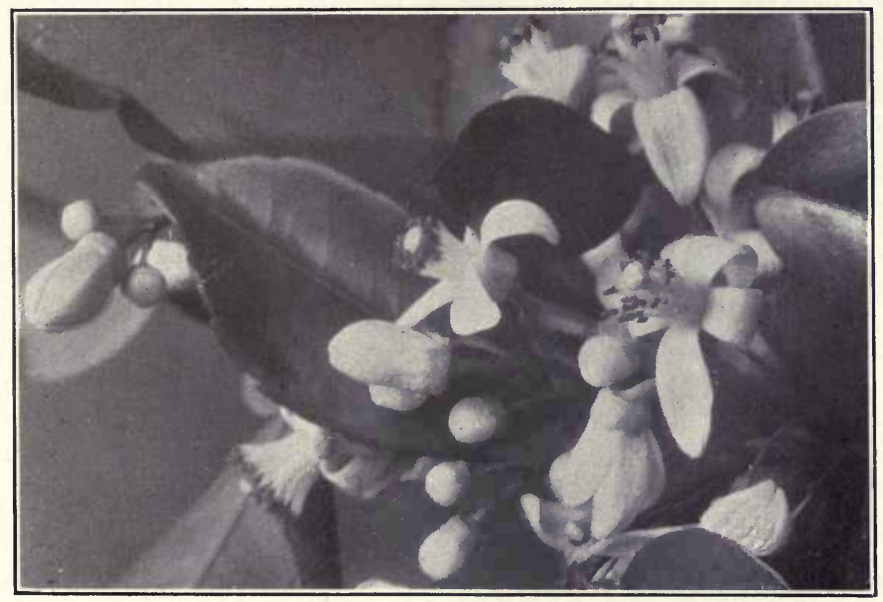

Fig. 9. Pomelo Blossoms, About natural size.

pomelo. It is of older origin than either of the others (if with some writers we allow the synonymy of shaddock), the Dutch word Pompelmoes, from which it is derived, having been in use at least two centuries ago. The name pomelo has been adopted by the best authorities and it is by all means advisable that they be followed and that we have some constant name by which to designate the fruit. The fruit now designated by the name shaddock. consid. 
ered horticulturally, is entirely distinct from the pomelo, but, botanically considered, the two cannot be separated; they belong to one species. The term shaddock is more properly applied to the large and coarse grained varieties. There are some other points of distinction between the two which may be incidentally mentioned here, although the distinctions are fully covered in the section on shaddocks. The fruit of the shaddock is much larger, often weighing fifteen pounds or more, the tree is smaller, the leaves on full grown trees are somewhat larger.

From the foregoing discussion of the common names it will be seen that pomelo is the name given the preference, grapefruit is synonymous, while shaddock is relegated to a fruit botanically the same as the pomelo but horticulturally distinct.

HORTICULTURAL STATUS OF THE POMELO.

No fruit of importance now grown in the United States has such a meagre American literature as the pomelo. Nor is this strange when we remember the fact that it is only within the last fifteen years or so that the pomelo has been regarded as a commercial fruit. After having been neglected for years, while the whole attention of growers of citrus fruits was directed to the orange and all their energies put forth in bringing that fruit to perfection, it has only in very recent years taken its present position, to which the critical taste of fruit consumers has raised it.

The pomelo was brought to Florida together with other members of the genus citrus by the Spaniards, who, under the leadership of Ponce de Leon, first landed upon the east coast of Florida in the year 1513. From that time until 1821 they disputed the possession of the State with 
their enemies in the Old World and the aborigines of the country, except during a period of twenty years-17631783-during which time Great Britain controlled the territory.

During the Spanish regime different citrus fruits were introduced and cultivated in Florida. These, through the agency of the Indian, were carried into all parts of the State. To this day the common lime, generally known as the Florida lime, the rough lemon and the sour orange are to be found in southern Florida growing luxuriantly under such conditions as would lead one, ignorant of their origin and native home, to believe them to be indigenous to the soil on which they stand.

Following the time of introduction, in many groves and gardens throughout Florida, pomelo trees were to be found, annually laden with hundreds of fruits. By the inhabitants the fruit was considered refreshing and tonic, but that it might have a commercial value did not enter the minds of the owners, or if it did, transportation in its then crude state rendered any attempt to place this then unknown and unappreciated fruit on the market, with an expectation of profit, a precarious and uncertain undertaking. Consequently the ground beneath the trees during a certain portion of the year was covered with the yellow fruit left to rot in the sun.

Just at this point it is interesting to note that this group of fruits was either unknown to or disliked by horticultural writers, or confounded with the shaddock even within very recent years. George Don, in his Gardener's Dictionary, page 596, 1831, says, "The shaddock is certainly the least useful of the species and is cultivated chiefly for show." Alexander Watson (1) in 1859 wrote

1. The American Home Garden, page 363. 1859. 
the following: "Shaddock is a still larger fruit (than the citron) ${ }^{*}$, in form more resembling the orange, curious, but worthless." W. N. White (2), in 1868 , says: "Pulp dry, sweetish or subacid, but not very desirable, except for its showy appearance." Rev. T. W. Moore, in his Hand Book of Orange Culture, 1881, does not mention it. Thomas, in his Fruit Culturist, makes no reference to it up as late as the edition of 1885 . Wm. A. Spalding (3), in 1885, makes the following remark: "Meanwhile the Pumalo and its congeners, when allowed growing space, continue to load themselves down with fruit as large as footballs. They are matters of wonder and that is all." Chas. Downing (4) (1885), under the head of Shaddock, has the following note: "The pulp is sweetish or subacid and the juice is rather refreshing. It is, however, more showy than useful, and certainly makes a magnificent appearance in a collection of tropical fruits."

Northern visitors to Florida learned to know and like the pomelo and a certain demand was created by their desire for the fruit upon their return. Somewhere about 1880 or 1885 the first pomelos were shipped from the State, sold in New York and Philadelphia, and netted the shippers about fifty cents per barrel. This was the beginning and better prices were soon realized. The freeze of 189495 greatly reduced the Florida crop and the small amount of fruit sold that year brought an enormous price, in some cases as much as $\$ 15$ or $\$ 20$ per box.

With a return of normal climatic conditions in Florida and a consequent increase in the quantity of fruit the price has dropped, the crop now generally bringing from $\$ 4$ to $\$ 7$ per box for good fruit and less for inferior pack-

2. Gardening for the South, page 384. 1868.

3 . The Orange in California, page 89. 1885.

4. Downing's Fruits and Fruit Trees of America, page 579. 1885.

*() Inserted by the author. 
ages. Very extensive plantings have been made in Florida, California and elsewhere within the past six or seven years and it is highly probable that prices in the future will not equal those in the past. Up to this time the supply has generally been inadequate to the demand, but with the increase in the amount of fruit a state of equilibrium between the supply and the demand will soon be reached. It is safe to predict that with a favorable climate the future price realized for pomelos will be much lower than the present one. The tree is a heavy bearer; it is no harder to propagate and care for than an orange tree; it comes into bearing as early; heavy plantings have been made, then why will it not eventually be placed on the same basis with the orange?

On the other hand it may be pointed out that there are many markets in which the pomelo is not known, and as it becomes better known and more widely disseminated, the demand will increase. This is likely to maintain the present prices for some time to come, but though it is believed that a balance will eventually be reached, and that after a time the ruling price will be lower than at present, to the careful, painstaking grower this need cause no uneasiness. There will always be a good demand for a first-class fruit, well colored, well grown, carefully selected, well packed and placed upon the market in inviting shape.

At present it seems probable that Florida will retain control of the pomelo market for some time to come, probably indefinitely, if the growers in that district are careful in maintaining the present excellence of the product. The California product has not up to this time met with the same favor in the markets, though it is possible that varie- 
ties may yet be brought forward better suited to the conditions in that State.

As a breakfast fruit the pomelo stands without an equal. It is an excellent appetizer and stomachic and probably contains tonic properties as well. It is frequently stated that it contains an alkaloid peculiar to itself, but its presence has not yet been demonstrated by the chemist. The partitions of the fruit contain a bitter principle of some kind. Some have thought it would be better to have this eliminated and that those varieties in which the bitterness is almost lacking are the better ones. But with this entirely absent, the fruit would not be a pomelo. The ideal fruit should have the bitter taste rather pronounced; the flavor should be characteristic of the pomelo-a pleasant, indescribable blending of bitter, sweet and acid. Lacking this, it falls short of the standard of excellence and must be classed as inferior.

In Cuba, pomelos of excellent quality are produced. They closely resemble the Florida fruit in flavor and general character. The favorite varieties at the present time, are Duncan, Marsh Seedless and Walters, and these appear to give excellent satisfaction. Plantings of considerable extent have been made, most of the trees having been supplied from Florida nurseries. 


\section{CHAPTER IX.}

\section{THE SHA D D O K S.}

The Shaddock was introduced into Barbados at an early date and from there carried to the adjoining islands and the adjacent mainland. Hans Sloane, in his work, A Voyage to the Islands of Madeira, Barbados, etc. (Vol. 1 , page 41,1707 ), tells of the origin of the name and also of the introduction of the shaddock into the Barbados in these words: "The Seed of this was first brought to Barbados by one Captain Shaddock, Commander of an East India Ship, who touched at that Island in his Passage to England and left its Seed there." The date, unfortunately, is not given. A good illustration of the fruit and leaf is given by Sloane.

As a group, the shaddocks are not of any commercial importance and but few trees are to be found either in California or Florida. They are reganded somewhat as curiosities. As an ornamental, the tree is of considerable value, but the pomelo has the advantage of combining utility with beauty. The fruit is used quite extensively for decorative purposes by the Chinese, who annually import thousands of them into California to bedeck their homes and joss-houses for their New Year festivities. To them it is known as gon lack and yu shu.

As already pointed out the pomelo and shaddock have been regarded by some writers as one and the same fruit, and though both have been placed with the sweet oranges, they are, horticulturally, distinct fruits and belong to an entirely separate species from the oranges. Botanically 
considered, the pomelo and shaddock belong to the same species, $C$. decumana L., but from the cultural standpoint they are quite different.

The fruit of the shaddock is either pyriform or oblate in shape and is larger than any other citrus fruit, sometimes reaching a weight of fifteen or twenty pounds. It is very coarse, with a thick rind and thick, leathery septa between the sections of the fruit. The juice sacks are not tightly bound together, as in the pomelo, but are loosely united. The juice is acid, bitter and comparatively scant. Everything considered, it is very much inferior to the pomelo. In the two varieties grown in Florida it has been observed in every specimen examined that the septa between the sections of the fruit is not continuous around the inner end, but the uncovered ends of the juice sacks project into the open core. Whether this peculiarity is constant or not, it is impossible to say, but I have never observed it in any other citrus fruit.

While the shaddock is a somewhat smaller tree than the pomelo, and possibly not such a rapid grower, it is likely that it might prove useful as a stock for other citrus fruits in the islands. 


\section{CHAPTER X. \\ THE K U M U A T S.}

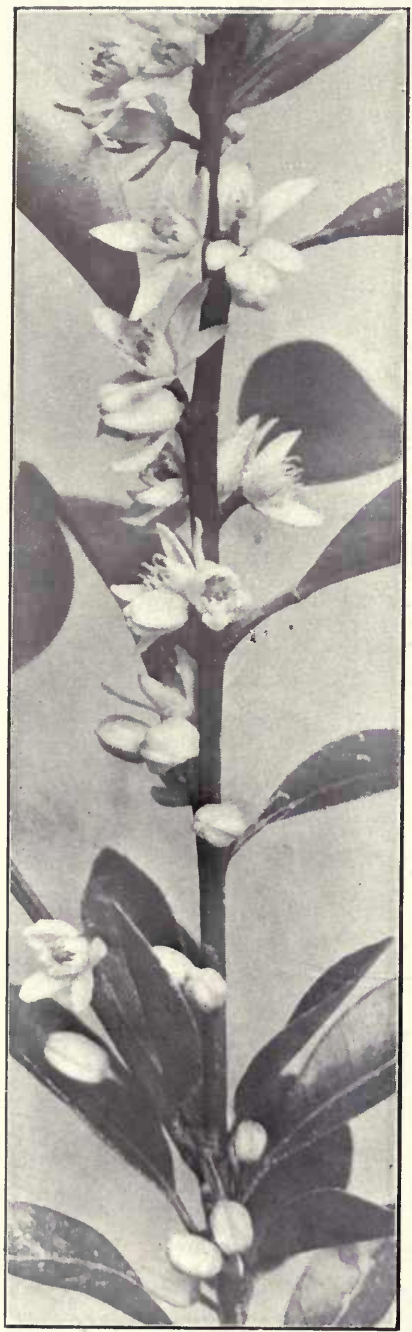

Fig. 10. Kumquat Flowers, nearly natural size.
Quite a number of common names have been given for unis fruit. Thunberg gives the common name, kinkan. Lourerio gives the common names $K$ in Kuit, Kin and Kuit $X u$ for the round fruit and Chu tsu and Chantu for the oblong form. Kaempfer gives the common names Kin Kan and Fime Tats banna, while Roxburgh uses the common name, kumquat. Siebold and Zuccarina, in their Flora of Japan, page 35, 1826 , give the common names kin kan or kin kit to the round variety, while to the elliptical, or oblong one, the name too kin kan is given. It might be added that siebold and Zuccarina give a better illustration of this fruit than has been published in any other work. The commonly accepted name for this fruit throughout the United States is leumquat, and this appears to be the common name in India. Kuniquat, sometimes spelled "comquot," "Kum Quat" and "Cumquot," is a Chinese word. meaning "gold orange" and the Japanese equivalent is "kin kan." 
The kumquat was probably first mentioned in horticultural literature by Kaempfer, who gave the following description of it in his Amœnit. Exoticarum, page 801, 1712 : "Malus Limonia fructu pumilo aureo, medulla dulci." Besides, he used the common name, Kin Kan in referring to this fruit. That it was also known to Rumphius there is little room to doubt. In 1741 he described and illustrated it in his Flora Amboyn., 1 vol., page 110, tab. 31. In 1784 Thunberg described it under the name, Citrus Japonica, and since that time it has been repeatedly described by different botanical and horticultural writers. To some of these the fruit was known, to others it was not, and they apparently based their remarks upon the descriptions published by previous writers. It may be interesting to give here a list of scientific names which at different times have been applied to the kumquat.

Malus Limonia fructu pumilo aureo Kaemp. Amoenit. exotic, 801. 1712.

Limonellus Madurensis Rump, Fl. Amboyn. 2:110, t. 31. 1741.

Citrus japonica Thunb. Fl. Jap., 292. 1784.

Citrus japonica Murr. Linn. 2:697. 1784.

Citrus Madurensis Lour. Fl. Cochin China. 467. 1790.

Citrus Margarita Lour. 1. c. above.

Citrus japonica Wild. Spec. Plant. Linn. 3: 1426. 1803.

Acrumen japonicum Gall. Traite du Citrus. 182. 1811.

Citrus inermis Roxb. Fl. Ind. 393. 1832.

The introduction of the kumquat into Europe appears to have been quite recent. Gallesio seems not to have known it. Risso and Poiteau make no mention of it in their exhaustive work, "Histoire et Culture des Orangers." Since none of these writers refer to the kumquats, we are safe in concluding that they were not grown in Europe at the time they wrote. So far as the author has been able to find out, the kumquat was introduced into Europe by Mr. Fortune, a collector for the Iondon Horticultural 
Society, who brought it with him from China to London, May 6, 1846. It was one plant of a lot collected in the districts of Foo-chow-foo, Chusan and Ningpo, China.

The Nagami (oblong) variety appears to have been the only one introduced by him, for in his remarks, published in the Journal of the London Horticultural Society, page 239, 1848, he says, "The fruit ripens late in the autumn, being then about the size of a large oval gooseberry." Very soon afterward specimens of the kumquat must have been forwarded to America. A. J. Downing. in his Horticulturist, of February, 1850, pages 375-377, gives a description of the variety Nagami, with illustrations, and quotes largely from the remarks of Mr. Fortune. He further makes the following statement: "We have a small tree growing on our own grounds, which was kindly sent us by $\mathrm{Mr}$. Ranch, exotic florist, near Greenwood Cemetery, Brooklyn. We believe Mr. Buist, of Philadelphia, and probably other men, now have it for sale, so that amateurs can make trial of it in various parts of the country." Some time later, probably very shortly after this date, it was brought to Florida. Since then several importations have been made by various nurserymen. The original trees imported by G. L. Taber, of Glen St. Mary, in 1885, were still standing in his grove in the autumn of 1901. Reasoner Bros., of Oneco, imported the variety Nagami in 1885 and the Marumi in 1890 from Japan.

The kumquat can scarcely be considered a tree, it partakes more of the nature of a shrub or bush.

The largest and most symmetrical kumquat bushes with which the author is acquainted are those growing in the grove, until recently owned by Mr. John Thompson, at Clearwater, Fla. The following are the actual measurements made December 10, 1901: 
Nagami, height 10 feet, 9 inches; distance across the head, 10 feet, 8 inches; stock, rough lemon.

Nagami, height 9 feet, 3 inches; distance across the head, 11 feet, 8 inches; stock, rough lemon.

Nagami, height 8 feet, 2 inches; distance across the head, 8 feet; stock, sweet orange.

Marumi, height 8 feet, 8 inches; distance across the head, 8 feet; stock, pomelo.

These were budded in 1894 on two-year-old stocks and were set out in their present position and started growth in the spring of 1895 . The tops are round and symmetrical, as the measurements would indicate, and the branches sweep the ground.

A large Nagami kumquat may also be seen on the grounds of Reasoner Bros., at Oneco, Fla. The specimen is 10 feet high and 10 feet, 6 inches across the top, while the trunk is 4 inches in diameter just above the union with the stock. The stock is a rough lemon shoot. The tree is badly shaded and the top, in consequence, is not symmetrical, but it bears well. At the time it was observed and meąsured (December, 1901) it was carrying a crop of from three thousand to three thousand five hundred fruits, of which it takes from forty to fifty to make a quart.

Seedling kumquats would not attain the size of those budded upon strong, vigorous stocks.

As pointed out in the chapter on Mandarin Oranges, they are an exceedingly hardy group of fruits, but the hardiest members of that group are fully equalled by the kumquats. While all of them are quite hardy, the variety Marumi appears to be considerably hardier than Nagami.

$\mathrm{Mr}$. Fortune saw large numbers of these plants in Southern China, where they were grown in pots, and said that it was a common plant in the nursery gardens of 
Fa-Tee. He believed, however, that it was of more northern origin, for he had met with numerous groves of it on the island of Chusan and elsewhere in that portion of China. There it grew in far gneater perfection than in the vicinity of Canton. Thus it would appear that the cultivation of the kumquat in China extends at least from latitude 20 to 30 degrees, a range of 10 degrees. It might be noted here that the main portion of Japan lies between 30 and 48 degrees, but the kumquat is cultivated probably only in the southern portions of that country. It must, however, be borne in mind that neither the climate of Japan nor of those portions of China to which reference has just been made, is by any means so variable as the climate of some of the citrus districts in our own country. In Northern Florida the kumquat has proved quite hardy and it appears to be considerably hardier than most other members of the citrus family. The natural hardiness of the kumquat is increased by using Citrus trifoliata as a stock and the low dwarfish habit of the tree gives every opportunity for successful and economical protection.

The fruit may be eaten raw, and when served in small glasses holding three or four fruits, they make a very pretty addition to the table. If cut with leaves attached they may be used as table decorations. In eating the fruit the skin is not removed, and the spicy, aromatic rind and acid pulp make a very delightful and palatable combination. An excellent preserve can also be made from the fruit; and the Chinese export considerable quantities put up in small stone jars.

The kuniquat cannot be regarded as anything else than a fancy fruit, and in most cases a demand must be created. Any market in the country could very easily be glutted by large shipments, but in a small way, the fruit 
is profitable. It is a comparatively new fruit and few people know what it is. As its merits become better known. the demand for it will undoubtedly increase. At present it brings from twenty-five to seventy-five cents a quart when carefully marketed. 


\section{CHAPTER XI.}

\section{THE CITRONS.}

The culture of few fruits antedates that of the citron. Of all the citrus fruits it was the only one known to classical writers. In Media and Persia and later in Palestine, it was cultivated at a very early date and in these countries the Greeks and Romans probably first met with it. The Greek writer, Theophrastus, shortly after the time of Alexander" the Great, gave a minute and unmistakable description of the citron tree, or, as it was then called, the Median or Persian apple. Virgil was one of the first Roman writers to mention it and used the same name as Theophrastus. By Pliny's time, the fruit had been sufficiently long in cultivation to receive a number of names, and he is the first to make use of the name Citrus, the botanical name afterwards adopted by Linnæus for all the related fruits as well as the citron. It appears, however, that the fruit was known by the Romans and imported into Rome long before it was cultivated there. But when its culture was finally established in Greece, Italy and the adjacent islands in the Mediterranean, it became one of the important fruits in those regions into which it was introduced and there it is grown to this day.

When it was first introduced into America is merely a matter of conjecture. But it must have been brought to the West Indies and to South America (Brazil) shortly after the discovery of the continent. The early Spanish writers on the history of the New World bear testimony to this fact.

But the citron did not receive the attention bestowed upon the orange. This may be attributed to the fact that 
the most important product obtained from the citron is the candied peel, a commodity restricted in its uses and of little importance to pioneers. On the other hand, the luscious orange was at all times a much appreciated addition to their limited bill of fare, while the acid of the lemon and lime is particularly refreshing in warm climates. Hence we can see that there is a good reason why these fruits would be cultivated to the neglect of the less important citron.

Up to the present time, the candied citron peel used in America $(12,000)$ cases of some 250 pounds, according to Lelong) is mostly imported in brine from Leghorn, Italy. By shipping it in the brine, duty is avoided. The salt is steeped out and the peel candied in New York and Chicago. Some candied peel is imported.

More or less interest has always been taken in the citron and its culture. The varieties cultivated in Europe have been imported and grown. Small plantings have been made both in Florida and California. At present, interest in the citron has died out almost entirely in Florida, but in California it still receives attention. Experimental lots of candied citron peel of excellent quality, fully equal to the imported product have been produced. Whether its culture will ever be increased sufficiently to produce enough peel to supply the American demand is somewhat problematical. There is a probability, however. that such will be the case, but the industry will need the fostering care of a protective tariff on the peel imported in brine. The citron succeeds well in the lemon districts of California and there alone large quantities of fruit could be grown. In the warmer parts of Florida and in the Islands the citron could also be grown, if its culture were placed on a remunerative basis. 


\section{CHAPTER XII.}

\section{THE LEMONS.}

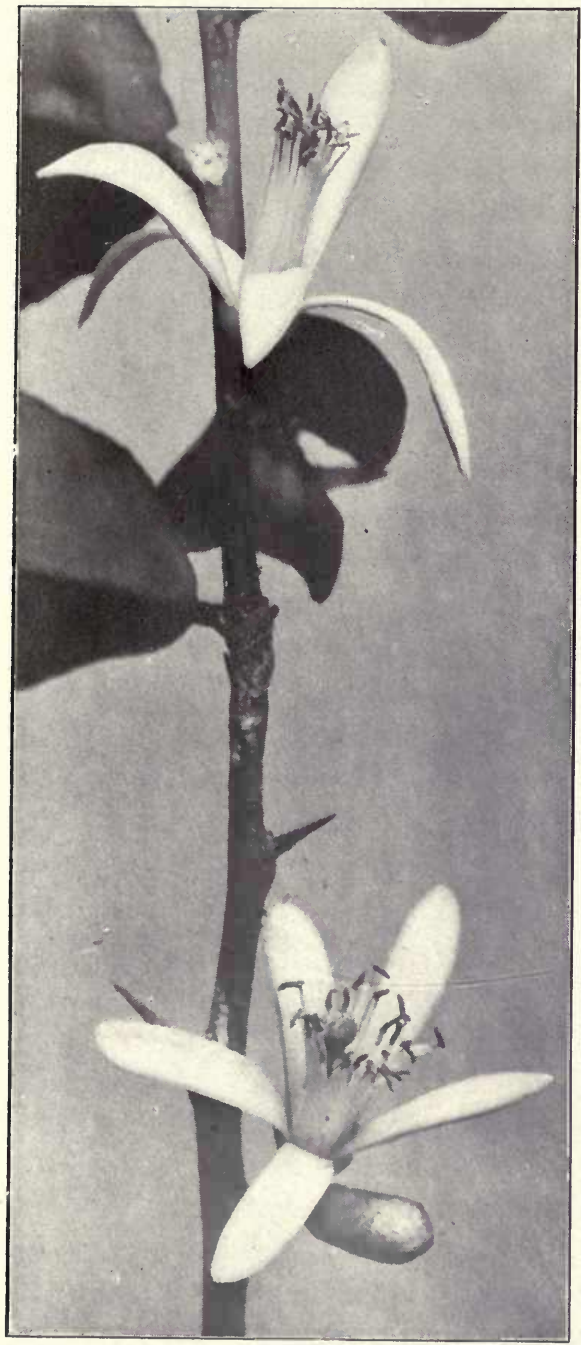

Fig. 11. Flowers of Villafranca Lemon, natural size.
The lemons were probably introduced into Europe about the same time as the sweet orange. Numbers of them are described by Ferrari, Volckamer, Commelyn, Sickler and other writers. As a commercial industry, lemon culture assumed very considerable pro portions in Sicily, Corsica, Genoa, and other parts of southern Europe many years ago. Most of the world's markets have been supplied with these lemons, even up to within very recent years. There has been no falling off in their culture and the European markets are still supplied from the same districts. There has been a considerable decrease in the amount of 
fruit exported from the Mediterranean to America because of the increase in the number of lemons grown at home.

Lemons were introduced into America at an early date by the Spaniards. The everbearing and rough lemons are in all probability Spanish introductions. The latter variety still grows in a wild state in southern Florida and in different parts of the West Indies. The fruit of these varieties is of no commercial importance and as a matter of fact nearly all the varieties now cultivated in America-Genoa, Lisbon, Villafranca, for instance-were introduced quite recently from Europe.

Previous to 1894 the lemon industry in Florida was of considerable importance, but the severe freeze of that winter greatly reduced the output. Previous to that disaster, at least 140,000 boxes of lemons were shipped out of Florida in one season, but the industry has not been built up again, and in the season of 1901-02 but 1,447 were produced. It is doubtful whether the industry will ever again assume the important place which it once held. The lemon tree is quite tender, being more subject to frost than the sweet orange, and in recent years the attention of Florida planters has been directed to the pomelo rather than the lemon. It may be, however, that lemon growing may become of some importance in the extreme southern portion of the State.

But the success which has attended the culture of the lemon in California is quite remarkable. In the southern and central parts of the State, on the mesas and foothills, the lemon grows and fruits well. The industry there has been placed on a paying basis wherever suitable soil and climatic condition are found, and where sufficient water has been secured. The fruit is of superior quality and has been well received in the American markets. As a result 
of this there has been a decrease in lemon importations from southern Europe. The California crop in 1902 was about 600,000 boxes and everything points to a material increase in the output. The product has secured a permanent place in our markets.

It is not improbable that we shall see considerable attention given to the lemon industry in the Islands. The next decade niay see the lemons of Porto Rico and Cuba in quantity in the large markets of this country.

The lemon is used in more different ways than any other citrus fruit. From the rind lemon oil is extracted. It is also used in making candied lemon peel, most of which is manufactured in Italy. From the pulp, citrate of lime, citric acid and lemon juice are obtained. The fruit is also extensively used in making lemonade and for flavoring food and drinks of different kinds. In fact, by far the greatest number of lemons are used for the last mentioned purposes.

As pointed out in the chapter on Stocks for Citrus Trees, the rough lemon is very valuable as a stock for certain kinds of soil and is now extensively used in Florida and the Islands. It is the only variety of the group free from the attacks of mal-di-goma. 
Plate III.

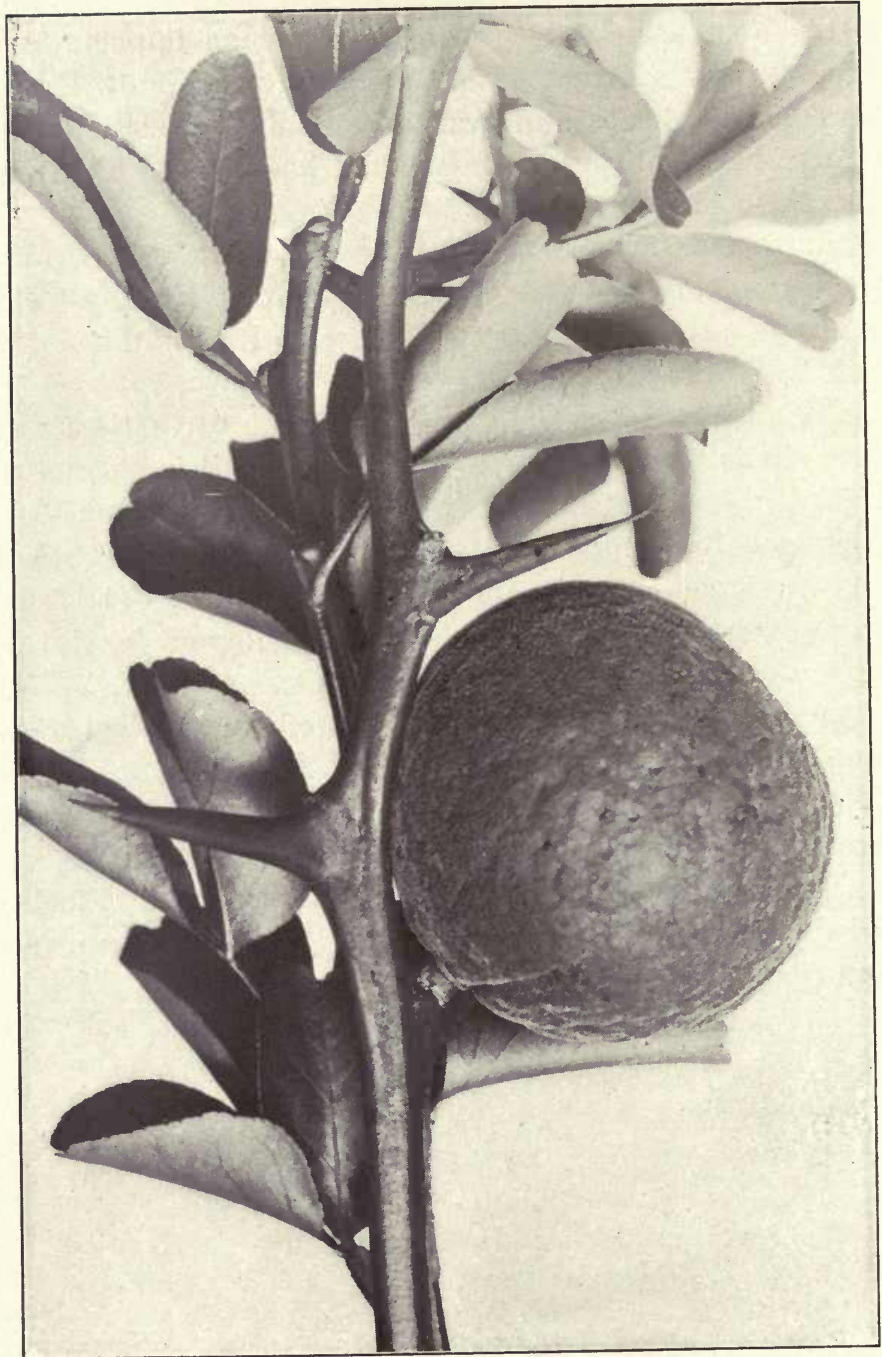

C. trifoliata, Fruit, Leaves and Thorns. (Natural Size.) 


\section{CHAPTER XIII.}

\section{THE LIMES.}

The acid limes, the only ones grown on a commercial scale in America, havequite generally been confused with the lemons, from which they are distinct. In habit of growth, in the winged petioles, in the clustered blossoms, in the flavor of the fruit, they are sui generis.

Owing to their having been grouped with the lemons, it is difficult to trace their history. 'They are mentioned by a number of the early writers on citrus fruits-Ferrari, Rumphius, Volckamer and others. Sloane enumerates a number of varieties in his Catalogue of the Plants of Janaica.

The lime was introduced into the West Indies and other parts of the New World by the Spaniards at an early date. It has become naturalized, and may be found in many parts of tropical

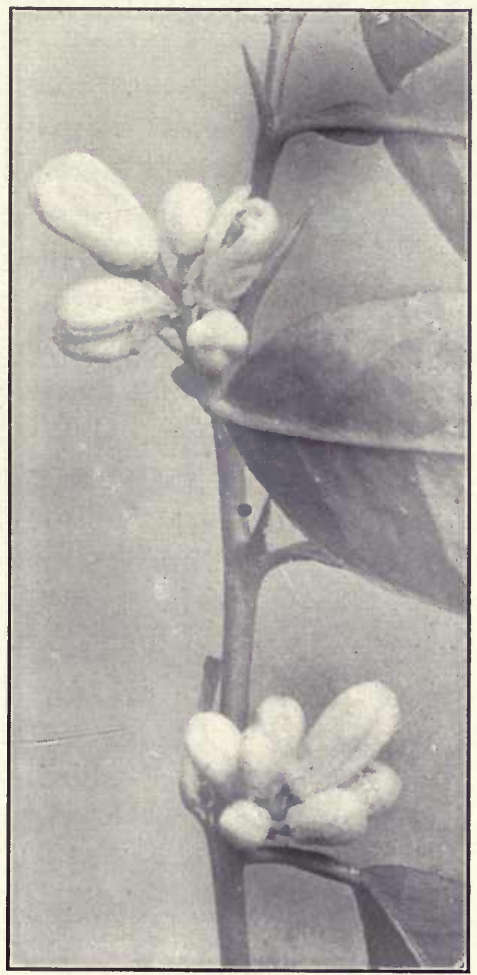

Fig. 12. Flower Buds of Mexican Lime, about natural size.

and sub-tropical America, growing side by side with the native trees. 
Since the tree is very tender (even more so than the lemon), it is not found in regions exposed to frost and its culture is, and must be, confined to districts exempt from heavy frosts.

No other species of citrus succeeds so well on poor sandy soils, or on the rocky soils of the Florida Keys, as the lime. It grows and fruits quite well when poorly cultivated and cared for, or even neglected entirely.

The Mexican lime, the most common variety in Florida and the Islands, is propagated entirely from seed, as a result of which it has varied greatly and at present the name Mexican is little better than a group name, embrac. ing a conglomeration of distinct forms. The fruit is very variable in size and shape, that borne by some trees being scarcely larger than a pigeon's egg, while others produce fruit as large as an ordinary medium-sized lemon. The name stands for no definite fruit.

If more attention were paid to the propagation of this group of limes, good fruit of uniform size and quality could readily be secured by selection, but under the present careless system, much of it is very inferior. Most of the groves which have been set are of the Tahiti variety, though in California one or two other varieties are planted to some extent. The so-called Rangpur lime is a prolific variety, the fruit of which is very acid and well flavored. It should not properly be classed with the limes, but I have placed it in the group provisionally.

The lime is used in much the same way as the lemon, in the making of "limeade" and for seasoning food. Citric acid and lime juice are obtained from the lime. At present most of the product comes from the West Indies, but there is no reason why they could not be manufactured in South. ern California and Florida as well. 


\section{TRIFOLIATE ORANGE GROUP-VARIETIES.}

Trifoliate. Form round or sometimes slightly pyriform; size small, $13-4 \times 2$ inches, $21-8 \times 2$ inches; color lemon yellow or light orange; apex creased, depressed, or with a slight creased elevation set in a ringed depression, generally terminated by a small dark speck; base elevated, creased and ridged; calyx represented by a ring minus the points of the segments; rind about 1-8 inch thick, rough, pitted, covered with minute hairs, rather easily detached; oil cells depressed, oval or nearly globose, filled with a sort of resinous, strongly aromatic oil; sections quite regular, not clearly defined, six in number, flesh greenish; juice sacks very slender, pointed; juice clear, acid; flavor quite good when not mingled with the oil of the rind; pith small, compact; seeds numerous, twenty-five to thirty oval, plump, rounded at one end, blunt pointed at the other, the rounded end marked with a round brown spot; season September-October.

Grown as a stock on which to work other varieties of citrus fruits, particularly for planting in frosty regions. Introduced in 1869 by the late Wm. Saunders, U. S. Department of Agriculture.

HYBRIDS.

Colman. (Hybrid \%rg). Form round and slightly flattened, sometimes lopsided; large, $27 / 8 \times 33 / 4$ inches; calyx, small; color, light yellowish orange; rind, smooth, thin, $1 / 8$ inch thick, sometimes slightly furrowed, covered with very short hairs; flesh, light lemon colored; juice sacks, slender; flavor, acid, bitter, peculiar; almost seedless; season, September-November.

Tree a strong, upright grower with stiff, upright branches and dense foliage. 
Morton. (Hybrid 7\%1.) Form, rounded or slightly flattened; size, large $3 \times 3 \frac{1}{4}$ inches; calyx, small; color, light orange; rind, slightly furrowed, smooth or somewhat roughened with depressed oil cells; sections, 9 or 10 ; flesh, light orange yellow, tender ; flavor, acid, slightly bitter; practically seedless; season, October-November.

Tree resembling Citrus trifoliata but with larger, trifoliate leaves. Very hardy and one of the most desirable hybrids.

Rusk. (Hybrid 716.) Form, neatly round; size, small, $13 / 8 \times 21 / 4$ inches; color, deep orange; calyx, thin, greenish, large; rind, smooth, bright, thin, $1 / 8$ inch thick; oil cells small, globular; sections, $\mathbf{1 0}$; flesh, yellow, tender, juicy; flavor, strongly acid and somewhat bitter; seeds, few in number; season, September-November.

Foliage, dense, trifoliate, dark green and glossy. A strong grower and prolific.

Rustic. (Hybrid 783.) Form, round or very slightly flattened; size, medium, $21 / 2$ x 27/8 inches; calyx, small; color, light yellow; rind of medium thickness, bitter; oil cells, elevated, balloon-shaped; sections, 6 to 12 ; flesh, greenish yellow, tender; flavor, acid bitter; seeds, few to many, or sometimes seedless; season, September-November.

Tree, a spreading, vigorous grower, with dark green trifoliate leaves. Very hardy.

Savage. (Hybrid 799.) Form, oblate, frequently furrowed; size, medium, $21 / 2 \times 3$ inches; calyx, small; color, light orange; rind, thin, $1 / 8$ to $3-16$ inch, covered with very fine hairs; oil cells, spherical; sections, 8 to 10 ; flesh, light yellow, tender, juicy; flavor, acid, rather bitter; seeds three or four to each fruit; season, Sept.-Nov.

This variety is prolific, vigorous and hardy, with both trifoliate and unifoliate leaves. 


\section{CHAPTER XV.}

\section{BIGARADE ORANGE GROUP-VARIETIES.}

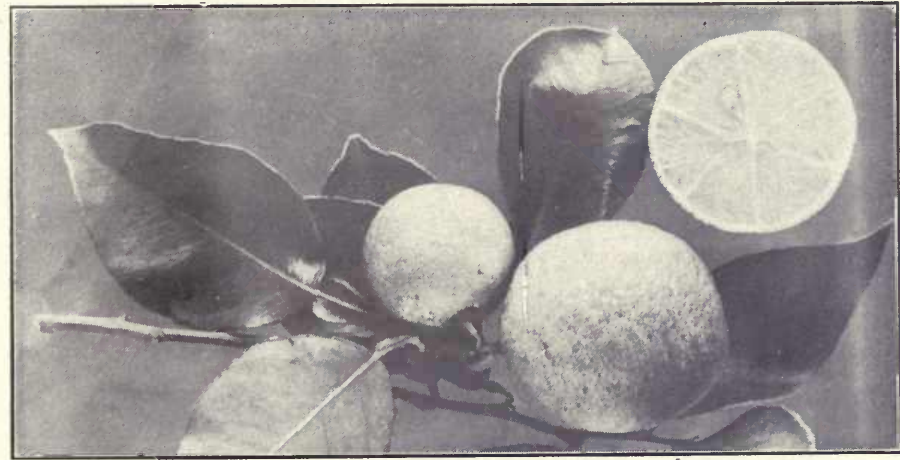

Fig. 13. Filer Bigarade Orange.

(Three-fourths natural size.)

Bitter Sweet. Form, oblong, flattened at the ends; size medium or large, $23 / 4 \times 27 / 8$ inches, $3 \times 35 / 8$ inches; color deep orange; apex flattened, depressed; base flattened, rough, depressed; calyx small, set in a depression; rind smooth or somewhat uneven, $1 / 4$ inch thick, adhering rather loosely; oil-cells of medinm size; flesh dark orange; sections 8 to 10 ; juice sacks of medium size, spindleshaped; juice abundant, colored; pulp melting; flavor of juice sweet or sweetish, inner rind and partitions very bitter, somewhat musky, peculiar; pith $1 / 2$ to $3 / 4$ inch across; seeds five to eight, wedged, season, January-March.

The history of this variety in Florida dates back to the first Spanish explorations and settlements. In tree and external appearance of the fruit, the Bitter-Sweet is indistinguishable from the sour orange, and the only striking difference is in the flaror of the fruit. the juice 
being sweet and pleasantly flavored, with bitter rind and partitions. On careful comparison the seeds show some slight differences.

Filer. Form round or roundish oblong; produced singly, or in clusters of from two to seven; size small, 1 1-8 $\times 13-16$ inches, $19-16 \times 1$ 1-2 inches; color yellow to reddish orange; apex rounded or flattened, sometimes with

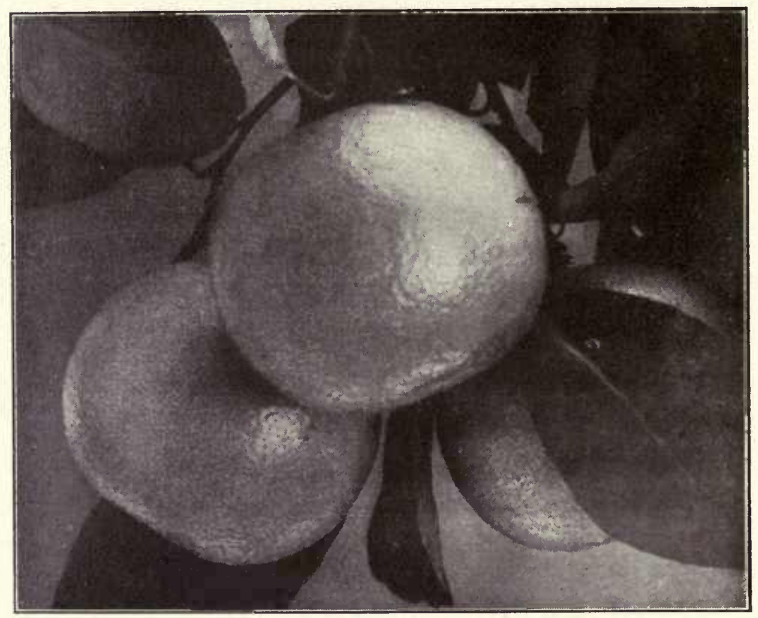

Fig. 14. Sour Orange Fruit.

the remains of the pistil still attached; base rounded; calyx small, elevated, stem slender; rind rather rough and pitted, 1-16 to 1-8 inch thick; oil cells small, flattened, frequently double convexed; sections six to eight, frequently very irregular, occasionally even being arranged in two rows at right angles to each other across the fruit; flesh fine grained, dark orange in color; juice sacks small, spindle-shaped ; juice plentiful, colorless ; pulp melting; flavor acid, rather musky; pith small, 1-8 inch or 
lacking; seeds small, 3-8 inch in length, wedge-shaped; three to four in number, many abortive; season December-February.

The original tree, and the only one knowu to the author, stands in the grove of Mr. S. Filer, Miami, Florida, and is now probably twelve or fifteen years old. Nothing is known of its origin, but I have placed it with this group, because the flavor of the fruit, the habit of tree growth and the flanged leaves resemble the Bigarade oranges.

Sour. Form rounded oblate; size large, 2 3-4 x 3 1-4 inches; color yellow or orange yellow, sometimes reddish orange when fully matured; apex flattened; base somewhat roughened, slightly depressed; the calyx set in the depression; rind smooth, or slightly rough, 3-16 inch thick; oil cells small, slightly compressed; flesh dark yellow, sections ten to twelve; juice sacks spindle-shaped and of medium size; juice plentiful, slightly colored; pulp melting; flavor sour, when thoroughly ripened rather agree able, peculiar and distinct; pith $3-4$ inch across; seeds numerous, many abortive, wedge-shaped, slightly ridged; season January-March.

This variety is of Spanish introduction, and is probably one of the first fruits which the Spaniards brought to Florida shores. In many parts of the State it became domesticated, forming dense thickets in the hammocks on the shores of rivers and lakes. The fruit is useful for making marmalades and orangeade, and the tree is extensively used as a stock for citrus trees. 


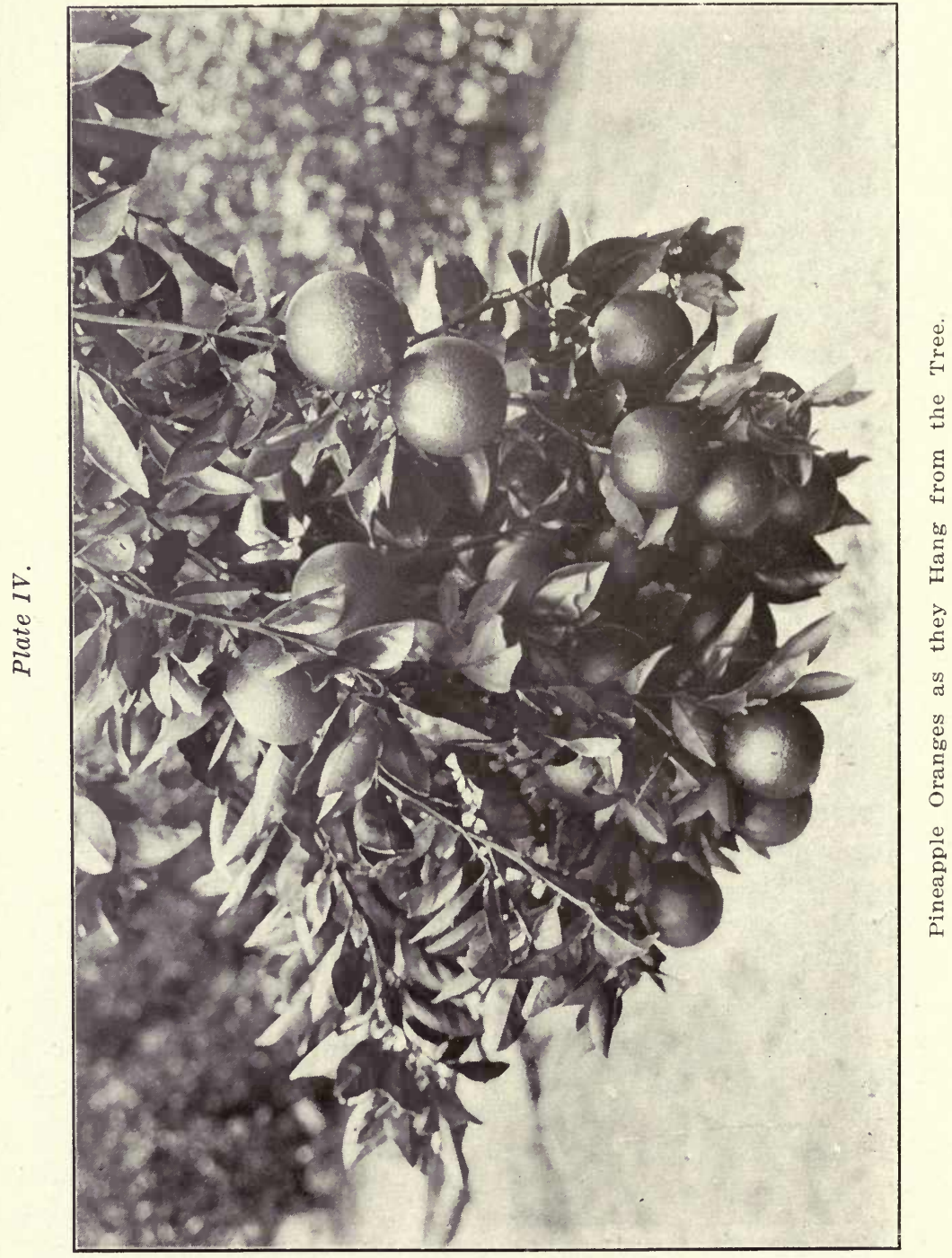




\section{CHAP'TER XVI.}

\section{THE SWEET ORANGES-VARIETIES.}

\section{SPANISH ORANGES.}

Acme (Beach's Acme). Form oblate; size medium to large, $25-8 \times 3$ inches; color orange; apex rounded, very slightly depressed, scarred; base slightly creased; calyx small; rind smooth, thin and leathery; oil cells large, flush with the surface; sections eleven, rather irregular in size; flesh of medium grain, orange yellow in color; juice sacks rather large; juice plentiful, colored; pulp melting, free from rag; acidity and sweetness well blended; flavor rich and vinous; quality very good; pith small; seeds present, oval, pointed, about fourteen in number, of medium size; season December-January. Introduced by the late A. J. Beach.

Arcadia. Form oblate or rounded oblate; medium to large, $3 \times 3$ 3-16 inches, $23-4 \times 31-4$ inches; color, orange; apex rounded; base slightly creased, rounded; calyx small; rind smooth or slightly pitted, thin; oil cells flush with the surface, or sometimes sunken; sections about thirteen in number, clearly marked; flesh coarse grained, orange yellow in color; juice sacks long, spindle-shaped; juice abundant, colored; pulp melting; acidity and sweetness not well blended, the acid being deficient; flavor rather insipid; quality fair; pith large; seeds present, oval, pointed or oblong, twenty-four in number, 1-2 x 3-8 inch; season December-January.

Arcadia is supposed to have originated as a seedling at Arcadia, Florida, and was introduced into cultivation by the Rev. William Watkin Hicks. 
Boone (Boone's Early). Form rounded; size medium, 2 7-8 $\times 3$ 1-16 inches, 29-16 $\times 3$ inches; color deep yellow; apex rounded, scarred, slightly depressed; base flattened; calyx rather large, segments pointed; rind smooth, 1-8 to $3-16$ inch thick; oil cells flush with the surface; sections eleven; flesh yellowish orange, medium coarse; juice sacks spindle-shaped, elongated or rather short; juice abundant, colored; pulp melting; acidity and sweetness fairly good, but the acid not strongly developed, flavor very good; pith medium size, 1-2 inch across; seeds present, short, pointed, of medium size, twenty-five in number; season October to middle of November. Should be shipped as soon as colored, as it is likely to drop.

This variety is said to have been originated by "Old Man Giddings," three or four miles south of Webster. The seed from which the trees came were given him by a man who passed that way about thirty years ago. The variety, according to Mr. W. S. Hart, was propagated and sold by David Collins, of Webster, for many years under the name of "The Giddings." Under the name "Boone," it was brought to notice by Mr. C. A. Boone, of Orlando, in the fall of 1889 .

Dummitt. Form rounded or slightly oblate; size large, $31-8$ × 31-16 inches; color light orange; apex rounded; base slightly creased; calyx of medium size, segments pointed; rind slightly pitted, thin; oil cells flush with the surface or somewhat sunken; sections eleven in number, rather regular in size; flesh yellow, coarse-grained; juice sacks of medium size, spindle-shaped; pulp melting; acidity and sweetness fairly well blended; flavor fairly good; quality medium; pith small, 1-4 to 1-2 inch; seeds about fourteen in number, large, oblong, creased or ridged; season December-February. 
In a letter from Mr. W. S. Hart, of Hawk's Park, Fla., dated July 12, 1903, he says: "This variety was budded from a wild sweet tree into the Captain Dummitt grove between Mosquito Lagoon and Indian River. These wild sweet trees were found in Turnbull Hammock back of Hawk's Park, by John D. Sheldon in 1832. He transplanted 600 of them to the Sheldon place, now known as the Packwood place, on the Hillsborough River, now known as Indian River North. Most of the Indian River fruit came from these trees."

Early Oblong (St. Michael's Egg). Form oblong rounded; size medium to large; $3 \times 3$ inches; color yellow to orange; apex rounded, sloping abruptly, slightly depressed; base flattened, slightly shouldered, smooth or somewhat creased; calyx small, elevated; rind smooth, 1-8 to $3-16$ inch thick; oil cells flush with the surface or slightly elevated; sections eleven to thirteen; flesh yellow to orange yellow, of medium grain; juice sacks spindleshaped, broad at the base; juice plentiful, colored; pulp melting; acidity and sweetness quite well combined; flavor sweet, good; pith compact, $1-2$ inch across; seeds present, twenty-two in number, oval, pointed or rounded, plump, rather large; season September-October.

A variety originally from the May's Grove, Orange Mills, Florida, and apparently identical with the St. Michael's Egg from Rivers' English Nurseries.

Enterprise (Enterprise Seedless). Form roundish, oblong; size large, $215-16$ x $31-4$ inches; color orange; apex slightly depressed; base creased, shouldered; calyx depressed; rind pitted, 1-8 inch or more in thickness; oil cells large; sections twelve, rather irregular in size; flesh coarse, orange in color; juice sacks large, spindle-shaped; juice abundant, colored; acidity and sweetness well com- 
bined; flavor rich, quality very good; pith rather open, 1-2 inch across; seeds present, six in number, large, oval, pointed; season October-November.

Said to have come from the old Dummitt grove originally. Its seedlessness was discovered by one of the Starkes, of Glenwood, Fla. The variety was named after the town of Enterprise, Fla.

Foster. For m rounded, oblate; size medium to large, 2 5-8 $\times 2$ 7-8 inches, $2 \quad 5-8 \times 3$ inches; color orange; apex rounded and slightly depressed; base rounded, smooth; calyx rather large, 3-8 inch a c ros s 1-8 inch thick; oil cells slightly elevated or flush with the surface; sections twelve, well defined; flesh rather coarse,

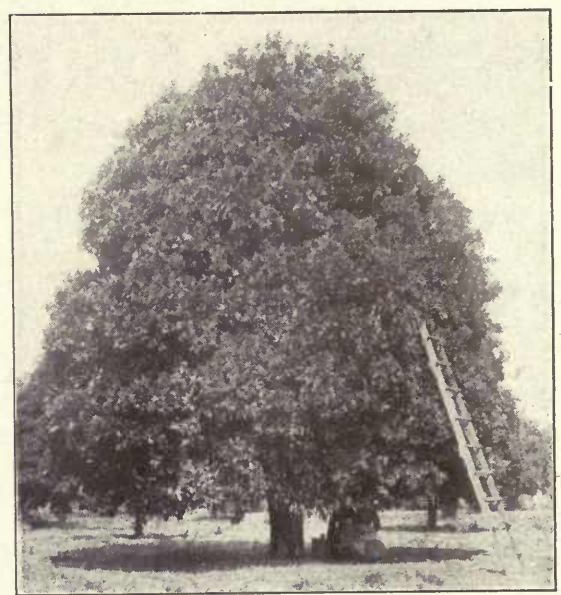

Photo by Ensminger.

Fig. 15. A Seedling Sweet Orange Tree in Fiorida. It carried a crop of 12,000 fruits when photographed. orange in color; juice sacks large; juice abundant, colored; pulp melting; acid well defined; flavor rich, quality excellent; pith 1-2 inch across, solid; seeds present, oval, pointed, large, thirteen in number; season OctoberNovember.

According to Reasoner the original tree of this variety was grown from seed obtained from Havana about 1847, and in 1887 it was still standing in the grove of Col. C. 
H. Foster, Manatee, Fla. It was introduced by Reasoner Bros. Oneco, Fla., about 1883.

Hick (Hick's Sweet Seville). Form rounded oblate; size medium, 2 7-8 $\times 3$ inches; color orange, bright; apex rounded, scarred; base smooth; calyx small; rind smooth or with the large conspicuous oil cells projecting a little above the surface, 1-8 inch or slightly more in thickness; sections regular, ten in number; flesh fairly coarse grained, yellowish orange in color; juice sacks medium to large, spindle-shaped; juice abundant, colored; acidity and sweetness not very well combined, scarcely enough acid; flavor agreeable but lacking in character; pith compact, 3-8 inch across; seeds present, oblong, ridged, large, 5-8 x 1-4 inch, ten in number; season early.

Hick is supposed to be a seedling variety, originated at Arcadia, Florida.

Homosassa. Form round or slightly oblate; size medium to large, $23-4 \times 21-16$ inches, $3 \times 3$ 7-16 inches; color yellow or orange yellow; apex rounded, slightly depressed and scarred; base round or somewhat flat, sometimes slightly creased; calyx small, slightly pointed; rind 1-8 inch thick, tough smooth; oil cells slightly sunken or flush with the surface; sections large, eleven in number, fairly regular; flesh coarse grained, yellow; juice sacks large, spindle-shaped; pulp melting; remarkably free from rag; acidity and sweetness well blended; flavor sprightly, rich and vinous; quality excellent; pitch 9-16 inch across, solid; seeds present, twenty to twenty-four in number, plump, beaked or pointed, large, 3-4 x 3-8 inch; season December-February.

This variety is one of the best of the Florida seedlings. According to Reasoner it originated in the grove of Hon. Mr. Yulee at Homosassa, Fla. 
Indian River. Form rounded; size medium to large, $3 \times 3$ 1-16 inches; color orange, bright; apex rounded, smooth; base rounded; rind 1-8 inch thick, smooth; oil cells flush with the surface or slightly indented; sections well defined, fairly regular, ten in number; flesh fine grained, orange yellow in color; juice sacks small; juice abundant, colored; pulp melting; acidity and sweetness well blended; flavor rich, excellent and sprightly; pith solid, 1-2 inch across; seeds present, seventeen to twenty in number, long. oval, pointed; season December-February.

A native seedling variety, originated on the Indian River, Fla., hence its name. Its origin is probably the same as that given by Mr. W. S. Hart for the Dummitt orange.

Madam Vinous. Form roundish-oblate; size small, medium or large, 211-16 x 27-8 inches, $23-4 \times 33-16$ inches; color orange; apex rounded or slightly depressed; base rounded, flat, sometimes creased; calyx small, segments pointed; rind fairly smooth, 3-16 inch thick; oil cells flush with the surface or slightly sunken, small; sections eleven in number; flesh coarse grained, color orange; juice sacks large, broad and elongated; juice plentiful colored; pulp melting; acidity normal, sweetness well combined with the acid; flavor rich and good; pith 1-2 inch across, solid; seeds present, roundish, flattened. plump and pointed, 1-2 $\times 3$-8 inch; season December-January.

An Indian River seedling originated by Major Magruder, of Rockledge, and introduced about 1882

Magnum Bonum. Form oblate; size large, $23-4 \mathrm{x}$ 3 1-4 inches; color orange yellow; apex indented, scarred; base rounded, quite smooth; calyx rather large, the segments blunt pointed, rind quite pitted, leathery, 1-8 inch 
thick; oil cells small, flush with the surface or slightly sunken; sections clearly defined, thirteen in number; flesh medium grained, orange; juice sacks spindle-shaped, of medium size; juice abundant, colored; pulp melting; acidity and sweetness well blended; flavor sweet, rich; quality excellent; pith 1-2 to $3-4$ inch across; seeds present, thirteen in number, large, plump, wedge-shaped; season December to middle of February.

According to Moore, the Magnum Bonum orange probably originated at Homosassa, Fla.

May (Dr. May's Best). Form rounded; size medium to large, $3 \times 31-16$ inches; color rather light yellow to orange; apex rounded; base rounded, somewhat flattened; calyx small, pointed; rind smooth, 1-8 inch thick, tough and leathery; oil cells flush with the surface; sections eleven in number, well defined, regular in size; flesh rather coarse grained, color orange; juice sacks large, spindle-shaped; juice abundant, colored; pulp melting; acidity and sweetness fairly well blended, but not strong in character; flavor very good; pith small; seeds present, six or more in number, some abortive, plump, oval, pointed, about $5-8 \times 3-8$ inch; season December-January.

Originated in the grove of Dr. May at. Orange Mills, Florida.

Nonpareil. Form rounded oblate; size medium to large, $25-8 \times 3,31-16 \times 31-2$ inches; color yellow to orange; apex rounded, somewhat flat, slightly depressed just at the tip; base rounded, somewhat depressed, creased; calyx of medium size, segments pointed; rind rather pitted, 1-8 to $3-16$ inch thick; oil cells small, sunken or flush; sections ten, regular, well defined; flesh of medium grain, deep yellow in color; juice sacks of medium size, spindle-shaped; 
pulp melting; acidity and sweetness well blended; flavor rich, vinous; quality excellent; pith small, $3-8$ inch across; seeds present, eleven to fifteen in number, oval, pointed, large, plump, about 5-8 x 3-8 inch; season December-January.

Nonpareil originated as a Florida seedling on the St. Johns River, Fla., and was introduced by the late A. J. Bidwell.

Old Vini (Beach's No. 4, Buena Vista). Form oblate or oblate rounded; size medium to large, $27-8 \times 215-16$ inches, $27-8 \times 21-4$ inches; color yellow to orange; apex rounded, slightly depressed; base smooth; calyx of medium size, with a rather stout stem; rind smooth, 1-8 inch thick, tough and leathery; oil cells flush with the surface, or very slightly depressed; sections clearly defined, fairly regular, eleven in number; flesh coarse, orange yellow in color; juice sacks large; juice abundant, colored; pulp melting; acidity and sweetness well blended; flavor very good and of good character; pith solid, 1-2 inch across; seeds present, sixteen in number, oval, pointed at both ends, plump, 1-2 × 3-8 inch; season December-February.

A seedling variety, originated by the late Col. F. L. Dancy, of Orange Mills, Fla.

Osceola. Form rather oblate or rounded; size large, 3 x 3 1-16 inches; color orange, bright; stems stout; apex with a small scar, set in a slight depression; base slightly shouldered and roughened; calyx of medium size; segments short, pointed; rind fairly smooth, 3-16 inch thick; oil cells rather sunken; sections twelve, variable in size, clearly defined; flesh coarse grained, orange in color; juice sacks large, elongated; juice plentiful; pulp rather melting; acidity and sweetness well blended and of good character; quality very good; pith small, $3-8$ inch across; 
seeds present, six to ten in number, oval, pointed, plump, large; season December and January.

The orignal tree was a seedling raised by L. H. VanPelt, Mandarin, Florida.

Parson Brown. Form rounded, somewhat oblong; medium to large, $213-16 \times 3$ inches, $33-16 \times 35-16$ inches; color yellow orange to yellow; apex rounded; base rounded; calyx small; rind smooth, bright, 1-8 to $3-16$ inch thick; oil cells flush with the surface; sections ten, regular, well defined; flesh rather coarse grained, yellow; juice sacks spindle-shaped, medium to large; juice abundant, colored; pulp melting; acidity and sweetness not well blended unless picked quite early; pith small ; seeds small, ten to nineteen in number, oval, flattened, pointed, sometimes rectangular, large, 9-16 x 3-8 inch; season about October-November.

The Parson Brown orange, according to Mr. F. D. Waite, was introduced by Capt. J. L. Carney, of Lake Weir, Fla., about 1878 and originated at Webster, Fla., in the seedling grove of Parson Brown.

Stark (Stark's Favorite). Form round or roundishoblate; size small to medium, 21-2 x 2 7-8 inches, $29-16 \times$ 2 7-8 inches; color light orange; apex rounded; base rounded; calyx small, segments pointed; rind smooth, silky, thin oil cells medium size, flush with the surface; sections rather irregular in size, ten in number; flesh rather fine grained, yellow; juice sacks of medium size; juice plentiful, colored; pulp melting; acidity and sweetness well blended, the sweetness predominating slightly; flavor rich and good; quality very good; pith compact, 3-8 to 1-2 inch across; seeds present, oval, pointed, plump, eighteen in number, medium to large, about 5-8 $\times 3-8$ inch; season December-February. 
This variety originated as a native Florida seedling.

Whitaker. Form slightly oblate; size medium, 2 3-8 x 2 7-8 inches; color yellowish orange; apex rounded, smooth; base slightly roughened; calyx of medium size; rind thin, smooth, tough, closely attached; oil cells of medium size, somewhat elevated; sections well defined, small, about twelve in number; pulp melting; acidity and sweetness not very well combined; flavor slightly flat, owing to the specimen being a little over ripe; seeds present, few in number, large, oval, pointed; season DecemberFebruary.

Introduced by Reasoner Bros., Oneco, Fla., about 1884.

\section{MEDITERRANEAN ORANGES.}

- Bessie. Form round or slightly oblate; size small to medium, $25-8 \times 23-4$ inches; color orange; apex rounded, slightly scarred; base smooth or somewhat roughened; calyx small; rind smooth, thin, tough, 1-4 inch thick, closely attached; oil cells rather depressed; sections small. well defined, ten in number; juice abundant, acidity and sweetness well blended; flavor rich, vinous; quality excellent; seeds present, about fourteen in number; season March-April.

Originated by the late Dudley W. Adams, of Tangerine, Fla., and named after his sister-in-law, Miss Bessie Hustis.

Centennial. Form round; size small to medium, 2 1-2 x 215-16 inches; color orange; apex scarred, set in a slight depression; base streaked or slightly ridged, rounded; calyx small; rind smooth, thin, 1-8 inch or less; oil cells pitted or flush with the surface; sections well defined, fairly regular, eleven in number; flesh fine grained, 
orange yellow; juice sacks small, spindle-shaped; juice abundant, colorless; pulp melting, free from rag; acidity and sweetness well blended; flavor rich and vinous; quality excellent; pith small; seeds present, about ten in number, long and pointed or oval, plump, 5-8 $\times$ 3-8 inch; season November-December.

This variety was brought to notice by the late $\mathrm{E} . \mathrm{H}$. Hart about 1876. Though the fruit ripens early, it can be held until quite late, and on the whole it is a very desirable variety. Introduced by Mr. E. S. Hubbard, of Federal Point, Florida.

Circassian. Form rounded or depressed; size medium to large, $23-4 \times 3$ inches, $3 \times 33-16$ inches; color light yellow; apex rounded; base rounded, smooth; calyx small, the lobes short and blunt; rind thin, 1-8 inch thick, quite smooth; oil cells slightly elevated, numerous and of good size; sections clearly marked, quite regular, ten to fifteen in number; flesh fine grained, yellow; juice sacks long, spindle-shaped, slender ; juice plentiful, colored ; pulp melting; acidity and sweetness normal and well blended; flavor very good; pith solid, $3-4$ inch across; seeds present, oblong or oval, pointed, ten to twenty-one in number, 5-8 $\mathrm{x}$ 3-8 inch; season December to February.

Circassian is a foreign introduction through the Riv. ers Nurseries.

$\mathrm{Du}$ Roi. Form oblong; size medium to large, 2 7-8 $\mathrm{x}$ 3 inches, 33 -16 $\times$ 31-16 inches; color yellow, deep orange or reddish when fully matured; apex rounded; base creased, flat; calyx of good size, segments pointed; rind creased or almost ribbed. rough, 1-8 to $3-16$ inch thick; oil cells flush with the surface or sometimes rather sunken; sections eleven, small, well defined; flesh fine grained, yellowish orange in color; juice sacks long, spindle-shaped; 
juice abundant, colored; pulp melting; acidity and sweetness well blended; flavor rich, vinous; quality excellent; pith small; seeds present, about fourteen in number, size large, 5-8 x 5-16 inch, oval pointed or oblong wedged; season February and March.

Probably introduced through Rivers' Nurseries.

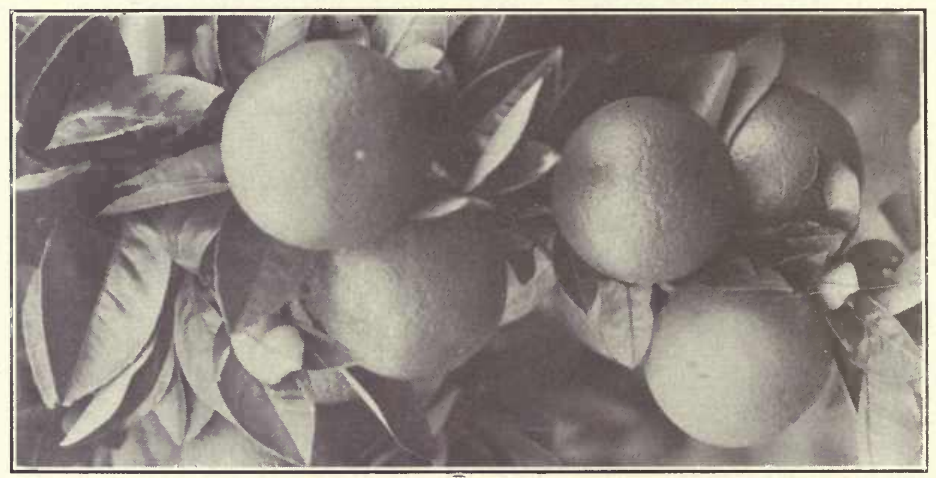

Fig. 16. Jaffa Oranges.

Exquisite. Form round or oblate; 2 7-8 $\times 2$ 7-8 inches, $23-4 \times 3$ 1-16 inches; color orange yellow; apex rounded; base rounded, smooth; calyx very small; rind smooth, tough, leathery, 1-8 inch thick; oil cells flush with the surface or slightly elevated; sections well defined, rather irregular in size, thirteen in number; flesh rather coarse grained, orange color; juice abundant; pulp not melting. containing a little too much rag; acidity and sweetness well blended; flavor very good; pith solid, small, 1-4 to 1-2 inch across; seeds present, oval, pointed, ridged, $5-8 \mathrm{x}$ 3-8 inch, about twenty-eight in number; season December. .January-February.

Reasoner, in Bul. No. 1, Div. Pomology, U. S. D. A., says that this variety was imported by General Sanford. 
Everbearing. Form oblong, tapering to the stem; size small to medium, about $23-4 \times 21-2$ inches; color orange yellow; apex rounded; base rather rough ; calyx depressed; rind pitted, 3-16 inch thick; oil cells small; sections ten, small; flesh coarse grained, yellow; juice sacks rather broad and short; juice plentiful; pulp melting; acidity and sweetness fairly well blended, frequently with the acid predominating; flavor quite good; quality good; pith small, 1-4 inch across; seeds present, ten in number, plump, oval, pointed, 3-8 x 1-4 inch; season from October to June.

Origin not known, but probably imported into America.

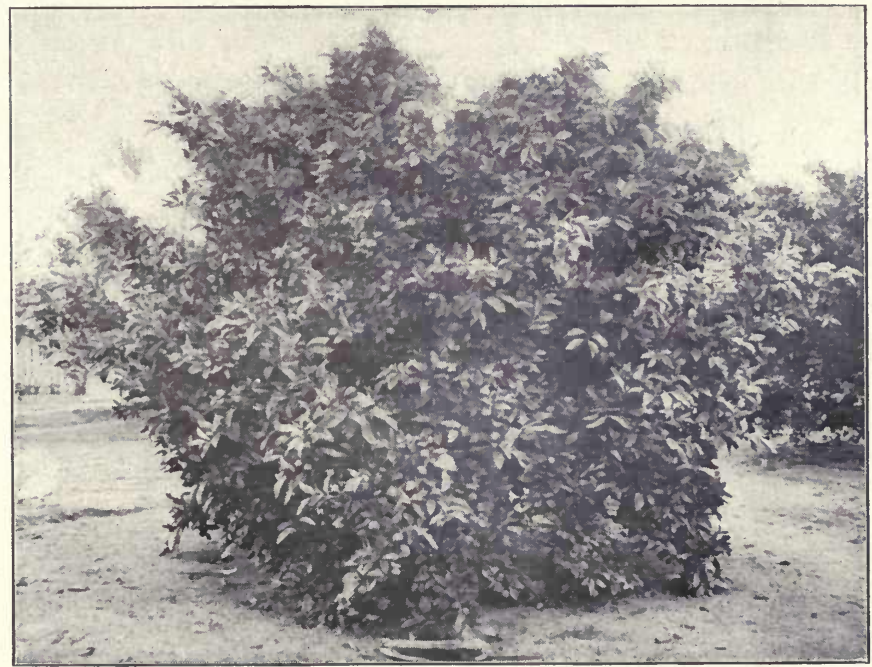

Fig. 17. Ever-bearing Orange Tree.

Jaffa. Form rounded oblate or occasionally very slightly rounded oblong; size medium to large, 23-4 $\mathrm{x}$ $31-16$ inches. $3 \times 3$ inches; color orange vellow to orange 
red; apex rounded, smooth; base rounded; calyx small, pointed; rind smooth, leathery, 1-8 inch thick; oil cells of medium size, flattened; sections eleven, well defined, fairly regular; flesh yellow in color, fine grained; juice sacks narrow, elongated; juice abundant, colored; pulp melting; acidity and sweetness normal and well blended; flavor rich; quality excellent; pith small; seeds present, about nine in number, plano-convex, short, rounded, plump, 1-2 x 1-4 inch; season December-February.

Imported by the late General Sanford from Palestine about 1883.

Joppa (Joppa Late). Form oblong, shouldered, largest below the median line, tapering towards the calyx; size medium, 27-8 × 213-16 inches; color orange; apex rounded, smooth; base slightly roughened and creased; calyx 3 inches across; rind somewhat rough; oil cells slightly indented in some cases, but usually flush with the surface; thickness, 3-16 inch; sections ten in number, well defined; fleśh fine grained, orange in color; juice sacks small, pointed; juice plentiful, colored; pulp melting; acidity and sweetness normal; flavor good, quality fair; pith small, 1-4 to 3-8 inch in diameter; seeds few, small, plump, roundish; season January-March.

Originated at San Gabriel, Cal., by Mr. A. B. Chapman, from seed secured from Joppa, Palestine.

Majorca. Form rounded or slightly oblate; size small to medium, $25-8 \times 2$ 7-8 inches, 2 7-8 $\times 3$ 1-16 inches; color orange; apex rounded; base rounded, smooth ; calyx small ; rind smooth, thin. tough, 1-8 inch thick; oil cells small, flush with the surface; sections small, regular, thirteen in number; flesh fine grained, orange colored, composed of slender, spindle-shaped juice sacks; juice abundant, colored; pulp melting; acidity and sweetness well blended; 
flavor sprightly, rich and vinous; pith small, 3-8 inch across, compact; seeds present, few, about five or six, small, plump, oval; season February-March.

Imported by the late General Sanford. The variety takes its name from the island of the same name in the Mediterranean Sea.

Maltese Oval. Form oblong or rounded oblong; size medium to large, $25-8 \times 2$ 7-8 inches; $35-16 \times 35-16$ inches; color yellow or orange yellow; apex rounded; base flat, shouldered, smooth; calyx small, segments pointed; rind smooth, 1-8 to 1-4 inch thick; oil cells large and conspicuous; sections well defined, eleven to thirteen in number; flesh yellow, coarse grained; juice sacks large, spindleshaped; juice plentiful, colored; pulp melting; acidity and sweetness well blended; flavor sweet, vinous, and of excellent quality ; pith small, about 7-16 inch across, rather open; seeds present, flattened, oval, pointed, large, 9-16 x 3-8 inch, six to thirteen in number; season March-April.

Introduced into America from the Mediterranean by General Sanford.

Marquis. Form slightly oblate; size medium, 2 5-8 x 2 3-8 inches; color orange, rather light; apex rounded; base rounded, smooth; calyx small; rind thin, smooth, closely attached; oil cells small, numerous; sections well defined, variable in size, about eleven in number; juice abundant, colored; flesh coarse grained, orange in color; acidity and sweetness well blended; flavor sweet and rich, quality very good; seeds present, about four in number. medium size; season December-February.

Imported from the Island of Malta by Colonel Church, of Orlando.

Paper Rind. (Paper Rind St. Michael). Form oblong; size medium to large, $23-4 \times 23-4$ inches, $3 \times 215-16$ inches; 
color orange; apex rounded; base rounded, shouldered; calyx small; rind slightly pitted, 1-8 to $3-16$ inch thick; oil cells depressed; sections ten, partitions thin; flesh coarse grained, orange colored; juice sacks small; juice plentiful, colored; pulp melting; acidity and sweetness well blended; flavor rich, vinous, quality excellent; pith small, 1-4 to 1-2 inch across; seeds present, oblong or oval, pointed, six in number, large or medium; season FebruaryMarch.

Imported from the Island of St. Michael into California and thence into all the American citrus districts.

Pineapple. Form somewhat variable, varying from nearly round to slightly oblate, occasional specimens being quite compressed; size medium to large, $21-2 \times 23-4$ inches, 2 15-16 x 3 1-4 inches; color deep orange, full ripe well colored specimens show a reddish tinge; apex rounded or very slightly depressed and scarred; base rounded, very smooth; calyx small, segments rounded, blunt; rind smooth, bright, glossy and satiny, 1-8 inch thick; oil cells small, quite conspicuous, flush with the surface or slightly elevated; sections eleven, slightly irregular; flesh of medium grain, orange yellow; juice sacks pointed, spindle-shaped, small; juice abundant, yellowish in color; pulp melting; acidity and sweetness well blended; flavor excellent, rich, vinous, sprightly; pith solid, 1-4 to 1-2 inch; seeds present, thirteen to twentythree in number, flattened, plump, pointed, large, 11-16 $\mathrm{x}$ 5-16 inch; season January and February, although it may sometimes be held later.

Introduced by Bishop and Hoyt, of Citra, Fla. By some it is said to have originated in a small clump. of seedlings near Citra, while others say it came from Lake Harris. 
Prata (Silver) Form rounded; size medium to large, 3 x 3 1-S inches; color light orange; apex rounded; base rounded, smooth; rind smooth, tough and leathery, adhering closely to the pulp; oil cells small; sections well defined, about eleven in number; flesh rather coarse grained, orange in color; juice sacks medium size, spindle-shaped; juice abundant, colored; pulp melting; acidity and sweetness well combined; flavor rich and good; quality very fair; pith 1-2 inch across; seeds about thirty in number, plump, oval, large; season December-February.

Imported into Florida through the Rivers Nurseries.

Star Calyx. Form round or rounded oblate; size medium to large, $29-16 \times 3$ inches, $3 \times 3$ 1-8 inches; color orange or orange yellow; apex flattened; base rounded, smooth; calyx large, conspicuous, usually five-pointed, 1-2 inch across; rind smooth, 1-8 to $3-16$ inch thick; oil cells flush with the surface or slightly elevated; sections fairly regular, thirteen in number; flesh rather coarse grained, orange colored; acidity and sweetness well balanced; flavor and quality excellent; pith 1-2 inch across; seeds present, oval, plump, large, about eighteen in number; season December-January-February.

Said to have been imported from the nurseries of Thomas Rivers, England.

Hart (Hart's Late, Hart's Tardiff). Form round or sometimes slightly oval; size medium to large, $31-8$ x 31 -8 inches; color deep golden orange; apex rounded, slightly flattened, scarred, base smooth, rounded; calyx small, sharp pointed; rind thin, smooth, tough; sections clearly marked, nine or more in number; flesh orange in color, of medium grain; juice sacks spindle-shaped, of medium size; juice abundant, colored; acidity and sweetness well combined; pulp melting; flavor rich, sprightly and vinous; 
quality excellent; seeds present, few, about six in number, large, oval, plump; season late March to June.

Introduced by the late E. H. Hart, of Federal Point, Fla. It came originally from the Rivers' Nurseries and was imported into America by Mr. S. B. Parsons, of Flushing, Long Island, about 1870. Said by some writers to be the same as Valencia Late.

White. Form round or slightly oblate; medium to large, $25-8 \times 3$ inches, $213-16 \times 31-16$ inches; color light yellow; apex rounded, scarred; base rounded, smooth; calyx small; rind smooth, thin, 1-8 inch or slightly less; oil cells flush with the surface; sections thirteen, small, fairly regular; flesh fine grained, yellow in color; juice sacks small, spindle-shaped; juice abundant, colored; pulp melting; acidity and sweetness combined in good proportions; flavor rich, vinous and of excellent quality; pith small, close; seeds present, twenty to twenty-seven in number, oval and pointed, or wedge-shaped and oblong, 5-8 x 3-8 inch, plump; season December-February.

Introduced from the Rivers' Nurseries.

\section{BLOOD ORANGES.}

Maltese. Form round, or oblong rounded; size medium to large $3 \times 3$ inches; color deep orange; apex slightly indented; base creased, calyx set in a slight depression; stem of medium size; rind smooth, medium thick; oil cells elevated $\mathrm{or}^{\mathrm{r}}$ indented, balloon shaped, large; flesh dark orange, streaked with red, sometimes varying to blood red, fine grained; sections well defined, eleven in number; juice sacks spindle-shaped, small or medium; juice yellowish or yellowish red; flavor sweet well blended with acid; quality very good; pith small, seeds four to eight, small roundish. 
An orange of very good quality with small, bright characteristic foliage. The blood marking in the fruit shows only on old trees and then not until late in the season, sometimes not at all. Its greatest failing lies in its not being sufficiently prolific. Introduced from Southern Europe.

Ruby Form round or slightly oblong; small to large, 2 3-4 x 31 -4 inches, $21-2 \times 23-4$ inches: color deep yellow

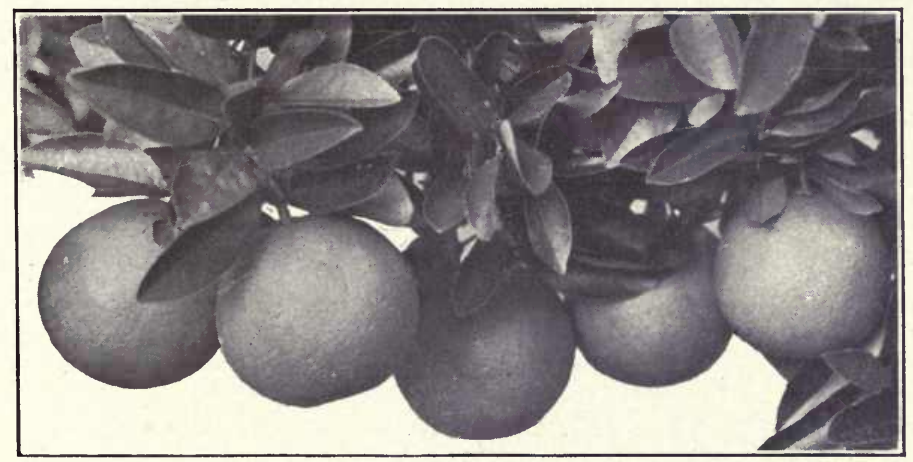

Fig. 18. Ruby Oranges.

or orange, reddish when fully matured; apex rounded, scarred, sometimes navel marked; base rounded, smooth; calyx small, lobes short and blunt; rind smooth, shing, 1-8 inch thick; oil cells small, almost globular; sections small, regular, twelve in number; flesh fine grained, yellow early in the season, streaked with red in mid-season. and blood-red when fully ripe; juice sacks small; juice plentiful, colored; pulp melting; acidity and sweetness well blended; flavor rich, vinous; quality excellent; pith small, compact, 5-16 inch across; seeds present, plump, 
oval, pointed, of medium size, 7-16 inch in length, eleven in number; season February and March.

An imported variety, probably brought from some one of the Mediterranean districts. It is a variety with no superior and few equals. Imported by General Sanford.

Sanford Blood (Sanford's Sweet Blood). Form rounded oblate; size medium, $23-4$ x 3 1-16 inches; color at first lemon yellow, gradually deepening to reddish; apex rounded, slightly scarred; base rounded, smooth; calyx of medium size; rind smooth, bright, glossy, thin and leathery; oil cells small, numerous, flush with the surface; sections eleven in number, regular in size, orange in color at first becoming streaked with blood markings and finally blood colored about April; juice sacks slender, spindleshaped; juice abundant, colored; pulp melting entirely; acidity and sweetness well blended; flavor rich, vinous; pith 1-2 inch across, solid; seeds present, about fourteen in number, plump, oval, pointed, smooth, large; season January to March.

Imported by General Sanford.

Saul Blood (John Saul's Sweet Blood). Form oblate; size small to medium, $23-4 \times 27-8$ inches; color dark orange; apex rounded, very slightly scarred; base smooth ; calyx small; rind thin, about 1-8 inch thick, smooth and tough, rather easily detached; sections not clearly marked, about ten in number; flesh fine grained, yellow at first, becoming blood marked when fully matured; juice sacks small, elongated; acidity and sweetness well blended; flavor rich, vinous and sprightly; quality excellent; pith small, solid; seeds about sixteen in number, of nedium size, oval and pointed; season December-February.

Introduced by John Saul, of Washington, D. C. 
St. Michael (Blood). Form oblong-rounded; size medium, 215 -16 $\times 2$ 15-16 inches; color yellow, with deep orange red blotches appearing on the rind as it nears maturity, orange red throughout when fully ripened; apex rounded, slightly scarred; base smooth, rounded; rind thin, 1-8 inch thick; oil cells quite conspicuous, flush with the surface or somewhat elevated; sections distinctly marked, regular in size; flesh fine grained. wine red in color; juice sacks rather large, spindle-shaped; juice plentiful, yellow in color, the coloring matter of the flesh apparently being located in the tissue of the juice sacks; pulp melting; acidity and sweetness well blended; flavor excellent; pith solid, 1-4 inch across; seeds present, rounded, short, plump, oval, medium sized; season January and February.

A fine variety of medium size, imported from the Mediterranean by General Sanford.

IV. NAVEL ORANGES.

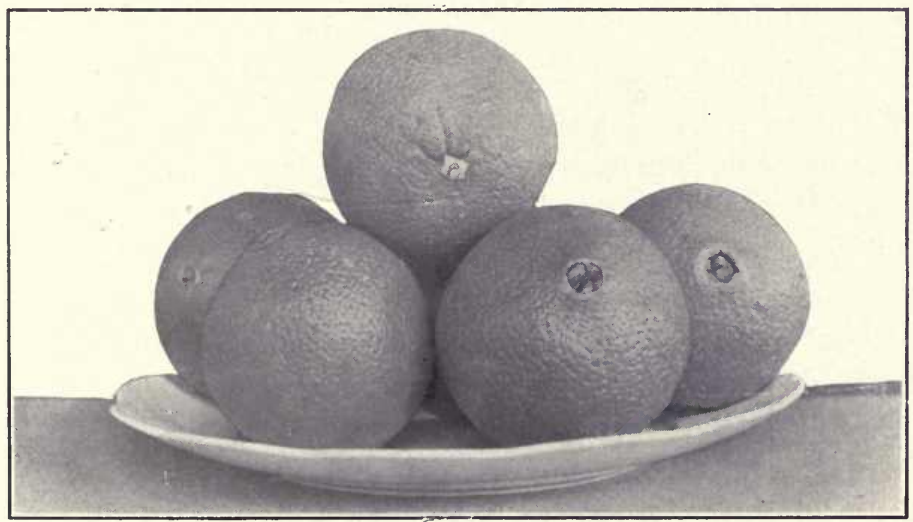

Fig. 19. Bahia Navel Oranges. 
Australian. Fruit seedy, varying in size from large to small, and splits at the navel, which is usually large and prominent. Tree strong grower, but a very shy bearer. (Lelong.)

Introduced from Australia by Lewis Wolfskill, of Los Angeles, Cal., in 1874. Once largely planted in California, but now replaced by Bahia.

Bahia (Washington Navel, Riverside Navel). Form rounded; somewhat tapering towards the apex; size large, $31-4 \times 31-4$ inches, $35-8 \times 31-2$ inches; color orange or orange yellow; apex terminating in an umbilicus, tapering slightly outwards, flattened on the tip; base rounded or somewhat flattened and frequently creased; calyx small; rind smooth, tough, leathery, 1-8 to 1-4 inch thick; oil cells-large, almost globose; sections well defined, nine to eleven in number; flesh rather coarse, deep orange yellow in color; juice sacks rather large, spindle-shaped; juice plentiful, but in poor specimens inclined to run slack in the stem end; pulp melting; acidity and sweetness well blended; flavor rich, vinous; quality excellent; seeds absent; season December-February, or later.

This is the great commercial orange of California, but in Florida it has not been a success owing to the fact that it is not sufficiently prolific. When planted in the latter State it should be worked either on rough lemon or trifoliate stock.

According to some writers the Bahia Navel was planted in Florida previous to 1835 , but disappeared in the freeze of that year. But whether this can be substantiated or not, the Bahia of to-day was received by the late Wm. Saunders, of the U. S. Agricultural Department, in 1870. Trees of this importation were distributed and two were 
received by Mrs. Tibbetts, of Riverside, Cal., in 1874. Mr. Alexander Craw also received trees about the same time. Fruit from Mr's. Tibbett's trees was exhibited at the Riverside citrus fair in 1879 and attracted a great deal of attention. The variety was propagated rapidly and planted so extensively that it has become the most important California orange.

The variety was also sent to Florida, and though some fruit is produced, it has received but little attention, as it has not proved to be a prolific variety.

Double (Imperial). Form rounded; size small, 2 1-2 x 2 1-2 inches; color golden yellow, bright; apex rounded, umbilicus hidden; base rounded, smooth; calyx small, pointed; rind smooth, closely attached; sections somewhat irregular, eleven in number, well defined; juice fairly abundant; pulp not entirely melting; sweetness predominating; flavor very good; seeds present, six in number, oval, of medium size; season December-February.

Introduced by Major Rountree, of New Orleans, La. It was originally imported from Brazil. It is inclined to hold its fruit a little better than most navel oranges in Florida, but for California planters it is inferior to Bahia.

Egyptian. Form, oblong, rounded, shouldered; size, large, $33 / 8 \times 3 \frac{3}{8}$ inches; heavy; color deep orange; apex navel marked, navel frequently included; base flat, creased and rough; calyx small, blunt; stem rather slender; rind rough, pebbled, $3-16$ inch thick, adhering tightly; oil cells elevated or depressed, balloon shaped, medium in size; flesh not meaty, fiber scant, color orange, coarse grained; juice yellowish, abundant, sometimes slightly lacking at stem; quality excellent; pith small, solid, seeds none; season December and January. 
Described from specimens from the grove of C. W. Butler, St. Petersburgh. Fruits well on rough lemonstock.

Melitensis. Form rounded oval; size large, $311-16 \times$ 31-2 inches; apex navel marked. umbilicus not constricted outward as in the Bahia, the apex being rounded instead; base flattened or rounded; calyx small, segments sharp pointed; rind 1-8 inch thick, smooth; oil cells large, conspicnous and flush with the surface; sections eight or more, well defined; quite regular; flesh rather coarse; color deep yellow; juice sacks rather large, spindle-shaped; juice plentiful, colored; pulp melting, free from rag; acidity and sweetness not well blended, not quite acid enough, rather flat in taste; quality fair; pith small, 1-4 inch or more; seeds none; season November-December.

This variety was introduced from Paris, France, by the United States Department of Agriculture. It is not prolific.

Parson. Form rounded oblate; medium size, $23-4 \mathrm{x}$ 3 1-8 inches, 3 × 3 7-16 inches; color light yellow, bright; apex rounded or somewhat flattened; navel marked; base rounded, sometimes creased; calyx small, blunt pointed; rind smooth, thin, 1-8 to $3-16$ inch; oil cells flush with the surface; sections well defined, ten in number; flesh rather coarse, orange yellow in color; juice sacks broad at the base, spindle-shaped; juice abundant, fruit being well filled out; pulp melting; acidity and sweetness well blended; flavor rich, vinous, excellent; pith close, 1-2 inch across; seeds present, twelve in number, oval, flattened, pointed, large, 5-8 x 3-8 inch; season December-January.

According to Reasoner this variety was introduced into Florida in 1869 by S. B. Parsons, of Flushing, Long 
Island, who imported it from the Rivers Nurseries, England. The variety is not prolific in Florida.

Surprise. Form rounded or very slightly oblate; size medium, packing 150-176 to the box, 2 15-16 x 215 -16 inches, $23-8$ × 3 inches; heavy, sinking in water leaving a space the size of a silver dollar not immersed; color deep orange; base rounded or very slightly flattened; calyx 3-8 inch across; stem small; apex navel-marked, navel small, 1-8 to 3-8 inch across, rounded, occasionally flattened, or protruding, as in Bahia; $3-4$ inch inside, the rind of the fruit incurved; rind smooth, tough, satiny, thin, 1-8 inch thick, adhering closely; oil cells prominent and slightly elevated above the surface; sections clearly defined, the dividing septa thin, thirteen in number, variable in size; juice sacks spindle-shaped, small; flesh fine grained, yellow in color; juice abundant, acidity and sweetness well blended; flavor rich, vinous; quality excellent; seeds none; season, November-February.

Surprise is an excellent orange, fully equal in quality to the best. It is juicy and heavy. Mr. E. S. Hubbard says that the variety fruits better than Hart's late, even - when budded on sour stock. He has fruited it for three years. It must, therefore, be looked upon as a decided acquisition of Florida planters. The variety is distinct from the other navel oranges, though occasional specimens resemble Bahia. No seeds have been found in any of the fruits. It is unreservedly recommended for trial. The bud from which this navel orange originated was discovered among a lot of King mandarin orange trees propagated by Mr. E. S. Hubbard, Federal Point, Fla., from budwood obtained originally from California. 
Sustain. Form rounded; size small to medium, $23-4$ x 2 5-8 inches; color yellow; apex navel marked, the navel small and not protruding; base flattened, rounded, calyx small, blunt pointed; rind thin, 1-8 inch thick, smooth; oil cells small, sections eleven, well defined; flesh fine grained, orange in color; juice sacks small; juice abundant; pulp melting; acidity normal, sweetness balancing the acid; pith 1-2 inch across; seeds present, oval, flattened, pointed, of medium size, three to four in number, with some abortive; season December-January. 


\section{CHAPTER XVII.}

\section{MANDARIN ORANGES-VARIETIES.}

Beauty (Beauty) of Glen Retreat.) Form oblate, decidedly flattened, sections showing through the rind; size medium, 21-8 $x \quad 215-16$ inches, $23-16 \quad x \quad 213-16$ inches; stem small and slender; apex flat or with a very slight depression; base slightly depressed and ridged about the calyx; color deep reddish

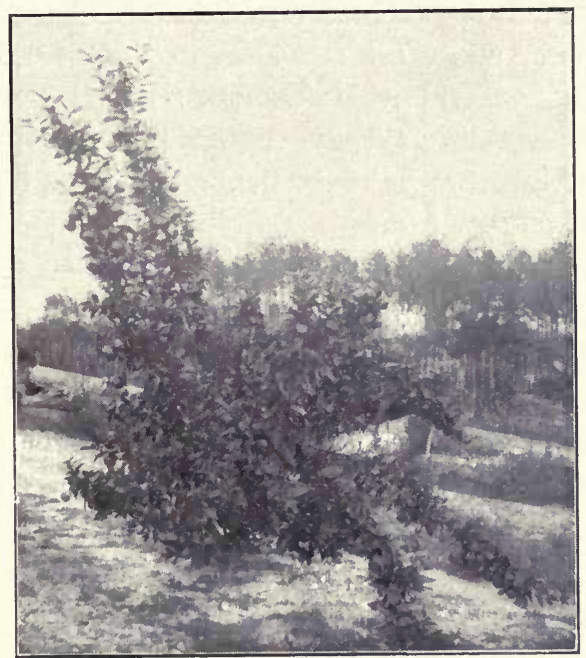

Fig. 20. King Mandarin Orange Tree orange, not so

highly colored as Dancy, glossy; rind smooth, very thin 1-16 of an inch or slightly more in thickness; oil cells flush with the surface, large, conspicuous, elliptical, oval or much flattened, frequently set in the pithy lining of the rind from which they may be detached easily; sections ten or more, clearly defined, regular; rag almost entirely lacking; flesh orange colored; juice sacks broad, blunt; pulp melting; juice plentiful, orange colored; flavor distinct, rich, vinous; acidity and sweetness well blended; seeds 
present, small, few, top-shaped; core small, open, 1-2 inch or less in diameter; season December to January.

Tree thornless, branches and branchlets slender and willowy; leaves small, resembling those of Dancy; petioles characteristically small and slender, 3-4 of an inch long.

The fruit of this variety is very heavy, and though it floats in water it sinks almost below the surface. The color, while not possessing quite so much of the reddish tinge as Dancy, it is decidedly darker than China. In flavor it resembles Dancy, though it is distinct. Beauty is a variety well worthy of propagation and trial.

The only orange grower in Florida known to have this variety is Cyrus W. Butler, of St. Petersburg. Mr. Butler received his buds of the variety from the Agricultural Department and Colonel Brackett informed the author that it was introduced from Australia by the U. S. Department of Agriculture in 1893. In a letter to the writer dated at Sydney, N. S. Wales, Aust., April 18, 1902, W. J. Allen, Government fruit expert for that colony, says: This mandarin was raised by Mr. W. H. Parker within a few miles of Brisbane (Queensland), Aust., and is, I believe, a seedling from either the Emperor or Scarlet mandarin. The original tree was raised some time in 1888 or 1889 . The fruit is of good size, solid, with a beautiful, thin, tough rind and carries well. It is usually a good cropper and proves a profitable variety to grow."

China (China Celestial, China Mandarin, Kid-Glove, Tangierine, Willow Leaved). Form oblate, compressed; size medium, 1 7-8 2 1-2 inches, $215-16 \times 3$ inches, usually about $2 \times 29-16$ inches; color dark orange, shiny; apex slightly scarred, depressed, depression very shallow and rather broad; base nearly smooth, somewhat necked or creased, the number of creases frequently corresponding 
with the number of sections; stem small; calyx small, set in a slight depression; rind smooth, generally marked with depressions, corresponding to the number of sections, 1-8 inch or less in thickness, very loosely attached; oil cells conspicuous, slightly depressed or flush with the surface; sections ten to thirteen, rather irregular in size, well defined; flesh coarse grained in appearance, orange in color; juice sacks short, broad and blunt; pulp melting; juice plentiful, colored; acidity and sweetness well combined; flavor vinous, peculiar and distinct (musky?) ; seeds fifteen to twenty-five, brownish white, top-shaped, roundish, beaked, plump; core open, spongy, 3-4 inch in diameter; season November to December.

Tree very willowy in growth, almost thornless; leaves small, narrow, deep green; fruit usually borne singly at the tips of slender branches.

China is not so extensively cultivated in Florida as the variety Dancy. In Louisiana it predominated before the freeze, and New Orleans is one of the best markets. The fruit is frequently in good shape for the Thanksgiving trade.

Introduced into Louisiana from Italy between 1840 and 1850. From thence it is said to have been brought to Florida by Major Atway, date unknown. The original tree was growing on the Atway place when purchased by the late Dr. Moragne, Palatka, Fla.

Cleopatra (Spice Tangierine). From oblate flattened and irregular in circumference outline; size small, 1 3-16 x 1 3-4 inches, 1 1-4 x 2 1-8 inches; color dark orange red, not so bright as Dancy; stem slender, base flat, slightly depressed or sometimes slightly elevated, roughened about the calyx; apex depressed, generally navel marked; rind rough or inclined to roughness, 1-8 inch or less in thick- 
Plate $V$.

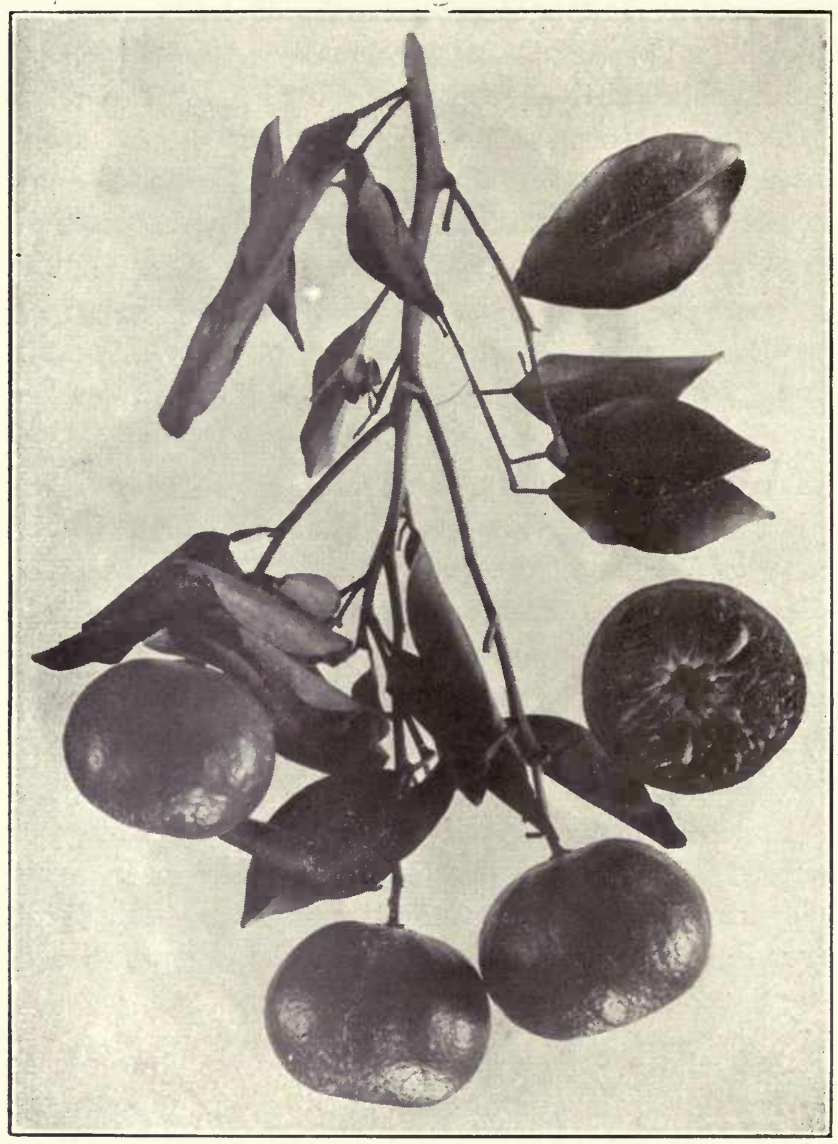

(From Bul. 66, Fla. Exp. Station.)

Dancy Mandarin Orange. 
ness, loosely attached, in very ripe specimens separating entirely from the pulp ball; oil cells small, numerous; sections fifteen, small; flesh orange colored, coarse grained; juice sacks typically broad and blunt; juice abundant, colored; flavor vinous, acidity and sweetness normal; quality good; seeds about twenty, small, top-shaped; pith small, open; season January and February.

Tree thornless, forming a dense top, upright but inclined to be willowy; leaves small; fruits produced singly or in bunches. As an ornamental this variety is very beautiful, but as a commercial variety it is not worthy of cultivation. The fruit is small and the trees not sufficiently prolific to make up for the deficiency in size by an abundance of fruit.

In Bulletin 1, U. S. D. A., Div. Pomology, Reasoner says that the Spice tangierine was introduced into Florida by Colonel Codrington from Jamaica. Under the name Cleopatra it had been known for a long time in Florida.

Dancy (Tangierine, Dancy's Tangierine, Bijou, Moragne's Tangierine). Form oblate, sections showing through the rind; size medium, $13-4 \times 25-8$ inches, $21-8 \times$ $31-16$ inches; color deep orange red, almost tomato red, shiny; stem slender; base sometimes smooth, frequently nippled or more or less corrugated; calyx small, segments blunt pointed; apex terminating in a broad, shallow depression, sometimes scarred; rind smooth,1-16 to 1-8 inch thick, leathery, easily removed, attached by a few strings to the flesh; oil cells small, usually flush with the surface, though sometimes slightly depressed; sections eleven to fourteen in number, fairly regular in size, easily detached from one another; flesh dark orange colored, coarse grained; juice sacks short, broad and blunt; juice abundant. colored; rag almost entirely absent; pulp melting; 
acidity and sweetness well blended; flavor rich and sprightly; quality excellent; pith open, $3-4$ inch across; seeds seven to twenty, rather small, short and blunt or top-shaped and beaked; season December and January.

Tree compactly headed, rather upright though tending to spread as the head is opened from year to year by the weight of the fruit, densely foliaged, fruit exposed on the outer portion of the tree. Dancy has been more generally planted than any other variety of the group. Its high color combined with excellent quality makes it a particularly fine variety. It is commonly known throughout Florida and in the markets as tangierine. The variety Dancy is said to have originated as a seedling at Buena Vista, St. Johns County, Fla. The parent tree was raised by Col. Geo. I. Dancy and was introduced into cultivation in 1871 or early in 1872 . It has proved to be a very prolific variety.

Pliny Reasoner says that Dancy is a seedling of China. I am inclined to doubt this, for if such were the case it is not likely that it would prove so strongly prepotent as it is. Every seedling of Dancy observed bears a strong resemblance to the parent. Moreover, in a letter dated at Palatka, Fla., Jan. 1, 1903, Miss S. W. Moragne states that a tangierine tree was growing on her father's place when it was purchased about 1843 , and further states that China was not the first of the group grown in Florida. Twigs of trees propagated from the original strongly re. semble Dancy. The author believes that Dancy originated from this variety.

King (King of Siam). (Bul. Div. Pomology, U. S. D. A. 1:73, 1887). Form oblate; size large, $23-8 \times 3$ inches, $31-16$ × 3 3-4 inches, $33-8 \times 41-4$ inches; color deep orange; 
Plate VI.

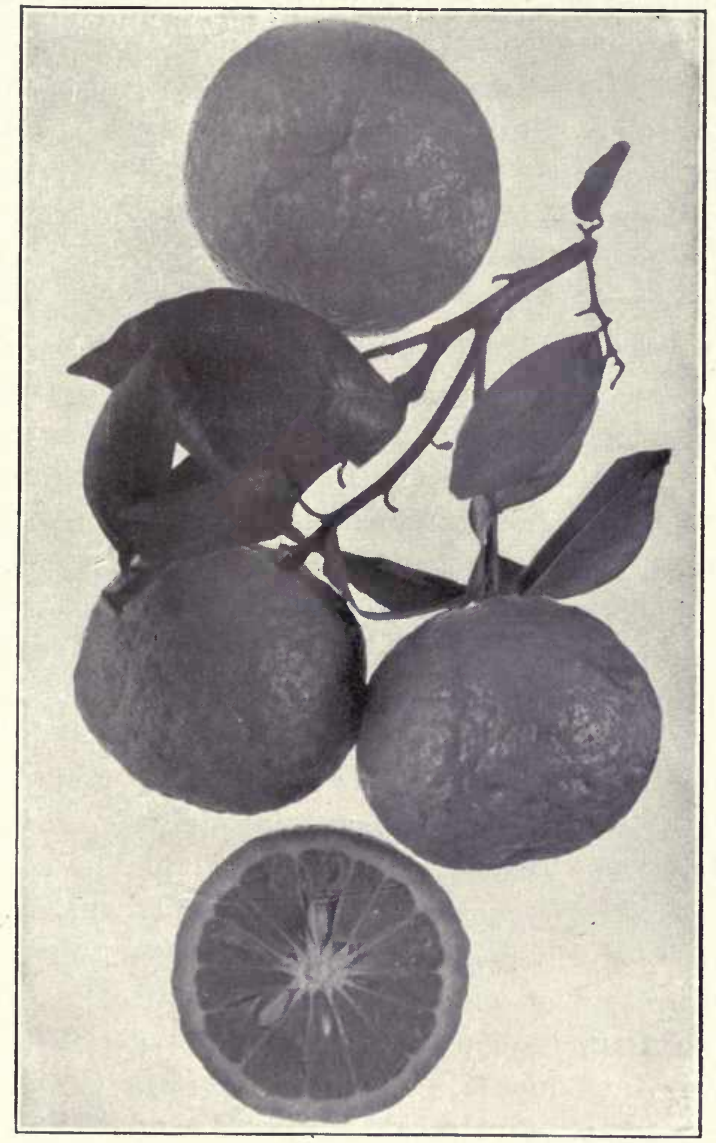

(From Bul. 66, Fla. Exp. Station.)

King Mandarin Orange. 
base somewhat roughened and creased; apex flattened, scarred and very slightly depressed; calyx small, five pointed ; rind rough, pitted, 1-8 to $1-4$ inch thick, separating easily from the flesh; oil cells large, flush with the surface or slightly depressed, mostly balloon-shaped; sections thirteen, fairly regular, easily detached from one another; flesh rather coarse grained, orange in color; juice sacks spindle-shaped, not so broad and blunt as in other members of the group; juice abundant, colored; pulp melting; acidity and sweetness well blended, flavor agreeable, sprightly; quality very good; seeds eighteen to twenty in number, large, resembling those of the sweet oranges, cotyledons white; season late, March-April.

Tree stiff and upright in growth, generally thorny, though some specimens have fewer thorns than others, foliage dark green, resembling that of the sweet oranges.

The King mandarin has been quite extensively planted in Florida, but at the present time does not appear to be held in quite as high estimation as it formerly was. The wood appears to be brittle and frequently the trees bear so heavily that they are almost stripped of their branches by the weight of the fruit. This might be obviated by thinning. The fruit is much exposed to the sun and is frequently badly sunburned and rendered unsalable. On the other hand it must be stated in its favor that the variety is prolific, of good quality, and since it matures late in the season, good prices are always secured. The variety was introduced into California from Cochin China in the year 1882 by Dr. R. Magee, Riverside, Cal. Introduced into Florida in the same year from California by Mr. John Carville Storin, of Winter Park, Fla.

Kinneloa. Form roundish oblate, size medium, 1 1-4 × 2 inches, $27-8 \times 27-8$ inches; color deep reddish orange; 
base somewhat nippled; apex with a small dot in a medium small basin; surface undulating, rough; oil cells numerous, depressed; rind loosely attached, 1-8 inch in thickness, pungent, aromatic; flesh translucent, tender ; juice cells small to medium, irregular; tissue thin; juice abundant, translucent, flavor and acidity medium; seeds present, plump, straw colored, of medium size, ten in number. Fruit heavy and of good quality. Description from specimens from J. E. Cutler, Riverside, Cal., by Division of Pomology, U. S. D. A., and procured through the kindness of Col. G. B. Brackett, Pomologist.

Kino Kuni. Form oblate, much flattened, size small to medium, $13-8 \times 2$ inches, $15-8 \times 25-8$ inches; color deep orange or orange red; stem slender; base usually creased or roughened with four or five ridges; calyx small, slightly depressed; apex ending in a broad, shallow depression nearly 3-16 inch deep; rind rather rough, separating readily from the pulp, 1-8 inch or slightly less in thickness; oil cells conspicuous, depressed; sections usually thirteen in number, irregular in size; flesh coarse grained, reddish orange in color; juice sacks short, broad, blunt; juice abundant, colored; pulp melting; acidity and sweetness well blended; flavor sprightly; quality quite good; pith open ; seeds thirteen to fourteen, top-shaped, beaked; cotyledons green; season November-December.

Tree compactly headed, resembling Cleopatra; leaves small; fruit of quite good quality, but not of much commercial importance.

It is not known when the variety Kino Kuni was first introduced into Florida, but at present the tree in the grove formerly owned by Mr. John Thomson at Clearwater Harbor, is the only one known to the writer. It is a Japanese 
variety and Mr. Thomson received his tree from Mr. J. L. Normand, of Marksville, La., in August, 1894.

Mikado. Form oblate; size medium to large, $13-8$ × 2 5-8 inches, $21-8$ × 3 inches; color orange yellow; stem stout, base slightly depressed about the calyx, rough or corrugated; calyx small, sunken; apex terminated by a broad, shallow depression; rind slightly rough, 1-8 inch in thickness; oil cells, occasionally 1-16 inch in diameter, conspicuous, slightly elevated or sometimes depressed; sections thirteen to fourteen, well defined, rather irregular, separating easily; flesh orange colored, coarse grained; juice sacks elongated, or broad and blunt; juice abundant, orange colored; pulp melting; acidity and sweetness well blended; flavor rich, sprightly; quality very good; pith open, 3-4 inch across; seeds nine, top-shaped, distinctly beaked, large, $3-4 \times 1-4 \times$ 5-16 inch; cotyledons green; season October-November.

Tree inclined to be upright, in general resembling Satsuma, but not so reclinate; leaves with petioles generally distinctly flanged. As already noted, this variety closely resembles Satsuma, of which it is a seedling. It differs from Satsuma in its more upright habit, in having distinctly flanged leaves, in the larger and more distinct oil cells of the rind, in the shape and number of the seeds, and the larger, broader depression about the apex. It cannot, however, be considered as being in anywise superior to Satsuma. Originated by Rev. Tyman Phelps, of Sanford, Fla.

Oneco. Reasoner's Catalogue, 1900. Form oblate, flattened at the apex and tapering from about the middle to the base; size medium to large, $25-16 \times 27-8$ inches. $21-2 \times 31-4$ inches; color deep orange yellow ; base slightly ridged or smooth; calyx very small; apex ending in a broad, shallow depression; rind 1-8 inch thick, generally 
Plate VII.

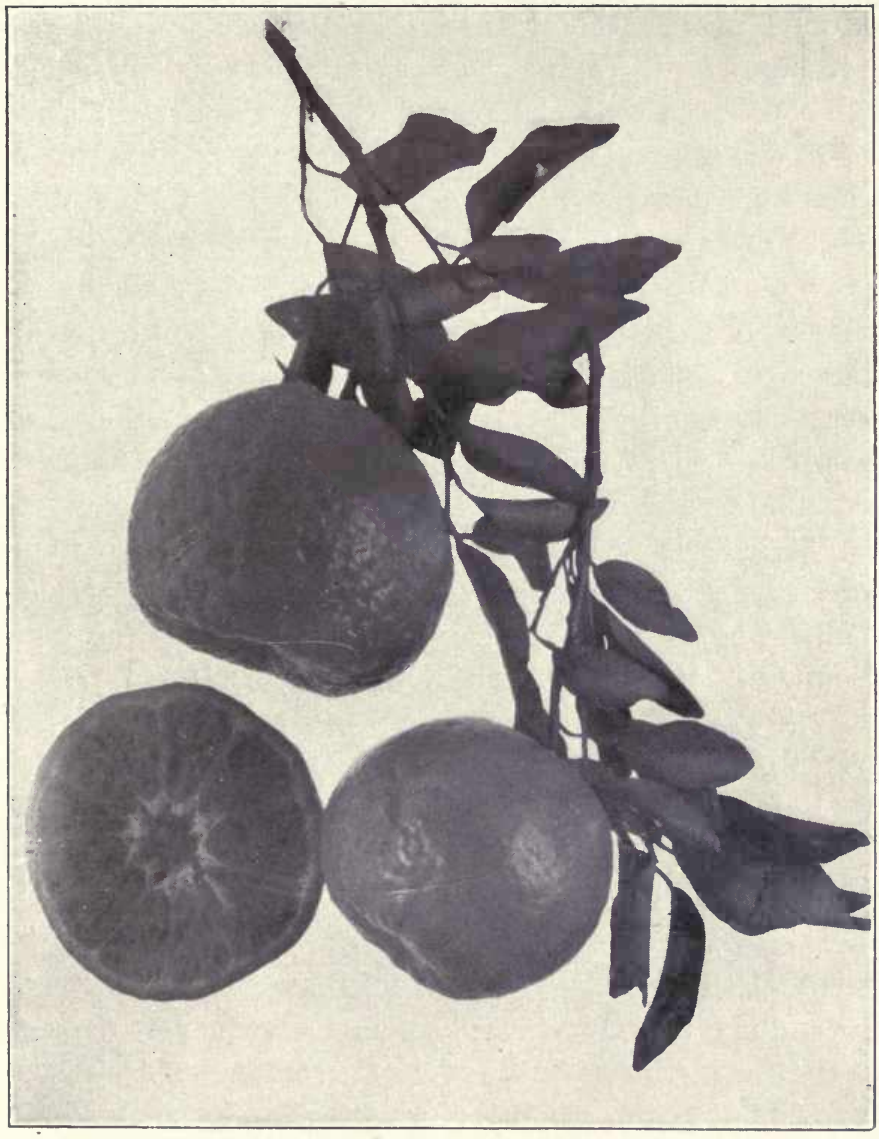

(From Bul. 66, Fla. Exp. Station.)

Oneco Mandarin Orange. 
inclined to be rough though frequently smooth, easily de. tached; oil cells large and conspicuous; sections twelve in number, fairly regular, clearly defined; flesh coarse grained, orange yellow in color, juice sacks broad, short; juice abundant, colored; rag absent; pulp melting; acidity and sweetness well blended; flavor distinct, rich, vinous; quality excellent; pith open; seeds small, twelve to fourteen, top-shaped, beaked; cotyledons green; season January-March.

Tree rather upright, foliage small with a pronounced fragrance when bruised; thorny, but with many thornless branches. The fruit is excellent in flavor and is not surpassed in quality by any other variety of the mandarin group known to the writer. The flavor may be said to resemble a combination of Dancy, King and Satsuma.

This variety was raised from seed received from northwestern India and planted by the late P. W. Reasoner in 1888. The original seedling tree is still standing on the grounds of the Royal Palm Nurseries, at Oneco, Fla.

Satsuma. (Oonshiu.) Manville's Prac. Orange Cult. 112. 1883. Form oblate; sections frequently showing through the rind; size variable, $17-8 \times 25-8$ inches and $25-8$ $x \quad 3 \quad 7-16$ inches representing the variation in size; color orange yellow; base usually slightly creased; calyx small; apex scarred with a round brownish spot situated in a broad, shallow depression; rind 1-8 inch thick, inclined to be rough; oil cells large, conspicuous, frequently depressed though sometimes flush with the surface; flesh coarse grained, deep orange in color; juice sacks short, broad; juice abundant, yellowish orange in color; pulp melting; acidity and sweetness well balanced; flavor sprightly, agreeable; quality excellent; pith open with the sections frequently separated at the inner edges; generally seedless 


\section{Plate VIII.}

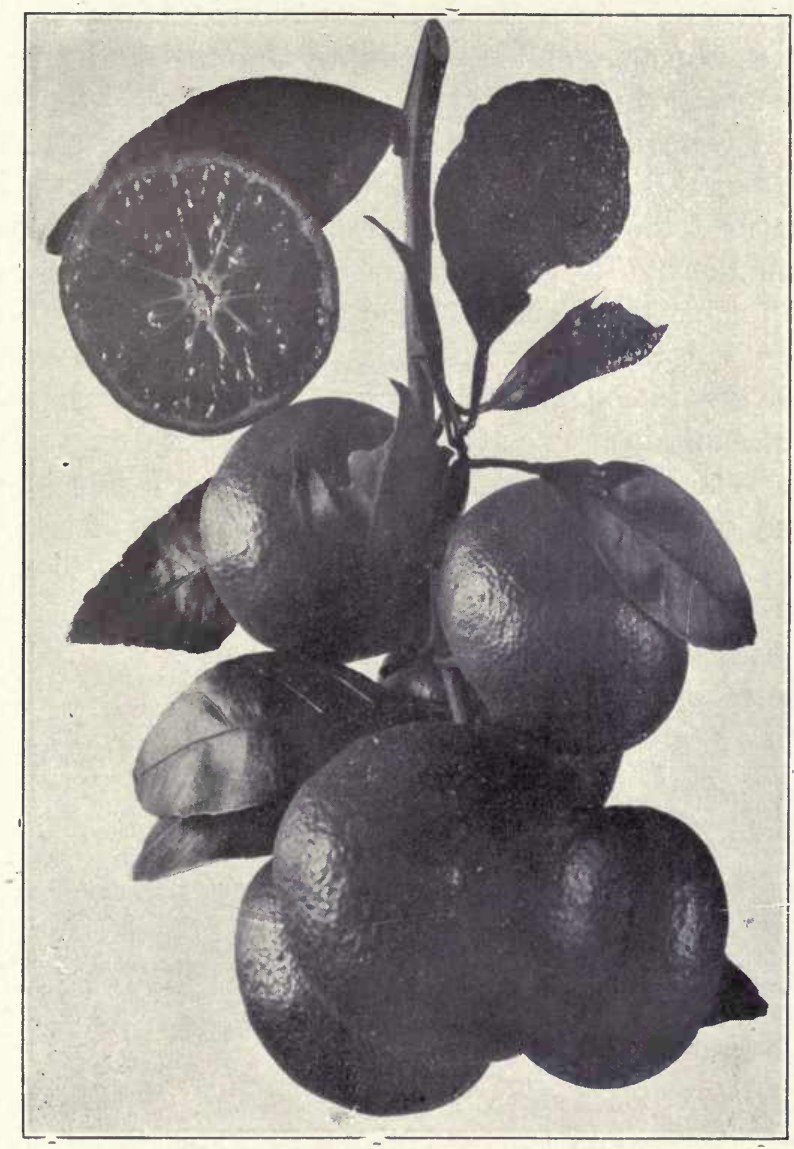

(From Bul. 66, Fla. Exp. Station.)

Satsuma Mandarin Orange. 
though occasionally from one to four seeds are found, topshaped, broad, plump, not distinctly beaked as in others of the group; season October-November.

Tree thornless and of spreading dwarf habit, branches reclinate, branchlets angled; leaves broad, tapering abruptly toward the apex, petioles scarcely margined. The leaves generally point upward and thus either follow the direction of the branches or are at right angles to them. The smaller fruits ripen first while the larger ones are later in maturing. The Satsuma is at its best just when it reaches maturity. In the extreme southern end of Florida it does not color well, but remains green or greenish for a considerable time after the juice has acquired its best flavor. The variety is very hardy in north Florida and is strongly recommended for planting in that portion of the State. The fruit is well received in the markets, the trees bear regularly a fair crop of fruit. Fruit and leaves sometimes attacked and distorted by the attacks of scab, caused by Cladosporium elegans Penzig.

Satsuma is a Japanese variety introduced into Florida by Dr. Geo. R. Hall in 1876, and again by Mrs. Van Valkenburg in 1878.

HYBRID VARIETIES.

Tangerona. Form roundish-oblate; sîze small, 2 3-16 x 2 1-2 inches, sinking 5-6 when placed in water; color orange yellow; base rounded, very slightly irregular; calyx small, lobes pointed; stem small; apex scarred, slightly depressed; rind pebbled because of the elevated oil cells, 1-8 inch thick, tightly attached; oil cells convex at the outer sides, elevated above the rind so as to give it a pebbled appearance and feeling; sections distinctly marked, firmly attached to each other, eleven in number, 
small, rather irregular in size; juice sacks broad and blunt like those of the mandarin oranges, of medium size; flesh coarse grained, melting, orange yellow in color; juice abundant, acidity and sweetness well blended; flavor rich and vinous, quality very good; pith proportionately large, 1-2 to 5-8 inch across; seeds present, wedged, broad and flat or oval, large, 5-8 x 5-16 inch; cotyledons white or sometimes a greenish one is found; season, NeptemberOctober.

The Tangerona orange originated in Brazil and was introduced into Florida a number of years ago. It is not cultivated to any extent. The quality is very good, but the small size is against it, and it is very susceptible to injury from frost. It appears to be a hybrid between one of the mandarin oranges and one of the sweet oranges.

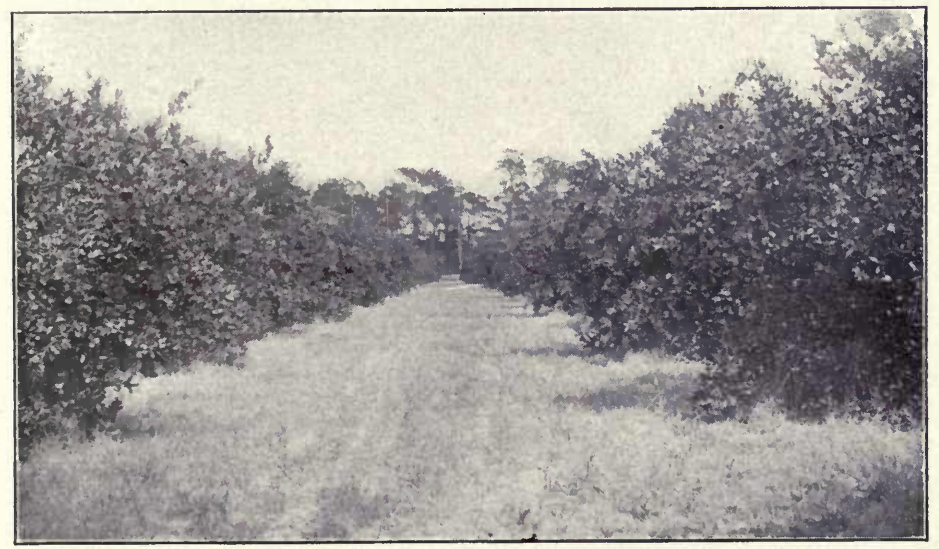

Photo by Ensminger.

Fig. 21. A Grove of Dancy Mandarins in Florida. 
Plate IX.

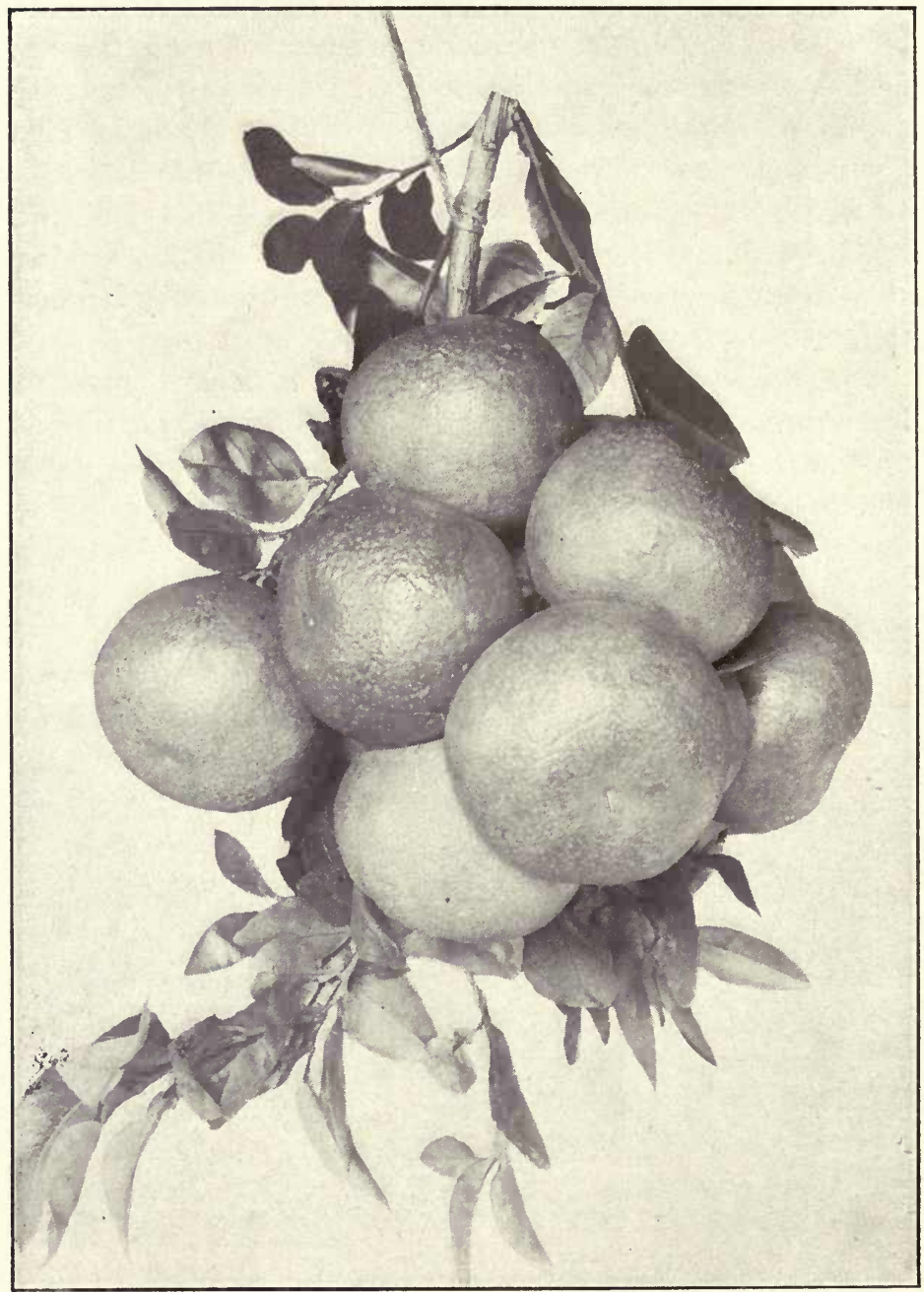

A Cluster of Hall Pomelos. 


\section{CHAPTER XVIII. \\ POMELO GROLP-VARIETIES.}

VARIETIES WITH PINK FLESH.

Tresca. Form roundish, necked or with a distinct tendency to pyriform shape; size large, 4 x 4 15-16 inches, 4 1-4 x 49-16 inches; color dark lemon yellow; apex broad, flat, scarcely depressed, scarred; base ridged and slightly roughened; rind smooth, 1-4 to 5-8 inch in thickness; oil cells rather small; sections distinctly marked, irregular in size, fifteen in number; flesh coarse, color pink or pinkish, the coloring matter apparently located in the walls and in the juice sacks, the inner rind and section divisions; juice sacks large, spindle-shaped; juice plentiful, colorless; pulp melting; acidity, sweetness and bitterness normal, well blended; flavor excellent; pith solid, 3-4 inch across; seeds pinkish, small, wedge-shaped or roundish, seventy-two in number; season February and March.

The pyriform shape of the fruit is somewhat objectionable, as the neck portion is filled with the inner rind. The quality compares well with any of the other varieties and the color of the flesh makes it interesting.

As to its origin, Mr. E. N. Reasoner sayș: "We found the Tresca pomelo in the grove of Capt. Fred Tresca about the year 1887; the Captain had brought seeds from the Bahamas some years previously and that season was their first crop. The color and flavor was so novel that we got buds and propagated from. it."

\section{VARIETIES WITH LIGHT COLORED FLESH.}

Aurantium (Orange). Form oblate; size 3 1-2 x 3 7-8 inches, frequently smaller; stem small; color light yellow; 
rind smooth, but with the oil cells slightly depressed; sections eleven, regular; flesh grayish green; bitter principle not marked or present only in a very slight degree; acidity medium; sweetness good; seeds thirty-five, of medium size; season late.

Aurantium is quite generally regarded as a hybrid. Mr. James Mott, who introduced the variety, has written the author as follows regarding its origin: "In the winter" of 1888, I found with Mr. J. C. Clouser, Longwood, Fla., what seemed to me was a very superior pomelo, two quite large trees, from buds he then told me he supposed were orange when he took the buds from a small tree which he found in an old abandoned seedling nursery. The nursery was planted by a Mr. Henkle at an early date from sweet orange seed procured from the noted Dummitt grove at or near the head of Indian River."

This variety, as already noted, is held to be a hybrid between the sweet orange and the pomelo, and the character of the fruit-so different from that of the pomelo-gives color to this view. The quality is good, but falls short of the standard of excellence for pomelos.

DeSoto. Form oblate; size 3 7-8 x 4 7-8 inches; stem stout; base creased; rind medium thick, compact; color light vellow; oil cells very slightly elevated; sections fifteen, large, irregular; flesh light grayish; juice sacks large, well filled, irregular; bitterness decidedly marked; acidity medium; flavor and quality both good, though slightly lacking in character; seeds forty-three, wedgeshaped, large and plump; season late. A good seedling variety.

In reference to the origin of this variety, Mr. John Thomson, of Clearwater, Fla., says: "The variety is one that I came across on the banks of the Peace River, near 
Zolfo, Fla. My attention was first called to it in 1892-3. * * * The fruit attracted my attention and I decided that it had distinctive merit of its own, hence I brought budwood from the tree with me to Clearwater in the spring of 1895."

Duncan. Form oblate; size $33-8 \times 4$ 1-8 inches, 4 1-2 $\mathrm{x}$ $51 / 4$ inches or larger; color light yellow; stem large; calyx segments broad, blunt; apex slightly scarred; rind medium thick, firm; oil cells large, sunken; sections fourteen; flesh light grayish green; juice sacks closely packed, large; bitterness well marked; acidity and sweetness good; core $5 / 8$ inch across, somewhat open; seeds five or more, large, plump, blunt, not winged; season late.

A fruit of excellent quality originated by A. L. Duncan, Dunedin, Fla., and cannot be too highly recommended for general planting.

Excelsior. (Excelsior Late). Form oblate; size $4 \mathrm{x}$ 4 3-4 inches; color lemon yellow; rind very slightly pitted; oil cells large, slightly sunken; sections thirteen, large, irregular; flesh light grayish ; bitter principle well marked; acidity normal; quality good; seeds thirty-one, wedgeshaped, large, plump; season late.

"This particular fruit, one of a number" of old seedlings, was brought to the notice of the manager of the Lakeland Nursery Co. in 1886 or 's7. He propagated about one hundred trees. In the year 1890 my personal attention was called to the desirability, quality and especially the bearing capacity, and after repeated demands for the variety, I propagated it for the first time in my nurseries located at Fort Meade in 1891."-C. M. Marsh in a letter to the author, dated June 5, 1903.

Hall. (Silver Cluster.) (Hall's) Klemm's Silver Cluster.) Form oblate; size 4 1-8 x 4 5-8 inches, or larger; stem large; color light yellow, but slightly darker than 
that of most pomelos; base smooth, or sometimes slightly creased; rind 3-16 inch thick; oil cells slightly indented; sections fourteen, large, variable in size; bitter principle strongly developed; acidity and sweetness well marked; juice almost transparent; seeds thirty-two, small, roundish, plump, quite a number aborted; season February-March.

There has been considerable discussion over the origin of this variety, but it seems to be a fact well established that it was originated by John W. Hall, of Caloosa, Fla. The original tree was grown from seed sown by him when he first came to the State about 1885. The synonymy as given above may be open to some objections, but in naming it the credit has been given to Dr. Hall, to whom it is believed to be due.

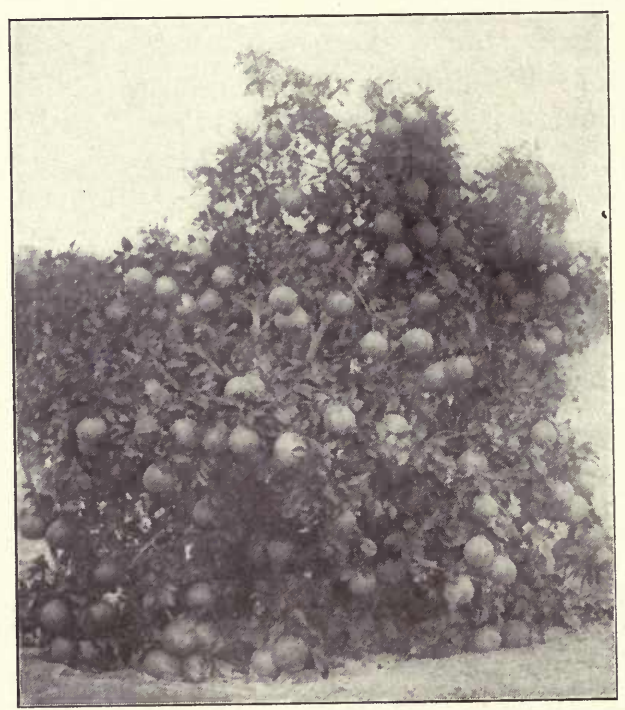

Photo by Ensminger.

Fig. 22. The Triumph Pomelo in Fruit in the Grove of Dr. Innman, Winter Haven, Fla.
Josselyn.Form roundishobovate; size $31.8 \quad$ x $31-2$ inches; stem medium; color yellow, darkest of all the varieties which have come under observation; rind smooth; oil cells slightly sunken; sections twelve, rather irregular, dividing tissue thick; flesh grayish green; pulp melting; 
bitterness strongly marked; acidity and sweetness well developed; core 1-2 inch in diameter, solid; seeds fortyeight, whitish, small and plump; season December-January.

This variety was introduced by Messrs. J. W. and F. D. Waite, of the Magnolia Nurseries, Belleview, Marion County, Fla., in 1888. The original tree stood in the old Josselyn grove at East Lake, on Lake Weir.

Leonardy. Form slightly oblate or rounded; size medium, 3 3-4 $\times 4$ 1-2 inches, 3 7-8 $\times 4$ 5-16 inches; color lemon yellow; apex smooth, not depressed, scar small; base smooth, slightly depressed; calyx small, 3-8 inch across, lobes not conspicuous; rind smooth, shiny, 1-4 inch thick; oil cells flush with the surface, large and conspicuous; sections well defined, large and regular, ten in number; flesh coarse, light grayish in color; juice sacks large; juice plentiful, colorless; pulp melting; acidity and sweetness well balanced; quality excellent; pith open, $3-4$ inch across; seeds present, large, broad, flat, twenty-eight in number; season January.

Manville. (Manville's Improved.) Form oblate; size medium to large, $35-8 \times 4$ 1-8 inches; stem small; color lemon yellow; rind 1-4 inch thick, smooth, the oil cells being flush with the surface or only slightly sunken; sections thirteen, large, fairly regular; flesh light grayish green ; juice sacks large, irregular; bitterness well marked; acidity and sweetness good; core 5-8 inch in diameter, compact; seeds sixty to seventy, large; season late.

In relation to the origin of this variety, Reasoner Brothers made the following statement: "Manville's Improved was sent us by the late A. H. Manville, from East Florida, years ago." 
Thus far this variety has not been catalogued, but the fruit appears to be very desirable.

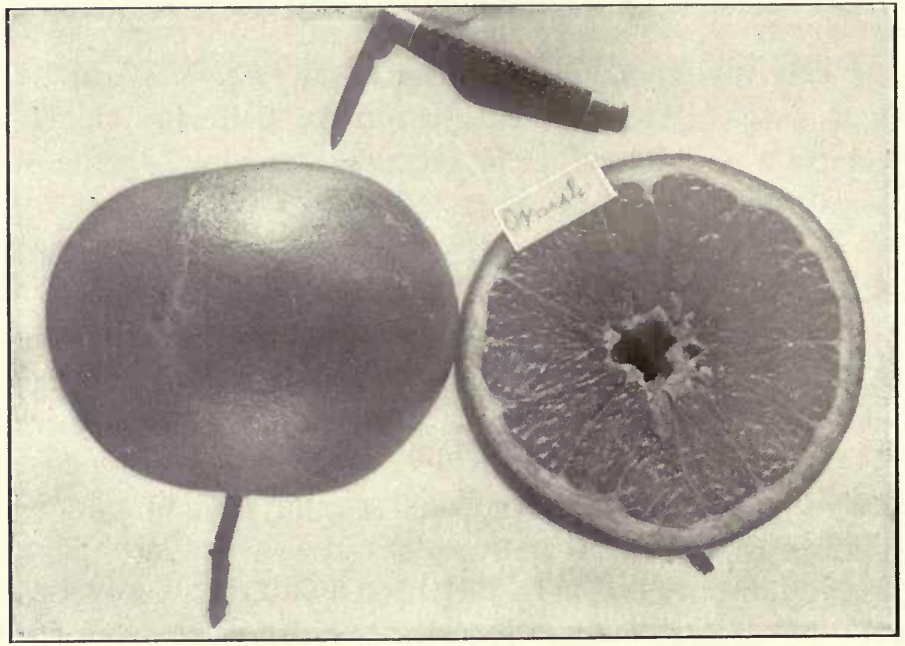

Fig. 23. Marsh Pomelo.

Marsh. (Marsh's Seedless.) Form oblate roundish; size $31-8 \times 4$ 7-8 inches, $31-2 \times 41-2$ inches, $35-8 \times 4$ 7-8 inches; stem small; color light yellow; rind 1-8 inch thick, smooth; oil cells small, scarcely or not at all indented; sections thirteen, regular, partitions thin; juice sacks small; flesh grayish green; bitter principle not strongly marked; acidity and sweetness medium; pith 5-8 inch in diameter, open; seeds two to six, or none, large, plump; season February-March.

This variety was introduced by C. M. Marsh, Lakeland, Fla., about 1895 or 1896 . The original tree was a seedling, growing in Lakeland, and was at the time of the freeze, fully sixty years old. This pomelo has not the distinct, pronounced flavor of the typical fruit, but the 
quality is good, and the fact that it is so nearly seedless is a very desirable feature.

May. (May's). Form oblate-rounded; size small to medium, 3 1-4 $\times 3$ 1-2 inches, 35 -16 $\times 3$ 3-4 inches; heavy in weight; color light yellow; base rounded, scarcely depressed; calyx small; stem small; apex rounded, with a very slight depression marked with a small dark spot; rind smooth, glossy, tightly attached, 1-4 inch thick; oil cells conspicuous, medium sized, just level with the surface; sections clearly defined, twelve in number, regular and of medium size; juice sacks large, broad, blunt; flesh coarse grained, light grayish in color; juice abundant; acidity and sweetness normal, bitterness marked; flavor and quality excellent; pith 5-8 inch across; seeds present, thick, plump, of medium size, 9-16 x 3-8 inch, light yellowish in color, forty-four in number and some abortive; season, November-February.

The May pomelo is an excellent variety, formerly well known in Florida, but for some time after 1895 it disappeared almost entirely. Previous to that time it won prizes wherever exhibited. The original tree, according to Mr. E. S. Hubbard, was probably set in the May's grove at Orange Mills on the St. Johns River with his orange trees in 1824 by Zephariah Kingsley Slaver.

McKinley. Form oblate, or slightly oblate conical; size $37-8 \times 43-4$ inches; color pale yellow; rind smooth, thin; oil cells large, conspicuous, scarcely indented; sections fourteen, large, slightly irregular; bitterness marked; acidity normal; sweetness good; quality of the best; core 3-4 -inch in diameter pithy; seeds sixty-two, wedgeshaped, large; season late. 
This is a pomelo of considerable merit and worthy of propagation. The variety originated as a seedling in the grove of A. A. Gardner, Fort Myers, Fla.

Nocatee. Form roundish or somewhat oblate; size small, $23-8 \times 23-4$ inches, $21-2 \times 3$ inches, $25-8 \times 31-4$ inches; stem small; calyx small; apex slightly marked; color lemon yellow, occasionally somewhat deeper; rind 1-8 to $3-16$ inch, easily detached; oil cells minute, slightly indented; sections twelve, variable in size, separating easily; flesh yellowish gray; tissue thin, translucent; juice almost transparent; acidity medium; bitter principle lacking; juice sacks small, short, plump, in shape resembling those of the tangierine; flavor a commingling of pomelo and tangierine; pith small, 3-8 inch in diameter; seeds three to twenty-three, small, slightly winged at the tip; cotyledons white or green, or partly green and partly white; season late; a good keeper.

This variety appears to be a well marked hybrid between the tangierine and the pomelo, and I have placed it with the pomelos because the fruit, in general appearance, more closely resembles that fruit.

It originated at Nocatee, Fla., and Mr. T. J. Watkins, the owner of the tree, in 1902 wrote the following notes regarding it: "The original tree is about twenty years old, and somewhat larger than an average sour orange tree of the same age. It is a hybrid of accidental origin, showing marks of grapefruit, tangierine and bitter-sweet orange. It is a distinct type, having fruit, bloom, wood, habit of growth and leaf different from all others, and is as easily recognizable as the tangierine or grapefruit. It is a strong, vigorous grower, with limbs long and somewhat slender. The leaves are medium size, broad, slightly bent upward from midrib and slightly curved backward, giving a shape 
bearing some resemblance to an apple leaf, but in color and texture it resembles the leaf of the common orange. In habit of growth it is loose, open-headed, and the foliage less dense than a grapefruit or common orange. The wood is almost thornless and the tree prolific, being laden with fruit every year. All characteristics of the tree and fruit are retained in budded trees. **** Growth of budded trees has been more rapid and vigorous than that of grapefruit buds under similar conditions.

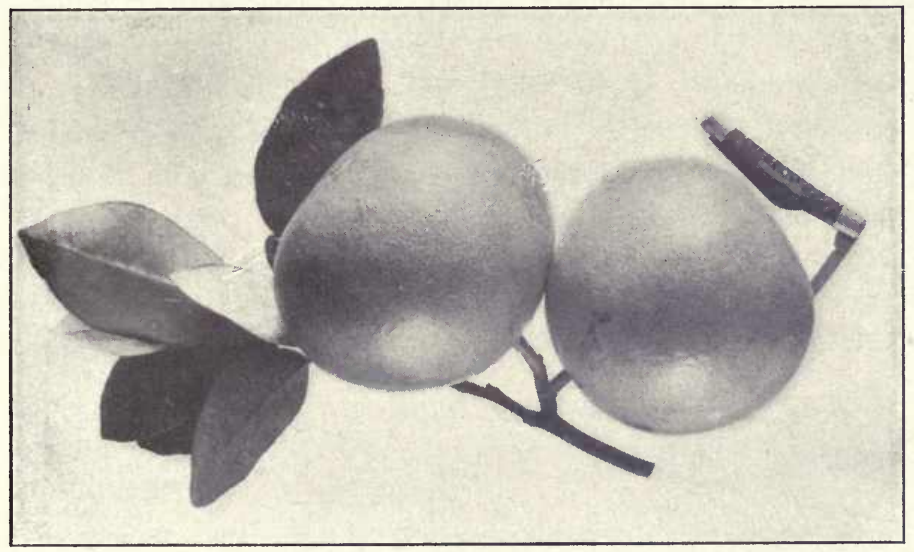

Fig. 24. Pernambuco Pomelo.

"The fruit is of medium size, running about one hundred and fifty to the box, in color a clear, pure yellow; has few seeds, many of the fruits being entirely seedless; has loose rind, separating from the fruit a little less easily than tangierine's. * * * It is good any time after December, and will hang on the trees until August, but reaches full maturity about April, when it develops a rare combination of rich and delicate flavor." 
The leaves of this variety are different from those of the orange or grapefruit. On some leaves the wings are entirely absent. In others the wing is cut in on one side only, leaving the other entire, while other leaves have a well marked wing on both sides.

The fruit is certainly unique and interesting. and possesses a considerable degree of merit.

Pernambuco. Form oblate; size $33-4 \times 4$ 3-4 inches, 3 7-8 $\times 4$ 1-2 inches; stem stout; calyx medium in size; color very light yellow; rind $1-4$ inch thick, compact, closely attached, smooth; oil cells large, sunken; sections twelve, uniform in size, well defined; flesh grayish green; bitterness well marked; acidity and sweetness good; char. acter well marked; seeds sixty to seventy-five, whitish, wedge-shaped, irregular; season late.

This variety was imported by the United States Department of Agriculture from l'ernambuco, Brazil. It is a variety of very fine quality.

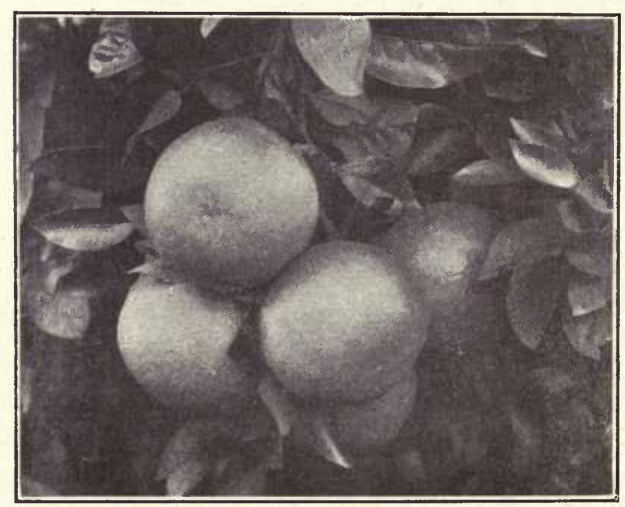

Fig. 25. Duncan Pomelos.
Royal. Form slightly oblate; $\begin{array}{lllll}\text { size } 3 \times & 3 & 1-2\end{array}$ inches, $3 \times 3$ 5-8 inches; s te m stout; color light yellow; rind 1-8 inch thick; oil cells small; sections eleven or twelve, small, regular; fl es h grayish; green; bitter principle almost entirely lacking; acidity medium; sweetness good-can be eaten from the hand as an 
orange; seeds forty, grayish in color, roundish and plump; core 3-4 inch in diameter, pithy; season medium early.

Mr. E. N. Reasoner, in a personal letter, says: "The Royal pomelo was brought from Cuba (probably) about thirty years ago, and is a large, fine tree yet, in this neighborhood. We budded from it and named it in 1891; listed it in 1892."

The fruit is quite desirable, but lacks the character of the pomelo. The tree is a good bearer, probably a hybrid.

Standard. (Indian River.) Form oblate; size large, $41-4 \times 5$ inches; stem small; base slightly creased; color very light yellow; rind $3-8$ inch thick; oil cells large, slightly depressed; sections thirteen, large, rather irregular; flesh grayish green; bitterness marked; acidity and sweetness normal; pulp melting; juice plentiful; juice sacks large; quality excellent; seeds forty-nine to fiftynine, large, long, creased; core 7-8 inch, open; season January-March.

The origin of this variety is unknown. C. T. McCarty, Eldred, Fla., from whom specimens were first received, wrote as follows regarding it: "This pomelo is known here as the Standard, or Indian River; I don't know its origin. It came here from Rockledge sixteen years ago." (Or about 1886.) One of the very best varieties.

Triumph. Form oblate or slightly oblate-oblong, slightly flattened at base and apex; size $35-8 \times 4$ inches; stem small; color light yellow; rind very smooth, 1-8 inch thick; oil cells slightly depressed; sections eleven; bitter principle not so strongly marked as in some; acidity and sweetness normal; juicy; pulp melting; seeds thirty-seven, medium, plump, roundish; core 5-8 inch in diameter, open or pithy; season medium early. 
The original tree of this variety grew in the yard of the Orange Grove Hotel at Tampa, but was killed during the severe winter of 1894-95. Propagation of the Triumph pomelo was commenced in 1884 .

Walters. (Walter.) Form oblate; size $33-4 \times 4$ 7-8 inches; stem small; color pale yellow; rind smooth, 1-4 inch thick; oil cells almost flush with the surface; sections thirteen, large; bitter principle strongly marked; acidity and sweetness good; quality very good; seeds fifty-eight. large, plump, wedge-shaped or irregular; core $3-4$ inch in diameter, solid; season medium.

The Walters pomelo was introduced in 1887 by a Mr. Walters, assisted by Waite Bros. The original tree grew near the village of Belleview, Marion County, Fla.

In habit of growth this tree very closely resembles the Hall, and by some they are thought to be the same, but the origin of the two is entirely different as may be noted from the descriptions. The seeds show a distinct varietal difference.

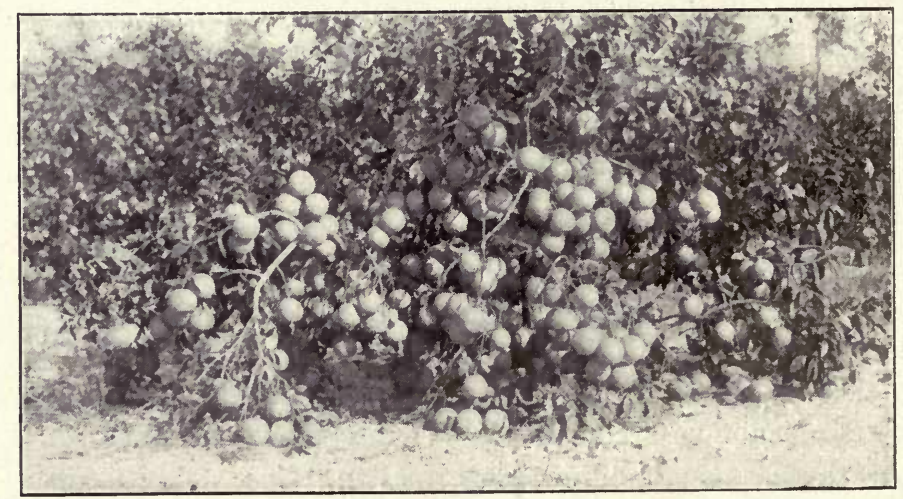

Photo by Ensminger.

Fig. 26. Walters Pomelo in Fruit. 


\section{CHAPTER XIX.}

\section{SHADDOCK GROUP-VARIE'TIES.}

Mammoth. Form oblate; size large, 4 7-8 $\times 6$ inches, or larger; color lemon yellow; apex rounded or flattened, marked with a large scar; base gradually rounded, with a broad shallowed depression, not creased; calyx large, irregular; rind 3-4 inch thick, fungous; oil cells large, conspicuous, globular; flesh coarse, white; juice sacks large, pointed, with the membrane thick; pulp not melting, but inclined to be tough; acid and bitter, sweetness slightly developed; flavor sweetish bitter; pith open; sections not covered with membrane on the inner edge; seeds present, large, wedge-shaped, twelve in number; season winter.

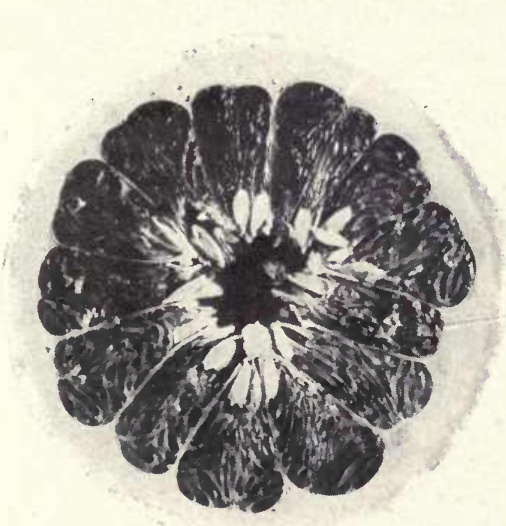

Fig. 27. Cross-section of Pink Shaddock. (About one-third natural size.)

Pink. Form oblatepyriform, n e c k e d ; size large, $6 \times 1 \times 5$ inches; color lemon yellow; apex slightly depressed, scarred; base depressed, slightly ridged; calyx set in a depression, seg. ments blunt; rind thick, $1-2$ to $3-4$ inch. fungous; oil cells large, conspicuous; sections twelve, irregular in size, distinct, separated by thick, leathery partitions; flesh coarse, pink or reddish in color; juice sacks large, spindle-shaped, 1-2 
to 1 1-4 inches long, not tightly fastened together; juice fairly abundant, not colored, the coloring matter of the flesh confined to the tissue; pulp not melting, rather tough; flavor bitter and acid with some sweetness; pith large, 11-4 inches across, not lined with membrane; seeds present, few, three to seven, medium size, 3-8 x 1-2 inch, blunt, rather oval, pointed; season winter. 


\section{CHAPTER XX. \\ KUMQUAT GROUP-VARIETIES.}

Nagami. (Oblong, oliveshaped). Tree dwarf, eight to twelve feet, bushy; young branches somewhat angled, light green ; leaves 1 1-2 x 3, 1-2 or 3-8 $x$ 1 $1-4$ inches, lanceolate, apex obtuse; base acute or obtuse; margin crenate down about half way from the apex; veins inconspicuous, surface dark green, glossy; lower lighter; borne on rather stout, usually very slightly margined petioles, 1-4 to $5-8$ inch in length. Fruit small ; obovate or oblong; 1 1-4 $\times 3$ 3-4 inches, $11-2 \times 1$ inch, $13-4 \times 11-8$ inches, $13-4 \times 13-16$ inches, golden yellow; stem short; calyx small; rind smooth, aromatic, spicy; oil glands large; juice acid, sparse; sections usually five; seeds two to five, oval, 1-2 inch long, greenish ; cotyledons two, green; season October-January.

Marumi (Round). Tree similar to Nagami, except that it is slightly thorny, and has the Fig. 28. Nagami and Marumi

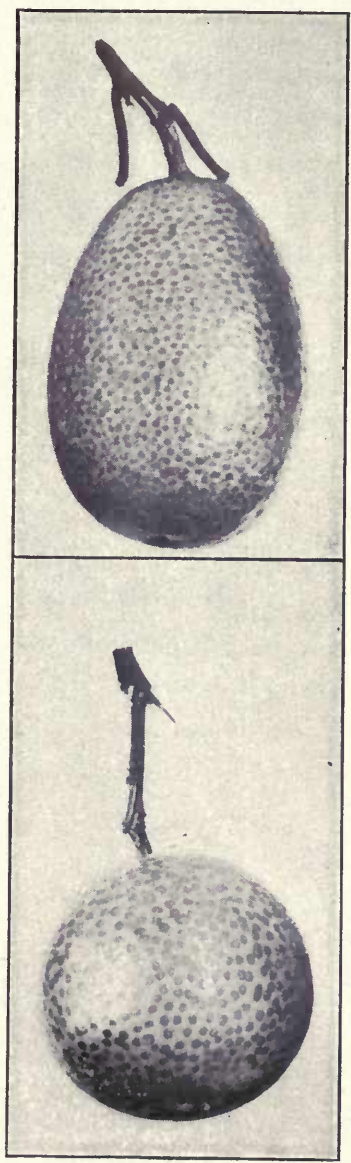


leaves somewhat smaller and rounder at the apex. Leaves oval; apex obtuse; base obtuse; margin crenate half way down the length; veins slightly more conspicuous than in Nagami, borne on short, rigid, inconspicuously winged petioles, 1-4 to 1-2 inch in length. Fruit spherical or somewhat oblate, 1 to 11 -4 inches in diameter; golden yellow, short stalked; calyx small; rind smooth, thin, spicy to the taste and aromatic when bruised; oil cells large; pulp sparse; juice acid; sections four to seven; seeds small, oval, greenish, one to three in number; cotyledons two, greenish; season, same as Nagami.

When eaten raw both Nagami and Marumi have a very pleasant flavor or combination of flavors. The juice is acid; the rind has an agreeable spicy taste; while the soft, white, granular inner portion of the rind is decidedly sweet. There is a slight difference in flavor between the two varieties, but it is better determined by taste than described in words. Of the two, Nagami is generally considered to be the more desirable, though among growers there is a difference of opinion. The fruit of the Nagami is more regular in size on young plants. Large sized plants of both varieties bear about the same amount of fruit of uniform size and both are very prolific.

Sour. Form rounded oblate; size small, 1 1-8 x 1 1-4 inches; color deep orange red; apex flattened; base rounded; stem small; calyx small, bluntly five pointed; rind smooth, very thin, easily separated from the pulp; oil cells of medium size, flush with the surface; sections six or seven, clearly defined, separating readily from each other, flesh fine grained, orange colored; juice sacks small; juice abundant, colored; pulp melting, free from rag; acidity very strong, but pleasant; pith small, rather open; 
seeds oval, smooth, plump, two to four in number, $3-8 \mathrm{x}$ 1-4 inch; season November-December.

The scent of the freshly cut fruit is very much like that of the Mandarin oranges. The leaves are thin, broadly oval in outline. The variety is subject to scab and is of little importance except as an ornamental. Buds were received from Dr. F. W. Inman, of Winter Haven, Fla., and from these the present specimens at the Florida Experiment Station were grown. I have been in doubt in placing it with the kumquats, but have been unable to make a better disposition of it. 


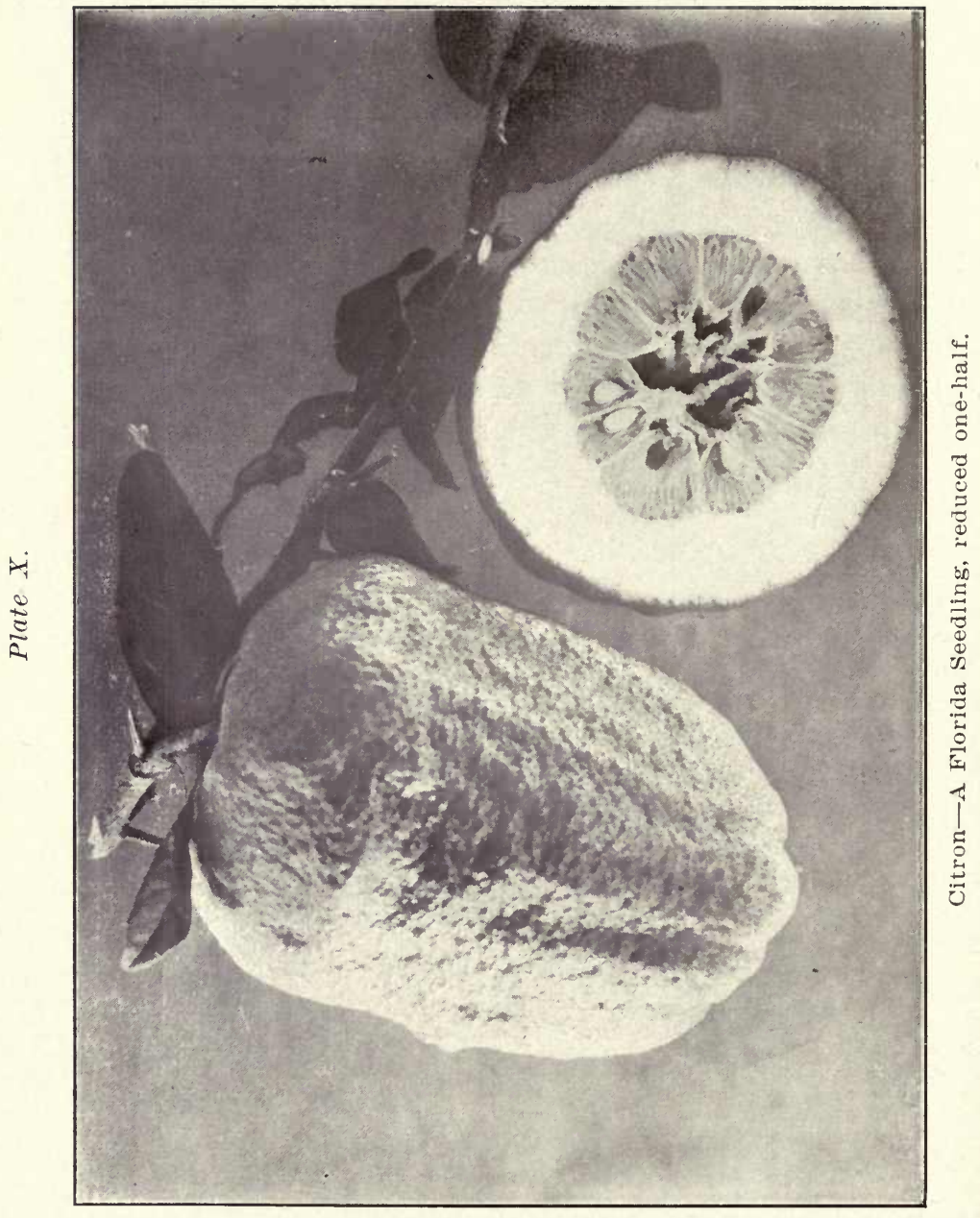




\section{CHAPTER XXI.}

\section{CI'TRON GROUP-VARIETIES.}

Lemon. (Sorrento). Form oblong; size variable, large specimens, $73-4 \times 5$ inches or larger, and weighing three to eight pounds; color bright lemon yellow; apex nippled, nipple small, abrupt; base rounded; rind pleasantly aromatic, rather smooth, with slight, broad elevations, 1 to $11-4$ inches thick; inner rind white, coarse, with very little bitterness; oil cells slightly elevated or flush with the surface; sections twelve in number, clearly defined, the partitions thick; pulp bitter, lacking in juice; juice sacks narrow, elongated, pointed; pith small; seeds present, small, oval, blunt; fruiting throughout the whole year in favorable sections.

The Lemon citron is an imported variety now grown in California and to a less extent in Florida.

Lyman. Form oval-oblong; size medium; color orange yellow; quality good. Cat. Fla. Hort. Soc., 1902.

Orange. Fruit somewhat cone-shaped, more pointed than common variety; color that of an ordinary orange; rind cream colored; pulp yellowish; rind sweet and highly aromatic; fruit possesses less bitterness than the common variety; tree a small, stiff, erect grower. (Moore from Fla. Fr. Gr. Association Report.) 


\section{CHAPTER XXII.}

\section{LEMON GROUP-VARIETIES.}

Eureka. Form oblong; size medium, 2 7-8 $\times 2$ inches, $3 \times 21-4$ inches; color lemon yellow; apex nippled, the nipple small and abrupt; base slightly tapered, frequently oblique; calyx of medium size, four to five pointed, points blunt; rind smooth, 1-4 inch thick uncured, 1-8 inch thick when cured, sweet; oil cells quite large, depressed; sections ten, well defined and regular; flesh fine grained, pale grayish yellow in color; juice sacks small, spindle-shaped, elongated; juice abundant, clear; pulp melting; acid pure and strong; flavor excellent; pith small, 1-4 inch across; seeds present, but mostly abortive, elongated, somewhat wedgeshaped, small.

The tree is half dwarf in habit and comparatively free from thorns. The fruit keeps well and is one of the best var-

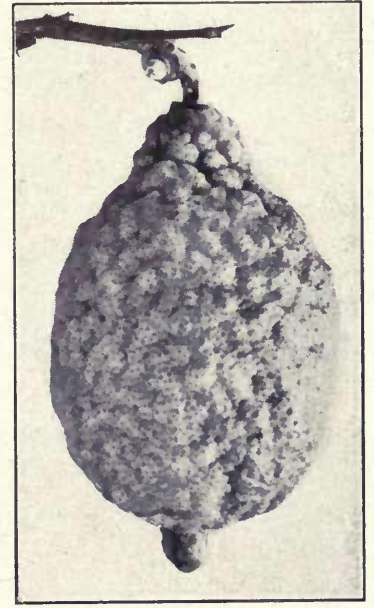

Fig. 29. Ever-bearing Lemon. (About one-half natural size.) ieties grown in California.

It has a tendency to bear the fruit at the end of the branches, and is poorly covered with foliage. It is an extremely prolific variety. It was introduced by Mr. T. A. Garey, of Los Angeles, Cal., and originated by C. R. Workman at the same place, the seed from which it grew having been imported from Hamburg in 1872. 
Everbearing. Form oval, pointed at both ends; size medium. 3 9-16 x 2 inches; color yellow; apex pointed, point about 5-8 inch long; base elongated, somewhat ridged about the calyx; calyx small; rind rough, almost warty; when uncured 3-16 inch thick; oil cells depressed, large; sections not clearly defined, eleven in number, regular; flesh fine grained, greenish gray in color; juice sacks elongated and narrow; juice plentiful, colorless; pulp melting; acid fairly good; flavor fair; pith small, about 3-16 inch across; seeds present, of medium size, nineteen in number shape oval, pointed; season, all the year round.

The Everbearing lemon is too rough and contains too many seeds to make it a desirable market variety. It is quite valuable for domestic use and especially so as it is always in flower and fruit. It has a strong tendency to produce an abundance of water sprouts and suckers, hence forms a bushy growth. It has been grown in Florida for many, many years, and is probably a Spanish introduction.

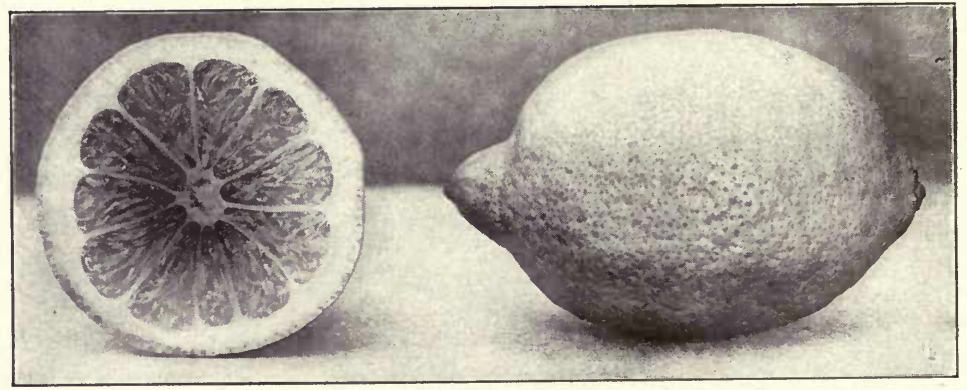

Fig. 30. Lisbon Lemion, and cross-section of uncured specimen. (Five-eighths natural size.)

Genoa. Form oblong, pointed at both ends; size medium, $33-8 \times 2$ inches, $35-16 \times 25-16$ inches; color lemon yellow, bright; apex nippled, nipple small and rather 
sharp pointed; base necked; calyx large, four to five pointed, points rounded; rind smooth, sweet, 1-4 inch thick or slightly more uncured, 1-8 inch thick cured; oil cells small, fairly conspicuous; sections seven to ten, regular; flesh fine grained, grayish yellow in color; juice sacks fairly large, spindle-shaped; juice abundant, clear; acid clear and strong; flavor excellent; pith very small, 8 inch or less; seeds few, abortive, oblong, small.

The tree is thornless, dwarf in habit and the fruit keeps excellently. Uncured specimens when placed in water, sink about four-fifths of the diameter beneath the surface, when cured, five-sixths of the distance or more. The Genoa lemon was imported from Genoa by Don Jose Rubio, of Los Angeles, Cal., and from thence into Florida by Mr. A. I. Bidwell about 1881 .

Lisbon. Form ablong; size medium, 3 1-4x2 1-8 inches, color lemon yellow; apex nippled; base somewhat necked; calyx quite large and prominent; rind fairly smooth, sweet to the taste, 1-8 inch thick in cured specimens, 1-4 inch thick in uncured; oil cells small and prominent; sections ten to eleven, small, regular in size; flesh fine grained, grayish yellow; juice sacks elongated, narrow, spindleshaped; juice abundant; pulp melting; acid clear, pure. strong; flavor excellent; pith small, 1-4 inch or less; seeds one to five, usually abortive, oval, somewhat plano-convex.

This variety is a strong, vigorous grower, prolific, thorny and well covered with foliage. The fruit is very uniform in size, ripens evenly and keeps well. The Lisbon lemon was imported from Portugal and was first grown at Riverside, Cal., by D. N. Burnham.

Ponderosa. Form necked, oblong, obovate pyriform; size large 4 3-8 x 4 1-8 inches; color lemon yellow; apex flat or roundish with a very slight indication of a nipple; 
base necked, rather rough, elevated about the calyx, which is quite depressed; rind rough, 1-2 inch thick; oil cells large, balloon shaped or oblong; sections twelve, distinct, separating tissues thick; flesh grayish, identical in color with that of the pomelo; coarse grained; juice sacks large, spindle-shaped or cylindrical and blunt; juice plentiful. colorless; pulp melting; acid quite strong; flavor agreeable, not exactly like a lemon; pith small; seeds present, oval, blunt pointed, somewhat wedge-shaped, twenty-five in number, of medium size; season winter.

This lemon appears to resemble the pomelo and there is a possibility of its containing some of the pomelo strain. The tree has not been seen but the leaves are rounded at the apex and wingless. This variety has been quite extensively advertised as a novelty by northern

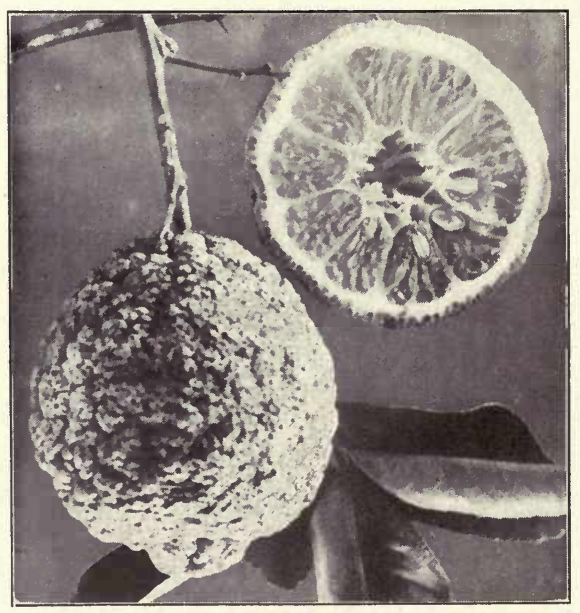

Fig. 31. Rough Lemon Fruit. (One-half natural size.) nurserymen f o $r$ pot culture.

Rough (Florida Rough, French.)F o r m variable, slightly obovate or round ovate; size medium to large, 2 7-16 $\times 25-16$ in-, $3 \frac{3}{4} \times 3 \frac{3}{4}$ in. ; color lemon y e llow sometimes shaded with a reddish tinge; apex rough, with a slightly depressed ring in which is set a roughened elevation having three or four ridges; base rough and elevated so as to surround 
the calyx; rind decidedly rough and warty, 1-4 inch thick; oil cells large, balloon-shaped or globular, frequently extending entirely through the rind; sections well defined, nine to twelve in number, separating freely from each other and from the rind; flesh coarse grained, greenish yellow in color; juice sacks large, broad and blunt; juice abundant, clear; pulp melting; acid quite strong; flavor agreeable; pith open, $1-2$ to 1 inch across, filled with white strings of tissue; seeds small, full, plump, blunt pointed, twenty-three in number; season winter.

This variety of lemon is presumably of Spanish introduction and has become naturalized in the forests of southern Florida. It is somewhat useful for home consumption, but as a commercial variety it is worthless. The rough lemon is quite extensively used as a stock upon which to work different varieties of citrus trees. When growing apart it reaches a height of upwards of twenty-five feet, the bark of the tree being brownish gray and smooth.

Sicily. Form oblong; size medium, 2 1-2 x 31 1-4 inches; color light lemon yellow, bright; apex nippled, nipple short, abrupt; base rounded; calyx rather large; rind thin, smooth, sweet; oil cells usually flush with the surface; sections distinctly marked, quite regular, twelve in number; flesh grayish yellow in color, fine grained; juice sacks small, spindle-shaped; juice abundant; pulp melting; acid strong, clear; flavor good; pith small; seeds twelve in number, of medium size.

Sweet. Size very small; form much flattened; color rusty, grayish yellow; instead of eye, a marked nipple set in a deep cavity; stem inserted in a slight depression; thickness of skin, 2-16 inch ; longitudinal diameter, 2 inches, transverse, 21 -8 inches; color of flesh, dark lemon; grain of pulp coarse; juice sweet and insipid, with slight lemon flavor. Curious, but unworthy of cultivation. (Moore.) 
Placed here provisionally; it should, doubtless, be grouped differently.

Villafranca. Form oval-oblong; size medium to large, $3 \times 25$-16 inches; color lemon yellow, bright; apex pointed, blunt, abrupt, about 1-2 inch long; base rounded; calyx of medium size, segments not distinctly marked; rind smooth, 1-8 inch thick when cured; oil cells depressed or flush with the surface; sections eleven, well defined and regular; flesh fine grained, light grayish yellow in color; juice sacks slender, pointed; juice colorless, abundant; pulp melting; acid clear, pure, strong; Havor good; pith small, 1-4 inch across or less; seeds present, thirty in number, of medium size, oval, pointed.

The tree has but few thorns, is a good grower and very productive. The variety was imported by General Sanford and is, perhaps the most commonly planted variety in Florida.

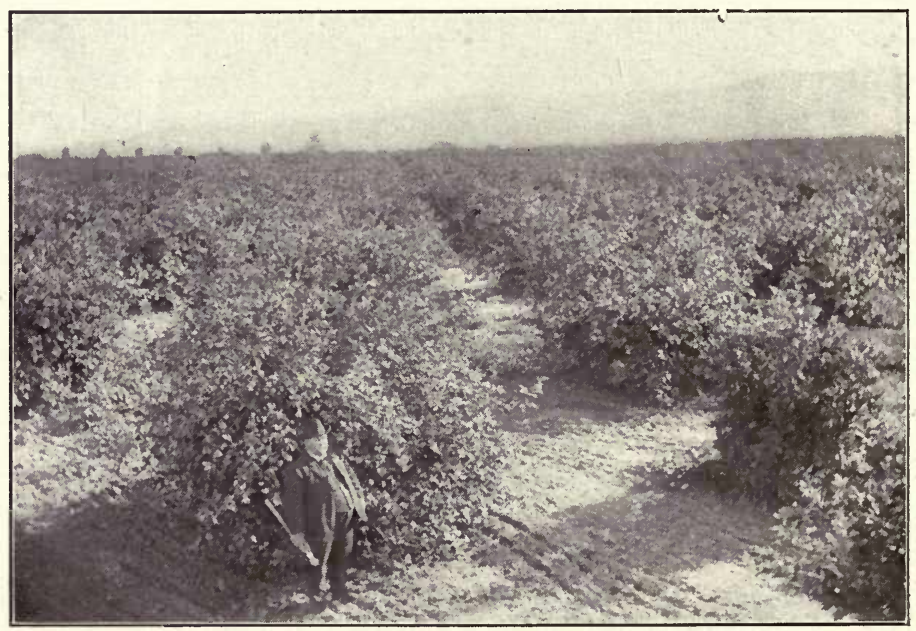

Fig. 32. View in a Lemon Grove, Corona, Cal. 
CHAPTER XXIII.

\section{LIME GROUP-VARIETIES.}

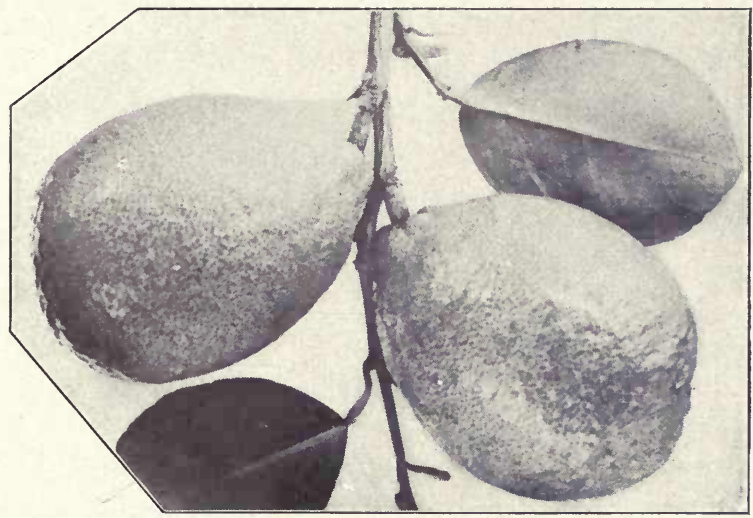

Fig. 33. Mexican Lime.

('- 'wo-thirds natural size.

Mexican. Form oblong or oval; size small, 2 1-16 x 13-4 inches, $23-8 \times 21-16$ inches, very variable; color light lemon yellow; apex usually smooth, sometimes slightly nippled and ridged, the nipple pointed or blunt, short and small; base usually smooth, sometimes elevated and ridged; rind smooth, very thin; oil cells very numerous, usually flush with the surface, the larger ones sometimes depressed; sections distinctly marked, dividing tissue thin, ten in number and regular in size; flesh fine grained, light grayish green in color; juice sacks small. spindle-shaped; juice plentiful, colorless or translucent; pulp melting; acid very strong; flaror distinctly of the lime; pith open, small; seeds few or none, pointed, broad and flat, or slightly wedge-shaped, $3-8$ to $1-2 \times 3-16$ incin; season all the year round. 
The Mexican lime was probably introduced by the Spaniards and grows wild in the forests of southern Florida. Size and quality of the fruit is very variable as it is propagated entirely from seeds. The tree grows as a shrubby bush, ten to fifteen feet high, well provided with small, sharp spines. The variety might be greatly improved by proper selection and propagation, but at present the name does not stand for any single well marked variety, but rather for a conglomeration of varieties for which the description given above may be considered fairly ac. curate.

Rangpur (Rungpur, Rungpore). Form roundish, oblate, or tending toward obovate, occasionally somewhat necked; size medium, $2 \times 2$ 1-8 inches, $25-8$ × $25-8$ inches; color orange red; apex sometimes flat, frequently with a tendency to become distinctly nippled-nipple, if present, small, sharp and short; base sometimes quite smooth, occasionally corrugated or ridged, sometimes quite rough, especially when necked; calyx depressed or projecting slightly around the point of attachment; rind usually fairly smooth, inclining to be rough about the base and apex, thin, 1-8 inch or less in thickness, separating readily from the pulp, coloring irregularly in the ripening process; oil cells quite conspicuous, the primary ones depressed; sections seven in number, fairly regular in size, separating readily from each other and from the rind; flesh coarse grained, deep orange in color; juice sacks large, long, 1-2 to 3-4 inch, narrow and pointed; juice plentiful, slightly colored (orange) ; pulp melting; acid clear, pure, strong; flavor distinct, not at all like a lime, very pleasant and agreeable; pith small, open, 1-4 inch in diameter; seeds present, fourteen in number, ovate, scarcely pointed, 3-8 inch long by 1-4 inch wide; cotyledons greenish; season. 
autumn and winter, remaining on the trees well on towards spring.

The Rangpur lime was grown from seed, by Reasoner Bros., Oneco, Fla., obtained from northwestern India. The variety appears to have come true from seed and seems to be identical with the variety described by Bonavia. The tree has very much the habit of the lime, but in nearly all respects the tree and fruit is distinct from the true lime group. By Bonavia it has been classed with the Indian group, "Suntara," which appears to be closely related to our mandarin group. It has been placed with the limes provisionally.

Tahiti. Form broadly oval; size large, $3 \times 2$ 5-8 inches; color lemon yellow; apex nippled, the nipple broad at the base, abrupt and sharp pointed; base rounded, slightly elevated about the calyx, creased or ridged; calyx adhering firmly to the fruit, blunt pointed; rind smooth, thin, 1-16 inch when cured; oil cells small, slightly depressed; sections well defined, irregular, ten in number; flesh fine grained, greenish in color; juice sacks cylindrical, narrow and pointed; juice plentiful, almost colorless; pulp melting; acid pure, strong; flavor agreeable, distinctly "lime"; pith open, small; seeds none; season fall and winter.

The Tahiti lime grows as a round-topped tree, twelve to fifteen feet in height. The fruit is produced singly or in clusters of two or three, usually well covered by the foliage. Branches are inclined to droop. The undesirable feature of the variety in Florida is that the fruit tends to decay on the trees about the time it matures. 


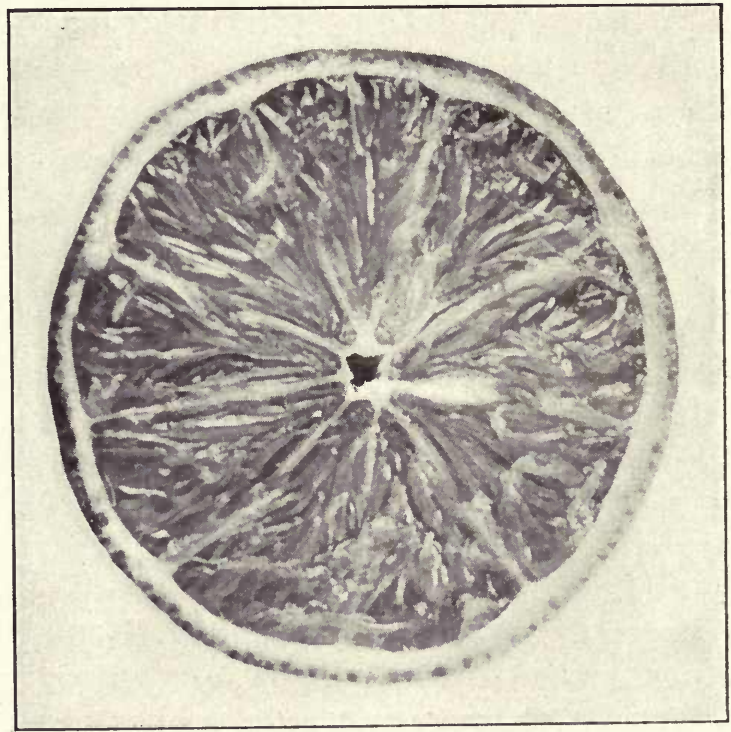

Fig. 34. Cross-section of Tahiti Lime. (Natural size.) 


\section{CHAPTER XXIV.}

\section{ORIGINATING NEW VARIETIES.}

The day has come when a knowledge of the art and science of crossing plants should be as much a part of a horticulturist's education as a knowledge of the art and science of budding and grafting. So great are the improvements, along certain lines, which may be brought about in citrus fruits through cross-pollination and consequent cross-fertilization, that it has been deemed advisable to give specific directions for the use of those who desire to experiment in this interesting and inviting field. The operations necessary for the performance of the work are so simple that any novice may perform them. All that is necessary is a knowledge of the methods, a little patience and a considerable amount of care.

While something may be done in improving varieties by bud-selection, still any radical improvements in the fruits under discussion must be brought about by raising, fruiting and selecting seedlings. The seeds used may be selected from fruits of desirable trees or they may be produced as a result of hand-pollination. The method of selecting and propagating desirable seedlings is the one by which all of the varieties now cultivated commercially in the State where produced, and it is, perhaps, not too much to say that their origin has been in a large measure due to chance. If attempts are made at improvement by cross pollination, the parent plants may be chosen at will, and there is always a strong probability of the offspring inheriting some of the desirable characteristics of the parent varieties. After persistent efforts for a number of 
years, it is almost certain that the desired end, held in view from the first, may be attained in the ideal fruit. The larger the number of crosses made the greater are the assurances of success. If a desirable variety is not secured in the first generations, it is best to continue the work by crossing one of the parents on the cross or hybrid already obtained.

When seeds form as a result of cross-pollination and plants are successfully raised, the offspring is termed either a cross or a hybrid. It is a cross if the seedling is formed as a result of the union of the elements of two varieties of the same species, while a hybrid is the plant resulting from the union of representatives of two distinct species. For example, if the pollen of the Duncan pomelo is placed on the stigma of the Triumph pomelo and following this fecundation takes place, seed forms and a plant is raised, this plant is a cross. But if the pollen of the Duncan pomelo is placed on the stigma of a Lemon citron and as a result a seedling is raised, it will be a hybrid. In the first case, the two pomelos belong to the same species, C. decumana, while in the latter case we have representatives of two species, C. decumana and C. Medica. By some plant breeders these two terms, cross and hybrid, have been discarded and the term hybrid used in the place of them, but the usage as given above is the long established one and the best to follow.

The Parts of the Flower. A knowledge of the structure of the citrus flower on the part of the operator is indispensable. On examining a flower the first part noticed is the large, white, showy portion, usually composed of five parts. This is the corolla, and each part or segment is termed a petal. (Fig. 35 E.) Outside the corolla at its base is a much smaller, yellowish or greenish, somewhat 
Plate XII.

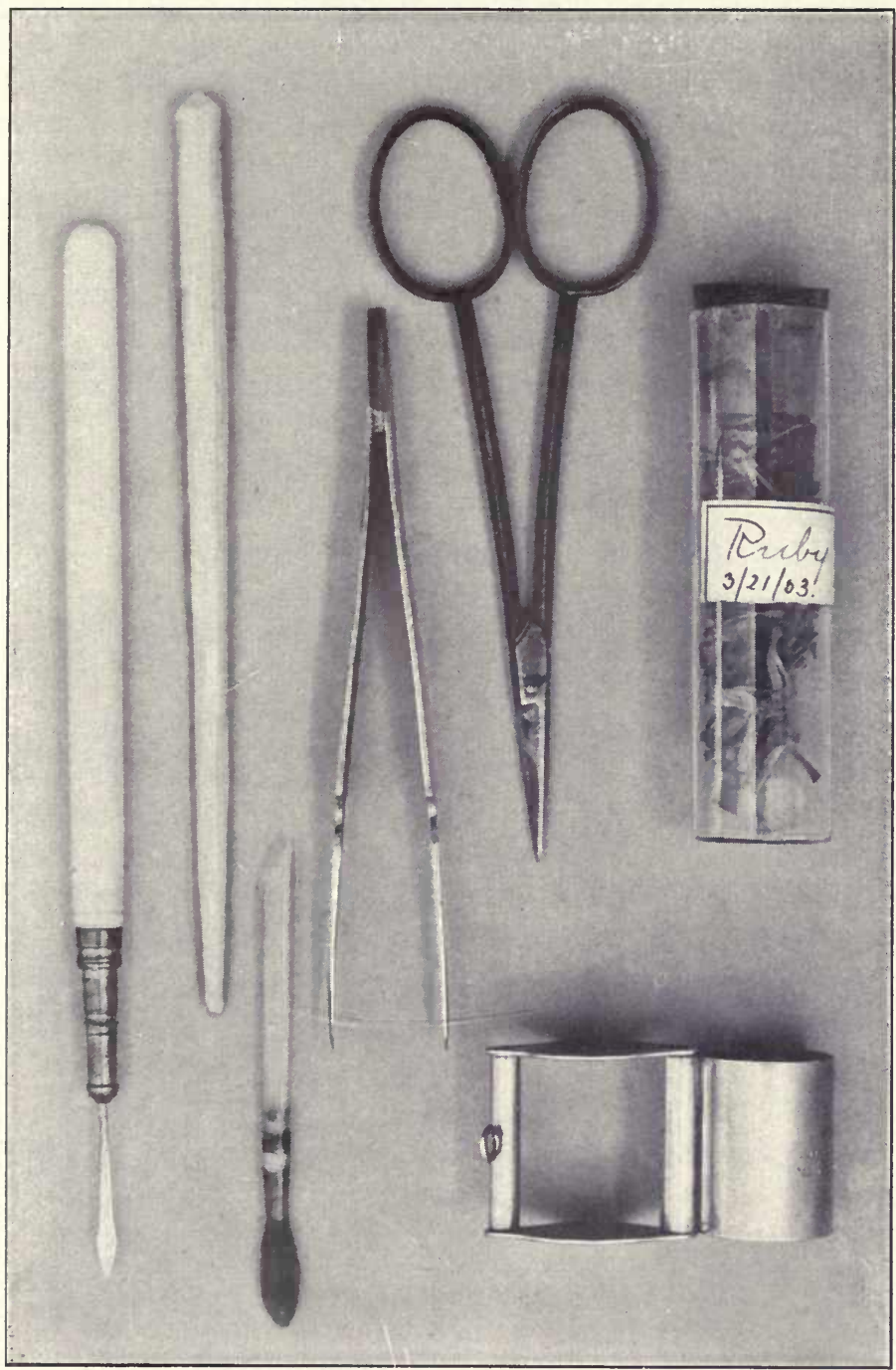

Pollinating Outfit.

Pin-Scalpel; Brush and handle; Tweezers; Surgeon's scissors; Phial of pollen; Hand-lens. 
cupped part, the calyx. In the calyx of some flowers five points may be made out (oftener only three or four), which represent the parts of the calyx, in the citrus flower fused into one. These parts are each known as a sepal. The calyx and corolla constitute the floral envelopes or protective part of the flower.

Inside the corolla, standing up in a ring, are the stamens (Fig. 35 D.). Each consists of a white stem or filament, surmounted by a yellow, pointed knob, the anther. If the anthers are ripe, a yellow dust, the pollen, will be found on them. The stamens are usually about twenty in number and the filaments are more or less united, so as to form a ring. The filaments of $\mathrm{C}$. trifoliata are not joined together.

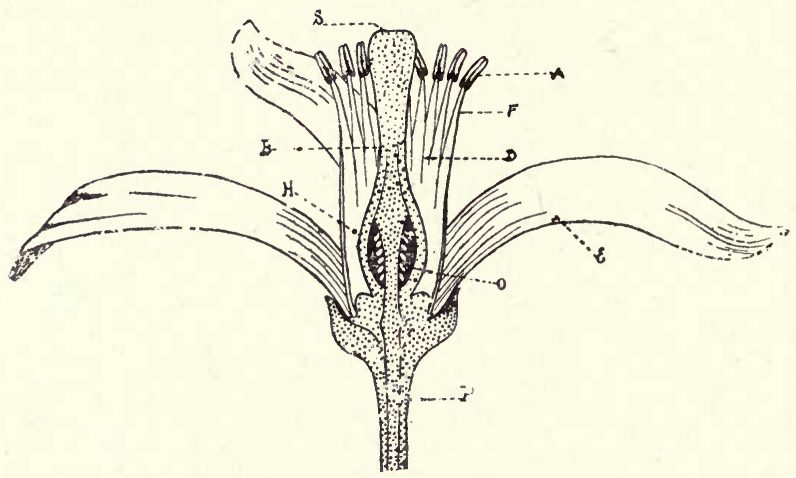

Fig. 35. Vertical section through a citrus flower, enlarged about two and one-half times. $P$, Peduncle, expanding into the calyx just above. E, petals. D, Stamens. F, Filaments. A, Anther. B, Pistil. $\mathrm{S}$, Stigma. B, Style. O, Ovules.

Within the ring of stamens the pistil (Fig. 35, B.) rises straight up from the bottom of the flower. Its upper knob-like end, the stigma, rises above, or to, the level of the stamens. Below the stigma is a rather thick, straight 
part, the style, joined to a round, greenish body, the ovary, at its base. This ovary, when fully developed, forms the fruit. If we cut through the ovary from top to bottom with a sharp knife and examine the section with a handlens, a number of small, light-colored bodies, attached along the central column, may be made out. These are the ovules (Fig. 35, O.), which, after being fertilized, grow and form the seed. The stamens and pistil are called the essential organs of the flower, because they are the parts which form the seed for the reproduction of the tree. It is with them that one making crosses is most concerned, for through their agency seed is produced and through them only can the work be done.

As already indicated the ovary grows and forms the fruit while the ovules develop into the seed. But seed-formation does not commence until the ovules are acted upon by the pollen. When the anthers are ripe the pollen is discharged through slits in the sides. The stigma must also ripen or become receptive to the pollen. This condition in citrus flowers is shown by its viscid appearance and by its being covered with a whitish, sticky fluid. Then if the pollen be placed upon the stigma it is held there by the adhesive surface and germinates, each pollen grain sending out a little slender tube, which grows through the style and finds its way into the ovary, where the contents are emptied into the ovules. Then fertilization or fecundation is accomplished and seed-development begins.

\section{MODE OF OPERATION.}

Having now become acquainted with the different parts of the citrus flower and their uses, the operator is ready for the actual work.

If any considerable amount of pollination, i. e., trans 
ferring the pollen from the anther to the stigma, is to be done, the pollen to be used should be collected and prepared some time before. It has generally been observed that the anthers of citrus flowers open and expose their pollen very shortly or within a few hours after the flowers open. In some cases the anthers are ripe as soon as they are exposed, by the separation of the petals enclosing them. Hence in collecting pollen, one may be quite certain of securing mature pollen from flowers which are just on the point of opening. It will not do to take pollen from open flowers, for some insect may have made a visit to them and depos-

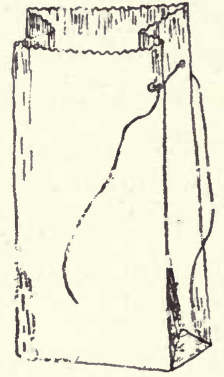

Fig. 36. Sack ready for covering poll1-
nated flowers. ited foreign pollen in some part of the flower. This pollen might unwittingly be gathered and used by the operator. Gather the flowers in paper sacks and afterwards spread them out in a thin layer on a smooth sheet of paper in a warm dry place, where the air is still. In two or three days the flowers will dry and shrivel; all the anthers will open and the pollen will be liberated. Then carefully gather the whole mass and replace it in the sacks. Each one should be labeled. For use in the field, the dried flowers and pollen together should be placed in wide-mouthed, loosely-stopped phials. These should be labeled with the name of the variety of pollen and the date of collection. (Plate XII.)

A sufficient number of bags should be provided with which to cover the flowers to prevent insects from visiting them. For this purpose we have found two-pound manilla bags, such as grocers use, the most convenient. These should be prepared by punching a hole through the two edges while the sacks are still flat. In the hole in 
one of the edges tie a string about ten inches long and draw one end through the hole in the other edge, as shown in Fig. 36.

Every precaution must be taken to prevent the access of foreign pollen to the stigma of the flower to be operated upon. It is best to select the flowers near the tips of branches as it is much easier to cover them with the bags. Remove all open flowers and those which are immature. No flower should be worked upon after it is open. Choose them in the stage shown in fig. 37, B. just before they are

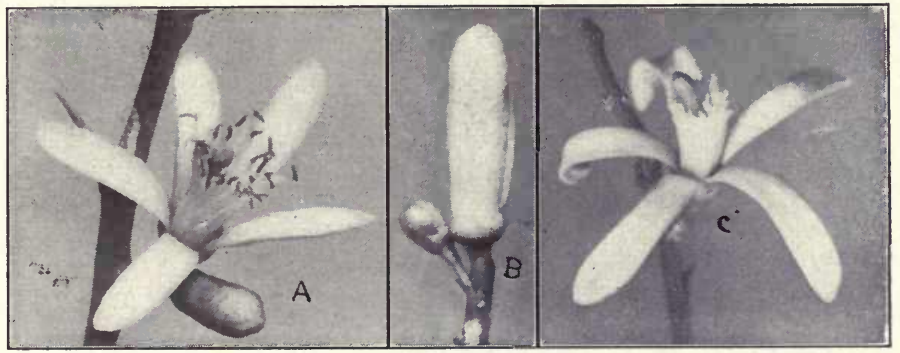

Fig. 37. A, Open citrus flower, showing petals, stamens and pistil. $B$, Bud at the right stage for emasculating. C, An emasculated flower.

ready to open. If possible, select the blossoms so as to be able to place a number under the same sack.

In performing the work, gently hold the unopened flower-bud in the fingers. With a pair of tweezers carefully pry the petals apart so as to expose the anthers and stigma. If the flower is in the right stage, it will be found that the stigma is on a level with the anthers or slightly above them and that its surface is viscid or sticky, as already noted. Then remove the anthers by catching the filaments some distance below them and nipping them off, or a pair of surgeons' scissors (Plate XII) may be used. This operation of removing the anthers is termed emascu- 
lation. Be careful to remove all the anthers and do not allow any of them to drop down between the filaments and the pistil. When the emasculation is completed the stamens present the appearance of those shown in fig. 37, C. Generally it will be found that the stigma is quite ready for the pollen at this stage. Hence it is not necessary to place a bag about the emasculated flower or flowers to

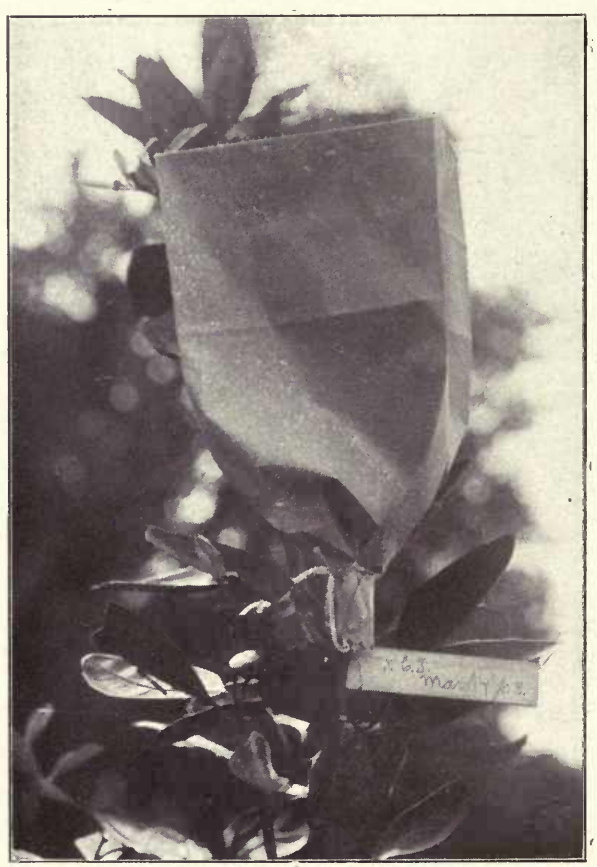

Fig. 38. Paper sack, covering cross-pollinated Satsuma flowers. await the ripening of the pistil or pistils, as must be done with the flowers of many other plants.

Pollination may be performed immediately after e nı as cul at i o n The pollen may be placed on the stigma by grasping one of the dried flowers by the base and bringing the anthers in contact with the stigma. $\mathrm{B}$ u $t$ generally we have used a small, soft camel's hair brush (Plate XII) fitted with a wooden handle four or five inches long. A fresh one should be provided for each different kind of pollen to be used. The brush is dipped into the phial con- 
taining the dried flowers and pollen and twirled around so as to fill it with the pollen grains. This method is rather wasteful of pollen and the one given above is preferable where only a small amount of pollen can be secured. but for working on a large scale we have found nothing better to substitute for it. After filling the brush with pollen it is gently applied to the stigma. See that plenty of pollen adheres to its surface. Then carefully cover the pollinated flower or flowers, if a number a $r$ e together, with a paper bag, tie it tightly around the branch and below the sack, place a label indicating the pollen used and the date (fig. $35)$.

Nothing more needs to be done until the fruit has set. This is indicated by the dropping of the style from the ovary. If at this time the ovary is deep

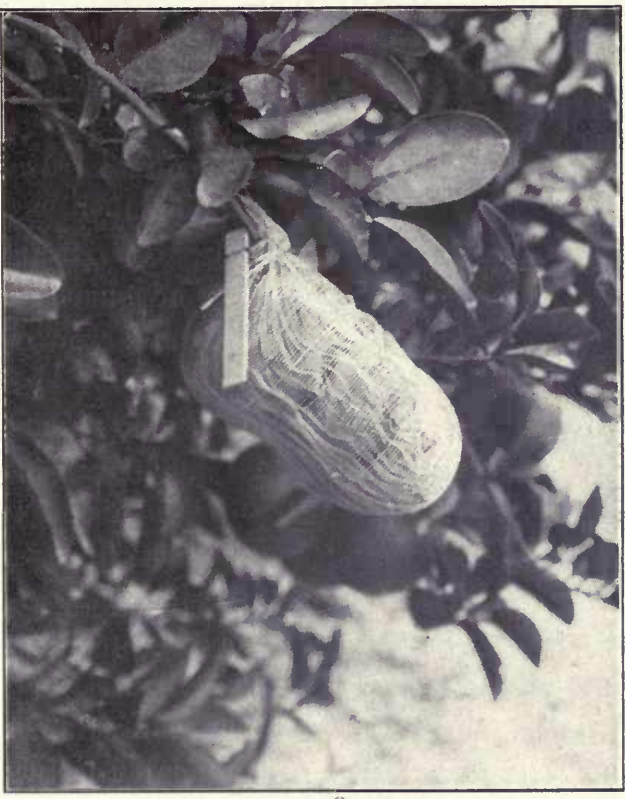

Fig. 39. Triumph pomelo fruit, the result of cross-pollination, enclosed in a mosquitonet sack for protection.

green in color we may feel reasonably certain that the fruit will stay and that seeds have commenced to grow. At this time, about ten days or two weeks after pollinating, the paper bags should be removed and replaced by sacks about 
$6 \times 8$ inches, made of mosquito-netting. For pomelos or other large citrus fruits, the sacks should be $8 \times 10$ inches, or larger, if a number of fruits are included under one sack. These mosquito-netting sacks admit the air freely, prevent many insect attacks on the young fruit and frequently save the fruit by holding it if it should drop after it is matured and before picking.

When the fruit is ripe it should be carefully gathered and the seed saved. If injury to the young plants from cold can be prevented, the seeds may be sown immediately. If there is danger from this source the seeds should be stratified as described later on and kept until the time is suitable for planting. In most citrus growing districts this can be safely done by March. Give the seedlings good care and by August, they will have attained a height of about two and a half or three feet.

Some seeds will give more than one plant, due to the presence of more than one embryo in the seed. All the plants should be saved as they may represent combinations of the parent forms in different proportions. Some buds may even be secured in. autumn and inserted in stocks to start growth the following spring. In spring, buds may be inserted in the tops of bearing trees. This will enable one to secure fruit sooner. It may reasonably be expected that fruit will be produced the third season after top-work ing. Five or six years must generally elapse from the time of pollinating until fruit is secured. Then, and not until then, can the results be known.

If desirable fruit is produced, well and good, if not, further work must be done, and it will generally be best to use one or more crosses or hybrids already obtained, as one of the parents of the next generation, provided the hybrid or cross obtained possesses a sufficient number of desirable qualities. 


\section{CHAPTER XXV.}

\section{JUDGING CITRUS FRUITS.}

Rules and regulations for the judging of most of the citrus fruits were adopted by the Florida State Horticultural Society in 1892 and by the Executive Committee of the Los Angeles, Cal., Chamber of Commerce in 1894, and these at present are the standards for the respective States. In neither of these sets of scales is any provision made for the pomelo, and since this fruit has come to take its place along with the orange and lemon as an exceedingly important citrus fruit, it seems but right that provision should be made for judging it.

Such a provision is here made by the following scale for pomelos, which has been prepared after having gone carefully over the ground with Messrs. G. L. Taber, E. N. Reasoner and E. S. Hubbard:

OFFICIAL SCALE AND RULES OF THE FLORIDA STATE HORTICULTURAL SOCIETY FOR JUDGING CITRUS FRUITS.

Scale. Points.

Size, $21 / 2$ to $31 / 4$ inches................. 10

Appearance, skin fancy and silky ........... 10

Juiciness, must sink in water $\ldots \ldots \ldots \ldots \ldots \ldots \ldots$

Thickness of peel, $3-32$ inch . . . . . . . . . . 10

Seedlessness, one point off for two seeds........ 10

Sweetness ....................... 15

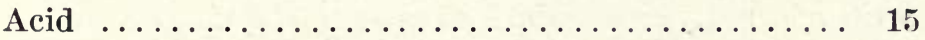

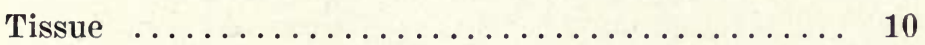

Bouquet ....................... 10 
RULES.

1. The executive committee of the Florida Horticultural Society shall choose a superintendent of exhibition and three judges, with a substitute and a secretary. The executive committee, including ex officio members and competing exhibitors, shall not be eligible as superintendent and judges. The three judges shall conduct tests, and their decision shall be final.

2. The deliberation of these judges shall be secret. The superintendent of exhibition, on application of the chairman of judges, shall from time to time supply the judges with specimens for judgment, and shall use diligence to secure them from intrusion.

3. Each exhibitor is expected to be present with and in charge of his own exhibit. His selection for entries, when ready, must be formally turned over to the superintendent of exhibits, who will then enter by name and number in a book of record, and furnish him a duplicate card to accompany each entry. Entries will be delivered to the judges in the order of their reception and entry by the superintendent. Responsibility for wasted fruit shall rest with the exhibitor, but poor specimens can be replaced or entries withdrawn by consent of the superintendent, before fruit is delivered to the judges. If an exhibitor is unable to be present, he can make a written statement of exhibits as to his fruit and entries, and the superintendent can make selections if necessary.

4. Diplomas or cash premiums, at the disposal of the Society, shall be divided into classes, 1 st, $2 \mathrm{~d}, 3 \mathrm{~d}, 4$ th, in ratio of merit as to premium with ratio of 3 and 2 for single plate premiums. Seven specimens shall constitute a plate to entitle to entry, and two of the specimens 
must be delivered to the judges, who will examine both and score the best. These scores will be eligible both for single plate and collection premiums. The judges reserve the right to debar unworthy or bogus specimens.

5. The judges shall use the amended scale giving ten points each to the following scores and standards of perfection: (1) size, $21-2$ to $31-4$ inches, diameter; (2) appearance - specimen must be fancy and skin silky; (3) for juiciness, it must sink below the surface of water, emergence the size of a silver dollar to count 9, one-half the bulk zero; (4) thickness of peel, 3-32 inch; (5) two seeds to count one point off and two rudiments as one seed; (6) absence of tissue, membranes to be very tender and core porous, 1-8 to 1-4 inch in diameter, as to size of fruit; qualities of flavor, acid, 15; sweetness, 15, and bouquet, 10 ; to be judged by the taste. Specimens of varieties excelling in balance and richness of flavor to be used as standards for reference. Lemons and limes to count 20 for acid and 20 for flavor.

6. These rules must be published with premium list, and after the judges have made the awards with the superintendent of exhibit, they shall deliver the entry book and scores to the executive committee and will receive their discharge.

CALIFORNIA SCALES AND RULES.

The following regulations have been adopted by the Executive Committee of the Los Angeles Chamber of Commerce in reference to the judging of citrus fruits:

No person will be allowed to serve as judge in any class in which he is a competitor. 
Any exhibitor who addresses a judge while the latter is in discharge of his duty, will be debarred from competition.

A majority of the judges present shall constitute a quorum for decision in any class.

Preliminary Classification. Season-Early, from December to April; Middle, February to July; Late, June to December.

Size: Large, medium, small.

(The managing committee from each competing State or section is to norninate varieties to any or all of the above classes, with months, and--when practicable-days, for tests of its own fruit. Fruit to be judged by standards of its class. So far as practicable, no committee is to judge fruit of more than one size, as per above classification.)

\section{ORANGE SCALE.}

IDivisions: size, form, color, weight, peel, fibre, grain, seed, taste; to be considered in order named. Counts. credits, points to be units and tenths thereof, expressed decimally; possible total of same to equal $\mathbf{1 0 0 .}$

1. Size. Possible credits, 10.

Standards- -

Large 126's-3 1-4 inches in diameter.

Medium, 176's-2 15-16 inches in diameter.

Small, 250's-2 7-16 inches in diameter.

Tangierines, etc.-2 1-8 inch in diameter.

One unit discount for each 1-8 inch deficiency or excess in any size.

2. Form. Possible credits, 5.

Standards-Round, oval, ovate, pyriform. 
Discount for lack of symmetry and for form blemishes. Navel marks not to be discounted, except when of abnormal size or of bad form.

3. Color. Possible credits, 19, divided as follows: bloom, 2; peel, 10 ; flesh, 7 .

Standards: Bloom to be perceptible, and to be discounted according to degree of deficiency or of injury thereto; peel to be of rich, deep orange color, in natural condition, and to be discounted according to degree of deviation therefrom, one or more points; rust, scale and smut to be discounted five to ten points, and fruit that gives visible evidence of having been cleaned of the same to be subject to equal penalty; also that has been rubbed or "polished," giving a gloss at the expense of breaking or pressing the oil cells, to suffer the same discount. Flesh to be rich, clear and uniform, in any of the shades common to fine fruit. (Omit consideration of "flesh color" until after concluding division 5, "peel").

4. Weight. Possible credits, 10.

Standards: Specific gravity, 1, with buoyancy of 3-4 oz. allowed to "large" fruit, 1-2 oz. to "medium," and 1-4 oz. to "small," all without discount.

One point to be discounted for first half-ounce of buoyancy in excess of allowance, and thereafter two points for each additional half-ounce.

(Noте-Buoyancy may be easily determined by clasping weights to the fruits with light rubber bands, and then placing in water.)

5. Peel. Possible credits, 10, divided as follows: Finish, 3 ; protective quality, 7.

Standards: Of finish, smoothness and uniformity of surface, and pleasant touch; of protective quality, firm and elastic texture, abundant, compact and unbroken oil 
cells; 1-8 to 3-16 inch thickness. Discount one-half point for first 1-32 inch above maximum or below minimum, and two points for second 1-32 inch, provided that too longpicked and fully-cured oranges the minimum shall be lowered to 3-32 inch; and that to fresh-picked and to slightly-cured "large" fruit the maximum shall be raised 1-4 inch.

Breaking oil cells, breaking of peel and abrasions of same to be subject to one to ten discounts, according to degree.

(Here consider "Color of Flesh"-see Division 3.)

6. Fiber. Possible credits, 4.

Standards: Septa delicate and translucent; maximum diameter of core, 3-16 inch in "large" fruit and 1-8 inch in other.

7. Grain. Possible credits, 4.

Standards: Fineness, firmness, compactness.

8. Seed. Possible credits, 4.

Standard: Absence of seed.

Discount one point for each seed. Each rudinent to be considered as a seed if any growth has been developed; otherwise allowed without discount.

9. Taste. Possible credits, 30, divided as follows: Sweetness, 15 ; citrous quality, 15 .

Standards: Clearness and definability of elements; sweetness rich, delicate rather than heavy; citrous quality pronounced.

Deficiency of absence to be cause for discounts against any element, and excess to be like cause against sweetness and against acid in "citrous quality".

Staleness and flavors of age or decay to be discounted from aggregate of points in this division. 


\section{JAMON SCALE.}

Divisions: Size, form, color, weight, peel, fiber, grain, seed, taste.

Rules of counts and discounts as in scale for oranges. Total of possible credits, 100.

1. Size. Possible credits, 10.

Standards-

Large, 250's-2 3-8 inches in diameter.

Medium, 300's - 2 1-8 inches in diameter.

Small, 360's-1 7-8 inches in diameter.

All sizes between 250's and 360's allowed.

Larger fruit to be discounted one point for each 1-4 inch in excess. Smaller to be discounted one point for 400's (13-4 inches), and four points for 450's (11-2 inches).

2. Form. Possible credits, 15.

Standard: Oblong, with allowance of well-formed points at stem and tip. Symmetry required.

3. Color. Possible credits, 15 .

Standard: Bright, clear lemon.

Discounts according to degree for green splashes, dashes of bronze or deep shades, or for sunburn.

Rust, scale and smut, with fruit that gives evidence of having been cleaned of the same, to be discounted five to ten counts.

Rubbing or dusting, if heavy enough to press oil from the cells, to be causes for discount.

4. Weight. Possible credits, 10.

Standard: Specific gravity, 1 (equal to that of water), with buoyancy of 1-2 oz. allowed to "large" lemons and $1.4 \mathrm{oz}$. to "medium" and "small," all without discount. 
One point to be discounted for first 1-2 oz. in excess of allowance, and two points for each 1-2 oz. thereafter.

5. Peel. Possible credits, 10; subdivisions of which are: Finish, 3 credits; protective quality, 7 credits.

Standard: For protective quality, to be strong, elastic and reasonably firm texture; abundant, compact and unbroken oil cells and thickness of $3-32$ to $3-16$ inch

To be discounted two counts for first 1-32 inch below minimum, and five counts for second 1-32 inch; one count for first 1-32 inch above maximum, and two for each succeeding 1-32 inch.

Fresh-picked lemons not allowed.

6. Fiber. Possible credits, 8.

Standard: Septa delicate and translucent. Core not to exceed 3-16 inch in "large" and 1-8 inch in "medium" and "small" fruit.

7. Grain. Possible credits, 8, divided as follows: Fineness, firmness and compactness, 4 credits; color, 4 credits.

Standard: Grain to be water-colored, shading to blue rather than to gray.

8. Seed. Possible credits, 4.

Standard: Absence of seed.

One-half point to be discounted for each seed. discount of 1-4 credit for each seed is now recommended as sufficient.)

Rudiments are to be considered as seed if any growth has been developed; otherwise allowed without discount.

9. Taste. Possible credits, 30, divided as follows: Acidity, 20 credits; absence of bitterness, 10 credits.

In interstate competitions the standard of acidity shall be the highest per cent of strength of acid found in any fruit, determined by chemical test. In other compe- 
titions such tests may be applied as committees or competitors may require.

Bitterness to be determined by slicing fruit (including peel) thin, covering with hot water, and cooling slowly; to stand twenty-four hours when practicable (no sugar to be used). Should a trace of bitterness appear to the taste, discount one point; should the bitterness be fairly defined, discount two points; if pronounced, discount five points; and if strong, ten points.

PROPOSED POMELO SCALE.

Scale.

Points.

External Characters-

Size ...................... 10

Color and form ............... 10

Weight or juiciness $\ldots \ldots \ldots \ldots \ldots \ldots \ldots$

Rind ..................... 10

Internal Characters-

Seedlessness $\ldots \ldots \ldots \ldots \ldots \ldots \ldots \ldots \ldots .10$

Freedom from fiber or tissue ......... 10 Juice Qualities-

Flavor

Sweetness .............. 15

Acidity ............... 10

Bitterness .............. 10

1. Size Standard-4 to 5 inches.

2. Color Standard-Bright, uniform, light yellow.

3. Form Standard-Round or slightly oblate.

4. Weight or Juiciness Standard-Heavy, sinking almost entirely in water.

5. Rind Standard-3-16 inch in thickness. 
6. Seedlessness Standard-No seeds. Deduct one point for each five seeds.

7. Freedom from Fiber and Tissue Standard-Free firom rag.

8. Flavor Standard-A harmonious blending of sweetness, acidity and bitterness. 


\section{PART II.}

\section{CULTURAL.}





\section{CHAPTER XXVI.}

\section{PROPAGATION OF CITRUS TREES.}

Citrus trees may be propagated by budding, by grafting, by seeds, by cutting or by layering. The last mentioned method is little used, except for the citron, and in America it is scarcely ever resorted to as a means for multiplying that tree. Budding is by far the most common method in all citrus districts. Seedling trees are not planted in such numbers as they formerly were. Fifty years or so ago, and even not so far back, it was the rule to plant seedling citrus trees, now it is the exception. The beginning of any tree fruit industry is usually marked by the planting of seedling trees. Budded or grafted trees represent adaptation to new conditions, divergence, specialization, progress. The planting of seeds as a method of propagation should not be entirely discountenanced, however. The seedling groves of Florida and other citrus districts of America produce good fruit in abundance and from them have been selected many of the prominent varieties now so commonly planted. This is one of the reasons why seedling trees should not be condemned and the planting of seeds for the purpose of originating new varieties is certainly commendable. But better results can probably be obtained by cross-fertilization of existing varieties as well as species.

Seedling trees may be depended upon to give fruit of good quality, but since they are not produced true to the variety from which the seed was obtained, they may not be prolific, the fruit may be undersized, or undesirable for some other reason. Generally, however, the fruit is good, 
so far as its eating quality is concerned. As much cannot be said for the fruit from seedling trees of any other kind. Seedling plums, apples or pears may be entirely unfit to eat. This is rarely true of the orange or pomelo.

But the advantages of budded trees are many. They bear at an earlier age. A crop of fruit of uniform size and quality can be secured. Varieties ripening at different seasons may be planted and a continual crop from September to June, or even later, may thus be had. The grower, besides having a choice of varieties, has a choice of stocks which he would not have were he to plant seedlings, and better results can be obtained on different soils than would otherwise be the case. Besides, mal-di-goma, that one-time dreaded enemy of the sweet orange and lemon may be avoided by using stocks which will resist it.

CITRUS SEED USED IN PROPAGATION, AND THEIR CARE.

There is considerable difference in the size and shape of the different kinds of citrus seeds commonly used in growing stocks. Every propagator should be acquainted with them, that substitutions may be avoided. The seeds of the pomelo, trifoliate orange, sweet orange, rough lemon and sour orange are shown in Fig 40, and these illustrations, with the accompanying descriptions may be found useful.

Pomelo. Plano-convex or wedge-shaped, pointed or broad and flat at the micropylar end; 11-16 inch long $x$ 1-2 inch wide $x$ 3-16 inch thick, 5-8 inch long $\times$ 7-16 inch wide $x$ 1-4 inch thick; smooth on two sides over considerable areas, marked with anastomosing lines or ridges on the other parts. 


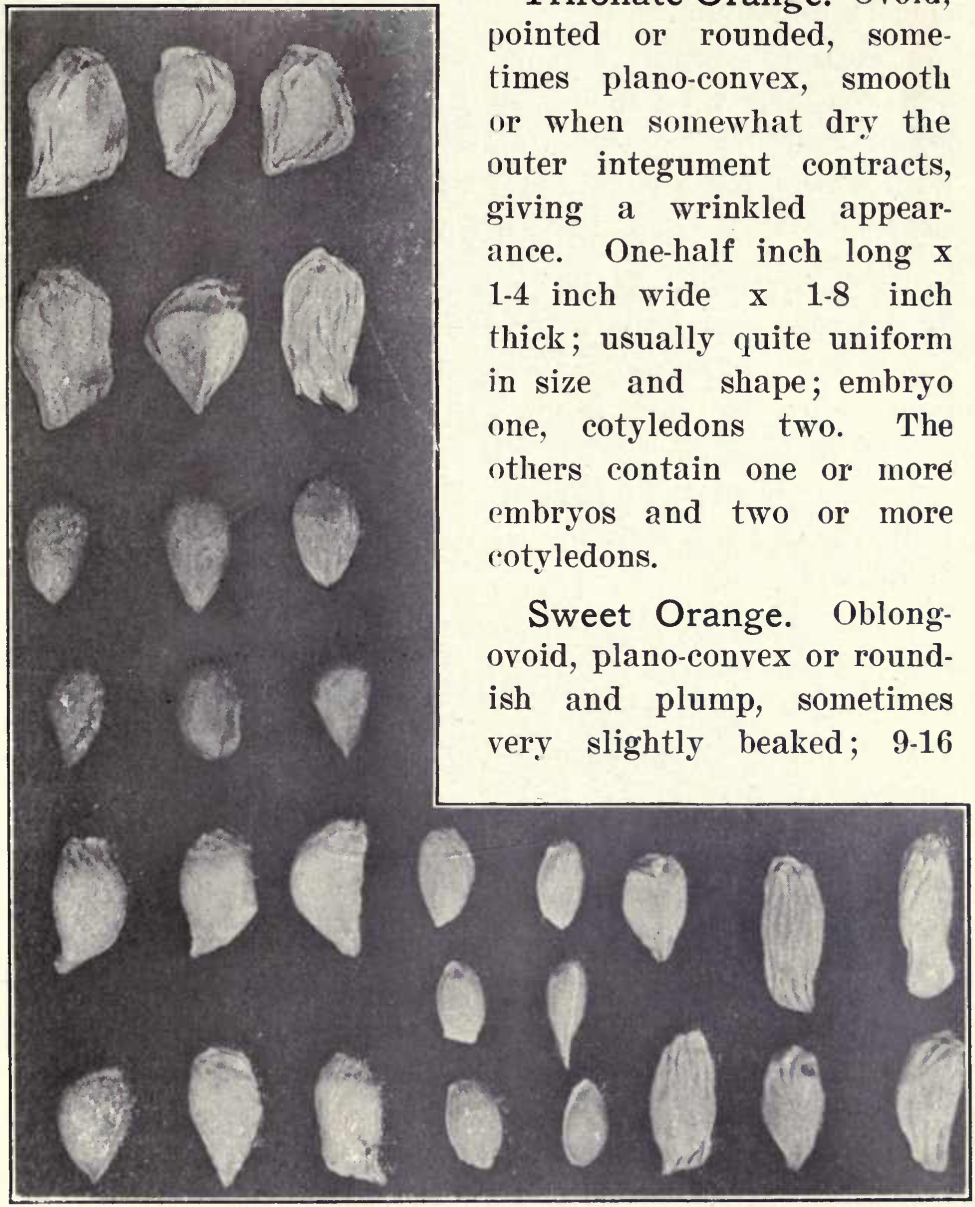

Trifoliate Orange. Ovoid, pointed or rounded, sometimes plano-convex, smooth or when somewhat dry the outer integument contracts, giving a wrinkled appearance. One-half inch long $x$ -4 inch wide $x \quad 1-8$ inch thick, usually quite uniform size and shape, embryo ne, cotyledons two. The others contain one or more mbryos and two or more

Sweet Orange. Oblongovold, plano-convex or roundish and plump, sometimes very slightly beaked; $9-16$

Fig. 40. Six seeds each of pomelo-trifoliate orange, sweet orangerough lemon-sour orange-arranged in the order named.

(Natural size.)

inch long $\mathrm{x}$ 5-16 inch wide $\mathrm{x}$ 1-4 inch thick, 1-2 inch long $\mathrm{x}$ 5 -16 inch wide $\times 1$-4 inch thick, or larger; lines not promi- 
nent, generally oblique in direction, one or two areas smooth and plain.

Rough Lemon. Ovoid or slightly tapering; small, 3-8 inch long $x$ 1-4 inch wide $x$ 3-16 inch thick, 7-16 inch long $\times$ 3-16 inch wide $\times 3-16$ inch thick; frequently marked with a prominent ridge along one edge, other lines small, rather in inconspicuous, anastomosing.

Sour Orange. Plano-convex or double-convex, pointed or flattened and wedged toward the micropylar end, long and narrow or slightly rounded; 11-16 inch long $x$ 5-16 inch wide $\times$ 3-16 inch thick, 9-16 inch long $\times 1-4$ inch wide x 3-16 inch thick. When plano-convex, there is a large, smooth area on the flattened side, the rounded side being ridged with long, more or less parallel ridges, which unite at the ends.

The seeds used in propagation work should be selected from healthy, vigorous trees, and small, immature seed should be discarded. Careful selection in this matter will do much toward procuring vigorous, well developed stocks.

Seeds may be separated from the fruit by cutting it in halves and squeezing them out into a sieve. This will allow the juice to run through and the seeds may be washed from the pulp afterwards. The work can be readily and cheaply performed by boys. Another method is to place the fruit in barrels and allow it to rot, after which the seed is washed free from the pulpy mass with running water, using a sieve as before.

If citrus seeds are allowed to become too dry, they do not germinate well and unless they are to be planted immediately, they should be stratified in damp sand or earth. The former, washed free from all impurities, is preferable, as organic substances in the soil may contain 
decay-producing organisms. These sometimes attack the seed.

THE SEED-BED AND ITS MANAGEMENT.

If only a small number of seedlings is desired they may be raised in boxes or flats. (Fig. 41). These should be six or eight inches deep and of any convenient width and length. They should be filled with good virgin soil. The seeds may be sown rather thickly in rows three inches apart. When six or eight inches high, they may be transplanted to the nursery row.

When a large number of seedlings is required, a seedbed must be provided. It should be composed of rich, friable earth, sufficiently moist to insure proper germination of the seed. If deficient in plant food, it may be en-

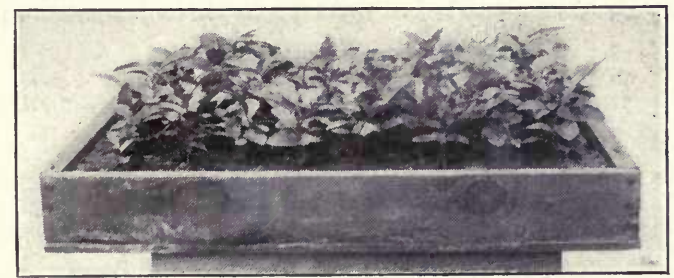

Fig. 41. Seedling pomelos raised in a flat.

riched by the addition of commercial fertilizer such as is recommended for young trees. This should be applied to the bed and worked into the soil two or three weeks before planting the seed. It is unsafe to apply commercial fertilizer and then plant the seed immediately afterward. The length of time which should elapse between the two operations will depend upon the amount of moisture in the soil and the quantity of fertilizer applied. If very dry weather follows the applying of the fertilizer, a longer time must be allowed to intervene than if there be plenty of rain. 
The seed should be sowed as soon as all danger of frost is past. Generally the seed is placed in the ground about the first of March, though it may sometimes be safely done a week or two earlier. Much depends upon the location. If a comparatively small number of seedlings are required, the rows may be placed quite close together, but where seedlings are raised by the thousands, hand labor is too expensive. Cultivation must then be done with a horse or mule and the space between the rows should be sufficiently great to admit of this, two and a half to three feet being about right. The seed should be planted quite thickly, at a depth of three-quarters of an inch or an inch. The ground should be moist at the time
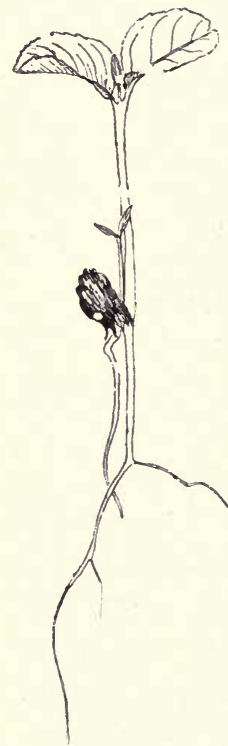

Fig. 42. Germination of pomelo seed showing two plantlets from one seed. of planting to secure the best results.

Throughout the season the ground should be cultivated thoroughly and frequently, and weeds should not be allowed to spring up. In many sections one or two additional applications of commercial fertilizer should be made during the summer. Care must be taken that the seedlings do not dry out. To prevent this it may be necessary to irrigate, but frequent shallow cultivation, to preserve an earthmulch will help very materially. Some resort to mulching to prevent the escape of moisture. Both in California and Florida seed-beds are frequently made under lath sheds. These keep the scorching rays of the sun from striking the plants, prevent rapid evaporation and afford protection to the young plants against frost. 
The seedlings should usually be allowed to remain in the seed-bed until they have had one or two season's growth They may be transplanted to the nursery rows when a quarter of an inch or so in diameter at the ground. The best time for transplanting is in winter though the same general laws apply as in transplanting larger trees.

In digging the seedlings from the seed-bed, the spade should be shoved down beside them to a depth of eight or ten inches. After they are loosened and the tap-root has been severed at about that depth, they may be lifted out readily. Before setting them in the nursery row, the tap-root should be trimmed back to insure a well-branched root system.

\section{THE NURSERY AND ITS CARE.}

The ground for the nursery should be carefully selected. A piece of ground with a rather heavy sub-soil and light, meliow surface scil is best. A good preparation for the nursery is to plant it in beggarweed or velvet beans the year previous to planting, and in regular nursery work, one of these legumes should always be planted after a block of trees is removed.

Seedlings may be transplanted from the seed-bed to the nursery in November and December. In frosty regions, a furrow may be plowed against each side of the row to protect them from frost.

Cultivate the ground thoroughly before transplanting and apply commercial fertilizer in rather liberal quantities. One application should be given some time before the seedlings are set out, a second in June and a third in August, about one ton in all per acre. The rows should be 
carefully laid off, perfectly straight, three and a half or four feet apart. This will give plenty of room for cultivation and for the work of budding.

The seedlings should be set in the rows from twelve to fifteen inches apart. If the soil is dry at the time of transplanting, water should be applied. The trees should be firmly placed in the soil with the earth firmly packed about them. At time of transplanting the well-developed, vigorous seedlings should be set out together. The smaller ones should be planted by themselves. Thorough, clean cultivation should be the rule. Make every effort to keep the little trees growing throughout the season. Cultivation must cease in time to allow the wood to harden up before cold weather. One year after transplanting, most of the seedlings will be ready for budding. By this time they should be upwards of one-half inch in diameter at the crown.

Since the scab fungus attacks sour seedlings severely, and interferes materially with their growth and development it is a good practice to spray them, both in the seedbed and nursery, with Bordeaux mixture. The disease can be kept down by its use and as a result a much better growth will be made during the season.

\section{CUTTINGS.}

Many varieties of citrus trees may be propagated from cuttings. The Otaheite orange, used as an ornamental and as a stock for dwarfing large-growing citrus trees is usually propagated in this way. The citron roots easily, so also does its near relative, the lemon. For these trees propagation by cuttings seems to give good results. Cuttings of the pomelo and orange are more difficult to root and, though it may be accomplished, the method for these 
trees has little to recommend it and is not practicable. The citron, lemon, trifoliate orange and Otaheite orange may be grown from cuttings.

Cuttings should be made from well matured wood of one or two season's growth. Each cutting should have at least three or four well matured buds and should be about five inches long. Trim off the leaves, cut the distal end with a smooth, sloping cut just above a bud and cut the proximal end so as to leave a similar surface just below a bud. The knife should have a keen, sharp edge to insure smoothness of the cut surfaces. A clean, smooth cut greatly facilitates the formation of a callus, which must take place before roots will develop.

Though the cuttings may be rooted in almost any well drained soil, still the better plan is to plant them in clean washed sand, free from organic substances. Organic matter nearly always contains the organisms of decay. These may attack the cuttings and cause them to rot. Place the cuttings in rows six to twelve inches apart and three or four inches apart in the rows. Give sufficient water to keep the cutting led moist, and protect it from the direct rays of the sun. If bottom heat can be applied, they will take root more readily. When the cuttings have formed a number of roots, and have sent out shoots bear-

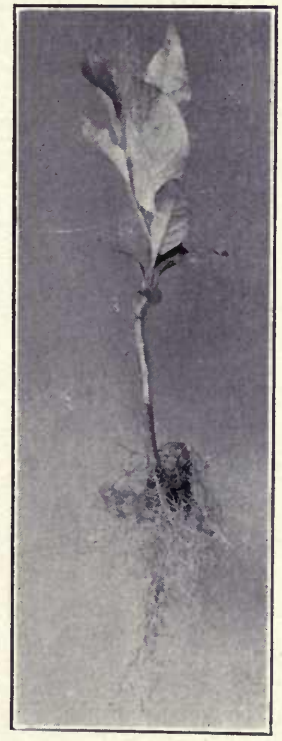

Fig. 43. Genoa lemon cutting, six months old; stem four inches long. ing two or three leaves, they may be transplanted to two or three inch pots. The cuttings may be allowed to de- 
velop into trees or they may be budded or grafted, if so desired, after they have attained sufficient size.

SELECTING, CUTTING AND KEEPING BUDWOOD AND CIONS.

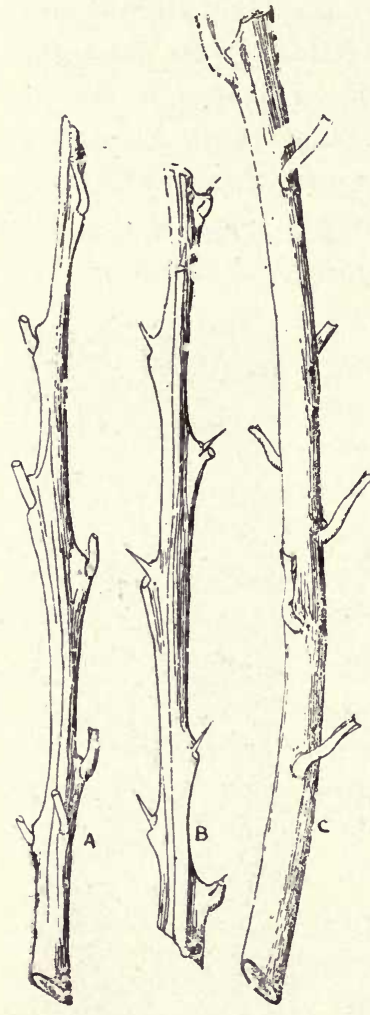

F'ig. 44. Different kinds of budwood . A, angled wood. $\mathrm{B}$, angled, with thorns. C, round.

The most rigid care should be exercised that no mistake be made in the identity of the tree or trees from which budwood and cions are to be cut. At all places in the process of propagation where it is possible for errors to occur, no precaution should be neglected to guard against mixing of varieties or the accidental substitution of one variety for another. Careful labeling of varieties, the providing of plantation maps, the employment of capable, conscientious men, and attention to all details of the work on the part of overseer's will, in large establishments, go a long way toward preventing the occurrence of mistakes and the consequent origination of supposedly new varieties or the mixing of old ones. Both budwood and cions should be chosen from well matured wood of not more than one season's growth. Usually it is best to select from wood of the last one or two growths matured just previous to the time of cutting, bear- 
ing in mind always that cirtus trees generally make and mature three or more distinct growths each season. In cases where the variety is especially valuable, almost any bud, small, immature or growing, may be used and made to grow, but for general propagation work, such are not desirable. For ordinary shield budding, round wood is preferable, and to secure this the older wood must generally be used. All very new growth is more or less angular, it becomes round only as it grows older. For shield-budding with a right angled or curved incision, angled wood must be chosen, while for graft cions, either will do, provided it is all right in other respects. No wood should be taken from diseased or unthrifty trees; the parent tree should be healthy and vigorous. Thorny wood should be avoided whenever possible. Thorns are very undesirable on citrus trees and every effort should be made to eliminate them. Rigid selection, throughout a number of bud generations, of buds or cions from thornless shoots borne on those trees producing the fewest thorns will eventually bring about the desired change in most varieties. It has been a somewhat mooted question as to whether it is a good practice to cut budwood or cions from anything except bearing trees. The general conclusion borne out by the experience of many growers is that wood from young non-bearing trees gives as good results in fruiting trees as when chosen from bear-) ing trees. Here and there in nearly every grove unproductive trees are to be found, a condition probably brought about by the use of naturally barren buds, but this is as likely to occur where one practice is followed as where the other is adopted.

There is no way to prevent this undesirable condition, and the best treatment for such trees is to top work them. 
By so doing they may be made fruitful in two or three years. On the other hand, it is believed that some varieties may be made more prolific by carefully selecting buds or cions from the most fruitful branches of those trees showing a tendency toward a more fruitful habit. Of most of our citrus varieties it may be said, however, that they are sufficiently prolific when worked on congenial stocks and grown under the right conditions.

For work in early spring, the bud sticks or grafts should be cut from the trees the previous December, if there is danger of injury from frost. The wood is thor-

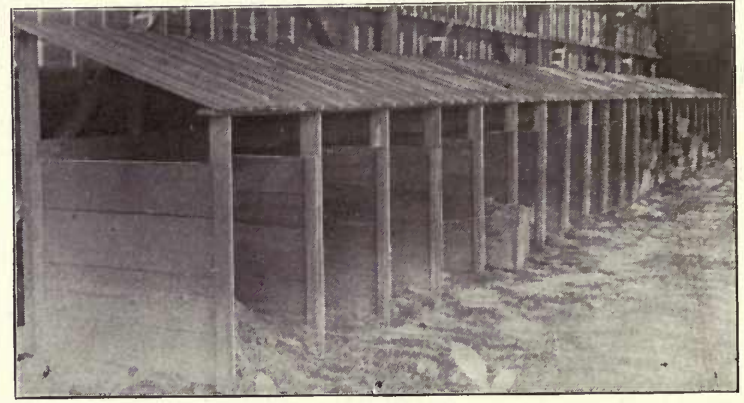

Fig. 45. Mr. Taber's method of keeping budwood. Each bin contains a separate variety, buried in sphagnum.

oughly hardened by this time and may be kept for use in June or July as well, though material may be secured from the trees at the time of June and dormant budding. In sections free from frost, the wood may be cut just previous to the commencement of growth in spring, if required for immediate use, but the better plan is to cut the wood in December.

It is poor policy to wait until after the trees have started to grow before attempting to secure budwood and cions. On citrus trees most of the desirable buds 
develop into growing shoots. Many of these new shoots must be sacrificed to obtain any quantity of wood and that which is procured is very inferior. Instead of trying to secure material out of season, cut it at the proper time.

Remove the leaves and cut the wood in lengths of a foot or so. If only a small quantity is required, tie in small bundles, pack them in moist sphagnum or saw-dust in a box, replace the cover and bury it six or eight inches deep in the earth in a shady place. The bundles should be carefully labeled and care should be taken not to have the moss too damp.

If large quantities of wood are needed in spring, the method of keeping it used by Mr. G. L. Taber, is one of the best. Select a well drained space. Place the budwood on the ground in layers with damp sphagnum between the layers. Then cover the whole with sphagnum. The piles must not be too large, and should be protected from the sun and rain. The air is allowed to circulate freely about and over the piles. The cions or budwood keep perfectly until needed for use, when it will be found that the cut surfaces have callused.

MATERIALS AND TOOLS FOR PERFORMING THE WORK.

The materials and tools used in budding and grafting are neither numerous nor expensive. While a considerable amount of work may be done with a piece of twine and a knife, still if a large amount of work is to be done, the following articles will facilitate the operations and should be provided: grafting wax, pruning knife, grafting iron, shears, a small mallet and labels.

Waxes and Cloth. The following recipes have been tried and found to be equally good for our conditions: 
Recipe No. 1. Resin, 6 lbs.; beeswax, 2 lbs.; linseed oil, 1 pint.

Recipe No. 2. Resin, 4 lbs.; beeswax, 2 lbs.; tallow, 1 lb. The directions for preparing them are briefly as follows :

Break the resin into small pieces, cut up the beeswax and place the two together in a suitable iron pot. Pour the linseed oil over them, or in case recipe No. 2 is used, place the tallow on top. Set the pot over a slow fire and allow the materials to melt. Afterward remove from the fire, pour into cold water, grease the hands and pull until it is light colored.

If a liquid wax is desired, take one pound of resin, two ounces of tallow, melt them together and mix thoroughly. Remove from the fire, cool slightly and add slowly six ounces alcohol and one ounce spirits turpentine Keep tightly corked in a wide-mouthed bottle. Apply with a brush.

For waxed cloth, procure thin muslin cloth and saturate it with wax made according to either of the recipes given above. Prepare the cloth by tearing into strips four or five inches wide and winding it around sticks about a foot or so in length and one inch thick. The rolls should not be more than two inches thick, else the wax will not penetrate to the center. Melt the wax over a slow fire, place the rolls in it and allow it to remain there until the wax has penetrated the cloth. The wax should not be allowed to become too hot, else there is danger of burning the cloth. Have it just hot enough to keep the wax in a melted condition. As soon as it is saturated, remove the cloth from the wax and store away. When required for use, unroll the desired length and tear it into strips one-half to three-quarters of an inch wide. 
Instead of tearing the cloth into strips four or five inches wide, it may be dipped into the wax in large sheets, immediately removed and stretched out on a flat surface. Or the cloth may be stretched out and the hot wax applied to its surface with a brush. When prepared by either of these methods, it may be torn into strips from one-half to three-quarters of an inch wide and wound around a stick as before, or carried to the field in small, rectangular sheets, from which strips may be torn as they are needed.

If twine is desired, procure balls of No. 18 knitting cotton and place them in the melted wax. Keep them immersed and turn them over frequently. In the course of five or six minutes the wax will have penetrated through and through, when they may be removed and set aside. Untreated cloth or twine or raffia may be used instead of the waxed material, but the advantage of the latter over the former is that while possessing sufficient strength, it is more easily broken and it is not necessary to tie them about the stock. They may be drawn tight, whereupon the sticky, waxy surface will hold the wrapping in place.

Tools. Good grafting and pruning knives may be procured from almost any hardware merchant or from dealers in horticultural implements and supplies. The budding knife should have a thin blade, rounded at the point. In the end of the handle a piece of thin bone is inserted, or the end of the handle is thinned down to serve the same purpose. This spatula at the end of the handle is intended for lifting the edges of the bark in budding, as explained in the section on budding, but as a matter of fact, it is seldom used, the blade of the knife being used instead. 
The best pruning knives are those with a heavy staghorn handle and straight or somewhat curved blades. This knife is used in propagation work to smooth the cut surface of the stock, for splitting the stock and frequently for removing small branches and thorns which may be in the way of the operator. For the latter purpose, however, the pruning shears are preferable.

The best shears are the solid steel ones. They are strong and durable. The blades are easily tightened and they can be taken apart for sharpening when so desired. Nothing is more unsatisfactory than to have to work with a poor pair of shears, and the best should be secured.

In cleft grafting, the grafting iron and

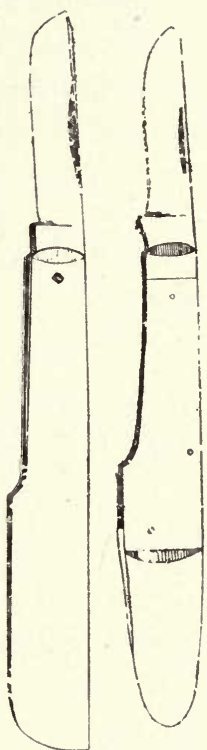
mallet come into use. An iron with a blade shaped as in Fig. 47 is best.

- (9) For nursery work, labels made of inch mater. ial, two and one-half inches wide and two and a half or three feet long should be provided. These are to be used as labels for rows of varieties, the name being plainly stamped on the upper portion. For block labels, nothing is better than cypress posts three or four inches in diameter. These are sloped off at the top, leaving a broad, smooth surface, three or four inches long by as 1: much in width. This area is then painted white and the block number placed on it. Wired, wooden Fig. 47.
Grafting Graftin
iron. 


\section{BUDDING.}

Time. In all citrus growing districts, nursery trees are propagated almost entirely by budding. Buds may be inserted in citrus stocks any time during the growing per10d. The trees are not periodic in their growth as apples and plums are, for instance. When well cultivated and fertilized, the stocks will make at least three growths during the spring and summer. Each one of these is matured and hardened before the next begins. During the hardening or rest period, the bark does not slip so well as during the time of growth. In most citrus districts the winter rest period, partial or otherwise, extends from about November to February, depending, of course, upon the latitude and the climatic conditions throughout the winter.

During this period, buds cannot be inserted to advantage as there is not sufficient sap moving to cause the bark to slip readily. In Florida, California and Louisiana, buds may be inserted in March and April. In the Islands, where the winter temperatures are not so low as in the districts just referred to, and where in consequence the winter rest period is of shorter duration, the buds may be inserted much earlier. Budding early in the season is termed spring budding. In June and July, or in Florida, just before the commencement of the rainy season, budding may be performed. This is summer budding. Generally, a very considerable amount of budding is done during September and October, dormant budding. In this case the buds remain dormant until the following spring, when they commence to grow. They are protected in the nursery rows in the cooler districts by plowing a furrow against them. The tops of the stocks may be frozen back, 
but no harn results. It simply takes the place of pruning and starts the buds growing soon after the furrow is removed, which should be done during the latter part of March or somewhat earlier. Summer budding is not to be recommended for all sections. In frostless regions, no objection can be urged against the practice, but in regions subject to frost, the growth, resulting from buds inserted at this time, is often not sufficiently matured to withstand the frosts of early fall and winter. Of course, the point of union with the stock may be covered with earth as mentioned above, but even then if the growth be soft and succulent, it may be stunted or killed outright.

Methods. As soon as the stocks have attained sufficient size, buds may be inserted in them. Occasionally stocks grown from seed planted in spring may be dormantbudded the following autumn, or they may be springbudded when one year old, or worked in June or the fol. lowing September. These are exceptions, however, and generally the stocks are budded when two or three years old, but there is no age limit beyond which buds cannot be inserted by some method, provided the stocks are of sufficient size and the bark will slip readily. One other matter must be considered before taking up the actual discussion of methods. It should be borne in mind that the point of union between the stock and cion is more subject to the effects of cold than any other part of the trunk of a budded tree. Besides, if all that part which has developed from the cion, perishes in cold weather, re-budding is necessary. This might be prevented by budding well down toward the crown roots, that the earth might afford protection or that it might be more easily banked against the point of union during the dangerous season. 
On the other hand, it must not be lost sight of that on many soils one would be running the risk of having sweet, mandarin or lemon trunks attacked by mal-di-goma, or foot-rot, even where worked upon sour orange, pomelo or other resistant stocks, if the point of union be placed too close to the ground. They are just as liable to attack as though they were seedling varieties of the groups just mentioned. To avoid this, the point of union should be some distance above the ground. In lemon districts, where irrigation either by furrow or basin methods is resorted to, as in California, for instance, the point of union between stock and cion should be a sufficient distance above the ground to protect the lemon trunk from the moisture provided by irrigation. Unless this be done the trunks may become diseased. From these remarks it will be seen that a knowledge of the conditions must determine the point at which it would be best to insert the buds.

The method of budding most commonly used, and the one used entirely in nursery work, is that known as shield or $T$ budding. In California the method properly known by this name is used, while in Florida and Louisiana the reversed method, or inverted $\mathrm{T}$ incision is used. The best practice in the Islands is to follow the Florida and Louisiana method. The reason usually assigned for the use of the reversed method is that it excludes water from the cuts. But if waxed cloth is used, this explanation has little force. Baltet says that it is used to avoid the smothering of the bud by the superabundance of sap. This holds good for our summer conditions, but is scarcely applicable to spring budding. It is perhaps true that the reversed method is commonly used as a matter of custom. At any rate we have secured as good results by one method as by the other. 


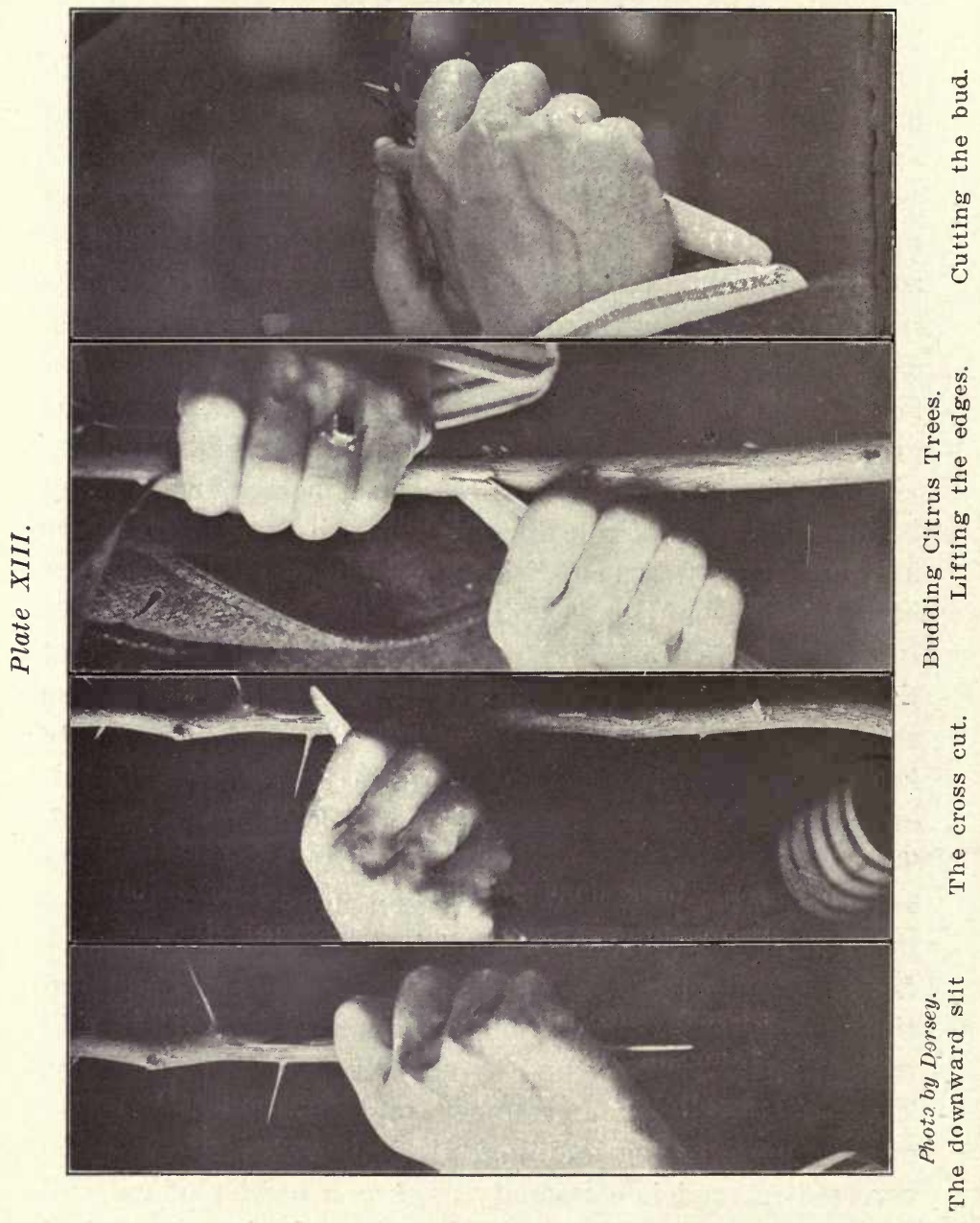




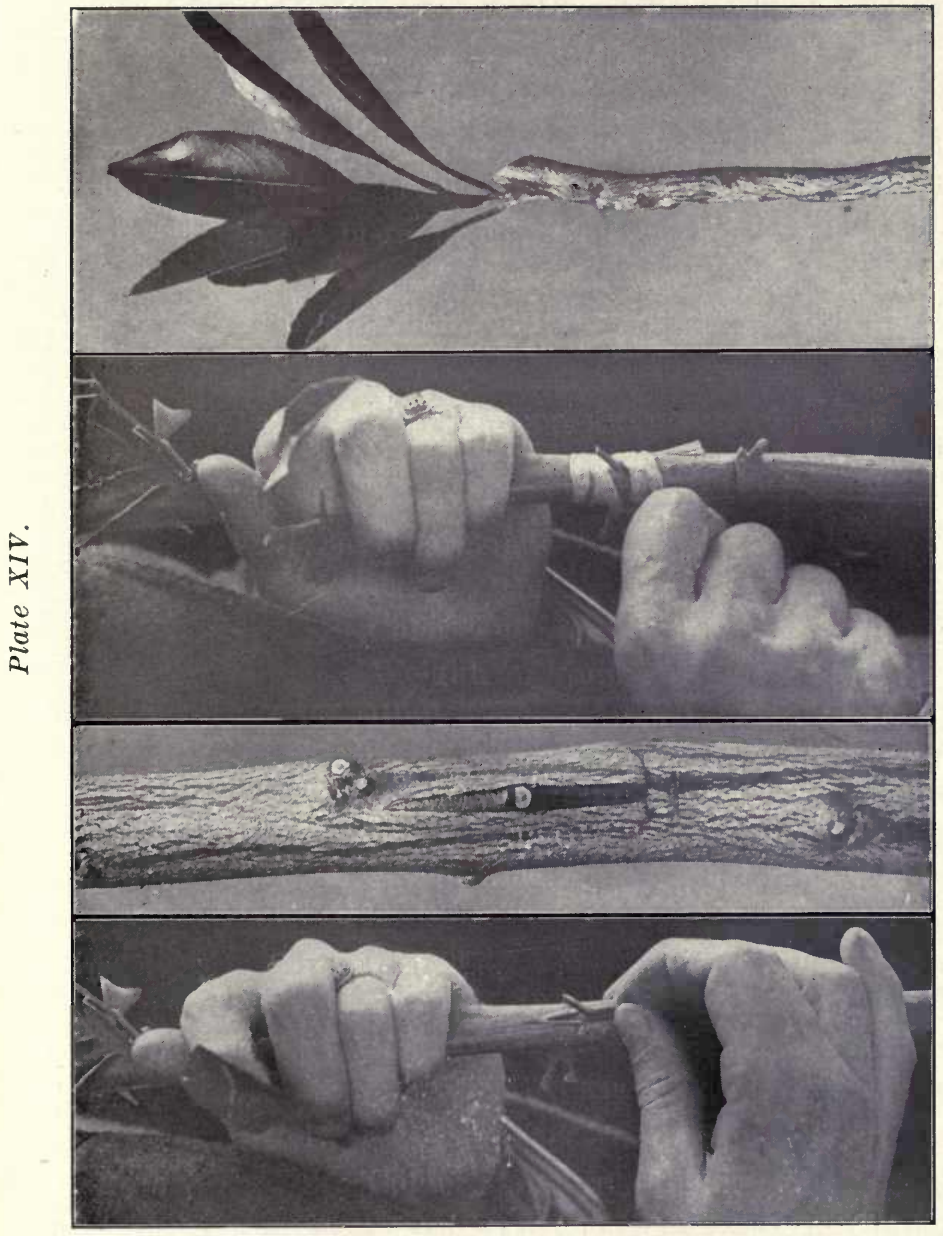


Plates XIII and XIV show the different steps in the process of shield budding citrus trees as done in Florida.

Select the point at which the bud is to be inserted and remove all thorns or branches which may interfere with the work. Then a perpendicular slit an inch and a half in length is made on the side of the stock (1) and at its lower end a cross cut is made with the cutting edge of the blade slanting upwards (2). A cut of this kind is preferable, as it makes it easier to insert the bud. Then the corners formed by the intersection of the two cuts are carefully lifted with the point of the knife blade to permit the entrance of the bud (3) or the bone end of the handle may be used instead. Then the bud-stick is grasped in one hand with its proximal end away from the operator. To remove the bud, start the knife in about one-half inch below it and pass it smoothly along beneath it and finish the cut about one-half inch above the bud (4). The cut is best made from below the bud, upwards, as there is less likelihood of its being injured by the upward pressure of the knife against it. After having removed the bud, it is held lightly between the thumb and fore-finger and shoved upwards in the incision made for its reception (5). Do not invert it in inserting. Generally each bud bears beneath it a leaf stalk or the scar left where it has been dropped or has been cut off. When the bud is inserted, this scar should be nearest the ground. Then the wrapping, a strip of waxed cloth, or raffia, is placed about the stock over the inserted bud to hold the latter snugly in place and closely in contact with the cambium of the stock (7.) In all cases the wrapping should be drawn over the intersecting cuts first, and then worked upward in the reversed method or downward in the ordinary one, as followed in California. 
Sometimes it is very difficult to secure anything except angled budwood. If a bud is cut from such wood by holding the knife directly under the bud, it is cut off with a shield so narrow as to be undesirable. In such cases the bud should be cut from the side, removing a shieldshaped piece of bark as before, but with the bud at one side of it instead of in the center. Then instead of making an inverted $\mathrm{T}$ incision for its reception, a right-angled incision should be made (Fig. 48) with the lower cut either to the right or left to suit the bud. The angle of the bark at the intersection of the cuts is then lifted and the bud inserted so as to have the bud in position in the upright incision. This method should be known as shieldbudding with a right-angled incision. After inserting, the bud is wrapped as directed above.

An examination made ten days or two weeks after the insertion of the buds will determine whether they have united with the stocks or not. If at that time the buds are still green and a grayish line of new tissue is seen around the edges of the incisions, it may be safely concluded that union has taken place and that the bud will grow, provided it is a perfect one. If the buds have united, remove the wrapping and after three or four days the stock should be either lopped, pruned back or cut entirely off. Those stocks in which buds have failed to take should be re-budded.

Lopping is not always necessary, particularly with small stocks. They may be cut entirely off. But lopping is the safest plan to follow with stock of considerable size and particularly with such vigorous growers as pomelo and rough lemon.

Cut in with the saw or pruning shears on the same side as that on which the bud is, making the cut about two 
inches above the bud and passing through the stock about two-thirds of the way. Then bend the top over, being careful, if it splits, that the line of cleavage runs upward toward the top, not downward toward the root. In lopping trees recently budded in the nursery rows, the
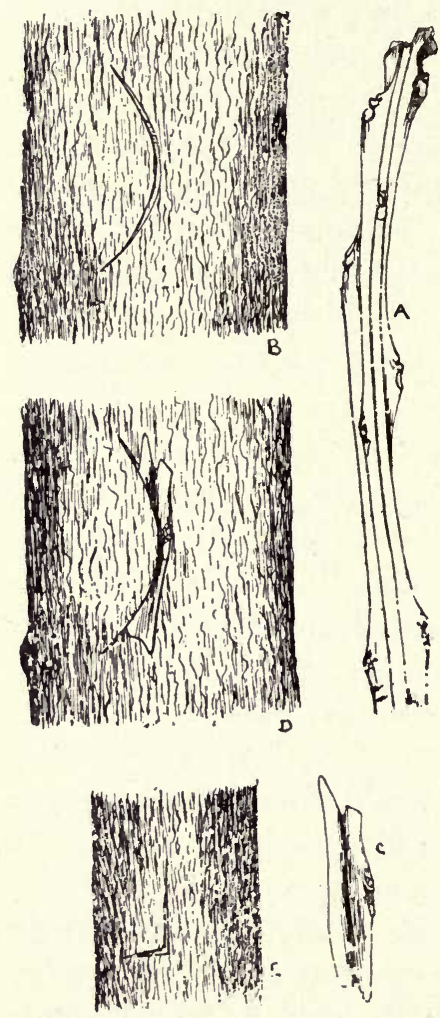
tops in each pair of rows should be turned into the space between them, thus leaving $\mathrm{each}$ alternate space free for cultivation.

When the buds have pushed out to a distance of a foot or more, the lopped stocks may be removed entirely by being cut smoothly off just above the bud. At this stage, whether lopping has been resorted to or not, each bud should have a stake placed beside it and it should be tied to the stake, using cotton twine, raffia, or cotton cloth torn in strips. The stakes may be split from heart-wood of pine or other durable wood and should be about three-quarters of an inch

Fig. 48. Budding old trees with firm, hard bark. A, angled budwood. B, curved incision. C, the bud ready for insertion. D, the bud partially inserted. $\mathrm{E}$, right-angled incision.

square and four feet long. As the bud grows upward, it should be tied to the stake to keep it from falling over. 
Budding old stocles. If an attempt is made to insert buds in old stems or trunks, it will be found a difficult task to perform by the shield method, with an inverted $T$ incision. The bark may separate readily from the wood, but even then, when the attempt is made to lift it away to allow the insertion of the bud, being quite thick and brittle, it generally breaks or cracks. But buds may be inserted by using a curved incision. Angular budwood, as shown in fig. 48 should be chosen. From this, buds are removed as already directed, but the stick is held with the bud well to one side so that when the bud is cut off it is either at the left or the right side of the shield instead of being in the center. Then the curved incision is made in the stock to right or left to suit the bud. The bark is then carefully lifted and the bud inserted and tied, leaving the bud well out at the side of the curve. This method should be known as shield-budding with a curved incision.

The after treatment of the buds is the same as in ordinary shield-budding.

GRAFTING.

As already stated, the propagation of nursery trees is accomplished almost entirely by budding. Grafting is objectionable in this line of work because it cannot be done so rapidly and besides the whole top of the stock is often wasted, whereas, in budding, if the bud fails to take, a second attempt may be made shortly afterwards on the same stock.

Nevertheless, in some special cases, grafting is preferable to budding. Such is often the case in working over old trees which have been frozen back. If they are to be budded, some time must elapse before the buds can be inserted. Sometimes it is necessary to wait until sprouts 
have started and reached sufficient size, but such trees can be crown-grafted at once, thus frequently saving a year's time. Trees girdled or injured by mal-di-goma, or in other ways, may frequently be saved by inarching small trees planted close to the diseased one, or in some instances, a number of sprouts around an old stump may have all their energies directed to the support of a single top.

\section{METHODS.}

The methods which will be found most useful are those known as cleft, whip, crown, side-grafting and inarching. Grafting may be done somewhat earlier in spring than budding or it may be done any time during the season when the sap is moving. Generally speaking, however, the work should be done some time before the end of June. The best time is before growth starts.

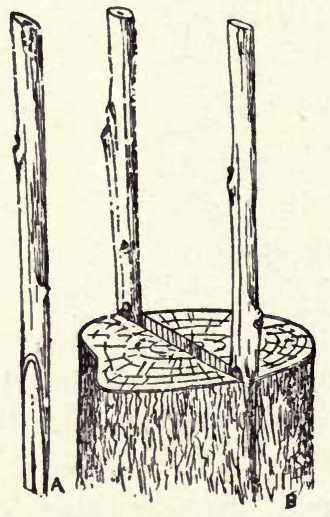

Cleft-Grafting. It may in some cases be desirable to work citrus trees by this method and it will be found useful in working large trunks, branches or old sprouts. The stock is cut off at right angles and the cut surface made perfectly smooth. Then it is split or cleft open, using either a budding knife (fig. 46) or a grafting iron (fig. 47) and the mallet. Frequently the line of cleavage in orange wood is very irregular, hence it is best Fig. ${ }^{49}$. Cleft-grafting. A, to drive the knife or iron in on the ready for tieing.

side of the stock before splitting it. This will leave a smooth, straight surface for the cion. After making the cleft, it may be held open with the wedge 
end of the grafting iron, or, if a knife is used, by a wooden wedge prepared for the purpose. The cions should have three or four buds and should be four or five inches in length. Prepare them by trimming the lower end to a wedge (fig. 49) with the outer edge slightly wider than the inner. The sloping cuts should be about one and a half inches long. Slip the cion down into the cleft until the whole of the cut surface is within the cleft (fig. 49.) The thicker edge should be outside, so that the stock may bring the cambium edges more intimately in contact by its pressure against it. If the stock be large, two cions may be inserted, one in each side of the cleft. After inserting the cion or cions, the stock should be firmly bound with strips of waxed cloth. The cut surface should be covered over with grafting wax to prevent loss of moisture. If the top of the cion has been cut off it should also be covered with a little of the wax. If the cion has been inserted below the ground, the earth should be heaped up around it, covering all except the last bud. No further attention is needed until growth starts, at which time the bandage should be severed, either in the space between the cions where two have been inserted, or in case only one has been put in, then on the side opposite it. The growing shoot should be tied as directed under budding.

This method is one of the best to use in top-working trees, when it is desired to change from one variety to another. In hot, dry climates, the removal of a large portion of the sheltering leaves and twigs leaves the trunk and main branches exposed to the hot rays of the sun. This will result in serious injury to the exposed parts. A very satisfactory protection can be afforded by a thin coating of whitewash, applied with a spray pump. 
Whip-Grafting. This method may be used on small stocks, three-quarters of an inch or less in diameter. It is best that the stock and cion be of the same size, but if' such is not the case, the stock should always be the larger. A sloping cut, an inch and a half long is made diagonally across the stock (fig. 50). A corresponding cut is made on the cion (fig. 50) and a tongue of wood is raised about the center of each cut with the knife held almost parallel to the sides of the wood. The tongue is raised a little on both stock and cion and the two are gently but firmly shoved to-

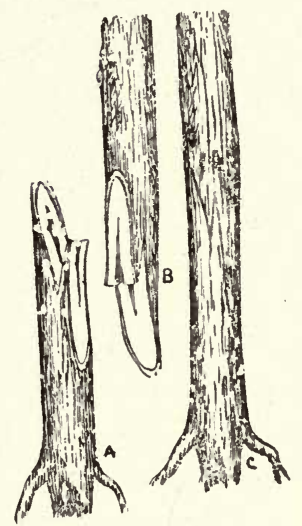

Fig. 50 Whip-grafting. A, stock. B, cions. C, stock and cion placed together ready for tieing. gether (fig. 50). Then the point of union is securely

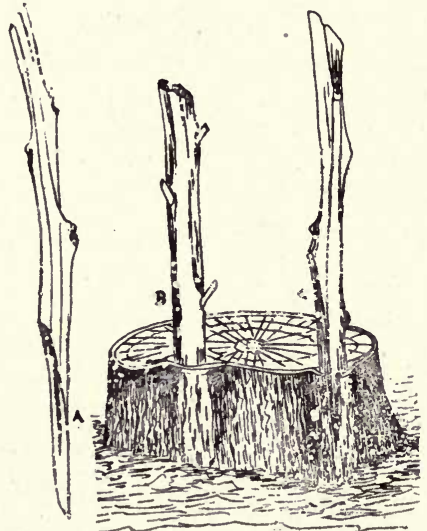

Fig. 51. Crown-grafting. A, cion prepared. B, cion inserted in concave part. $C$, cion inserted in convex part. bound with a strip of waxed cloth. The after-treatment is the same as for cleft-grafting. Crown-Grafting. $\quad \mathrm{Th}$ is method is one of the best for working trees which have been frozen back or for working large trunks at the ground. The trunk is cut squarely off at or somewhat below the ground and the cut surface is made smooth with a knife. If the outline of the trunk is irregular, as is frequently the case, concave places should be chosen for 
inserting the cions. With the point of a budding knife, gently spring the bark back. In cases where this cannot be done, it may be necessary to slit the bark down a distance of an inch or so and then lift the bark. The cion is prepared by making a single sloping cut one and onehalf inches in length at the base. The cion should be tapered off thin and smooth. Then it is inserted between the bark and wood of the stock with cut surface inward. Sometimes a number of cions may be set around the crown. Then firmly tie in place and cover the cut surface of the stock with grafting wax.

Side-Grafting. This method is also known as sprig-budding, but since it is more properly a method of grafting, the former name is the better one. For working old stock with thick, hard bark, it possesses the same advantages as the meth od of shield-budding with a curved incision. The method is also useful when small; slender twigs are the only ones available for propagating work.

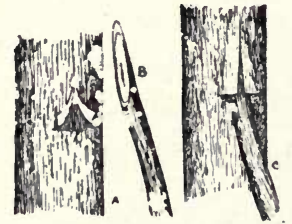

Fig. 53. Inarching. $A$, cion prepared for stock. B, stock prepared with sloping cut. C, stock inserted ready for tieing.

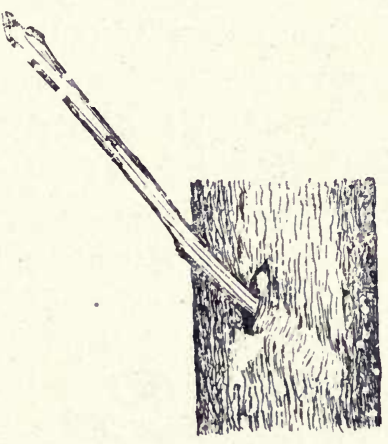

Fig. 52. Side grafting, showing mode of inserting the graft.

An oblique curved cut is made in the side of the stock in such a position as will place the cion, when inserted, at an angle of about 30 degrees with the line of the trunk. The bark is then separated gently from the wood: The cion is prepared with a long sloping cut. It is best to cut 
rather deep at first then bring the knife out almost straight to the end of the cion (Fig. 51). The cion is then inserted and tied in place (fig. 52). When the parts have united, the stock must be lopped or cut off as in shield-budding.

Inarching. The advantages of this method have already been pointed out. The work is accomplished thus :

All branches are removed from the shoot or small tree and the top is cut off with a sloping cut about two inches in length (fig. 53). Then in the side of the larger tree at the right distance above the ground an inverted $\mathbf{T}$ incision is made (fig. 53), and the corners formed by the inter-

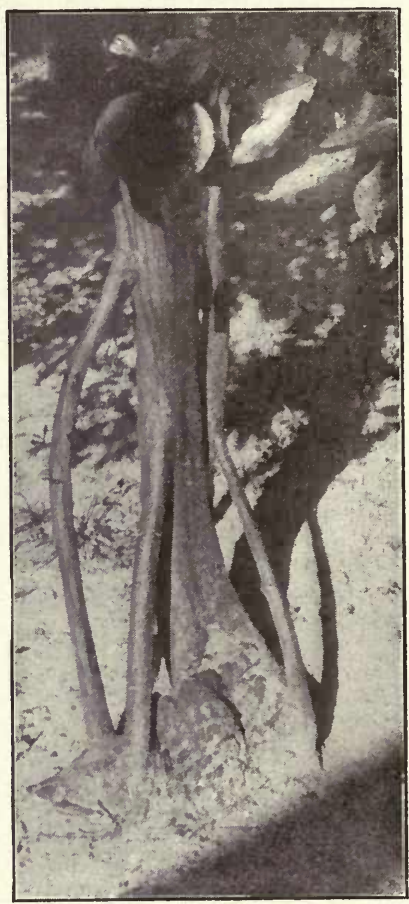

Fig. 54. Three sprouts inarched into the main trunk of an orange tree.

secting cuts are turned back as in shield-budding. The prepared end of the shoot or tree is inserted in the cut (fig. 53), and firmly tied in place. All the incisions are then carefully covered with wax. The bandage should not be disturbed until union has taken place and the parts have firmly knitted.

Other methods of working may be used, for citrus trees are very tractable subjects, but those given in this chapter are all that are of practical importance and all the grower need know. 


\section{CHAPTER XXVII.}

\section{STOCKS FOR CITRUS TREES.}

The more important stocks and those most commonly used in propagating citrus trees are sour orange, pomelo, sweet orange, rough lemon, trifoliate orange and occasionally the lime. The Otaheite orange is sometimes used, particularly in the production of dwarf specimens, but for general orchard purposes it is not to be recommended. Not all the above stocks are adapted to the same conditions of soil and climate, and it cannot be said that any one of them is best for all conditions. It follows that the prospective planter should be acquainted with their relative merits for different localities, and should at the same time be thoroughly informed in regard to the soil, climatic and other conditions in the region in which he intends to plant. Unless this be the case, mistakes may be made which otherwise might be avoided. For instance, it would be poor policy to plant citrus trees on sweet stock, on low ground, where they are likely to be attacked by mal-di-goma, and it would be equally foolish to plant trifoliate orange stock on dry shell ridges. Besides, the question of adaptation to certain soil and climatic conditions, the mutual influence of the stock and cion must not be entirely overlooked. That such an influence is exerted cannot be doubted, but its extent still remains to be investigated. Among the influences to which attention will be called later on are those affecting the hardiness, the rate of growth, the size and shape of the top, the precocity and prolificness of the tree, the time of ripening and the quality of the fruit, the relative amount of juice and rind in the fruit and the amount of acid and 
consequently the flavor. Not all of these effects are noticable in all varieties and only here and there are they sufficiently marked to attract attention. But if differences stand out prominently here and there, it is not unreason able to suppose that they exist in some degree in many other instances to which attention has not been directed.

\section{SOUR ORANGE (C. VULGARIS).}

Next to the trifoliate orange, the sour is the hardiest of all the varieties or species of citrus trees used as stocks. As compared with C. trifoliata, it is not nearly so hardy, but it is considerably hardier than the sweet orange. Of course, a very low temperature causes all differences in hardiness between sweet and sour orange trees to disappear and after such periods of cold no difference can be detected, but the fact remains that a degree of cold which frequently injures the sweet orange has no effect on the sour. Sufficient cold to destroy the young growth and defoliate sweet orange trees does little or no injury to the sour orange. It is impossible to state the relative hardiness in so many degrees, as so much depends upon the condition of the trees.

The roots of the sour orange are produced abundantly and penetrate well into the soil. In this respect it possesses an advantage over the sweet stock for some districts in that it is not so readily affected by variations in moisture. The roots penetrate sufficiently deep to be in contact with a more or less permanent water supply.

Sour orange stock is not subject to the attacks of mal-di-goma, and in Europe where this disease worked great havoc years ago, the groves have again been built up by using sour orange stock. On soils subject to the disease it is a safe stock to use. The sour orange tree is 
very much subject to "scab," a disease which attacks the fruit, leaves and young twigs. It is frequently a serious drawback in the production of stocks for budding, as noted in the section on diseases. But such citrus as are not susceptible to the attacks of the disease are in no wise rendered susceptible by being worked on sour stock.

Sour stock sprouts readily, if the top be frozen back, thus giving an opportunity for re-budding. It is best adapted to soils containing a liberal supply of moisture and its natural habitat, if one can judge from its behavior in Florida as an introduced tree, is the shores of lakes and the banks of rivers where the soil is liberally supplied with water and humus. On dry soil, trees worked on sour stock do not grow so rapidly and do not reach the same size as when rough lemon stock is used. In general, it may be said that it is best adapted to high and low hammock and flat woods land in Florida, to the low lands of Louisiana and to all soils where a good supply of moisture is present or to which a liberal amount can be given. Almost from the first cropping, the fruit borne by trees worked on sour stock is of good quality, a statement which is not generally true of trees worked on rough lemon. During the first years of fruiting, trees on sour orange stock are not quite so fruitful as those on some other stocks, but this difference disappears as the trees become older. In very old trees worked on sour stock, it will sometimes be noted that the sweet trunk is enlarged above the point of union, having in some measure out grown the sour root. In conclusion, it may be said that wherever the soil and climatic conditions are suited to its best growth and development, it is a most satisfactory stock to use and its resistance to the attacks of the dreaded mal-di-goma is a strong point in its favor. 
As a stock for the Satsuma, the sour orange is a failure. When worked on sour stock, this variety makes a stunted, unsatisfactory growth; in short, it is a total failure. Why this should be so it is difficult to say, but for some reason or other the union is decidedly uncongenial. In certain cases the same condition is noted when the stock is used for kumquats, but in the majority of instances it is quite satisfactory.

\section{ROUGH LEMON (C. LIMONUM).}

The rough lemon tree is not so hardy as the sweet orange and is more liable to damage by cold than the pomelo. Of all the stocks commonly used for citrus trees it is the most susceptible to damage by cold and hence cannot be expected to increase the hardiness of the top, but on the contrary, it is inclined to make it less hardy. In southern Florida it grows wild and appears to be per. fectly adapted to its surroundings, but it is not found in the northern portion of the State, being much too tender to stand the climate of the more exposed sections unless protection is afforded.

The main roots of this stock show a wide variation. In all instances the crown roots extend a good distance from the trunk and a good tap root is produced. But in some individuals, here and there, these large lateral roots lie quite close to the surface and most of the feeding roots are in the top fifteen inches of soil. On the other hand, most trees worked on this stock have the roots well distributed through the soil. A root system of this kind is particularly desirable for dry soils and for those which need irrigation.

Rough lemon stock is capable of inducing a more rapid growth in the top worked on it than any other kind 
of stock now used for citrus trees in America. For this reason and because of the great foraging power of its roots, it is an excellent stock for use on high, dry soils or on those containing a small amount of plant food, or on soils where the plant food is not readily obtained because of some undesirable soil condition. For planting on low ground, sour orange stock is preferable, and on this class of soils rough lemon should never be used for the kumquat. Attention is called to this point in Bulletin 65 of the Florida Exp. Station in the following words:

"A number of kumquats on rough lemon stock planted on rather moist ground have come under personal observation in which it was found that there was a more or less copious flow of gum from the region just above the union of the stock and cion. In all cases where this occurred it appeared that the cion was the only part affected. The trees were in an unhealthy condition. The diseased condition, if we may so designate it, did not appear to be mal-di-goma, though in some respects it resembled it. The trouble may have been due to the fact that the great foraging power of the roots enabled them to collect, in certain soils, more food than the less rapidly growing top could readily assimilate."

"On the other hand, on soils containing less moisture and presumably less fertility, a number of trees budded upon rough lemon roots have been examined which were vigorous and perfectly healthy. If one desires to use the rough lemon stock for the kumquat on some soils the best plan would be to adopt the method used quite extensively by C. W. Butler, St. Petersburg, Fla. His practice is to insert kumquat buds in sprouts from rough lemon roots which already support and feed a sweet or mandarin orange top. A perfectly healthy union is se- 
cured in all cases, as most of the food gathered by the roots is used by the larger and more vigorous top. Strange to say, however, the kumquat frequently outstrips the other top, sweet or mandarin orange as the case may be, in growth in beight."

Generally the first crop or two of fruit produced by trees worked on this stock is thick-skinned and deficient in juice, because so much food is collected by the roots. After one or two seasons of fruiting have passed, this undesirable feature disappears and the fruit produced is equal in quantity of juice and thinness of rind to that borne by trees worked on any other stock.

Rough lemon stock usually influences the shape and growth of the variety worked on it. There is a pronounced tendency toward the production of tall, upright branches in the center of the top. This tendency will correct itself after a time, or, if deemed necessary, these upright branches may be cut back somewhat, to assist in the formation of a compact, symmetrical head.

Whether rough lemon stock has any marked influence on the fruit, beyond that already mentioned, is rather difficult to say. Still the indications are that it increases the size of the fruit and the acid content as well. In the winter of 1902 two samples of fruit were picked from adjoining trees of the same variety in the grove of $\mathrm{C}$. $\mathrm{T}$. McCarty, Eldred, Florida, the one worked on rough lemon and the other on sour orange. The difference in acid content was distinctly appreciable to the taste and as the fruit was fully matured, it was thought well to have the two samples analyzed. This was done by Prof. H. K. Miller, of the Florida Experiment Station. The specimens grown on sour orange stock contained .72 per cent acid and 9.8 per cent sugar determined as dextrose in the 
juice; those on the rough lemon .91 per cent acid and 7.24 per cent sugar determined as dextrose, a difference of .19 per cent acid and 2.56 per cent sugar. Too much weight must not be laid on these results, as many analyses should be made to establish any difference which may exist.

This stock has a marked influence on the fruitfulness of the Bahia navel orange in Florida. It is much more prolific on rough lemon stock and with the exception of C. trifoliata, it is the only stock which can be recommended for the variety in that State. As a stock for pomelos and the oranges of the mandarin group, it is preferred by some growers to all others. Rough lemon is resistant against the attacks of mal-di-goma, or foot-rot, in this respect ranking with the sour orange.

\section{TRIFOLIATE ORANGE (C. TRIFOLIATA).}

Perhaps the first mention of this species as a stock for citrus trees is that made by Mr. Fortune, who in 1848 said, "The kumquat is propagated by grafting on a prickly, wild species of citrus, which seems of a more hardy nature than the kumquat itself." This remark undoubtedly referred to the trifoliate orange. The tree itself was described and illustrated by Kaempfer in his Amønitatum exoticarum in 1712. Undoubtedly it has been used for ages by the Chinese and Japanese as a stock for citrus trees, but it is only within recent years that trees have been worked on this stock in America. Its use on any extensive scale dates back only about eight or ten years, but even yet its exact limitation of soil and climate have not been fully determined.

Of all the stocks used for citrus trees, it is the hardi est and it has, in some degree, the power in the colder 
regions of imparting to many varieties worked upon it, some of its own hardiness. While it should be borne in mind that the point of union between the stock and cion is the one point in the trunk of a citrus tree most sensitive to cold, still this point of union may be protected and thus a distinct gain in ability to withstand low temperatures is made. Besides imparting to the cion some of its ability to withstand cold, it has a tendency to retard growth in spring. C. trifoliata has been known to withstand a temperature below zero, a temperature sufficiently low to establish the claim that it is not injured by severe cold. This claim would be worthless, however, were it not distinctly periodic in its growth and, moreover, it is not responsive to sudden changes of temperature during the dormant period.

As a general rule those trees which reach their maximum development in cold or comparatively cold climates cannot be transferred to distinctly tropical or sub-tropical climates and there grown successfully. Now, since the trifoliate orange succeeds admirably and appear's to be well adapted to regions distinctly outside the tropical isotherm, it is doubtful whether it is advisable to use it as a stock in regions removed from all effects of frost. In view of this fact, it would be unsafe to recommend it as a stock for use in the Islands, and on the whole it is safest to use it only in the colder regions. In southern California it is not likely to prove satisfactory, except at comparatively high altitudes. It has proved quite satisfactory in northern Florida and also in Louisiana and Texas.

The trifoliate orange should not be used as a stock on high, dry or calcareous soils. For such situations, it is a failure. It grows well and vigorously on good flat 
woods and hammock land in Florida and it appears to be well adapted to this class of soils. Plantings should be made on this stock only on these classes of soils or on those correspondingly well supplied with moisture and capable of retaining it. In California it is said to succeed well on alkali lands and Mr. C. H. Shime, of the California Experiment Station, recommends it for planting in such localities.

So far as known this stock is not subject to mal-digoma, and in some of the world's citrus districts it is used as a resistant stock.* It is sometimes quite severely infested with San Jose scale. This does not interfere with its use as a stock as the other species of citrus are free from this scale.

The root system produced by the trifoliate orange is very good. The roots penetrate well into the soil and fibrous roots are produced abundantly.

When supplied with a vigorous top, the root becomes more vigorous, and, strange to say, not a single case has come under observation where the stock did not outgrow any variety worked on it. The trifoliate root is larger just below the point of union than the cion trunk is just above. This goes to show that the stock is influenced by the top and made to grow much more vigorously than might be expected. The diameter of worked trifoliate trunks just below the point of union greatly exceeds that of seedling trifoliate trees of equal age at the same distance from the surface of the ground.

Many writers on citrus propagation have stated without reservation that $C$. trifoliata stock dwarfs the top worked upon it. Fxception must be taken to the breadth

* Ed. Gardener's Chronicle, 27:270, Ap., 1900. 


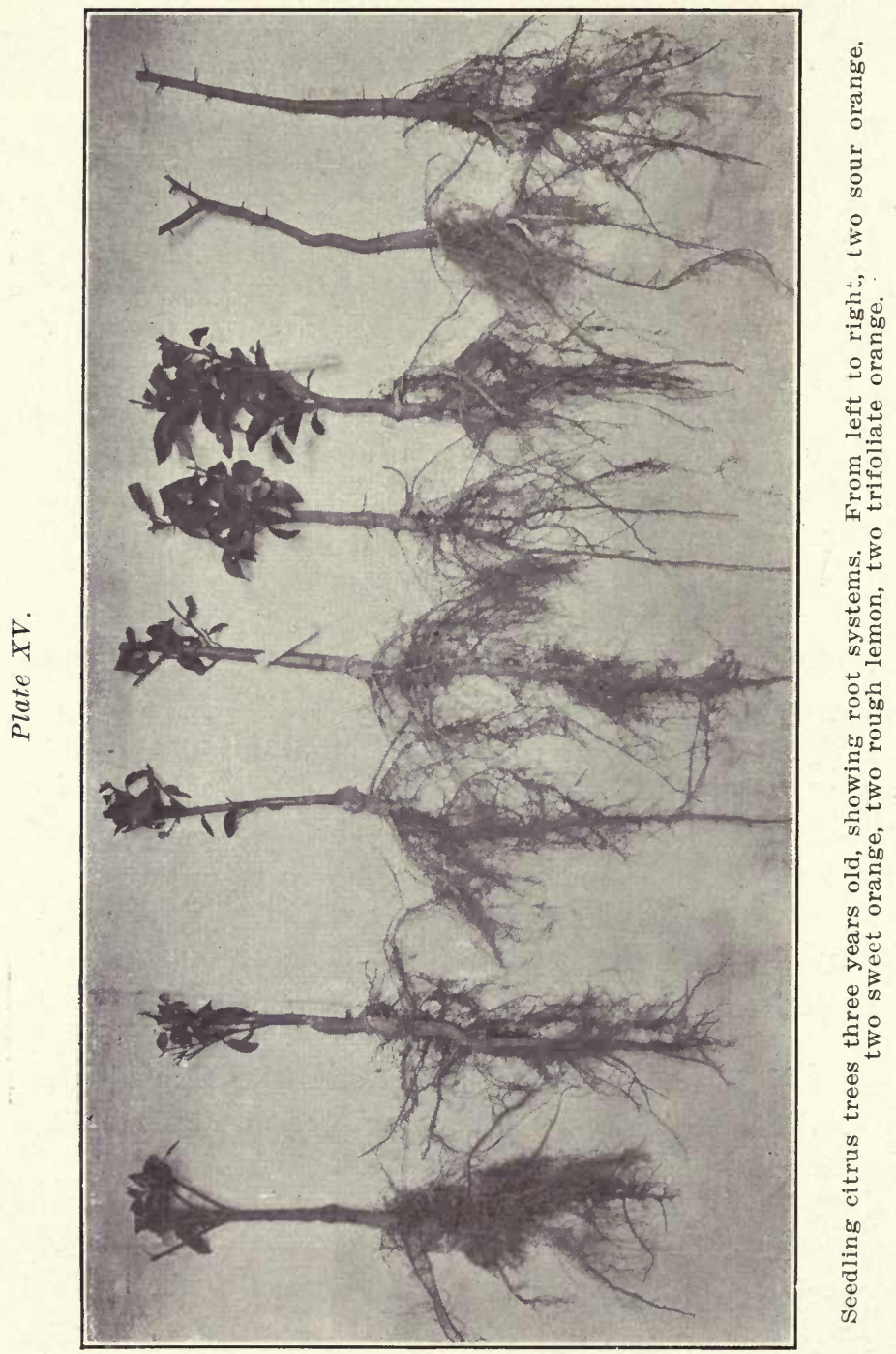


of this statement. It is not always true. Some varieties of citrus appear to grow as rapidly and attain as large a size when propagated on trifoliate orange stock as they do on sour or sweet. It will be found, however, that the fruit borne on young trees worked on trifoliate orange is usually superior in quality to that borne on trees budded on most other stocks, and it may be added that they are decidedly more precocions and prolific.

The most extensive set of experiments which have been made to determine the relative merits of $\mathrm{C}$. trifoliata and other stocks are those which were started and are still being carried on by G. I. Taber, of Glen St. Mary, Fla. The results of the experiments for the years 1901 and 1902 were published in the Florida Farmer and Fruit Grower. The results of this work are given herewith. The soil on which the experiment was instituted lies about half way between flat woods and high pine land. The sub-soil is clay at a depth of about eighteen inches and the land is well supplied with moisture.

TRIFOLIATE, SWEET AND SOUR.

FRUITFULNESS OF THE ORANGE ON THESE STOCKS.

Editor Farmer and Fruit-Grower:

Having received a great many inquiries as to the behavior of orange trees budded upon Citrus trifoliate stock, I have gone over my test orchard, planted two years ago, and made careful memoranda, which are herewith submitted:

I have heretofore given some account of this test orchard, but would say for the benefit of those who do not remember the conditions under which it was planted, that the trees were set out in March, 1899, on absolutely wild land that had never been touched with a plow. Holes were dug in the wiregrass sod, and a moderate application of lime was mixed with the earth where the trees were to be planted. This was done three 
or four weeks ahead of time of planting. At the time of planting we used about three-quarters of a pound of commercial fertilizer to each tree, thoroughly mixed with the earth.

\section{A TEST ORCHARD.}

The test orchard planted in this way consisted of four trees. each of many of the most prominent varieties of oranges and pomelos. Half of the trees planted were upon Citrus trifoliata stock, and the other half upon sour and sweet stocks-mostly sour. In planting, the trees upon sour and Citrus trifoliate were interspersed, one being on sour, the next on trifoliata, the next on sour, and the next on trifoliata, so that neither the trees on sour nor those on trifoliata have any benefit of any variation in quality of land, should any exist, throughout the orchard. The trees were planted thirty feet apart each way, in order to give each tree the benefit of all the ground that it could utilize and to make the test as thorough as possible.

The trees that were planted had been dug and heeled in just previous to the unprecedented freeze of February 12, 1899, during which the thermometer went to ten degrees above zero. All of the trees had their tops severely frozen back, and when we came to plant, the majority of the trees showed but a few inches to a foot of live wood above the bud. Planting frozen-back trees on absolutely wild, sour land is not, under ordinary circumstances, a commendable project, and would hardly have been done in this instance except for the purpose of inaugurating at the earliest possible moment, a test orchard that should show the comparative growth, productiveness, hardiness, time of ripening, etc., of all the prominent varieties on sour and Citrus trifoliata stocks.

The tabulated statement herewith given was made June 20 . 1901, twenty-seven months after the trees were planted. In obtaining the height, breadth and number of fruits each tree was accurately measured and the fruits carefully counted; and the result given is the average of two trees, except in a very few instances, where one tree of a variety had died and had to be replaced a year later. In such cases the comparisons are between one tree each of sour and Citrus trifoliata. 
ORANGES.

Variety

Bessie

Bessie

Centennial

Centennial

Du Roi

Du Roi

Early Oblong

Early Oblong

Hart's Late

Hart's Late

Homosassa

Homosassa

Jaffa

Jaffa

King

King

Mad. Vinous

Mad. Vinous

Magnum Bonum

Magnum Bonum

Majorca

Majorca

Maltese Blood

Maltese Blood

Maltese Oval

Maltese Oval

Nonpareil

Nonpareil

Old Vini

Old Vini

Pineapple

Pineapple

Ruby

Ruby

St. Michael's Blood

St. Michael's Blood

Tangerine
Stock. H'ght. Br'dth

Sour

C. T.

Sour

C. T.

Sweet

C. $\mathrm{T}$.

Sour

C. T.

Sour.

C. T.

Sour

C. T.

Sour

C. T.

Sour

C. T.

Sour

C. T.

Sweet

C. $\mathrm{T}$.

Sour

C. T.

Sour

C. $\mathrm{T}$.

Sweet

C. T.

Sour

C. T.

Sour

C. T.

Sour

C. T

Sour

C. $\mathrm{T}$.

Sour

C. T.

Sweet

$61-2$

4

6

4 1-2

6 1-2

6 1-2

6 1-2

5 1-2

6 1-2

4

6

6 1-2

6 1-2

5 1-2

8 1-2

8

7

$61-2$

7

5

6

5

5

3 1-2

5 1-2

3 1-2

6 1-2

6

6 1-2

4

5 1-2

5 1-2

6

4 1-2

5

3 1-2

6
7

8

5

6 1-2

8

5

No. of

7 1-2 0

5 1-2 58

$71-2 \quad 1$

4 1-2 87

5 1-2 0

61

0

6 1-2 95

3

44

7 1-2 4

5 1-2 26

0

34

81

281

4

36

3 1-2 35

61-2 96

41-2 62

$71-2 \quad 0$

$61-250$

61-2 4

44 
Variety. Stock. H'ght. Br'dth. No.' OI

Tangerine C. T. 4 1-2 5 78

Washington Navel

$51-2$

$61-2$

Washington Navel

C. T.

3 1-2

4 1-2

32

POMELOS.

Duncan ...................... Sour

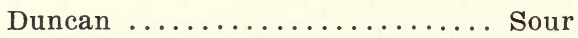

5

7

Marsh Seedless .............. Sour

6

7

27

Marsh Seedless

C. T.

7

$71-2$

10

Triumph

Sweet

3

$41-2$

33

Triumph

C. T.

$71-2$

$61-2$

6

6

75

TABULATED STATEMENT.

Recapitulation of the above figures shows that of the twentythree varieties above named thirteen on sour stock failed to hold any fruit this year, while on Citrus trifoliata the whole twenty-three have fruit on. The average number of fruits on the whole number of trees on sour stock is thirteen, and the average number on Citrus trifoliata is fifty-seven. The average excess of height of trees on sour over those on trifoliata is one and one-fourth feet, and the average excess of breadth of those on sour over those on trifoliata is one foot.

While the trees average larger on sour than on trifoliata, yet there are a few varieties that show no appreciable difference, and two of the varieties show actually larger on Citrus trifoliata than on sour or sweet. One of these is Du Roi orange and the other, Duncan pomelo. A few of the other varieties are so nearly of the same size on the two stocks that one would have trouble in designating which of the trees were on sour and which on Citrus trifoliata if he did not know. Amongst these sorts are King and Madam Vinous. In the whole twenty-three varieties there are only two in which the trees on sour stock show an excess of fruit over those on trifoliata. These are Maltese Oval orange and Duncan pomelo. In the former there are a large number of very small oranges from late bloom which are not noticeable in any other variety.

It should be mentioned that all of the trees planted were as nearly of the same size as it was possible to obtain; the idea 
being to make the test as accurate as possible in every particular. For instance, in the pineapple variety we could have planted larger trees on sour, but instead of doing so we planted the same size that we were able to obtain of the same variety upon Citrus trifoliata. In another part of the orchard-entirely independent of the test part-we planted larger trees of Pineapple and several other varieties upon sour stock which are now fruiting. The comparisons above given are made only between the trees that were planted side by side for test purposes, all of which have been given the same treatment in every particular. In another part of the grove we have both Washington Navel and Tangerine upon Citrus trifoliata that show up much better than the test trees; but, as above stated, for comparative purposes we have confined the test strictly to the test trees.

\section{A SATSUMA ORCHARD.}

In this particular test orchard the Satsuma is not included from the fact that we had several orchards of this variety already planted upon both sweet and Citrus trifoliata stocks. A comparison of two of these orchards, planted in the winter of $97-98$, and which were, of course, frozen to the ground in the freeze of '99, shows the following averages: The Satsuma on sweet, height six feet, breadth eight feet, number of oranges, twenty; Satsuma on trifoliata, height five and two-thirds feet, breadth six and two-thirds feet; number of oranges, one hundred.

We have also some twenty other varieties of oranges and pomelós on Citrus trifoliate in orchards that were planted in '97-'98, but with no trees on sour, side by side, for test purposes. Of these older trees, Washington Navel, Tangerine, Parson Brown, Homosassa, Nonpareil, Du Roi and Madam Vinous oranges and Duncan pomelo now average about eight feet in height and the same in breadth, and all are bearing well. The Washington Navel tree is carrying seventy-nine oranges.

\section{EARLY BEARING OF TRIFOLIATA STOCKS.}

One thing has been fully determined and that is that all varieties come into bearing at a very early age when budded upon Citrus trifoliate. Another thing that is fully determined is that the fruit from trees on Citrus trifoliata roots is fully 
equal in quality to the same variety on sour roots, and still another thing that experience has proven is that the same varieties ripen earlier in the season upon Citrus trifoliata than upon sour. The longevity of the trees on Citrus trifoliata, the ultimate size that they will attain and their comparative value, in the long run, with those on sour, remain to be proven. It is probable that as the trees get older, there will be more difference in size between trees on the two stocks than is now apparent. This will be the natural consequence of the trees fruiting so heavily when young. This smaller ultimate size of trees is a quality, whether advantageous or otherwise, each can figure out for himself. It admits of close planting, and a consequent heavy crop from a given acreage. It is also probable that some varieties will show more affinity for the trifoliata stock than others, and that while some varieties will prove permanently successful on this stock, others may not. The exact extent to which extra hardiness is induced by using Citrus trifoliata stock is also more or less conjectural, but experience has shown that the claim for extra hardiness is well founded, with certain varieties. Whether it will prove equally so with all varieties is one of the points that further careful comparisons in the test orchard must determine. The test orchard established is one of these long time experiments in which years must pass before actual definite comparisons can be made that will cover all the points involved.

In the meantime it is an inspiriting sight to see the trees on Citrus trifoliata bearing heavily, not only in the orchard, but in the nursery rows, and it suggests promising possibilities for the colder sections of the State; with thick planting and banking of the trees in winter. For if the trees are frozen back to the banking, they immediately put on a new top and come into bearing again very soon. In my own orchards and nurseries, situated at Glen St. Mary, in northern Florida, within ten miles of the Georgia line, the crop for this year is estimated at 1,000 boxes. All of the trees that are bearing in nursery, and a large proportion of those in orchard are upon Citrus trifoliata stock.

\section{G. L. TABER.}

Glen St. Mary, Fla., June 22, 1901. 
EXPERIMENTAL GROVE.

\section{TREES ON SOUR AND CITRUS TRIFOLIATA STOCK.}

Editor Farmer and Fruit-Grower:

It may interest your readers to hear how my test orchard of oranges on sour and Citrus trifoliata stocks is coming on. I made a report on this one year ago, and now, July 26, 1902, having just finished the annual record of it for this year, will give a summary of the results.

The experimental grove referred to was planted in March, 1899, about a month after one of the heaviest freezes that Florida ever experienced-the thermometer having gone to $10 \mathrm{de}$ grees above zero at my place. With twenty acres of grove frozen to the banking it looked a little like tempting Providence to go ahead and set out five acres additional that I had already planned, but that was what I did. And right here I would say that the conditions under which this five-acre grove was planted were far from ideal-in more ways than one. In the first place our nursery planting for the season had overrun my estimate and used up all the available cleared land, and the grove, if planted at all that spring had to be set in absolutely wild, unbroken pine sod. In the second place not a nursery tree in my own, nor any other nursery for a long distance south, remained unfrozen-except that small portion of the bud covered by the banking. Interesting conditions under which to place a grove, weren't they?

A1though five acres were planted that spring, as per above. there were really but a little over two acres strictly experimental. On this experimental plot were planted one hundred orange and pomelo trees, twenty-five varieties, four of a variety, half on sour stock and half on Citrus trifoliata stock, planted alternately at thirty feet apart each way. Taking Jaffa, for instance; the first tree planted was on sour, the second on C. trifoliata, the third on sour and the fourth on C. trifoliata. The distance of thirty feet was given them so that each tree might have absolutely all the room it wanted. The entire orchard has received the same treatment in the way of fertilization and cultivation, and the experiment, as far as it has progressed, is as fair a one as it is possible to make. A part cf 
the trees of two varieties of the twenty-five had to be reset, leaving but twenty-three varieties-92 trees-for actual comparison. It would require too much space to give exact sizes of every tree and the actual number of oranges on each tree, although the record that $I$ have just completed shows this. Following is a summary of the twenty-three varieties:

Average height trees on sour stock, 8 feet, 2 inches. Average breadth trees on sour stock, 9 feet, 2 inches. Average height trees on C. trifoliata, 6 feet, 2 inches. Average breadth trees on C. trifoliata, 7 feet.

Adding together the average height and breadth the trees on sour stock would be represented by 17 feet, 4 inches.

Adding together the average height and breadth the trees on C. trifoliata would be represented by 13 feet, 2 inches.

Adding the actual number of fruit that these trees are now holding to the number they produced last year, and dividing by the number of trees, we find those on sour have a total average of 69 oranges per tree for the two years, and those on C. trifoliata have 93 oranges to the tree for the two years-an increase to date of just about one-third over those on sour.

It is not to be expected that these trees on C. trifoliata will continue indefinitely to produce more oranges per tree than those on sour, and it may be that when the trees on sour attain full size results per tree will be in favor of those on sour. But, be that as it may, here is a point that is generally overlooked: by setting the trees on C. trifoliata two-thirds or three-quarters as far apart as those on sour the number of trees per acre is doubled. This is about the comparative distance that we would recommend-one-quarter to one-third less distance on C. trifoliata than would be given those on sour. As above stated, this will double the number of trees to the acre and, figured on that basis, the result so far would have been an increase in fruit of 270 per cent from the trees on C. trifoliata above those on sour for an equal acreage. This, taken in conjunction with the fact that trees on C. trifoliata can be frozen to the banking one year out of three and still produce a good crop of fruit one year out of three, proves its extra advantages for frosty sections, even if we leave out entirely the question of hardiness. Last winter I personally picked a box and a half of Ruby oranges 
off from a section of a row sixty feet long of two-year-old nursery trees-trees one foot apart in the row. I am not at all sure but what these trees planted four to six feet apart in the rows and rows twelve to fifteen feet apart-to leave room to fertilize and cultivate one way-would be a good investment. The fruit, for the first few years at least, would be a sight to behold.

The above suggestion is perhaps unfair to the $\mathbf{C}$. trifoliata as applied to all varieties budded on it, from the fact that several years of experiment prove that there is quite a distinct difference in the varieties, as to their comparative growth, when budded on this stock. In fact out of the twenty-three varieties summarized in this article there are two varieties of orange, Jaffa and King, and one variety of pomelo, Duncan, that actually average larger on C. trifoliata after having been planted a little over three years than the corresponding varieties on sour alongside.

In addition to the varieties above mentioned, the following on C. trifoliata compare well, as regards growth, with those on sour: Du Roi, Early Oblong, Homosassa, Madam Vinous, Magnum Bonum, Nonpareil, Pineapple and Tangerine. There are quite a number of these kinds that would put a man to guessing as to which stock they were budded on unless he examined the roots. And speaking about the roots, here is an illustration showing how facts may and often do, confound theories: The C. trifoliata, although naturally a much more dwarf tree than are most of the varieties that are budded on it, will invariably keep ahead of the bud inserted on it. In other words, if the diameter of the bud is, say three inches just above the point of union, the C. trifoliata stock just below the point of union will be about $31-2$ inches. The stock of C. trifoliata always develops growth faster than the bud inserted on it, although the natural inference would be that, as the stock itself is of a dwarfish nature, the bud would outgrow the stock.

Comparative results so far are distinctly in favor of C. trifoliata as a stock for this section. I know of no reason why this should not apply equally to other sections subject to frequent freezes. In the Islands, or at points outside the range of Jack Frost's visitations, the reason for using C. trifoliata as 
a stock might not be so pronounced. Its precocity in throwing the bud into early fruiting, makes it desirable however, wherever immediate results are wished for. As a matter of fact this article is not written as a plea for the Citrus trifoliata, but simply to record comparative results based upon what is perhaps the most extensive and comprehensive line of experiments with it that have ever been systematically undertaken in this country.

G. L. TABER.

Glen St. Mary, Florida, July 26, 1902.

SWEET ORANGE (C. AURANTIUM).

The sweet orange is not so hardy as the sour and trifoliate oranges. For colder regions, other things being equal, one of the latter two is to be preferred. It has been pointed out that in California sweet stock is not deep rooted, most of the roots being found in the top eighteen inches of soil. J. W. Mills, on page 11 and 12 Bulletin 138, California Experiment Station, states the results of his investigation in these words: "In short, the general experience on all kinds of soils and under different methods of cultivation shows that it is the nature of the sweet orange seedling to form a shallow root system," and further: "To sum this up, the sweet orange is a surface feeding stock which has few or no deeply penetrating roots." In Florida, investigations have not been carried far enough to prove what the conditions are, but of nursery trees it may be said that the sweet stock is equal in root development to sour stock.

Sweet stock is subject to the attacks of mal-di-goma and hence should not be used on soils where this disease is likely to occur. Damp soils, such as are found in the hammocks and flat woods of Florida should not be planted with trees on sweet stock; even on higher ground they are frequently attacked. On the other hand, it may be pointed 
out that on light, well-drained soils, trees worked on this stock make a good growth and develop into shapely, symmetrical trees. The growth of trees on sweet stock is more rapid than on sour or trifoliate orange and in general it may be said that in rapidity of development, it is surpassed as a stock only by the rough lemon and pomelo.

When frozen back, sweet stocks sprout readily and seldom is it necessary to replace them. In some sections it may be advisable to use sweet stock, but the planter should never forget that it is susceptible to the attacks of mal-di-goma, and should not use it without counting the risk. In Florida its use as a stock has been discontinued almost entirely, but in California, Australia and other districts, it is still used.

\section{POMELO (C. DECUMANA).}

As already pointed out, the pomelo surpasses the rough lemon in hardiness, but does not equal the sweet orange. It is a strong, vigorous grower, and seedling pomelo trees throughout Florida have attained a size surpassed by no other species of citrus, and generally surpassing all others in the amount of fruit borne.

Within the past few years, attention has been directed towards its use as a stock, most of the citrus trees on this stock being planted on the lower west coast region of Florida. But outside of this region it has not been used to any considerable extent and most of the plantings in South Florida are still made on sour orange and rough lemon stock. In southern California this stock appears to be replacing the sweet orange stock to a very considerable extent and it appears to be superior to the latter. As a stock for dry soils, it is surpassed by none, excepting the rough lemon, and if we are to judge by the behav- 
ior of seedling trees, it is successful on soils of intermediate moisture content.

The pomelo root system is well developed and well distributed in the soil and, so far as observed in Florida, no cases of mal-di-goma have been noted and none have been authentically reported. In regard to its behavior in California, J. W. Mills, in Bulletin 138, California Experiment Station, says, "It is resistant, to a certain extent, to the form of gum disease that attacks the roots of citrus trees."

\section{LIME (CITRUS LIMETTA).}

In the southern east coast of Florida this stock has been tried to some extent and the results on rocky soils, or those underlaid with rock, appear to be quite satisfactory. Trees on this root upwards of twenty years old may be seen at Palm Beach, Florida, and they are certainly growing there under conditions where it is extremely doubtful whether any other stock now in use would have succeeded. It may reasonably be expected that this stock will be used to a greater extent than it now is. It is probably better adapted to tropical regions than the trifoliate orange and may be instrumental in extending the citrus industry into those regions. Lime trees succeed well on drov soils and make a good growth. 


\section{CHAPTER XXVIII.}

\section{CITRUS NOILA.}

While citrus trees possess a wide range of soil adap tability, it is true that any and every kind of soil cannot be used for their culture. Many soils can be planted to citrus trees where certain seedlings would not succeed, if the right stock be chosen on which to work them, and, fortunately, there is a goodly number of stocks with a fairly wide range of adaptability from which to choose.

But even with this advantage there are certain classes of soils which should be avoided and, of course, of those which may be used, many are more suitable than others. Sticky, heavy soils, through which water does not readily percolate should be avoided and those which are extremely dry, unless they can be irrigated, are unsuitable. Again, soils which are damp and wet and those which are underlaid with hardpan should not be chosen for the citrus grove, unless the strata of rock or hard soil can be broken up so as to allow the roots to penetrate deeply into the soil.

Citrus trees succeed best on well drained soils of a rather open nature. If naturally well drained, so much the better, but if not, drainage must be provided. No stagnant water should stand in the grove, neither should the soil be completely charged with water. Soils of an extremely open, porous nature are unsuitable, as they do not hold sufficient moisture and if they are deficient in plant food and recourse has to be made to commercial fertili. zers to make up the lack of fertility, these leach readily from the soil, and the full effects from their use cannot be obtained. If the surface is good, tillable earth, with a 
fair admixture of sand, so as to open it up, and the subsoil is somewhat closer so as to bold moisture and prevent leaching, the ideal conditions have been secured.

\section{FLORIDA SOILS.}

The soils of Florida are commonly grouped according to elevation and the growth which they support or have supported in a virgin state. Those commonly used for citrus culture are high pine land, flat woods, high hammock and low hammock. On all of these citrus fruits have been and are grown successfully.

High pine land, as the term denotes, is well elevated and well drained. In a native state it is covered with a growth of long-leaf pine (Pinus australis Michx.), with little or no undergrowth. Sometimes a few high ground willow oaks (Quercus Cinerea Michx.), and other trees are found. Those with a mixture of deciduous trees are usually conceded to be somewhat superior to those covered with a pure growth of pine. The surface soil generally contains a fair amount of humus, the sub-soil is clay or a rather loamy sand, though frequently the clay is not found until a considerable depth is reached. These soils are not rich, but they respond readily to good treatment and make good citrus soils. They contain about .026 per cent nitrogen, .016 per cent potash, .022 per cent lime and .05 per cent phosphoric acid.

The flat woods land likewise supports a growth of long-leaf pine (Pinus australis), but the elevation is considerably less and the ground is quite flat and level. In the southern part of the State, in the vicinity of Miami and Punta Gorda, for instance, and generally south of a line from Cape Canaveral to Tampa Bay, the long-leaf pine is replaced by the Cuban pine (Pinus Cubensis Gris- 
eb.). Frequently flat woods land is thickly covered with an undergrowth of saw palmetto (Serenoa serrulata Hook.), and gallberry (Ilex glabra). In many places the flat woods land approaches the high pine land in elevation. Such lands are usually well adapted to citrus culture. On the other hand, much of the land designated as flat woods is low, flat and undrainable and is entirely unsuited to the growth of citrus trees. The surface soil contains a considerable amount of humus, while the sub-soil may be clay, hardpan or rock. Those which are subject to overflow, not readily drained and which have a hard, compact sub-soil, should be avoided. On the other hand, those of intermediate character, as noted above, are among the best of Florida's citrus soils.

High hammock lands correspond in a large measure to the high pine lands. They are well drained and elevated, but are covered with a native growth of hardwood, evergreen and deciduous trees. Among these may be men. tioned holly (Ilex opaca Ait.), hickory (Carya tomen. tosa Nutt.), live oak (Quercus virens Ait.), dogwood (Cornus Florida) and magnolia (Magnolia grandiflora). Lands of this character are well supplied with humus, have a comparatively deep, rich soil and are well adapted for citrus culture. The analyses of these soils show about .0658 per cent of nitrogen, .06 per cent of line, .014 per cent phosphoric acid and a trace of potash.

The high hammock lands shade off into the low hammocks. These latter are covered with a growth of nearly the same character, but the live oak is more in evidence and the cabbage palmetto (Sabal palmetto R. \& S.) is quite abundant. The surface soil contains a large amount of humus and they are consequently rich in nitrogen. They are generally difficult and costly to clear, but if well 
drained, or the evil effects of a superabundance of water can be avoided, they are very desirable for citrus fruits. It is on these soils that large numbers of citrus trees have been set and good groves established along the Caloosahatchee River as well as elsewhere in Florida.

In addition to these soils, mention should be made of the hickory or the hickory scrub lands, stretching in broken areas along the shores of the Indian River, from about Cape Canaveral northward. They are covered for the most part with a growth of hickory and the soil is a pure sellow sand with a goodly admixture of humus in the surface layer. In some respects they correspond to the high pine lands of the interior and appear to be well adapted to citrus fruits. The chemical analyses show the following percentage of the important plant foods: .07 per cent nitrogen, .0862 per cent lime, .0431 per cent phosphoric acid and .011 per cent potash.

Other soils are used for citrus culture in the State, but those described above have generally proved most satisfactory.

\section{LOUISIANA.}

In Louisiana, the rich, alluvial soils of the Mississippi delta are used for citrus trees. These correspond in some degree to the low hammock soils of Florida, but are much richer and contain more humus. Particular attention has to be given to drainage.

\section{CALIFORNIA.}

The best citrus soils in California are found on the higher levels and among the foothills. In most parts of the State the actual composition of the soil, whether it be red soil, granite or sandy loam, does not matter so 
much as does the drainage and the possibility of supplying water by irrigation.

The soil of the famous Riverside district is of a deep reddish color, while the Redlands section takes its name from the color of the soil. The mesas are among the best citrus soils of the State, for though the fruit may be produced on other soils, it is not equal in quality to that produced on this class of land and on the foothills. In southern California, the great lemon industry has been built up on the mesas and foothills, lands long untouched, many of them covered with a forbidding growth of cacti, sagebrush and like vegetation peculiar to such soil and climatic conditions.

In California soils underlaid with hardpan, alkaline soils, heavy clay soils (adobe), should be avoided and the lower lands, containing larger amounts of humus and moisture do not produce fruit of as good quality as the uplands.

\section{CUBA.}

In Cuba there are a number of different types of soil which may be used for citrus groves. Not all of them are equally adapted, and it will require considerable practical experience to determine which class or classes will be most satisfactory. Not until bearing groves have been grown to considerable age can the question be definitely answered. The health and longevity of the trees, the flavor and quality of the fruit are all influenced by the character of the soil.

The soils which are more or less adapted to citrus fruits may be divided into three general classes. Of these the sandy soils are preferred by many. Soils of this type are easily cultivated, and while some commercial fertilizer 
will have to be used, other advantages may more than offset this expense. They retain moisture well and, like the sandy soils of Florida, will doubtless produce thinskinned, juicy fruit of excellent quality.

On the red lands found in large tracts in the provinces of Havana and Matanzas, and in smaller areas elsewhere, many old bearing orange trees are to be found. The old groves planted on them have been quite successful. The chief drawbacks in their management are that they part readily with their moisture, bake and crack open during dry weather. They are sticky and pasty during wet weather and, in consequence, are rather hard to cultivate. By incorporating vegetable matter, and perhaps by the use of lime, these conditions can doubtless be considerably improved.

The black lands are likely to produce rank growth in tree and fruit, though by care in fertilizing, when the trees begin to bear, a portion of this difficulty may be overcome. In selecting the location, attention should be given to the question of drainage, as these soils, particularly when low and flat, are likely to be wet. 


\section{CHAPTER XXIX.}

\section{LOCATING THE CITRUS GROVE.}

In selecting a location for planting a grove of citrus trees a number of points have to be carefully considered. The facilities for transportation, the susceptibility of the region to frosts, the nature and direction of the prevailing winds, the exposure and the insect problem must all be studied in their relation to the prospective gains, the welfare of the trees and the quality of the output.

Citrus fruits have a great advantage over many other kinds of fruit. They are not perishable in the same sense that plums and peaches are, and after being removed from the trees they may be kept for weeks, even with ordinary care. Their ability to withstand the inroads of decay producing organisms is not dependent upon the resistant power of the inner portion of the fruit, but upon the leathery nature of the cured rind. Their keeping quality has an important bearing on the transportation problem. With proper care they may be shipped to any of the world's great markets.

The susceptibility of citrus trees to injury from frost decrees that they must be grown in regions far from the effects of rigorous cold and such sections are far distant from the great markets of the United States in the Northeast and Middle West. Consequently, it is impossible to produce the fruit in proximity to the markets and this phase of the question may be dismissed.

But in regions where the fruit is grown it is best, other things being equal, to locate the grove in proximity to a railroad station or steamboat landing. Transportation by team is expensive and a distance of five, ten or fifteen 
miles from a railroad must not be overlooked in the pre. liminary reckoning of expenditures and returns. If the grove can be located conveniently near two railroads, so much the better. Competition sometimes has an influence on freight tariff.

It may be safely said that few districts where citrus fruits are grown within the confines of the mainland of the United States are entirely free from the effects of frost, still some localities are notoriously frosty while others may be considered entirely free, so far as damage to the trees, flowers or fruit is concerned. Freedom from, or susceptibility to frosts is not dependent entirely upon either latitude or altitude. A certain situation may not be subject to the baneful effects of frost, while, within a very short distance, another may be repeatedly visited. Even in Florida where the land is comparatively flat and level and where one might expect greater uniformity to prevail, isolated spots are visited by frosts, while others much farther north escape. The topography of the region, the proximity of bodies of water, the presence of mountain barriers, the direction of the prevailing winds are the factors which largely control the climate of a given region.

It is frequently noted that frosts occur in valleys, hollows and low areas while the adjacent hillsides or elevated portions are untouched. The explanation of this phenomenon is that the cold air drains off into the lower levels and settles there, while the warm air rises to replace it. This interchange of air goes on until frost occurs in the lower area while the higher portion escapes. Low ground so situated as to receive the cold air from a higher level should be avoided, a location on the side of the slope or on the top of the elevation being much prefer- 
able. Even a few feet of rise suffices to protect the trees. Frequently it may be observed that the lower portion of a grove is badly frosted while the remainder, only a few feet higher, escapes. Sometimes the banking of the cold air is materially increased by a wall of timber so situated, adjoining the lower portion, as to prevent air drainage.

This trouble may be obviated by opening up the timber belt sufficiently to allow the cold air to drain off.

It will be seen from the above, that if the grove or a portion of it be situated in a depression, air drainage may be actually injurious, but on the other hand the fact that the cold air flows off into the lower areas may be turned to good advantage, if precaution is taken to select a proper location. The site for the grove in regions subject to damage by frost should be selected on sloping or elevated ground, to permit the removal of the cold air.

It is very desirable to locate the grove on the shore of a lake or other body of water. The proximity of such bodies of water have much to do with equalizing the temperature. In Florida, as shown in Chapter XXXV, there are large numbers of lakes and rivers and in that district it is best to locate the grove, if possible, either on the east or south side of a lake. The freezes which have struck the State have generally come either from the north or northwest. If the lake be of considerable depth, the water does not part with its store of accumulated heat so rapidly as when it is shallow and the heat slowly given up will in some measure raise the temperature. In prevention of frosts, bodies of water play an important part. The heat which they have accumulated during the day is given off slowly during the night thus raising the temperature of the air over the adjoining land. 
Frosts and freezes must not be confounded. Frosts generally occur in restricted areas on clear, still nights. Freezes on the contrary usually follow or accompany storms of wind and rain. Their effects are not local, but they sweep across great stretches of territory.

Solid timber areas frequently do much toward staying their progress and preventing damage. But these should be opened up sufficiently to allow some movement of air, or a still air space may be created into which the cold air will settle. Moore, in his Hand-book of Orange Culture, recommends clearing the land and the laying out of the grove in blocks, each block separated from the adjoining ones by a belt of the native timber. The twenty acre grove of Mr. W. S. Hart, of Hawk's Park, Fla., is laid out in blocks of five acres, separated by belts of native hammock growth, fifty feet wide. Ditches are run along these belts to prevent the roots of the native trees from reaching out into the grove. Mr. Hart has, on a number of occasions, demonstrated the great advantage of this system of planting. So favorably impressed have we been that we can unhesitatingly recommend it to anyone about to locate where frost protection is necessary. When open fires have to be resorted to, the heat is confined and becomes much more effective. Cutting off the rays of the morning sun is a point of further importance. If trees have been touched by cold, their power to recuperate is greatly increased by the shade provided in such a location.

\section{WIND-BREAKS.}

The foliage and fruit of citrus trees may be greatly injured by high winds. In coast regions such winds frequently blow almost steadily and great damage is some 
times wrought. In fact, it is well nigh impossible to establish and maintain a grove under these conditions unless shelter of some kind be provided. If the native growth is sufficient to afford protection, a belt should be left, if not, a wind-break should be planted or an artificial one constructed. Along the shores of the Indian River in the famous Indian River district in Florida, wind-breaks have to be provided to break the force of the whipping wind. The shores of the river are usually fringed with a dense growth of cabbage palmetto and other trees. This growth has generally been left by planters, fig. A., plate XVI, but occasionally it has been necessary to build a wind-break. Fig. B., plate XVI, is an illustration of one of these. It is built of slats, sixteen feet long, three inches apart and nailed to three, two-by-four stringers supported by fiveinch posts placed ten feet apart. To give additional support, the whole structure is guyed with No. 8 wire every twenty feet on opposite sides.

A slat wind-break may be advisable if land be very expensive, or if it is felt that shelter must be provided without delay. Generally, however, it is best to provide a more substantial one of trees. In California the Monterey cypress, pepper trees and gums are most desirable for wind-breaks. The cypress is generally planted alone, while the pepper trees and gums are frequently mixed. The pepper trees are spreading while the gums are tall and upright, consequently the combination is a good one. The best trees for wind-breaks in Florida are the upland willow oak, willow leaved oak and other native trees. They are usually exempt from frost injuries. The Australian pine (Casuarina equisetifolia) and camphor tree are quite good. The camphor tree is considerably hardier than most species of citrus, yet not sufficiently so to render it 


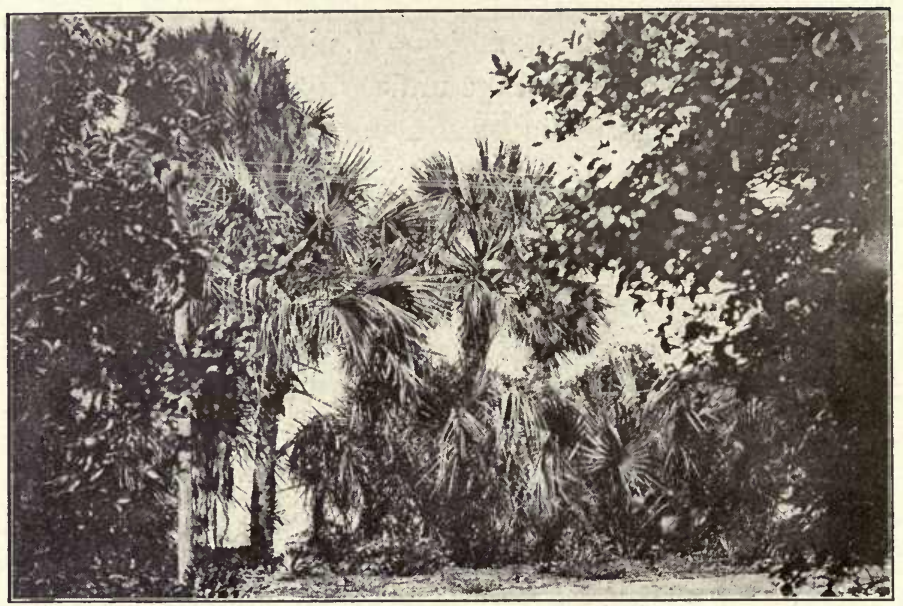

Fig A. A wind-break of native growth, mostly palmettos, on the shore of the Indian River, Florida.

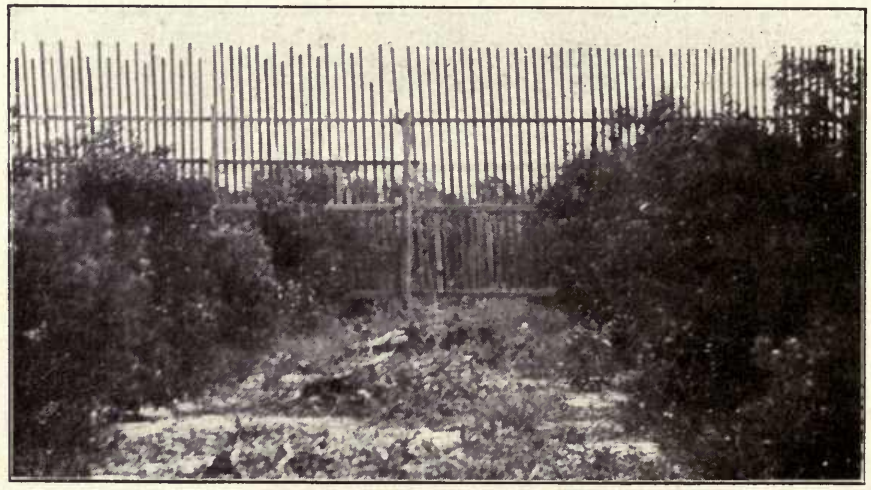

Fig B. An artificial wind-break of slats. 
a very desirable tree to use in the more exposed sections. It does not do well on high, dry soils. The Australian pine is also subject to frost injury and should be planted only in the southern portion of the State. Where frosts do not prevail, the Mexican lime planted as a hedge and allowed to attain a height of ten to twelve feet is quite desirable.

Preferably the wind-break should be planted at the same time as the grove. In any case, it will be found necessary to ditch the ground between the line of windbreak and the first tree row, to prevent the roots of the wind-break from spreading out into the grove and depriving the citrus trees of food and moisture. This ditch may be filled up again after cutting the roots, if so desired, but will need to be opened up and the roots cut back again every third or fourth year. It need not be wide, a foot or fifteen inches is sufficient, with sufficient depth to cut off the surface feeding roots.

Generally speaking, an exposure opening to the south is best for citrus trees, but in frosty districts it is advisable to plant on the south or east side of a lake or other body of water as already stated, in which case the grove should be set on ground sloping toward the lake.

In irrigation districts a piece of ground should not be selected which cannot be irrigated, and the prospective planter should assure himself that the available supply will always be ample for his needs. Many failures have resulted because this rule was not observed. As one writer has expressed it, "find water, then find a piece of ground to put it on."

The insect problem is one to which some considera. tion may be given. The insects affecting citrus fruits are pretty well distributed and it is perhaps not too much to 
say that conditions are nearly equalized throughout the country. Regions which are free from one pest generally have another equally troublesome. No one section can expect to long remain free from their inroads. Still some climatic conditions appear to be more favorable for the development of some insects than others. The black scale of citrus trees is a great pest in the coast regions of California, while farther inland it is not so troublesome. 


\section{CHAPTER XXX.}

\section{PREI'ARATIONS FOR PLANTING.}

\section{CLEARING THE LAND.}

If the piece of land selected for the grove is covered with timber, one of two plans may be adopted-partial clearing or complete clearing. In all cases the latter is preferable, but the former can be made to give good results.

If it has been decided to plant the trees in a partial clearing, the rows in which the trees are to stand should be cleared out, or the ground should be staked off and a space in the form of a circle cleared where each tree is to stand. 'This row or space, as the case may be, should be carefully cleared. No roots of the adjoining standing timber should be left in it, but it should be free from all roots to a depth of not less than fifteen or eighteen inches. The timber which stood on the ground may be burned and the ashes returned to the soil, or the larger wood may be saved for firing in some cases, or the wood may be piled and allowed to rot on the ground, while the brush in small quantities may be used as a mulch. All the remainder of the standing timber should be cut out not later than the next winter and every precaution must be taken to guard against the newly planted trees being deprived of food and moisture by the native growth.

In clearing standing timber, wind-breaks should always be allowed to remain. A fifty-foot belt will usually 
suffice, and the plan advised by Moore, of planting in small blocks with shelter belts intervening, is by all means advisable. In exposed regions this plan should always be adopted.

Having decided to make a complete clearing, it is best to commence operations one year previous to planting. The standing timber and all growth should be cut down. Then the stumps should be removed. The use of a good stump-puller is always advisable and dynamite is often a necessity. Clear thoroughly and either dispose of the wood and brush and plant a cover crop in summer or allow the brush, roots and trunks to shelter the ground during the summer. If the latter course is adopted, the brush should not be piled and should be allowed to remain spread out over the surface.

Preferably the ground selected for the citrus grove should be cleared the winter before the one during which the trees are to be planted. After having removed the standing stumps and rubbish, the ground should be plowed, harrowed and leveled. During the intervening summer season, a cover crop should be planted. The roots of this crop will open up the soil, nitrogen will be added (if a legume is planted), humus will be added and on the whole no better preparation can be given the soil for the future grove than by adopting this plan. If possible to do so, it should always be followed, and if a piece of old ground is to be planted in trees it is the best method of insuring satisfactory results. In the latter case, more than one season may be required to get the ground in shape. As a cover crop, beggarweed, velvet beans or cowpeas may be planted, and the remarks on these crops in Chapter XXXIII apply equally well here. Cowpeas gen. 
erally give excellent results on new ground. Mr. W. S. Hart, of Hawks' Park, Fla., a successful grower of more than twenty-five years' experience, makes the following statement regarding this method of preparation: "The quickest profits that I ever realized from an orange grove was where I thoroughly worked the soil and planted it in cowpeas the first year after clearing, and before I set the trees."

Cultivation. Before planting the trees the ground should be put in thorough tilth. It should be loosened up and stirred. It is not advisable to turn the top soil under unless the sub-soil brought to the surface is quite rich. But the soil should be stirred to a good depth in all cases. If the lower soil is firm and compact, a subsoil plow should be used to loosen the soil sufficiently to allow the roots to penetrate. After the plowing, the cultivator or harrow should be used. This followed by the float or planker will leave the ground smooth and mellow, in excellent condition, both for staking off and for planting.

Dead furrows should be avoided unless it is desired to use them as open ditches afterward. To do this the plowing should be done from a line down the center of the field, two furrows being first thrown together, then others added on either side until the work is completed.

\section{GROVE PLANS.}

A number of different systems may be used in the planting of citrus groves. The most important of these are triangular, square or rectangular, hexagonal or septuple, quincunx and double or mixed plantings. 
Triangular System. The triangular system is sometimes referred to as the hexagonal system, but the latter system is one of equilateral triangles, while the term triangular, as here used, is applied to the method of planting in inequilateral triangles. For instance, in fig. 55, the trees are set in rows thirty feet apart in the rows running east and west. But in every other row the trees are set not

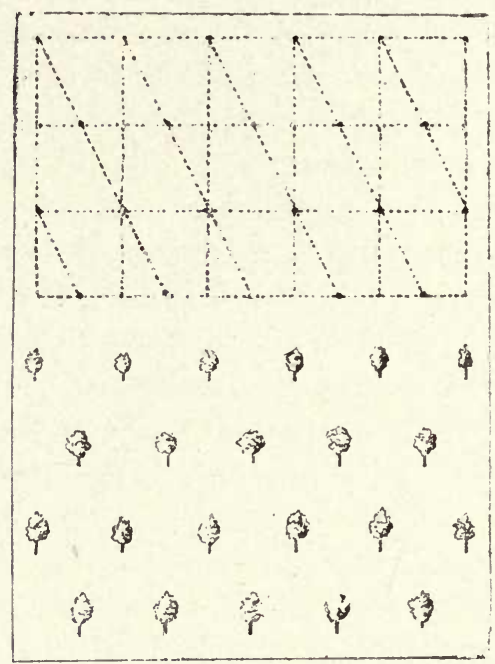

Fig. 55. Triangular system of planting. on the corners of the th i r ty-f o ot squares, but half way between the corners, and the distance from tree to tree diagonally across the field is, planted per acre than thirty feet. In fact, they are about thirty-threeand a half feet apart. By this method fewer trees are planted per acre than by the square system. In laying out a grove by the triangular method, the field is first laid out in squares. A line is

Fig. 56. Square system of planting. 
then run diagonally across the field and a tree is planted wherever this line passes through the corners or cuts the side of a square.

There is little to be gained by this system of planting, except that it makes it possible to cultivate readily three ways through the grove. The trees are given somewhat more space. But by planting trees according to the triangular system at thirty foot distance, for instance, is the same as planting in rectangles $30 \times 331-2$ feet, so far as the number of trees is concerned. Triangles laid out on twenty-foot squares would be the same as planting in rectangles $20 \times 22.4$ feet.

Square or Rectangular System. In this system is in. cluded only the methods of setting trees in rectangles, either square or oblong. It is by far the most commonly used of all the systems and the ease with which a field can be laid off in rectangles is greatly in its favor.

The rows of trees intersect each other at right angles and cultivation may be carried on conveniently either crosswise or lengthwise of the grove. The planter has the choice of placing the trees the same distance apart both ways or of planting them closer together in the rows than the distance between the rows.

It has been argued that space is not equally divided among the trees and while this is apparently true, yet, on the other hand, the roots of citrus trees, in most cases, penetrate and permeate all the space allowed in ordinary distances. The roots will certainly secure all the food and moisture in the top fifteen inches of soil.

When trees are to be planted by this system, the stakes must be set so as to be exactly in line, whether viewed from the end or from the side of the field. 


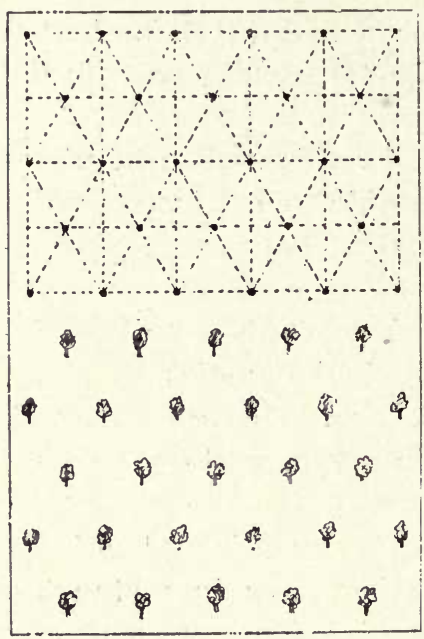

Fig. 57. Hexagonal system of planting.

triangles.

It is the only system whereby each tree is placed equally distant from each of its adjoining neighbors and the only system which equal1y divides the space among the trees. By this method about 15 per cent more trees can be set per acre than by the rectangular.

For permanent plantings, at regular distances this system and the rectangular should be recommended before the others.
Hexagonal, Septuple or Equilateral Triangle System. By this system six trees are set equidistant from a seventh placed in the center. The ba. sis of the system is not the square but the circle, since the radius of the circle is approx. imately equal to one-sixth of the circumference of the circle. The name septuple, sometimes applied to this system, refers to the fact that the number of trees in each group-unit is seven. Equilateral triangle system refers to the planting of the trees in equilateral

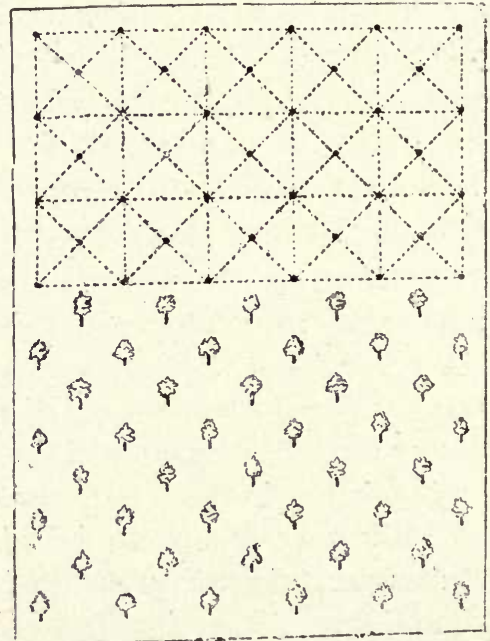

Fig. 58. Quincunx system of planting. 
Quincunx System. By this system four trees constitute a square, and a fifth is set in the center of each square. Hence the number of rows is greatly increased and about 78 per cent more trees can be set per acre than by the rectangular system.

For permanent plantings of varieties of uniform size, it does not possess any particular advantage. But if it is desired to set a tree of some smaller variety in the center of each square then the system of quincunx planting becomes useful.

In double plantings, where the intention is to remove some of the trees, this system can be recommended. If for instance, peaches are set with oranges, a peach tree may be set in each square of oranges, and after serving four or five years of usefulness, can be cut out.

APPROXIMATE NUMBER OF TREES PER ACRE FOR DIFFERENT PLANTING SYSTEMS.

\begin{tabular}{|c|c|c|c|c|}
\hline DISTANCE APART & Triangular & $\underset{\text { lar }}{\text { Rectangu- }}$ & Hexagonal & Quincunx \\
\hline $10 \times 10$ feet. & 396 & 436 & 501 & 831 \\
\hline $12 \times 12$ feet $\ldots \ldots \ldots \ldots \ldots$ & 275 & 303 & 348 & 523 \\
\hline $15 \times 10$ feet $\ldots \ldots \ldots \ldots \ldots$ & 164 & 290 & & \\
\hline $15 \times 15$ feet. . . . . . . . . & 175 & 193 & 217 & 347 \\
\hline $20 \times 15$ feet. . . . . . . . . & 132 & 145 & $\therefore$ & 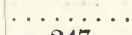 \\
\hline $18 \times 18$ feet. . . . . . . . . . & 122 & 134 & 142 & 247 \\
\hline $20 \times 20$ feet. . . . & 98 & 108 & 124 & 199 \\
\hline 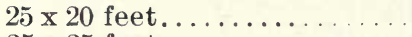 & 79 & 87 & 01 & \\
\hline $25 \times 25$ feet $\ldots \ldots \ldots \ldots \ldots$ & 64 & 70 & 81 & 126 \\
\hline $30 \times 30$ feet. . . . . & 44 & 48 & 55 & 83 \\
\hline $35 \times 35$ feet. . . . . . . & 33 & 36 & 41 & 65 \\
\hline
\end{tabular}

Hedge Plantings. Some growers have occasionally resorted to this system of planting. The trees are set so as to form a dense line one way while a space of twenty feet or so is left between the rows. Large quantities of fruit are obtained from a small area and the 
system, for a few years at least, works well. But it can scarcely be recommended for general adoption. Eventually the trees will crowd each other and many of the branches may die.

Double Planting. By this system of planting is meant the setting of two or more kinds of fruit trees or plants in the same area. In Florida, citrus trees and pineapples, citrus trees and guavas, and citrus trees and peaches are frequently planted together. In Louisiana

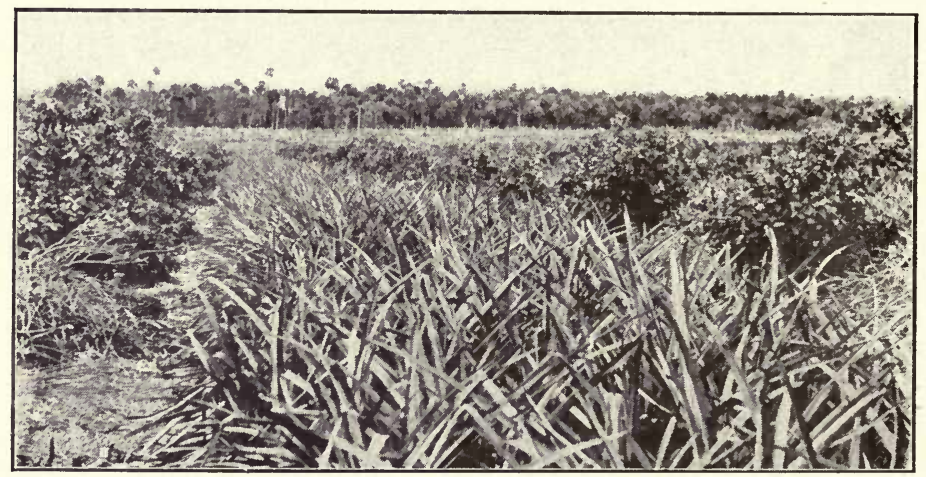

Fig. 59. Double planting-Citrus fruits and pineapples.

citrus trees and pecans are often so planted. A double planting of pomelos and pineapples, a method quite successfully used by $\mathrm{Mr}^{2}$. C. T. McCarty, on hickory scrub land a little north of Fort Pierce, Fla., is illustrated in figure 59. The plan shows the pineapples occupying a portion of the space between the rows of trees. The pomelos are set 17 feet apart in rows which are 22 feet apart. Six rows of pineapples, $15 \times 20$ inches apart are set in each twenty-two-foot space.

This leaves a six-foot space on each side of the pineapple bed between the edges and the row of trees. The 
plan has worked quite successfully. After three or four years the pineapples will be removed entirely and the whole space given up to the trees.

Whenever this plan is adopted, one mistake must be guarded against. The favorite pineapple fertilizers used in Florida to-day contain organic sources of nitrogen. If these be used on a double planting of pineapples and citrus trees, the latter will almost surely be affected with die-back. A fertilizer containing sulphate of ammonia and a little nitrate of soda as sources of nitrogen is the only safe one to use.

Peaches and citrus trees may be planted together. The quincunx method may be used and after the peaches have served their term of usefulness they can be removed. Both kinds of trees succeed well when given the same kind of cultivation and supplied with the same fertilizer, viz., one containing no organic sources of nitrogen.

Other double plantings may be made, but in general it may be said that no tree or plant should be set with citrus trees and allowed to occupy the ground to the detriment of the latter. Vegetables are permissible in the citrus grove only in regions not exposed to frost, and when supplied with fertilizers congenial to the trees. In frosty regions there is always a chance that the cultivation, fertilizing and watering of the soil, when planted in vegetables, will cause the trees to grow during the winter months. Generally, vegetables should be planted elsewhere than in the citrus grove, for the trees succeed best when given all the space.

\section{LEVELING AND SMOOTHING.}

Lands upon which citrus trees are to be planted are frequently quite rough. If the ground is left in this con- 
dition, its uneven character will prove to be a considerable nuisance in after years. It will interfere with all kinds of horse work among the trees. Pains should be taken to have the ground level and smooth. Small, abrupt elevations or knolls should be removed. Long, sweeping slopes are not objectionable, and if they give the right exposure, they are a decided advantage. In the irrigation districts they are quite necessary for the successful distribution and disposal of the water. But in those dis. tricts small knolls, two or three feet in height, or even less may act as a barrier over which water cannot be successfully carried. Grading should be very carefully done before planting, and only after a careful survey of the ground. In fact, the best advice that can be given is to turn this part of the work over to a competent surveyor

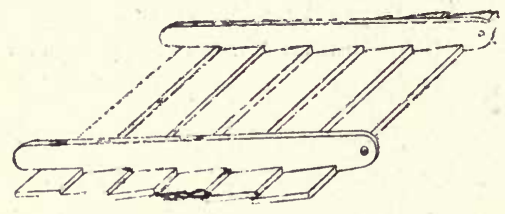

Fig. 60. Float for smoothing ground.

Before attempting to grade the ground, it should be plowed. The depth will depend upon the nature of the soil and the character of the surface. It may be necessary to use the scraper to remove some of the knolls, in which case the plow should be run somewhat deeper on the higher portion. If only very slight inequalities are present, they may be disposed of by harrowing after plowing and then following the harrow with the float or planker shown in fig. 60 .

This is made of six pieces of $8 \times 2$ inch plank, seven feet long. Two of these are rounded off at each end and a hole is bored in one end of each piece. These two pieces are then notched as shown in the figure. The notches on 
the two pieces must correspond, and the first notch should be cut about a foot back from the front end. They are two inches deep at the front, and slope out to the edge of the plank six inches back, thus leaving two inches of the plank for overlapping. The six pieces of plank are then laid in the notches and nailed or bolted firmly in place. A chain is run through the holes already provided and to this the whiffletrees are attached. This has proved to be a very satisfactory device for leveling lumps and even for filling up shallow depressions.

\section{DISTANCES FOR PLANTING.}

Growers differ greatly regarding the distance apart at which citrus trees should be set. As a matter of fact, no set of distances can be given which will be best for all conditions. Many things have to be considered in deciding the point. Much depends upon the natural moisture content of the soil, the amount of water that can be secured, either by irrigation or from rainfall, the amount of fertility in the soil, the kind of stocks, the variety of tree, and whether it is necessary to protect the trees from frost-all have to be taken into consideration. A canvass of the situation in Florida some years ago showed that sweet oranges are, or have been, planted all the way from $15 \times 15$ feet to $35 \times 35$ feet; pomelos the same; mandarins $15 \times 15$ feet to $25 \times 25$ feet; lemons $20 \times 20$ feet to $30 \times 40$ feet; and limes $15 \times 15$ feet to $20 \times 20$ feet.

If the trees are planted in a region subject to frost, and protection by means of open wood fires is to be practiced, it is best to plant the trees so as to leave sufficient space for firing. A plan sometimes adopted is to plant sweet orange trees $15 \times 15$ feet and omit every third row. It must be remembered also that the effects of frost or 
freezes is not so severe on densly planted groves as it is where the trees are separated by wide avenues through which the wind can sweep unchecked.

The insect problem must be considered as well. If spraying or fumigating has to be adopted to control insect pests, the trees should stand sufficiently far apart to allow either of these operations to be carried on conveniently.

In general it may be said that if the trees are planted in rectangles, it is better to place them, not in squares. but in oblongs, the spaces between the tree rows being greater than the distance between the trees in the row.

The following distances may be regarded as being approximately correct, though much depends upon the habit of growth of the different varieties in each group:

Kumquats ................ 10 to 12 feet.

Mandarin oranges ............. 15 to 20 feet.

Lemons and sweet oranges .........20 to 25 feet.

Pomelos ................... 25 to 30 feet.

Limes ................. 15 to 20 feet.

\section{LAYING OUT BEFORE PLANTING.}

The trees should stand in straight rows. It looks better and cultivation is easier. Nothing looks worse than zigzag rows of trees, and it is impossible to plow or cultivate straight through the grove.

Laying Out Squares or Rectangles with the Plow. If a good plowman can be secured, very satisfactory work can be done with the plow. In some cases a man can be found who needs nothing in the way of a guide, except two or three stakes. But with a sufficient number of stakes and a marker attached to the plow, good results can be secured by almost any plowman. 
Furrows should be run both lengthwise and crosswise of the field, their intersections marking the place where the trees are to stand. A stake should be set for each tree, ordinary building laths answering very well for this purpose.

It is essential that a true, square corner should be secured. This may be done by sighting with an ordinary carpenter's square set upon three posts.

Laying Out in Rectangles with a Wire. A wire long enough to reach down one side of the field should be provided. Stretch this straight out between two posts and mark off the distance which the trees are to stand apart, upon it. At each point marked firmly twist a piece of small wire about the larger one. These should then be soldered in place. It will not do to have them shift. This wire may be rolled upon a roller when not in use.

Measure off along both ends of the field and set small pickets on the tree rows. Tightly stretch the wire down the first tree row, attaching it firmly at the ground level to a pair of good, stout posts. Then plant a lath stake at each mark on the wire. Set all of them on the outside of the wire, so as not to interfere with moving it. When this row is completed, lift the end stakes with the wire attached, stretch on the second row, set the stakes as before and repeat the operations until the work is completed.

Laying Out in Triangles. This system can be most easily marked out by using the wire already described. On every other row stretch the wire, so that exactly onehalf of a tree space will lie outside the end tree row, then proceed to set the stakes on the marks on the wire as be. fore. 
Laying Out in Hexagons. Stretch the wire down one side of the field and firmly set the tree stakes, or stake out the base line by any method, firmly setting a stake for each tree. Then procure two pieces of wire with rings at each end, the length of wire and rings to be exactly the distance between the stakes as set on the base line. Stretch these wires out toward the side where the next tree row is to stand. At the point where the rings overlap set a stake for a tree. Remove wire number one and set it on the third stake in the base line, stretch the two tight and set a tree stake. Repeat as often as necessary. In setting the third row of stakes, use the second as a base line and so on.

Laying Out in Quincunx. By this method the trees are in groups of five, four forming a square, the fifth placed in the center.

The best plan is to lay out with a wire, though the plow may be used. In setting with the wire, each space on the wire should be divided in the center and marked as before. If, for instance, to reduce the discussion to a concrete form, we say the trees are to be set in squares of twenty-seven feet, with a fifth in the center, divide the spaces on the wire and mark each one at the thirteen-anda-half-foot point. On the base line set the trees at the twenty-seven-foot point. Then stretch the line for the next row, thirteen and a half feet in from the base line. On this row set the stakes at the thirteen-and-a-half-foot marks, thus leaving the stakes twenty-seven feet apart as before. Set the third row to correspond with the base line, the fourth with the second, and proceed in this way until the work is completed. 


\section{CHAPTER XXXI.}

\section{SETTING THE GROVE.}

The planting of the trees is the actual starting of the grove and any reasonable amount of time and care spent in the operation is well spent. All the details should be carefully looked after and the work should be done either under the supervision of a competent foreman or under the direction of the owner himself. The varieties must be selected, the trees purchased, the ground laid out and the trees set. When the ground is placed about the last tree, mulched and shaded on the south side, the work may be considered finished.

\section{SELECTING VARIETIES.}

In the colder or more exposed sections it is best to plant the hardier varieties and those which mature early. The fruit will not stand the same amount of frost as the tree, and if it is sufficiently mature to pick before the cold comes on it is a decided advantage; the cost of protection will be materially lessened. But it should be borne in mind that for early shipments from any section, early maturing varieties should be planted. Green fruit should not be shipped, just because the market happens to be good. It is ruinous to the reputation of any section that carries on the practice.

Groves in sections farther south or free from the effects of frost should pay attention to late varieties such as cannot be safely matured in sections more exposed to frosts. As a matter of fact, either very early or very late fruit brings the most money in the markets and by grow- 
ing late varieties competition with the sections growing early varieties would be obviated.

It is, however, the best policy, where weather conditions permit, to make a selection of such varieties as will give fruit continually from the early shipping season until the end. The grower who can do this has his fruit in the market all the time and if his fruit is of good quality and it is handled as it should be, his customers can be held for the whole season. Most handlers of fruit much prefer a steady supply of fruit from a reliable shipper to having it come in spasmodically.

The number of varieties selected should not be large. Only he who grows citrus fruits as an amusement or the nurseryman who desires to have a known and reliable source from which to secure budwood, or who desires to test the relative merits of varieties, should attempt the planting of any large number. In dollars and cents, it does not pay the ordinary man. Select, at most, a sufficient number of varieties to give a continuous crop of good sized, marketable oranges throughout the shipping season and stop at that.

Just because certain varieties fruit well in some sections and bring fancy prices, planters too frequently jump at the conclusion that the same varieties will do as well in other localities far removed from that in which they are apparently at home. In California, the Bahia is the commercial orange, but it would be folly for a Florida grower to plant large areas with this variety. They fruit fairly well on rough lemon and trifoliate orange stock, but even then it is extremely doubtful whether the variety will hold and mature sufficient fruit to make it profitable. The point in question is further illustrated by the action of some California 
planters immediately following the disastrous freeze in Florida-1894-95. The demand for pomelos could not be supplied and the price increased enormously, which led many in the western State to plant heavily. In 1900 Professor Wickson said, "The results of these attempts were not satisfactory, and unless some new conditions should arise, it is possible that the California pomelo passion may subside as rapidly as it uprose." Florida varieties were the ones planted, but Lelong points out that some varieties of California origin have been more successful since.

Another problem, one which frequently arises, is that concerning the relative number of each citrus group which should be planted. In most groves there are to be found a number of pomelos, mandarin oranges and sweet oranges. How many of each group would it be well to set out? No one can say but the man who is going to set them. He should know best what his aims and objects are. The mandarin orange is a fancy fruit of exquisite quality, but is a fancy fruit; the sweet orange is a staple commodity, always in demand and never out of season; the pomelo has become a staple fruit and all markets have not been reached yet. It is a new fruit commercially, but it has come to stay. The writer once said, "The sweet orange must, however, be considered the staple product, and it would probably be best to make three-quarters of the planting from this group, leaving the remaining onefourth to be divided between the pomelos and mandarin oranges," but now he is prepared to place the pomelos with the sweet orange in a commercial venture, in sections where both will grow and fruit equally well. 


\section{PURCHASING TREES.}

Citrus nursery stock matures in autumn and is put on the market during the winter months-November to March. Whether for winter or summer planting, the trees should be purchased in good season. Then there will be fewer disappointments. Buy in September or October at latest. "First come, first served," is true in purchasing nursery trees, but it is equally true that he who comes first will be best served. Generally speaking, the supply of nursery stock in California and Florida is inadequate to the demand and may continue to be so for several seasons to come.

As a general rule it is best to purchase directly from the nurseryman. Beware of the unaccredited tree peddler as you would of the very devil! The expression may not be elegant, but it contains the soundest advice. A legitimate nursery business may be done through properly accredited agents, but too frequently it is difficult to obtain definite information regarding the kind of stock, and where it is grown. Should a mistake of any kind occur in dealing with a responsible nurseryman, he will always be found willing to rectify it, but if a mistake be made through an agent, the responsibility is too frequently shifted.

If possible, visit the nursery. See the conditions under which the trees are grown, make a thorough inspection and select the trees desired. Become personally acquainted with the nurseryman. Buy only from those of good repute. In most cases there are no marks by which the genuineness of a variety may be known and in the end the only assurance the planter can have that the stock is true to name, is the truth and honesty of the man from whom he purchases. Fortunate is the nurseryman 
whose character warrants a reputation for square, honest dealing.

The best citrus tree for setting out is one having a root system about three or four years old with a stocky, healthy, vigorous top of one or two season's growth Trees should be free from insect pests and should not show signs of poor, stunted growth. Nor, on the other hand, should they show evidence in long internodes* and sappy, angular growth, of having been unduly forced to bring them up to size. Some have thought to gain time by purchasing large nursery trees, four or five years old or even older, but in the end they have generally found that nothing is gained and frequently much is lost. If given particular care and attention, well supplied with water and planted in a favorable season, they sometimes repay the trouble, but speaking broadly, such trees are a poor investment for the average planter. No mistake can be made in selecting first-class trees fourt to six feet high. The very best that ean be secured are the cheapest in the end, and poor stock is dear at any price. Have nothing to do with hard, stunted stock.

Trees on trifoliate stock are more difficult to transplant than on other stocks and if this stock is used. the purchaser should insist that the nurseryman puddle the roots before shipment. The crust of mud should be washed off just before planting.

The price of citrus stock is, of course, subject to the laws of supply and demand. In Florida the price varies in proportion to the height of the tree. At present the price of first-class nursery trees per hundred is about as fol-

\footnotetext{
* Spaces on the branch between leaves, thorns or buds.
}

$\dagger$ In California, nursery trees are usually sold by the diameter of the bud one inch above the point of insertion. 
lows: 2 to 3 feet, $\$ 25.00 ; 3$ to 4 feet, $\$ 30.00 ; 4$ to 5 feet, $\$ 40.00$; and 5 to 7 feet, $\$ 50.00$. In lots of 1,000 the prices are from 4 to 6 per cent lower and for smaller lots they are increased considerably. In California, trees are sold by caliper measurement of the bud one inch above the point of insertion. The prices are furnished by $\mathrm{Mr}$. R. M. Teague, of the San Dimas Nurseries, San Dimas, Cal., for one-year-old trees are as follows: $3-8$ to 1-2 inch caliper, 50 to 70 cents each, $1-2$ to $5-8$ inch caliper, 60 to 80 cents each, 5-8 inch caliper and over, 70 to 90 cents, depending upon the variety. Trees lifted with a 40-1b. ball of earth, or less, cost five cents extra and two-yearold buds with a 60 to $75-1 b$. ball of earth, ten cents extra.

It is probable that a combination of the Florida and California methods would be advisable, that is to designate both the height and diameter of the trees in listing them for sale.

If orders arrive late, the vexed question of substitution of varieties usually arises. But if the orders have been placed in good season this difficulty is not so likely to come up. The planter with well defined ideas of what he wants should be content with nothing except what he orders. Provided one nurseryman cannot supply the desired trees, try elsewhere before changing the list of varieties. In some cases, varieties are so nearly alike that substitution may be permissible.

The directions for shipment should be plain and explicit. Give the route, the time when shipment is to be made and write the address plainly.

\section{BEST TIME TO PLANT.}

As already noted, citrus trees are not periodic in their growth. Several growths are made each year and 
so long as they are transplanted during their dormant periods, they may be set out at almost any season of the year so far as the condition of the tree is concerned. But while this is true, much better results attend the transplanting of the trees at certain periods than at others, because of more favorable climatic conditions. The best time for setting citrus trees in California is in spring, just after the completion of the first growth and before the starting of the second.

In Florida and the Islands, trees may be planted during the winter months or just after the beginning of the rainy season. Some hesitate to plant in winter in certain sections, because of the risk of injury from frost, but, all things considered, it is more satisfactory to set the trees then and, if necessary, bank them immediately after planting. Bearing in mind that the dry season in Florida generally commences in March, it is best to set the trees some time between December 15th and February 15th. The winter rains will settle the soil firmly about the roots, the roots may make some growth, the cut surfaces will at least callus, and with the warmer days of spring they will start off vigorously. Summer planting is quite successful, if the trees can be secured in a dormant state and sufficient water is provided either by irrigation or by rainfall. It sometimes happens, however, that summer planted trees have a tendency to prolong their growth too late in the fall.

\section{PLANTING.}

When trees are shipped in boxes or bales, as is most commonly done, they should be unpacked as soon as received and heeled in, in a shady place. Plow out a furrow of sufficient length to accommodate the trees when 
spread out singly, side by side. With a shovel slope off the furrow at an angle of forty-five degrees, place the roots of the trees in the furrow, spread the roots out well, pack the earth about them and water.

Everything having been arranged for planting, remove the trees from the furrow, a few at a time as needed for setting, trim the roots and wrap them in a damp blanket for carrying to the field. Under no consideration should

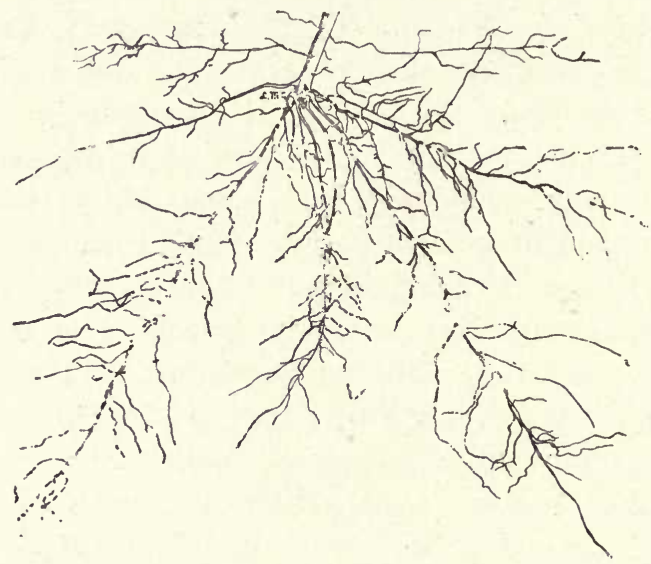

Fig. 61. Branching of citrus roots in the soil after trimming.

the strong sunlight or the wind be allowed to strike the roots. The roots of citrus trees are extremely susceptible to injury from these causes.

In trimming the roots, remove the broken ones, cutting them smoothly off with a sloping cut from the under side. The advantage of a smoothly cut root end over a torn and ragged one is that it calluses and heals much more readily. From the root just back of the callus, large numbers of small roots start out (fig 61), which soon 


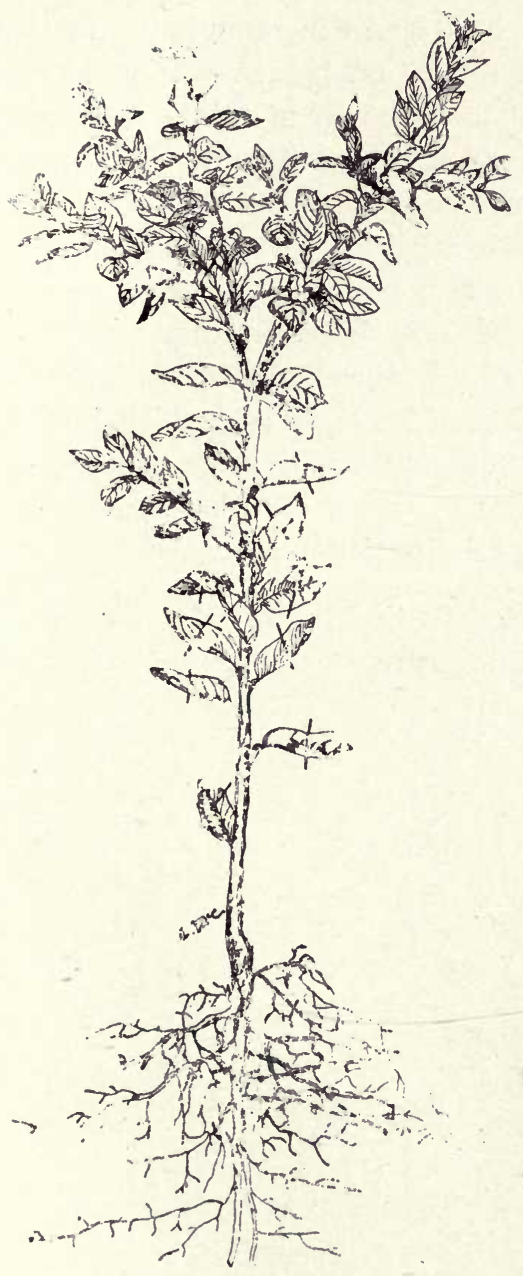

Fig. 62. Pruning and root trimming of citrus tree at time of planting. Foursear tree on trifollate stock, 5 feet 6 inches from crown to top of branches. Cuts to be made where the lines cross the roots, stems, branches and leaves. take the place and do the work of the portion removed. A goodly portion of the small, fibrous roots, all if they have become slightly dried, should be removed and all roots should be cut back somewhat at the tips. Where a double taproot is found, it is gen. erally considered best to leave one of the parts somewhat longer than the other. Some idea of the root systems of trees as they come from the nursery and the method of trimming them may be secured from an examination of figures 62 and 65 .

If possible to so arrange the work, the holes should not be dug until just before planting. The soil will still contain its natural moisture when placed about the trees and in some soils the 
sides of the holes become hard and compact, so much so as to necessitate their being shaved off before setting the tree in them. The planting board shown in figure 64 is very helpful in keeping the rows of trees straight in the grove. It should be made from a piece of inch board, four $\mathrm{Or}^{\circ}$ five feet long and four inches wide. In each end bore an inch hole and cut a notch in one side at the center. Place the notch against the tree, stake and shove a pair of small wooden pegs through the holes in the ends. Remove the board and the tree stake, leaving the pegs in place. Dig the hole, making it large enough and deep enough to hold the root system without cramping. Place the planting board in position over the pegs and

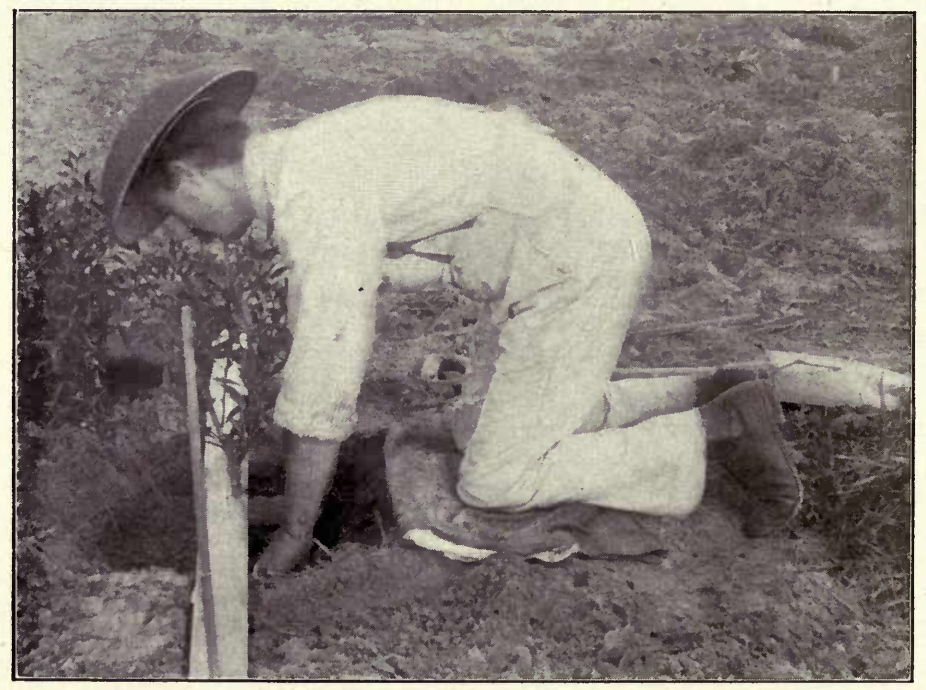

Fig. 63. The right way to plant a tree.

holding the tree in the central notch, fill in the soil with the hands. A helper may place the earth in the hole in small 
shovelfuls. Pack the soil well around the roots, spreading and straightening them out at the right level, as the hole is

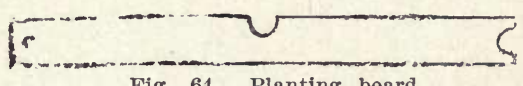

Fig. 64. Planting board. filled up. Fig. 63 illustrates the best method of planting a tree, and it may be said that the man who will not get down on his knees to plant a tree does not deserve to have it live for him. Trees planted in poor soil will be much benefited by thoroughly incorporating a pound of good commercial fertilizer with the soil before placing it about the roots. The surface and subsoil should be kept separate, the surface soil to be placed in first, in filling up the hole. Water may be applied when the hole is filled in about three-fourths, and after planting is completed a liberal supply of water, sufficient to establish the capillary movement of the soil moisture should be given. In California about half a barrel should be given to each tree. Having applied the water, mulch the surface with grass, leaves or dry dust about the tree, to prevent evaporation. In the irrigation districts, apply water every ten or fifteen days until the trees are well established.

Trees should never be set deeper than they stood in the nursery row. The better plan is to set them higher rather than lower, to allow for settling. They do not do well if planted too deep.

In the hot, dry districts, the trunks of the young trees should be protected from the rays of the sun to prevent sunburn. Thousands of trees are annually destroyed by this cause and many other's are so injured that they never afterward make a satisfactory growth. Lath cylinders or those made of yucca or paper serve the purpose well. The trunks may be wrapped in paper or straw, or they may be covered with whitewash. 
As soon as the trees are set, the tops should be pruned back. It is better to do it at this time than before planting, as more uniform trees can be secured throughout the grove. The disposition on the part of most planters

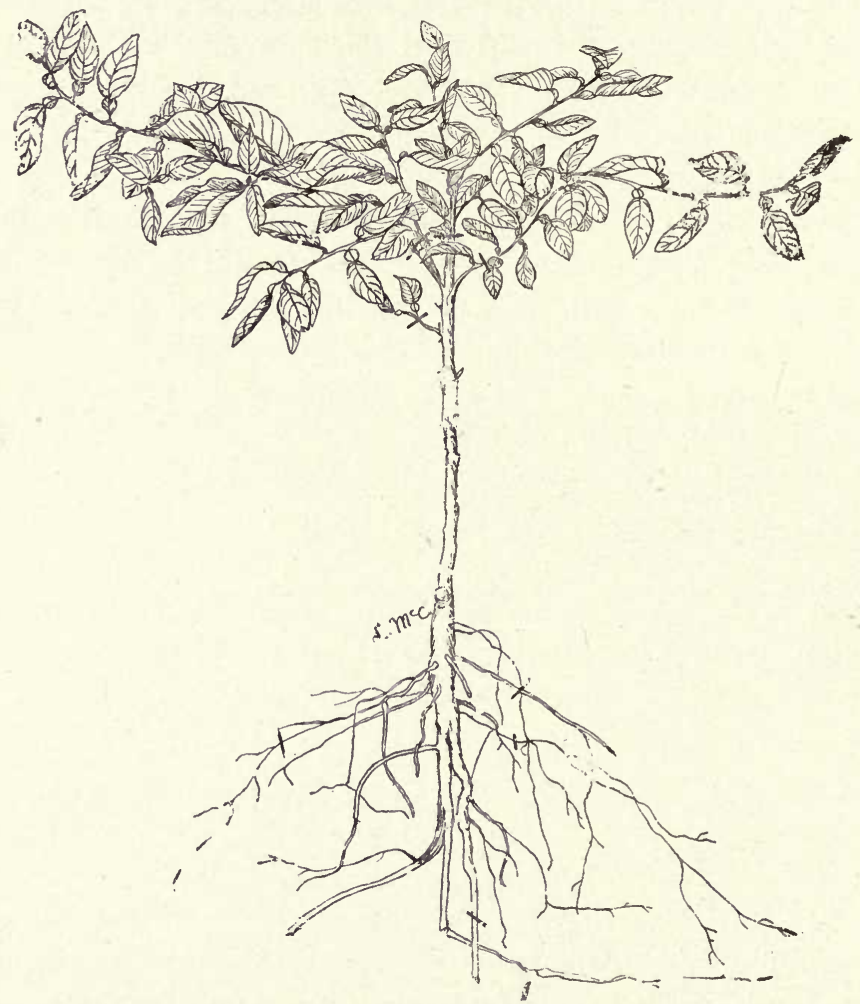

Fig. 65. Pruning and root trimming of citrus tree at time of planting. Two-year Tardiff orange tree on a four-year rough lemon root, thirty inches from crown roots to branches. Cuts to be made where lines cross the roots and branches.

is to retain too much of the top. When the trees are lifted from the nursery row, more than half of the root system is left in the ground. The top and leaf area 
should be reduced proportionately and all trees should be shipped cut back and defoliated. If the trees have been grown to a single shoot, without branches, they should be cut off with a sloping cut just above a node, about two or two and a half feet from the ground. If well-developed branches are found at this height or perhaps a little higher, trim them in to spurs with two or three buds. Should the trees not start promptly they should be more severely cut back. Figures 63 and 65 illustrate the methods of pruning the top and reducing the leaf area of citrus trees.

The system of lifting the citrus trees with a ball of earth still remaining about them and then encasing this in a sack is an excellent one. The trees may be transported long distances and planted out without even wilting the foliage, if the work is carefully done. To lift the trees a trench is dug along one side of the nursery row, about eighteen inches deep and six or eight inches away from the trees. In digging this trench, the layer of lateral roots are cut off, and at the bottom the tap-root is severed. The top soil is then removed so as to barely expose the crown roots and a sharp spade is thrust into the soil on the three uncut sides to sever the remaining laterals. When all the roots have been cut the tree is carefully lifted from its place. The angles are rounded off and the tree is set on a piece of burlap sufficiently large to completely cover the ball. The burlap is carefully drawn around and tied about the earth. The size of the ball should correspond with the size of the tree. Smaller trees have about forty pounds of earth, larger ones about sixty. This method of digging trees cannot be pursued on loose, sandy soils, but only on those which have sufficient clay to make the ball adhere well about the roots. 
THE REED SYSTEM OF TRANSPLANTING.

A system of transplanting citrus trees that has been used by Mr. J. H. Reed, of Riverside, California, has proved very successful. The method is hardly applicable to Florida conditions on account of the loose nature of the soils, but wherever practicable, it is an excellent one to follow. Prof. J. W. Mills thus describes it in Bul. 138, Cal. Agri. Exp. Station:

"According to this method, vigorous trees are selected in the nursery, and are well watered before removal. The longer branches are but slightly cut back, leaving most of the foliage on. The trees are then lifted with large balls of earth, and are taken directly to the plantation, where holes two feet deep and two and a half feet wide have been prepared, into which they are placed. and the earth is walled in around each ball, not firmed, but settled with water, so that the trees will stand at the same height as they did at the nursery. No planting should be done unless there is irrigation water available at the time. After the ground has been soaked for several feet on all sides of the newly set trees, thorough cultivation should follow, as soon as the land is in a proper condition. Under this system of transplanting this is a good practice."

"Mr. Reed says further: 'A small amount of ferti. lizer is applied soon after planting, for the young roots to use when they first start out from the balls. A pure bat guano with a high percentage of nitrogen, about threefourths of a pound to the tree, has been found to give the best results; but any commercial fertilizer rich in nitrogen, or animal fertilizer, if placed properly and kept moist, answers well. It is applied in trenches each side of the ball, at right angles with the irrigation furrows, 
and reaching to them. They may be made by plowing a deep furrow and deepening with a shovel to ten or twelve inches. The material is carefully distributed and slightly mixed with the earth at the bottom of the furrows; the water from the irrigating furrows keeping this always moist, it is available as soon as reached by the rootlets. This also tends to deep rooting. Thorough irrigation should follow planting every twelve or fifteen days during the first summer. The whole space between the rows should be thoroughly and deeply wet-not merely a narrow strip on each side of the rows. I have traced roots that have grown during the first summer over six feet from the tree and these should be well sup. plied with moisture at all times.

"The advantage claimed for the Reed method is that it retains the top of the tree, and makes use of it immediately. This retention of nearly all the leaves and branches enables trees under proper conditions to produce a much more vigorous growth than under the ordi nary system of severe pruning, when moved from the nursery. The best care is essential to success in this method. If trees are to receive poor or only ordinary treatment after being set in the orchard, the common method of severe pruning is best. Mr. Reed himself prunes back any trees that show lack of vigor after being transplanted, watered and fertilized.

"The good start given to trees by the Reed method is shown in their size, vigor and productiveness for an indefinite time, and it is also claimed that a crop of oranges is obtained, without injury to the trees, one year earlier than if they were planted by the usual method. Trees thus planted (on the Reed system) produced over one hundred boxes of oranges on ten acres the second 
year from planting, and one box per tree three years from the time of planting. Ten acres of trees five years old produced 2,500 boxes. There was no appreciable injury done the young trees on account of the early bearing, for they continued to make a sturdy growth while maturing the crop of fruit. 'Trees planted in the usual way one year before, on adjoining land that is similar in character, although receiving good care from the start, are not now as large as those of Mr. Reed, though apparently thrifty.

"This method of transferring trees to the orchard and securing their rapid establishment there, is based upon intelligent selection in the nursery and very careful attention to details after transplanting. Mr. Reed does not claim that he originated the method, but it has not been observed except in his orchard, which furnishes an excellent illustration of its value under proper conditions."

\section{LABELS AND MAPS.}

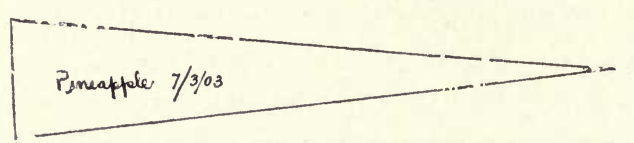

Fig. 66. Zinc label.

After the trees have been planted and pruned. they should be labeled. For this purpose there is nothing better than a piece of zinc, five inches long, 3-4 inch wide at one end and tapering to a point. (Fig. 66). On this the name is simply written with a lead pencil and the tapered end is then wrapped about a branch. The labels should be placed on the same side of each of the trees and on branches as nearly as possible in like positions. If many varieties are planted on any considerable area, the grove should be mapped and the name of each tree and its position designated thereon. The best material for the map is a piece of glazed muslin such as is used by architects. 


\section{CHAPTER XXXII.}

\section{CULTIVATION OF CITRUS GROVES.}

There is probably no practice connected with the growing of citrus fruits regarding which there is more difference of opinion than there is upon the question of the best methods of cultivation. In the citrus districts of America, the soils are so varied in character and in the amount of fertility and moisture which they contain, that it is not to be wondered at that such is the case. To anyone who understands the nature of these soils it must be patent that in a large measure, the system of cultivation adopted must meet the requirements of the particular soil. After all, though practices may differ and many different methods may be advocated, it will generally be found that underlying each and every system from which good results are obtained, there is some broad, general principle, applicable in all cases.

Benefits of Tillage. Because of their loose, open nature, it is not so difficult to keep citrus fruit lands in good condition. Neither the same amount of time, nor the same amount of hard labor is necessary to keep citrus groves in good tilth as is required by fruit plantations in most of the fruit growing districts of America. Perhaps, herein lies the reason why some have neglected cultivation altogether on lands that would be benefited by it, while others have, in many cases, carried the practice too far. But, if our soils are in apparently good condition and roots can easily penetrate them in all directions, then in what way does cultivation benefit the trees and why is the operation necessary? 
Cultivation is beneficial in the following ways: It increases the water-holding capacity of the soil and conserves moisture, both by allowing rain to sink more freely into it and by checking evaporation. It pulverizes the soil and allows the air to penetrate, thus supplying oxygen to the roots. It assists in setting free plant food and makes the soil fine, thus enabling the roots to reach all parts of it. In cultivated soils, decomposition and nitrification go on more readily and if the materials are present from which nitrogen can be set free, its liberation takes place more rapidly than if the soil be left uncultivated.

Most of the moisture in tillable soil is held as a minute film surrounding the soil particles. It necessarily follows that the more numerous the soil particles in a given space, i. e., the smaller they are, the greater will be the water-holding capacity of the soil, because the total surface area of all the particles increases as they are reduced in size. And it is true, within certain limits, that the water-holding capacity of a soil increases as the size of the particles diminishes. If, however, the particles become too small, they may become too closely packed, and thus this object of cultivation will be defeated. This condition is not likely to occur in light, sandy soils as a result of cultivation. The size of the particles can be reduced by cultivation by breaking up masses which may have become more or less cemented together, and the waterholding capacity may be thereby increased.

The opening and loosening of the soil permits the rain to penetrate. If the surface of the ground becomes hard and compact, the water will run over the surface or collect in puddles and disappear by evaporation. In either 
case, the loss will be great. But if the soil is well stirred and loose, the water will enter.

Once it is safely beneath the surface, it is necessary to keep it there; it has gained entrance by a passage through which it should not be allowed to escape. The water will again make its way to the surface by capillary attraction, passing upward through the minute spaces between the particles of soil. If these minute tubes or passages extend right to the surface, the water rises to the top, comes out and is carried away by evaporation. Frequent shallow cultivation will prevent this escape of water, by breaking the capillary tubes. If the top inch or two of the earth is stirred, it parts with its moisture and becomes quite dry. Then it acts as a dust blanket and the great amount of moisture below is not allowed to reach the surface to be carried away by the moving air above. Thus moisture is conserved and held for the use of the trees. During the rainy season, it is not necessary to conserve moisture, but often in April, May and June in Florida, and sometimes even later, week after week goes by without a shower. The California cultivator is confronted by even worse conditions and must resort to irrigation. During the period of drought is when water is needed, the time for which preparation should be made before it comes. The horse and cultivator are often a most excellent substitute for an irrigation plant.

We know that a hard, compact soil, into which air does not enter, is no fit place for the roots of plants to grow and live in. The roots absorb water and food in solution only through their newer parts, and new roots must be formed constantly to carry on this work. For the formation of roots, oxygen is necessary, and if the air cannot enter, oxygen cannot be supplied, and the roots 
suffer in consequence. The soil should be kept loose and friable during the period of greatest growth that the roots may be freely supplied with air.

If, in addition to this, the rootlets can reach and penetrate every portion of the soil, growing here and there at will, they then have every opportunity to come in contact with and absorb the plant food in the soil. While it is true that food materials in solution may move towards the roots, still, in general, the roots must search out and procure the plant food. How can they do this important work if the soil is hard, compact and impenetrable?

The food materials in any soil are found either in chemical substances present in the soil, or in organic combinations. If fertilizers are applied or added to the soil. they, too, fall into either one or the other of these classes. Most of these materials do not immediately yield up the plant food which they contain, but they must be acted upon by certain agents before their store of food becomes available, i. e., so that the roots can absorb and the plants use it. A large part, or practically all, of the plant food in organic substances is liberated through the agency of microscopic plants called bacteria. That these may thrive and multiply, plenty of air should be admitted to the soil, and the soil should at the same time be warm and moist. Cultivation goes a long way towards making the conditions ideal for the growth and development of soil bacteria. The other class of agents is those which act chemically. To this group belong the acids and other substances which are capable of breaking up the food-containing materials in the soil. Some of these disintegrators are present in the air, and are carried to the soil 
in the rain. Here, again, cultivation helps by admitting the air to the soil and allowing the rain to penetrate.

\section{CLEAN CULTURE OR NO CULTURE.}

The practice of keeping the ground on which the orange grove stands perfectly free from herbage and thoroughly cultivated throughout the whole season, year in and year out, has been indulged in by many and is still followed by some. This practice has little to recommend it. A soil so treated soon becomes depleted of its natural fertility and the humus soon becomes used up through constant cultivation and the application of various fertilizers. No amount of fertilizer will do the work it should if the soil once loses its natural body and becomes deficient in humus. In spite of every effort in the line of fertilizing, such a soil will become poor and infertile and the trees will soon show the effects in their unhealthy condi. tion, and the owner will realize it in his diminishing returns.

If clean culture is adopted, humus must be supplied in some way, and the plan used by a number of successful growers in the citrus districts is to cover the ground with a liberal coating of leaves and leaf mold from an adjoining woods. By this means, a mulch and the material from which humus may be formed are provided for the soil. It is far easier to maintain the humus content of soils than it is to replace it after it has been once worked out of them, a fact which it is well to bear in mind.

Humus, one of the most, if not the most important ingredient in any fertile soil, is generally found in inade. quate amounts in citrus soils, and any system of cultiva. tion which does not tend to increase the amount or main- 
tain a considerable quantity of this substance in the soil is not based upon scientific principles.

Any piece of ground denuded of its natural covering of vegetation, and so exposed continually to the burning heat of a sub-tropical sun, rapidly loses most of its fertility and becomes dead, lifeless and useless. The soil must not be regarded only as a place for roots to grow and live in, it must be looked upon as nature's food-producing laboratory, in which multitudes of micro-organisms or bacteria, are busily engaged in preparing food for the plants which grow on it. They fail utterly in the performance of their work if their natural element, a soil rich in humus, is by some means converted into a sandbank. This is exactly the result of long-continued. clean cultivation.

On the other hand, many growers do not cultivate the soil at all, and on some classes of soil, this method is really the best. Only on naturally moist soils, low, damp hammocks in Florida, for instance, should this plan be adopted. On high pine lands, or on those lands naturally deficient in moisture, it is not a safe method to follow. Cultivation conserves soil moisture, and increases the water-holding capacity of the soil. Perhaps never before in the history of citrus culture in Florida was the necessity for frequent cultivation so forcibly borne in upon the minds of all thinking growers as it was in the spring of the year 1902, and yet if all the moisture, or even a considerable portion of that which the soil contained at the beginning of the season could have been held and dealt out gradually to the trees, there would have been sufficient for their needs. Frequent shallow cultivation would have helped materially in this direction. 
In June, 1902, two samples of soil were taken as representative of cultivated and uncultivated soil. Both were from the horticultural grounds of the Florida Experiment Station, one from soil planted in citrus trees, cultivated frequently from March until that time, the other from a piece of ground which had received no cultivation at all during the season, but which had lain bare and exposed to the sun. The samples were weighed, then dried and weighed again. The weights and differences were as follows:

Cultivated soil-

Weight when collected ...... 247.8 grams.

Weight after drying ....... 230.5 grams.

Loss of moisture in drying ... 17.3 grams. Uncultivated soil-

Weight when collected ...... 251.4 grams.

Weight after drying ....... 240.9 grams.

Loss of moisture in drying .... 10.5 grams.

Per cent. of moisture in sample No. 1-

$$
17.3 \div 24 \% .8 \times 100=6.9 \% \%
$$

Per cent. of moisture in sample No. 2

$$
10.5 \div 251.4 \times 100=4.1 \% \%
$$

The cultivated soil contained 6.97 per cent, moisture, while the uncultivated soil contained 4.17 per cent. moisture-a difference in favor of the former of 2.8 per cent, or, expressed otherwise, cultivation had increased the moisture content of the soil by 66.5 per cent. It is true that the water-holding capacity of most citrus soils, and particularly of those rich in humus, is well up to the average, but this does not mean that every effort should not be made to hold and conserve the moisture for use during periods of drouth. Lands deficient in moisture 
should be cultivated frequently during the first half of the year, or rather from the commencement of the growing season until the rainy season begins in districts where the heaviest rainfall comes in summer.

Humus and Its Value. Humus is a product of the decay of organic substances. When these undergo decomposition in the soil, humus is the intermediate product formed; that is, just before the resolution of the organic material into its component chemical parts. It is probably not too much to say that humus is the most important substance found in any fertile soil and its presence may generally be taken as the index of fertility. The truth of this statement may be realized more fully when we remember the fact that all barren soils are lacking in this substance and the chief difference between a barren and a fertile soil is usually a difference in humus content, not in the mineral ingredients.

The changes which are constantly taking place in soil may be grouped as physical, chemical and biological. The first relates to movement of water, the size of the particles and the mechanical changes, such as those produced by the displacement of the soil particles by animals or the roots of plants. The second includes all changes wrought by the action of acids or other disintegrators of a chemical nature, while the third, in its use here, refers to the changes brought about by soil bacteria. All three of these changes, whether physical, chemical or biological, are intimately associated with the presence of humus.

In regard to the first, it may be premised that soils rich in humus are not solid and compact, but loose, open and better aerated than those lacking humus and that the water-holding capacity is materially increased by a 
fair admixture of humus. Now, if the ability of a soil to retain moisture is increased by the presence of humus, it follows that all plant food in solution will be held as well and this is an important feature.

Humus contains from three to twelve per cent of nitrogen and ihis in itself is a fact worth bearing in mind, but it has been ascertained besides that soils rich in humus are usually well supplied with phosphoric acid and potash.

Reference has already been made to the bacteria which play such an important part in the formation of plant food and which are so intimately associated with the work of providing nitrogen for the use of the trees. It may be said that but little nitrogen from those materials in which it is usually found in or supplied to the soil would be available for the trees were it not for their presence, and the bacterial content of the soil, other conditions having been met, is dependent entirely upon the presence of humus.

Hence, it will be seen that humus is a very valuable soil component and is intimately associated with the life activities of a fertile soil. Growers of citrus fruits in Florida use commercial fertilizer in large quantities and in all districts the same practice will have to be followed eventually. Many of the substances applied must undergo certain changes before they can become available. This change from an unavailable to an available state is dependent either upon the action of soil bacteria or chemical agents. Humus forms the media in which the bacteria work and, furthermore, it holds the plant food when in solution until the roots have a chance to use it. The best and fullest effects cannot be secured from appli- 


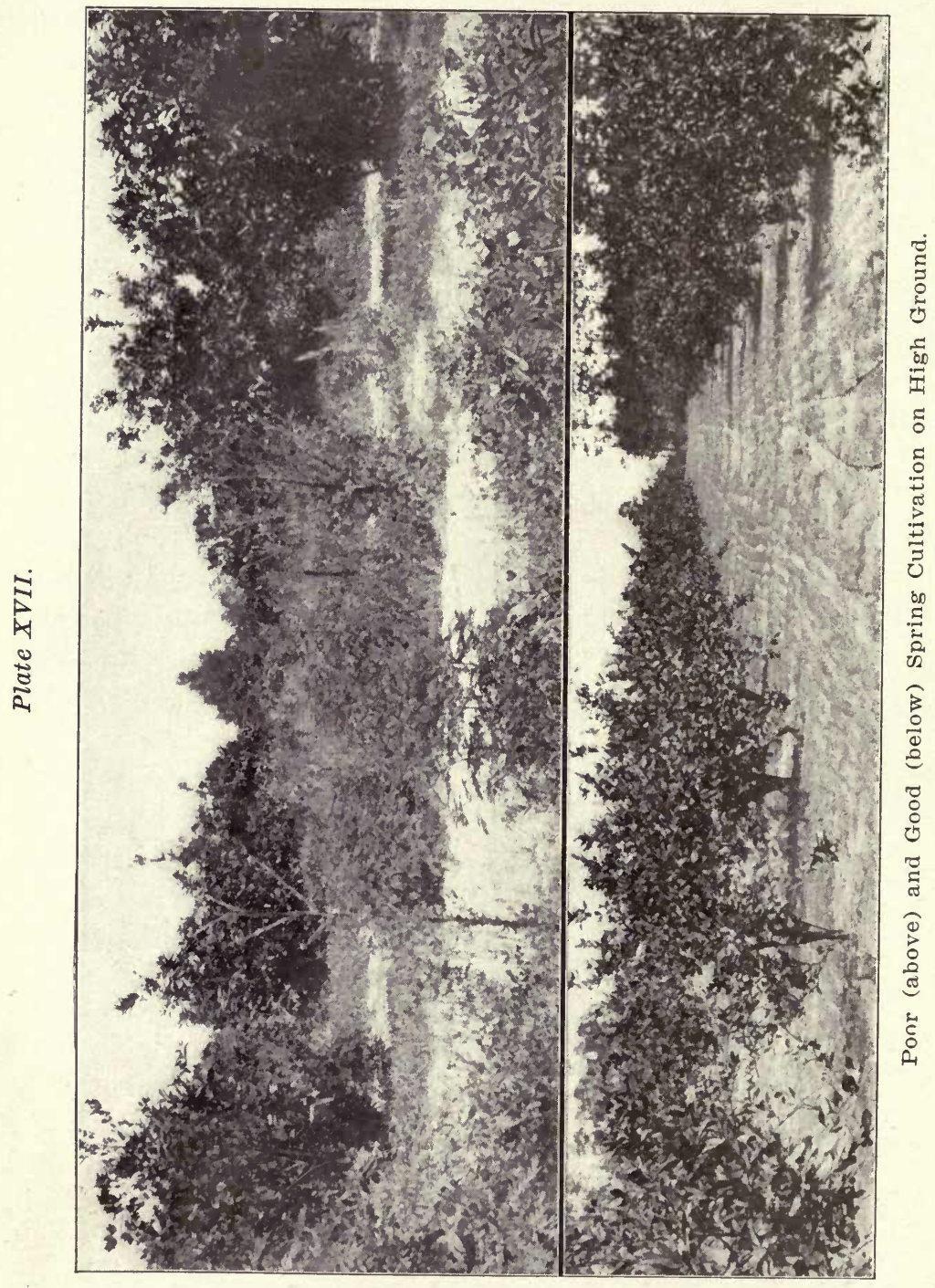


cations of fertilizers to citrus trees unless the soil be plentifully supplied with humus.

\section{DEPTH OF CULTIVATION.}

It is always preferable to prepare the ground well before the trees are planted. The earth should be well stirred and free from roots and stumps. During the first years of the life of the young grove, the ground may be plowed, if deemed advisable, provided always that the plow is not run deep close up to the trees. The tree rows should be cultivated comparatively shallow. This treatment will have a tendency to send the roots deeper into the soil as they spread out from the tree. If plowing is resorted to, the depth should be varied from year to year, so that the soil may not become hard and compact at a certain fixed depth, as is likely to be the case if the plow is always run at the same distance from the surface.

Florida. When the trees have attained considerable size and the roots have occupied the whole space between the tree rows, the plowing should be very shallow, or should be abandoned entirely, the plow giving place to the cultivator. The method followed in the old groves around Orange Lake was to give three or four hoeings during the year, all the cultivation the trees received, and results were highly satisfactory. The plow as an implement for continuous cultivation should not be used. If used at all, plowing should be done only during the dormant period, early in spring or late in autumn. Its use after this time should not be resorted to. Large numbers of roots are broken or torn by the plow as a result of which new ones are formed rapidly, food is absorbed in great quantities and a die-back condition only too frequently results. 
In most cases, the fibrous feeding roots in old groves form a solid mass and these extend quite close to the surface. In such cases the cultivation should be shallow, but if a proper system of cultivation has been carried on from the first, the roots will not be too close to the surface. This mat of roots is usually disturbed to some extent, but considering the fact that commercial fertilizers are used extensively, it is not good policy to cultivate deeply and break them up too much. Shallow cultivation should be the rule, a rule to which there may, of course, be exceptions.

California and Arizona. On the heavier soils of California and Arizona the plow can be used to advantage, and, in fact, as an implement of cultivation, it is well nigh indispensable.

Irrigation is an essential part of citrus culture in all western districts and after each irrigation the ground must be cultivated. Frequently the mistake has been made of cultivating at exactly the same depth year after vear. The result has been the formation of a hard, impervious layer just below the top layer of cultivated soil. This layer of hard earth has been termed "hard-pan," "irrigation hard-pan," and "plow-sole." Through it the water cannot penetrate. As a result none reaches the lower roots and the trees suffer.

To break up this hard-pan, the sub-soil plow has frequently been brought into operation, and while good results have followed in some cases, much damage has been done in others. Frequently the difficulty may be overcome by slightly increasing the depth of cultivation after each irrigation, until the cultivator or plow finally makes its way down through the hard-pan. 
To prevent the formation of this hard-pan, the depth of cultivation should be varied from year to year. The usual depth of cultivation is about eight inches. This should be increased from year to year until a depth of thirteen or fourteen inches is reached, then cultivate at eight inches again, gradually increasing to fourteen, and so on.

Frequency of Cultivation. During the period of most active growth, the citrus plantation should be cultivated frequently. The only exception to this is when it is located on damp soil, such as the low hammock soils of Florida, where there is an abundance of moisture.

If the weather is dry, the ground should be cultivated every week or ten days to prevent the evaporation of moisture. It is an excellent plan to keep the cultivator going all the time. As soon as the work is finished on one side of the area, it should be commenced again on the opposite. A light harrow or weeder should be used. If showers fall during spring, it is a wise plan to cultivate as soon as possible after each one, that the water which has entered the soil may be retained.

In the irrigation districts the soil should be cultivated after each application of water, just as soon as the surface is dry enough to allow a horse to walk over it. Generally two or three days must elapse before cultivation can be started, depending upon the nature of the soil.

Weeds should not be allowed to grow in the grove during the period of cultivation. They pump the water from the soil and in a measure defeat the objects of cultivation. After cultivation has been discontinued for the season, a cover crop should then be given possession of the ground. 
Cultivation in Relation to Irrigation. Perhaps the most important thing to be considered in those districts where irrigation must be carried on is the relation between cultivation and irrigation. One of the best discussions of this phase of citrus culture is that given by J. W. Mills in Bulletin No. 138 of the California Experiment Station, here reproduced in full:

"In order to achieve the highest results, it becomes more and more essential that the grower shall keep the soil in the most perfect condition, shall apply all needed water and plant food in sufficient, but not in excessive, amounts, and shall pay especial attention to keeping the feeding roots as low as practicable, and to preventing the formation of what is called 'hard-pan,' but is only the well-known 'plow-sole,' aggravated by shallow irrigation.

“'Hard-pan,' some growers say, appears now where it was never known before. The fibrous roots of orange trees run along the surface and thus are subject to every vicissitude. It often happens that what orchardists call 'hard-pan' is only the firm layer of soil caused by uniform cultivation, or plowing, whether deep or shallow. The depth to which the soil is stirred should vary from year to year; eight inches, twelve inches, ten inches, fourteen inches, and then eight inches again, would put an end to much of the present outcry against 'hard-pan.' Cultivator teeth should always be kept sharp and should be 'set down' to various depths, so as to prevent the formation of 'plow-sole' of any description, and to assist in breaking up that which former neglect has caused.

"Very few orange groves have been planted upon true 'hard-pan' and if so planted have seldom succeeded. Only a few trees, such as our native oaks, are capable of thrust- 
ing roots through the iron-like layer of natural sub-soil that is properly termed 'hard-pan.' When found to exist it should be deemed sufficient to debar citrus culture, unless so thin that by boring or blasting the root system can be established in good soil below the 'hard-pan', or when it is so constituted that when kept irrigated the roots will penetrate it.

"An instance of the latter occurred at Riverside, where Mr. Reed planted a few trees on a terrace bordering on an arroyo, and found what was reported as true 'hard-pan' near the surface. The trees received 'an abundance of water over the whole area for a year,' and it was then found that the roots had penetrated it to a considerable distance.

“The term 'irrigation hard-pan' is quite generally used in some orange-growing districts to describe the condition of some small areas in orchards where irrigation and subsequent culture have been careless, or where sufficient attention has not been paid to the difference of treatment required by lighter and heavier soils.

"Of course, very sandy soils can be handled sooner after irrigation than can heavier soils, and when a sandy piece of land containing areas of heavy soil is cultivated as soon after irrigation as the sandiest part will permit. trouble may be expected with the so-called 'irrigation hard-pan,' by the puddling of the sub-soil, partly directly by the plow, partly by the soaking in of clay-water.

It is usual for orchardists to put in a sub-soil plow to help in breaking up the heavy spots of what is called 'irrigation hard-pan.' But this difficulty can easily be overcome without using a sub-soil plow, as was shown by the experience of Mr. W. J. Cox, of Glendora, Los Angeles County, who found that 'irrigation hard-pan' was 
forming in a part of his orange grove. He irrigated a few trees that were within reach of the domestic water supply, and followed this up at the proper time with thor. ough cultivation. After each irrigation he cultivated a little deeper. As a result of deep irrigation and cultivation, the soil took in water as readily as ever and the trees regained their vigorous appearance. He simply used a chisel-tooth cultivator and plenty of water.

"A somewhat different case was that of Mrs. McKenzie, of Riverside, whose orange grove failed to be profitable, though apparently well irrigated. This orchard had been cultivated to the same depth until a hard, clay 'plow-sole' had been formed. The stratum of hard sub-soil was several inches thick and contained a number of large surface roots. She wrote to the California Experiment Station, sending samples of soil for examination. It was found that the plow-sole prevented the irrigation water from reaching the deeper roots, and she was advised to plow the entire orchard, roots and all, as deep as the plow would go. This was done, much to the alarm of many growers, and great numbers of orange roots of all sizes were turned to the surface. Following further advice, she irrigated and cultivated the ground deeply, and the following season she harvested the largest crop ever taken from this grove.

"The Glendora grove, to which allusion has been made, had had deep cultivation from the beginning, and the roots were mainly below the so-called hard-pan. The McKenzie grove had many roots in the hard 'plow-sole,' so that the only remedy was to destroy these useless roots and force the growth of new and deeper ones, at the same time giving the irrigation water a chance to penetrate. This rather drastic root-pruning was necessary, and if 
the Glendora grove had been cultivated to a uniform depth a few more seasons, deeper plowing and the destruction of the surface roots would have become inevitable there also. The breaking up of all hard layers of soil caused by improper cultivation or careless use of water is of the first importance to the health and profit of an orchard.

"After Mrs. McKenzie's experience at Riverside, previously mentioned, sub-soilers of different forms were used, and the idea soon became common among growers that the deeper a plow could be run, the better would be the results that would follow. The injurious results of such practice cannot be estimated without careful study of the root systems of orange trees on various stocks and soils. A number of bearing citrus groves were so much injured by the reckless use of sub-soil plows, that the leaves of the trees actually wilted down immediately after the operation. In these cases, the sharp-cutting plow was run close to and on all sides of the trees. When trees over ten years of age, which have been subjected to uniform shallow plowing and irrigation, are submitted to such treatment, they probably lose at one blow not less than seventy-five per cent of their active roots. The shock is such that it would take several years of careful treatment to restore the trees.

"It is almost always more economical to use a subsoiler or plow where 'irrigation hard-pan' has been formed than it is to use the large amount of water necessary to soften it; but according to the best practice the deepening of cultivation should be gradual, and the implement should never run deeper than fifteen inches. One must remember that the really serious loss in sudden deep cultivation comes from the destruction of thousands of fibrous 
roots that grow from the hundreds of laterals branching from the large main roots.

"If a plow is run to a depth of one foot, in three furrows, between the rows, and water percolates slowly for a long time through these furrows, no need can arise for a sub-soiler. 'Irrigation hard-pan' within reach of the plow simply shows, as has been said, that too shallow and too uniform cultivation has been practiced. In that case the entire surface should be thoroughly broken up, and irrigation in deep furrows after this will restore the proper conditions.

"Experience also shows that when the water is slowly run in deep furrows for a long time and the greater part of the surface is kept dry and is deeply cultivated, better results are obtained than when the basin or block method or even the shallow-furrow plan is used, even though they are followed by deep cultivation. When the water is applied below the first foot of soil, and the soil above is kept comparatively dry, there is nothing to attract the roots to the surface; and when the water is thus applied, a team can be driven along the dry strips of land between the furrows, and with a harrow or other appliance the dry soil can be dragged into the wet furrows, to lessen the evaporation, immediately after the irrigation water is turned off. By any other system it is absolutely necessary to wait at least twelve hours, and sometimes much longer, before a team can be driven over the ground. Then, too, when a soil irrigated by these more wasteful methods has been cultivated, it is still moist near the top, and is soon filled with a mass of new roots so close to the surface that they must be destroyed.

"Water applied to the soil sinks and spreads. Some of it is being taken up by the still dry soil underneath 
and at the sides long after the last drop is visible. Some of it, too, is being drawn back to the surface and thence evaporated into the warm air. Irrigation after sundown has some distinct advantages, if the water can be handled. Sub-irrigation upon soils adapted to its use is the ideal system of applying water, and greatly lessens waste. Orange roots will not enter a pipe-line, unless it is full of water all the time. If the pipe is on a grade and open at bottom and top so that air passes through it, there will never be trouble from orange roots. Valves, once thought necessary, are not now used. The high cost of the present sub-irrigation systems places them beyond the reach of most orange growers."

Cultivation in Relation to Dormancy and Frosts. In regions subject to frost every effort should be made to have the trees in a perfectly dormant condition during the period when frosts are likely to occur. Citrus trees are notoriously responsive to slight elevations of temperature during the winter months. In a perfectly dormant condition they will withstand a considerable degree of cold, but if the sap is moving, a very slight degree of cold may injure them seriously.

Unfortunately, they cannot be put in a complete state of dormancy, to remain so throughout the winter despite changes in temperature. Still, something may be done. Fertilizers, particularly those rich in nitrogen, which have a tendency to prolong the growth of the tree, should not be applied late in the season. Cultivation should not be continued late into the fall, as the stirring of the soil tends to cause the trees to grow late into the autumn.

All cultivation should be discontinued early. Grass and weeds should not, however, be allowed to remain in the grove during the winter months. If open fires are 
used to protect the trees, the presence of dry herbage among them is a menace to the safety of the grove. Fire may easily spread through the grove and the trees suffer greatly in consequence. Moreover, it has been observed in Florida, that trees standing among dead grass and weeds are much more injuriously affected by frost than are those in clean-cultivated soil. Hence, the best practice is to cultivate sufficiently to partially incorporate the dead herbage with the soil about the middle of November.

The Die-Back Problem. In groves where trees are affected by die-back, the trouble may be seriously aggravated by continuance of cultivation. Particularly is this the case where the disease has been caused by the use of organic fertilizers or by too much humus having been incorporated with the soil. Where the disease is caused by the presence of hard-pan or by poor drainage, and not by cultural mistakes, the problem is, of course, an entirely different one.

In the former case, however, much may be accomplished by changing the method of cultivation and fertilizing. Cultivation should be discontinued, thereby restricting the growth of the trees and lessening the amount of available nitrogen in the soil. The fertilizers used should contain no nitrogen and when fertilizers are again applied, organic sources of nitrogen should be rigidly avoided. If beggarweed is growing in the grove, it should be cut frequently and removed. By this line of treatment groves can usually be brought back to their normal condition. The question is discussed further in the chapter on Fungous and Physiological Diseases.

Implements. The implements used for cultivating must be adapted to the soil conditions and in the end each grower should know what will best answer his pur- 
poses. Various cultivators can be procured, adapted to shallow or deep cultivation, to light or heavy soils.

Of the implements used for shallow orchard cultivation, one of the best is the Acme harrow. To this may be added a weeder and a light harrow. For deep work, a disc harrow is very useful, while a Planet Jr. cultivator will be found very good. A cornstalk-smasher is frequently quite useful in disposing of a heavy cover crop.

Gencral Remarks. Cultivation should be intrusted only to a careful man. The Sherwood harness should be used, or, if not possible to procure it, the ends of the whiffletrees should be covered so as to prevent injury to the trunks of the trees. The California whiffletree, the ends of which are protected by the tugs, is made on correct principles. Hames with tall iron tops should not be used. The hames should not project above the collar.

Cultivate thoroughly and intelligently, as the conditions indicate. 


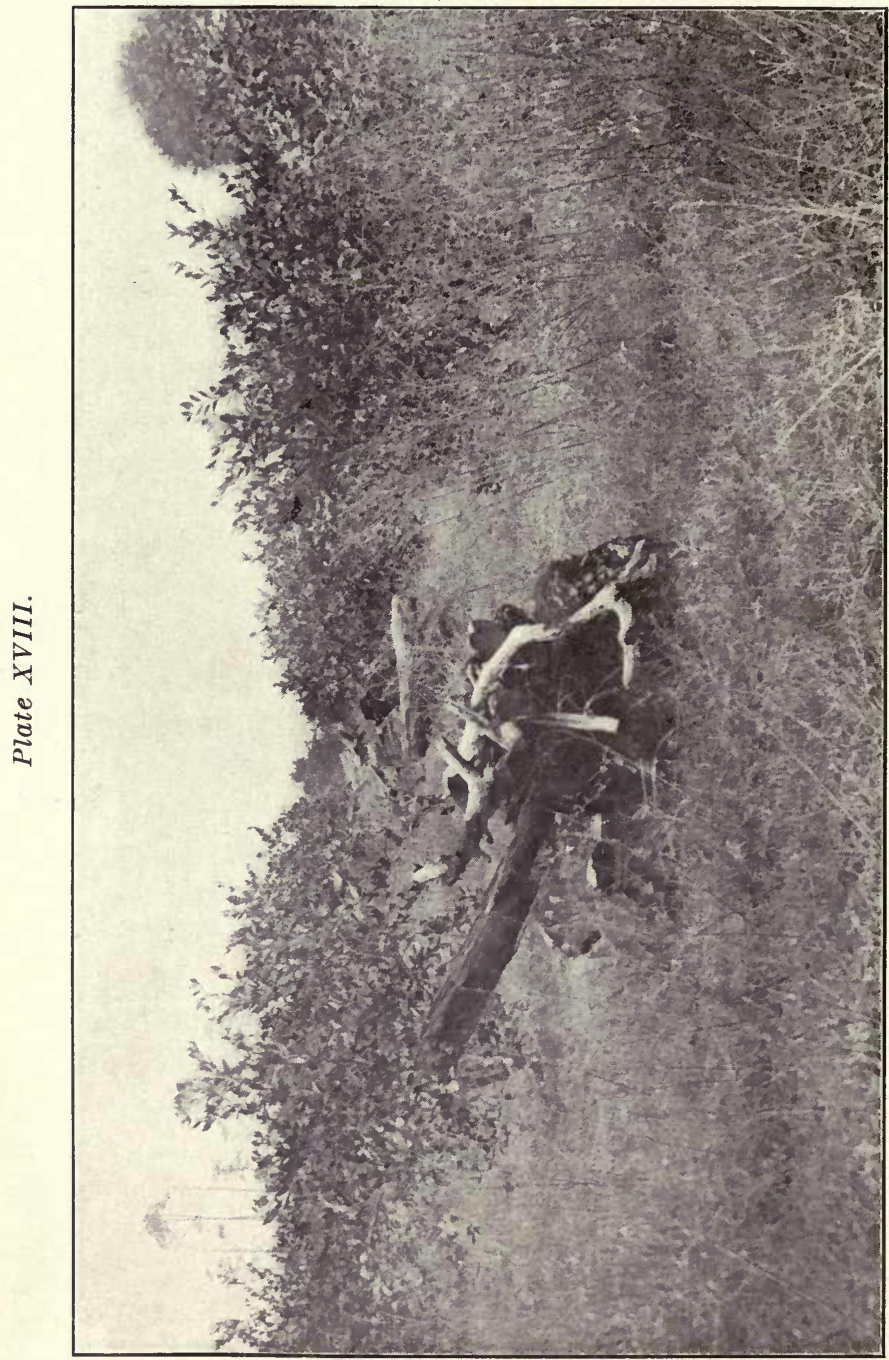




\section{CHAPTER XXXIII.}

\section{COVER CROPS.}

In the judicious management of the citrus grove, the use of a cover crop is frequently an important factor and one well worthy the consideration of the producer of citrus fruits. Not all soils can be treated in the same way. The soils are unlike, conditions differ and no one should know the peculiarities of any soil better than the man who tills it, who comes in contact with it day after day. He should study it carefully, become acquainted with all its peculiarities and then he is in a position to handle it to the best advantage. No other person can know so much about a given piece of land, as the intelligent man who tills it and studies it as he works. He, in the end, should be best able to decide whether clean culture throughout the year, clean culture with a cover crop or no culture is best for his conditions. The amount of fertility in the soil, the amount of available moisture, the physical qualities of the soil and the climate are the more or less known quantities with which he must work out the equation of citrus fruit production. When the different conditions are brought to mind it may readily be seen that no one kind of treatment will be best for all groves.

The benefits to be derived from the use of cover crops in the citrus districts are in part the same as those which obtain in more northern fruit regions, but the problem is, in some respects different. The advantages, presented briefly at this point, are as follows:

1. Affecting the physical condition of the soil. 
(a). Humus is added and the water holding capacity of the soil is increased.

(b). The soil is opened up, hard layers are prevented from forming and clay soils from becoming compact.

(c). Moisture is removed from the soil during the rainy season in Florida and the Islands.

(d). Prevents surface washing in rainy season.

2. Affecting the fertility of the soil.

(a). Prevents leaching of nitrates during the period of excessive rainfall.

(b). Promotes nitrification.

(c). Adds plant food (leguminous crops).

(d). Breaks up the plant food in the soil and renders it available.

Cover crops are usually divided into two classes: nitrogen collectors and nitrogen consumers.

To the first group belong the leguminous plants, such as clover, cowpeas, beans, peas, beggarweed, velvet beans vetch, lupines, alfalfa and many others.

Buckwheat, rye, oats, grasses of different kinds, rape, and, in short, all cover crop plants not belonging to the Family Leguminosae are placed in the second group.

The groups are based upon the fact that upon the roots of leguminous plants, nodules of various shapes and sizes are found. Two kinds of these are shown in figures 67 and 69 . There are usually various different shapes for each species of plants, each having its own form, and they vary considerably in size. They are formed by the action of bacteria which find entrance to the roots through the root-hairs. These nodules are distinct in form, and must not be confounded with the irregularly shaped swellings caused by the action of the root-knot, producing nematode 
worm, Heterodera radicicola, so common in southern regions.

These bacteria are commonly known as nitrogen fixers, because of their ability to collect and store the free nitrogen of the air in the tubercles formed by their action. This nitrogen eventually becomes available to the plants growing on the soil. The tubercles are most in evidence during the earlier period of growth of the legumes. The greater number of them decay and become shrunken later in the season, their nitrogen contents having been taken up by the plants.

Rye, oats, crab-grass, sand-spurs and other grass plants do not collect nitrogen, but when returned to the soil, give back only that which they have withdrawn. However, they add fibre to the soil, increasing the humus content and have a.general ameliorating effect.

The benefits derived from cover crops may be rendered entirely negative, unless proper care is exercised in handling them. In the hot climate of the citrus districts, they should not be plowed under while green, but should be allowed to become dry and partially rotted before being incorporated with the soil. Unless this plan be followed, an acid condition of the soil, inimical to the growth of citrus or any other fruit trees, may result. When commercial fertilizers are used, the potash content should be increased in proportion to the amount of nitrogen returned by the cover crop and only pure chemical fertilizers should be applied. None containing organic source of nitrogen should be used, else in many localities, die-back will but too frequently result.

VALUABLE COVER-CROP PLANTS FOR THE SOUTH.

The legumes most serviceable as cover crops in Florida are Beggarweed (Desmodium tortuosum DC.) and 


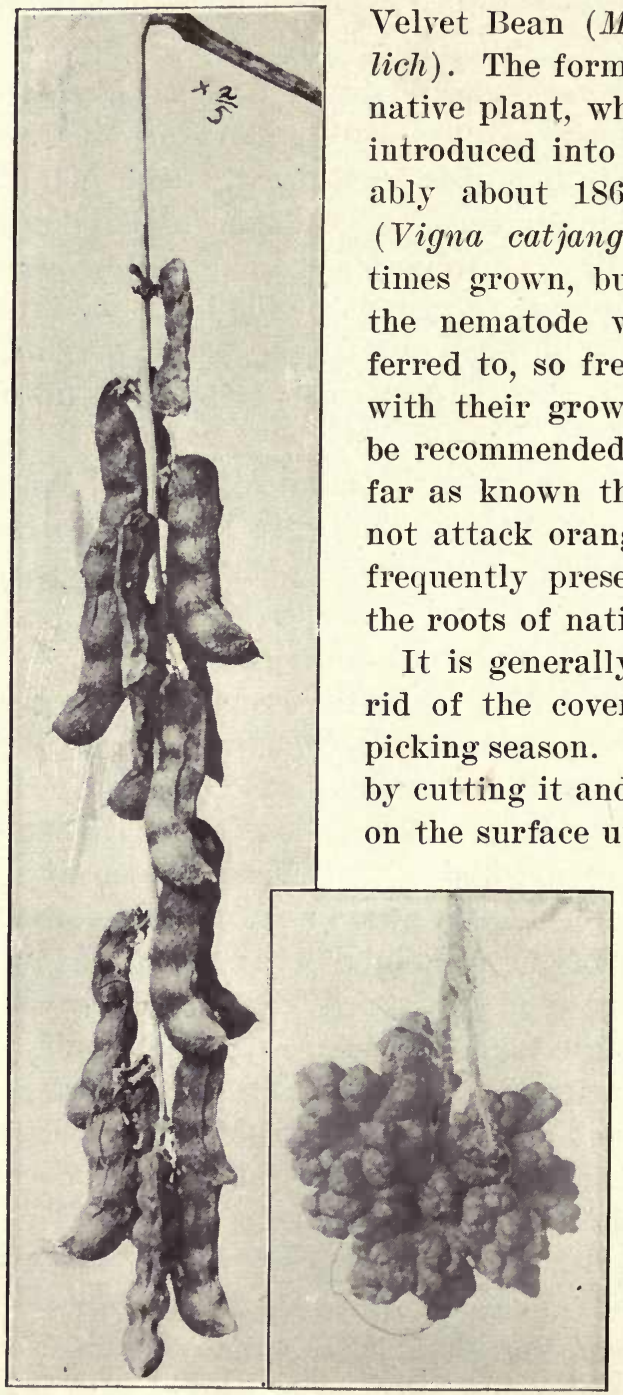

Fig. 67. Velvet bean pods, two-fifths natural size, and a nitrogen nodule, natural size. tially, or it may be harrowed into the soil if dead and dry.

\section{VELVET BEAN (MUCUNA UTILIS).}

The velvet bean makes a $n$ enormous growth, and, in autumn, a f t e r being lightly 
touched by frost in Northern Florida, several inches in depth of dead leaves and vines cover the ground. No other legume will make such a growth in the same length of time. In the full vigor of its growth it covers the ground to a depth of two or three feet with a tangled mass of vines, individuals of which are frequently upwards of seventy-five feet long. Miller has estimated the amount of green material on an acre to be 21,132 pounds, or 5,953 pounds of dry substance. As a cover crop it is difficult to handle in regions remote from frost, as it continues growing and the plants in a green state are difficult to handle. It can, however, be cut with a mowing machine and drawn aside between the tree rows, if still green in the autumn, for it is generally advisable to get the cover crop out of the way before the picking season approaches.

Nitrogen is collected in very large amounts by this cover crop. The following table is given by Prof. H. K. Miller in Bul. 60 of the Florida Agricultural Experiment Station, and shows the results obtained by the Alabama, Louisiana and Florida Experiment Stations with velvet beans as a field crop:

\begin{tabular}{|c|c|c|c|}
\hline & ALABAMA & LOUISIANA & FLORIDA \\
\hline 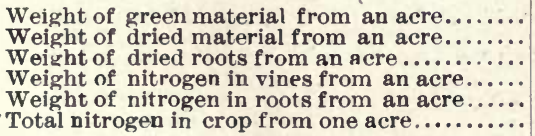 & $\begin{array}{r}19.040 \\
8,240 \\
1,258 \\
201.3 \\
12.6 \\
213.9\end{array}$ & $\begin{array}{r}22,919 \\
7,495 \\
191 \\
170 \\
2.9 \\
172.9\end{array}$ & $\begin{array}{r}21,13 \% \\
5,953 \\
690 \\
131.5 \\
9.7 \\
141.2\end{array}$ \\
\hline
\end{tabular}

Such results could not be obtained in the citrus grove, as the whole space cannot be planted, but one hundred pounds of nitrogen per acre would probably be a conservative estimate. 
The root system spreads out well from the plant and the roots penetrate the soil deeply. The tubercles formed by the nitrogen-fixing bacteria are very large, frequently an inch and a quarter or more in diameter, black or brownish black, and covered with projections. (Fig. 67).

The seed should be sown not later than the end of May and earlier if possible. The crop is benefited by cultivation, as it is somewhat slow in starting and the weeds should be kept down until it is well established. Cultivation may be continued for three or four weeks after planting. While the seed may be sown broadcast, it is better to sow in drills, four or five feet apart, or in hills, three or four beans to the hill in checks four or five feet square. One bushel is sufficient seed for four acres. They should not be planted closer to the tree row than six or eight feet and care must be exercised to turn the vines away from the trees, else they may cover and smother them. This has happened in the groves of careless cultivators.

Baron H. von Luttichau, of Earleton, has been very successful with velvet beans as a cover crop. His method of handling it, as given in his own words in Bul. 69, Florida Experiment Station, is well worth reproducing here:

"Since our first big freeze, when all the trees went, I handle my groves in a different way from what I had up until that time. The velvet bean was introduced and with that, the change. Until then my groves were worked and fertilized according to established rules.

"Last week in January, or thereabouts, before the bloom and growth starts, the plow is run, very shallow, straight along six feet away from the tree rows. The strip between the trees is left, never being disturbed, either by plow or hoe. Nothing further is done until about March 1st, when all the rest of the land and the old 
stubble of last year is planted as thick as possible with velvet beans. The vines receive one working with a plow, no hoeing. They grow, covering everything with a dense mass of vines and a layer of rotten leaves. An Acme cultivator is run along the six feet of plowed ground as long as the vines will permit. Nothing more is done, except to keep the vines from the trees, and the trees are never plowed. When the cold kills the vines, they are drawn into piles with the horse-rake, and later they are placed around the trees and on the strip between. No beans are picked, except enough for seed. The trees are banked by December 1st. No other fertilizer than the velvet beans has been used now for six years or more. Date of writing, all trees look luxuriant, covered with new growth and extra heavy bloom. Last fruit was perfect, pronounced by Mr. Arnold, of Jacksonville, who bought it all on the trees, as being the best he had ever handled. I will not claim that I shall never have to use any other fertilizer, but thus far there is no indication of the need of it. Expenses per year are about $\$ 25.00$, except cost of banking and removing same."

Some growers have objected to the velvet bean as a cover crop because it harbors insects, particularly the soldier bug, cotton stainer and allied insects. These, when the crop is removed or dies down, transfer their attentions to the fruit on the trees, to the consternation of the grower, and much damage is sometimes done. But these insects are more or less periodic and rarely, if ever, attack a grove year after year in numbers large enough to prove injurious. Whether the velvet bean is more likely to attract them than any other crop is also somewhat problematical. 
BEGGARWFED. (DESMODIUM TORTUOSUM.)

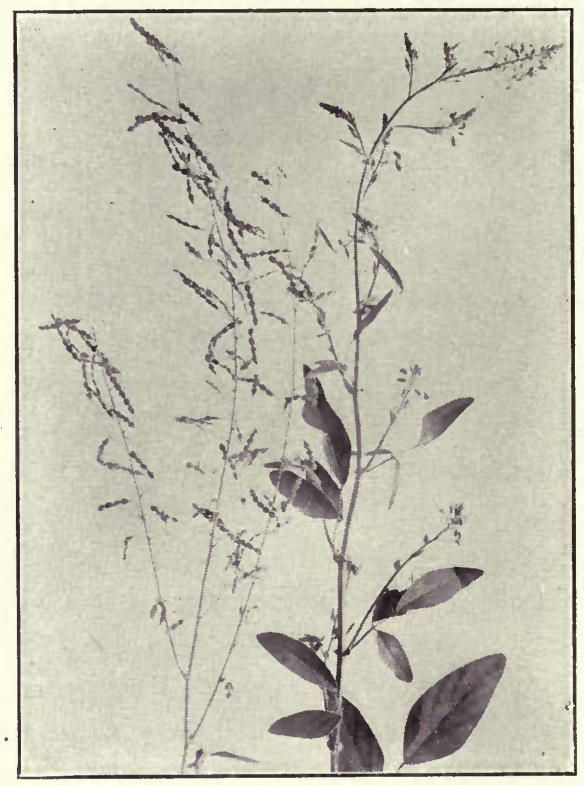

Fig. 68. Seed stern and flowering stem of Beggarweed.

Beggarweed is a strong, erect, annual plant. It is a native of Florida and is perfectly at home in all parts of the state. When standing apart, unshaded by other plants, it is much branched, but closely planted, it produces a single stem without branches. In soils where plenty of tubercles are formed, it frequently grows to a height of six or eight feet, the stem being nearly three-quarter's of an inch thick at the ground. At the end of the season a goodly covering of partially decayed foliage is found on the ground. As a cover crop, it is easily managed. On many soils it should not be allowed to grow throughout the whole season unchecked, as the stems become hard, woody and difficult to incorporate with the soil. The crop should be cut once or twice during the season and if a good length of stubble be left, it will stool out, producing another crop. Each cutting may be allowed to decay on the surface, ${ }^{2}$ 
one or two may be removed for hay, though by this plan the full benefit of the crop cannot be secured. The last cutting should not be so late as to prevent seed formation, for if once well established, the crop will reseed itself year after year, if well managed.

The amount of nitrogen collected, up to the time of the formation of flower buds, is shown by the following unpublished analysis made by Prof. W. A. Blair, of the Department of Chemistry, in the University of Florida:

Weight in pounds of dried stems and leaves per acre $3,489.15$ Weight in pounds of dried roots per acre.......... 105.85 Weight of nitrogen per acre in stems and leaves..... 90.71 Weight of nitrogen per acre in roots............ 10.02 Total nitrogen in roots, stems and leaves per acre... 100.73

But a single cutting is represented in the above analyses. If allowed to grow throughout the whole summer, or if cut once or twice and the crop allowed to return to the soil, the amount of nitrogen collected during the entire season would probably be increased one-half.

A straight, strong tap-root with numerous laterals is produced. These penetrate well into the soil, loosening and opening it to a depth of twelve to fifteen inches, or even more. The nodules are comparatively small, rounded, smooth, and under favorable conditions, produced abundantly. Figure 69 shows the nodules natural size and also gives a fair idea of how plentifully they are formed on the roots.

From five to ten pounds of seed are required per acre, but, as already noted, when once seeded, sowing is not necessary for the next season. The seed should be scattered broadcast on freshly harrowed ground, and a second harrowing then given. If it is deemed necessary to 
continue cultivation after sowing the seed, it may be done for a time, but this will have to be confined to the tree rows eventually, cultivating one way only, and allowing the beggarweed free possession of the middles. After having become well established, so as to produce plenty of seed, cultivation may be carried on over the whole surface from early spring to about the middle of June, after which the plants will spring up and cover the ground.

This cover crop can easily

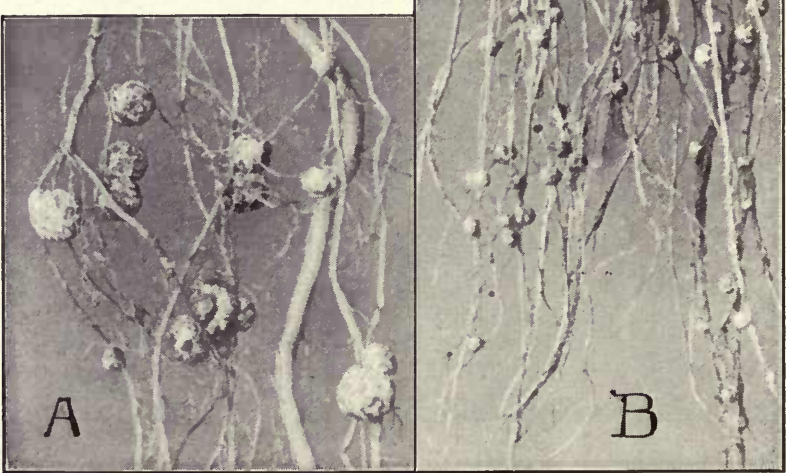

Fig. 69. A, nodules on Beggarweed roots natural size. B. root system of Beggarweed, with an abundance of nitrogen nodules. 
be disposed of in autumn by cutting with a mower and allowing it to remain on the surface until it becomes dry and brittle, when it may be worked into the soil. If it has not been cut during the summer and has become dry while still standing, it may be broken down with a corn stalk smasher. This followed by a cutaway harrow will incorporate it fairly well with the soil.

If, for any reason, it is deemed advisable to get rid of the beggarweed in a grove, it may be done by cutting frequently to prevent seeding and by prolonging spring cultivation well into the rainy season, when the rapid growth of crab-grass and other native plants will choke it out.

OTHER COVER CROPS.

A crop of sand-spurs, crab-grass and other plants may also be allowed to grow in the grove after cultivation ceases. This plan is adopted by some Florida growers who prefer to apply the nitrogen required, instead of depending upon a leguminous cover crop for the supply. Seeding for these crops is not necessary as they spring up spontaneously. Some people object to these plants as cover crops, but better by far to have them than to have bare, exposed ground.

COVER CROPS IN CALIFORNIA.

In California and Arizona, where recourse has to be made to irrigation to keep up the water supply, the growing of cover crops does not receive the same attention as it does in the eastern sections. Whether they are planted or not depends largely upon the amount of water available. If a supply sufficient for both cover crop and 
trees can be had, then the latter may be grown between the tree rows. If a plant could be secured which would make a good growth during the winter season and which could readily be disposed of in spring, so as to permit of frequent cultivation during the dry summer months, it would be very desirable. Unfortunately, it is too dry, early in autumn, to start a crop satisfactorily without recourse to irrigation, and heavy applications of water at this season are not best for the trees. The Canada field pea, Bur clover and lupines have received the most attention. Fortunately the more retentive nature of the California soils and their greater store of fertility has not as yet rendered the growing of a cover crop of so much importance as it is in Florida.

In some cases, however, the soils are becoming depleted, and the day is not far distant, in fact has already come in some instances, when the cover crop question will be one of great moment to the growers on the Pacific coast. Clean culture cannot produce good results indefinitely and the sooner cover crops are given attention, the better for the future of the citrus industry. 


\section{CHAPTER XXXIV.}

\section{FERTILIZERS AND FERTILIZING.}

The problems connected with the supplying of the proper food materials to citrus trees are extremely important. Fertilizers in some form must be used sooner or later in all citrus districts, for no soil is inexhaustible. In many sections, however, they must be used even from the planting of the trees. In Florida, where the soils are very deficient in plant food, the kinds, quantities of materials, and the time of their application constitutes the great problem of citrus culture. In California the most important problems connected with citrus fruit growing are not those which have to do with the use of fertilizers, but with the best methods of irrigation and cultivation instead. As pointed out elsewhere, the soils of California and the arid region generally, are extremely rich when compared with those of Florida, and in some places the need of fertilizers has not yet been evidenced. Most growers in the western districts, however, already realize the importance of keeping up the fertility of the land and make regular applications of fertilizers. The fact should be borne in mind that crops of fruit cannot be harvested year after year from a given area without depleting the soil, decreasing the quantity and impairing the quality of the output, unless some return be made to the soil to replace the plant food removed. The elements which enter into the composition of plants are carbon, oxygen, nitrogen, hydrogen, potassium, calcium, magnesium, phosphorus, sulphur, iron and sometimes chlorine, but of those obtained from the 
soil, all except phosphorus, potash, nitrogen and sometimes lime, are usually present in sufficient quantities for the needs of the trees. In some soils, even these four may be present in the virgin soil in sufficient quantities to last some time, but they become exhausted after a few years cropping.

The following analyses show the amounts of the three more important fertilizer ingredients removed in the fruit of pomelos, mandarin oranges and kumquats in Florida, as determined by Professors Miller and Blair, of the Department of Chemistry of the University of Florida, and of sweet oranges and Eureka lemon as computed from the data given by Mr. Hubert L. Dyer in Bul. letin 93, University of California, Agricultural Experiment Station :

FERTILIZER ANALYSES OF THE FRUIT OF SIX VARIETIES OF POMELOS.

[From Bul. 58, Fla. Exp. Station.]

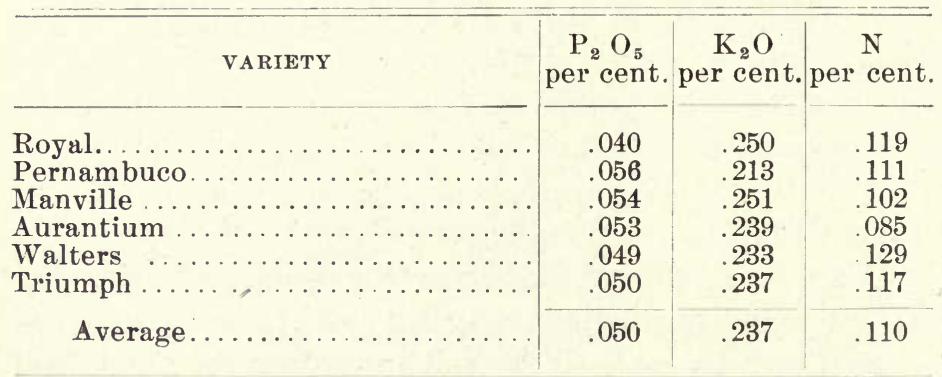


FERTILIZER ANALYSES OF THE FRUIT OF SIX VARIETIES OF MANDARIN ORANGES.

[From Bul. 66, Fla. Ag. Exp. Station.]

\begin{tabular}{|c|c|c|c|}
\hline VARIETY & $\mid \begin{array}{c}\mathrm{P}_{2} \mathrm{O}_{5} \text { to- } \\
\text { tal perct. }\end{array}$ & $\left|\begin{array}{l}\mathrm{K}_{2} \mathrm{O} \text { tot' } 1 \\
\text { per cent. }\end{array}\right|$ & $\begin{array}{c}N \text { total } \\
\text { per cent. }\end{array}$ \\
\hline 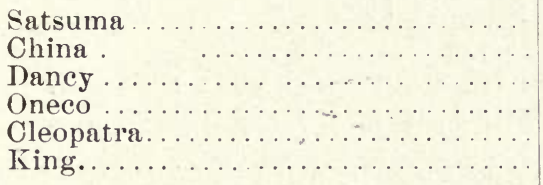 & $\begin{array}{l}.0386 \\
.0758 \\
.0591 \\
.0573 \\
.0529 \\
.0531\end{array}$ & $\begin{array}{l}.2121 \\
.2576 \\
.1903 \\
.2732 \\
.3199 \\
.2791\end{array}$ & $\begin{array}{l}1661 \\
.1404 \\
.1500 \\
.1653 \\
.1639 \\
.1506\end{array}$ \\
\hline Average ................. & .0561 & 2570 & .1560 \\
\hline
\end{tabular}

FERTILIZER ANALSES OF THE FRUIT OF TWO VARIETIES OF KUMQUATS.

[From Bul 65, Fla. Ag. Exp. Station.]

\begin{tabular}{|c|c|c|c|}
\hline VARIETY & $\begin{array}{c}\mathrm{P}_{2} \mathrm{O}_{5} \\
\text { per cent. }\end{array}$ & $\begin{array}{c}\mathrm{K}_{2} \mathrm{O} \\
\text { per cent. }\end{array}$ & per cent. \\
\hline $\begin{array}{l}\text { Marumi } \ldots \ldots \ldots \ldots \ldots \ldots \ldots \ldots \ldots \ldots \ldots \ldots \ldots \ldots \ldots \ldots \\
\text { Nagami } \ldots \ldots \ldots \ldots \ldots \ldots \ldots\end{array}$ & $\begin{array}{l}.0528 \\
.0531\end{array}$ & $\begin{array}{l}.2623 \\
.2796\end{array}$ & $\begin{array}{l}.114 \\
.132\end{array}$ \\
\hline A verage... . & .0529 & .2709 & .136 \\
\hline
\end{tabular}

FERTILIZER ANALYSES OF THE FRUIT OF FIVE VARIETIES OF SWEET ORANGES.

[Computed from Bul. 93, Univ. Cal. Ag. Exp. Station.]

VARIETY

Navel Oranges.

Med. Sweet

St. Michael's

Malta Blood

Average

\begin{tabular}{c|c|c}
$\begin{array}{c}\mathrm{P}_{2} \mathrm{O}_{5} \\
\text { per cent. }\end{array}$ & $\begin{array}{c}\mathrm{K}_{2} \mathrm{O} \\
\text { per cen }\end{array}$ & $\begin{array}{c}\mathrm{N} \\
\text { per cent. }\end{array}$ \\
\hline .051 & .215 & .211 \\
.065 & .225 & .154 \\
.053 & .216 & .228 \\
.062 & .221 & .168 \\
\hline .058 & .219 & .190
\end{tabular}


FERTILIZER ANALYSIS OF THE FRUIT OF ONE VARIE'TY OF LEMON.

[Computed from Bul.93. Univ. Cal. Ag. Exp. Station.]

\begin{tabular}{|c|c|c|c|}
\hline VARIETY & $\begin{array}{c}\mathrm{P}_{2} \mathrm{O}_{5} \\
\text { per cent. }\end{array}$ & $\begin{array}{c}\mathrm{K}_{2} \mathrm{O} \\
\text { per cent. }\end{array}$ & $\underset{\text { per cent. }}{\mathrm{N}}$ \\
\hline Eureka. & .058 & .253 & .151 \\
\hline
\end{tabular}

It will be seen from these analyses that the fruit of all kinds of citrus contain practically the same percentage of fertilizer ingredients. The averages of the five tables given above are .055 per cent. phosphoric acid, .249 per cent. potash and .149 per cent. nitrogen.

For purposes of computation it may be assumed that a box of citrus fruit will weigh about eighty pounds. No fixed and definite weight can be given. Much depends upon the size of the fruit, the season, the curing, and the methods of cultivation, irrigation and fertilization. The weights may vary anywhere between sixtyfive and one hundred pounds, but the weight fixed upon, viz., 80 pounds, will not be far from a general average. The weight of ten boxes would then be 800 pounds. This amount of fruit would remove from the soil .440 pounds phosphoric acid, 1.976 pounds of potash and 1.192 pounds of nitrogen.

That soil depletion may be prevented, these are the losses which must be made good for each crop of ter boxes. In addition, provision should be made for a variable and unknown quantity of plant food which leaches from the soil and besides, the tree must have a sufficient food supply to enable it to add new growth in roots, branch and leaf. A fair approximation, eovering the fertilizer removed in the fruit and that lost by leaching and required for new growth would be two or three times 
the amount estimated for every ten boxes of fruit. Fertilizing is a more or less local matter, one which it is well nigh impossible to reduce to a matter of absolute facts and figures, and each grower must determine for himself how much his trees require and how much it is economical to use. It has generally been observed in Florida, where commercial fertilizers are largely used, that the grower who fertilizes liberally with the proper material generally meets with the best success. This, perhaps, is not only the result of the additional fertilizer applied, but because a liberal policy along this line leads him to give greater attention to all details connected with the care of the trees. A citrus tree may get along after a fashion and give some returns with poor treatment. It may live and eke out a miserable existence when abused and neglected, but in all cases it amply repays good care and attention and will not be profitable unless it is given.

THE FUNCTIONS OF PHOSPHORIC ACID, POTASH, NITROGEN AND LIME.

Phosphoric Acid. This substance is a very essential one and plays an important part in the life activities of plants. It enters into the formation and is a constituent of a certain class of nitrogenous compounds known as proteids. Phosphoric acid is found in considerable amounts in the different parts of the fruit of citrus trees, but the seeds contain the highest percentage. The fresh rind of pomelos contains .035 per cent.; the pulp .044 per cent.; and the seeds .315 per cent. and these percentages may be regarded as close approximations for all citrus fruits. Unless the requisite amount of phosphoric acid be available, the fruit does not develop normally, 
and the maturity of the fruit is somewhat hastened by heavy applications of this material, unless offset by an abundant supply of nitrogen.

Potash. In the formation of starch, sugar, fruit and woody parts of the tree, potash plays an active part. By photosynthesis, starch is formed in the leaves, as a solid substance. Before it can be transferred to the different parts of the plant, it must be dissolved. Potash assists in this process, thus enabling the starch to pass through the cell walls of the plant. Sugar is probably formed from starch and various other related compounds in the plant which enter so largely into the composition of the wood and fruit are probably derived from the same source. The great importance of a goodly supply of potash can thus be easily understood.

If large amounts of potash are taken up by the trees it will be found that the rind of the fruit will be much thinner than otherwise and the amount of rag will be greatly lessened. A plentiful supply of potash in the fruit has an excellent influence on its keeping quality. If too little be present, the fruit will be soft and is likely to break down shortly after removal from the trees. To increase the keeping and carrying quality of citrus fruits a large amount of potash with a small amount of nitrogen should be used. The influence of potash on the hardening of the wood is worthy of note. Trees plentifully supplied with potash are more likely to form firm, hard wood, less liable to damage by cold and the attacks of insects than if a preponderance of nitrogen be applied.

Nitrogen. The effects of an abundant supply of nitrogen are much more apparent than the effects of an excess of either potash or phosphoric acid. When the leaves have a dark green, glossy color they are receiving plenty of nitro- 
genous food. The effects are further shown in the increased area of individual leaves, strong, vigorous, sappy growth and long internodes. Very large amounts of nitrogen impair the fruitfulness of the tree, wood formation taking place at the expense of fruit. It has a tendency to retard the maturity of the fruit and large amounts materially increase the amount of rag and the thickness of the rind.

On the other hand, when the nitrogen supply is not sufficient, the leaves become yellow, the trees have a stunted, starved appearance and do not make a normal growth of branch and leaf.

Lime. The value of lime as a fertilizer may be viewed from two points: its effect upon the soil and its effect upon the plant. Both of these have a direct bearing on the subject under discussion.

Much of the fertility of the soil depends upon the number and activity of soil bacteria. These liberate plant food and make it available so that the roots of trees and other plants may take it up. Soils, especially in warm climates, have a tendency to become acid and under such conditions the bacteria cannot live. The presence of lime counteracts the acid condition and it should be applied whenever necessary. Furthermore, it helps to bring about the decomposition of humus and liberates the nitrogen which it contains. Large amounts of plant food may be liberated by or through the use of lime, hence, in applying it to citrus groves it is best to use it sparingly or, at the time of its use, discontinue the nitrogenous fertilizer and depend upon the amount of nitrogen liberated to make up the deficit.

In the plant, the presence of lime appears to favor the formation of stronger cell walls and thus aids in mak- 
ing the trees stronger and more sturdy. Citrus trees planted on soils fairly well supplied with lime have a tendency to mature their fruit somewhat earlier and the fruit is bright and clean.

Sources of Plant Food. The most noteworthy sources from which the required fertilizing elements may be secured are barnyard manure and commercial fertilizers. A good quality of the former, when well rotted, will contain about .03 per cent. of phosphoric acid, .05 per cent. of potash and $.0,6$ per cent. of nitrogen, while the latter may be of almost any conceivable composition.

The use of stable manure as a fertilizer for citrus trees in California has been followed by satisfactory results, but in Florida, its use has too frequently been followed by attacks of die-back and by other troubles. Whether this be true in all cases or not, in the vast majority of instances the benefits to be derived from the use of stable manure are doubtful. It is essentially a nitrogenous fertilizer, and, whenever used, should be accompanied by heavy applications of potash, unless the soil is already rich in this substance. Potash is notoriously deficient in Florida soils. An additional supply of phosphoric acid may also be needed. The greatest difficulty encountered in the use of stable manure is that people generally fail to realize that it is, at best, a one-sided fertilizer.

Sources of Phosphoric Acid. The principal sources of phosphoric acid are bone and phosphatic rock. The bone is sold either as ground bone, steamed bone or dissolved bone. The other as super-phosphate (acid phosphate) and double super-phosphate. Ground bone contains about 22 to 26 per cent. phosphoric acid. Steamed bone about the same; dissolved bone, 16 to 19 per cent.; 
super-phosphate, 13 to 15 per cent. available; a high-grade super-phosphate, 16 to 19 per cent. available; and double super-phosphate, 45 to 57 per cent. available.

The readiness with which the phosphoric acid may be obtained from bone depends largely upon the fineness of division of the particles. The finer it is ground, the more readily the roots of the tree can take it up. It must undergo decomposition before yielding up its phosphoric acid and for this reason it is not well to use it where quick results are desired. It is an excellent substance to use to increase the phosphoric acid content of the soil, supplying a store from which the tree may draw gradually. Its use is strongly recommended at the time of planting citrus trees. A pound or two incorporated with the soil before placing it about the roots, is an excellent practice.

For general use in citrus fertilizers, dissolved bone is the best of the materials derived from bone to use. It contains, as already noted, from 16 to 19 per cent. of available phosphoric acid.

Phosphoric acid fertilizers derived from phosphate rock are of two kinds: super-phosphate, known to the trade as acid phosphate or high-grade acid phosphate and double super-phosphate. The latter is not used to any great extent. It has been claimed that it is best to use dissolved bone as a source of phosphoric acid, and yet acid phosphate has been used in some groves in Florida continually for ten or fifteen years with uniformly satisfactory results. Each year the crops have been all that could be desired.

In the face of results obtained from the use of either dissolved bone or acid phosphate, we are probably safe in saying that one is as good as the other as a source of phosphoric acid. 


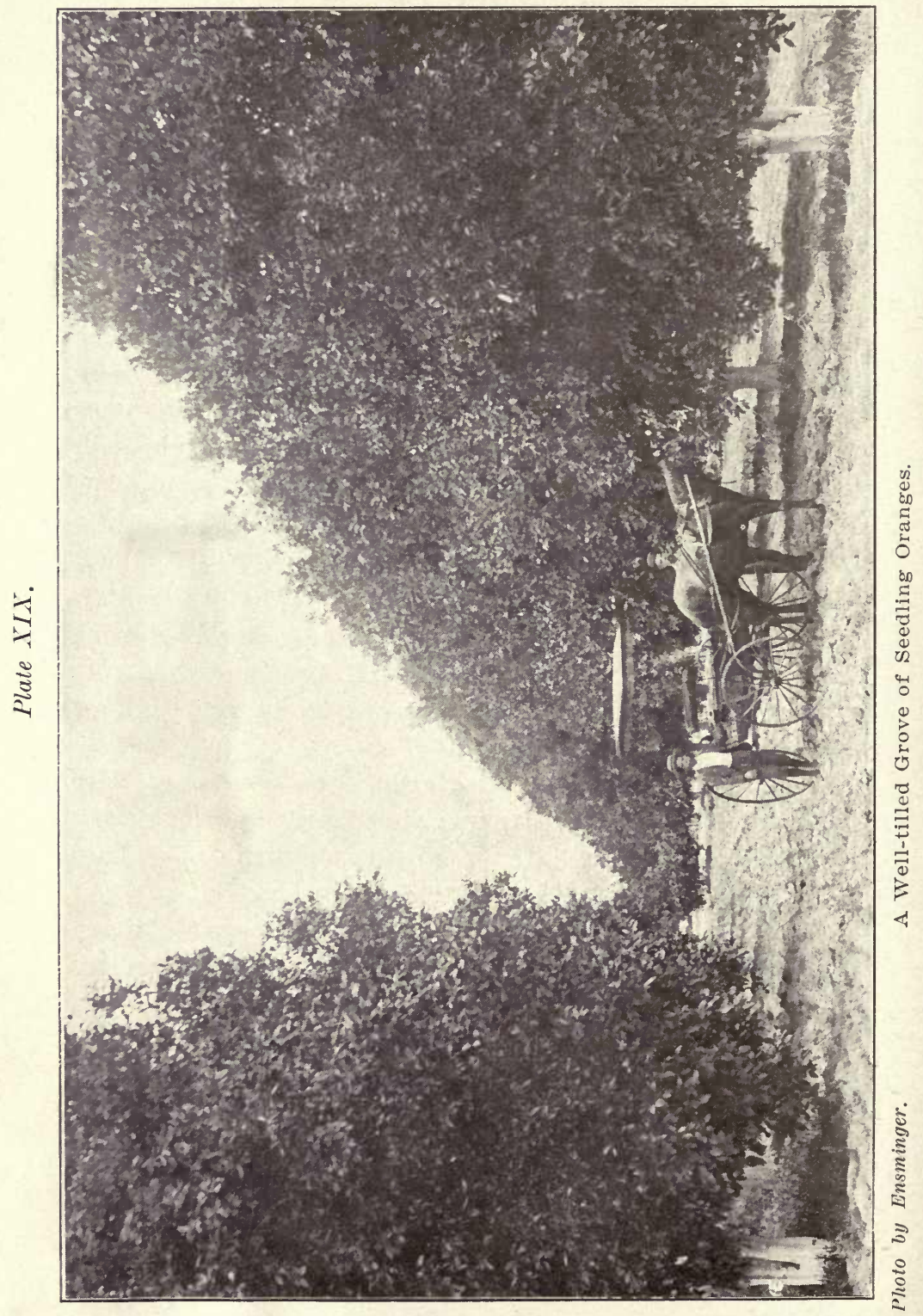


Sources of Potash. The forms in which potash may be supplied to citrus trees are: high-grade potash, con taining about 51 per cent. available potash; low-grade sulphate of potash, containing about 26 per cent.; and muriate of potash, containing about 50 per cent. The raw salt, kainit, is also used sometimes, but the bulk per unit of potash is so great that it is too expensive to be recommended.

Of all the materials used, the sulphates are the safest and best. It is well established that it is not well to use muriate of potash on some crops. Their quality is impaired thereby. This is true of tobacco, the Irish potato, the sugar beet and perhaps other crops. The deterioration is ascribed to the presence of chlorine, which interferes with the accumulation of starch as a stored product. There is a general impression abroad that muriate of potash is not a good substance to use on orange trees, and while its deleterious effects have never been properly elucidated, the impression is probably well grounded. It may be that chlorine interferes with sugar formation and we know that starch and sugar are very closely related compounds, fruit sugar being $\mathrm{C}_{6} \mathrm{H}_{12} \mathrm{O}_{6}$; starch, $\mathrm{C}_{6} \mathrm{H}_{10} \mathrm{O}_{5}$.

High-grade sulphate of potash is usually preferable to low-grade, as the cost of freight and handling is less per unit of potash, but either may be used.

Sources of Nitrogen. Nitrogen may be obtained as nitrate of soda, sulphate of ammonia, dried blood, cottonseed meal and castor pomace. Tankage, generally sold in the markets as blood and bone, is also another source of supply. Nitrate of soda contains approximately 16 per cent. nitrogen; sulphate of ammonia, 21 per cent.; dried blood, 14 per cent.; cottonseed meal, 6.5 per 
cent.; castor pomace, 6 per cent.; and tankage, 6 per cent. The last three also contain some phosphoric acid. These six substances may be divided into two groups, the first two being designated as chemical sources of nitrogen, the last four as organic sources, vegetable or animal.

In Florida the use of the chemical sources is always advised, owing to the fact that applications of cottonseed meal and blood and other organic sources, or of mixed fertilizers containing these materials, have been followed by die-back. This has happened so repeatedly that any organic source of nitrogen is always, and justly, regarded with suspicion. Their use is always attended with considerable risk and it too frequently happens that all the growth added may be lost owing to the disturb. ance of the functions of the tree. In sections where dieback does not follow their use, organic sources are good. if used with discretion, but heavy applications may impair the quality of the fruit.

The nitrogen in nitrate of soda is available as soon as it is dissolved in the soil. Most of the nitrogen taken up by plants is in the form of nitrate, which explains why the trees respond so readily to applications of nitrate of soda. It must be used with discretion, else a considerable part may be leached from the soil, and it is preferably applied in a number of separate dressings of two or three hundred pounds per acre.

Sulphate of ammonia is of such physical character as to be readily distributed through the soil. The form of the nitrogen has to be changed before it can be used by plants, hence it does not act so quickly as nitrate of soda. It is an excellent form of nitrogen to use on citrus groves, particularly among bearing trees. Iime should 
be present in goodly quantities in the soil to seetre best results from its use.

Some have said, and perhaps on good grounds so far as some crops are concerned, that it does not matter from what source the three important plant foods are derived. While this may apply to some crops and some fruits, of citrus it is not true. They reflect the food supply; they may be thin-skinned, heavy and juicy through the use of the proper materials and the very flavor may be influenced by the materials used as fertilizer. On the other hand, they may be thick-skinned, full of rag, insipid and lacking in character, owing to the use of poorly balanced fertilizers. The tree itself may come to an untimely end through the persistent use of rank organic sources of nitrogen.

Formulas. A number of years ago it was very difficult to secure fertilizer from any except domestic sources. Now, however, various brands of fertilizers for use on citrus trees are placed on the market. Many of these give excellent results and annually bear testimony to the scrupulous care exercised in their preparation. Still there is no question but that in these brands the cost per unit of plant food is greater than in the raw materials. Even after making allowance for the cost of mixing and sacking there still remains a substantial bal. ance in favor of the raw material. Excellent results have been obtained from the use of formulas made up by growers themselves. These results, together with the difference in cost, has led to the use of home mixtures on the part of many. Much may be said both for and against them, but on the whole they are to be advised rather than condemned. 
The greatest difficulty is in securing a uniform mixture, but if sufficient care be exercised, this may be overcome. Many growers, however, prefer to have the dealer, from whom he secures his raw materials, mix them for him. If the dealer can be relied upon to do the work right, this plan has much to commend it. But good, uniform mixtures can be made at home, as has been demonstrated time and again to our own satisfaction. For home mixing of fertilizers a strong box, with smooth sides and bottom, sufficiently large to contain from 500 to 1,000 pounds, should be provided, or the mixing may be done on a tight, smooth, board or cement floor.

Young and old trees differ in their fertilizer requirements. Young trees use their food supply in the formation of wood and leaves. For the first two or three seasons they grow vigorously. When the bearing period is reached, a gradual change comes about; the trees do not grow so rapidly and a large portion of the food supply is diverted to fruit formation.

The demands on the trees being different, the food supplied should be different in character. Young trees require a large amount of nitrogen, while bearing trees require less nitrogen relatively and more phosphoric acid and potash.

For young trees the fertilizer should contain about 6 per cent. phosphoric acid, 8 per cent. potash, and 4 per cent. nitrogen, while one containing 8 per cent. phosphoric acid, 12 per cent. potash and 3 1-2 per cent. nitrogen should be applied to the grove of bearing trees.

The following formulas contain approximately the percentage of the three important plant foods given above for young and for bearing trees. It is not possible to make up an exact ton of fertilizer, using the most desira- 
ble materials, without putting in some make-weight. This is frequently done, land plaster and other materials being used for the purpose. Land plaster, as a source of lime, is valuable to some extent. Sand or other extraneous matter is also used, but anything of this kind always adds to the cost of handling. It is recommended that the make-weight be omitted, in which case a smaller amount of fertilizer should be applied to each tree, if the total amount is less than one ton, and more if it is more than one ton. Formula No. 1, for instance, without the makeweight, calls for 1,614 pounds of material and this weight contains as much actual phosphoric acid and nitrogen as a ton weight of fertilizer analyzing 6 per cent phosphoric acid, 8 per cent. potash and 4 per cent. nitrogen. It should then be used in place of one ton of fertilizer. On the other hand some of the formulas call for more than a ton of materials. These should be used as a ton would be.

FORMULAS FOR YOUNG TREES.

FORMULA NO. 1.

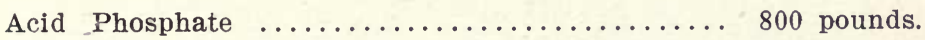

H. G. Sulphate Potash ................. 314 pounds.

Nitrate of Soda ................. 500 pounds.

Make-weight .................... 386 pounds

2,000 pounds.

FORMULA No. 2.

Dissolved Bone.................... 666 pounds.

H. G. Sulphate Potash.................. 314 pounds.

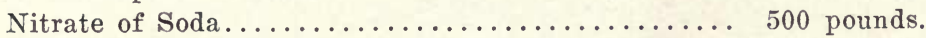

Make-weight ....................... 520 pounds.

2,000 pounds. 
FORMULA No. 3.

Acid Phosphate .................... 800 pounds.

H. G. Sulphate Potash ............... 314 pounds.

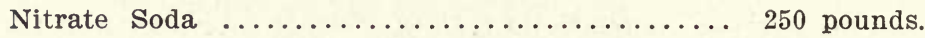

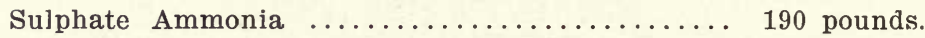

Make-weight ................... 446 pounds.

2,000 pounds.

FORMULA NO. 4.

Dissolved Bone ....................... 666 pounds.

H. G. Sulphate Potash .............. 314 pounds.

Nitrate Soda ...................... 250 pounds.

Sulphate Ammonia .................. 190 pounds.

Make-weight ...................... 580 pounds.

2,000 pounds.

FORMULA NO. 5 .

Acid Phosphate ................... 800 pounds.

H. G. Sulphate Potash ................ 314 pounds.

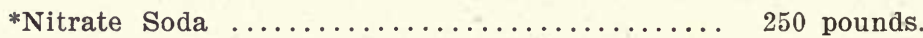

Cotton-seed Meal ....................... 615 pounds.

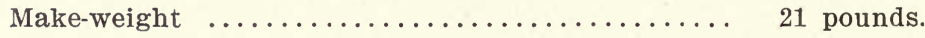

2,000 pounds.

FORMULA NO. 6 .

Dissolved Bone ....................... 666 pounds.

H. G. Sulphate Potash .............. 314 pounds.

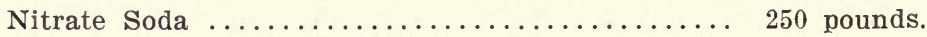

Cotton-seed Meal .................... 615 pounds.

Make-weight ..................... 155 pounds.

2,000 pounds.

* Nitrate of soda or sulphate of ammonia, when used in conjunction with an organic source of nitrogen such as cotton-seed meal or dried blood, should be applied only as a separate dressing, either before or after the organic fertilizer has been applied, to avoid denitrification. 
FORMULA NO. 7 .

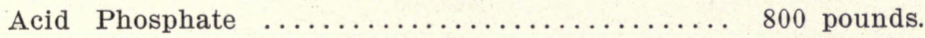

H. G. Sulphate Potash ................ 314 pounds.

Sulphate Ammonia ........................ 190 pounds.

Cotton-seed Meal ................... 615 pounds

Make-weight $\ldots \ldots \ldots \ldots \ldots \ldots \ldots \ldots \ldots \ldots \ldots \ldots . \quad 81$ pounds.

2,000 pounds

FORMULA NO. 8.

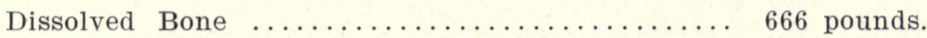

H. G. Sulphate Potash ................ 314 pounds.

Sulphate Ammonia ................... 190 pounds.

Cotton-seed Meal .................... 615 pounds.

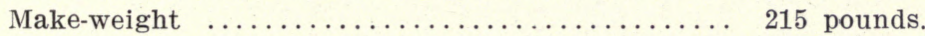

2,000 pounds.

FORMULA NO. 9.

Acid Phosphate .................... 800 pounds.

H. G. Sulphate Potash ................ 314 pounds.

Cotton-seed Meal ..................... 1,231 pounds.

2,345 pounds.

FORMULA No. 10.

Dissolved Bone ...................... 666 pounds.

H. G. Sulphate Potash $\ldots \ldots \ldots \ldots \ldots \ldots \ldots \ldots \ldots \ldots \ldots \ldots$ pounds.

Cotton-seed Meal ......................

2,211 pounds.

The cotton-seed meal may be replaced by about one-half its weight of dried blood, if so desired, or the high-grade sulphate of potash by double its weight of low-grade sulphate of potash, but for use in Florida neither cotton-seed meal nor dried blood is recommended. 


\section{FORMULAS FOR BEARING TREES.}

$$
\text { FORMULA NO. } 1 .
$$

Acid Phosphate .....................

H. G. Sulphate Potash $\ldots \ldots \ldots \ldots \ldots \ldots \ldots \ldots .470$ pounds.

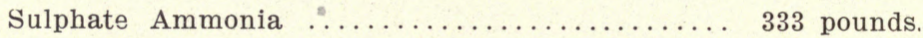

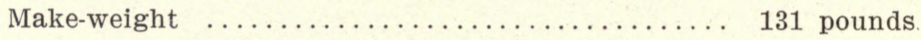

2,000 pounds.

FORMULA NO. 2.

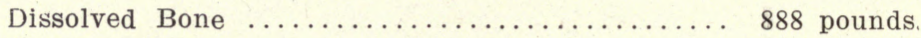

H. G. Sulphate Potash .............. 470 pounds.

Sulphate Ammonia .................. 333 pounds

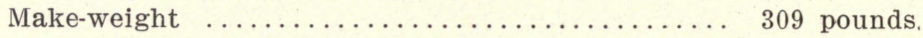

2,000 pounds.

FORMULA NO. 3.

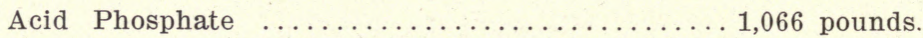

H. G. Sulphate Potash .................. 470 pounds.

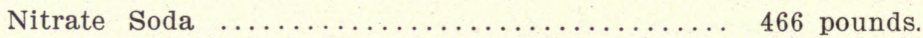

2,002 pounds.

FORMULA NO. 4.

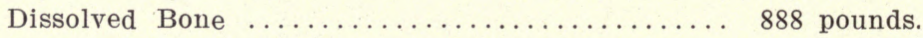

H. G. Sulphate Potash $\ldots \ldots \ldots \ldots \ldots \ldots \ldots \ldots$........ 470 pounds.

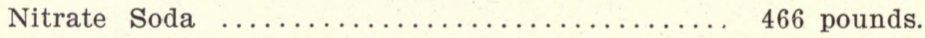

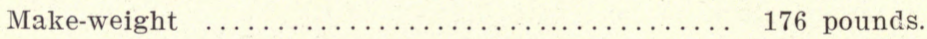

2,000 pounds.

FORMULA NO. 5.

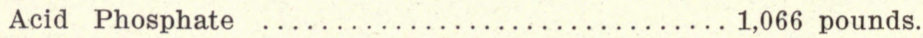

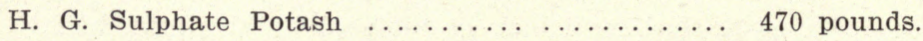

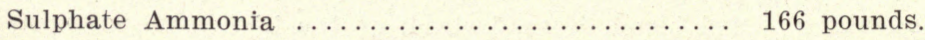

Cotton-seed Meal .................... 588 pounds.

2,290 pounds. 
FORMULA NO. 6.

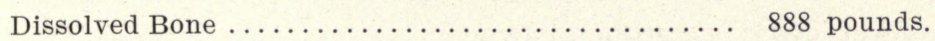

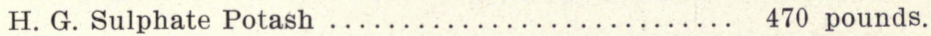

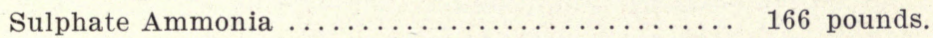

Cotton-seed Meal .................... 588 pounds.

2,112 pounds.

FORMULA NO. 7.

Acid Phosphate ...................... 1,066 pounds.

H. G. Sulphate Potash . . . . . . . . . .

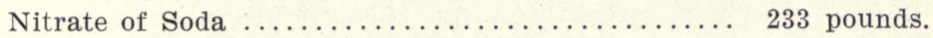

Cotton-seed Meal ..................... 588 pounds.

2,357 pounds.

FORMULA NO. 8.

Dissolved Bone ..................... 888 pounds.

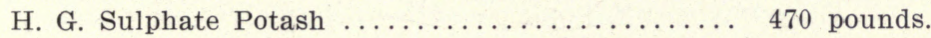

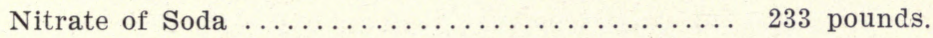

Cotton-seed Meal ................... 588 pounds.

2,179 pounds.

FORMULA NO. 9 .

Acid Phosphate .....................

H. G. Sulphate Potash . . . . . . . . .

Cotton-seed Meal .................... 1,077 pounds.

2,613 pounds.

FORMULA NO. 10 .

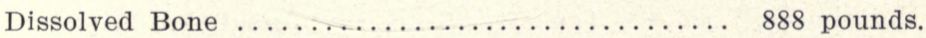

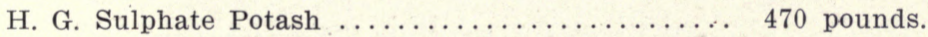

Cotton-seed Meal ..................... 1,077 pounds.

2,435 pounds.

Amounts Required. The amounts of fertilizer required depends upon the age and size of the trees, the quantity of fruit borne, the amount of fertility already 
in the soil and the amount of nitrogen supplied by the cover crop, if one be grown.

On poor soils a pound or two of the fertilizer used for young trees should be incorporated with the soil at the time of planting. If the trees are set in winter an additional pound should be given in June. The second year the amount to the tree should be increased as the trees will be well established and can use more to advantage. Each succeeding year the amount must be increased, never allowing the trees to become stunted or to assume a starved appearance. It is better to anticipate their needs than to wait until they are badly in need of food.

Where a leguminous cover crop is grown, the amount of nitrogen may be lessened and on all soils rich in certain plant food, those which are present in sufficient quantities should be omitted in the fertilizer applied. If it is noted that the trees are growing too vigorously, the amount of nitrogen should be decreased. In case of die back, nitrogen should not be used and the actual amount of potash and phosphoric acid may be increased to good advantage.

When the trees begin to fruit, the formula should be changed to one for fruit and the formula for growth may be applied at any time it is seen that the trees are not adding sufficient new wood. Trees producing ten boxes of fruit on Florida soil should receive about thirty or thirty-five pounds per tree. This same proportion may be preserved for each ten boxes of fruit. It may be noted that the pomelo is an exceedingly vigorous grower and can use more fertilizer to advantage than some other kinds of citrus. 
Applying the fertilizer. In applying fertilizer to young trees it should be scattered in a circle of four or five feet radius or more, depending upon the extent of area covered by the feeding roots. It is best that none be applied closer than two feet to the tree as injury may result to the crown roots. Fertilizer for large, bearing trees should be scattered broadcast through the grove.

After applying fertilizer the ground should be cultivated. This prevents the formation of a crust on the surface and the wasting of fertilizer. Besides, some materials become fixed soon after being applied, and it is best that they be incorporated with the soil before this takes place.

Fertilizers are generally applied some little time before growth starts in the spring and again about the month of June. Some growers make an application about October. Care should be exercised in regions where citrus trees are liable to damage from frost that the growing period is not prolonged too late in autumn. The growth should be well hardened up before frost comes. In the hope of evading this evil, Mr. Cyrus W. Butler, of St. Petersburg, Fla., says he fertilizes, "First about the last of Jamuary, using a high percentage of nitrogen; second, during May, using a small percentage of nitrogen; and third, in September or October, using little or no nitrogen." His practice is founded on sound principles. 


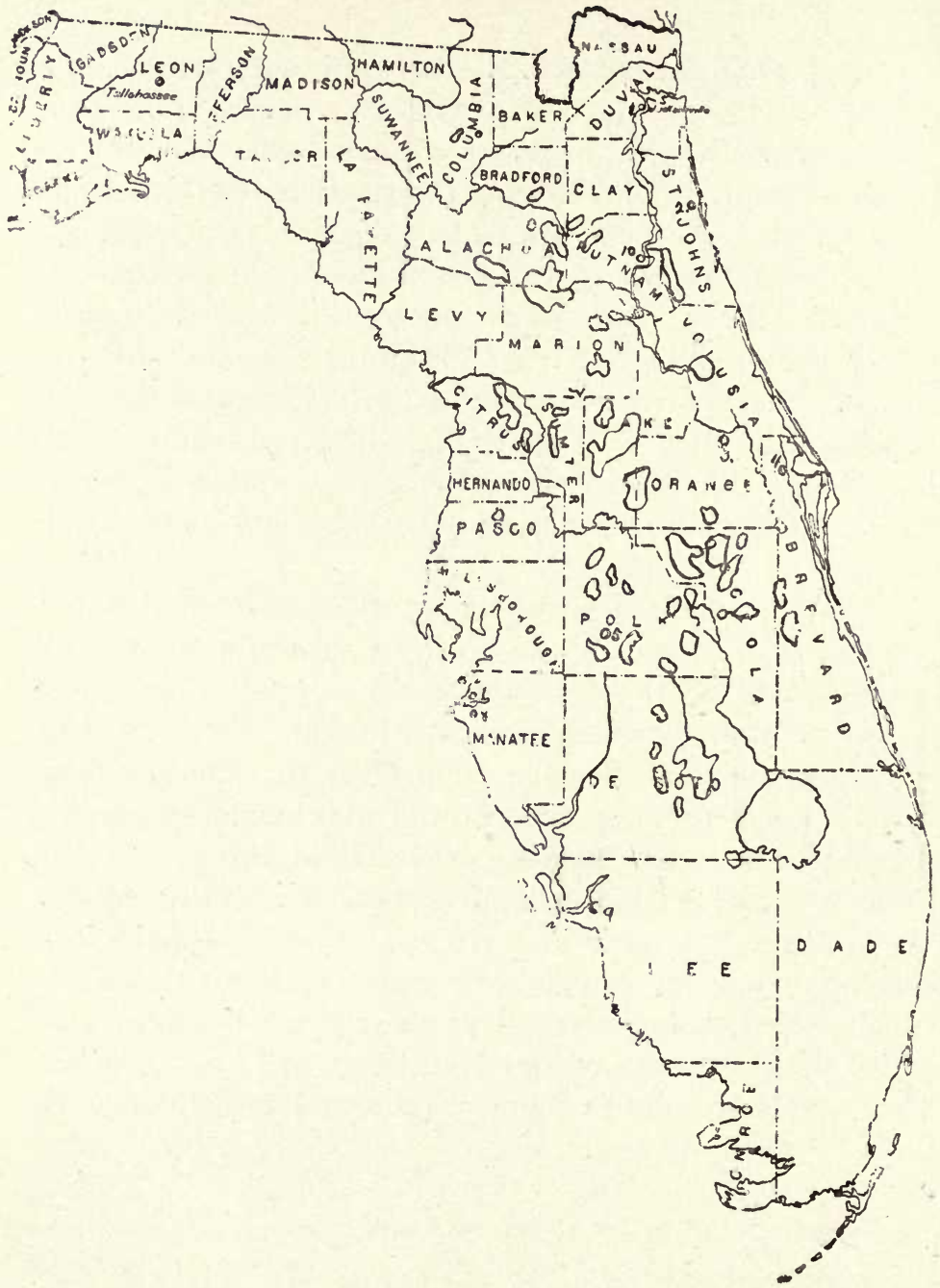

Fig. 70. Map of Florid乞, showing Lake Regions and Artesian Well Area.

1, Jacksonville. 2, St. Augustine. 3, Sanford. 4, Titusville. 5, Bartow. 6, Terra Ceis. 7, Pa'inetto. 8, Manatee. 9, Myers. 10, Palatka. 


\section{CHAPTER XXXV.}

\section{THE IRRIGATION OF CITRUS GROVES.}

It is useless to attempt the culture of citrus fruits where an adequate supply of water cannot be secured, either naturally as rainfall, or artificially, by irrigation. If the trees do not receive a sufficient amount of water, the results will not be satisfactory. When an inadequate quantity, only, is available, the trees do not make a normal growth, the leaves curl and drop, the young fruit falls off and such as is brought to maturity is deficient in juice and inferior in quality. Under such conditions, the trees become fit subjects for the attacks of fungous parasites and scale insects. The combination of unthriftiness due to the lack of water and the inroads of different enemies, soon brings about the death of the trees or the abandonment of the grove by the owner.

Hence, in selecting a site for a grove it is well to be assured that a sufficient amount of water will always be available. It should be borne in mind that citrus trees require more water than deciduous trees of equal size and age. Transpiration is greatly reduced during the winter season or dormant period in such trees as peaches, plums and pears. They shed their leaves in autumn and, in consequence, the transpiration area is greatly lessened. On the other hand, the leaf area of citrus trees is the same winter and summer alike and a like amount of water is transpired in wintel as in summer, where the climatic conditions are favorable to growth. As a matter of fact, citrus trees are more or less active all the time. 
The minimum quantity of water required depends upon the character and depth of the soil, the kind of stock, the age and the bearing capacity of the trees.

In California, where irrigation of citrus fruits is practiced on an extensive scale and where intelligent care is exercised in the conservation of moisture, the total amount of water provided by rainfall and irrigation is, in most cases, between thirty and forty inches. In times of extreme drought and scarcity, even less than two feet has sufficed. But if the attempt were made to make this amount do season after season, failure would result in most cases.

In relation to irrigation, the areas in which citrus fruits are grown in the United States may be divided into two sections. The first embraces California and Arizona, in which water must be supplied artificially that the trees may grow and mature fruit. The second consists of the citrus sections of Florida, where irrigation is the exception, not the rule, but where it is occasionally resorted to, to supplement a copious, but sometimes irregular, rainfall.

IRRIGATION IN FLORIDA.

ANNUAL PRECIPITATION IN INCHES AT FOUR POINTS IN FLORIDA FOR FIVE YEARS, AND THE AVERAGE PRECIPITATION FOR THE STATE.

\begin{tabular}{|c|c|c|c|c|c|}
\hline & 1898 & 1899 & 1900 & 1901 & 1902 \\
\hline $\begin{array}{l}\text { Jacksonville ..... } \\
\text { Jupiter .......... } \\
\text { Key West . . . . . } \\
\text { Tampa . . . . . . . }\end{array}$ & $\begin{array}{l}53.85 \\
52.65 \\
48.81 \\
55.45\end{array}$ & $\begin{array}{l}54.22 \\
76.08 \\
37.02 \\
42.06\end{array}$ & $\begin{array}{l}55.52 \\
45.79 \\
38.61 \\
50.38\end{array}$ & $\begin{array}{l}45.71 \\
39.10 \\
43.39 \\
50.53\end{array}$ & $\begin{array}{l}38.59 \\
61.93 \\
29.55 \\
63.82\end{array}$ \\
\hline State average... & 52.30 & 51.72 & 44.98 & 48.36 & 51.77 \\
\hline
\end{tabular}


The annual rainfall in Florida, as shown in the accompanying table, is certainly ample for the development of citrus fruits. In fact, viewed in the light of the statements made regarding the amounts of water used in California, it might by some be deemed excessive. But even with such a heavy precipitation, it sometimes happens that the groves suffer to some extent, or at least they would at times be benefited by an additional supply of moisture. If the heavy rainfall were divided up into a large number of equal portions and these distributed at regular intervals, citrus trees would certainly never suffer from lack of moisture. Frequently the total rainfall for a month comes in a few hours, and most of it runs off in the streams and rivers. The water has no opportunity to sink in, and consequently the soil is not capable of retaining it.

The period during which this is most likely to occur and the period likewise in which the rainfall is most uncertain and during which the groves are most likely to suffer is between the first of March and the middle of June. Frequently during this time, weeks pass without a shower, while at other times, an amount of water sufficient for the whole period is precipitated within a few hours. It is during this time that groves would be benefited by being irrigated and the constant recurrence of these conditions, year after year, has led many growers located even on comparatively moist soils, to make provision for applying water artificially. The period from June to October is usually designated as the "rainy season," the season of heavy precipitation, during which showers are of daily occurrence and during which irrigation is unnecessary and needless. 
As pointed out in Chapter XXVIII, the soils of Florida are light, sandy and porous. Compared with California soils, their water holding capacity is considerably less. Hence, under similar climatic conditions, at equal altitudes, Florida soils would prove greatly inferior to those of California, if the irrigation problem alone were considered.

On the other hand, it must be noted that were it necessary to irrigate to the same extent as it is necessary both in California and Arizona, under present existing conditions, it could be done much more economically in Florida than in the above mentioned sections. The innumerable lakes, streams and springs afford an ample water supply, one which might be drawn on at a small cost. while the underground waters are in close proximity to the surface and quite accessible. A glance at Fig. 70 will give an idea of the number of lakes scattered throughout Florida. In the lake region of Polk County, for instance, they are so thickly scattered that large numbers are in view from a single elevated point, and within a radius of five miles from Winter Haven, there are one hundred and fifteen lakes.

\section{ARTESIAN WELLS.*}

The Florida artesian basin is an important feature. Commencing at Jacksonville, Fig. 70 the area follows the St. Johns River and somewhere south of Sanford swings across to Bartow, Myers and the Manatee section. Flowing wells have been obtained at St. Augustine (Fig. 70, 2), Palatka (10), Sanford (3), Titusville (4), Palmetto (7),

* It is probably best to secure water from lakes, rivers or shallow wells in Florida. In this State, artesian water has frequentlly proved injurious to citrus trees. 
Terra Ceia (6), as well as at the points already mentioned and many others not indicated on the map. One of these wells is shown in Fig. 74 .

While the surface of Florida is remarkably flat to the eye and such elevations as do occur are not strongly marked, there are two main anticlinal folds, the higher

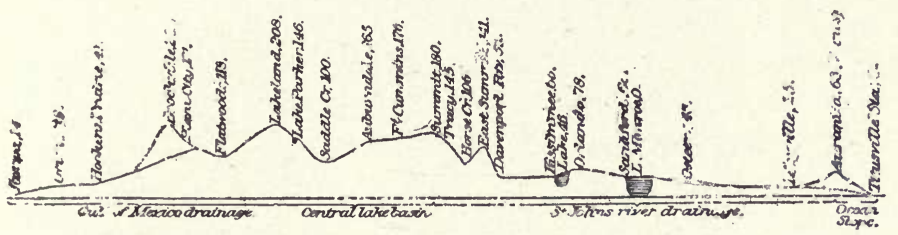

Fig. 71. Elevations and depressions in Florida, between Tampa and Titusville. (From Rep. U. S. S. Survey.)

one passing through Jasper, Lake City, Gainesville, Brooksville, Lakeland, Bartow, Fort Meade, Arcadia and gradually disappearing at the southern end of the peninsula. Some points upon the crest of the other are Macclenny, Lawtey, Starke, Hampton, Interlachen, Summit, Highland, Orlando and Narcoose. It may be noted here that some of the points on these ridges, as Brooksville, Lake City and Highland, are more than 200 feet above sea level, while many of the points in the syncline or valley between the two folds, as well as points on either coast are but a few feet above sea level. These folds give plenty of head for the downward flow of water. Fig. 71, which represents a section of the State from Tampa to Titusville, illustrates this point.

The artesian wells are made possible by the collection of water in an inclined pervious layer of rock which lies between two impervious layers. Water collects in this layer under pressure and when wells are drilled into it, it rushes upward, reaching nearly the same level as 
the plane at which it entered. Now, it is not improbable that the lakes in the higher sections of Florida are the source of many artesian wells. Numbers of these lakes are not drained by rivers or streams and have no visible outlet, but in a number of cases they have been entirely emptied for a time, by the disap-

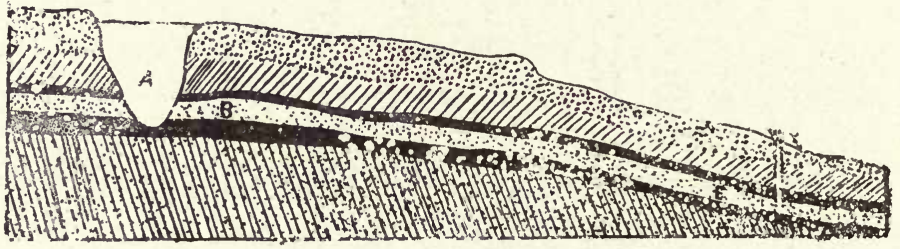

Fig. 72. Diagram showing how artesian wells are formed. A, lake. $B$, pervious layer of rock. C, artesian well.

pearance of the water through an opening in the bottom. It is probable that water frequently escapes constantly through a pervious stratum located in the bottom or opening into the side. Fig. 72 shows how this might be. Opening into the lake, A., is a pervious layer, B., located between two impervious layers into which the water passes. The water following the dip in the strata flows downward, and if a well is bored at $\mathrm{C}$., the water will rise above the surface. The Florida wells are usually between forty and two hundred and fifty feet deep, though some are even deeper. From this it will be seen that irrigation from artesian. wells is feasible only on the lower levels.

\section{PUMPING WATER.}

The higher grounds can, however, be irrigated by pumping from wells or lakes. Many lakes are located on the higher levels. In the vicinity of Lake City, two hun- 
Plate $X X$.

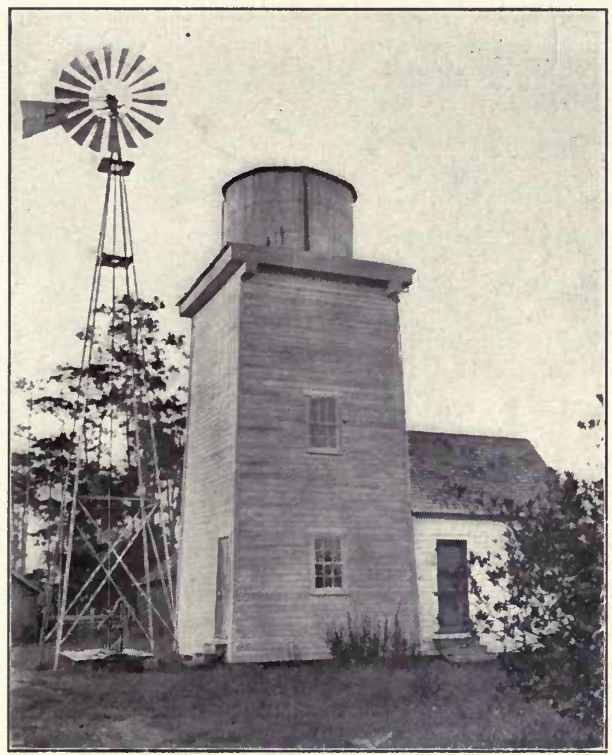

Fig. A. Wind-mill, pump and tank in a citrus grove.

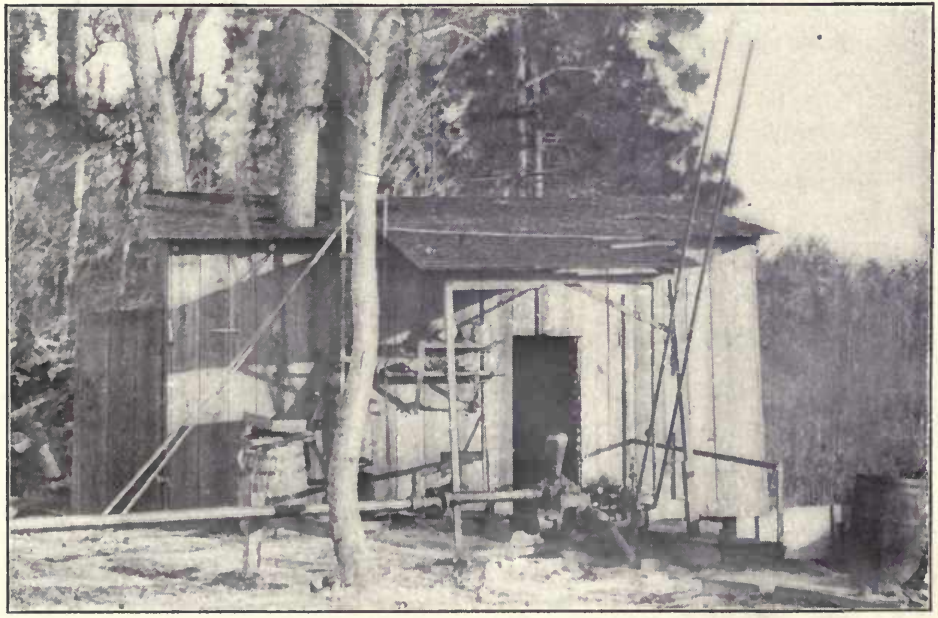

Fig. B. A temporary steam pumping plant on a lake-shore in Florida. 
dred and two feet above the sea level, there are eight lakes. From these water could readily be obtained by pumping, using wind, steam or gasolene power. A temporary steam pumping plant on the shore of a Florida lake is shown in Fig. B, Plate XX.

In most sections of the State, water can easily be secured from wells. These are sometimes dug, but in many cases, a sharp, hollow, perforated joint at the end of an inch and a half galvanized iron pipe is driven into the soil until a water-bearing level is reached, often at a depth of not more than fifteen or twenty feet, and water is then pumped out by means of a windmill. In such cases, a tank must always be provided, as the stream pumped directly from the well would be much too small to accomplish any good. A pumping plant with windmill power is illustrated in Plate XX.

The following table was given by King in Farmers' Bulletin, No. 46, U. S. Department of Agriculture, and is of interest as showing the amount of work that can be accomplished by wind-motor power:

NUMBER OF ACRES A FIRST-CLASS WIND-MILL WILL IRRIGATE TWO AND FOUR INCHES DEEP EVERY TEN DAYS WHEN WORKING EIGHT HOURS PER DAY, AND LIFTING WATER TEN, FIFTEEN AND TWENTYFIVE FEET, RESPECTIVELY.

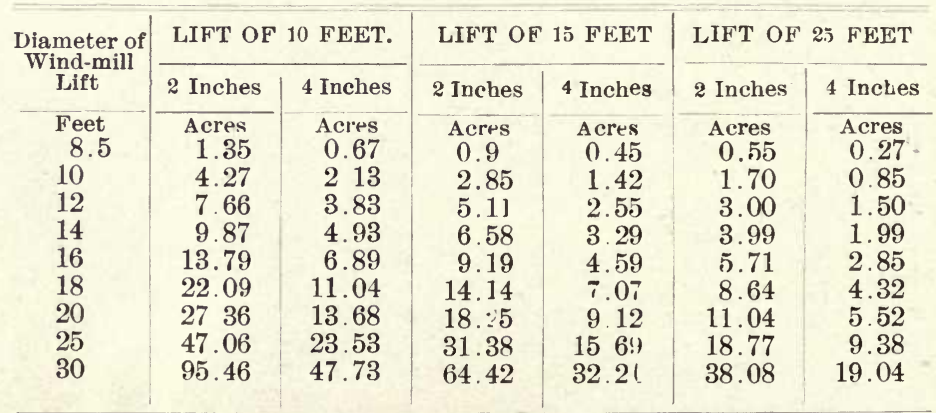


Sub-irrigation with jointed tile or perforated pipe is not feasible in citrus groves, as the tile or pipe soon becomes plugged by the fibrous roots. In a few cases

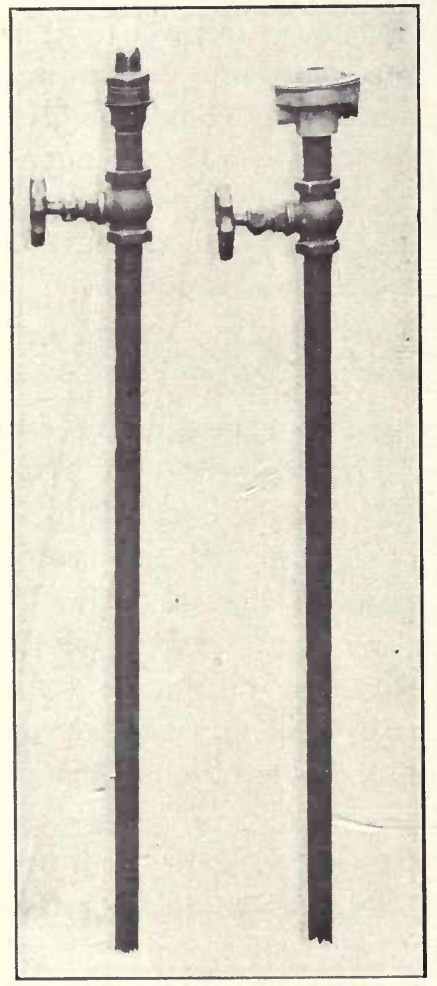

Fig. 73. Spraying stands used in Florida, provided with Japanese and Cyclone nozzles. cement tile has been used. but in most cases the water is conducted to the trees by means of iron pipes laid beneath the surface so as not to interfere with cultivation. From these, stand. pipes, provided with taps or spraying nozzles, are brought up near each tree. In irrigating by steam engine or gasolene power, the water may be pumped directly into the pipes. Generally the power provided is not sufficient to irrigate the whole area at one time. The taps in one section are opened and the ground is thoroughly moistened. This accomplished, they ar e closed and another set is opened, and so on until the whole grove receives its quota of water.

Soils provided with a comparatively compact clay sub-soil at a depth of eighteen to twenty-four inches may be irrigated by the furrow system, as described further on. If water is conducted to the grove under pressure in iron pipes, it may be sprayed upon 
the trees during the dry season to check the ravages of red spider. This insect cannot withstand the presence of a considerable amount of moisture on the trees.

It must be conceded, however, that the cheapest way to distribute water in a grove of orange trees is to allow it to run in furrows over the surface of the ground and, other conditions being equal, this method should be given preference. Less power is required to provide the supply and the equipment is, on the whole, less expensive. On clay soils or soils with a clay subsoil close to the surface, and with sufficient fall, it is the best plan to follow.

\section{IRRIGATION IN CALIFORNIA AND ARIZONA.}

In California and Arizona, it is not possible to maintain a grove of citrus trees without resorting to irrigation. The water supplied by rainfall is insufficient for their needs, and a considerable amount of the cost of fruit production must be charged to the irrigation account. Prof. Newell says, "The annual charge for the irrigation of citrus lands in southern California varies from $\$ 5$ to $\$ 30$ per acre, and will probably not average far from $\$ 10$ per acre irrigated, the supply being usually 12 inches in depth of irrigation water."

The amount required in different localities and even on adjacent ranches varies greatly. The following table copied from Bulletin No. 108, U. S. Department of Agriculture, Office of Experiment Stations, by Prof. E. J. Wickson, shows the season of year during which irrigation is practiced, the amount of rainfall and the amount of irrigation water supplied in several of the citrus districts : 
SUMMARY SHOWING IRRIGATION SEASON AND FREQUENCY OF APPLICATION AND AMOUNTS OF WATER USED FOR CITRUS FRUITS IN CALIFORNIA.

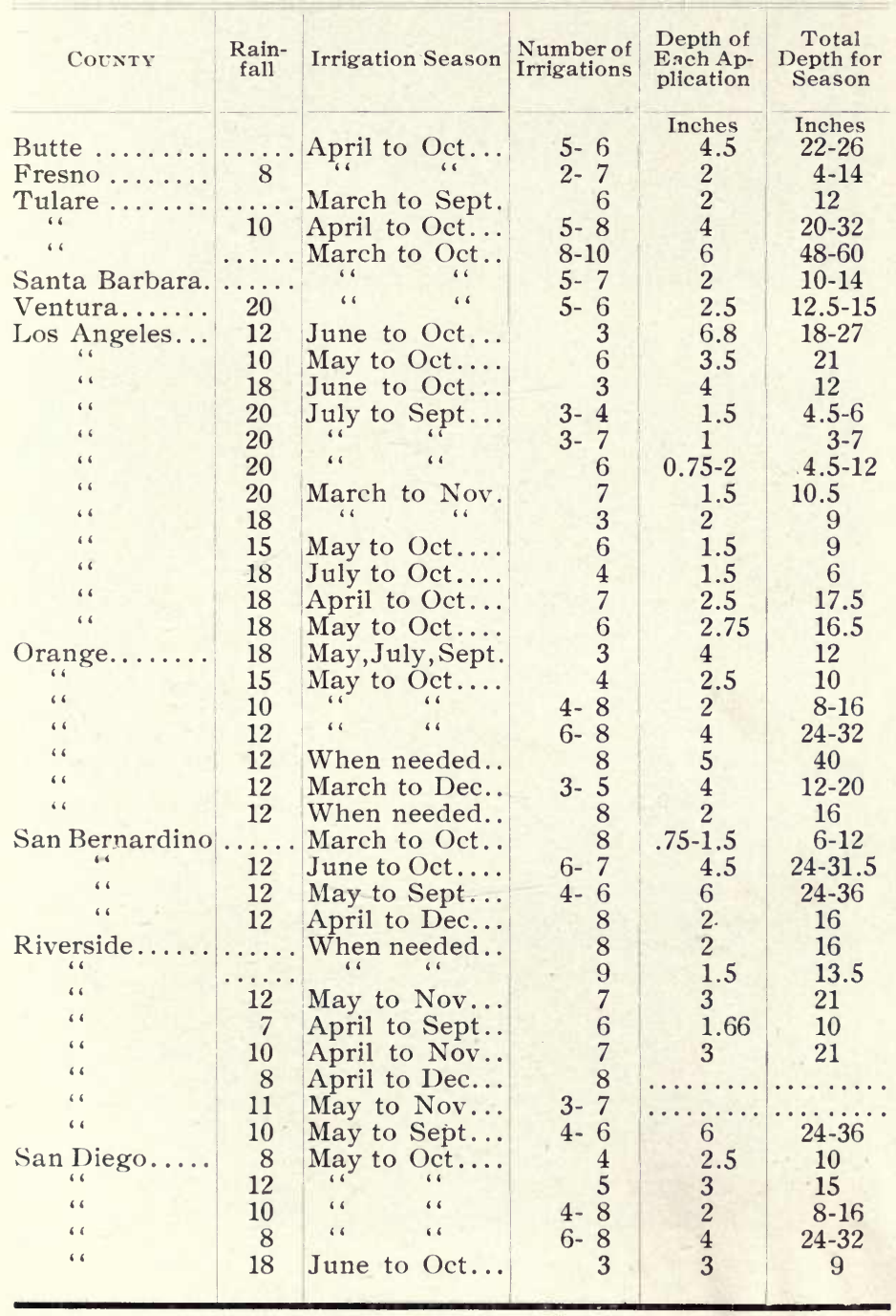




\section{Plate XXI.}

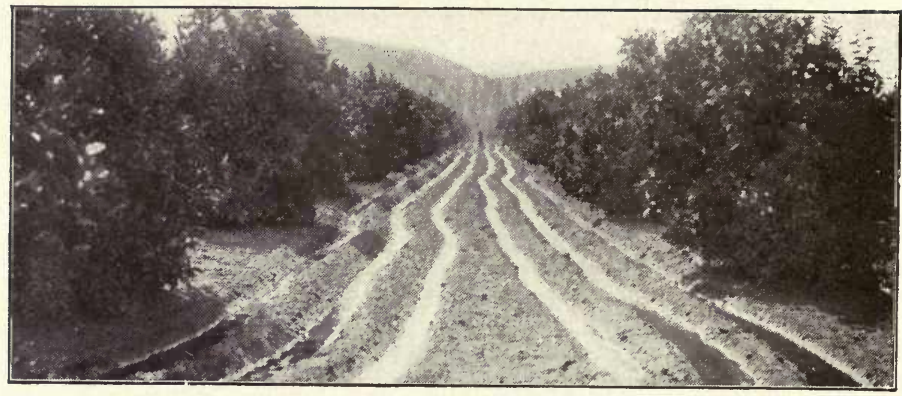

Fig. A. Irrigating by means of furrows.

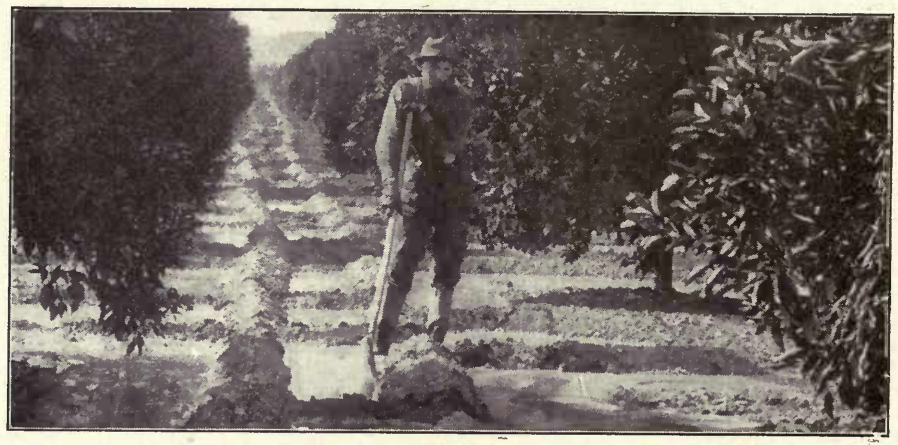

Fig. B. Basin irrigation of citrus trees.

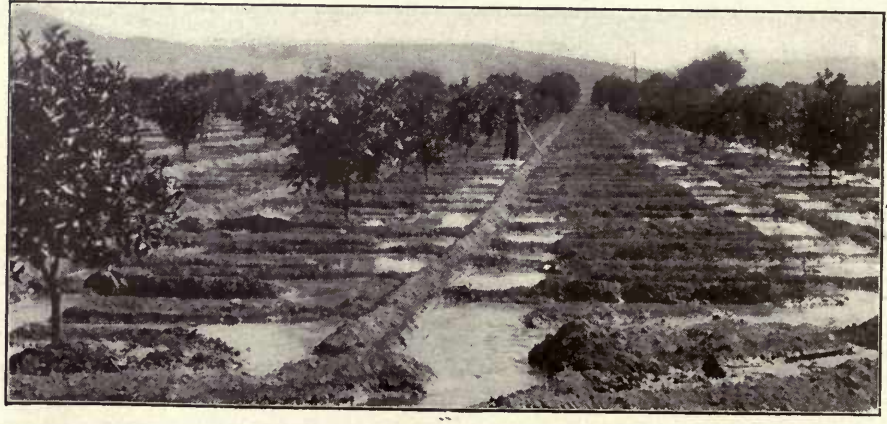

Photos from S. M. Teague, San Dimas, Cal.

Fig. C. Zigzag irrigation of citrus trees. 
From this table it will be seen that the average annual rainfall is $\mathbf{1 3 . 7}$ inches, but that it varies all the way from 7 to 20 inches. It will be noted further that the irrigation season runs from March to about October, this being the period of greatest heat, least rainfall and most vigorous growth of fruit and branch. The amount of irrigation water in most cases does not exceed thirty inches and by far the greater number of citrus groves receive twenty inches or less in addition to the rainfall.

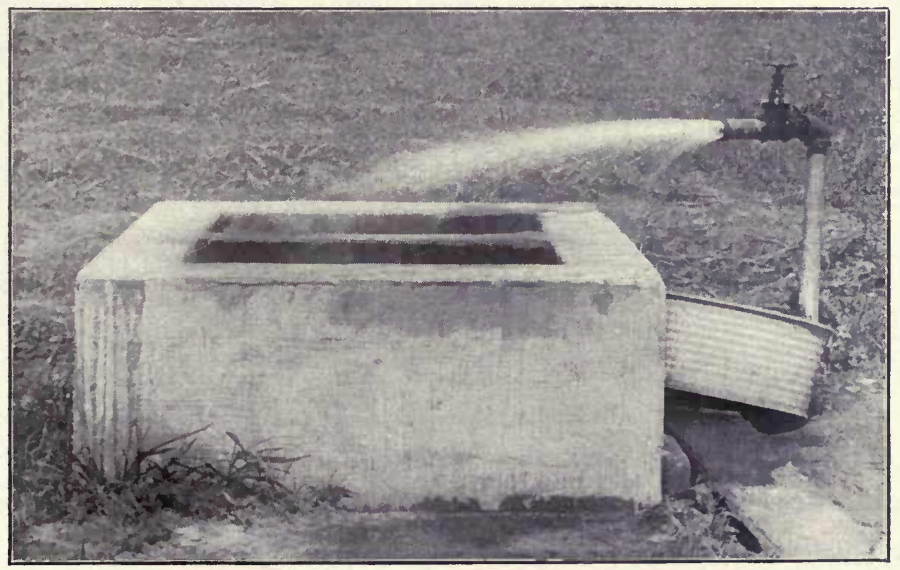

Fig. 74. Artesian Well at Sanford, Florida.

The variation in the amount used is due to the elevation, the temperature, the character of the soil and the rainfall. Some localities are specially favored in receiving a large amount of water at a small cost and there it is generally found that it is used more freely than where higher rates prevail. Still, the amount used in all cases is small and bears testimony to a careful and conservative use of water by the growers. 
Though in some cases water is obtained from wells, most of it is procured from reservoirs in the mountains or from rivers, being conducted to the fruit districts in pipe lines or canals. From these each individual grower receives his supply.

\section{DISTRIBUTION OF WATER.}

The water is usually delivered in ditches, cement flumes, wooden flumes or cement tile lines at the highest part of the grove and from there distributed to the trees. The methods of irrigation commonly used are the furrow and check, the former being the one most generally adopted.

\section{FURROW SYSTEM.}

In the furrow system the water is delivered in a flume along the higher portion of the grove and the water is delivered through the gates into the furrows which run out between the tree rows. The number of furrows to each interspace varies with the size of the trees as well as their age. In irrigating small trees fewer furrows are used, while in groves of large trees set twenty to thirty feet apart from five to nine furrows are used. The water is not turned into all the furrows of the grove at once, but is supplied to a small number at one time. Through these furrows the water makes its way, until it reaches the lower end when the gates in the flume are closed and the water diverted into another set of furrows.

The continued application of water at the same depth frequently brings about the formation of what has been termed "irrigation hardpan." The soil on a level with the bottom furrows becomes hard and compact and prevents 
the water from entering. This difficulty was overcome by breaking up this hard layer with a subsoil plow and in many cases this method was so vigorously followed that great injury was done the trees. Large numbers of roots were torn up and destroyed. Following this a reaction set in and experience has taught that the best method to pursue in treating irrigation hardpan is to deepen the soil gradually instead of attempting to accomplish it at one operation. The depth of cultivation should be varied from time to time, and the irrigation furrows should open well into the lower soil to permit the free entrance of water.

In distributing the water through the grove it should be allowed to flow gradually and sink well in. By this plan better results will be obtained with the same amount of water than by applying it in a shorter space of time.

Following the application of water the soil should be cultivated as soon as its condition will permit. Shallow cultivation at this time will prevent the formation of a hard crust on the surface and the consequent loss of moisture by capillary movement.

\section{CHECK SYSTEM.}

Citrus trees may be irrigated by the check method and, when thoroughly done, it leaves little to be desired. It entails a great amount of hard labor in preparing the surface to receive the water, in distributing it and in getting the soil leveled and in tillable condition after the work of irrigation is completed. Generally, the method gives better results on porous soils than the furrow system. This method is described as follows by Mr. Sydmer Ross, of Fullerton, Cal., in Bulletin No. 108, U. S. D. A., Office of Experiment Stations: 
"The ground must be cultivated, say, about five inches deep, so as to have plenty of loose soil with which to throw up a high ridge. Then a four or six-horse 'ridger' should be run once each way between the rows, if it is a citrus or deciduous orchard, or twice should the trees be walnuts, because these trees are grown about forty feet apart. After this is done the ridger should be run entirely around the outside of the piece to be irrigated, so as to have as perfect a ridge as possible on the outside. One man will ridge about fifteen acres in a day. The ridger should be built with a steel plate extending along the bottom of both sides, bolted to the inside and projecting about two inches, so as to take a good hold of the ground. Then with one horse attached to what is locally known as a 'jump scraper,' one side of the checks should be closed up, for the ridger in making the cross ridges breaks down the first ridge at its intersection. These repairs were first made with a shovel, but the 'jump scraper,' also locally called the 'horseshovel,' closes up the gaps very quickly. The practice generally followed is to close up the high side of the checks if the land does not cut by running water, but if it cuts, close up the lower side.

"After closing up the checks the ditches are plowed out and then the V-shaped 'crowder' is run through them. On lands inclined to cut, it is advisable that the length of the rows to be irrigated should not be over 250 feet, but in heavy land this distance can be considerably increased, if necessary, without danger of cutting the ridges by too long a run of water.

"If the checks have been closed up on the low side of the ridge, it is better to run the water to the ends of the ditch and water the last row first; but if the high 
side has been closed up, it is best to water first the row nearest the gate or the main ditch, as the case may be, as in each instance dry earth will thus be available, if necessary, to close up the checks. The water is run down the row to the end tree, and as soon as the last check is filled it is closed up, and so on till all are filled and closed, when water is turned down the next row.

"To do good work, it is usual to allow three men for every fifty inches of water, but in our own practice we have had much better results by dividing up our water and running from 35 to 40 inches to a ditch and allowing two men for such streams. In doing this we get better work and find it much easier for the men. If everything is well in hand, each man will irrigate about thirty acres in a day.

"For turning the water from the ditches into the checks metal dams or tappoons are used. The gate is not a great success, as the water is apt soon to cut its way under the tappoon, but it may be much improved by hav ing a shelf for the water to drop on after it passes through the opening. The common practice for dividing water is to throw a tappoon partly across the ditch, putting a gunny-sack on the opposite side to prevent cutting by the water. This is, on the whole, fully as satisfactory as using the tappoon with a gate.

"All who follow this system should get ready for the water before it comes. A great many seem to think that if they ridge up their land, close up the checks and plow out their ditches, everything necessary has been done. Such is not the case, as ditches that are liable to cut should be fixed in the weak places with brush or burlaps. Old gunny-sacks cut open and spread out are excellent for this purpose. Occasionally there are places 
where it is impossible to get a perfect ridge. These should be looked up and fixed with a shovel. The jump scraper will not entirely close up a check; it generally requires a shovelful or two to complete it. It is usual after the water is turned down one row to fix up the next one, but it is an excellent plan to have a few rows ahead, for there come times when breaks occur and there is not time to make the necessary repairs, and when water once gets the start there is apt to be much trouble and hard work before it can be put under control, besides doing poor work.

"After the ground is dry enough to work, the ridges are split with a listing plow or a furrower attached to a cultivator. Then the ground should be run over with a harrow, setting the teeth to go well in, so as to pulverize the surface thoroughly. By using the harrow the ground can be worked about one day earlier than with the cultivator, and it also prevents the ground from baking till such times as it can be worked with the latter implement, besides doing far better work than with the cultivator alone, especially when there is much land to go over, as some of it is certain to get too dry before it can be reached, and then it will not pulverize well. All trees should be worked around by hand with either a fork or a hoe as soon after irrigation as the ground becomes dry enough and before it becomes hard." 


\section{CHAPTER XXXVI.}

\section{FROST PROTECTION.}

The question of frost protection is one which has been forcibly brought to the attention of citrus growers, during the last decade, in nearly all districts in the United States in which oranges or other citrus fruits are grown. The frequent occurrence of frost and an occasional freeze, injurious to trees or fruit, or to both, has awakened great interest in the methods of protecting citrus groves from the effects of cold. As a result, many different plans have been brought forward. Some of these have stood the test of many trials, while others have been discarded in favor of better or more economical methods. In no region has the growing of citrus fruits been abandoned entirely be. cause of the effects of cold, and a very considerable degree of success has rewarded the efforts of many to maintain their groves in exposed regions. No matter what means of protection may be adopted, the principal factor in the success of any one of them is the individual himself. Provision must be made beforehand, everything must be in readiness. It will not do to leave the preparations for protection until the last moment and then expect to get good results.

One of the most necessary and essential things in frost fighting is that the grower should have some means of knowing when frosts are to be expected. If forewarned. everything will be in readiness, and he will be on the alert. In giving warning of the approach of cold waves, the United States Weather Bureau has done excellent service. People are usually warned through the newspapers, and by 
telegrams placed in the postoffice or in other conspicuous places, that cold is to be expected. Much good results from these forewarnings. In Florida, knowledge of an approaching cold wave is also given by the railways. They receive news of an expected fall in temperature and give notice to those along the railroad line by special whistles blown at intervals. Thus timely warning has frequently been given.

But, nevertheless, the grower should not be entirely dependent upon some one else for his knowledge of what is to be expected. Sometimes the weather bureau fails to report the full extent of what is to be expected, or local conditions may cause the cold to be more severe in one locality than in another. Hence the citrus grower should rely upon himself to some extent.

\section{THERMOMETERS.}

If a good alarm thermometer can be secured it should by all means be purchased. A number of different kinds have been placed on the market, but unfortunately they are not all satisfactory, and usually they get out of repair and do not read accurately after having been used for one or two seasons. But if tested from time to time by comparing them with a good standard thermometer, they may be of considerable service.

The outfit for setting up an alarm thermometer consists of an electric bell, a battery, a thermometer, and sufficient wire to permit the latter to be placed in a position where it will accurately represent the temperature in the grove. The bell should be placed where it will be heard -just outside a window being a good place. From this the wires should lead out into the grove where they are attached to the thermometer. 
Two kinds of thermometers are in use, one depending upon the contraction of a column of mercury, the other depending upon the contraction of a piece of metal, a thermostat in short. In fact, an ordinary thermostat, costing about two dollars and a half, makes an excellent substitute for a thermometer. When the mercury falls or the metal contracts the circuit is closed and the bell rings, warning the grower of approaching danger.

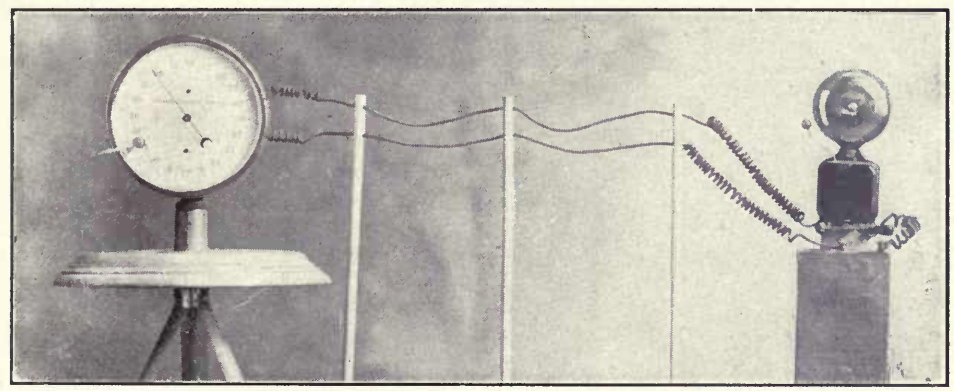

Fig. 75. Bolton alarm thermometers, showing thermometer, wires, bell and battery.

The thermometer must be adjusted so as to give sufficient time to light fires or for covering the trees. Ordinarily, if set or fixed at 30 degrees Fahr., sufficient warning will be given.

\section{INJURIOUS TEMPERATURES.}

It is difficult to determine exactly the degree of cold at which the different parts, trunk, branches, leaves and fruit will be injured. The danger point is determined by many factors, principally, however, by the state of dormancy of the tree, the variety, the duration of the cold, and by the weather conditions immediately preceding the cold snap. If the tree has already been partially or wholly 
defoliated by cold, the danger of injury to the branches and twigs is very materially increased.

As an approximation, it may be said that green fruit is injured at 29 degrees, and ripe fruit at 26 degrees. Dormant sweet oranges have been known to stand a temperature of 18 to 20 degrees $\mathrm{F}$., for a short period. This approaches the limit. A large Satsuma tree on the Experiment Station grounds at Lake City, Fla., stood, on one occasion, a temperature of 16.5 degrees $\mathrm{F}$. without loss of foliage. The tree was dormant at the time. On the other hand, when the sap is moving in the trees they may be severely injured or killed to the ground even at much higher temperatures. One of the most critical periods is when the trees are in bloom.

\section{EFFECTS OF COLD.}

On the Leaves. The effect of a slight amount of cold on the tree is to curl the leaves to such an extent as to make them appear as though suffering from lack of moisture. If chilled only to a slight extent, they may regain their normal condition and still remain on the tree. Whether leaves thus affected will serve a useful purpose, on the tree, as long as those which have not been so affected, is doubtful. At any rate it appears that their usefulness is materially impaired for one season at least and it is possible that the life of such leaves is shortened.

If still further frosted, the leaves are curled and, in the course of a few days, drop from the trees. Usually the upper leaves fall before the lower, some of the latter frequently remaining, even when the upper portion of the tree is practically defoliated, as shown in Fig. 76. Defoliated 
trees are in great danger of severe injury from a second cold wave. The blanket of thick foliage serves as a very material protection to the branches.

On the Twigs. The young, tender growth of the trees may be injured to some extent by cold sufficiently intense to defoliate the tree without severe injury being done to the larger branches. Much depends, of course, upon the degree of dormancy. If sufficiently dormant, the twigs will resist a considerable degree of cold; but, of course, they are

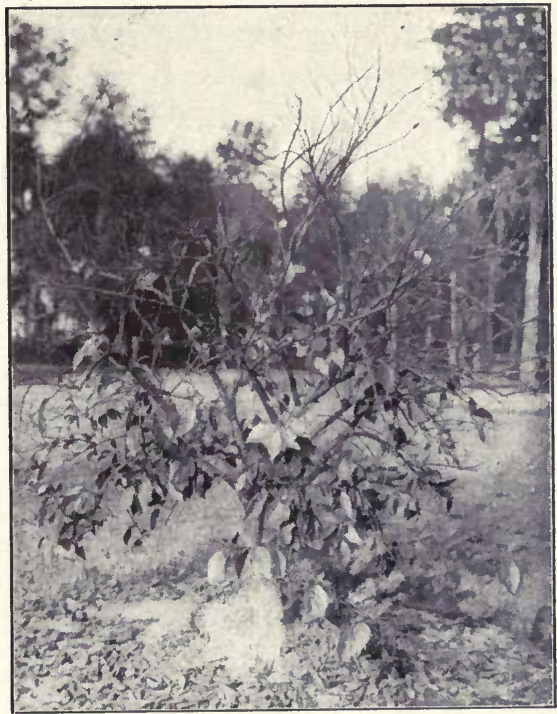

Fig. 76. Effects of a slight frost on growing orange tree. Nearly all the leaves have dropped.

much more susceptible to injury than the branches. It may be stated as a rule that the resistant power of a branch becomes less and less as it decreases in size, or in other words varies directly with the diameter. Large branches are injured only by intense cold, and the top of a tree may be very decidedly cut back by frost before the large branches are injured. The exact amount of injury to the twigs cannot be determined until sometime after the frost occurred.

On the Trunk. No portion of the tree can withstand more cold than the trunk. When severely frozen, however, 
it is killed to the ground, and may frequently be split open if the cold is sufficiently intense. As with the branches, its resistant power is in direct ratio to the diameter. It does not appear that there should be much difference in ability to withstand cold, between a citrus trunk four inches in diameter and one eight inches in diameter, but such is the case, nevertheless. It may be that larger trees become more dormant than smaller ones and their sap does not respond so readily to elevations of temperature.

The weakest spot, in the whole anatomy of a budded or grafted citrus tree, is the point of union of stock and cion. This point should be protected by placing about it a mound of earth and, moreover, the union should be as close to the ground as possible. Protection afforded the trunk by a dense mass of foliage, twigs and branches is frequently not appreciated to its fullest extent. The warm air is held to some extent, and the cold is prevented from penetrating to the framework of the tree. Isow-headed trees are preferable to high-headed ones, because in the former case, the branches serve as a protection to the trunk. High-headed trees should not be grown in exposed regions.

On the Fruit. Up to the present time no statement has been made as to whether the fruit of any variety of citrus is more resistant to cold than others. It is probable that no appreciable difference exists, or if there is a difference, it is too slight to be of any practical value.

Small, whitish specks, 1-2 millimeter in diameter, appear in the tissues of the fruit after it has been slightly touched by frost. These are evidently due to chemical changes and are probably present in all kinds of citrus fruits. They have been noted in lemons, sweet oranges, mandarin oranges, kumquats and pomelos. Their pres- 
ence may be regarded as an indication that the fruit has been frosted, as they are not known to be caused in any other way.

When touched by frost over a small area, the frosted portion of the rind assumes a light color. Blue-mold soon attacks the fruit and its destruction is complete.

Frequently citrus fruit may not be sufficiently in-

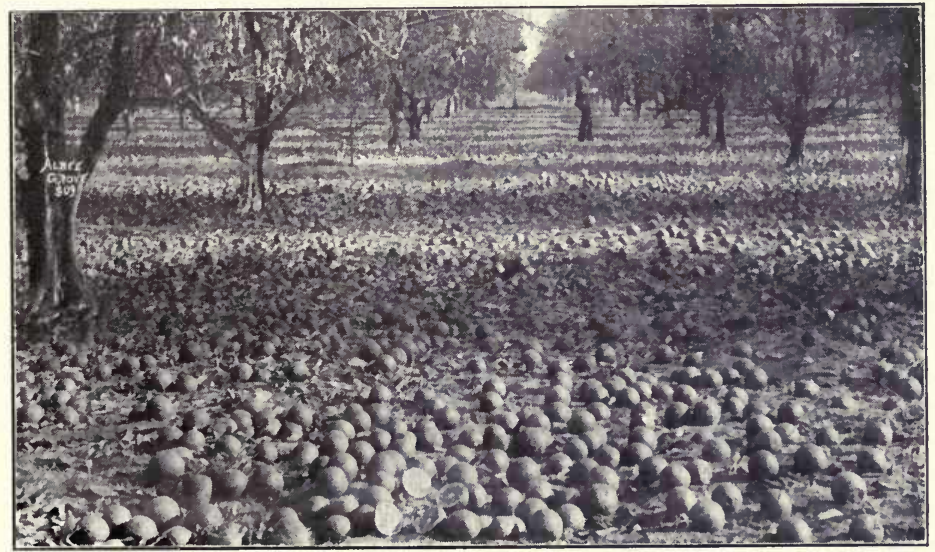

Photo by Ensminger.

Fig. 77. Oranges dropped by the effects of cold.

jured to show on the rind, and yet the rind may be injured or its nature changed in such a way as to permit the evaporation of the juice. After a time, nothing is left in the fruit except a chaffy mass of juice-sacks. On the surface the fruit may appear all right, yet it may have so deteriorated in value as to be worthless.

In the handling and marketing of frosted fruit, growers cannot be too careful. If it is suspected that fruit has been touched by frost, it should not be shipped until it is determined absolutely that the fruit has not been injured. 
Even when only slightly affected, the juice will disappear, no matter whether the fruit is on or off the trees, and in such cases considerable time must elapse before the actual extent of the frost injury can be determined.

When severely frosted, the fruit falls. This is the inevitable consequence of severe injury to the twigs and branches, see Fig. 77.

\section{CONDITION WHEN MOST RESISTANT.}

Under certain conditions citrus trees are more resistant to frost than under others. The presence of insects, diseased conditions, starvation, and the degree of dormancy of the tree all bear an important relation to the amount of cold which a tree can successfully withstand.

The Insect Factor. On many different occasions it has been noticed that trees affected by white-fly or scaleinsects suffer to a far greater degree during a cold period than those free from these pests. A rough estimate of the difference in favor of trees free from insects would be four or five degrees. It may be more, it certainly is not less. The insects suck the sap from the tree, devitalize it; in consequence, it is in poor condition to withstand cold. In view of this, every precaution should be exercised to keep the trees free from insects.

The Disease Factor. Diseased conditions brought about by die-back, foot-rot or other disturbing factors, either of a physiological or a fungous nature, reduce the resistant power of the tree as much as attacks of insects do. The trees must be kept in a healthy, growing condition.

The Food Factor. When well supplied with food, so as to form healthy, vigorous shoots and well-developed 
leaves, citrus trees are in a much better condition to withstand cold than when they are starved, or only poorly supplied with food. A sufficient supply of nitrogen to give a healthy, dark green color is essential. The trees must not be over-stimulated, however, else the sappy, immature wood formed, will suffer severely; but a sufficient supply of well-balanced food should be available to keep the trees in a healthy condition. A starved condition is analogous to a diseased state. Nitrogen must not be supplied in excess of other elements, but it will prove to be poor policy to reduce the amount, in the hope of keeping the tree dormant, so as to interfere with the normal development of the branches and leaves.

Dormancy as a Factor. Unfortunately, the citrus tree is not distinctly periodic in its growth. It responds readily to short periods of warm weather; the sap starts to flow; the buds commence to swell. In this condition it may be severely injured by a comparatively high temperature. In a perfectly dormant condition, citrus trees will withstand a very considerable degree of cold. How many degrees more of cold a tree will stand when dormant, than when not dormant, cannot be definitely stated, but the difference is very appreciable. Practices or treatment of the trees having a tendency to start growth during the danger period, should be promptly discontinued. Among these may be mentioned, heavy pruning and fertilizing and tilling the soil too early.

\section{FERTILIZERS AND CULTIVATION IN RELA'IION TO DORMANCY.}

Heavy applications of nitrogenous fertilizers followed by cultivation have a tendency to start growth in the trees. As a general rule cultivation should not be commenced 
in spring until all danger of frost injury is passed. It is preferable that the bulk of the nitrogen applied in the fertilizer should be given early in spring and that the amounts be gradually lessened in each successive application as the season progresses.

Cultivation should not be continued late into the season as it has a tendency to prolong the period of growth. Cutting the surface soil with a cutaway harrow or a shallow plowing after the cessation of growth, will not affect the trees to any appreciable extent but it must be carried too far.

Liberal amounts of potash have a decided effect on hardening and maturing the new growth, and this feature should not be overlooked in fertilizing.

Effects of the Stock on the Hardiness of the Top. That there exists a mutual inter-relation between the stock and cion, cannot be doubted. A hardy stock has, in many cases, a marked influence on the power of the cion to withstand cold without injury.

As pointed out in the chapter on stocks, they vary considerably in their resistance to cold. In order of frostresistance they may be arranged as follows: trifoliate orange, sour (Bigarade) orange, sweet orange, pomelo and rough lemon. It is probably not too much to say that other things being equal, the hardiness of the tops worked on these stocks will stand in the same order.

The gain in many cases may be scarcely appreciable, but in others it is well marked. In colder regions, the distinct superiority of sour (Bigarade) orange over rough lemon is quite noticeable, even on young trees, while Citrus trifoliata imparts its hardiness to the top worked upon it to such an extent as to make a very decided difference in its favor. 
In cold regions where soil conditions are suitable, the hardier stocks should always be given the preference. A slight gain in hardiness, due to the influence of the stock on the cion, may frequently be as effective as a decided gain.

\section{HARDY VARIETIES.}

A decidedly hardy stock we already have. If a variety could be secured, equally as hardy, total immunity from frost would be secured throughout the whole of the citrus regions. The attempt to secure such a variety has been made by Dr. H. J. Webber. Some measure of success has been attained and further results may be expected from this work.

But, while we may look to the final outcome of these investigations and experiments with some degree of hope, we must not lose sight of the fact that for many, many years to come, the citrus growers must depend upon the varieties we now have for the continued prosperity of their industry.

Some varieties of citrus fruits, fortunately, are considerably hardier than others. Satsuma is the hardiest of the mandarin group, and the hardiest known largefruited, edible citrus. Duncan is the hardiest of the pomelos, Tresca being one of the most tender. Duncan is equally hardy with most of the sweet oranges, in fact, there appears to be but little difference between them. The Marumi kumquat is decidedly hardier than Nagami. In the lemon group, but little opportunity has been afforded for observation. Slight differences probably exist. Villafranca is apparently quite hardy. Of the sweet oranges, Jaffa and Ruby are hardier than some others, though a number of others are quite as hardy as they are. 
In severe freezes, slight differences in resistance to cold disappear entirely, but frequently they are distinctly noticeable.

\section{PROTECTING WITH EARTH.}

Banking to Save the Trunks. No method of protecting the trunks of citrus trees from cold is more efficacious than banking. Never yet has a temperature sufficiently low to injure the trunk of a tree through a mound of earth been reached in any of the citrus districts, and implicit confidence can be placed in this method for protecting the parts covered.

The banks should be placed about the trees early in November. In Northern Florida, for instance, severe frost is likely to occur as early as the middle of the month. If the tree trunks have been slightly touched by frost before the banks are placed about them, very unsatisfactory results are obtained. The bark rots during the winter if it has been slightly frosted and the trees are frequently killed outright in consequence, when they might otherwise survive, provided, of course, that the winter is mild. The best plan is to place the banks about the trees sometime about the beginning of the second week in November.

The earth should be heaped well up about the trunk so as to protect as much of it as possible. Young trees should not be totally covered however, but a considerable portion should be left exposed. If they are banked too high, respiration will be prevented and death of the trunk and branches will follow. In budded trees the part most susceptible to the effects of cold is the point of union between stock and cion. This point should be close to the ground and the earth should be well banked about it so as 
to cover and protect it. After the earth has been placed about the trees, it usually settles somewhat or is washed down by the rain. For this reason it is usually best to go over the work three or four weeks afterward and place more earth about the tree.

All grass and weeds should be cleaned away from the trees and nothing but fresh, clean soil should be used in banking. If weeds and grass are placed in contact with

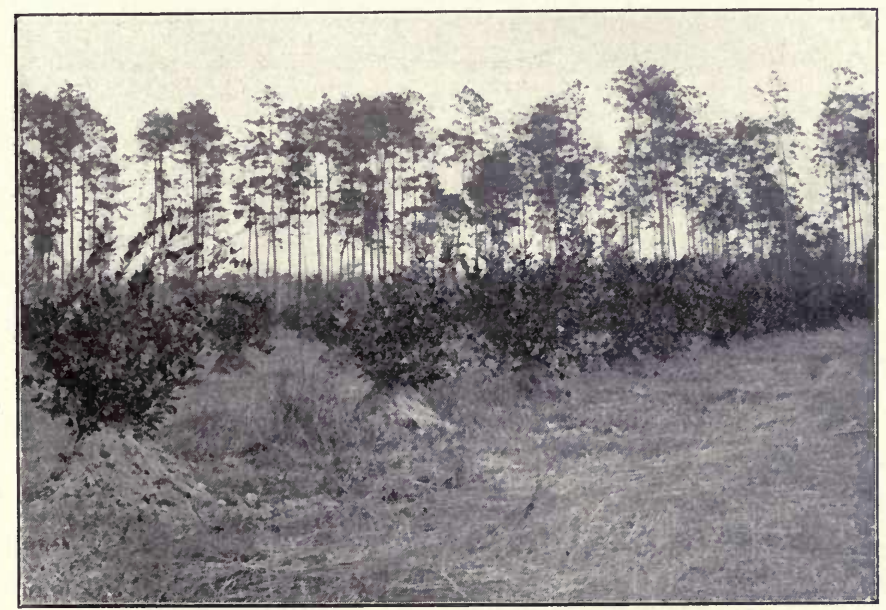

Fig. 78. Citrus trees banked to protect the trunks from frost.

the trunks, wood-lice too frequently cause considerable damage. They commence work first in the decaying vegetation and then transfer their attentions to the trunk. One of the best ways to secure fresh, clean earth, free from organic matter, is to remove the weeds and four or five inches of surface soil from an area of two square feet or so, then dig a hole deep enough to supply sufficient earth for the tree. In spring the earth can be thrown 
back into the hole. If the ground where the trees stand is low hammock, containing a great deal of humus and more or less decayed vegetable matter, it is unsafe to place the soil about the trees. In such cases it may be advisable to haul clean earth with which to bank the trees.

In spring, usually about the end of March, or as soon as danger of damage from cold is past, the banks should be removed from about the trees. By no means should they be left about the trees throughout the summer, as mal-di-goma may attack the trunk above the point of union of stock and cion.

Protecting the Whole Tree With Earth. While this method of protection can be applied only to small trees, still it is of considerable importance, and the following experiments carried out by J. Y. McKinney, * of Candler, Fla., are very interesting. "To test this form of protection, we had about thirty young trees covered entirely over with sand. Ten of these were covered on December 15, and opened up March 21. These died back to within three inches of the bud union. The other twenty were opened at different times with the following results: Those covered four weeks were but little damaged. Those covered six weeks lost all their foliage and were otherwise so devitalized that they were slow in recovering. Some of my neighbors, however, banked as high as six and seven feet and left the banks for from five to seven weeks, aside from losing their leaves, the trees are but little damaged.

From other sources on this point I get varying results, so that in forming judgment on this form of protection, it would be said there is great risk attending it, so much so, indeed, that if we place any financial value

* Fla. State Hort. Report 1900, 29-30. 190. 
on young trees we must exclude this expedient from a plan of orange culture on a sound basis.

The next device, an original one, we shall term the ventilated sand case. We had 150 fine young buds, four to six feet high, placed under this treatment. The trees were first tied up into as small a space as practical by means of No. 18 galvanized wire; a case was then placed close around the tree. Most of these inner cases were of thin boards-some few, even, of paper. A second case was then made about three inches from the first; this outer case was made of small boards placed laterally between troughlike corner pieces. The space between the two cases was packed with sand. At the bottom a ventilating box ex. tended from the outside into the tree. This vent and the top were closed and covered with sand during the coldwave period only. The labor of putting up this device and attending to it during the winter and clearing it away in the spring cost us 20 cents per tree. The lumber used was odds and ends from our mill and did not figure in the expense.

The trees were placed in these cases during the week of December 15, and so remained until the week of March 21, with the following results: A number came out without loss of leaves and in excellent condition. Others were defoliated on the lower branches, the top branches retaining their leaves. Some were entirely defoliated, but the wood was in good condition and quickly put on leaves when the cases were removed. On the whole, this plan may be regarded as a safe one, and if the vents are large enough there will be no serious risk attending it from either suffocation or cold. Its practical use, however, is limited to small trees." 


\section{FIRES.}

The protection of citrus trees by means of open fires has been successfully accomplished both in Florida and California. The materials most commonly used are coal and oil in California, and wood in Florida.

Wood Fires. In Florida, the wood is probably the cheapest material at the present time. Wood is abundant, easily and cheaply secured, and in consequence will be most commonly used for some time to come. The protection of an acre (80-100) of orange trees with wood fires in Florida, has been variously estimated at from ten to fifteen dollars per acre per year. The total cost in any given winter will, of course, depend upon the number of times the fires have to be lighted. Six or seven is about the usual number.

There is considerable difference in the kind of wood used by different growers. In size it varies all the way from eighteen-inch stove wood to logs six or eight feet long and a foot or a foot and a half in diameter. Some have kept the stumps and roots, which are usually burned in clearing the land, for use in firing. In the more exposed regions, as in North Florida, for instance, large wood should be given the preference; while farther south. smaller fires, one for each tree may answer as well. All things considered, however, cordwood is probably the most convenient.

Plenty of wood should be provided for immediate use and an ample reserve supply should be close at hand. When large fires are used, they should be placed close together around the grove. Freezes are usually accompanied by high winds. The practice in Florida has often been to make ample provision for protection on the north 
and west sides, but it has often been noted that before the cold passes over the wind blows from every point of the compass. For this reason wood should be scattered, and provision made for firing all around the grove.

Throughout the grove, one large fire in every square of four trees will usually be sufficient. Sufficient wood must be provided to keep the fire going for seven or eight

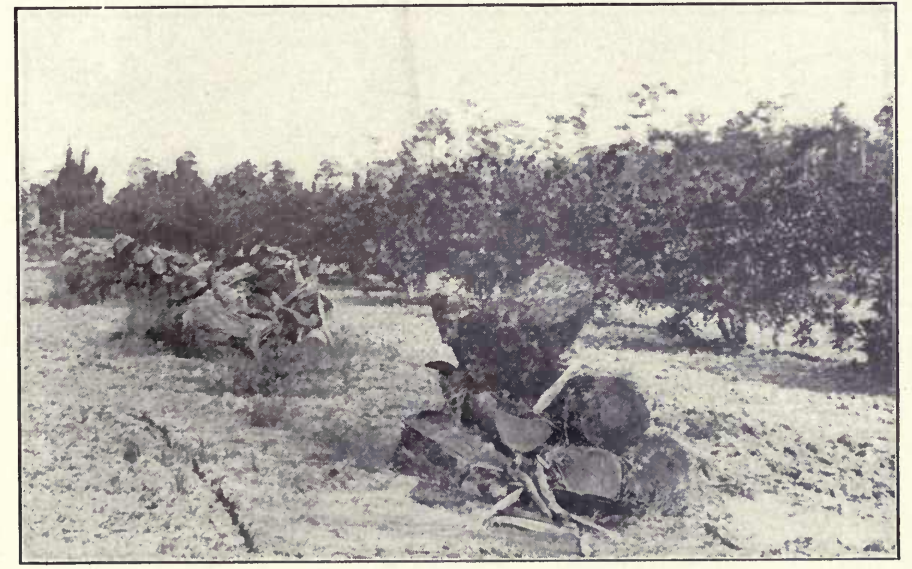

Fig. 79. Wood in place, ready for firing. - North Florida. The piles are torn down and used gradually. Note the large size of the wood. See also plate XVIII.

hours at least. In less exposed regions, one small fire should be provided for each tree.

The temperature at which the fires must be started depends upon the condition of the trees, and the rapidity with which the temperature is falling. Ordinarily, the mercury should not be allowed to drop much below 25 or 26 degrees $\mathrm{F}$., though much will depend upon how rapidly the temperature is going down. 
Everything should be in readiness for building the fires. Sufficient kindling should be distributed. Nothing is better for starting the fires than the waste (chips covered with rosin), obtained from the turpentine stills, but in addition kerosene or crude petroleum should be provided. Rain frequently accompanies the cold, in which case it is difficult to get the fires started.

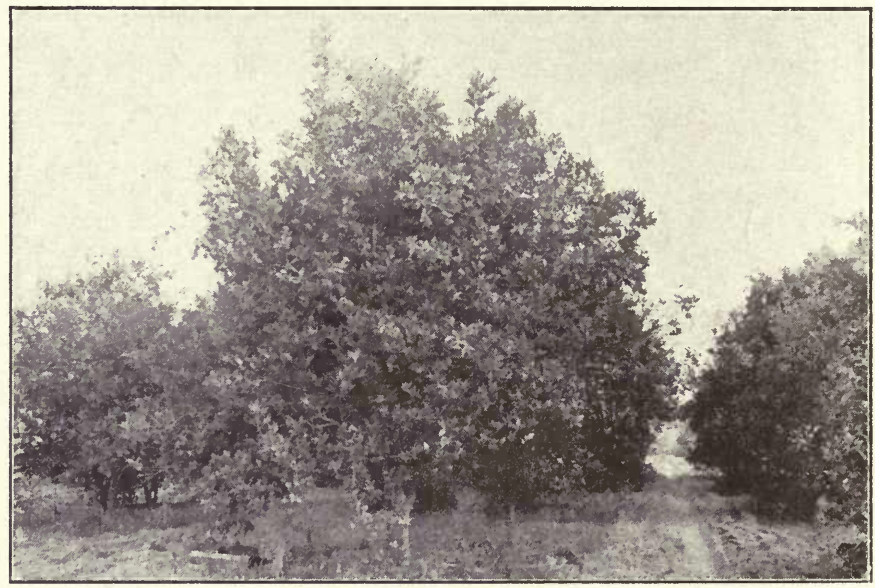

Fig. 80. Orange trees on the Kinney place at Pierson, Fla., planted in 1888 and successfully protected in ' $94-' 95$ and '99 with wood fires.

Have the wood piled together, have one man to throw on a gill or so of kerosene, let another follow to start the fires, followed by a third to see that they burn well, and others to provide wood and keep the fires replenished. Everything must be done systematically and without delay.

A good torch or a number of them should be provided for lighting the fires. Mr. W. S. Hart has an excellent one which he uses for the purpose. It consists of a 
long, hollow, brass cylinder, fitted with a piece of round wick at the end. The cylinder is filled with kerosene.

In Florida the temperature in the fired area of grove has been raised as much as twelve degrees above that of the surrounding area. Fig. 80 shows sweet orange trees at Pierson, Fla., planted in 1888, and never touched by frost. They were protected by open fires, while adjoining groves not so protected were killed to the ground in $\mathbf{1 8 9 5}$, and again in 1899. This shows what may be done. It was probably in this grove that open wood fires were first used in Florida for the protection of citrus trees.

Coal and Oil. As noted above, these two materials have been used to a greater extent in California than in Florida, though they have been used in the latter State as well.

The comparative costs of the two materials given, as the results of experiments in California * are as follows:

Wire coal baskets, each .....71-2 to 8 cents.

Ten pounds coal ( 4 hours) ... . . . 5 cents.

Total cost. . . . . . . . . . . . .13 cents. Oil pots $(3$ gals. $) \ldots \ldots \ldots \ldots$... . 25 to 30 cents. Two gallons Oil.. . . . . . . . . . 6 cents.

Wicks (if used) . . . . . . . . . . . . $\ldots 3$ cents.

Total cost............... . . . 34 to 39 cents.

The cost is in favor of the baskets, while the oil was more readily ignited, but opinions differ as to the amount of heat given off.

The difficulty of readily igniting the coal might be obviated in some such way as that adopted by Mr. James 
(1) of the Uplands Lemon Exchange, Cal. His method is as follows: "Cover bottom of basket with dry eucalyptus or palm leaves, cut into four-inch lengths; make a mixture of melted rosin, not above 85 degrees temperature, and kerosene, mixed to consistency of molassesthree quarters kerosene, one quarter rosin; sprinkle over leaves. Dip a few short kindlings into this and place in basket, followed by untreated kindling, then fill with coal, small lumps at bottom, coarse above, "cone" up on the top. For protection against rain, cover with at least four thicknesses of newspaper." In Florida, the waste from the turpentine stills might be secured for kindling or "fat" pine might be provided.

The experience of Mr. C. C. Teague, (2) of Limoniera, Cal., in fighting frost with coal baskets is well worth reproducing here:

"We found that the self-registering thermometers which we had were utterly unreliable as a guide, and that if we had been governed by them and had followed the advice of all our authorities on frost protection, we would have burned up coal early in the night when it was not necessary, and our grove would have been frozen in the earlier, colder hours of the morning. When our thermometer registered cold so early in the evening, we were in a quandary as to what to do. We feared if we refrained from lighting too long we would be injured, and on the other hand if we lighted early our coal would not last. While worrying over this, the thought occurred to us to put out shallow pans with about an inch of water in them. reasoning that the latent heat in the trees and fruit would

1. I. C. 264 . 
keep the juice in the fruit from congealing and therefore without injury until the water in the pan began freezing over. Developments proved that we were right, as I shall attempt to demonstrate to you. Our experience on both our coldest nights, the 11th and 12 th, was almost identical, and I have selected the 12 th, which was the colder, and the following is the record of our thermometers on that night:

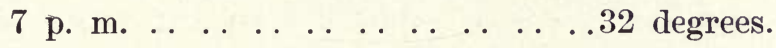

8 p. m. ................28 degrees.

9 p. m. ...............26 degrees.

10 p. m. .. . . . . . . . . . . . . . 24 degrees.

11 p. m. ..................22 degrees.

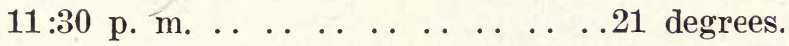

"At this time the water in the pans began freezing over and we began lighting our baskets. Our men were divided into squads, and each squad being in charge of a competent man. Our reason for this was that it would not be economical to have a large crew of men working together, as they would be obliged to do a great deal of unnecessary walking. In other words, a crew of forty men lighting on forty rows would oblige the man on the first row to walk across the end of forty rows to reach the forty-first, or his next row. On the night in question we had forty men lighting, and it took from one and a half to two hours to light 2500 , or one-half the baskets. At 12 o'clock, midnight, before the baskets were well under way, and giving off a good heat, the thermometer registered 20 degrees; at 1:00 o'clock 22 degrees; at 1:30 22 degrees. (At this time we began lighting the other 
half of our baskets) ; $2: 00$ o'clock 22 degrees; $3: 00$ o'clock 24 degrees; $4: 00$ o'clock 26 degrees; and the thermometer did not register 26 degrees after this time.

"Please note that the thermometer registered below 28 degrees for three and one-half hours before the pan of water was frozen over, and for four hours after the temperature was affected by our fires. Also that the drop in temperature up to the lighting had been about 2 degrees per hour, which was checked and forced up, until, when all our fires were going, it reached 26 degrees, and did not again get below this, notwithstanding the fact that the temperature usually continues falling until sunrise unless a breeze springs up, which in this case did not occur. Notwithstanding this, however, our thermom eters registered below 28 degrees for ten hours without injury to our trees and lemons. I cannot account for this, except that possibly after we lighted our fires, the heat and smoke rising from them and hanging over the grove acted as a sort of blanket, preventing the cold air from settling. Our thermometers are hung on posts about three feet from the ground, and it has been suggested to me as an explanation of the low temperature shown by the thermometers resulting in no injury, that the heat radiating from the baskets would radiate in streaks, and that the whole body of cold air would not necessarily become heated, and the thermometers being protected by the post and boxing, would not be sensitive to the heat radiation, and would therefore read colder than the heat was in reality. I have since regretted that I did not take the temperature ten and twelve feet from the ground.

"In a few of the coldest spots in our grove, there is a slight singeing of the tenderest leaves, but nothing of any consequence. The portion of the grove where this singeing 
is most in evidence is a small portion where $I$ have before mentioned, and which had only one coal basket to five trees.

"In conclusion, I will say that after two years' careful experience with coal baskets, I am more than ever convinced that by careful, intelligent handling, we can save our groves and fruit during our most severe freezes. We concluded with 37 baskets to the acre, we were running too close to the danger line, and have since doubled our supply, and I would recommend that 75 to the acre be used in groves that are subject to frost visitation. It is not probable that it will be necessary to light all only in

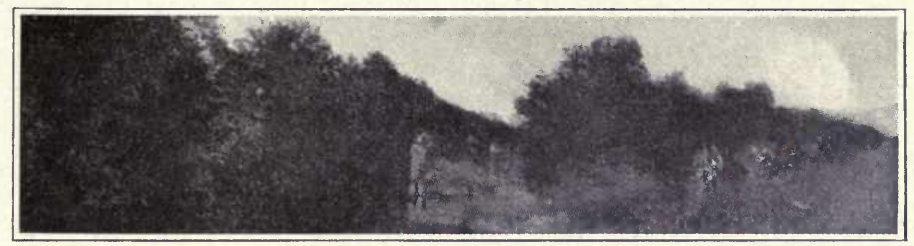

Fig. 81. Firing a California grove, using crude petroleum in Froude's oil pots.

extreme cases, but the extra insurance is well worth the outlay. It is also certain that a small operator would not get nearly as good results and should therefore have more baskets to the acre.

"My last word is, do not forget the importance of knowing when to begin lighting. And if you will remember the pan of water it will save your nerves."

The best, as well as the most commonly used receptacle for firing with crude petroleum, is the Froude crude petroleum pot. This has given good satisfaction in many instances in California. Fig. 81 illustrates this pot in use in protecting a citrus grove in California. 


\section{WALLS AND FIRES.}

Great difficulty may be encountered in protecting citrus trees by means of open fires, because it so frequently happens that freezes are accompanied by high winds, rain and sleet. The wind is often so strong as to extinguish the fires and even though this is not done, the heat is blown away. It has been noted that while the temperature was sufficiently high on the side of the tree nearest the fire, on the opposite side the thermometer registered several degrees below freezing.

To overcome this undersirable condition of things, triangular or circular walls have been used in many cases with excellent results. Sometimes these are movable, at other times they are built stationary on the north and west sides of the trees. The wind frequently shifts its direction, making the movable ones somewhat more desirable. A fire can be placed on the opposite side from the triangle with very effective results. Wood, oil or coal may be used.

Wind-breaks and Water Protection. These have been fully discussed in a former chapter, to which the reader is referred. In many respects, the wind-break: either artificial or natural, may serve the same purpose as a wall on the northwest sides of the trees. The windbreak stops the force of the driving wind and prevents the dissemination of the heat. In many cases, growers, in Florida, finding that their sheds were not entirely satisfactory, have removed the covering, leaving the walls still standing. These have acted as very efficient checks to the wind.

Protection by irrigation or by applying water to the ground and trees as a spray may, in certain cases, be 
used to advantage. If the water has a constant temperature of 60 to 70 degrees $\mathrm{F}$., much can be accomplished, provided sufficient of it is available, and can be readily applied.

The ameliorating influence of adjoining bodies of water should not be overlooked, and, whenever possible, the grove should be so located as to receive the beneficial influence of the heat given off slowly by a body of water. The water becomes heated during the day. It parts with its heat more slowly than the land, during the night, and its influence is considerable.

\section{TENT PROTECTION.}

Protection of citrus trees by means of tents has been quite successful.

Various kinds of tents and structures working on the same principle have been tried from time to time. Trees have been boxed, or covered over with boards or veneer, but more usually cloth of some kind has been used.

The two styles of tents which have been most commonly used in Florida are shown in Plate XXII, Figs. A and-B. The first known as MacFarland's tent, consists of three posts, supporting a cypress hoop surrounding the tree. The tent itself is shown at the left, drawn together about the derrick-like frame. It is strengthened from top to bottom by means of slats which project below the bot. tom of the cloth and are shoved into the ground to keep the tent more securely in place. On the approach of cold weather, the tent is drawn around the framework, closed up and the supporting slats shoved into the ground.

Mr. E. O. Painter, of the E. O. Painter Fertilizer Company, Jacksonville, Fla., was the originator of the second style of tent. It consists of four posts set in the 
Plate $X X I I$.

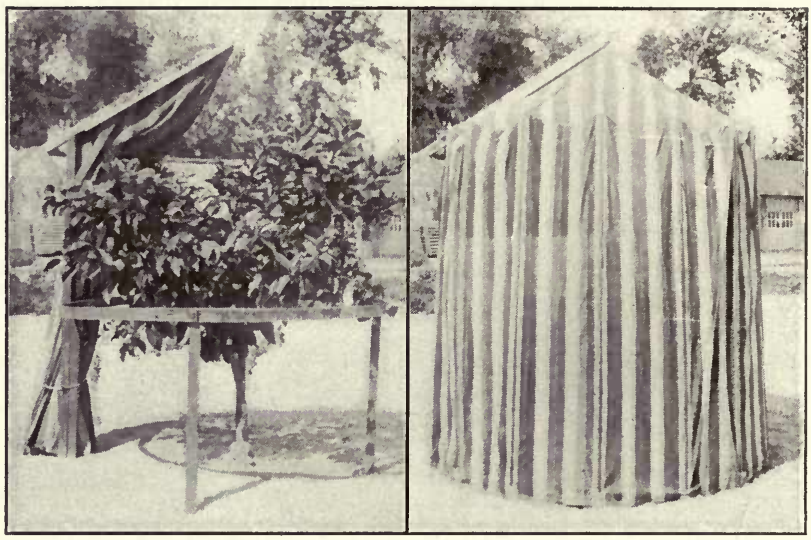

Fig. A. Protection by Tents. MacFarland's Tent, open and closed

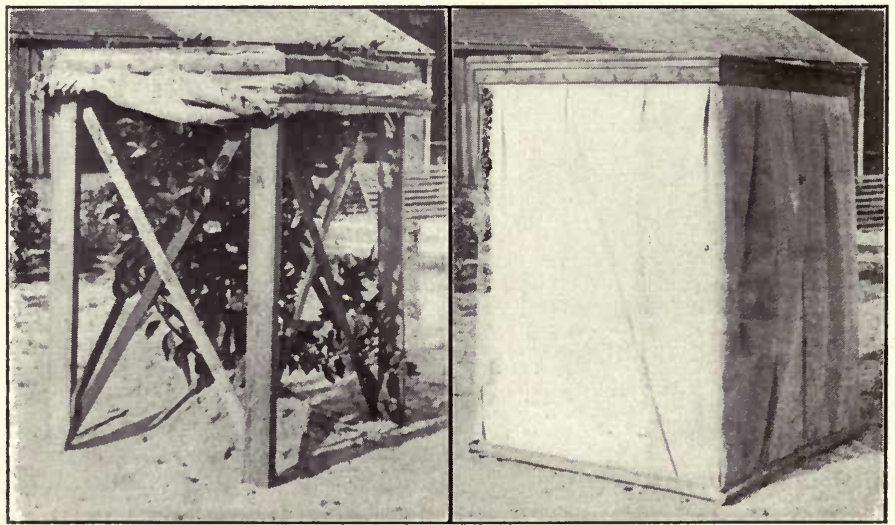

Fig. B. Protection by Tents. Painter's Tent, open and closed. 
ground, at the corners of a rectangle, enclosing the tree. Around these posts good, stout cloth is stretched and attached to a frame at the bottom. The top of the structure is covered, as illustrated on the right, with a frame covered with the same cloth. This cover is removed and the cloth sides lifted up in opening the tent.

Tents afford an excellent method for protecting a few trees. Citrus trees might be grown as ornamental trees in gardens about the home, far outside the regions where they are cultivated commercially, if tents are used to protect them. The objection to their use in commercial groves, however, is that they are too costly, and have to be enlarged too frequently. For protecting young trees, they have many desirable features, and are probably sufficiently economical.

Tents alone will not protect the trees. In fact, it may be colder inside the tent than outside. The tent must be warmed up, for which purpose some sort of kerosene lamp is usually most serviceable. An ordinary lantern may be used or a lamp made from a can with a burner attached may suffice.

\section{SHEDS.}

Both in Florida and California, sheds have been erected to protect citrus trees from cold. In some cases these have proved quite satisfactory, in others they have not. If properly managed, there is no reason why the shed should not prove satisfactory. Provision must be made for allowing the entrance of plenty of light and air, a shed which may be opened or closed in a short time is the ideal. The shed should be left open as much as pos: sible, closing it only on the approach of severe cold. The methods of cultivation and fertilizing must be changed. 
Moisture is present in the soil in greater abundance under the shed than outside. Die-back may result from the same methods of cultivation as might be used with perfectly satisfactory results outside. Less cultivation should be given shedded groves and chemical fertilizers only should be used.

All things considered, a shed constructed after the model of Mr. Stevens, manager of the J. B. Stetson groves, at DeLand, Fla., is probably the most satisfactory. A shed of this pattern, erected by G. L. Taber, of Glen St. Mary, Fla., for the purpose of protecting healed in nursery stock, is illustrated in Plate XXIII. The posts are four by four, the framework is made of inch boards, built together like angle iron. An ample supply of braces is provided and the structure is very substantial. The cover and walls are made in panels. These are made of one-half-inch boards, four feet long, nailed between three one-inch strips which run lengthwise of the panel. The panels may be made of any desired lengths, sixteen feet being found quite desirable. They must, however, be of such a length as to lap on the cross beams of the roof. When it is desired to open up the shed, the panels of the roof are piled on top of one another on the framework. If so desired, the side-walls and all the covering may be removed, leaving nothing but the framework.

It must be borne in mind that, as in the case of tents, the shed alone will not protect the trees. Fires must be provided with which to elevate the temperature; either wood, coal or oil may be used. 


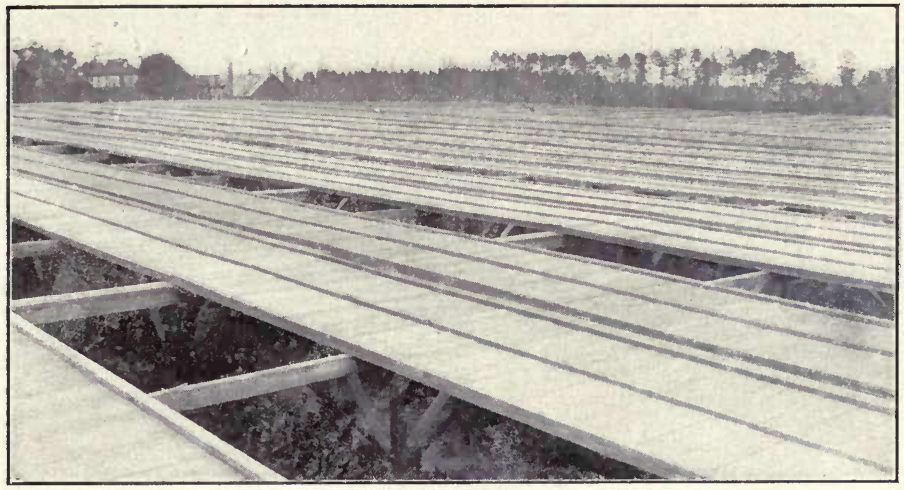

Fig. A. Cover of Shed.

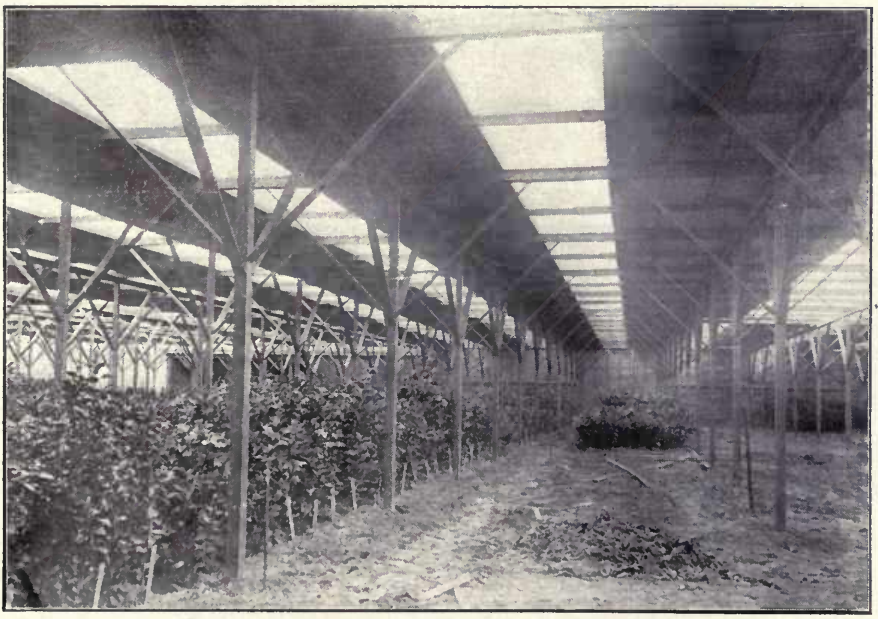

Fig. B. Interior view, showing construction. Shed erected by G. L. 'Taber, Glen Saint Mary Fla. 
FLORIDA SHEDS.

In the Florida State Horticultural Report for 1903, an excellent report on. the condition of the shedded groves in Florida is given by Mr. E. O. Painter. The descriptions of the protection of the Mead grove at Oviedo, Fla., the Swift grove at Pomona, Fla., the Haw Creek grove at Crescent City, Fla., the Wetumpka grove at Hastings, Fla., and the Barney shed (J. A. Stevens) at Citra, Fla., are reproduced here.

\section{THE MEAD GROVE AT OVIEDO.}

The cloth is twelve feet above the ground, and has now been made movable by ropes and pulleys, so as to let in the sunlight whenever it is not too cold.

The trees are planted $5 \times 20$, the intention being that each row shall be practically one tree 250 feet long. Have used 10,000 pounds of fertilizer on one acre in the past two years, using one pound per munth to each tree till signs of die-back appeared. Have put on no fertilizer since last June. Prior to that, had used only Simon Pure Die-back for some months, and the trees have mostly recovered. I have had some good fruit, mostly grapefruit, each year, including the first year the trees were planted. The trees are 250 tangierines, 125 grapefruit, 84 Ruby Blood orange, making 495 trees to the acre.

The shed is irrigated and warmed by sulphur water from a deep six-inch well, and supplied by a powerful steam pump. Hydrants, forty feet apart each way, each with a spray-nozzle covering a circle forty feet in diameter, nearly cover the ground, like rain, and in cold nights keep the shed as warm as can be desired, the temperature of the water being always at seventy degrees. 
When the thermometer outside stood at eighteen degrees for several hours, the temperature inside ranged from forty-eight to fifty degrees, with a dense vaporous fog that acted like a blanket. When the cloth is open the spray keeps off frost only where it actually falls. The capacity of my pump is 300 gallons per minute, which is enough to keep frost out of a good many acres, if covered in. In summer the cloth is taken off and stored away. It is absolutely necessary to have it movable in winter, otherwise the fruit is watery and tasteless, and the trees fail to bloom properly in the spring. The sides are of $1 \times 8$ lumber put on clapboardwise. The cost of the structure itself, including cloth and labor, was $\$ 1,200$ and it covers $11-10$ acres.-Theo. L. Mead.

\section{THE SWIFT GROVE AT POMONA.}

So far the shed has proved to be a success. A shed will easily pay for itself in a comparatively short time on the poorest pine land. The shedded grove has many advantages that the open grove does not have. The wind cannot get in to blow off the fruit or twist the trees around so as to thorn it. Last spring and summer, during the great drouth, the trees in the shed did not suffer at all-not one of the healthy trees even wilted, and none of the fruit either dropped off or was stunted. Down three or four inches the ground was quite moist, while outside you could hardly strike moisture at six inches. I attribute this to the partial shade which the shed afforded. Of course, I cultivated twice a month regularly.

I find that the insects are about the sanie inside the shed as they are in the open grove.

The trees are easily kept from freezing by means of a few fires which are easily attended to. Night labor 
costs but 25 cents per hour, and one man can keep from twenty to forty fires going. When the shed is closed the temperature is from four to ten degrees higher without any fires than it is outside. In the winter when the trees are dormant, I build fires between twenty-eight and twenty-nine degrees, but in the early spring, when the trees begin to grow, I "fire" up at thirty-two degrees. My shed covers about two and one-half acres, and during a freeze when the temperature outside fell to 17 1-2 degrees, I kept the temperature between 31 and 34 degrees without any trouble and had only ten fires, burning not more than one-quarter of a cord of wood in nine hours and a half.

Some people think that trees will not bear under a shed, but it is a mistake. My trees bore well in the spring of 1902, and I fertilized them last fall for fruit, and this spring they are bearing as heavily as they can. My trees look fine and are free from disease. The shed is a woodtop one, and opens and shuts by means of doors thirtytwo inches by seven feet, which are fastened to stationary walk-ways twenty-eight inches wide. Two rows of doors are fastened to one walk-way and constitute little more than two-thirds of the top. The doors are fastened by means of wire loops hooked over nails, and can be readily taken down. Part of the sides of my shed are made of veneer panels four feet wide and part of one-inch boards. The panels and boards are set in racks so they can be readily taken down and put up without nails. In my opinion, the panels are far superior to the boards, as they make a tighter wall and are much easier and quicker handled. The cost of taking down the sides and doors and putting them up again is about $\$ 40$ per year. $-F$. Swift. 
THE HAW CREEK GROVE AT CRESCENT CITY.

The covered shed of this company was constructed during the fall of 1901, but was not finished on account of the wet weather, in time to entirely protect the young trees from the severe cold of December of that year. On about half of the grove the framework was up and material scattered about, and this slight protection sufficed to preserve the trees from the injurious effects of the cold, while the other or east half being without any protection whatever, was cut by the frost so as to be set back about a year behind the west half. The trees were young buds set out in the summer and fall of 1900, all tangerines. The present structure covers a little less than ten acres, about 650 feet square. It is surrounded by a wall sixteen feet high, with posts supporting the overhead structure placed 121-2x17 feet apart. The overhead covering is cotton cloth, Osnaburg, treated after a process of our own to preserve it from mildew. We use sheetiron stoves in which we burn coke to raise the temperature in severe cold, about 125 to the ten acres, but think we should use more. Each strip of canvas is pulled by itself one-half across the grove. We design, however, to pull two strips all across the grove at one pull. At present, one pull of twelve and one-half feet covers a space of seventeen feet wide by 325 feet long, and it takes about two and a half hours to cover the whole grove. The condition of the trees under the shed, so far as our experience goes, is perfectly normal and healthy. The trees untouched by the cold have made an astonishing growth and give fine promise for fruit. Last fall's crop was forty boxes. This year we anticipate a crop of 400 to 500 boxes, mostly from the west half. Of course, it is too early to estimate profits from the venture, but we be- 
lieve we can grow and protect the fruit successfully if the market will continue favorable. We have an additional ten acres which we expect to cover in a year or two, as soon as the trees are a little larger, protecting them in the meantime with fires and banking.--Thos. $H$. Stryker.

THE WETUMPKA GROVE AT HASTINGS.

You ask in regard to cost of shed. As you know, we have the Rollins patent, board wall and cloth top. It has cost us more than I think it can be done for again, from the fact we were inexperienced to start with, and ruined one set of cloth by running it through paraffine wax. It seemed to take the life out of the cloth. It has cost about $\$ 1,200$ per acre, besides the cloth that was ruined. Our trees when we put the shed up were $20 \times 25$ feet apart, but a year ago this spring we doubled the number, making about 160 trees to the acre. The last trees set are of the Tardiff variety, and have made a very satisfactory growth. Many of them have twenty-five or fifty fruits on them now. Last year our trees bore very shy, and I laid it to the treatment, viz: no fertilizer, for fear of bringing on die-back. Some of the trees were showing symptoms of it, but last fall they were healthy; so I put on the following mixture, five pounds per tree: seven hundred pounds boneblack and 400 pounds H. G. sulphate potash on half an acre. On the balance of the shed, three and a half acres, I used your Special Simon Pure. The grove to-day is in perfect health and has set fruit plentiful. ly. I am satisfied the trees can be kept healthy and free from scale and see no reason why. they will not bear as heavy crops as they used to outside of protection. 
We have the shed arranged now so that we can cover one acre at a time, and can do it in seven or eight minutes. It is the most satisfactory cover I have seen.-G. $W$. Leonard.

\section{COVERED GROVE AT CITRA.}

The Barney shed, covering three acres, was originally built on the same plan as the Clifford shed, but because of the difficulties of operating that style of cover, as enumerated in my letter describing the Clifford shed, this has been made over. The framework of this shed divides the area covered into squares of twelve and a half feet each, and where two swinging shutters of $6 \times 12$ feet each originally filled the square, these two swinging shutters have been made over into three panels of $4 \times 12$ feet each. One of these panels is put down stationary, and four rafters are put up over it, two at each end, to support the other two panels, which, when open, are raised up and leaned against the rafters toward each other and form a roof over the lower or stationary panel.

When the cover is open in this way two-thirds of the cover is open, one-third is always closed. When closed the two side panels are turned down until they lie flat on the framework and the whole top of the shed is closed snug.

This plan gives the trees both sunshine and shade. The openings in the cover, when open, run east and west. The sun in passing over throws sunshine and also casts a shadow upon the trees below in its day's journey. The trees in this shed are doing well and now have a nice crop of young oranges on them. I could give you numerous experience we have had with our sheds, but I understand 
that you are principally interested in the construction of the sheds.

As to the cost of this shed, it would be pretty hard to come at it, as we had to make it over from another style. But I should say that a shed on this plan could be built for $\$ 800$ per acre.

Trees in this shed are twelve and a half feet apart each way. There are 735 of them; varieties, Pineapple orange, Triumph pomelo and Dancy Tangierine.

Cost of firing is the same per acre as in the Clifford shed. (Four acres $\$ 14$ per night with wood, $\$ 9$ with coke.)

This shed is opened and closed by two men walking on top, taking hold of each end of a panel and raising or lowering it as the case may be. It cannot be operated quite as rapidly as the Clifford shutter-shed. It takes two men half a day to go over the whole shed. But in the winter we do not open it all at once, except on bright, warm days. Every night in winter we have at least half of the cover down, so as to be able to close the rest quickly if it should be necessary.-J. A. Stevens.

The protection of citrus trees by the Everest Rancho Incorporation in California is thus described by B. M. Lelong.*

ROOFING PROTECTION AGAINST FROSTS, AND HEAT IN SUMMER.

"After having tried several other methods of protecting trees from frost, none of which proved absolutely safe, the Everest Rancho Incorporation at Arlington Place, Riverside County, decided to roof over a portion of their orange grove. Such were the results of the first trial on three

- Cinlture of the Citrus in California, 158-160. 1902. 
acres that the company extended it over seventeen acres. *********** The proposition embraced in the covering is to prevent the warm air from leaving the immediate vicinity of the trees at night. During the day the earth and trees become warm, but as night cools the atmosphere, the process of radiation sets in, and the heat from the earth and the trees is carried off, the cold, frosty atmosphere taking its place. The idea was conceived of covering the orchard with canvas, which could be rolled up in the morning and let out at night. One acre was covered in this way, but it was found to be too expensive and unstable, as the canvas would get wet and decay. The present method costs about $\$ 450$ an acre. The fruit borne by the trees under this covering has matured perfectly and the covering serves two purposes, $i$. e., protecting the trees from the effects of frost, and from excessive heat in the summer.

The posts are $3 \times 4$ redwood, 18 feet long. The trees are so planted that the posts are placed 21 feet 3 inches apart each way, setting them 3 feet in the ground, thus allowing about 15 feet in the clear for height of the trees, which is sufficient for most Navel trees. These posts are connected by pieces of $1 \times 4$ pine suitably braced, on top of which another strip of $1 \times 4$ has been securely nailed to prevent the whole from swaying sideways with the weight of the cover. This, when placed in position, is braced horizontally with braces of $1 \times 3$ pine, 7 feet long. Thus is secured a framework that is quite rigid and on which a man may walk freely, provided he has a head clear enough to walk on a four-inch strip.

Over this were stretched galvanized-iron wires, diagonally, of No. 11 wire, which are securely stapled on top of each post and to the horizontal braces. These diag- 
onal wires are stretched very tight with iron stretchers, and throw a portion of the weight of the cover on to posts directly that would otherwise be borne by the pieces of $1 \times 4$ pine, 21 feet 3 inches long. These diagonal wires are supplemented by wires running across the framework at right angles to the direction in which the cover is laid. These four wires-two diagonal and two cross wiressteady the whole construction and distribute the weight more evenly.

Thus is the framework completed. For the cover Arizona lath were used, being the lightest and best for the purpose, and were woven on a lath machine into common chicken-fencing, placing the lath one inch apart and weaving with six wires - three double strands. This is made in sections 21 feet 3 inches long and rolled up preparatory to being taken to cover. In covering the framework four rolls made of four-foot lath and one roll of five-foot lath are used, thus filling out the space over each tree of 21 feet 3 inches as nearly as is necessary. It takes 100 lath to each roll, or 500 to each tree; and as the trees are planted 100 to the acre, 50,000 lath are required to the acre. This Arizona lath is cheaper than ordinary pine in that part of the State.

The crop of fruit under this covering was of good size, color, and quality, and while the construction of the cover could be, and no doubt will be, improved upon, it has proved of great benefit as built." 


\section{CHAPTER XXXVII. \\ PRUNING CITRUS TREES.}

As a whole, no group of fruit trees require less pruning than citrus trees, after they are once set out and established in the grove. Most of the pruning is, in many cases, given at the time of planting, and with the exception of the lemon systematic pruning, such as is given peaches, is not practiced. Excellent specimens of citrus trees, to which the pruning shears are entirely unknown, may be found throughout the citrus districts. But while this is the case, pruning must generally be done to some extent at some period in the life of the tree.

High vs. Low-headed Trees. Some years ago it was invariably the rule to grow high-headed trees, trees with from four to six feet of bare trunk. Now the tendency is the other way, viz.: in favor of low-headed trees, with branches sweeping the

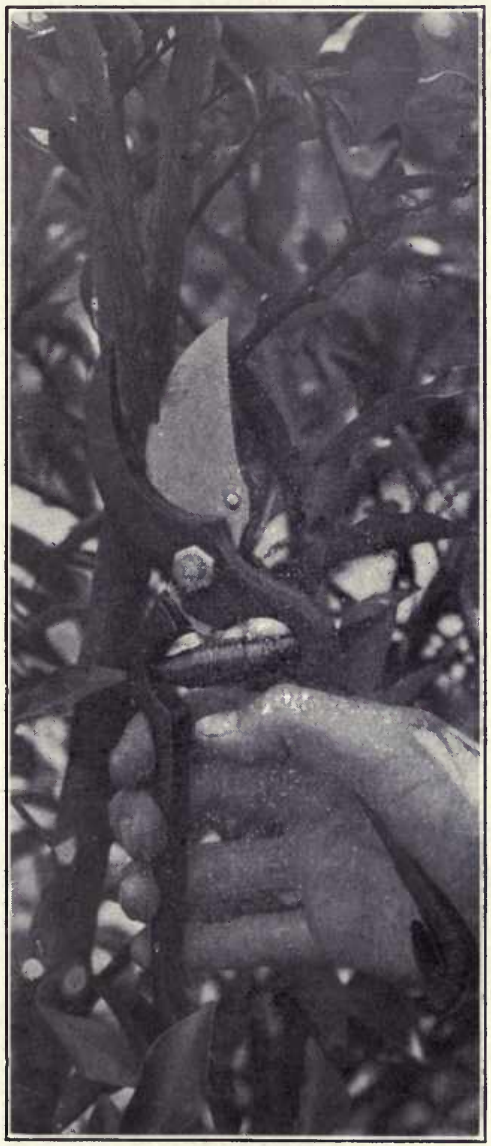
ground, as illustrated $d_{\text {agganst the }}^{\text {in }}$ Fig. 82 . The correct way to hold the shears 
in Figs. 17 and 22. Experience has proved that the latter style of tree is much preferable. The trunk is protected from the rays of the sun and from the effects of cold by the branches and dense foliage. Few realize the amount of protection afforded the trunk and large branches by the mass of leaves. The fruit is more easily and economically removed from low-headed trees than from high-headed ones. Low-headed trees are not so liable to injury during wind storms. Air does not circulate through a grove of low-headed trees so readily as through plantings of high. headed ones, consequently protection by open fires can be carried on to better advantage. Low-headed trees shade the ground beneath them and prevent the rapid evaporation of moisture. The low, hanging branches serve all the purposes of a mulch. On soils, however, which are inclined to bake and become hard, it may be necessary to have the lower branches sufficiently elevated above the ground to permit of cultivation, but generally this is unnecessary. The expense of spraying is lessened considerably by heading the trees low. To secure low-headed trees, they should be cut back severely at the time of planting. Not more than eighteen or twenty-four inches of trunk should be left. The branches which form the strong framework of the tree should be allowed to de. velop from three to four buds at the top.

Old, high-headed trees may often be improved by building the head downward. Frequently suckers spring from the large branches and shove their way up through the top of the tree. Many growers remove these as soon as they appear. This is not good policy. They should be allowed to remain, for after rising above the surrounding top, they branch and bear fruit. Unless they are needed to fill out a space in the top, or if they crowd or interfere 
with branches already developed, they may be carefully drawn down out of the tree, below the lowest branches and bent out to one side, there to grow into large, strong branches, thus bringing the head of the tree closer to the ground.

Pruning for Insect Treatment. If citrus trees are to be sprayed, it is often essential to thin out some of the interior branches, that the spray may be thoroughly and easily applied. The pruning must not be too vigorous, however, and no more of the center branches should be sacrificed than is absolutely necessary. Heavy pruning is too frequently followed by a vigorous growth of watersprouts, and unless these are promptly checked, the interior of the head will become as dense as before. Upon no condition should so many of the branches be removed as to allow the rays of the sun to penetrate and strike the branches. It is essential that the trunk and larger branches be protected by a mass of leafy twigs. Dead, dry branches, the result of the strong rays of the sun, clearly show the necessity of this. Citrus trees, as a whole, are not like deciduous trees. The latter should be pruned so as to admit the strong sunlight to all parts of the head; but not so with citrus trees. A head, the shape of a hollow cone, may be developed, but the outer band or zone of foliage must be sufficiently dense to exclude the strong, and to the branches, injurious rays of the sun.

Pruning in Relation to Die-back. In Florida it has frequently been observed that die-back follows the freezing back of the tops of citrus trees. The roots, as a rule, remain uninjured, and large amounts of materials in solution are collected. The enzyme producing die-back enters the trunk in large quantities, and the disease becomes manifest. Exactly the same condition may result 
from severe pruning of the tops. For this reason so much care must be exercised that the advice is so often given: "Keep the pruning shears away from the trees and let them develop as they will"-advice which it is best for the Florida grower to follow as a general rule.

When trees are affected with die-back, much may be done toward effecting a cure on most soils, by root-pruning. The amount of pruning required will depend upon the severity of the attack, the size of the tree and the character of the soil. Pruning may be done by cutting a circle around the tree with a sharp spade, thrusting it well into the soil so as to sever a large number of roots. The balance of the tree is restored by this method, and a complete recovery frequently follows the practice. It should be borne in mind, however, that in addition to this treatment, the cause of the disorder in the tree, should be sought for and the conditions favoring the development of die-back removed as far as possible.

Pruning Frowen Trees. In treating trees which have been severely injured by cold, three courses are open: first, to leave them alone; second, to cut them back to the ground; third, to cut them back part way.

The first mentioned method is open to the objection that after the tree sprouts, (and the roots of a citrus tree, in the citrus districts, are seldom, if ever, entirely killed by frost) the old, dead trunk and branches must necessarily be removed sooner or later, and much of the new growth must be sacrificed in the final pruning of the old top. In addition the shade cast by the dead branches may cause a weak, sappy growth of sprouts. For these reasons it is best that some pruning be done. If, however, the trees are but slightly injured, no pruning need be 
done immediately, but the injured twigs and branches may be broken out after they become dry.

In cases where the trees have been severely injured, so as to leave but little of the trunk, it is best to cut it off at the ground. Grafts may be inserted or sprouts allowed to develop, to be budded when they have attained sufficient size. But on the other hand, if a considerable portion of the trunk still remains uninjured, the upper portion only should be cut away. Just below the line of division between the sound and the frozen wood, is the best place to cut, but unfortunately it cannot be definitely located; hence, each must use his own judgment in decid. ing where to cut. The best plan is probably to wait until sprouts start and then cut back below the top ones to where they are healthy, strong and vigorous. The usual tendency is to leave too much old wood; the heart wood rots away, leaving nothing but a shell, frequently so thin and weak that the branches which develop upon it break down when they become loaded with fruit. Wiring must be resorted to to support them and even this is not always successful.

Where sprouts are slow in starting, the removal of the earth from about the crown and crown roots will hasten them. Good cultivation, loosening and opening the soil will also assist in bringing them forward.

It has been repeatedly demonstrated that there is a distinct relation between the size of the trunk and its resistance to cold. Small trees suffer much more severely than large ones. For this reason a single trunk from each frozen back tree is desirable. A scheme frequently adop. ted is to allow one good strong sprout to develop in the trunk, and inarch a number of others into it. At most, no more than two or three sprouts should be allowed to de- 
velop. Thin them out after they have grown sufficiently to make it possible to choose the more vigorous ones. Apply the rule of the survival of the fittest and remove the weaker sprouts.

After the sprouts have started, it may be necessary in some cases to resort to root-pruning to secure a more vigorous and healthy growth. This may be accomplished by plowing rather deeply, or by the use of the spade. The amount of pruning should be governed by the size of the trees.

Wiring Sprouts from Frozen Trees. Supporting sprouts by one or more wires drawn tightly around them to hold them together is probably the best means of preventing their breaking away. Telegraph wire is best. Some have taken infinite pains in boring a small hole through each branch, through which to pass the wire, believing that if it were simply tied about them that the wire would gradually cut into and destroy the branch. Though such would seem to be a logical conclusion, it does not appear to be the case, and observation has shown that the wire or wires may be simply tied around the branches. The wire cuts into the wood but the wood grows over and unites on the outside, leaving the wire firmly imbedded in the wood. Branches wired in this way in $\mathbf{1 8 9 6}$ have been noted. They are now three to five inches in diameter and the wire passes directly through their centers, with the wood firmly united about it. The flow of sap and the growth and development of the branch are not interfered with.

If the sprouts start from the ground, a wire should be placed about them three and a half or four feet from the ground.

Pruning Tools. The tools used in pruning should 
be made of the best materials. The cutting edges should be keen and sharp. Only with a well-sharpened tool can a clean, smooth cut be made; and a smooth cut is essential to rapid and complete healing of the resulting wound, and the sooner it is healed the better. The injury resulting from the removal of a branch frequently allows the germs of decay to attack the wood and destroy it, and every possible precaution should be taken to avoid their attacks.

For the removal of small branches nothing is better than a good pruning-knife with a curved blade (Figure $83 \mathrm{E}$.). In nearly all cases the pruning-knife has been supplanted by the pruning-shears. Many different kinds are placed on the market, but it is generally conceded that durability, ease of operation and everything else consid-

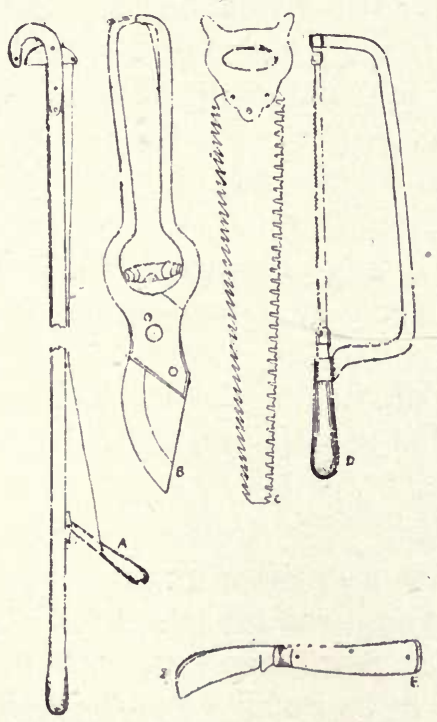

Fig. 83. Pruning Tools. $\Lambda$, Waters tree-pruner. B, Pruning-shears. C, Two-edged pruning-saw. D, Callfornia pruning-saw. E, Pruning-knife. ered, pruning-shears of the type illustrated in Figure 83 $B$, are the best. They can be obtained in several different sizes. For the removal of small branches high up in the trees, a pair of tree-pruners such as illustrated in Figure 83A, are essential. They are provided with a handle ten or twelve feet long and are operated from the ground, thus making it possible to remove branches fifteen to eighteen feet from the ground without the use of a ladder. Two kinds of pruning-saws are shown in Figure 83 . The two-edged saw is a very use- 
ful tool, but is open to the objection that it is not suited to the removal of branches in close contact, as the remaining ones are frequently injured by the teeth on the back of the saw, i. e., the side opposite the one in use. The California saw is a very convenient tool. The blade may be placed at any angle, thus making it possible to remove branches in cramped positions and to cut them at any angle. In pruning lemon trees, a pair of long-handled shears, commonly called lopping-shears are frequently quite useful.

\section{GENERAL REMARKS.}

Dead branches should be cut off and burned. Frequently they harbor insects or the spores of fungi, and these may attack the living parts. All cuts should be made parallel and close to the trunk or branch from which the part is removed. Stubs should not be left. The cut should be smoothed off with a knife, and as soon as completed the cut surface should be painted with white-lead paint. In no case, where a branch of any considerable size is removed, should this precaution be omitted. The paint preserves the part by preventing the entrance of the germs of decay.

All heavy pruning in Florida and the Islands should be done before June or the period of heavy rainfall.

\section{PRUNING THE LEMON.}

The Baronio System. This method of pruning the lemon so as to form a low, flat top was brought forward by Mr. A. C. Baronio, of La Mesa, San Diego County, California. The method appears to be best adapted to shallow soils, and is not held in favor by those who cultivate the lemon on stronger and heavier soils, as it does not permit 
of a sufficiently large fruiting area on the tree. The method is fully described by Mr. Baronio in Culture of the Citrus in California, by B. M. Lelong.

The ideal tree of the Baronio system is one with a low, flat, wide-spreading top as shown in Plate XXIV. The natural habit of the lemon as in the case of most citrus trees is to develop one or more leading, upright branchesin the center of the tree. In pruning by the Baronio system these must be removed from old trees or their formation prevented in the case of young ones. The first branches are allowed to form within sixteen to twenty-four inches of the ground. Large, horizontal branches which form the framework of the tree are allowed to develop. These branches should be some distance one above another, no two of them being allowed to start out at points directly opposite. Three or four primary branches are sufficient. In re-modeling old trees it is frequently necessary to bend these backward and outward until they touch the ground, where they are held in place by stones placed upon their tips. Upon each of these strong laterals, "two suckers are allowed to run, say, one about one foot and the other sixteen inches from the trunk (all other growth being suppressed), and when properly matured these suckers are similarly arched, one to the right and one to the left of the respective original three branches, which by this time will be set into position and may therefore be shortened in, leaving to each a sufficiently projecting stub to which the corresponding newly-arched suckers may be fastened, and thus no longer obstruct the ground below. There will then be three main branches, each subdivided into two secondary branches, giving six structural points around a circle; and by a succession of similar operations these are in due time doubled to make twelve, and so on. 


\section{Plate $X X I V$.}

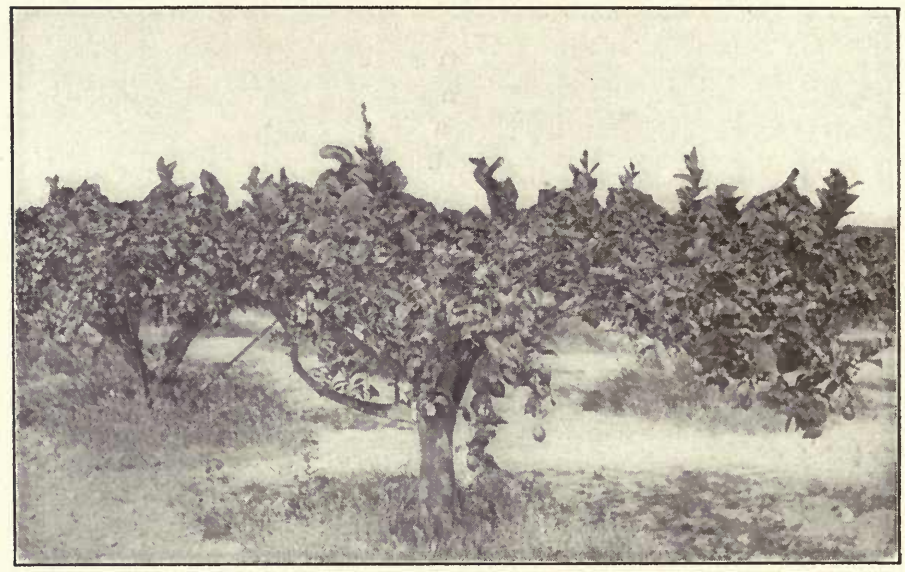

Fig. A. Baronio system of Lemon Pruning.

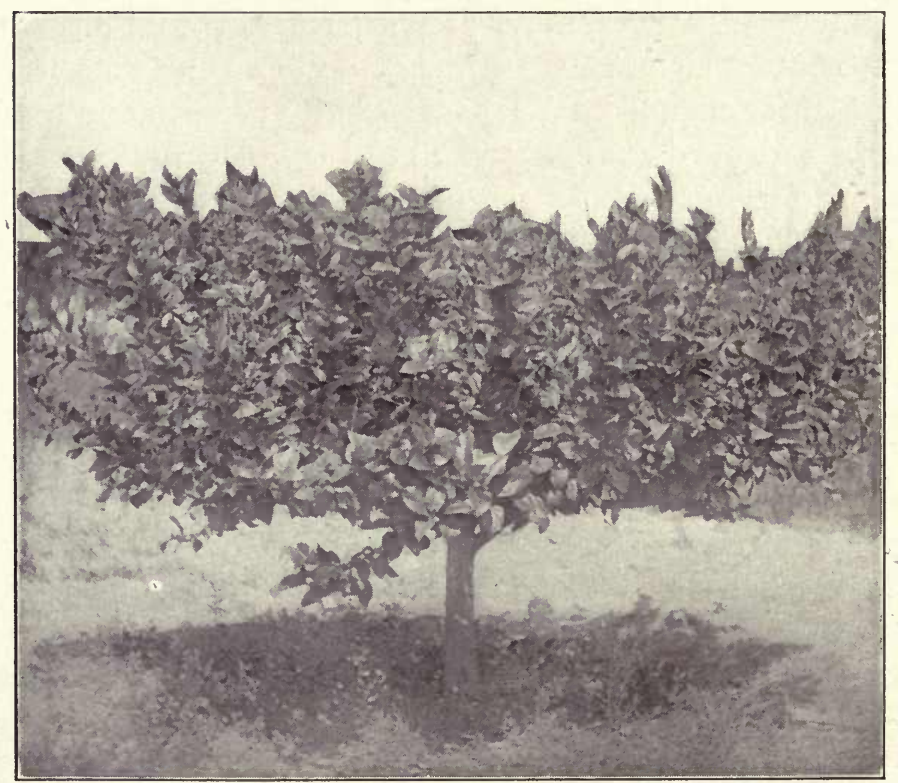

Fig. B. Baronio system of Lemon Pruning, adapted to shallow soils. 
always remembering to leave sufficient space between each of these fan-like main branches so as to allow a man to crawl through them and get into the middle of the tree to command the inside surface as far as he can reach."

Open-center System. To meet the demand for a large tree and still make it possible to eliminate the central upright portion of the tree, a number of systems have been brought forward. The most important of these, and one which is steadily growing in favor is the Open-center System. By this method, the central branches are dispensed with and the fruit-bearing branches are confined to the outer zone of branches. When the work is well done the tree top resembles an inverted cone when viewed from above the tree, downwards.

The system is well described as follows by Mr. C. W. Leffingwell, Jr., manager of the Leffingwell Orchards, Fullerton, Cal.*

"In the early days of citrus culture in California many lemon-growers did not believe in pruning. At the present time there may be a few who still cling to the idea that nature should be let alone; but nearly all observant grow. ers have been forced, by the logic of facts, to the conclusion that the lemon tree, in all its varieties, needs pruning, more or less severe, to bring about the best results.

While the untrained tree grows rapidly and produces heavy crops, the fruit runs largely to culls, and often fails to come to a profitable size. The tree, with its great load of fruit growing at the ends of long limbs, is at the mercy of the winds, and is often split and ruined by the mere weight of its burden. Therefore, it may be true that the lemon tree left to itself will produce heavily, but it is

* Culture of the Citrus in California, pp. 191-196. 
generally recognized that to produce the largest per cent of good-sized and fancy lemons the tree must be intelligently pruned.

In the method of pruning (usually adopted) the main object has been to shorten back and strengthen the scaffold or main limbs, so that they will carry their load nearer the center of the tree and be stocky and stiff enough to withstand strong winds without swaying and bruising the fruit. This method, properly carried out, has produced good results. It has, however, caused a tendency in the tree to form too thick and dense a head; a tendency very hard to combat. Even when carefully thinned out, trees shortened back in this way grow faster in their tops than in their lateral branches, on the principal that the sap flows most freely in vertical lines. The result is apt to be a tree high and all top; and this top, while beautiful to behold (to a "tenderfoot") is not fruitful, but consists chiefly of rank-growing, vertical leaders, commonly called suckers. These suckers are not supplied with fruit spurs, and are as worthless as so much bamboo. Even did they bear fruit, it would be almost inaccessible, and expensive to pick. The lower limbs, naturally the most fruitful, are robbed of sap by the superior drawing powers of the top, and fail to do their duty.

To overcome these difficulties the "open-center" style of pruning has been tried, and has given good results By eliminating the top entirely, the sap is thrown into the lower branches. These limbs being horizontal rather than vertical, and more or less bent, elaborate or digest the sap and produce heavy crops of good-sized fruit. This fruit, moreover, is within reach from the ground and can be economically picked. When the tree is once adapted to this form, the regular pruning is more easily and 
quickly performed, the number of limbs to be cut being greatly reduced, and all being within reach from the ground.

An explanation of the details of this system should properly come under two heads: "Pruning of young trees," and "Altering old trees." As most of the lemon trees in California are three years old or over, this paper will be confined to a discussion of the method of altering old trees to conform to the "open-center" style.

It is assumed that the trees to be altered are branched fairly near the ground. If they have been up high no system of pruning will bring the fruit within a reach from the ground, but to cut out the tops will save sap and make the lower limbs, such as they are, more fruitful.

Assuming, then, that the grower has trained his trees near the ground, and has not caused the branches to grow up for elephants to walk under, the method of procedure is as follows: Draw an imaginary line around the outside of the tree, as high up as a man can reach standing on a picking-box. All the limbs that terminate above this line should be cut out. Cut them off at their juncture with the limbs that terminate below the imaginary line. When this is done the top of the tree, looking down into it, will look like the inside of an inverted cone, and the tree may be called open-centered.

If the trees are small, cut out all limbs that extend up from the center of the tree at an angle greater than forty-five degrees from the horizontal. The tree in appearance will then be proportionately the same as the older tree above described, and can be trained gradually to the same limit of height.

The after-treatment of an open-centered tree, whatever its size, resolves itself into two distinct operations: 
the treatment of the hollow top, and the training of the main branches.

The hollow, cone-shaped opening in the top of the tree will soon be filled with shoots springing from buds on the main limbs, these buds being now exposed to the sun and excited into growth. Some of these shoots will stop growing when from six to twelve inches long, and will harden up and form fruit spurs. Others of these shoots will continue to grow at their terminal bud, retaining the color and appearance of tender sucker growth. When all have grown long enough to show their character, cut out the suckers and leave the fruit-spurs. As a result, the saucer-like top of the tree will in time be clothed with short spurs, shading the main limbs, and bearing fruit of finest quality. The top, before a dense thicket, is now made fruitful, without in any way interfering with the remaining (most fruitful) branches. With each growth the suckers will for some years persist in coming, but are easy to take out as soon as they show their identity.

The treatment of the lower branches which remain is the same as if the top had not been removed. If the tree has been well trained from the start its skeleton will consist of three or four strong main branches leaving the trunk near the ground, and running out more or less horizontally; and one or two more sets or decks of the same number of branches, leaving the trunk above these and extending out at an angle of from thirty to forty-five degrees. These limbs will have been pruned back at intervals, and, forming forks at each pruning, will be found to support an increasing number of branches as the out side of the tree is approached. 
The problem is how to handle the new growth on the tips of these branches. In solving this problem we should keep in mind the objects in view, which are: to make the tree stocky, and at the same time to keep it from getting too dense. The pruning should be confined entirely to an effort to control the growth of the skeleton of the tree, letting nature take care of the fruit-spurs with which this skeleton is clothed.

The terminal shoots or leaders of the tree should be left alone until they have grown to be several feet in length and from one quarter to one half inch in diameter. They should then be cut back, leaving from six to ten inches from the last pruning. In cutting back a vertical leader, cut to a bud that points out, away from the tree; horizontal leaders should be cut to a bud that points up. By persevering in this practice the limbs can be trained out, then up, then out again; they will be angular and crooked, which is conducive to fruitfulness. Their angling direction will help to brace them against the evergrowing leverage of their fruit and foliage, so that, while they may in time be bent down to the horizontal, they will never droop and rest upon the ground.

After each cutting back these leaders should be left alone and nature given full sway; and this is what will happen: Five or six buds nearest the cut will be excited into growth. Then will ensue a struggle to see which of these buds will get the most sap. The terminal bud is sure to get its share, and become a strong, sucker-like shoot. Probably one or two others will secure enough nutriment to become suckers likewise. The rest of the buds will have to give up their ambition to shine, and will settle down to the domestic role of bearing lemons, and thus perpetuating their species. These are the shoots 
that we are after. Were it not for the cutting back these buds would become dormant and lost to use; the leader on which they are situated would grow five or six feet perhaps, before nature would make another branch ing, and give more buds a chance to go to housekeeping.

How to handle the shoots which get the sap and become leaders is an important question. It is right here that judicious thinning should be done, to keep the tree from becoming too dense. All the shoots should be left until long enough to show which will be fruit-spurs and which leaders. All but one of the leaders, the one which points in the desired direction, should be cut off clean This leader will thus become the foundation of all future growth on this branch. At the next pruning it would be well to leave two leaders, laying the foundation for a new branch. By alternating in this way we can increase the number of ramifications of the tree, without getting it too dense- the trouble with most lemon trees.

These new leaders, when grown big enough, should in turn be cut back, and treated in the same manner. Beyond this, and keeping water-sprouts out of the center, little need be done to the tree. Nature will take care of the rest.

It may seem impracticable to apply one set of rules to all varieties of the lemon tree, but in the experience of the writer, all have responded to this method of treat ment. The Lisbon, being first and last a lusty grower, is bound, whatever the style of pruning, to make a rank mass of new wood. Let it grow, and cut off what is not wanted; let it grow again, and cut it back again. It can be made to bear plenty of fruit within easy reach, if left to itself it will produce little but stovewood. 
The Eureka and Villafranca, being of more tractable habits, form less and less new wood as they grow older and their crops increase; so that in time little or no pruning is necessary.

The question has been asked whether the fruitspurs of the lemon go on bearing, or die after bearing a few crops; making necessary a constant growth of new wood, as with the orange and peach. From observation, the writer believes that the lemon spur, with the apple and pear, is long lived and goes on bearing for years. If, on the other hand, the spurs are really short lived, severe pruning alone will insure new wood.

No radical system should be generally adopted without careful trial. The "open-center" system has been applied to a large acreage of lemon trees, with unmistakable benefits, and the number of acres so treated is increasing. In the orchards in charge of the writer sixteen thousand trees, mostly three years old, have been changed to con. form to this style. Hardly a tree has been lost in the transformation, and prominent horticulturists pronounce the trees unsurpassed for their age, in size, condition, or fruitfulness. Where before was despair as to what to do with the troublesome tops, now all is simple and easily done. It would pay every lemon-grower to try these suggestions on a few trees, and let the results speak for themselves."

Other systems of pruning the lemon are in use in California, but the two just described are probably the most important which have been brought forward up to the present time. 
Plate $X X V$.

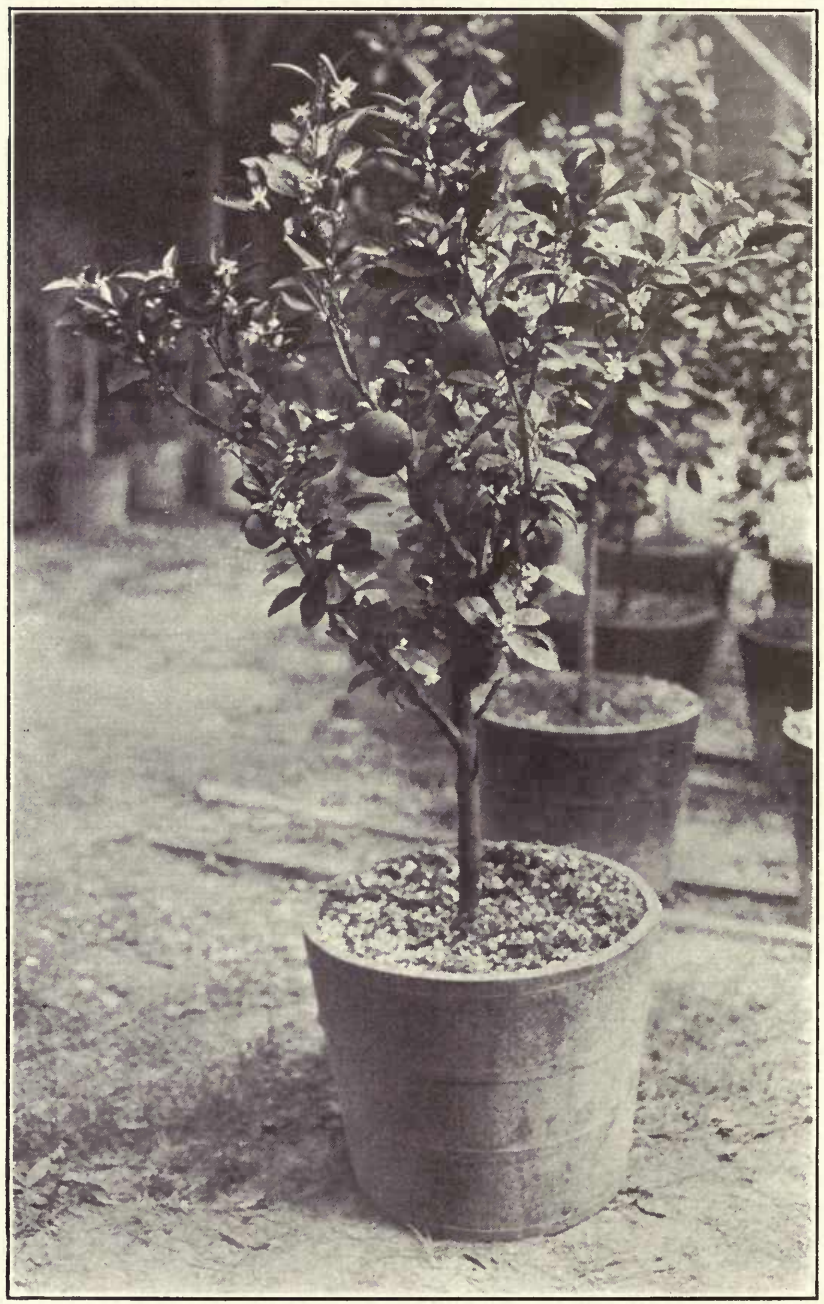

Tub-grown Orange Tree in Flower and Fruit. 


\section{CHAPTER XXXVIII.}

\section{POT CULTURE OF CITRUS FRUITS.}

All varieties of citrus fruits may be grown in pots or tubs. The perfumed flowers and the rich, glossy foliage of well-kept specimens make them exceedingly desirable plants for the greenhouse or house conservatory. Fruit can be secured in greenhouses if care is exercised, but when grown in an ordinary livingroom, the chances for fruit production are not so good. The writer has grown the pomelo so as to secure a box of fruit from a single tree, fruit, too, that was juicy and of good quality.

Specimens for planting in pots can usually be secured from nurserymen in the eitrus-growing districts. They should be of small or medium size, with well-developed root systems. Plants may be propagated if so desired. Cuttings may be made, rooted and afterwards either budded or allowed to retain their own tops. Specimens raised from cuttings of such varieties as can be raised from cuttings, are quite satisfactory. It is possible to raise Otaheite and trifoliate oranges, lemons and citrons from cuttings, but it is not practicable to root cuttings of sweet orange, pomelo and lime. If so desired, citrus seeds may be procured and sowed in flats (Fig. 41). When they have germinated and reached a height of three or four inches they should be transferred to pots. As soon as they are as thick as a lead pencil or a little larger, they may be budded. Buds can be secured from any citrus nurseryman.

Perhaps the most desirable stock for potted plants is C. trifoliata, but the Otaheite orange is also good. Either of these, it is believed, will make the potted plant 
a little more precocious and prolific. But good results. can be obtained with almost any stock. Even Rough lemon, than which there is no more rapid-growing stock, has proved satisfactory. The confinement of the roots by the pot or tub, reduces all stocks to nearly the same level so far as inducing fruitfulness is concerned.

In dealing with potted plants, the soil is almost entirely under the control of the grower. A number of different soils give good results. One composed of equal parts of virgin soil from the woods, sand and well-rotted cow manure has proved satisfactory. When the materials can be obtained easily, a soil made up of one-quarter good garden soil, one-quarter sand, one-quarter leaf mold and one-quarter thoroughly-rotted cow manure is probably as good as can be put together. The composition may be varied greatly, but in all cases a sticky, pasty soil, too retentive of moisture should be avoided.

Careful attention must be given to the size of the pot. As the trees increase in size, they should be transferred from one size to another as they become pot-bound. Older trees should be placed in large tubs, but in general it may be said that it is not advisable to increase the size of the tub beyond a diameter of three feet. Perfect drainage should be provided, a point too frequently overlooked. This may be secured by boring holes in the bottoms of the tubs, and filling in to a depth of two or three inches with large pieces of broken pottery. The soil should be well packed about the roots in potting. The large tubs should be filled only to within four or five inches of the top with soil. Afterward, when the plant has become established and the soil somewhat depleted, this space can be filled in with potting soil containing a half or so of well-rotted cow manure. Re-potting may be obviated by replacing this top layer with fresh material from time to time. 
Dwarf varieties, such as Otahite (useless for its fruit), the kumquat and the Myrtle-leaved orange. ( $C$. Myrtifolia of Risso) make excellent pot plants. They do not need large pots and do not require re-potting as frequently as the large varieties. They produce flowers of rather small size but in great abundance and fruit may be easily secured. If flowers are the desired object, no variety surpasses Satsuma, which produces its flowers densely packed along the branches. The sweet lemon produces a profusion of sweet-scented flowers, purple on the outside of the corollas. Of the sweet oranges, it is best to choose those which can be dwarfed by growing on C. trifoliata, if that stock is used. The following lists of varieties are recommended :

Sweet OrangesM a j o r c a, Jaffa, Pineapple, Centennial, Ruby, Maltese Blood and Tardiff.

Pomelos - Duncan, Hall, Pernambuco, Marsh and Royal.

Lemons - Villafranca, Genoa, Ponderosa and Sweet.

Limes - Tahiti, Mexican and Rangpur.

Kumquats - Marumi and Nagami.

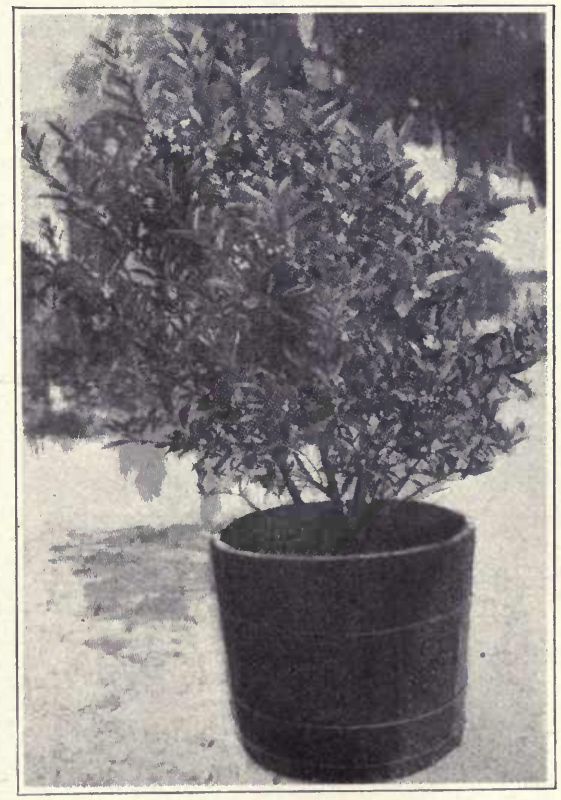

Fig. 84. Pot-grown Marumi Kumquat. 
Mandarins-Satsuma, Dancy and China.

Miscellaneous-Otheite and Myrtle-leaved.

It is not advisable to grow seedling specimens in pots, as they seldom bloom or fruit.

\section{PRUNING POT PLANTS.}

From time to time it is necessary to prune the tops of pot plants. Small, immature branches accumulate and should be removed before they die. Every five or six years it may be necessary to head-in the tops to keep them within bounds and to favor the production of new, vigorous wood. In doing this, all the large or medium-sized branches should be cut back, leaving three or four good buds on each one and the smaller branches should be removed entirely. As a result of this treatment no fruit will be borne for at least two seasons, but a healthy, vigorous top will be secured.

\section{FERTILIZING AND WATERING.}

Fertilizers may be given in the form of liquid manure and top dressings of bone meal and sulphate of potash. This latter substance should be used with caution, else injury to the roots may result. It should be given only in numerous small applications. Good results have also been obtained from the use of dried blood and bone meal in combination with sulphate of potash. Plants should not be allowed to become starved. This condition is readily shown by the yellowing of the foliage and by poor wood development.

Water must be supplied in sufficient quantities. No citrus tree will long remain in a healthy condition if a sufficiency of water is not supplied. If an insufficient amount is given, the leaves curl and drop. fruit, if present, also 
falls and the smaller twigs die back. On the other hand if too much water is applied, the leaves become yellow and fall and the whole plant assumes a sickly appearance. The remedy for the first condition is to give water, and if the plant has been exposed to strong sunlight, it should be shaded or transferred to a shady place. If the plant is suffering from a superabundance of water, it should be turned out of the pot or tub immediately, a large portion of the wet soil removed and the plant repotted. A moist atmospheric condition is beneficial to citrus trees.

Some make the mistake of thinking that citrus trees do not need a rest, forgetting that a period of rest is as necessary for their welfare as it is for ordinary deciduous fruit trees. For about two months during the winter season, the full amount of water should not be given and the temperature should be reduced to 40 or 50 degrees. Water should, of course, be given but not in sufficient quantities to excite growth, though this would hardly happen at so low a temperature, but enough should be supplied to make good the loss through the leaves and prevent their falling.

This treatment will cause the wood to harden and prepare it for blooming. Following this rest period, a higher temperature, 75 degrees or more, should be given, water should be supplied in the usual amounts, fertilizer applied and the plants placed in a well-lighted, airy place. Plants of sufficient age, treated in this way will bloom during the spring or summer months. In summer the potted plants may be set out of doors.

\section{TREATMENT OF INSECTS.}

Considerable difficulty is usually experienced in keeping potted plants free from insects. The worst and most 
common enemies are the scale insects and mealy-bug ( Dactylopius citri). The scales can best be held in check, either by spraying, for which purpose Good's Potash Whale Oil Soap No. 3 is recommended, or by fumigating. The mealy-bugs are more difficult to deal with. The cottony substance by which they are generally covered is impervious to sprays and the only method which is at all efficacious is to go carefully over the trees and brush the mealy-bugs off, then spray thoroughly with whale-oil soap and follow with thorough applications of the same mixture at intervals of ten days. It should be worked-in well so as to penetrate the woolly covering. For further notes on these insects see section on insects. 



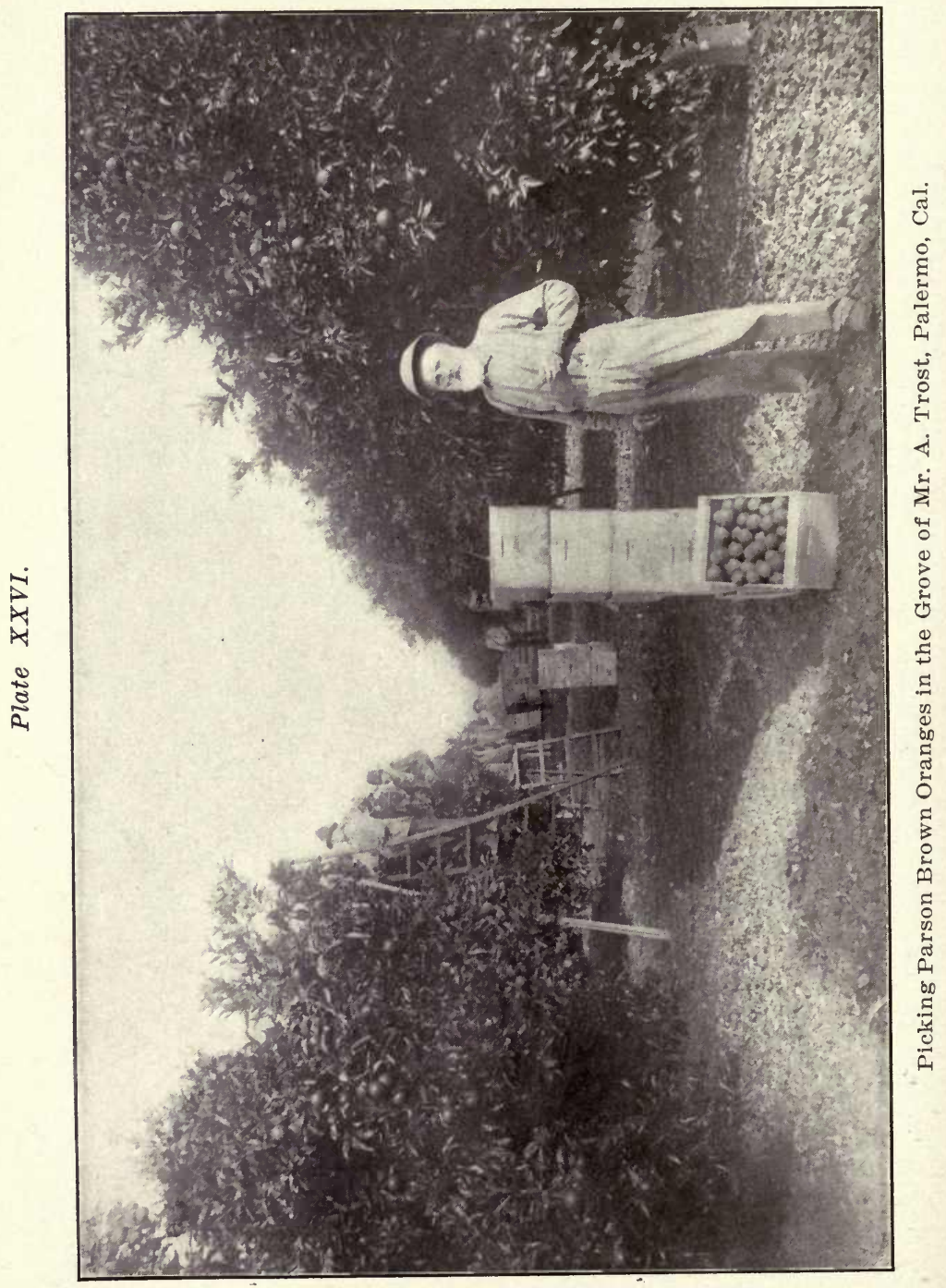




\section{HANDLING THE CITRUS CROP.}

No portion of the history of citrus fruit culture is more interesting than that which pertains to the evolution of our present systems of preparing the fruit for market. When the first oranges were shipped to nearby points from the Florida districts, boxes and barrels of various sorts and sizes were used. The curing of the fruit and its preparation for market were not understood as they are now. As a natural result, heavy losses were frequently suffered and many became disgusted with the growing of citrus fruits.

Mr. F. G. Sampson, of Boardman, Fla., under date of August 2, 1903, has written the following interesting letter to the author, giving his first experiences in marketing citrus fruits. Many others went through much the same trials before they discovered the secret of placing the fruit on the market in inviting shape:

"When we came to Florida in 1874, oranges were poured into second-hand barrels, shaken down and headed up and rather roughly handled all the way through. After two or three years the supply of barrels was not enough for the increasing crops, and boxes were brought in from Maine. They were of different sizes and we found a great deal of trouble in filling them, often having to take the fruit out and repack so as to make the box right on top.

"I should think it was in '76 that Mr. E. Bean (who lately died at Jacksonville) bought a number of crops of oranges on Orange Lake at Citra, and he, with Messrs. 
Harris and Bishop-I think they were the chief onesdecided that the square box, $12 \times 12 \times 27$, was the most convenient size. They figured up the size of orange for each pack and practically the present style of packing and number per box as generally packed now. We sized the fruit by holes cut in a piece of thin wood, handling each orange and placing it in the box, but Mr. H. B. Stevens, then with Bishop \& Co. (now manager for J. B. Stetson, DeLand), got up a sizer which did much better work and saved an immense amount of labor.

"It was the second year of our shipping that we got a bit of experience which showed us the need of careful handling. Our fruit had to be hauled twenty miles to the railroad and the time those railroads made was very slow, so that, although our crops were being sold in South Carolina, we often had complaints of rot. We had a visitor who urged us to ship a few barrels to a friend of his in the commission business in New York, and we made a shipment of six barrels. The reports said that half were rotten. The remainder sold for $\$ 11.00$ per barrel for the three barrels of sound fruit. Before we got those returns six barrels more were on the way. That trip the steamer picked up a disabled steamer and, bringing her back to port, made a very long passage for our fruit. The report came 'seventy sound oranges only. Please remit balance on freight.' That seemed to settle the matter, as a neighbor said, 'It is as I told you, you can't ship oranges to New York,' and told of his experience the year before.

"I was not satisfied, however, that fruit which would remain sound on the trees for months could not be put in New York sound. I knew the fruit was not being handled decently anyhow, so I said I would make one more shipment. Captain Keep said he wanted to join in, 
so he took three of the barrels to his house (first being more careful in picking and handling fruit) and he packed them first a layer of black moss, then a layer of oranges, and so on, and marked the number of oranges on each barrel outside. I packed one barrel first a layer of oranges, then a sheet of newspaper, second barrel papered each orange, and third barrel no paper (same as all shipments before), and marking the number of fruit in each barrel. We requested an exact report on each barrel by number. The report came: 'Not a rotten orange in any barrel,' and they sold at $\$ 16.00$ per barrel. That seemed to tell the story and from that day my brand has had the reputation of standing up. An orange does not show a bruise, but it is likely to be there all the same, and the only safe way is to handle, not pour the fruit. If fruit drops the shortest distance, it should not go in the regular shipment."

For convenience in discussing the marketing of citrus fruits we have considered the subject under these heads: (1) Picking, (2) Curing, (3) Grading, (4) Packing, (5) Marketing.

PICKING THE FRUIT.

Time. Early in the season, when the markets are good, there is a strong temptation to pick sweet oranges, pomelos and mandarin oranges before they are ripe. Only too frequently large quantities of green fruit are placed on the market, particularly during the months of September, October and November. The result is that the market is weakened, the reputation of the growers suffers and frequently loss of money brings the folly of the practice more strongly to the notice of those who would be 
first in the market, whether the fruit is ready to ship or not.

For the early market, early ripening varieties should be planted. If oranges and pomelos are removed from the trees before they are matured, they assume a light yellow color and an exterior appearance which may deceive one into believing they are ripe, but they never acquire the rich, delicate flavor of the fruit ripened on the trees and, more than that, they generally have a decidedly disagreeable bitter flavor. The taste and flavor of the fruit first eaten, leaves no wish or desire to sample another. The practice of picking and marketing green fruit cannot be too strongly condemned.

The early varieties of oranges, such as Early Oblong, Parson Brown and Boone, should be picked just as soon as matured. It is a fact that but few of the early oranges ever equal the late varieties in quality and flavor, and they become very flat and insipid if allowed to remain on the trees after they reach maturity. The best rule is to pick them immediately they have acquired their best flavor. This, unfortunately, is often a little before they are fully colored.

In the case of mid-season and late oranges there is a longer period during which they are in good condition and there is much less danger of their deteriorating in quality, because of over-ripeness. The period during which they are in good marketable condition may extend over a number of weeks and the grower has an opportunity to market his fruit to better advantage. Mid-season and late varieties should not, however, be picked until fully ripened. The sugar content and quality gradually increase up to the time of full maturity and if removed from the trees before this time, the quality and flavor is 
not all that might be desired. On the other hand, if held on the trees too long, oranges may become deficient in juice and a considerable amount of fruit may drop.

Though most of the pomelos grown in Florida are shipped before the first of January, it is a fact that but few varieties reach their highest perfection until February or March, or even later. To secure the finest quality of fruit it should not be picked until about that time.

Lemons and limes must be picked while green, but. they should be well grown before they are taken from the trees. The rule for lemons is to pick them when they will pass through a two-and-a-quarter-inch ring. But any variety of lemon which is not well grown at that diameter is not desirable. If allowed to ripen on the trees, lemons become overgrown and do not develop the strong, clear acid that characterizes the well-cured fruit.

Kumquats should be picked as soon as well matured and colored.

During the time of picking, it is preferable that the weather be dry and the atmosphere free from fog or other moisture. Bright, clear weather, with a temperature of about seventy degrees is ideal.

Clippers. Since all citrus fruits should be cut, not pulled, from the trees, because the rind of pulled fruit is broken, giving a chance for decay to set in, clippers of some sort are a necessity. The blades of orange clippers must have sharp cutting edges, and so curved as to make it possible to cut the stem close to the fruit. No portion of the stem should remain on the fruit, else it may puncture the rinds of other fruits in the processes of picking and packing, therefore the cut should be made close to the calyx. 
Many different kinds of clippers have been put on the market, but those of the Weiss type, with rather thin, curved blades, permitting close cutting of the fruit stems are best. They can be obtained of any dealer in horticultural supplies at a cost of about one dollar per pair.

Field Boxes. Quite a number of different kinds of field boxes are in common use in our citrus groves or orchards. Some growers use the ordinary orange boxes, those in which the fruit is to be shipped, filling them in the grove, transporting them to the packing house and then repacking them in the same boxes after curing, sizing and wrapping. This method is very good where the fruit has to be transported long distances to the packing house, but there is danger of soiling the boxes and they are somewhat awkward to handle.

Convenient field boxes may be made from orange boxes by providing them with handles by cutting a hand hold through the ends two or two and a half inches down from the upper edges. These cannot thereafter be used for shipping fruit, but must be used entirely as field boxes.

A handy field box is illustrated in Fig. 85. Mr. W. S. Hart, of Hawks' Park, Fla., who invented it, thus describes it in the Report of the Florida State Horticultural Society for 1892 :

"The ends or heads are $1 \times 10 \times 12$ inches, and have a hand hold two inches down from the upper edge; on the inside at the top is a half-inch rabbet, cut one-half inch deep; and across the ends of the heads, except for one inch up from the bottom is nailed a cleat, $1 \times 1$ 1-2 inches. This strip forms a stop at each end of the rabbet and also prevents the heads from splitting. Just flush with the bottom of the rabbet is nailed a half-inch cleat along its 
length that serves to make the bottom of the rabbet one inch wide.

"The heads are one inch further apart at the top than at the bottom.

"The sides and bottoms are the ordinary sawed pine, 1-4 inch thick by 6 inches wide and $265-8$ inches long; these are bettel than reneer, being stiffer, which prevents pinching of the fruit; the sides are nailed 1 inch up from the bottoms, leaving free circulation of air; the ends stand 3 inches above the sides.

"These boxes hold about two-thirds of a standard

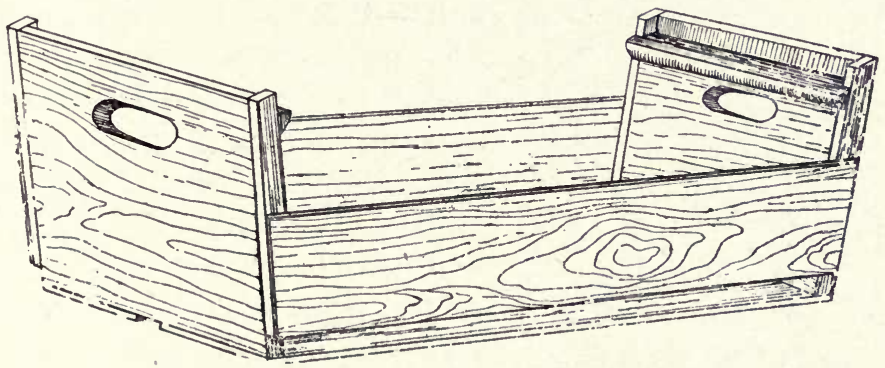

Fig. 85. Field box for handling fruit.

box of packed fruit, and can be piled, one above another, as high as a person can reach without danger of crush ing the fruit. The rabbets hold them from slipping, when tiered up in hauling, and as there is free ventilation and no heavy mass of fruit in any one box, they can be stacked up in the packing house and left until the fruit is needed, with as little danger of injury as though they were in slatted bins."

Picking Bags or Baskets. The most common form of receptacle for holding the fruit in picking is a canvas or duck bag, slung across the shoulder with the mouth opening on the left hand side. The objection to any form of 
picking bag or sack is that the fruit may be jammed or bruised through the sack against the sides and rounds of the ladder or the branches and trunks of the trees. Injury to the fruit would not occur from this source if careful, conscientious pickers could always be secured, but even then it is difficult to keep from bruising the fruit. Furthermore, there is always a strong temptation to pour the fruit from the picking bag into the field box without removing it from the shoulder. As a matter of fact, under ideal methods of handling the fruit, it should

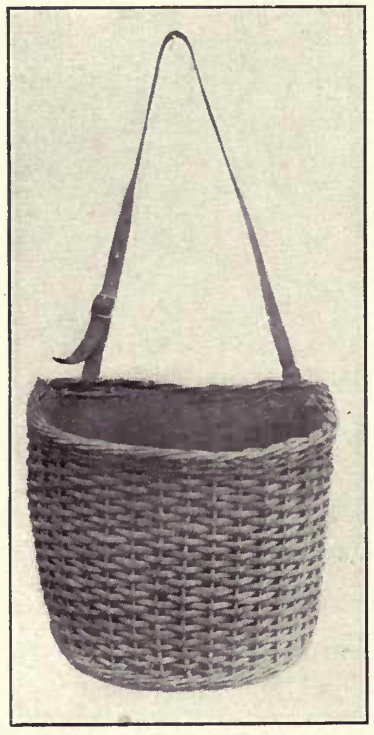

Fig. 86. Wicker-work picking basket. never be poured out.

All things considered, one of the very best picking receptacles is the wickerwork basket-Fig. 86-manufactured by the Wakefield Rattan Company, of Boston, Mass. The bottom is of wood and inside it is lined with heavy duck. By means of a stout, broad strap it is slung across the shoulder. Inside it measures $131-2 \times 151-2 \times 73-4$ inches. The newer ones have the front higher than the back, which increases its capacity, as it dips forward somewhat when filled. The advantage of this basket is that the sides protect the fruit from injury and the fruit can be conveniently lifted out with the hands and placed in the field boxes. 

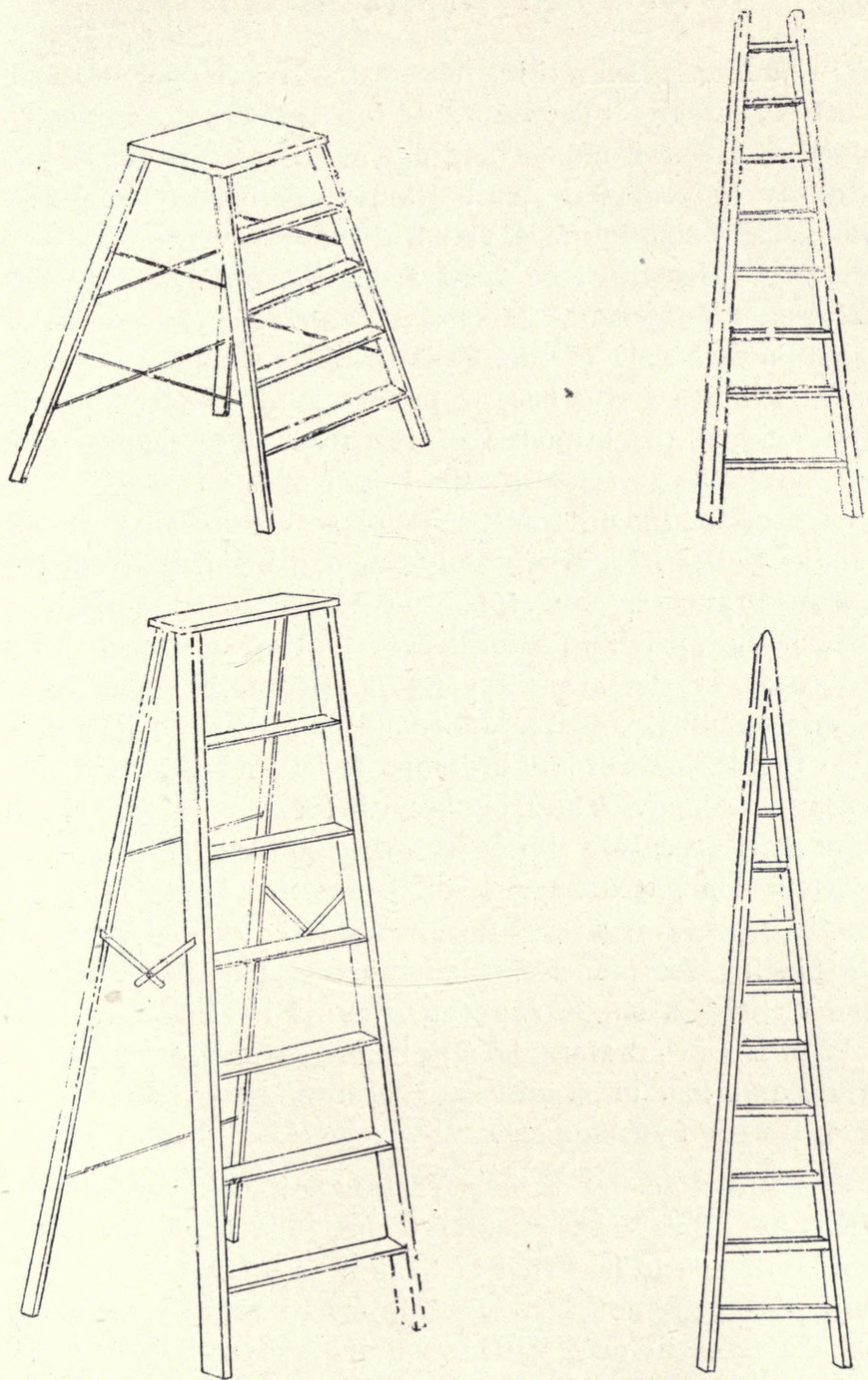

Fig. 87. Ladders for picking fruit. 
Ladders. In picking citrus fruits a ladder of some sort is generally a necessity. If the trees are low and compactly headed, a ladder may not be in much demand, but usually in removing fruit from trees of any considerable size something of the kind must be provided.

For removing the fruit from the outside branches a light, strong ladder, such as illustrated in the upper right-hand corner of Fig. 87 is best. It should have sufficient breadth at the base to prevent its tipping when laid flat against the branches of the tree. The length will, of course, be governed by the height of the trees.

It is a difficult matter to place an ordinary ladder in the centre of a tree when removing the fruit from the inside branches. For this part of the tree a ladder in which the uprights are united at the top is not so likely to catch in the branches and is, therefore, much more easily handled. Such a ladder is illustrated in Fig. 87.

Stepladders of the ordinary type are somewhat diffcult to manage. The trouble with them is that they will not stand securely unless the ground is perfectly level, a condition not always secured, and the lower branches of the tree frequently interfere with the double supports in placing the ladder straight against the tree. A stepladder with a single support, such as is shown in Plate XXVI is much preferable, much more easily placed in position, and just as secure and substantial as though provided with two supports.

Field Wagons. A low truck is best for hauling fruit from the grove to the packing house. The height to which the fruit has to be lifted in loading is much less and the low wheels are not so likely to interfere with the branches of the trees in passing through the grove. The wagons 
used in hauling fruit should be provided with good springs.

It is best that the fruit be not exposed to the sun after it is removed from the trees. Neither should the packed boxes of fruit be exposed to the strong rays of the sun. To protect the fruit, either in hauling from the grove to the packing house or from the packing house to the shipping point, a duck or canvas cover should be thrown over it.

Pickers and Picking. Good, reliable pickers only, should be engaged. They should be careful men, who can be trusted to handle the fruit carefully. Too much stress cannot be laid upon the proper manner of handling the fruit at this stage. When the fruit is removed from the trees, the rind is charged with moisture, particularly early in the season, and great care must be exercised in handling it. The pickers should be in. structed that fruit must not be dropped, poured from one receptacle to another, or bruised in any way. Slight bruises cannot be seen, but they may be there nevertheless, and will eventually show up in the form of soft, rotten spots. Any picker who handles fruit carelessly, and who will not mend his ways should be promptly dismissed. If a number of pickers are engaged they should be placed in charge of a competent foreman.

The picker's fingernails should be trimmed short, particularly in picking lemons. The rind of the fruit is frequently cut and punctured by long, sharp nails, and fruit otherwise good and sound frequently has to be consigned to the cull heap for this reason alone.

Pickers may be engaged by the day, week or month. or the picking may be paid for by the box. In the latter case, some system of checking must be employed. The 
fruit picked by each individual may be designated by a number marked on the end of the field box.

CURING.

Washing. If it is necessary to wash the fruit, it should be done as soon as it is brought to the packing house. Washing, whether by machinery or by hand, should be very carefully done. Care must be taken not to bruise or injure the rind of the fruit. Various machines are in use for washing and brushing the fruit so as to make it bright and clean. Among these may be mentioned the Warner washer, manufactured by S. C. Warner, Palatka, Fla., and the Tangent Fruit Washer, manufactured by Wright Bros., Riverside, Cal. The ideal washer should do the work thoroughly without injury to the rind of the fruit. While it is a fact that the appearance of fruit which shows the presence of sooty mold, fly-speck fungus or scales, can be very materially improved by washing, still the process must not be so severe as to injure the shipping quality of the fruit.

If small lots of fruit are to be washed, it may be done by hand, using a medium stiff brush or the membrane of the dish-rag gourd. To polish fruit so as to give it a bright, glossy appearance nothing is better than a handful of natural sheep's wool or a piece of soft flannel rag.

Effects and Need of Curing. When citrus fruits are freshly removed from the trees, the cells of the rind are filled with moisture to their fullest extent. In this condition, the rind is brittle and easily cracked or broken in handling. This is more particularly true of the fruit in the first part of the season than it is along in Marcb and April. 
If the fruit is bruised or bumped when the cells of the rind are congested, it is very injurious to its keeping quality. In fact it would be very difficult to put it through the processes of grading, sizing and packing without doing serious damage to the fruit. In packing, it is always advisable to have the fruit a half inch or so above the edges of the box before putting the head or cover on it. The cover is pressed down in a header or press and considerable pressure is necessary. The writer has stood in packing houses and seen the heads put on boxes of uncured fruit with such force as to burst the rinds of the fruit and send the juice spurting in tiny streams through the cracks in the box or trickling down the sides. Such practice is ruinous to the keeping quality of the fruit and to the trade.

Citrus fruits should not be packed without curing. Late in the season there may be occasional exceptions. In the process of curing, the rind decreases in thickness, parts with much of its moisture, becomes tough and leathery, and adheres closely to the pulp ball. When thoroughly cured, the fruit may be squeezed out of shape and properly packed without bursting the rind. Fig. 88 shows a cross-section of a well-cured pomelo, while Plate XXVII illustrates the difference in thickness between a cured and an uncured lemon. Note how the rind of the pomelo is indented and bent from its former spherical shape. Its ability to withstand injury has been materially increased, and so in the curing of all citrus fruits.

The loss of the moisture from the rind is another important item. If packed fresh from the trees the moisture leaves the fruit after packing, and the damp, wet condition in the box is particularly favorable to the development of decay. In the process of curing, all slight im. 
perfections and bruises show plainly, thus making it possible to select and pack a finer grade of fruit.

Curing Oranges and Pomelos. The treatment of these fruits preparatory to shipping is different from the curing or processing of the lemon. Fruits of these groups should generally be cured about four or five days. Under

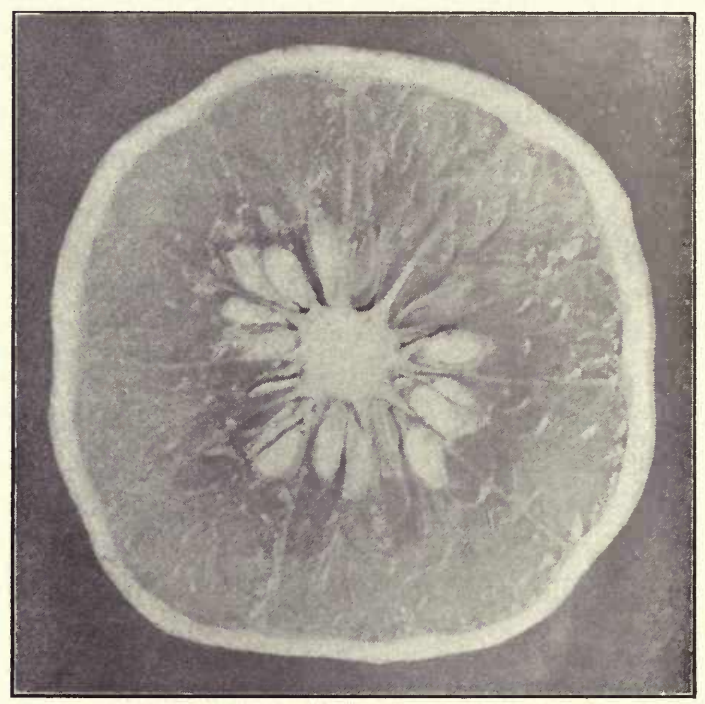

Fig. 88. Cross-section of a well-cured Pomelo. Note the thin, leathery rind.

special conditions a shorter time will suffice, and if very long distance shipments are to be made, it may even be necessary to cure for a longer period. Fruit has been shipped from Florida to England, Russia and Australia without refrigeration and arrived in perfect condition, but special pains were taken in curing and packing. This simply illustrates what may be accomplished. 
The packing house must be sufficiently commodious to accommodate a considerable amount of fruit. During the process the fruit may be placed in shallow bins placed against the wall. These should be padded on the bottoms and sides. One of the most efficient arrangements of bins for citrus fruit curing is that used by W. S. Hart, of Hawks' Park, Fla. Trays are provided, 6 x 5 feet and sufficiently deep to hold two or three layers of fruit. They are placed in two tiers across the room, pivoted in pairs between upright posts. Pins placed through the posts hold them in place. When it is desired to roll or move the fruit about, the pin in a certain tray, holding that tray in a horizontal position, is withdrawn and it is tipped either to one side or the other. This gives an excellent chance to expose the fruit to the air. The bottoms are made of slats two or two and one-half inches wide and rounded off on the edges, spaced about onehalf inch apart.

Fruit may be cured very nicely in field boxes, such as illustrated in Fig. 85. A sufficient number of these must be provided to hold the picking and they may be stacked in the packing house in tiers, as high as convenient.

During the process of curing there should be a free circulation of cool, dry air.

Curing Lemons. The curing and holding of lemons for market is a much more difficult undertaking than the curing of sweet oranges, for instance. The latter are usually marketed as soon as cured, but the bulk of the lemon crop must be held for a considerable length of time before it is marketed. In the first place, the fruit is green when cut, and must be cured and colored before being marketed, and in the second, the fall and winter months are not the ones for lemons. Much of the fruit 


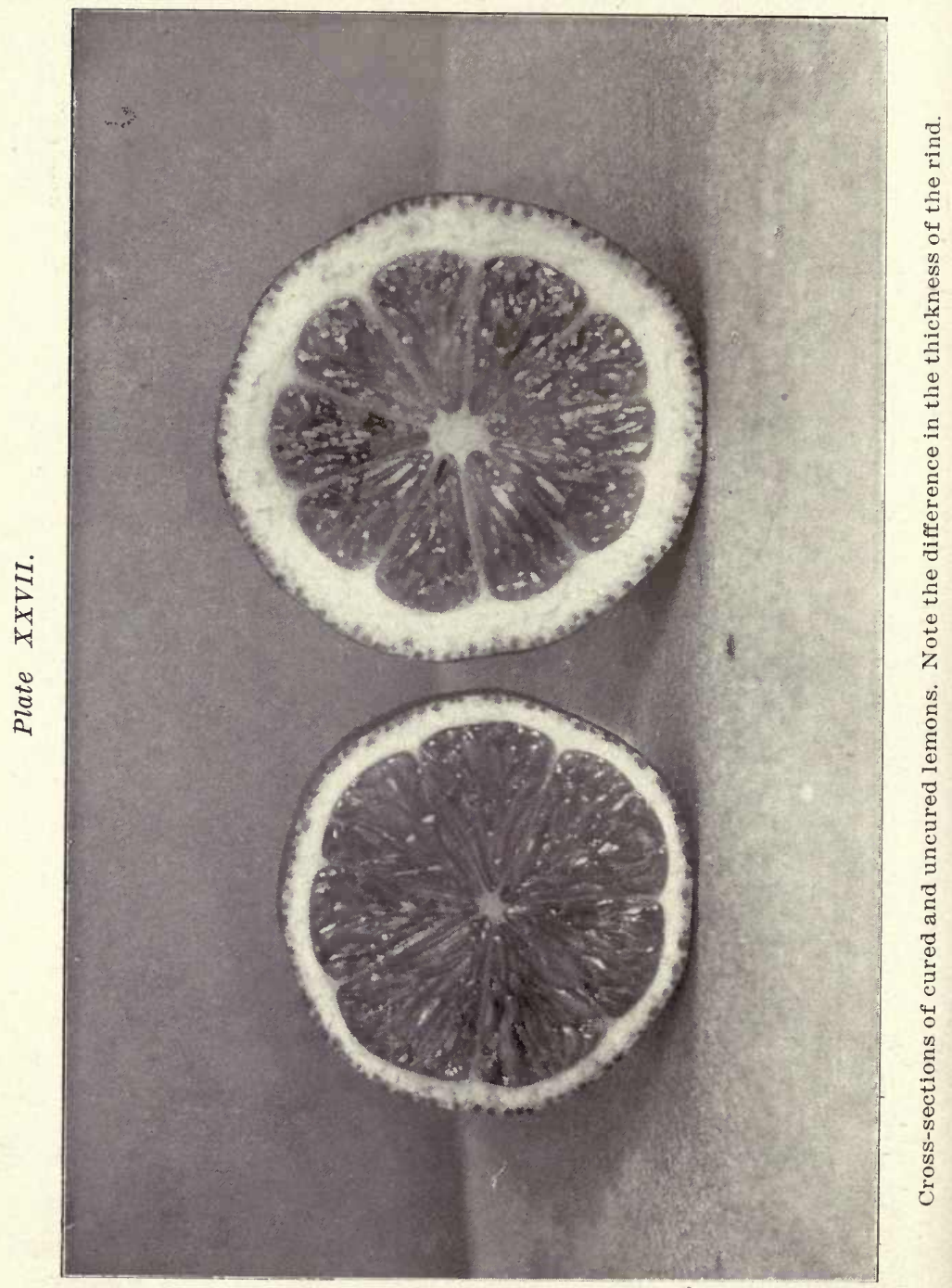


matures so late that it cannot be placed on the market for a number of months after it is picked.

The objects to be held in view in curing the lemon are: to reduce the thickness of the rind, make it smooth, tough and leathery; to increase its juiciness proportionately; and hold it in perfect shape until the market season. Many methods for securing these desirable and necessary conditions have been brought forward, but it is, perhaps, not too much to say that an entirely satisfactory method has not yet been advanced. Something still remains to be desired, and in the interests of the industry a thorough investigation should be made.

What appears to be one of the most satisfactory methods of curing lemons and one from which very satisfactory results have been secured, is that used by the Limoneira Company, of Santa Paula, Cal. Mr. C. C. Teague, the manager, thus describes it in the California Fruit Grower, July 11, 1903, and comments as well upon the practicability of shipping lemons east to be held in cold storage:

"The past year marked one of the greatest, if not the greatest, strides that has been taken in the lemon business since the shipping of lemons from California has assumed anything like commercial proportions; a stride that has been a complete revolution of old methods and one that is destined to have a far-reaching effect upon the future of the business. I refer to the open air method as it has been termed, of holding and curing lemons.

Unfortunately, about 75 per cent of our lemons are gathered in the winter and spring months, and up to last year the experience of our growers and shippers who had attempted to hold their fruit until the summer months, had been so disastrous, on account of the 
heavy decay, that they had concluded the most profitable way was to ship the fruit within from four to six weeks after gathering. The result was that the fruit was not equably distributed throughout the year, and at times the market would be so glutted that the shipper would get "red ink" for his shipment. Not being able to hold his lemons when the market was low, and having only the smaller percentage of his crop in the summer, when the

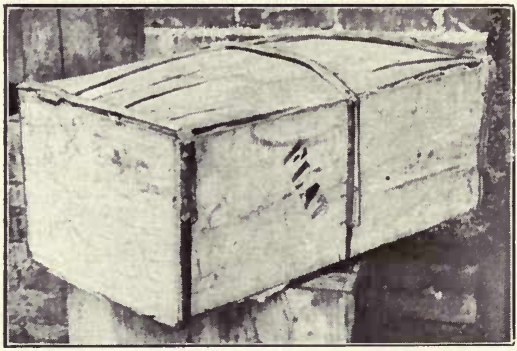

Fig. 89. A package of Italian lemons as they arrived in an American market. price is usually high, one can perhaps imagine how the lemon growers' books have been balancing at the end of the year and will probably be able to answer the question often asked: Why are so many lemon groves being

budded over to oranges?

"STYLA OF PACKING HOUSES.

"The old style lemon house, and the one still used by many of our growers, is a double-walled, double-roofed affair, some of them having patent systems of ventilation, and others depending simply upon doors and windows. When attempting to hold lemons by this method, they are massed in the house and the fruit just clipped given exactly the same ventilation as that which has been in the house several months; when, as a matter of fact, lemons in different stages of curing require radically different treatment as regards ventilation. As a result of this treatment some of the fruit is usually wilted from 
receiving too much air, while the greater portion of it is badly decayed from receiving too little.

"Proper ventilation is the keynote of success in keeping lemons, and after extensive and expensive experience along the old lines, I assert that it is entirely impractical to hold lemons in large quantities, for any great length of time by the old method. We have all been on the wrong track in believing a low temperature first in importance. If the ventilation is right the temperature will take care of itself. I have always said that the proper keeping point for lemons is just that point between where they will wilt and where they will sweat.

"The Limoneria Company, of Santa Paula, was the first to equip a house on the open air plan, and as that company has the most extensive plant and the widest experience in this method, perhaps a description of its lemon house and its methods may be of interest:

\section{"THE METHOD OF PACKING.}

"To begin with, the lemons are very carefully gathered, great care being taken in handling so as not to bruise the fruit. Rings of 25-16 inches in diameter are used for winter pickings and 2 1-4 inches in diameter for spring and summer, never more than six weeks being allowed to elapse between clippings, and the fruit is usually gathered about once a month. By careful attention to this, desirable sizes and good keeping stock are obtained. I want to say right here that this is the weak point of over 90 per cent of the lemon growers of California. I have just returned from a tour of the principal lemon growing sections of the State, and I found, as I have always found, that the carelessness with which clipping is done is almost criminal. In grove after grove which I visited at 
least 50 per cent of the value had been lost by allowing the fruit to hang on the trees too long. Not only on account of the large sizes would it have been discounted $50 \mathrm{c}$. per box, but the keeping quality of the lemon which is allowed to mature on the tree is never good. Good results cannot be obtained, even by the best methods of keeping lemons, unless the fruit is picked at the proper time and carefully handled. A little illustration will, perhaps, be in point.

"Some time ago I visited one of the Southern California packing houses and they happened to be getting out a car of lemons at the time. I noted the rough, careless manner in which the fruit was being handled, and spoke to the manager about it, remarking that our fruit would not stand that kind of treatment, and asked him if he did not have tronble with decay. His reply was that they had practically no decay and that their fruit was giving fine satisfaction. Before leaving I took note of the car number and watched it in my bulletin. When the car arrived East, 25 per cent decay was reported.

\section{"THE PACKING HOUSE.}

"The Limoneira Company's house is 300 by 100 feet. The flooring is 2-inch planking and the roof covered with gravel paper roofing. The building has no sides whatever, allowing free circulation of air. The fruit for storage is put into regular shipping boxes, piled in blocks of 560 boxes. There is a double row of these blocks on either side of a twenty-foot space which extends the entire length of the building and which answers the double purpose of a workroom and an air space. The boxes are so piled as to permit of the circulation of air around each box. Each block of fruit is covered with a canvas $10 \times 10 \times 20$ 
feet, made box shape and open at the four corners. The ventilation is controlled by the raising or lowering of this canvas, and each block of fruit can be given exactly the ventilation that it requires irrespective of the other fruit in the house. By this method fifty or even one hundred cars of fruit can be handled and kept in as good condition as if there was only one. Each block being numbered, a complete record of the lemons from each of the six sections of the ranch is kept from the time it is gathered until shipped. The fruit is all washed in a lemon washing machine and is piled up in the house wet just as it comes from the machine. The canvas covers are not dropped over it, however, until it is thoroughly dry.

"The Limoneira Company handled over one hundred cars by this method last year with perfect success, some of the fruit being kept for nearly six months in good condition. Not a lemon was shipped under ice, and no allowance was allowed nor claim made for decay, excepting on une car which contained weak stock and which, by reason of a mistake in transportation, was nearly a month in transit. In this case $\tilde{5}$ per cent deduction was allowed. There were, some weeks ago, about sixty-five cars of lemons in the company's packing house and we did not feel the least uneasiness regarding it, knowing that by this method we are masters of the situation. Anyone trying to handle that quantity of fruit by the old method would be gray-headed in a single season.

\section{"AN IMPRACTICABLE PLAN.}

"We hear a great deal of late about sending our lemons East as soon as cut, there to be held in cold storage for a favorable market. I must say that I have no 
faith in the plan, and the following are a few reasons why I think it impracticable:

"(1) The lemon when picked and handled properly should stand shipment to the eastern markets without ice, and the ventilated lemon that arrives in good condition invariably gives better satisfaction than fruit that has been iced. True, sometimes fruit that is a little weak can be iced and made to arrive in fairly good condition, and will, perhaps, sell well; but what does it do when taken out of the low temperature of the car and subjected to the hot, humid atmosphere of the East? It decays and goes in as evidence that California lemons are not good keepers? I believe that the keeping quality of hundreds of cars of California lemons is injured every year by icing. In the early summer months a few cars of lemons will, perhaps, arrive in bad condition and the order will be sent out: 'In the future, ice your cars.' And the shipper immediately goes to icing regardless of whether the fruit to be shipped is hard, good keeping stock or not. If it is bad practice to refrigerate fruit in transit it is certainly not good practice to put it in cold storage after it arrives in the East.

“(2) To be successful in the lemon business means eternal vigilance as to care in handling, so as not to bruise the fruit. When we who grow the lemon and are so deeply interested in having it handled properly have such difficulty in securing help that will touch it carefully, what could we expect when it went from under our watchful eye to the cold storage plant in the East, there to be stored, sorted over and repacked before going to our customers?

"(3) The expense of storage and repacking; freight on decay. 
"(4) Why ship them East when they can be held here as long as it is necessary?

"But we do not want to hold all of our lemons. What we should do is to have them more evenly distributed throughout the year and to sell them when we can get a fair price, and be able to hold them when we cannot. If we can do this, and I think we can; and if we will strive to pick our lemons carefully and at the proper time; handle them carefully all of the time; put up an honest, well-graded pack: if we will do these things, good market conditions are sure to follow, and we will all find our lemon groves profitable."

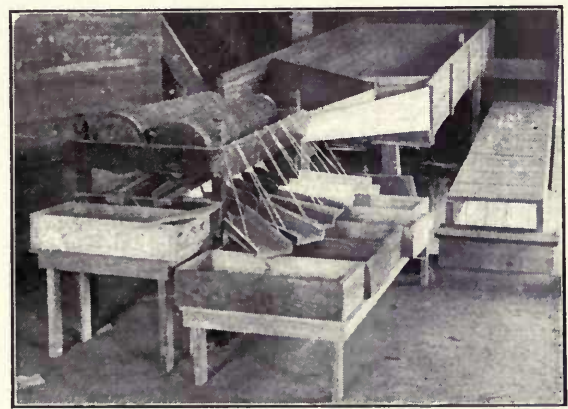

Fig. 90 The Huntley sizer.

GRADING.

No part of the process of preparing is more important than the grading. Seldom is the fruit fit for market without it, and were it shipped without grading, serious losses would frequently result. The grade of a package is usually established in the market by the poorer specimens. A box of oranges might contain seventy-five good fruits, but if it contained seventy-five, or even fewer, poor specimens, it would certainly be graded and sold on the market as an inferior package.

It does not pay to ship poor fruit. One or two poor specimens in a box injures the appearance of the whole 
and there is no use in paying transportation charges on poor fruit that will injure the sale of the good.

To any one examining the citrus fruits in any large market the fact that there is a great lack of uniformity in grading soon becomes apparent. California shipments are usually well graded owing to the fact that so much of the fruit is packed and shipped by large fruit companies. The output is graded better and it is possible. to maintain more uniform standards. But where the fruit is shipped by a large number of small growers, each of whom has his own ideals of grades, there is very likely to be great lack of uniformity. Each one seems to be impressed with the fact that he must label his best oranges "Fancy," when as a matter of fact there may not be a strictly fancy box of oranges in his whole grove. Again. the fancy package put up by one grower may not equal the second grade of another.

There is no good way of getting over this difficulty. and yet growers should have a well defined standard of grades and adhere strictly to it. A fancy orange mar be difficult to find and yet it may be possible to put up a package of good marketable fruit. It is the package taken as a whole that establishes the grade.

Grades. In Florida, two classes of fruit must often be made. A certain portion of the fruit has been attacked by the rust mite and shows the effects of its work in the rusty color of the fruit. Certain localities are free from its ravages, while many growers keep the insect down by spraying. But in general the fruit must be classed as Bright and Russet. They should be rigidly classed. Every fruit showing the least russet mark should go in the russet class. Each of these classes must be divided into grades. The question of the number of grades at 
once arises. The California grades are thus described by B. M. LeLong :

"Oranges classed as 'fancy' should be extra bright, with very smooth, thin skin. Rough, thick-skinned fruit, be it ever so bright, should never be classed as fancy.

"Oranges classed as 'choice bright' should be strictly bright and of fairly smooth skin and desirable size.

"Oranges classed as 'bright' should be bright and free from smut."

Mr. W. S. Hart's grades may be thus described:

Fancy-Bright, smooth, thin-skinned, without specks, spots or injuries. Quality and appearance fancy.

No. 1-Smooth, thin-skinned, with a few small spots or specks. Quality equal to Fancy grade.

No. 2-Large spots or marks, slight indentures and discolorations.

The author's preference would be to use a classification of grades somewhat like the latter and designate the fruit as Bright Fancy, Bright No. 1, Bright No. 2; Russet Fancy and Russet No. 1. Two grades of russets will generally be found sufficient.

The fruit should be carefully culled. Fruits showing large unsightly marks, sunburned specimens, thorned or bruised fruit, fruit showing marks of die-back (ammoniated), creased fruit and fruit that for any reason does not look well and will not carry well should not be shipped. Its place is in the cull heap.

Time to Grade. Grading may be done in the grove or the fruit may be graded in the packing house. The former plin will save handling, but if there is sufficient room, the fruit may be graded better in the packing house than in the field. 
Plate XXVIII.

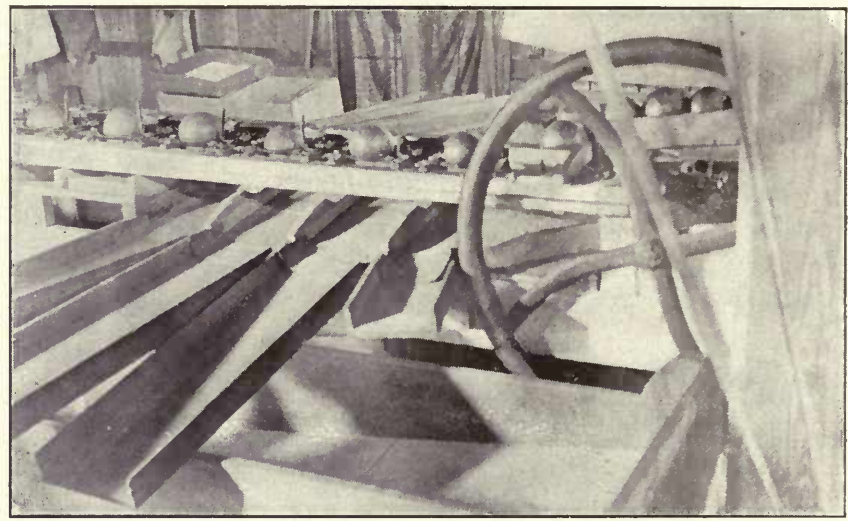

Fig. A. The Ayer sizer in operation.

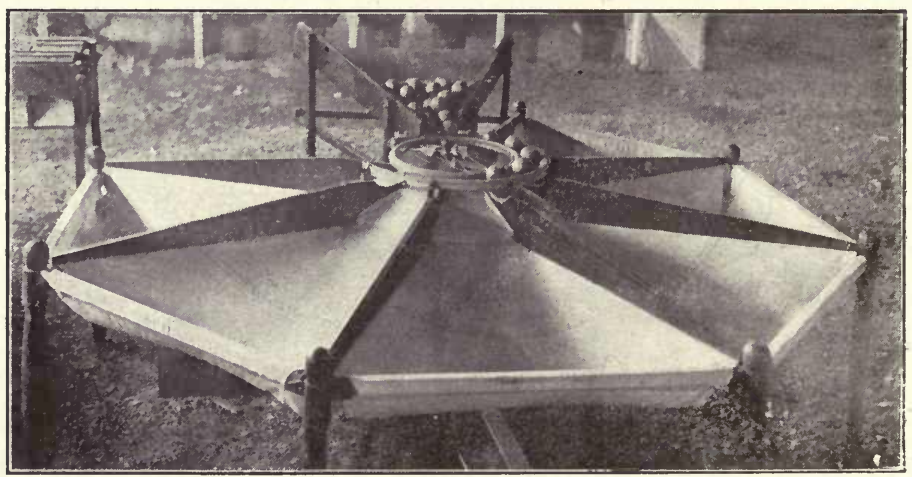

Fig. B. A pneumatic sizer made by Maull and Jones. 
With a double sizer, such as the Huntley, the bright and russet oranges may be separated as they go to the sizer, running one class through one side while the other goes through the opposite side.

Sizers and Sizing. Citrus fruits of round or oblate form can be accurately sized by machinery. Lemons and limes must be sized by the eve and either sized before or at the time of packing.

Many different kinds of sizers are on the market and nearly all of them are good, though some are better than others. The most recent styles brought forward are the pneumatic sizers, one of which is shown in Fig. B, Plate XXVIII.

A good sizer must possess the following points:

It must size all fruit accurately, whether round or flat, passing the fruit through on its greatest diameter. It must not injure the fruit. It must be easy to operate, for in many cases it is necessary to run it by hand or foot power, though in up-to-date packing houses an engine is provided to operate all machinery. It must have sufficient capacity.

For an ordinary machine a carload per day is very good work. It should be easy to keep in repair and easily adjusted to different sizes. It should be capable of sizing all kinds of round and oblate citrus fruits.

The diameters of the different sizes of citrus fruits are given in the tables accompanying the section on packing. The sizes of lemons are considerably smaller than those of sweet oranges. The sizes usually packed are: $210,240,275,288,300,360$ and 420 . Sizes 300 and 360 are regarded as standard or regular sizes, while the others are designated as "off size." 
PACKING.

The late Mr. E. Bean, of Jacksonville, Fla., was the originator of the present package used for citrus fruits in Florida, and it is perhaps not too much to say that the influence of his work has been felt in every citrus district in America. More than that, the rational methods of packing and handling introduced by him have been of paramount importance in the success of the industry and have had a moulding influence on the methods of handling every other tree fruit in America. The following letter from his pen, giving the interesting details of his early experience, appeared in the Florida Agriculturist, Nov. 7, 1900 :

"In compliance with your request for some reminis. cences of the origin of the systematic handling of Florida oranges, I will say that I arrived in Florida on Thursday evening early in November of 1875, and on the following Monday accompanied my brother-in-law, Mr. P. P. Bishop, went to Fernandina to attend a meeting of the Fruit Growers' Convention. During the meeting I introduced a resolution making the $12 \times 12 \times 27$ box the standard package of the State. The resolution was adopted and the package has been used since. I opened a packing house at $\mathrm{Pa}$ latka and commenced the use of them at once, having them cut from cypress at Mr. Boyd's mill. The next year as there were no veneer mills in Florida we ordered a cargo from Maine. After securing the box it was necessary to learn how to pack it so as to fill and make a solid pack. This we found to be a difficult problem. We spent much time in experimenting, sizing and learning how to place the oranges in the box, eventually developing the 225, 200, $176,146,128,96,80$ sizes, which with slight variations have been used since. 
"It might interest your readers to know why the $12 \times 12 \times 27$ box was decided upon.

"Before coming South I canvassed the cities of Buffalo, Rochester, Syracuse, Utica, Albany and New York, soliciting orders for Florida oranges. I found that the few that had reached those markets were packed in soap boxes, meat boxes, dry-goods boxes and old flour barrels, unwrapped and arriving in very bad order. I secured a few small orders in Buffalo and Rochester, but could not sell an orange in New York, although I canvassed faithfully. I was met in every case with the statement that the oranges were no good, that they would not bear transportation. They jeered me when I said that I was going down to engage in the business of handling them. One prominent dealer said that he thought that I would simply illustrate the proverb that a fool and his money would soon part company. In the course of the canvass I was seeking information, not only as to the best package to use, but also to learn all that I could about the manipulation of oranges in older countries. I called on several Italian packers, who kindly gave me a full description of their methods of handling and packing and showed me photographs of their packing houses. From all the information that I could gather I reached the conclusion that a square box that would give a multiple of 3 inches would be the best. After reaching here and conferring with Mr. Bishop, going into a storehouse where there was a quantity of loose oranges, piling them up, comparing the $12 \times 12$ space with the $10 \times 14$ of the foreign box, we decided that the $12 \times 12$ was far preferable and that size was agreed upon.

"I might add in conclusion that the results of my shipments from Palatka during the winter 1875-6 were 
satisfactory, as they demonstrated that with a suitable package and careful handling and manipulation that oranges could be transported and sold; for when we closed the packing house in the spring, we had standing orders from New York alone for about 200 boxes per week. In my canvass among the dealers and packers in New York I came to the conclusion that the success or failure of the enterprise would to a great extent depend upon the care in handling and the proper classification of the fruit, and that only perfect fruit should be put in the box. We, therefore, from the start rejected creased, plugged, thorned and all imperfect oranges. As the result of this care, we had but one complaint of fruit arriving in bad order. We had a considerable quantity of very fine oranges from the Lee grove, Leesburg. One lot came in a little soft. We shipped twenty boxes of it to Mills \& Everals, New York, billing them at $\$ 6.00$ per box, f. o. b: Palatka. They complained they were not quite up to standard in condition, and asked for a reduction of $\$ 1.00$ per box, which we, of course, conceded. This close assorting left a considerable quantity of cull fruit. A laughable incident in connection with it is worth relating:

"Judge Gillis, a prominent lawyer of Palatka, came into the packing house one day to see what we were doing. Looking about he saw quite a pile of culls in one corner, and asked what we intended to do with them. I replied that we expected to sell them in Palatka, but if we failed, we should dump them. He expressed some surprise, and soon left. Meeting a friend on the street he said to him that he had been down to see that Yankee who had come to show them how to pack oranges; that he was shown quite a pile of nice-looking fruit in one corner and was told that unless it could be sold in Palatka it would be 
dumped into the river. He guessed that Yankee would not last long.

"We did get more culls than we could sell in Palatka. Selecting the best of them, we packed and shipped them to parties in New York who were very pronounced in their expressions of the opinion that the Florida oranges would not stand transportation. They reached them in good order and sold for satisfactory prices, and we continued to ship them during the winter. The house was so much pleased with the result that they sent a man down in the spring to negotiate for an interest in the business.

"The most of the oranges handled at Palatka were pulled from the trees and as a consequence many of the stems were pulled out and the skin broken, and besides, many were bruised by rough handling, and had to be put in the cull pile. We, therefore, concluded that in the future we must buy the oranges on the trees, have the stems cut, and provide for careful handling in the various stages of the work. This policy was inaugurated for the next season's business, and as most of the fruit came from the St. Johns and Ocklawaha Rivers, a packing house was built at San Mateo, as being the most convenient point for concentration., Contracts were made for most of the oranges in sight, but the severe cold of December 1, 1876, destroyed all the fruit north of Lake Munroe, and we practically lost the season's business. In 1877-8 there was a considerable quantity of fruit.

"Carrying out the policies outlined above we were fairly successful and did a satisfactory business.

"As our system required tight packages, we found that the fruit must be held until the skin softened and became flexible, for if packed when it was hard and crisp 
the cells would be broken and more or less decay would follow. We, therefore, held them for several days after they were taken from the trees before assorting, which enabled us to detect the bruised, injured and thorned fruit. Our assorting and classification was very carefully done; each orange was taken up separately and carefully examined and placed in the class where it belonged.

"We made three grades of bright oranges and two of the russets, putting them under separate brands. I put my name on the first class, which was supposed to be absolutely perfect, and will relate a little incident that occurred in relation to it. I was making a trip through the West and, being detained several hours at a junction point, strolled up into the town, a place of two or three thousand inhabitants. Passing up the main street, and happening to look up, I found that I was standing directly under a sign, 'Headquarters for E. Bean's Oranges.' I went in and inquired what there was about E. Bean's oranges that justified so prominent a notice. The proprietor replied that when they saw that name on a box of oranges, they knew that it meant that they were perfect.

"I have written the above, which I think is about what you asked for. It is largely personal, but this could not be avoided, as there was apparently no one else who had the courage to undertake such an enterprise. Later on many dealers and growers became packers, using substantially the same methods."

Citrus Fruit Packages. With the exception of the lemon box, which is the same in both sections, the packages used in Florida differ in size and shape from those which are used in California. Each section has come to regard its orange box, used also for pomelos, as the stan- 
dard package, and it is not likely that a uniform package, however desirable, will be adopted.

The Florida packages in common use are as follows: The standard box and standard half box for sweet oranges and pomelos, the strap for mandarin oranges, the standard box for lemons (uniform with the California box), the 16 or 24 quart carrier for kumquats and the six-basket Fig.91. Kumquats packed in quart baskets. carrier sometimes used for limes.

The Florida standard orange box should be so constructed as to contain exactly two cubic feet of fruit. It does not, however, always do so, owing to slight variations in the length of the sides and the thickness of the ends and partition. The sides of the original box were 27 inches long, and one-inch solid heads and partitions were used. Seven-eighths-inch solid heads and partitions afterward came into use and the length of the sides was reduced to 265-8 inches. Later the paneled heads and partitions came into use. These vary somewhat in thickness, being about 1 or 1 1-6 inch thick, and the length of the sides has in many cases, even with one-inch heads remained at $265-8$ inches. Anything of this kind is a departure from the standard measurements. Whatever changes may be made, 
the length of the sides and the thickness of the heads and partitions should be so adjusted relatively as to give two equal compartments in the box, each $12 \times 12 \times 12$ inches.

The Florida standard half box for sweet oranges and pomelos is generally made by reducing the length of the ordinary box so as to make it 14 inches long outside with one-inch heads, or $133-4$ inches outside with seven-eighths inch heads.

The mandarin oranges must be regarded as fancy fruit and should therefore be placed on the markets in smaller packages. For oranges of this group, the best package is the strap, consisting of two half-boxes, packed separately and strapped together with the tops inward. When they have reached their market the half-boxes can be taken apart and sold separately while the two together can be shipped at the same rate as an ordinary sweet orange box.

It is conceded that the length and thickness of the heads and partitions should be the same as the sweet orange and pomelo box. Opinions differ, however, as to the depth. Some hold that the inside measurement should be six inches for each half, while others believe that it should be 5 3-4 inches inside, so that when strapped together they measure 12 1-2 inches outside, the same as the standard sweet orange box. No rule can be laid down which should govern in this matter, but the latter size is preferable, particularly when mixed shipments of sweet oranges or pomelos and mandarin oranges are made in carload lots. If boxes of different outside measurements are used, it complicates the loading of the car.

In Louisiana, the China mandarin is a favorite variety, and it is frequently shipped to the New Orleans market in ordinary sweet orange boxes. The fruit is cut 
with leafy twigs, four or five inches long, and packed in the boxes. Before displaying them on their stands the dealers frequently string them together.

The California standard lemon box is used both in California and Florida for lemons and the larger limes. It measures 11 - $2 \times 14 \times 255-8$ inches, inside measurements. While, as noted above the lemon box is sometimes used for limes, it is not suited to the shipping of the smallsized Mexican limes grown in Florida and other citrus districts. The best package for these, one occasionally seen in the markets, is the six, ten-pound basket carrier, such as is commonly used for tomatoes and other vegetables. They are generally packed without wrapping and the ten-pound basket is a convenient receptacle for handling them in the retail trade.

FLORIDA STANDARD ORANGE AND POMELO BOXES.

$121-2 \times 121-2 \times 265-8$ inches outside; $12 \times 12 \times 247-8$ inches inside-if heads and partition are $7-8$ inch thick.

Ends and partition.......3 pieces, $7-8 \times 12 \times 12$ inches. Sides, top and bottom ...4 pieces, $12 \times 265-8 \times 1-4$ inches. Straps ....... 3 pieces, half round, $54 \times 3-4$ inches.

HALF ORANGE AND POMELO BOXES.

Ends ............ 2 pieces, $7-8 \times 12 \times 12$ inches. Sides, top and bottom ...4 pieces, $12 \times 137-8 \times 1-4$ inches. Straps .........2 pieces, half round, $54 \times 3-4$ inches.

\section{FLORIDA STANDARD MANDARIN STRAP.}

Ends and partitions . . . . 6 pieces, $7-8 \times 12 \times 53-4$ inches. Sides ...........4 pieces, $14 \times 265$ 5 $8 \times 53-4$ inches Tops and bottoms .....4 4 pieces $1-4 \times 265-8 \times 12$ inches. Straps .......... 3 pieces, half round, $54 \times 3-4$ inches. 


\section{LIME CARRIER.}

Carrier holding six ten-pound baskets.

$$
\text { KUMQUAT CARRIER. }
$$

Strawberry crate holding 16 or 24 or 32 cups.

\section{CALIFORNIA STANDARD ORANGE BOXES.}

\section{1-2x11 1-2x26 inches.}

Ends ......... 3 pieces, 11-16x11 1-2x11 1-2 inches. Ends ......... 3 pieces, 11-16x11 1-2x11 1-2 inches. Sides ............ 8 pieces, $1-4 \times 51-4 \times 26$ inches. Cleats .......... 2 pieces, $3-8 \times 11-16 \times 11$ 1-4 inches.

\section{STANDARD ORANGE BOXES.}

11 1-2x11 1-2x26 inches.

Ends ......... 3 pieces, 11-16x11 1-2x11 1-2 inches. Sides and bottoms ......9 9 pieces, 1-4x3 1-2x26 inches. Tops ............. 2 pieces, 1-4x5 1-4x20 inches. Cleats ...........2 pieces, 3-8x11-16x11 1-4 inches.

STANDARD ORANGE BOXES.

11 1-2x11 1-2x26 inches.

Ends . . . . . . . 8 pieces, 11-16x11 1-2x11 1-2 inches. Tops and bottoms and sides, 12 pieces, 1-4x3 1-2x26 inches. Cleats .......... 2 pieces, $3-8 \times 11-16 \times 111-4$ inches.

HALF ORANGE BOXES.

$53-4 \times 111-2 \times 26$ inches.

Ends .......... 3 pieces, 11-16x5 3-4x11 1-2 inches. Slats . . . . . . . 6 pieces, $1-4 \times 51-4 \times 26$ inches. Cleats .......... 2 pieces, $3-8 \times 11-16 \times 111-4$ inches. 
HALF ORANGE BOXES.

$53-4 \times 11$ 1-2x26 inches.

Ends.............. pieces, 11-16x5 3-4x11 1-2 inches. Tops and bottoms.......6 pieces, 1-4x3 1-2x26 inches. Sides.............2 pieces, $1-4 \times 5$ 1-4x26 inches. Cleats............2 pieces, $3-8 \times 11-16 \times 11$ 1-4 inches.

HALF ORANGE BOXES.

11 1-2x11 1-2x13 inches.

Ends...........2 pieces, 11-16x11 1-2x11 1-2 inches. Slats.............. 8 pieces, $1-4 \times 5$ 1-4x13 inches. Cleats............2 pieces, $3-8 \times 11-16 \times 11$ 1-4 inches.

STANDARD LEMON BOX.

$101-2 \times 14 \times 255-8$ inches inside.

Ends................. pieces, 11-16x10 1-2x14 inches. Sides..............2 pieces, $1-4 \times 97-8 \times 27$ inches. Tops and bottoms.......4 pieces, $1-4 \times 63-4 \times 27$ inches. Cleats.............2 pieces, $3-8 \times 3-4 \times 13$ 1-2 inches.

All materials which enter into the construction of packages for citrus fruits should be bright, clean and well seasoned. All similar parts should be of uniform size. Yellow pine is commonly used in Florida. Though both solid and paneled heads are in use, the latter are more common in Florida, while in California the solid heads are at present used almost entirely. The solid heads are preferred by some because of the greater solidity of the box, but when expressmen and others have once handled boxes with the paneled heads, they dislike very much to have anything to do with solid-headed boxes.

If the edges of the sides used for boxes are rounded off with a spokeshave or plane, it adds much to the tidy appearance of the package. 
The strips used for strengthening the package is Florida are usually made from the outside of birch and are brought in from Maine. By some, strips of thin, rounded cypress are used, but they are rather too brittle to come into general favor. In a few instances the long petioles of the leaves of the saw palmetto are used. They must be used while green.

Making Packages. It is essential that the boxes used for shipping citrus fruits should be strong and well made. The fruit is heavy, and the box must therefore be ca. pable of standing a considerable amount of strain. Wire nails should be used. All stained or discolored pieces should be discarded, so that all boxes, when completed, may be bright, clean and attractive.

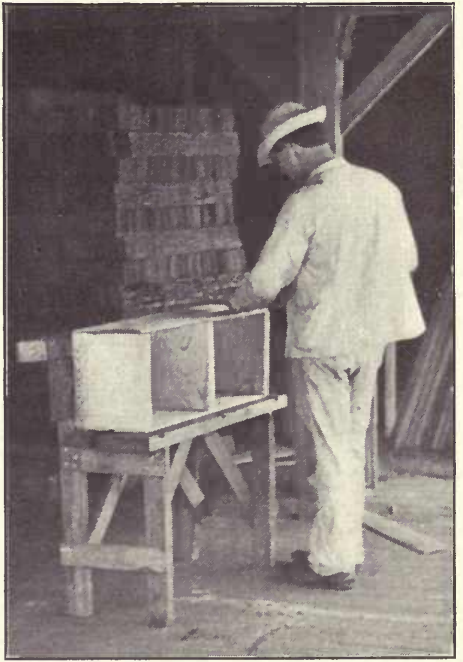

Fig. 92. Making crates.

For making boxes a table such as is illustrated in Fig. 93 A., may be used. The cleats tacked upon the top should be about one inch square and just far enough apart to admit the ends and partition. For making Florida standard orange boxes, with oneinch heads, the distance from center to center of $\mathrm{the}$ groves between the cleats should be exactly thirteen inches. Variations in the thick. ness of the heads or the size of the compartments will 
render it necessary to change the position of the cleats, but they must always be so adjusted that the finished box will have two compartments of exactly the same dimensions. The slightest variation increases the difficulties of packing. Instead of using cleats, grooves may be cut in the table top.

Fig. 93, B., illustrates a frame for making citrus boxes invented by W. S. Hart, of Hawks' Park, Fla., used by Cyrus W. Butler, of St. Petersburg, Fla., and others. It has many desirable points to recommend it. To make this frame four pieces of board and three steel springs are required. The baseboard should be somewhat longer than the length of the box and not quite so wide. The upright pieces should not equal the depth of the box in length. They should be slightly wider than the baseboard, and should be rounded off on one edge and one side. They should be firmly attached to the baseboard with wood screws. The springs are placed against these so that, when the heads are dropped down against the uprights, they will hold them firmly in place. It is preferable that one of the end springs be a stiff spring with a coil so as to hold one head very firmly in place. The distance between the uprights must be carefully adjusted according to the box to be made, for the reasons given above. By means of this frame, boxes may be well and accurately made, there being no danger that the center head or partitions will be a quarter of an inch or so to one side or the other of the middle of the box.

The directions for making an orange box, as given by the Florida Fruit Exchange, are full and explicit. They are as follows: "Put heads in frame with grain of wood running horizontal. Then nail on the first side, by putting two nails in each head. Then put on hoops 
by putting ends of hoops at longitudinal center or sides over the heads. Nail with two nails. The hoops pro jecting opposite from where the operator stands. Turn box over towards operator. Put on side No. 2. Bend hoops down and put four nails in heads. Two nails in center piece, about one and a half inches from edge of box, and should be so nailed as to be easily removed. Turn box toward operator, place on side No. 3, bend down hoops, put in four nails, ends and center piece. Turn box toward operator. Bend hoops neatly over the open side and fasten at place of beginning on side No. 1, with one
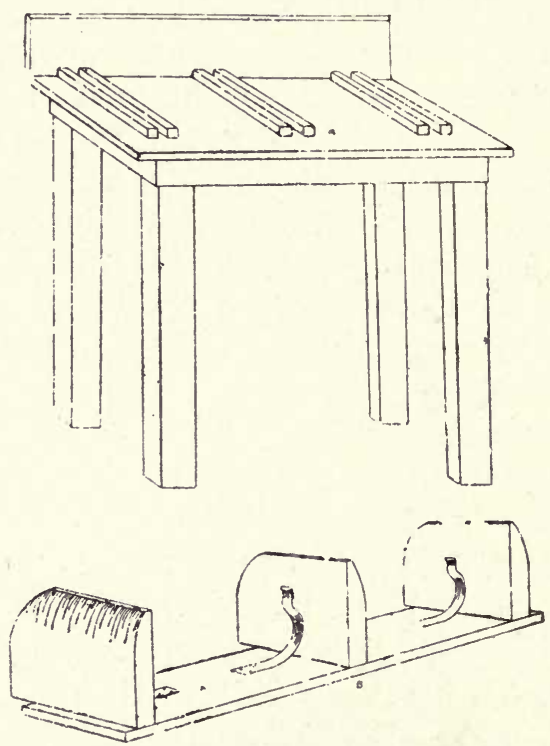

Fig. 93. A,table for making citrus boxes.

$B$, a frame used for the same purpose. nail half driven in. Then this can be easily drawn when box is full and side No. 4 put on just as side No. 3. No. 4 becomes the bottom of the box and No. 2 the top for opening."

In making boxes with the frame illustrated in Fig. 93, the three sides and the strips or hoops are put on as described above, after which the box is drawn off the frame and the loose end of the strips is then temporarily tacked down.

When large quantities of fruit are to be handled, it is well to have a considerable number of boxes made up in advance of the picking season. 
Paper. The paper used for wrapping citrus fruits should be thin and strong. Frequently the wrappers supplied are so thin and weak that the fruit cannot be wrapped and packed without breaking the paper. The paper serves as a protection to the fruit and should surround the fruit intact when snugly placed in the box.

The size should be varied according to the diameter of the fruit, but must be sufficiently large to allow enough margin for a good twist. The following sizes are approximately correct:

Fruits per box.

Size of paper.

$36-46 \ldots \ldots \ldots \ldots \ldots \ldots \ldots \ldots \ldots \ldots \ldots \ldots \ldots \ldots$ inches.

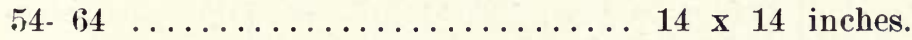

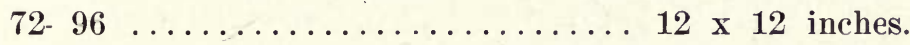

$112-150 \ldots \ldots \ldots \ldots \ldots \ldots \ldots \ldots \ldots 11 \times 11$ inches.

$176-200 \ldots \ldots \ldots \ldots \ldots \ldots \ldots \ldots \ldots 10 \times 10$ inches.

$216-226-252 \ldots \ldots \ldots \ldots \ldots \ldots \ldots \ldots .9 \times \ldots$ x 9 inches.

$270-360 \ldots \ldots \ldots \ldots \ldots \ldots \ldots \ldots .6 \times \ldots$ x $8 \ldots \ldots$ inches.

Paper printed with a suitable design and the name and address of the grower is somewhat more expensive than fancy paper, but fruit wrapped with such paper presents a much more attractive appearance than if plain paper is used. Colored and fringed paper is also sometimes used to advantage. The Italian lemons shipped to this country are usually wrapped in colored and fringed paper. Note the appearance of the boxes shown in plate.

Packing Conveniences. The fruit runs out from the sizer, each size in its own bin. The box is placed on a table of convenient height by the side of the bin so that the packer can readily reach the fruit. When the end of the box nearest the bin is packed, it is picked up and 
reversed so as to bring the empty compartment close to the bin. The labor of lifting the half-filled box is considerable, besides time is wasted.

A handy table used by W. S. Hart, Hawks' Park, Fla., who has one of the best equipped and most conveniently arranged packing houses in Florida is shown in

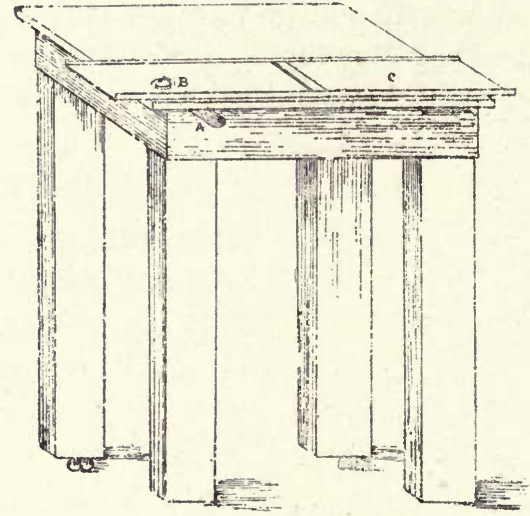

Fig. 94. Packing table. A, spring. B, stop. C, revolving table Fig. 94. The table is solidly built, the legs being $2 \times 4$ inches. The front pair of legs are provided with double castors. The top slopes toward the packer and upon it is a second revolving top, Fig. 94, C. In the center of the second top is a groove to receive the center hoop of the box that it may sit level. The revolving top is held fast by a pin, B., coming up through the lower top and into the upper one, and when it is desired to turn the top, the spring is bent down, the top is revolved and the spring is released. The pin or stop is attached to a wooden spring, A.

Small trays should be provided for holding the wrap: ping paper. The bottom should be made from a piece of board, slightly larger than the paper. The back should be of 1-2 inch board, two inches high, and the sides of the same material, and sloping off in front. The paper can be placed in these trays and the backs and sides will prevent, in some measure, its being blown about by the wind. 
Plate XXIX.

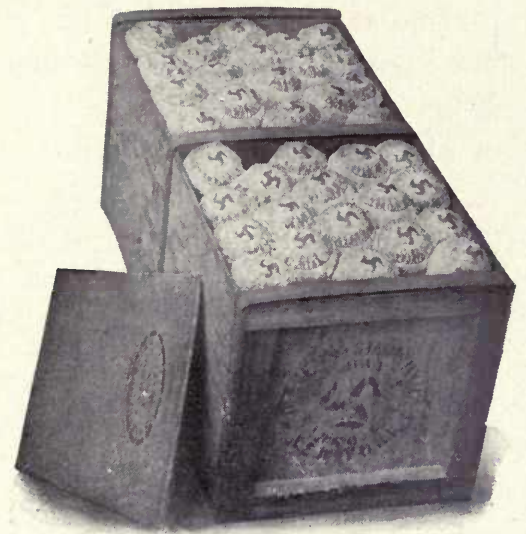

Fig. A. A well-packed box of Sweet Oranges, 176 in pack.

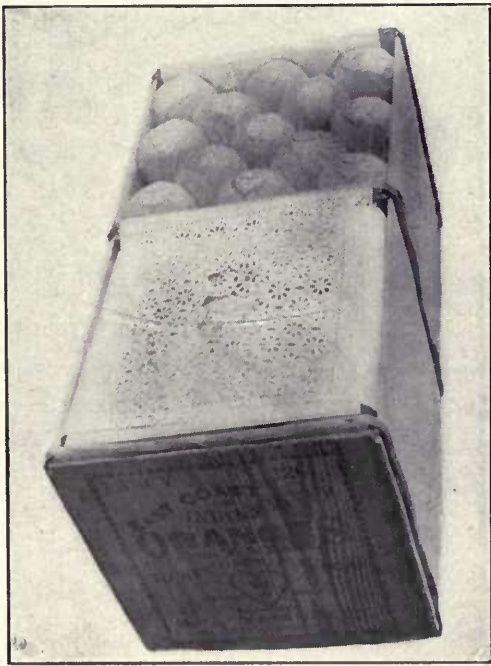

Fig. B. Shelf paper used in packing oranges. A fancy package of fancy fruit, 126 in pack. 
Packing. After accurately sizing the fruit, previous to which it has been properly graded and cured, it is ready for packing. The packer grasps a piece of paper with the tips of his fingers, so as to leave it spread out in his hand, with the right hand he places a fruit on the paper in the palm of his left hand, and then with the right draws the edges together, giving them a dexterous twist to hold it in place. It is then placed in position in the box.

The first two layers of fruit in the bottom of the box (the top when opened), should have the twists on the paper upward, afterwards they should be turned down. Each layer should be snugly packed and each fruit gently but firmly placed in position. If a system of packing diagrams is used and the boxes are properly made, each individual fruit has its own special place in the box into which it should fit snug and tight.

When packing is completed the fruit should stand about one-half inch above the sides of the box. Mandarin oranges should project less, rather than more.

If linings are used, a good quality of shelf paper should be secured for the purpose. It should be cut into lengths of 11 inches and should be about $81 / 2$ inches wide. It may be glued to the inner edges of the box, or it may be folded about two and a half inches back from the straight edge. Place it in place so that the first layer of oranges will rest upon it and hold it in place. The lower box in Plate XXIX shows the lining paper covering one-half the box, while from the other it is thrown back to show the fruit. Colored paper may be used, but pure white paper is very neat and attractive. Colored paper is open to the objection that a slight amount of moisture causes the color to run. 
Plate $X X X$.

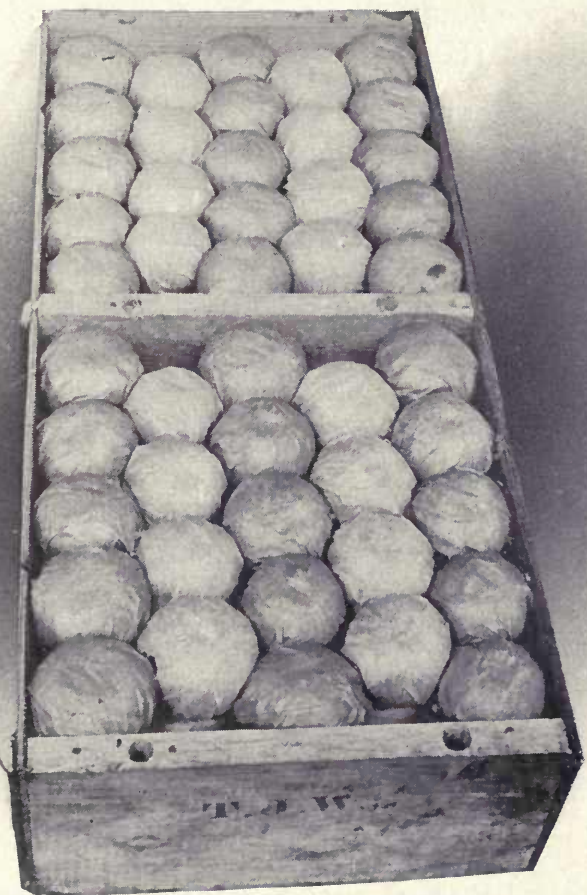

A well-packed half-strap of 136 Dancy Mandarin Oranges 
Packing Diagrams. That the fruit may exactly fill the box it must not only be properly sized, but each fruitmust be placed in position in the box according to a definite arrangement. These arrangements are commonly referred to as diagrams. Each layer contains a certain number of fruit placed in position. The fruit in the next layer above should never rest directly upon the individual fruits in the layer below, but should be placed so as to come between two or more fruits with a tendency to spread them. With the fruit placed so that the spaces or joints are broken, the contents of the box are solidly packed and yet, retain a certain amount of elasticity.

The following tables give the size of the fruit, the number of layers, their arrangement and the number of fruits in each layer for the packing systems now commonly used in Florida and California:

FLORIDA SWEET ORANGE PACKS.

\begin{tabular}{|c|c|c|c|}
\hline $\begin{array}{c}\text { No. and } \\
\text { Size }\end{array}$ & $\begin{array}{l}\text { Diameter } \\
\text { of Fruit }\end{array}$ & \begin{tabular}{|l} 
No. of \\
Layers
\end{tabular} & HOW PACKED \\
\hline 96 & $31-2$ & 4 & Layers 1 and $3=12 \mathrm{fr}$ \\
\hline 112 & $31-4$ & 4 & Layers 1 and $3=14$ fruits ; layers 2 and $4=14$ \\
\hline 126 & $31-8$ & 5 & $\begin{array}{l}\text { Layers } 1,3 \text { and } 5=13 \text { truits; layers } 2 \text { at } \\
\quad 4=12 \text {. }\end{array}$ \\
\hline 150 & $3 \quad 1-16$ & 5 & $\begin{array}{l}\text { Layers } 1,3 \text { and } 5=15 \text { fruits; layers } 2 \text { and } \\
4=15 .\end{array}$ \\
\hline 176 & $215-16$ & 5 & $\begin{array}{c}\text { Layers } 1,3 \text { and } 5=18 \text { fruits; layers } 2 \text { and } \\
4=17 .\end{array}$ \\
\hline 200 & $213-16$ & 5 & $\begin{array}{l}\text { Layers } 1,3 \text { and } 5=20 \text { fruits; layers } 2 \text { and } \\
4=20 .\end{array}$ \\
\hline 216 & $211-16$ & 6 & $\begin{array}{l}\text { Layers } 1,3 \text { and } 5=18 \text { fruits; layers } 2,4 \text { and } \\
6=18 .\end{array}$ \\
\hline 226 & $29-16$ & 5 & $\begin{array}{l}\text { Layers } 1,3 \text { and } 5=23 \text { fruits; layers } 2 \text { and } \\
4=22 .\end{array}$ \\
\hline 252 & $27-16$ & 6 & $\begin{array}{l}\text { Layers } 1,3 \text { and } 5=21 \text { fruits; layers } 2,4 \text { and } \\
\quad 6=21 .\end{array}$ \\
\hline
\end{tabular}


FLORIDA POMELO PACKS.

\begin{tabular}{|c|c|c|c|}
\hline $\begin{array}{l}\text { No. and } \\
\text { Size }\end{array}$ & $\underset{\text { Fruit }}{\text { Diamter of }}$ & $\begin{array}{l}\text { No. of } \\
\text { Layers }\end{array}$ & HOW PACKED \\
\hline $\begin{array}{l}28 \\
36 \\
46 \\
54 \\
64 \\
72 \\
80 \\
96\end{array}$ & $\begin{array}{ll}5 & 1-4 \\
5 & \\
4 & 3-4 \\
4 & 1-2 \\
4 & 1-4 \\
4 & 1-8 \\
4 & \\
3 & 5-8\end{array}$ & $\begin{array}{l}3 \\
3 \\
3 \\
3 \\
4 \\
4 \\
4 \\
4\end{array}$ & $\begin{array}{l}\text { Layers } 1 \text { and } 3=5 \text { fruits ; layer } 2=4 .^{*} \\
\text { Layers } 1 \text { and } 3=6 \text { fruits; layer } 2=6 . \\
\text { Layers } 1 \text { and } 3=8 \text { fruits ; layer } 2=7 . \\
\text { Layers } 1 \text { and } 3=9 \text { fruits; layer } 2=9 . \\
\text { Layers } 1 \text { and } 3=8 \text { fruits; layers } 2 \text { and } 4=8 \text {. } \\
\text { Layers } 1 \text { and } 3=9 \text { fruits; layers } 2 \text { and } 4=9 \text {. } \\
\text { Layers } 1 \text { and } 3=10 \text { fruits ; layers } 2 \text { and } 4=10 . \\
\text { Layers } 1 \text { and } 3=12 \text { fruits ; layers } 2 \text { and } 4=12 \text {. }\end{array}$ \\
\hline $\begin{array}{r}76 \\
90 \\
120 \\
168 \\
216\end{array}$ & \begin{tabular}{ll|}
\multicolumn{2}{c}{ FLOI } \\
3 & $1-4$ \\
3 & \\
2 & $3-4$ \\
2 & $1-2$ \\
2 & $1-4$
\end{tabular} \mid & $\begin{array}{c}\text { RIDA } \\
3 \\
3 \\
3 \\
4 \\
4 \\
4\end{array}$ & $\begin{array}{l}\text { SATSUMA MANDARIN PACKS. } \\
\text { Layers } 1 \text { and } 3=13 \text { fruits ; layer } 2=12 . \\
\text { Layers } 1 \text { and } 3=15 \text { fruits ; layer } 2=15 . \\
\text { Layers } 1 \text { and } 3=20 \text { fruits ; layer } 2=20 . \\
\text { Layers } 1 \text { and } 3=21 \text { fruits layers } 2 \text { and } 4=21 \text {. } \\
\text { Layers } 1 \text { and } 3=27 \text { fruits ; layers } 2 \text { and } 4=27 .\end{array}$ \\
\hline $\begin{array}{r}60 \\
76 \\
90 \\
106 \\
120 \\
136 \\
144\end{array}$ & \begin{tabular}{ll|} 
& FLO \\
3 & $1-2$ \\
3 & $1-4$ \\
3 & \\
2 & $3-4$ \\
2 & $1-2$ \\
2 & $3-8$ \\
2 & $1-4$
\end{tabular} & 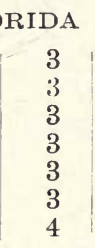 & $\begin{array}{l}\text { Layers } 1 \text { and } 3=10 \text { fruits ; layer } 2=10 . \\
\text { Layers } 1 \text { and } 3=13 \text { fruits ; layer } 2=12 . \\
\text { Layers } 1 \text { and } 3=15 \text { fruits ; layer } 2=15 . \\
\text { Layers } 1 \text { and } 3=18 \text { fruits ; layer } 2=17 . \\
\text { Layers } 1 \text { and } 3=20 \text { fruits ; layer } 2=20 . \\
\text { Layers } 1 \text { and } 3=23 \text { fruits ; layer } 2=22 . \\
\text { Layers } I \text { and } 3=18 \text { fruits ; layers } 2 \text { and } 4=18 \text {. }\end{array}$ \\
\hline $\begin{array}{l}210 \\
250 \\
270 \\
300 \\
360 \\
420\end{array}$ & $\begin{array}{ll}2 & 3-4 \\
2 & 5-8 \\
2 & 1-2 \\
2 & 3-8 \\
2 & 1-4 \\
2 & -21 / 8\end{array}$ & \begin{tabular}{l}
\multicolumn{2}{l}{ L } \\
5 \\
5 \\
5 \\
5 \\
6 \\
6
\end{tabular} & $\begin{array}{l}\text { EMONS AND LIMES. } \\
\text { Each layer, } 21 \text { fruits. } \\
\text { Each layer, } 25 \text { fruits. } \\
\text { Each layer, } 27 \text { fruits. } \\
\text { Each layer, } 25 \text { fruits. } \\
\text { Each layer, } 30 \text { fruits. } \\
\text { Each layer, } 35 \text { fruits. }\end{array}$ \\
\hline
\end{tabular}

CALIFORNIA SIZES OF ORANGES.

112 .

Inches in Diameter

126 $32-8$

150 $31-8$

176 3

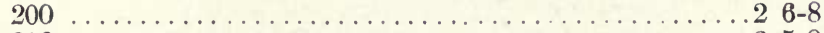

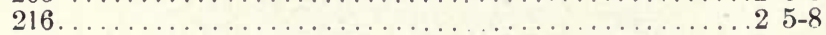

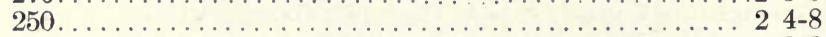

300 .

$23-8$

* This $4-5$ or $5-4$ pack is well adapted to all sizes up to 64 . 
Headers. It is necessary that the fruit should be absolutely tight and solid. To this end, it is quite essential that the fruit stand one-half to three-quarters of an inch, depending on the size of the fruit, above the sides of the box when packed. Then when the head is placed on and pressed down, the fruit will not jostle or shift in transit, provided it has been well cured.

Various types of headers or presses are in common use. Most of these are home-made and quite simple in construction. Two different types are shown in figures 95 and 96.

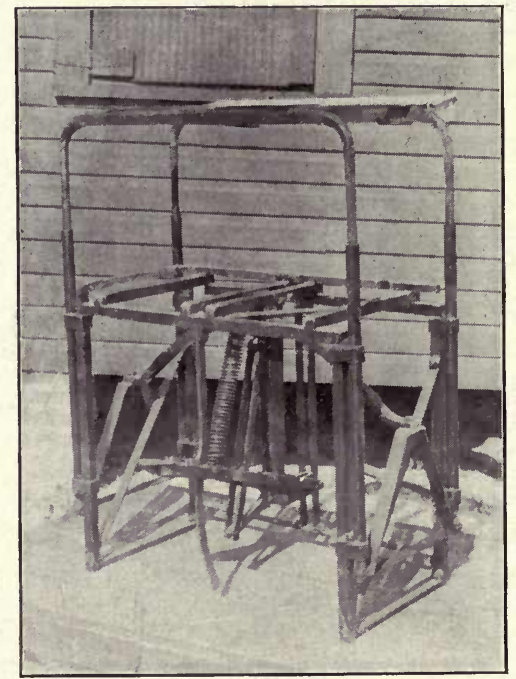

Fig. 95. Header, or press, used by P. J. Bayley,Largo, Fla.

The first of these is used, and was made by a blacksmith, according to plans provided by Mr. P. J. Bayley, of Largo, Fla. The box is placed on the frame under the curved uprights. The strip hoop, which until now has been tacked down, is loosened and the head or cover is placed in position. The foot is placed on the lever attached to the spring shown in the illustration. The whole top frame then moves down on to the box as the foot is passed down. A set of notches catch and hold the lever, thus sustaining the pressure on the cover. Three cross-pieces between the 
top bars press down just inside the ends and to one side of the partition of the box. The top is then nailed down, the hoops are placed on and the box is complete. The other, shown in Figure 96, is much simpler in construction. Two pieces of curved metal are loosely attached to a pair of horizontal pieces of wood, which are held together at the outer end by a cross-strip at the ends.

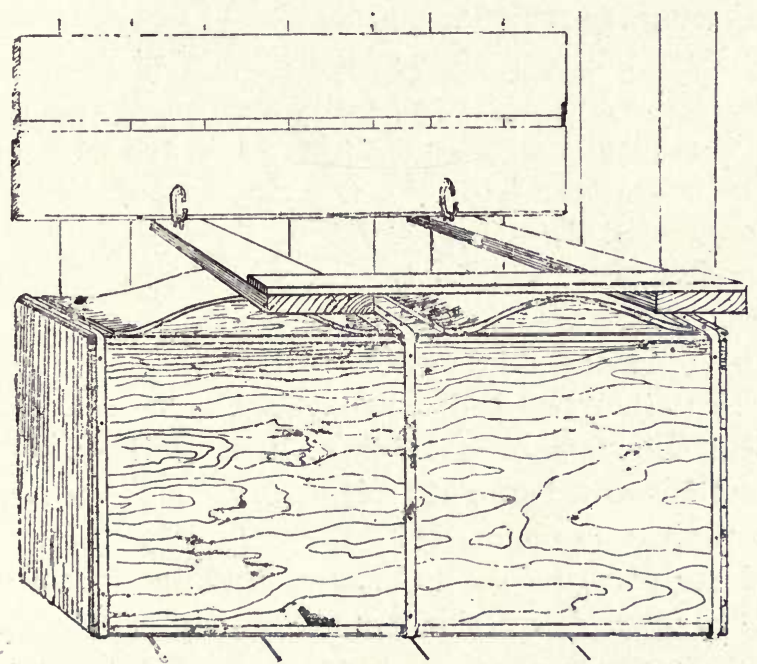

Fig. 96. Press used by Mr. W. S. Hart for putting heads on orange boxes.

At the inner end they are attached to a horizontal piece by two links. The upper horizontal piece against the wall is nailed firmly in place, while the lower one is at. tached to it by a link at each end. This allows some play, necessary to the smooth working of the header. The pieces of curved metal are just long enough to fit inside of the ends without resting on the partition. In nailing the cover on the box, the operator sits down on the outer 
strip, his weight presses the head down, whereupon it is nailed in place.

Any man of ordinary ingenuity can readily make a simple press of some description to press the heads into place. They may not be so good as those described above, but will be just as efficient.

Packing and Shipping Don'ts. Every separate step in preparing the fruit for market should increase its value by at least the cost of the labor expended and the materials used. But, strange to say, the money value of the crop is frequently greater as it hangs on the trees than it is after it has been gathered, and made ready for market. In many cases the actual worth of the fruit is decreased at every separate step in the process of preparing it for market. The value is, too often, lessened by careless handling, by unbusinesslike methods.

The author has had the opportunity on a number of different occasions of examining citrus fruits in the market, and has seen boxes of fruit showing proof of many of the practices condemned in the following suggestions:

Never place bright and russet fruit in the same box.

Do not pack inferior grades of fruit and stencil it fancy. No one is deceived thereby and the shipper loses in the end.

Do not pack different sizes in the same box.

Do not wrap oranges with three or four pieces of paper to bring them up to size.

Do not pack fruit until it has been properly sized.

Do not pack and ship uncured fruit.

Do not pack slack boxes. The buyer is honestly entitled to a full box of fruit.

Do not stencil packages falsely. For instance, do not mark 200 on a box containing 150 fruits. 
In each box place only fruit of uniform grade and ripeness. The boxes should not be falsely faced and poor fruit placed in the centers. The outer layers should fairly represent the contents of the box. False packing of any. kind soon becomes known in a market.

Don't criticise the commission merchant too severely, for there is too frequently a vast difference between the fruit in the packing house and the same fruit when it arrives in the market.

Don't ship fruit to unknown commission men without first investigating their standing.

Stenciling. As soon as the covers have been placed upon the boxes they are ready to be stenciled or labeled. Fancy pasters are sometimes placed on the ends of the boxes. In California this is commonly done, in Florida it is the exception rather than the rule. Upon the end of the box there should be stamped the grade of fruit, the name of the variety, the number which also indicates the size, the consignee, and if the fruit is of fine grade, the name and address of the consignor. Growers whose names have won a place in the markets frequently place their private brand only upon first-class fruit, while all other fruit is shipped without it.

While it is best for a shipper not to stamp inferior fruit with his name, on the other hand, all fruit that is sound and salable should bear his name. His reputation will suffer no injury, if he honestly stamps the grade of fruit on the box. Fruit that will not carry and is not of good quality should not be shipped. Bruised fruit, thorned fruit, cracked fruit, creased fruit, fruit showing distinct marks of die-back, fruits touched by frost, should go in the cull heap. This done, and after careful grading 
and selection of that which is shipped, no grower need fear to have his name appear on his packages.

When properly stamped, the ends of the box should appear somewhat like this:

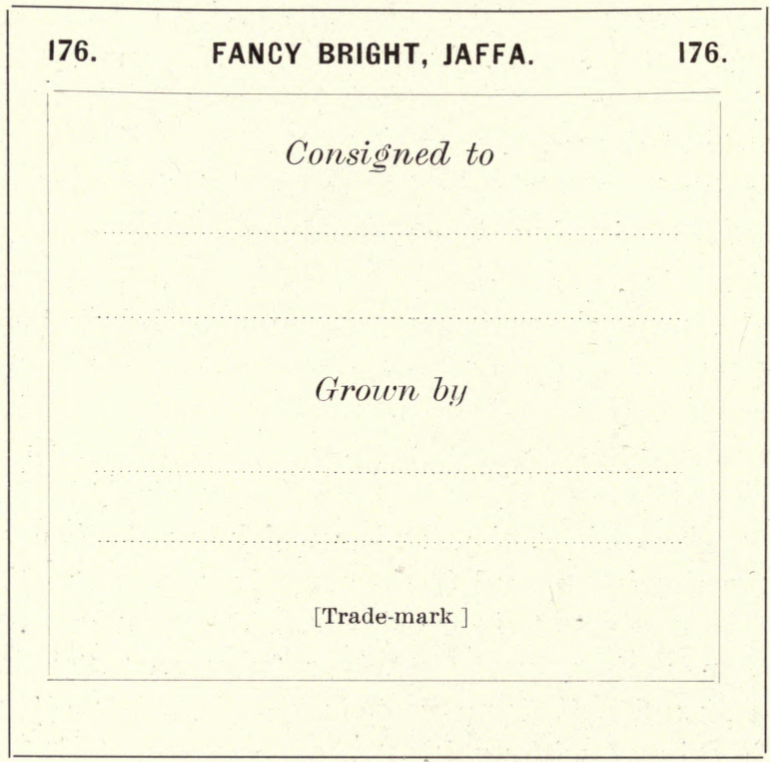

Packing Houses. Every grower of citrus fruits has his own ideal of a packing house, whether he has that ideal house or not. There are as many different kinds as there are growers. Hence, it is not possible to describe an ideal packing house, and the attempt will not be made at this time.

The capacity of the packing house depends upon the quantity of fruit to be handled. The floor space should be ample to provide room for storing the fruit before 
packing, for storing fruit for a short time after packing, for making boxes, for storing boxes and box materials, for headers or presses, for the sizer, and yet leave sufficient room for moving about. The boxes may be made and the materials and made-up boxes may be stored on the second floor of the building, but this is practically all the second story can be used for.

As a general rule, the fruit should enter at one end of the packing house and as it passes through the several processes of grading, curing, sizing and packing, it should move toward the opposite end. Sometimes it is possible to have the fruit move gradually downward from the point of entrance to the place of exit, and this is always advisable, as it saves much hard labor in lifting and handling the fruit.

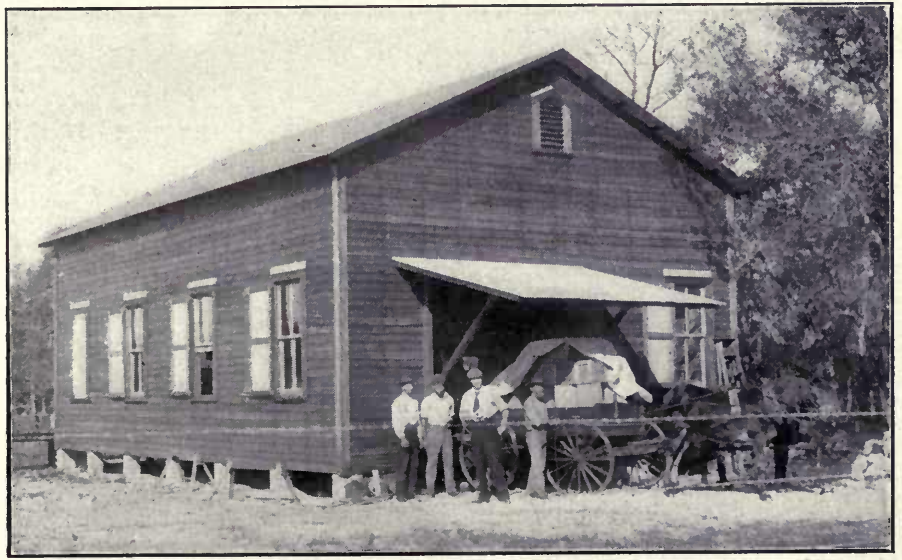

Fig. 97. Packing house of P. J. Bayley.

Fig. 97 is an illustration of the packing house of $P$. J. Bayley, Largo, Fla. The building is rectangular, with a lean-to on one side (not shown in the figure), in which 
the boxes are made. The fruit is delivered at the rear on a high platform. Just inside, floor space is provided for storing the fruit in field boxes. The sizer occupies a central position in the room and just inside the front door the fruit is packed and stenciled ready for shipping. The floor at the front is high enough from the ground to allow loading of the fruit into the wagon without unnecessary labor.

Plate XXXI shows the packing house of W. S. Hart. Here the fruit is delivered at the platform shown in the front, and to which a flight of steps lead up. In the corner is a small gasoline engine, used in operating the machinery in the packing house. As soon as the fruit is delivered, it is run through the large vat-like washer standing on the back of the platform. From the washer the fruit is lifted out and placed on the raised drying table at the right-hand end. The bottom of this table is composed of slats and it slopes gently away from the washer. From this drying table the fruit is gently rolled with a cloth covered broom into field boxes, and lifted into the curing racks inside. These run across the end of the lean-to, at the right end, down the entire length of the building. From the curing racks the fruit goes to the sizer, which stands in the peak-roofed portion at the left. The packing is done just inside the door at the left and the heads are placed on the boxes on the platform at the left. From this platform the fruit is hauled to the shipping point. Thus it will be seen that the fruit travels somewhat in a circle. The second story of the left-hand part serves for a store-room for materials and made-up boxes, and in this room the boxes are made as well.

Shipping. The express car is the ideal way of shipping, but it is, unfortunately, too expensive. Hence, in 


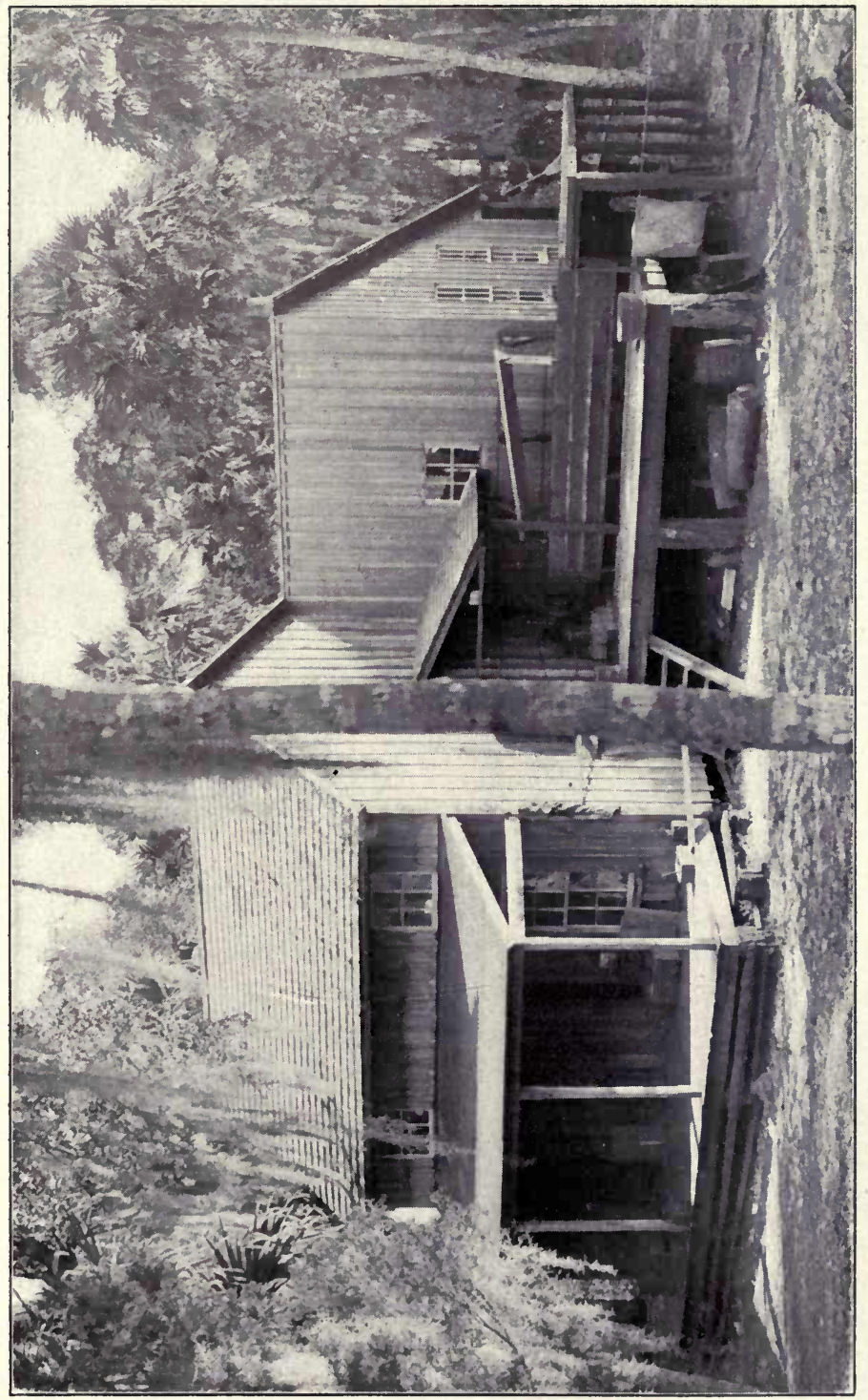

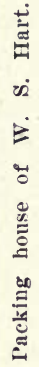


the majority of cases, the shipper must fall back upon the freight train. Most railroads in the citrus districts run through freights. Citrus fruits can generally be shipped without refrigeration, but clean, ventilated fruit cars should be used. Whenever possible, ship in carload lots. The fruit is not handled so frequently, there is not so much confusion at the receiver's end of the line and rates are usually less per box for carload lots.

The standard car of oranges, as given by the Southern California Fruit Growers' and Shippers' Association, is as follows :

"Navel Oranges. A standard car of navel oranges to consist of sizes 96 's and 200 's, inclusive; not over 15 per cent 96 's and 112's. Any excess of 15 per cent 96 's and 112's to be considered off-sizes and invoiced at a reduction of 50 cents per box. Sizes 64 's, 80 's and 250 's, navel, to be considered off-sizes and invoiced at a reduction of 50 cents per box from the price for regular sizes. Size 216 's in navels to be considered off-sizes and invoiced at a reduction of 25 cents per box.

"Seedlings, Mediterranean Sweets, etc. The standard car of other varieties (except Valencias and Paper-rind St. Michaels) to consist of sizes 126 's to 250 's, inclusive; not to exceed 15 per cent 126 's and 15 per cent 250 's. Any excess of 15 per cent 126 's and 15 per cent 250 's to be considered off-sizes and invoiced at a reduction of 25 cents per box. Sizes of seedling oranges, larger and smaller than 126's and 250's, inclusive, to be considered off-sizes and invoiced at a reduction of 25 cents per box. It is understood that each car of oranges may contain a reasonable quantity of off-sizes at the reduction named above." 
MARKETING.

The ways in which the fruit is disposed of may be roughly divided into-(1) Selling to a private trade. (2) Selling through commission merchants. (3) Selling through associations. Each person must make his own choice, after carefully considering the merits of each system.

The Private Trade. The fruit supplied to the private trade must be strictly fancy, and first-class in every respect. It must be neatly and carefully packed, in clean, neat packages. Everything in the appearance of the package and the quality of the contents must be indicative of a desire to please and satisfy the taste of the consumer.

Large quantities of fruit cannot be handled in a private trade. But when a trade is once established, there is a handsome profit from a comparatively small number of boxes.

The price obtained is, of course, much above that paid for ordinary packages. A fair price should be set on each package, and if a prospective buyer does not care to pay that price, then let him purchase elsewhere.

Every effort should be made to supply the same kind and grade of fruit each month or year. Do not ship a box of oranges of superior quality to a private customer one month and follow it up thirty days later with a somewhat inferior package. That is likely to create distrust, but let the fruit in the different shipments be uniform. The object should always be to hold a customer, once he is secured. Give him fruit that will make him want more of the same.

The fruit, going out as it does in small lots of one to five boxes, must generally be shipped by express. Express rates from the citrus districts are high, hence the 
private trade is usually dependent for its existence upon fruit consumers of considerable means.

Commission Merchants. The commission merchant either directly or indirectly handles the greater portion of the citrus fruits put on the market in America. He seems to be a necessity in reaching the consumer, both in large cities and in out-of-the-way places. Much has been said against him, little in his favor. We hear much of the dishonest commission man; we hear little of the dishonest, unscrupulous shipper, of the man who puts up false packages and who ships boxes, the contents of which are a disgrace to the labels they bear. The truth of the statement that the shipper is entirely at the mercy of the commission merchant cannot be denied, the selling of the fruit is left entirely in his hands. Still, there are honest men in the commission business and there are always ways of finding out whether a firm is reliable or not. Frequently shippers themselves are responsible for the existence of bogus commission houses. It may be well to discuss the selling of citrus fruits through commission men under separate heads.

Irresponsible Firms. Every now and then one hears of shippers who made a consignment to a certain house from which no return came. The loss might as well be placed on the credit side of the experience account. If a shipper has been sending his fruit forward for a number of seasons, he should know that his best policy is to stick to the firm he knows. The new shipper should find out whether the firm is reliable or not. Too frequently the fruit is picked and packed before the shipper has the remotest idea of where or to whom to send it. A letter is received giving glowing quotations, guaranteeing satisfaction, smoothly written and-well, the shipment is made 
and never heard from. Know the firm to whom you ship. If they are new, consult Bradstreet; enquire and go slow.

Dividing Shipments. Frequently the man with fifty boxes of oranges to ship will consign them to four or five different commission merchants in the same city. This practice seldom pays. He has to write four or five advices of shipment where one would suffice, and he annoys and worries the express and freight agents by compelling them to write out a greater number of receipts. The fruit arrives in the city. Along comes a small fruit dealer who in a few minutes makes a rapid tour of the commission houses. In four or five of them he finds fruit shipped by Mr. A. and plans his campaign accordingly. Of a commission merchant he asks the price, then blandly states, "I saw the same fruit down at- and they quoted it to me at twenty-five cents less." Another comes along and does the same thing and then another. Eventually that commission merchant believes the tale. The prices are cut and all the fruit of that kind in the market goes for less than it should. Ship to one man in a city.

Spasmodic Shipments. A grower shipping to New York learns that pomelos are fifty cents a box more in Boston. He ships to Boston, and perhaps by the time his fruit arrives the market has dropped and he gets just what he was receiving in New York. Then he hears of better prices in Philadelphia, ships there and gets fifty cents less per box than he could have got in New York. This may be somewhat exaggerated, but similar things happen nearly every day. If a small quantity of fruit is to be shipped, choose a market for it and ship it there. ship right along. The ups and downs will average as well as the spasmodic shipments will, and generally bet- 


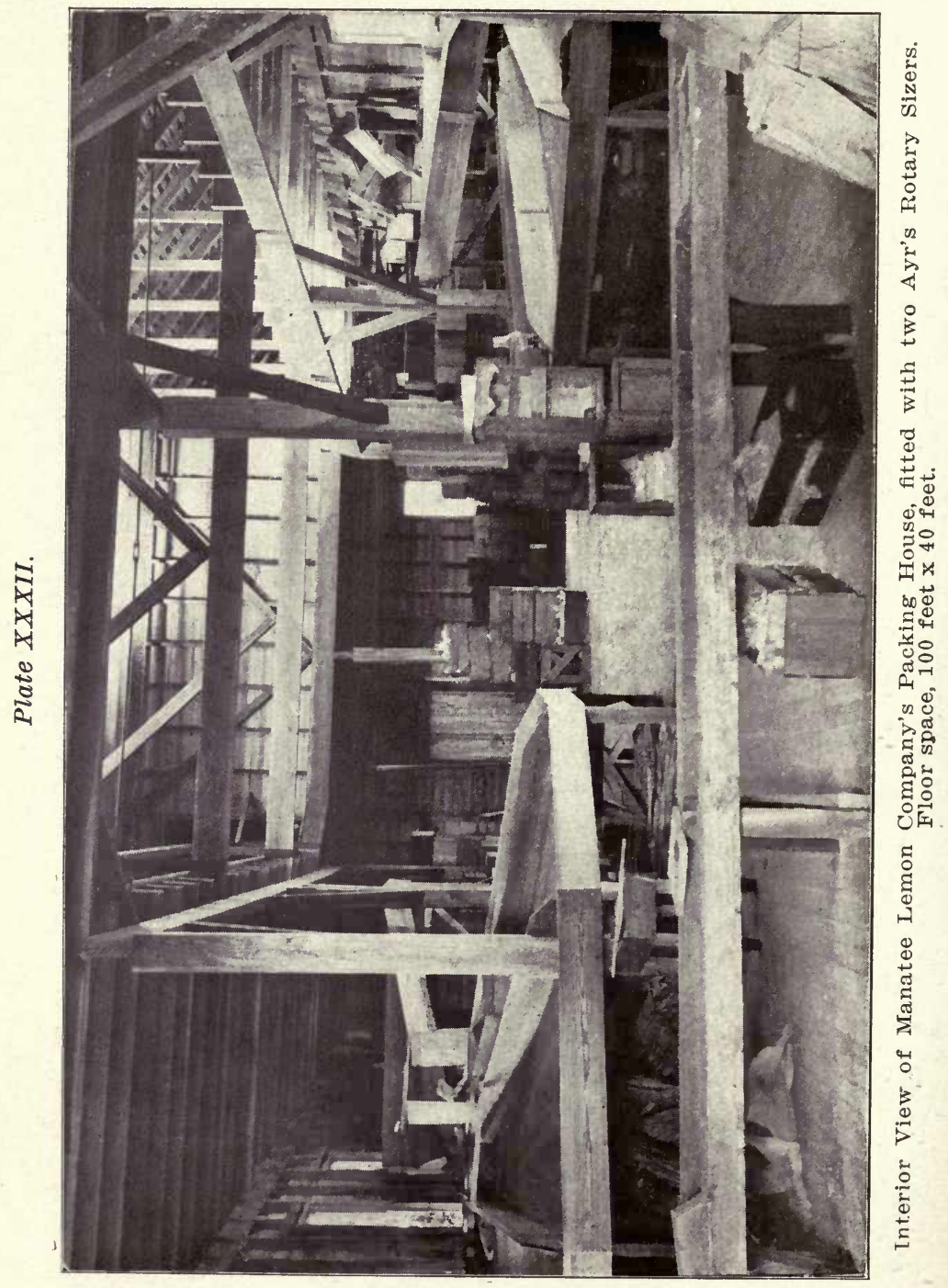


ter. If a large quantity of fruit is to be sold, distribute it to two or three markets and ship it right along, week after week, day after day.

Choose a Trade-mark. If a good grade of fruit has been grown, it will pay to select a design and put it on the packages. Put up neat, honest packages and send them forward. The result in time will be, "Have you any of that Crown Brand to-day?" "No, but a shipment is due to-morrow." "Well, I'll wait." Or the reply may be, "Yes, we have a shipment of one hundred boxes." "What is the price?" "Three dollars and fifty cents." "Very well, I'll take it." The buyer has not seen the shipment, but he knows that that Crown Brand stands for the best quality of oranges, first-class all the way through, and buys them on their reputation. That sort of a reputation pays. Read E. Bean's letter again.

Associations. The association has been brought forward as a substitute for the commission men to do away with the middleman and to bring the retailer and producer into closer contact. Much can be said in its favor and considerable can be said against it. It possesses some of the advantages of the large corporation over the small dealer. Lower rates of transportation can frequently be secured and fruit can be distributed to better advantage. Advertising can be done better, and more fruit can be handled. Uniform grades of fruit can be put up, if central packing houses are used, and many other desirable advantages can be secured.

But in practice the association has not always been an unbounded success. The fruit is generally sold by pool and this is unsatisfactory to those who grow fine fruit; result — trouble. Too frequently the salesman of the association is lacking in business capacity and ability. 
It is no easy matter to handle large amounts of fruit and market it advantageously. Again, he may be hampered in his work by having to please or try to please too many people. Trouble and dissensions arise and the association, however good in theory, too frequently, perhaps, goes to pieces in practice.

In California associations have met with considerable success and it is unfortunate that there are not more of them in existence in the citrus districts. 


\section{PART III.}

\section{DISEASES AND INSECTS.}





\section{CHAPTER YL.}

\section{FUNGOUS AND PHYSIOLOGICAL DISEASES.}

While the number of diseases affecting cirtus fruits is not nearly so large as that affecting many other groups of fruits, still they are of sufficient importance to attract serious attention. As a general thing they can be successfully combated by means at the disposal of every grower. Some, however, are due to negligence or maltreatment. Others of these diseases are intimately associated with the methods of cultivation and fertilization, but they may appear in groves where the best and most intelligent care is given.

Many of the diseases are due to the attacks of fungi. These attack different parts of the plants-the roots, stems, branches or leaves-and interfere with their functions, eventually bringing about the death of the part attacked and, in some cases, the whole tree succumbs. These fungi are spread by means of spores which bear the same relation to the fungus as seed does to the higher plants. The spores are scattered by the wind or rain and under favorable conditions of heat and moisture, grow and enter the tissues of the plant. Slender fungal threads, the mycelium, grow about in the tissues until they have obtained food enough and have grown suffciently to produce spores again. These are again scattered, and so the life circle is completed. In the following pages diseases of this nature are placed under the heading of Fungous Diseases.

There is another class of disease which attack citrus and other trees or plants. These are intimately associ- 
ated with the life functions of the cells. These are grouped under the general name of Physiological Diseases.

FUNGUS DISEASES.

Foot-rot, Gum Disease, Mal-di-goma. So far as known, this disease occurs in nearly every citrus district in the world and none of our American centers are free from it entirely. Its history in Europe extends back to about 1845 and it worked destruction in the groves of the Azores some years previous to that time, and, in fact, seems to have been first noted there. In Florida, it has been responsible for the disappearance of many of the old sweet seedling groves and the discontinuance of the use of the sweet orange as a stock, as noted in the chapter on stocks.

Foot-rot is clearly marked and not likely to be confounded with any other disease. It is confined to the crown and main roots of the tree, extending a foot or so above the ground and downward along the roots. Its presence is first indicated by an exudation of gum, which forms in drops on the bark covering the diseased spot. Further examination at this time reveals a brownish coloration of the outer cortex and a decayed condition of the inner. The affected areas emit a fetid odor similar to that from a decaying orange. All plants, when attacked by a disease, strive to overcome it, and this the orange tries to do by cutting off the affected portion by a wall of new tissues similar to that formed around an ordinary wound. Following this, the bark covering the spot dries up, breaks away from the adjoining parts, and drops off. The wood is then found to be decayed for a short distance beneath. 
Though the tree still continues to bear fruit, its appearance is far from healthy; the leaves become yellow, the twigs and young branches die, and the whole tree assumes an unthrifty appearance. Where the affected tree can be seen from a distance, it stands out in marked contrast to its neighbors. Unless the disease is checked in some way, the tree attacked eventually succumbs and has to be removed.

Fortunately, all varieties of citrus stock are not in the same degree subject to this dreaded disease. In order of foot-rot resistance they stand about as follows: Sour orange, Citrus bigaradia; rough lemon,

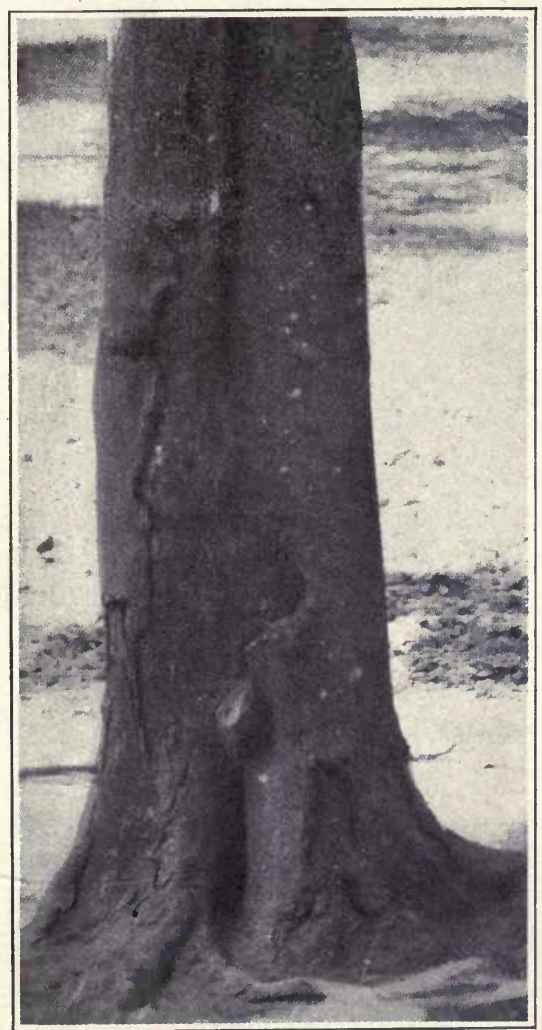

Fig. 98. Foot-rot on crown roots and trunk of sweet crange.

C. Limonum; trifoliate orange, C. trifoliata; pomelo, $C$. decumana; lemon, C. Limonum; sweet orange, C. aurantium. Roughly, we may class the first four as decidedly resistant, the last two as very much subject to the disease. 
Cattle-penning; deep-setting; a wet, soggy soil condition; the use of rank, organic nitrogenous fertilizers; planting in localities underlaid with hard-pan; faulty drainage; a shaded condition of the soil, and many similar circumstances and practices have been given as the cause of foot-rot. While it is not probable that the disorder is due to any of these, there is no doubt that they have a deleterious effect on the general health of the tree, and so act as a predisposing cause. A healthy, vigorous tree has all the chances in its favor for withstanding the inroads of disease, and any decrease in its vitality simply gives its enemies an opportunity to gain a foot-hold.

The specific cause of the disease is still in doubt, but it is probably due to some form of vegetable parasite. Prof. Giovanni Brioze, * in 1878, found a fungus, Fusisporium limonii, constantly associated with the disorder, but was not certain as to whether it was the specific cause or not. Regarding it he states: "But that its presence ought to accelerate the disorganization of the tissue and contribute to extend the evil, I think I see without any doubt."

As pointed out above, there are many conditions which bear an important relation to foot-rot, and a brief discussion of some of these will not be out of place. (a) Cattle-penning and pasturing, so often resorted to for the purpose of fertilizing the groves, is, to say the least, a questionable practice. The sharp hoofs of the animals cut and bruise the bark on the crown roots, and thus, through their agency, this possibly parasitic disease may be more rapidly carried from affected to unaffected trees.

* Intorno al Mal Goma Delgi Agrumi, Statione Chimico-Agraia Sperimentale Di Roma. pp. 1-16, p1. I. 1878. (Estrata dal Vol. 11, Series 3a Atta della R. Academia del Lincei.) 
Then, too, the rank manure may act injuriously, and there is no doubt that there are better means for supplying the requisite plant food than this. In fact, we believe that the best orange is produced $\mathrm{by} \mathrm{the}$ judicious use of commercial fertilizers. (b) Close planting is often resorted to as a means for shading the ground. A moist or damp condition of the soil is produced about the tree, which, in the warm citrus climates, is exactly suited to the development of disease. It would be decidedly better to provide a surface mulch, either by the growing of leguminous crops or by providing a mulch of leaves and leaf-mold. Air would then be freely admitted, and the sunlight, one of the best germicides we have. would be allowed to reach the soil. (c) The piling of rubbish, old tin cans, palmetto roots, etc., about the trunks of trees is to be strongly condemned. Where a mulch of leaves or grass is placed close to the trunks it should, from time to time, be removed to allow the soil to dry out on the surface. When banking with earth as a protection against frost is practiced, the banks should be promptly removed in spring. $(d)$ Strict attention should be paid to drainage, that no stagnant water be allowed among the trees. A soggy, ill-drained soil is not conducive to the health of an orange tree. In sections where the basin method of irrigation is used, a cone of earth should be banked against the trees to keep the water from the trunks. This bank should be removed shortly after irrigating. ( $f$ ) New groves should be set only on resistant stocks and where injury from frost is not feared, they should be worked a considerable distance above the ground. The disease frequently attacks the trunk above the point of union, particularly if it be close to the ground. 
Treatment. This consists in removing, as far as possible, the detrimental conditions to which reference has just been made and particular attention should be paid to everything conducive to the health of the grove.

Carefully remove the earth from about the tree, avoiding injury to the healthy roots. With a sharp, strong knife, cut out all the diseased tissue down to the healthy wood. Burn the material removed. With a brush paint the freshly cut wood with solution No. (3), (4), or (5), or sprinkle solutions Nos. (4) or (5) over the cut surfaces and the adjoining soil.

Leave the earth removed until such time as the tree has recovered, and then it would be better to fill in with fresh, porous earth. In closely planted groves remove a sufficient number of trees to let the light reach the ground. These can be set out in another plot of ground. Disinfect cultivators, plows and harrows with carbolic acid after using them in diseased groves, and before use among healthy trees. As a preventive measure, use resistant stocks, as already indicated, and where trees have died out, re-set with others budded on sour orange, rough lemon or pomelo, as the soil conditions render necessary.

Frequently trees may be made to serve some years of usefulness by planting a number of small resistant stocks around the affected tree and inarching them above the injured parts.

Scab, Lemon Scab, Sour Orange Scab. This citrus disease attacks the sour orange, bitter-sweet, lemon, Satsuma, Rangpur lime, and it has been found slightly affecting the King mandarin, the pomelo and kumquat. In some districts it has become a serious inconvenience in the production of smooth. marketable lemons, but for- 
tunately it has not made its way into the California districts, at present the most important in America.

While the sour orange is very badly affected by scab, little notice is taken of the disease on that host, as it is used principally as a stock on which to work other varie ties, and is usually cut off Fig. 99. Scab on young fruit and leaves or Satsuma. when a year or two old. It is, however, a drawback in the production of healthy, vigorous stock. But it is with the injury done to the fruit of the lemon that we are most concerned from an economic standpoint. Lemons, to sell well, must be perfectly bright, clean and smooth, and when they are badly affected by this disease, they are rendered unsalable. A rough, distorted fruit finds no place in our markets.

The scabby leaves, twigs and fruit are very characteristically marked. Warty, corky elevations cover the surface, giving to it an unsightly, roughened appearance. Often the leaves are twisted or drawn out of shape, and they are in a considerable degree deprived of the power to fulfill their natural functions, namely: respiration, 
transpiration and the assimilation of food. Beneath the warts on the opposite side of the leaf, there is often a well-marked, conical depression, corresponding to the elevation on which the excrescence is situated. Under the warts on the fruit there is an abnormal thickening of the tissue, resulting in the formation of somewhat conical elevations. Thus the corky portions are lifted above the normal level of the rind. The warts are at first yellowish, then grayish, becoming dusky in appearance as the disease advances, until they become almost black, and eventually crack and open. When the excrescences are isolated they are minute and of the shape of a cone or truncated cone. Generally, however, they are confluent, presenting the appearance of a bark-like substance firmly at-

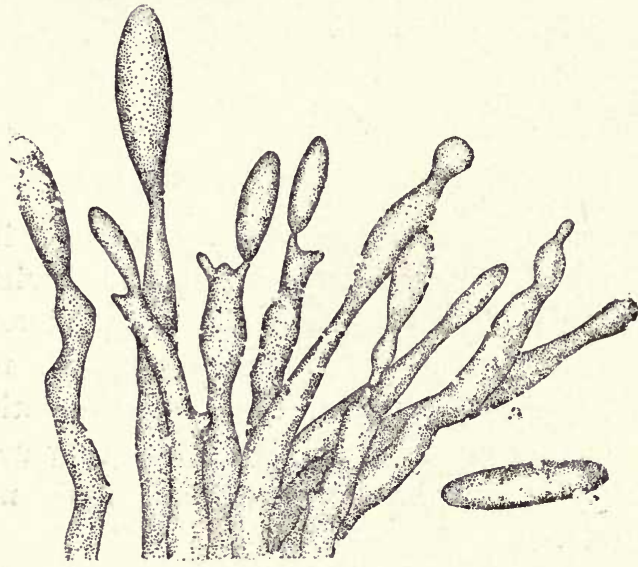

Fig. 100. Spores and spore-bearing parts of scab fungus (Cladosporium elegans penzig). $B$, spores. A, spore-bearing parts. tached to the epidermis.

The specifio cause of the disease is a minute parasitic fungus, a species of Cladosporium described b y Prof. F. Lamson-Scribner in 1886, probably identical with $C$. elegans Penzig. The spores are very small, smoky in color, and usually one or two, though sometimes three-celled. They are borne on brown- 
ish colored sporophores (spore-bearing filaments). When mature, they become detached and, through the agency of the wind, they are carried about from one tree to another. Falling upon the young leaves of their host, under favorable conditions they germinate by sending out a delicate, slender tube, which enters the leaves and gives rise. in due time, to the well-marked and easily recognized diseased condition.

Remedies. The disease can be successfully controlled by using one of the copper spraying solutions, Bordeaux mixture or ammoniacal solution of copper carbonate. The latter must receive the higher recommendation, as it is less likely to injure the tender leaves and blossoms of the lemon, but a weak solution of Bordeaux mixture is likely to prove quite as efficacious, without any harmful results.

The question at once arises, "Am I not likely to do injury by killing as well the parasitic species of fungi that work destruction to the various scales that infest the trees?" This will have to be borne in mind, and, if necessary, follow the spraying with an application of whale-oil soap, kerosene emulsion or resin wash. To prevent scab, spray three times. Give the first application just after the petals have fallen from the first blossoms and two others inside the next six weeks. If the disease gains ground on the young fruit, further spraying will be necessary. Shoots of sour orange and diseased fruit should be removed and burned.

Leaf Spot. Frequently upon the leaves of citrus trees round dead spots are found. These spots eventually break away, leaving the leaf tattered and torn. The fol- 
lowing description of the disease will assist in recognizing it :

Large, some-

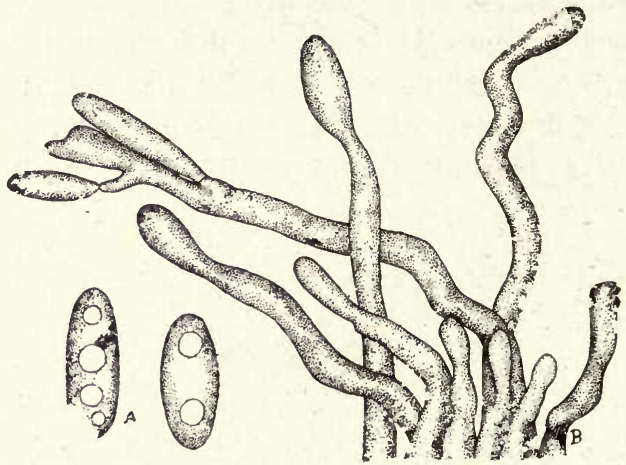

Fig. 101. Spore and spore-bearing parts of leaf-spot fungus. B, spore-bearing branches. A, spores.

what circular, yellowish spots are noticed on the leaves. Close examination reveals the presence of minute dark dots scattered thickly over the discolo r e d areas. These small, dark spots contain the spores of a parasitic fungus, which is the cause of the trouble. The sporules are borne on short filaments which are contained in the brownish-black conceptacles. Fig. 101 shows some of these conidia and basidia, greatly enlarged.

This fungus has been known under two different names. It was described as Phyllosticta adusta E. \& M. from the specimens collected by Dr. Martin. Later it was referred to the genus Colletotrichum and named $C$. adustum E. It appears, however, to be identical with Colleto trichum gloeosporioides Penz.

More recently, Rolfs has demonstrated that two or three diseases, hitherto not investigated, are caused by the same fungus. It is responsible for the dying back of the twigs of citrus trees, for the death of the blossoms of the lime, for the anthracnose of the lime and the black-spot disease on the rind of the lemon.*

* More recently the author has investigated a serious disease of pomelo fruit caused by the same organism. 
Treatment.-The disease can be held in check by spray-

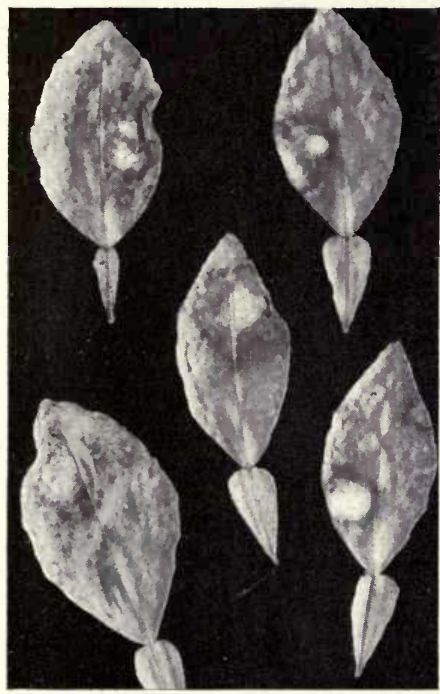

Fig. 102. Leaf-spot fungus on pomelo leaves. The light areas are the spots affected. ing with Bordeaux mixture or ammoniacal solution.

Ripe-rot of Citrus Fruits. Frequently ripe specimens of $\mathrm{citrus}$ fruits, more particularly, perhaps, oranges and lemons, show a yellow covering of dust-like, bluish powder. If observed in an earlier stage, the area will be whitish, instead of bluish, later the whole fruit ball becomes small and shriveled and the powdery substance occupies a relatively larger space.

The rotting of the fruit is caused by a fungus, Penicillium Italicum, closely allied to the common blue mold which forms on bread, and the powdery mass is composed of innumerable spores. The white coating of the fruit, on some injured spot, is the "mycelium," the vegetative part, which bears the same relation to the fungus that the roots do to a higher plant. The mycelium grows into and through the tissue of the fruit. After de veloping for some time and reaching a certain stage of growth, the fungus forms spores. These are visible as the bluish, powdery moss. The spores are joined together in the early stages in bead-like strings. As they become matured, they break off and blow away. They are 
thin-walled and oval in outline. The upper portion of Fig. 103 shows a number of these spores much enlarged.

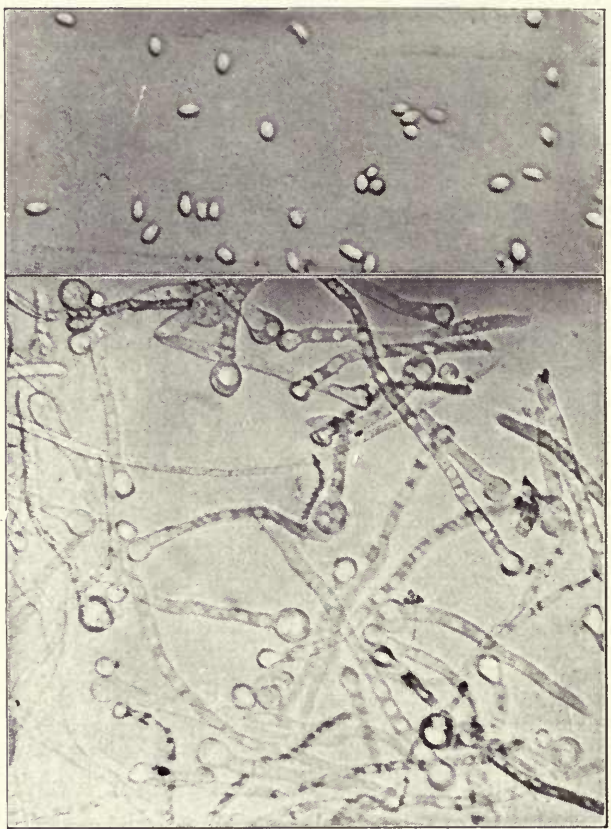

Micro-photograph by Miss L. McCulloch.

Fig. 103. Spores of ripe-rot fungus above, germinating spores below, greatly enlarged.
The spores are blown about by the wind and fall up on the fruit. There in the presence of moisture the $\mathrm{y}$ start to grow, as shown in the lower half of Fig. 103. A slender tube is sent out which continues to lengthen. If it can find an entrance into a fruit it grows a n d develops, forming a mycelium, and spores are again soon produced.

$\mathrm{C}$ e $\mathrm{r}$ t a i $\mathrm{n}$ weather conditions are particularly favorable to the disease. Hot, damp days and nights are ideal for the growth of the fungus, while cold, dry weather does not favor its development.

The disease most frequently gains access to the fruit in some injured spot. A slight bruise is sufficient. Insects puncture the rind and give a chance for it to enter. If fruit is improperly cured and tightly packed into the 
boxes, it may be injured and the fungus have a chance to attack the fruit, most usually developing where two are pressed closely in contact. In the field it frequently attacks fruits hanging together on the trees and causes considerable damage. In California, Woodworth reports the entrance of the fungus through the navel end of the Bahia orange as being quite common.

Treatment. Fruit should be carefully handled and packed. The fruit should be thoroughly cured and dry when packed. Carefully wrap the fruit, using a good quality of paper, one not readily affected by moisture. This will prevent the spread of the disease from one fruit to another in the box. If the spores of the fungus have become abundant in the packing house, it should be tightly closed and fumigated by burning sulphur in it. Plenty should be used. Thorough ventilation of the packing house will assist materially. Cull fruit should not be left about to rot and decay. Decayed fruit should be destroyed, preferably by burning.

Sooty-mold, Meliola Camelliae (Catt.) Sacc., is widely distributed throughout the different sections where citrus fruits are grown. It occurs as a sooty. black covering on the leaves, fruits and twigs of many plants, and is intimately associated with various insects belonging to the families Aleyrodidae Coccidae and Aphididae. In Florida it follows Lecanium oleae on $\mathrm{Ne}$ rium oleander and Persea Carolinensis; Aphis gossypii on the orange, eggplant, and many other herbs, shrubs and trees; Lecanium hesperidium, Ceroplastes floridensis, Icerya purchasi, Aleyrodes citri and other insects on citrus trees. In short, may be said that it is found with all the scale and allied insects which exude honeydew in any considerable quantities. 


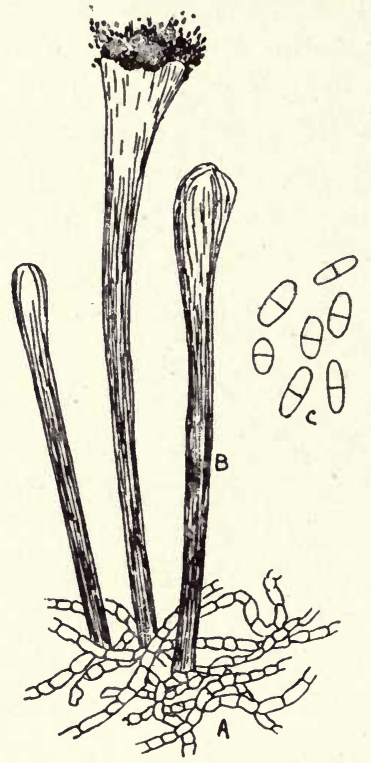

Fig. 104. Sooty-mold. A, Myceliun. B, Conidiophores. C, Conidia or spores. (Eniarged.)

The fungus is a saprophyte, and is dependent upon this honeydew for its sustenance. The insects already referred to are gregarious in their habits. Consequently, the honey-dew accumulates in considerable quantities on various parts of the plant, and in this substance the fungus lives. The black covering is composed of its vegetative threads. A number of different kinds of reproductive bodies are produced, and, through the agency of the wind, are carried about from tree to tree. Wherever suitable food material is found, there the fungus develops.

It is when it follows the attacks of the white fly, Aleyrodes citri, or allied insects occurring in enormous numbers on citrus trees, that it does the most damage. The white fly spends a great portion of its life on the under sides of the leaves. The honey-dew exuded by it falls upon the upper sides of the leaves beneath and upon the twigs and the stem ends of the fruit. In this honey-dew the fungus grows and soon covers the trees with a thick, black, sooty covering, so that they appear from a distance as though covered with a liberal application of stoveblack.

Sunlight is necessary to the leaves of a tree, that they may carry out their work in the plant's economy. The 
black screen of fungal threads prevents the light from reaching the leaves. Their natural functions are interfered with and the tendency is to keep the tree in an unhealthy condition. Often the yield of bearing trees is greatly lessened as a direct consequence.

Bearing on the effects of sooty-mold and white-fly on citrus trees, the following remarks by H. A. Gossard, in Bulletin 67, Florida Experiment Station, are of interest:

"The following table shows the results of a chemical analysis made at my request by Professors Miller and Blair, of three lots of fruit picked the same day from adjoining Dancy tangierine groves, both of which were infested with white-fly and had been given practically the same treatment as regards cultivation and fertilizing. Fifteen or twenty oranges were selected for each of the three lots, representing as accurately as possible the average condition as to size and maturity on each of the three trees from which they were taken.

"Sample No. 1 was from a tree that had been infested for several years and had been left to take care of itself.

"Sample No. 2 was from a tree about forty feet from No. 1 and was regularly and properly sprayed three or four times each year, but stood in the row adjoining the unsprayed grove, and the insects could not be prevented from developing upon it in numbers sufficient to cause more or less mold.

"Sample No. 3 was from a tree eighty feet from No. 1 and was properly sprayed as was No. 2, but with better results. A few larvæ were present on the leaves, but, practically, white-fly could be considered wholly absent. 
No.

Reducing Sugar- Total Sugar Dextrose-Citric Acid-
Per Cent.

Sample No. $1 \ldots \ldots .2 .18$

6.71

.425

Sample No. 2.... 2.23

6.25

.394

Sample No. $3 \ldots \ldots 2.58$

7.91

"These samples were collected in February, after they had passed their best, but it is believed that they kept their relative quality."

The immediate damage is to the crop. The stem end of the fruit becomes covered by the mold; it colors irregularly and, unless cleaned in some way, is often unfit for market. Various methods are used to remove the sooty covering from the oranges. Some use a lidless box. Over the open side, a piece of coarse sackcloth or canvas is stretched and on this cross-cut sawdust is scattered. The oranges, one or two at a time, are taken and ground about on this until the soot is removed. Another machine consists of a hollow cylinder mounted on stationary posts, and having a crank attachment. This is partially filled with oranges and sawdust and revolved until the fruit is bright. Washing with a cloth or brush is also resorted to, and some simply use a dry brush. Often, however, the oranges appear on the market with the mark of mold upon them. This is particularly the case if the fruit is anywise rough-skinned, the fungal threads still remaining in the depressions.

The additional cost of harvesting and marketing a crop of oranges is very considerably increased and the fruit can not help but suffer to some extent from the harsh treatment it often receives. Oranges have been noticed which had been so vigorously cleaned that the epidermis had been torn and the oil-glands of the rind laid open. 
This, together with the injury occasioned by bumping the fruit about, is certain to impair the keeping qualities.

For washing the fruit, the cylinder-washer manufactured by S. C. Warner, of Palatka, Fla., is one of the best.

Treatment. No method of treatment for the fungus alone can be recommended, the insects should be destroyed and, if this be done, the fungus will disappear, as the honey-dew provided by the insects will no longer be present.

Flyspeck or Sooty Fungus (Leptothyrium Pomi (Mont. et Fr.), Sacc.) The flyspeck fungus covers the rind of the citrus fruits with a superficial sooty covering of greater or less extent. Sometimes this covering is almost continuous over considerable areas, while in other cases it occurs in isolated, irregular patches. When the rind is badly affected, it gives the fruit a blotched appearance far different from the bright yellow or golden hue of the fruit. The blotched appearance is caused by the sooty patches alternating with patches of unspotted rind.

On the sooty areas, large numbers of minute black specks, each about the size of an ordinary pin point, are frequently found. Generally they are more or less aggregated. Sometimes these specks are found without any accompanying sooty growth, in which case it may be concluded that the sooty growth was at one time present, but eventually disappeared, leaving only the small, black spots. The sooty covering must not be confused with sooty-mold, so common a companion of various insects, as already noted. It is entirely distinct from it and the flyspeck fungus is in no way connected with the attacks of insects or their presence on citrus trees. 
The cause of the trouble is a fungus, the scientific name of which is Leptothyrium Pomi, common in apple districts, where it develops on the fruit, both on the tree and in storage.

The sooty spots consist of a formation of the fungal threads; on the rind they are black, but viewed under the light, they are light brown in color. The minute spots appear to consist of more closely-woven strands of fungus, as though a small spore case were in process of formation. Whether this is the case or not, spores, by means of which most fungi are disseminated and propagated, have not yet been discovered in this fungus, and appear in all cases to be entirely lacking.

Anything which may be said regarding the way in which the fungus spreads must be more or less conjectural. The fungal threads may become detached and blow about, or it may be that spores, not yet discovered, may be produced. Since citrus fruits frequently grow ir clusters, the fungus may easily spread from one fruit to another.

So far as lias been observed, no damage is done the fruit, but when the fungus is present in abundance, it renders the fruit unsightly, and, consequently, depreciates the market value.

Treatment. Nearly all traces of the fungus may be removed if the fruit is washed, and since it makes its appearance about the time the fruit matures, this is the best possible treatment. It will yield readily to an application of solution No. 1, but this treatment can scarcely be recommended.

Melanose. This disease was first brought to notice by Webber and Swingle in 1896. It was quite prevalent in the vicinity of Citra, Fla., at that time. Since then, 
it has been found in a number of different places, but as yet has not caused sufficient damage to attract serious attention.

On the leaves, fruit and twigs of affected trees small brownish-black spots are to be seen. These spots are sometimes separate and sometimes confluent. Where separate, the intervening tissue is apparently quite normal, but where confluent to any considerable extent, a brownish tinge is given to the whole leaf. The spots are somewhat elevated and are occasionally found to be cracked or fissured at the apex. Under diseased trees large numbers of leaves are found, showing to what extent the disease has been injurious. The disorder causes damage to the trees by defoliating them, rendering the leaves unable to carry out assimilative processes for quite a time before they drop, and also in rendering the fruit unsightly, because of the irregular dark-colored areas which cover the surface.

Careful microscopical examination has been made of the diseased spots, but nothing has been found to which the trouble might be attributed. It has been suggested that it may be caused by some vegetable organism, but thus far nothing has been found to establish this fact beyond the observation that the disease seems to spread from tree to tree, and the fact that it yields to applications of fungicides.

Dr. N. A. Cobb, of New South Wales, called attention to a disease of citrus fruit to which he applied the same name, believing them to be identical. McAlpine,* however, after carefully comparing Australian and Florida specimens of diseased leaves, says, "For the present, at any rate, the two diseases cannot be considered identical."

* Fungus Diseases of Citrus Fruits in Australia. 16. N., 1899. 
Treatment. Experiments have shown that this trouble may be controlled by the use of Bordeaux mixture in very weak solution, one to twelve and one-half or fifteen used as a preventive, not as a curative. The dangerous period to the fruit is while it is still young. It would be best to commence spraying during the dormant period, before the trees bloom, and spray once a month until the fruit is well formed, that is, about the month of July.

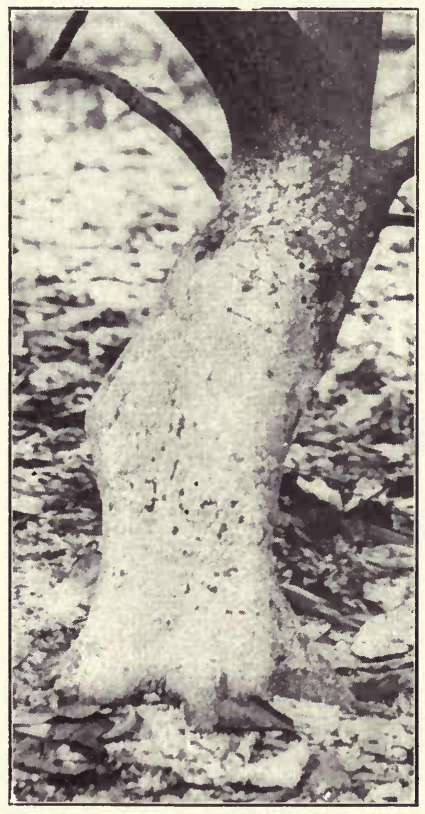

Fig. 105. Lichens on trunk of an orange tree.

Lichens. These plants are found growing upon stones, logs, boards, fences and living trees throughout the country. In color they are yellow, green, reddish or gray. Their forms are many and varied; some adhere closely to the substances on which they grow (crustaceous); some are branched and elevated (fruticose); while others present a rough, crumpled surface (foliaceous). From the botanist's standpoint, lichens are among the most interesting members of the vegetable kingdom; they consist of a fungus and an alga growing together, each contributing to the welfare of the other (symbiosis). The fungus furnishes water containing food in solution and shades 
the alga, which, in return for these good offices, supplies the former with the result of its assimilative processes.

The moist, warm climate of some of the citrus districts is ideal for their development. In many orange groves the trunks and the larger branches of the trees are covered with lichens; they are obnoxious to the eye, and to a certain degree detrimental to the health of the tree. They are not parasitic, but they prevent a free interchange of gases through the bark, thus to some extent, producing a condition injurious to the health of the tree; and certain it is, they are never so plentiful on healthy, vigorous trees as upon those which are in poor condition. They serve also as a harborage for insects and insect eggs.

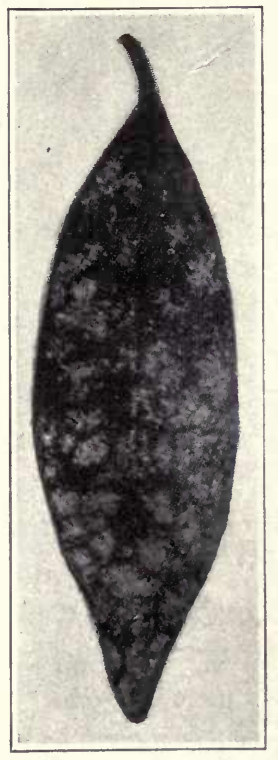

Consequently, it is very desirable that the trunks of the trees should be kept free from lichens, and, fortunately, this is easily accomplished at a very slight cost. One treatment every two or three years will be sufficient to keep the trunks in a clean, healthy condition.

Besides those found on the trunk and large branches, a lichen, Strigula complanata (Fee and Mont.) $\mathrm{Nyl}$, is frequently met with on the leaves of citrus trees. It occurs in the form of small ashy-gray dots and blotches on the upper surface of the leaves, Fig. 106. Here and there on these blotches may be seen small, black specks, the fruiting bodies of Fig. 106. Lichen (Strigula the lichen. This species injuriously
complanata
[Fee \& Mont.] complanata [Fee \& Mont.]
Nyl.), on leaf of Kumquat. 
access of light and upon the action of light, the assimilation of food depends.

Treatment. Spray the leaves with formula (1), and either apply to the trunks as a spray or apply with a stiff brush and scrub them clean. Scrub

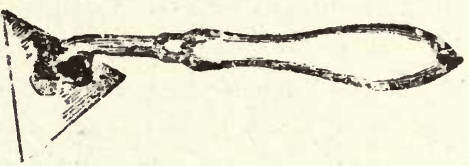

Fig. 107. Tree Scraper. trunks and limbs with soap suds. A tree scraper may frequently be used to advantage.

\section{PHYSIOLOGICAL DISEASES.}

Die-Back. This disease takes its name from the fact that the young twigs and branches of affected trees die

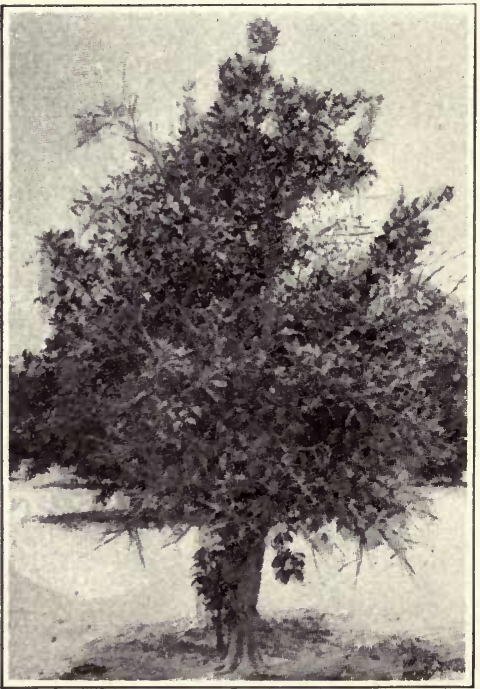

Fig. 108. Orange tree showing effects of die-back. back to a distance of f r o m two to eight inches, or even more, from their tips. Subsequently the older and larger $1 \mathrm{imbs}$ and branches are affected, unless the disease is checked.

No citrus trouble is more widely distributed throughout Florida than die-back, and it occurs in California and other citrus districts as well. No locality is exempt from it and no variety free from its attack. Trees, 
young and old, suffer alike, and a few trees have been found affected which were still standing in the nursery rows. Very often, little notice is taken of it, and it gradually works its way, nipping off the new growth, and the trees, in consequence, make very little progress. Years of work and much capital are often wasted in mistaken efforts to bring a grove into healthy condition.

The disease is easily recognized. The young twigs die back several inches. Irregular, reddish-brown elevations, at first closed, later cracked open and filled with a resinous substance, make their appearance on the small branches and twigs. These vary greatly in length, height and shape. Often elevated pustules, filled with a gummy substance, occur on the young growth. These seem, in some cases, at least, to develop into open ruptures. Adventitious buds are frequently produced, and those which are not smothered by the resinous exudation develop, thus giving rise to several branches from a single node. Sometimes the only noticeable mark of the disorder on a branch is the presence of a resinous knot in the axils of the leaves, where the buds should be. Slightly affected branches have often a dark, greasy appearance. The small growth is usually twisted and bent. On the fruit the disease is manifested by the presence of dark, brownish blotches and by cracking or splitting. Many fruits drop off. As the disease advances the trees try in vain to throw out new branches. Symptoms become more strongly marked, the tips of the bare, distorted branches protrude above the dark-green foliage. Gradually the larger branches are embraced, water-sprouts develop only to become affected and die. Eventually the tree succumbs.

Die-back is not a fungous disease, no spores nor fungal threads having been found connected with it as causal 
agents. It appears rather to be a disorder brought about by a variety of circumstances, and the external marks of the disease are to be regarded as an indication of a deranged condition of the whole tree. In certain localities it seems to be brought about by the presence of hardpan in proximity to the surface. Again, the condition seems to be due to a wet, poorly aerated soil. But perhaps the most prolific source of the trouble is the use of fertilizers unsuitable to the orange tree. Now, whether we should make a distinction in die-back as induced by these several causes, it is difficult to say, but it is probable that in each and every case, the same causative agent, an enzyme, is at work.

Many instances have come under the observation of the writer, of the occurrence of the disease where trees were planted in ground previously used in growing vegetables, and which was heavily fertilized with blood and bone and cotton-seed meal. Then, too, in some localities the spaces between the tree rows have been used for growing vegetables, the same fertilizers applied as in the cases just mentioned, and with the same deplorable effect on the orange trees. The disease has been observed in groves regularly fertilized with rank nitrogenous fertilizers, and trees standing near and receiving nutriment from stables, closets and hencoops are generally affected. The general conclusion reached by all observers during the past fifteen years or more has been for the most part to the effect that the excessive use of organic nitrogenous fertilizers will cause die-back, and the matter has been pretty thoroughly discussed in the horticultural papers of the citrus districts. 
Treatment. This consists for the most part in removing conditions and discontinuing practices which induce the disease. Make a thorough study of the soil and the methods of fertilizing. In some places, with trees growing on hard-pan, the following plan was adopted and they made a complete recovery: The trees were cut back, lifted from the ground, the hard-pan removed, either by blasting or picking it out, and the trees re-set. The remedy for trees growing in damp ground consists in paying proper attention to drainage and fertilizing. Tile or box drains should be put in to remove the water and allow the air to enter.

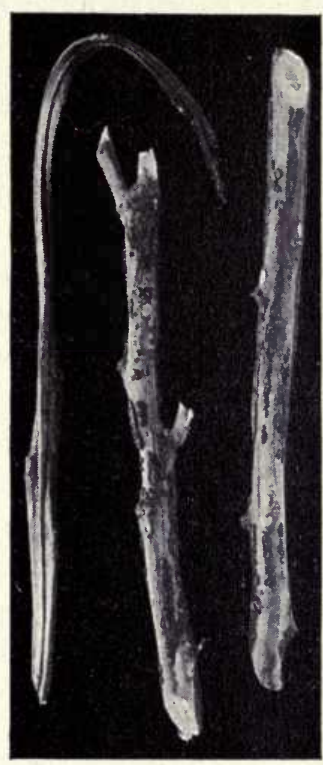

Fig. 109. Die-back on orange twigs.

Where the disease has been brought about by the use of fertilizers, as before indicated, discontinue their use, discontinue cultivation, allow the natural vegetation to spring up and apply potash and phosphoric acid as usual. Continue this treatment until recovery takes place; then resume cultivation and fertilization, using nitrate of soda or sulphate of ammonia as a source of nitrogen.

Solution No. (1) has in many cases given excellent results, but sometimes no results have been obtained. It is doubtful whether the injurious effects of a hardpan sub-soil can be overcome by spraying. But in other instances it may prove beneficial. Because Bordeaux mixture is a fungicide and has given results in cases of 
die-back, some have argued that this disease is due to a fungus. This is not the case, however, and the beneficial results must be attributed to the chemo-toxic effects of the solution in accelerating the assimilative processes in the leaves and other green parts of the trees.

If the spraying method of control is adopted, three or four applications should be given at intervals of about thirty days. It must be borne in mind that Bordeaux mixture is not an insecticide, but on the other hand its use is generally followed by an enormous increase in the number of scale insects. Therefore, it is absolutely necessary to follow the applications of Bordeaux up with a good insecticide, such as Good Potash Whale-oil Soap, No. 3, to keep the scale insects in check. If the grower is unwilling to do this then spraying must be left alone and the cultural treatment adopted.

Blight. This is the most dreaded of all citrus diseases, because, thus far, no satisfactory means have been discovered of preventing or combating it. The history of the disease is not definitely known, but it has been prevalent in the Florida districts for a number of years. Many of the worst affected groves have disappeared, but the disease is still quite prevalent.

Blighted trees appear as though suffering from drought, or look as though they had recently been transplanted. The leaves wilt, droop and finally drop off. In some cases the disease works very rapidly, in others its progress is decidedly slow. It often manifests itself on a single branch and from that gradually spreads over the whole tree. Trees affected in this way live for a considerable length of time. But in many cases it soon brings about the death of the tree. Shoots spring out from the trunk and crown roots of the tree. These also succumb 
eventually. The leaves produced on these shoots are usually quite yellow between the veins and have a peculiar constricted appearance.

Thus far, the cause of the disease remains unknown. Trees may be attacked at any age, whether old or young, but as a general thing it appears most commonly in old bearing trees. Up to the time when they are attacked they generally appear to be quite healthy. No external agent has been found connected with it. It appears rather to be the result of internal derangement of the functional processes carried on within the tree. It may be that it is caused by an enzyme, a poisonous substance present in the soil. In fact, it appears at the present time that this is about the only plausible explanation of its cause. A number of other plant diseases, such as peach-yellows and rosette, may belong to this same class of diseases, though in none of these cases has this theory been actually proven.

Color is given to this theory of the cause of the blight of citrus trees by the fact that it is usually more or less localized in a grove and there may be a number of separate centers of the disease in a single grove. The peculiar nature of the new growth and the frenched appearance of the foliage tend to strengthen this view.

Treatment. Pruning does not stay the progress of the disease. Diseased branches may be removed, leaving only the healthy ones and yet the disease will reappear. Observations have led to the belief that it is contagious, at least, trees adjoining those diseased also become affected in due time. In the premises the best suggestion that can be made regarding the control of the disease is to dig out and burn the diseased trees as fast as they show symptoms of the disease. Dig them up and destroy them 
root and branch. It is probable that the causative agent moves through the soil in the ground water. This may explain the apparently contagious nature of the disease. Nevertheless, the trees should be destroyed as already suggested as the decaying roots in the soil may tend to increase the disease. If the disease is ever successfully combated, it will probably have to come through the application of some chemical substance to the soil. 


\section{CHAPTER XLI.}

\section{INSECTS INJURIOUS TO CITRUS TREES.}

The insects attacking citrus trees may be conveniently grouped as biting and sucking insects. The first group, including the grasshoppers, orange-dog and a few other insects of less importance, injure the trees by eating the foliage and other tender parts. The sucking insects, however, obtain their food from the trees by sucking the juices out of the cells. Many of them also appear to inject a poisonous substance into the tissues which assists in destroying the cells. The members of this second group are far more numerous than those of the first; in fact, the most dreaded insect enemies of citrus trees are found here. This group may be further divided into Scale Insects and Insects other than Scales, the latter embracing the white fly and different kinds of mites. The scales may be divided into armored or protected scales and unarmored or unprotected scales. The armored scales have a protective covering and are unable to move about after having once settled themselves in a certain position. The unarmored scales have no hard covering and are motile during the greater part of their existence, moving freely while young, but in a very lim. ited way when matured. If we present a graphic outline of the groups of the more important citrus insects as described in this chapter we have-

I. Biting Insects.

II. Sucking Insects.

(1). Scales. (a) Armored Scales. (b). Unarmored Scales.

(2). Insects other than Scales. (c) White Fly. (d) Citrus Mites. 
Those insects which feed by biting off and chewing parts of the plant can be destroyed by putting a poisonous substance on the part of the plant attacked; not so with those which obtain their nourishment by sucking the juices of the plant. These can only be destroyed by spraying over them some penetrating or sticky substance, such as kerosene emulsion, whale-oil soap or resin wash, which will enter their bodies through the walls or close out the air from them by plastering them under.

Poisonous gases, liberated under tents over the trees, suffocate them, and fine powders, such as pyrethrum, prevent their breathing by stopping up their spiracles.

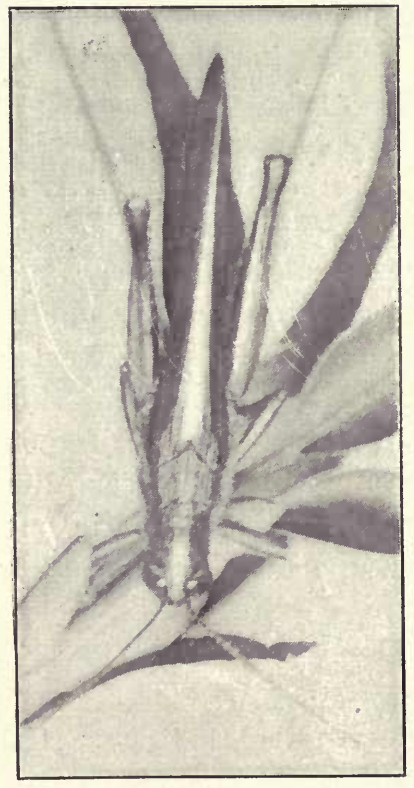

Fig. 110. Grasshopper feeding on orange leaves. (Schistocera obscurum Burm.)
I. BITING INSECTS.

Grasshoppers, a m o $\mathrm{n} \mathrm{g}$ which may be mentioned Rhomalea microptera Serv., Schistocera americanum Send., and Schistocera obscurum Burm. Fig. 110 frequently prove troublesome on citrus trees. They feed upon the tender leaves and growth, thus reducing the foliage area of the trees and lessening their vigor. They most frequently attack the outer rows of trees in the grove, those adjoining grass fields or pastures. When they become more numerous they spread through the grove and do considerable damage. If 
they attack first the young fruit and bite a small area of the rind, this area enlarges as the fruit grows and presents a rough, scurfy appearance. Such fruit must be classed as seconds or culls.

Treatment. In the Canadian northwest, the Criddle mixture, formula (15), has given excellent satisfaction and has in many sections supplanted all other means of fighting these pests. It should be scattered well through the groves and the insects are said to be attracted to this bait from a distance of forty feet. No injury to poultry has resulted from its use.

The Orange-Dog. (Papilio Cresphontes Cramer). Frequently a large, disagreeable-looking caterpillar, 2 1-2 inches, or slightly more, in length may be observed feeding upon the leaves of citrus trees. It is dark brownishblack in color and marked with large blotches of a dirty white color on the posterior end, the sixth and seventh segments and the sides of the head. The anterior end is much enlarged and when at rest the mouth parts are drawn in under it as shown in Plate 33. When irritated or disturbed, the insect protrudes a pair of golden-colored, horn-like feelers and at the same time a liquid having an exceedingly disagreeable and repellant odor is emitted.

It is in the larval stage that damage is done. The appetite of the caterpillar is enormous, an ordinary sized orange leaf being disposed of in about five minutes. After feeding to satisfaction, the caterpillar retreats to a shady place and rests until its next feeding time. A great deal of damage may be done to a tree in a very short time and particularly on young trees the effects of their presence are very noticeable.

When full grown, the larva seeks out some secluded spot on the side of a limb or leaves the tree entirely, 
Plate XXXIII.

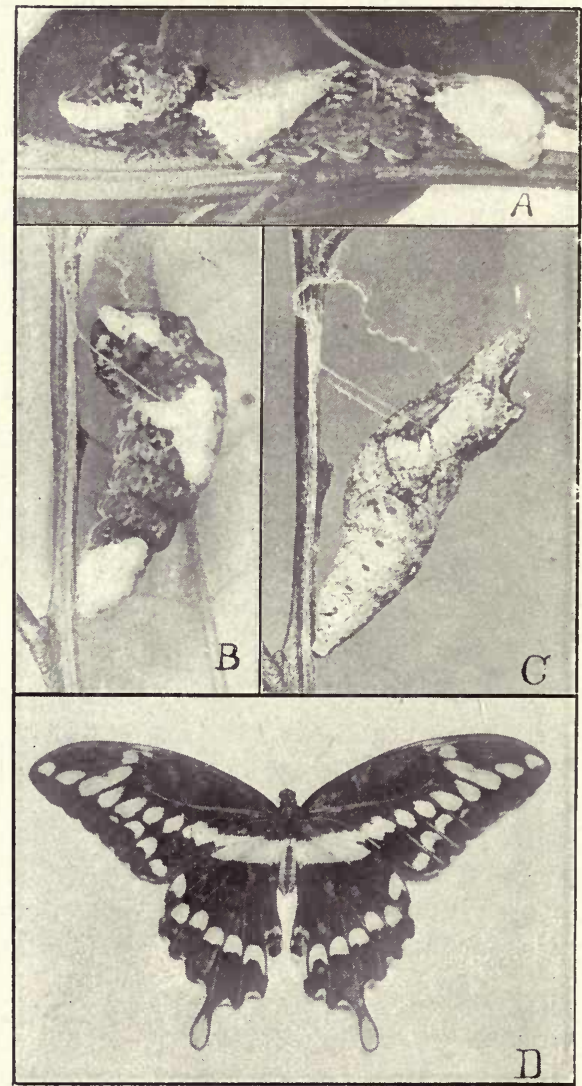

Orange Dog-(Papilio Cresphontes Cramer.)

A, Larva, two-thirds natural size.

B, Larva, prepared to pupate; two-thirds nat. size.

C. Pupa case; two-thirds natural size.

D, Butterfly; one-third natural size. 
makes its way to an adjacent fence, tree or log. There it enters the chrysalis stage. First an attachment is made by means of a matted web joining the posterior end to the chosen place. Then a strand of silk is attached to the support, passed around the body, and with head upwards and the body inclining outward at an angle of about 45 degrees, it spends its period of pupation, lasting from twelve to seventeen days, depending somewhat upon weather conditions. The chrysalis is inconspicuous on account of the strong similarity in color between it and the object to which it is attached. It is brown and gray-spotted and has a number of projections on the anterior end. (Fig. C, Plate 33.)

From this case, emerges a gorgeous black and yellow butterfly (Fig. D), about six inches across the tips of the expanded wings. The yellow markings form two bands, the upper one crescent-shaped, the lower almost semicircular. On the projecting tips of the hinder wings are two yellow, oval spots surrounded by a margin of black and at the rear inner edges of the same pair of wings, are two brownish or reddish spots with a small crescent of blue dots above. Each female is capable of depositing from four to five hundred eggs, which are deposited on the tender shoots and there are usually four broods each season.

Treatment. Hand-picking of eggs and caterpillars. Paris green at the rate of four ounces to fifty gallons of water may be sprayed on the foliage when the larvæ are present.

Hubbard recommends shooting the butterflies.

Besides citrus trees, the caterpillar feeds upon Xanthoxylum, on Ptelea and some other trees. 


\section{ARMORED SCALES.}

The Purple Scale, (Mytilaspis citricola Packard). This is one of the commonest and most conspicuous citrus scales in Florida. The insect seems to be widely known wherever the orange is grown, either in this country or abroad. Hubbard observed in 1885 that it was more abundant in the northern than in the southern portions of the orange belt. The freezes since that time seem to have reversed this order of distribution.

The scale of this species is one of the largest in the genus. The scale of mature females sometimes reaches a length of 0.12 of an inch $(3 \mathrm{~mm}$.), and that of the male 0.05 of an inch $(1.4 \mathrm{~mm}$.). The name, "Oyster Shell Bark-louse," has been applied to one member of the genus, Mytilaspis pomorum, a common apple pest, because the general outline of the scale, together with its ridgings and markings, are so suggestive of an oyster shell in miniature; the purple scale, Mytilaspis citricola, and in lesser degree, the long scale, Mytilaspis gloverii, share this resemblance, and so it is not uncommon to hear the term, "Oyster Shell Bark-louse," applied to any one of them by the general public. The form may be described as broadly trumpet-shaped, increasing in width behind, often curved like an oyster shell, but rarely or never with the sides parallel. The surface is glossy and smooth and from a light to a dark red-brown purple color. The male scales, being less than half the length of the females, of a more linear shape and straight outline, may suggest some other species of insect upon superficial examination, but its identity cannot be confused with any other species than the long scale, Mytilaspis gloverii, the female of which is twice as long as the male citricola. and the male of which is shorter and rather more slender. 
both absolutely and relatively. The characteristic purple color with the male gives to a mass of scales belongs to no other species of Mytilaspis.

The eggs are pearly white, very minute, elongateoval, and are usually laid in four rows, but sometimes promiscuously. Each female deposits from 25 to 70 eggs.

The newly-hatched larva is irregularly oval in shape, 0.12 of an inch long, of a transparent white color, and with fiery red eyes, which have been likened to grains of cayenne pepper. This young insect wanders about a very short time, and then settles upon the bark or leaves; when upon the latter, preferably along the midrib, and is soon covered with a white film of wax threads, some of which stand out from the rest, and if not carried away by the wind, they accumulate and form cottony tufts or tangles.

The shedding of the larval skin or first moult occurs about three weeks after hatching, and the formation of the true scale is begun. A second moult of the female occurs three or four weeks later, and when nine or ten weeks old egg-laying begins, the eggs being deposited beneath the scale, from beneath which the young begin to issue in about a week after the eggs are deposited, unless retarded by cold weather.

The male goes through its second moult and changes into a pupa several days earlier than the fernale, from which it emerges as a winged fly, and is ready for mating at the time the females are passing through their first moults.

There are three or four generations per year, but the separation into distinct broods is often more or less confused, one generation overlapping the succeeding one, so 


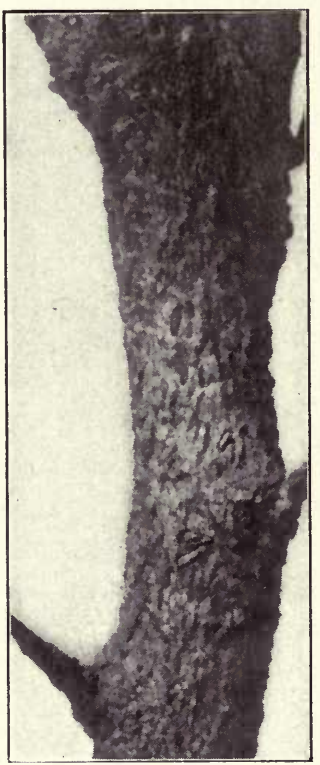

Fig. 111. Purple scale (Mytilaspis citricola Packard) on orange.

that all stages of the insect may generally be found at almost any season of the year upon infested trees. Generally speaking, the greatest numbers of migrating young may be found in one of three periods, namely: in the spring, usually in March and some times extending into April; in June or July; and in September or October. During mild winters a fourth brood commences in Janwary and straggles through this and the following month.

The recorded food plants of the insect are as follows:

Banksia integrifolia, Croton Eucalyptus. Murraya exotica: Orange and Ptelea trifoliata.

Treatment: Solutions Nos. (9), (8) or (7).

The Long Scale, (Mytilaspis gloverii Packard). The long scale is of a more linear shape than the purple scale, with which it is so often associated. The outline of the body is not so often curved as is that of the pur. ple scale.

The female scale is brownish, about 0.11 of an inch (3 mm.) in length, and less than one-fourth as wide. When crowded the scales adjust themselves to their surroundings by taking all sorts of shapes, and many wil! be dwarfed and malformed almost beyond recognition. except by microscopic examination. The young insects themselves are of a translucent waxy white, with the 
outer edge of the last joint yellowish. As they grow older they incline to purple, which becomes deeper as the insects increase in age. The adult female is about 0.05 of an inch $(1.3 \mathrm{~mm}$.) in length. The sucking proboscis is longer than thebody.

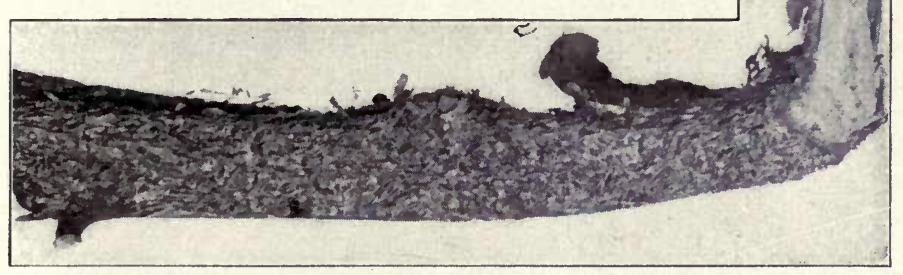

Fig. 112. Long scale (Mytilaspis gloverii Packard) on orange branch.

The scale of the male is smaller than that of the female, about 0.04 of an inch $(1 \mathrm{~mm}$.) in length, and usually straight. The color varies from shades of brown to yellow when young, becoming darker with age, and reaching a dark brown in the older females. Generally speaking, densely clustered colonies, including both sexes, have a reddish hue. The male insect is a minute, two-winged fly, 0.01 of an inch in length. Its body is pale pink in color, and about one-fourth as wide as long. The eggs are elongate-oval in shape, passing from a light to a purple color before hatching.

The life history of this scale is so nearly parallel with that of the purple scale that it is unnecessary to enter into details. It has practically the same number of broods, which occur at about the same time as those of the other species. Sometimes the broods of the one species precede or follow those of the other by a few davs, but they are often simultaneous. The times of ap- 
plying remedies, therefore, can be stated to be parallel with those chosen for the purple scale. The parasites of the two species are, likewise, the same.

Treatment: The same as for the purple scale.

Red Scale of Florida. (Aspidiotus ficus Ashmead). The female is circular, dark reddish brown to black in color and two $\mathrm{mm}$. in diameter. The scale of the male is considerably smaller, being about one-fourth the size of the female scales.

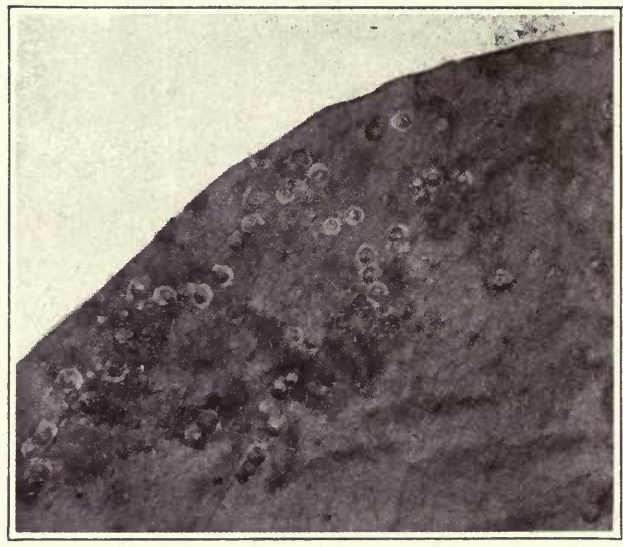

Fig. 113. Florida Red Scale (Aspidiotus ficus Ashmead) on the under side of pomelo leaf. About natural size. duced into ably introFlorida from the present Cuba, but at It was probThis species infests b r a n c h es, leaves and fruit alike. time it is not very widely distrib u t e d and does not cause nearly so much damage as the purple and long scales.

Remedies: (9), (7) or (8).

Red Scale of California. (Aspidiotus aurantii Maskell). This species of scale insect appears to have attracted attention within the confines of the United States only in California, and, on the other hand, it is worthy of 
note that the Red Scale of Florida has not gained a foothold in California.

The female scales of Aspidiotus aurantii are light grey in color, but the brown body of the insect showing through it gives a reddish brown cast. The male scale is one-fourth as large as that of the female, and the posterior end is a projecting flap.

Like its close relative, the Aspidiotus ficus, it infests the trunk, branches, leaves and fruit. It has proved to be a very troublesome pest in California and since no predaceous enemies have been secured to control it, the grower must rely upon his own efforts.

Remedies: Fumigation, spraying with formula (7), ( 8 or 9 ).

Chaff Scale. (Parlatoria pergandii Comstock). The female scale of this species is 1.4 to $1.6 \mathrm{~mm}$. long. It is thin, light straw colored and more or less circular in outline. The body of the insect showing through the scale, imparts to it a somewhat greenish cast. Several faintly marked ridges, radiating from the point of origin of the scale are to be found. The male scale is smaller than the female, being $1 \mathrm{~mm}$. in length. It is thin, white and almost oblong in outline, the sides being nearly parallel.

This scale is found most commonly on the trunk and larger branches of citrus trees, spreading to the fruit and leaves only when it becomes very abundant. Frequently its presence is overlooked, owing to its resembling the bark in color and the trees frequently suffer severely before the grower finds out where the trouble lies.

Remedies: Same as for Purple Scale.

Remedies: Same as for Purple Scale.

The Orange Snow Scale or Orange Chionaspis, (Chionaspis citri Comstock). The female scale 
is flat or very slightly convex and the more recently shed skins are toward the narrow end. The male scales are smaller, white and marked with three parallel ridges. When clustered on the twigs or leaves of the citrus plants, the males are very conspicuous (Fig. 114).

This scale is rarely found in Florida, but is abundant in Louisiana, Bermuda and Cuba.

Remedies: Same as for Purple Scale, formula (9), (8) or $(7)$.

III. UNARMORED SCALES. The Turtle-back scale (Lecanium hesperidum Linn.) The Turtle-back scale, with others described in the fol. lowing pages, belongs to a sub-family of naked or waxy scales, known as Lecaninæ; and are not covered

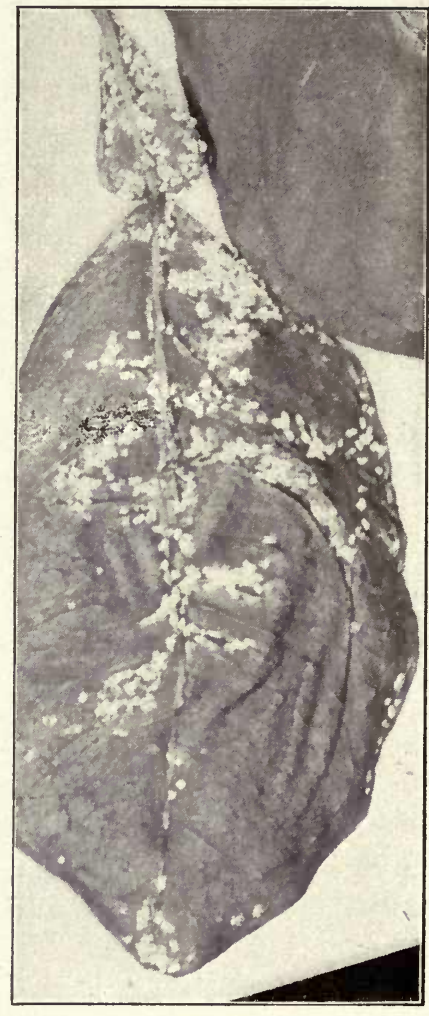

Fig. 114. The orange snow scale (Chionaspis citri Comstock), on under side of orange leaf.

with a true scale. The genus of Lecaniums is unprotected by any covering, except their skins, which becomes tough. ened with age so as to resemble parchment.

The full grown insect is from 0.12 to 0.16 of an inch (3 to $4 \mathrm{~mm}$.) long, broadly oval, more or less swollen and convex upon the disk, surrounded by a thin, flat 
margin, which is notched on the sides and behind; this shape, with the brownish color, gives it its popular name. The legs are concealed beneath the body.

The young insect is of a yellowish color, and always settles upon the bark and leaves of tender growth. The adult insects appear to be unable to pierce the bark of the trunk or older branches, always being found upon wood of newest growth.

In the spring and early summer, when new growth is forming, the increase of the insect is most rapid, especially during the month of June. Later in the season the colonies disappear, only a few gravid females remaining to restock the plants at the next favorable opportunity. The young, hatching in the latter part of the season, often starve, because they are unable to reach tender twigs upon which to feed.

Treatment. Solutions Nos. (9), (8), (7) or (6).

The Black Scale, (Lecanium olex Bernard.) This scale is nearly black in color, approaching hemispherical in form, and longer than broad. Length from 0.16 to 0.20 of an inch ( 4 to $5 \mathrm{~mm}$.), height about 0.12 of an inch $(3 \mathrm{~mm}$.). The middle of the back carries an elevated keel, which is crossed at right angles by two elevated ridges, the latter dividing the body into three nearly equal parts. The body is slightly margined, the outer part of the disk being marked with many small ridges, which extend from the margin half way up to the centre of the back.

The eggs are long, oval in shape, about .0012 of an inch in length and of a yellowish color.

The young larvæ prefer the smaller twigs of the plants which they infest, and usually settle upon the leaves. The development of the species is slow, so there is probably not more than one brood per year. It lives 
upon all citrus plants, olive, pear, apricot, plum, pomegranate, apple, eucalyptus, rose, cape jessamine, live oak, holly, oleander and some other plants.

Treatment: Solutions Nos. (9), (7), (6) or (8).

The Hemispherical Scale, (Lecanium hemisphoricum Targioni). This scale is of a more rounded form than the other common species of Lecanium, approaching the form of a hemisphere; about 0.14 of an inch (3.5 mm)

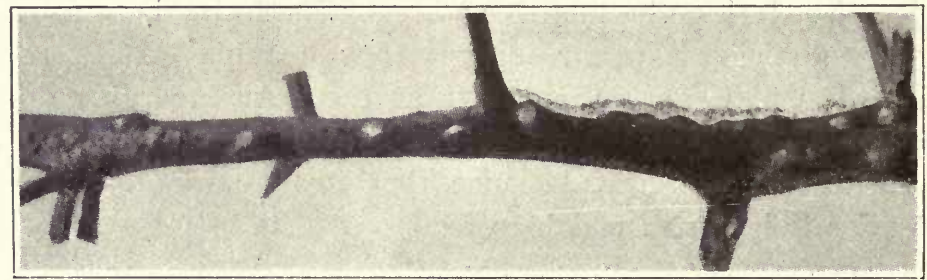

Fig. 115. The hemispherical scale (Lecanium hemisphaericum Targioni) on an orange twig.

in length, 0.12 of an inch $(3 \mathrm{~mm})$ in width, 0.08 of an inch $(2 \mathrm{~mm})$ in height. The color varies from a light, almost reddish brown, when young, to a dark brown, slightly tinged with red when old. The insects found upon twigs are usually more elongate than those found upon leaves.

The egg is of an ellipsoidal shape, about 0.006 of an inch $(0.15 \mathrm{~mm})$ in length, and of a whitish color, inclining to yellow.

It feeds upon orange, palms, orchids, Camellia japonica, guavas, chrysanthemums and quite a number of other plants.

Treatment: Solutions Nos. (9), (8), (7) or (6). 
The Wax or White Scale, (Ceroplastes floridensis Comstock). This beautiful insect is 0.08 to 0.12 of an inch $(2$ to $3 \mathrm{~mm}$ ) in length, of an oval form, convex above, and concave beneath. The upper surface presents a rounded protuberance in the centre, around which are arranged six or eight smaller prominences or lobes, which are separated by a groove from the central projection. The white covering consists of soft wax, quite similar to the commercial article. The color in clean specimens inclines to a beautiful, flesh-tinted white, the pinkish tinge being given by the reflection of the light through the wax from the red insect beneath. The insect itself bears on its upper surface six tubercles, three on each side, and shows a short anal tube, the end of which is seen projecting from the posterior extremity of the waxy covering at the bottom of a deep pit. The walls of the body are very thin, and enclose liquids or eggs of a dark red color. The egg is 0.01 of an inch $(0.25 \mathrm{~mm})$ long, and of ellipsoidal form.

The eggs, 71 or 100 in number, are extruded from the body and hatched beneath the waxy scale. The young, escaping from beneath the scale, attach themselves by their beaks to the surfaces of the leaves, chiefly along the midribs and veins. As they approach maturity they go to the bark of the twigs and smaller branches. The exudations of wax first form in ridges, the marginal ones uniting around the central one.

About a dozen or fifteen similar tufts of wax arise around the centre, and the young louse, when about a week old, has been compared to an oval white star upon the leaf. At this stage it has some superficial resemblance to some of the stages of insects belonging in the 
Aleyrodidæ. The adult insect is covered with six large plates, three upon each side, and three smaller plates, located one at each end and one in the centre. The wax finally becomes covered with dust and dirt, giving it an appearance quite different from that possessed when its development was just completed.

There are about three broods, each extending over three or four months. The first brood occurs in April and May, the second in July and August, and the third in October and November. This insect is native to Florida, and is very commonly found upon gallberry in great numbers. It also occurs upon quince, apple, pear, the citrus fruits, ferns, figs, myrtles, guavas and a number of other plants. As the insects become aged many of them fall to the ground and perish, being unable to reascend the plants from which they fell. The insect does not often become numerous upon orchard or grove trees, but sometimes gets thick enough to cause some alarm.

Treatment. It is not often that the wax scales require particular attention, but we have some reports indicating that they may inflict considerable damage during a short period. If fully developed, they will probably lose their hold and fall to the ground in a short time, so are not worthy of much attention while in this stage. When the growing larvæ become numerous they can be checked by an application of resin wash, kerosene emulsion or whale-oil soap if made while very young.

The Barnacle Scale, (Ceroplastes cirripediformis Comstock). This insect agrees with the preceding species in possessing a white, waxy covering, but is differently marked. The average length is 0.20 of an inch $(5 \mathrm{~mm})$; width, 0.16 of an inch $(4 \mathrm{~mm})$, and height, 
0.16 of an inch $(4 \mathrm{~mm})$. The naked insect is dark reddish brown in color, of sub-globular shape, and with a strong spine-like projection at the posterior end of the body. The general white color is often mottled with shades of grayish or light brown, the boundary lines of the plates remaining apparent, even at an advanced age. The back is covered by a convex dorsal plate which is met on each side by six lateral ones, each of which is marked by a radiating nucleus in the centre. The posterior plate is larger than the others, possessing two nuclei, thus indicating that two plates are joined together. The eggs are 0.014 of an inch $(0.35 \mathrm{~mm})$ in length, and of a light reddish brown color.

The newly hatched larvæ are dark brown in color, and follow pratctically the same course of development as Ceroplastes floridensis.

It feeds on oranges, quince, Eupatorium and probably upon a number of the same food plants as $C$. floridensis, but the species is much more rare than the white scale.

Treatment: Same as for the preceding species.

The Cottony Cushion Scale. (Icerya purchasi Maskeil). Immediately after the moult by which the female insect passes into the adult stage it is free from waxy excretion and presents a broadly oval form with two prominent raised surfaces on the second and third thoracic segments. Its color is still reddish brown, with several dark spots along the front sides, and along the sides of the posterior part of the body, while the antennæ and legs are black. Just after the insect in any stage has withdrawn from its old shell in moulting, the legs are perhaps the most transparent and whitish parts of the body; but they begin to darken in about a half hour 
and within two hours are black in this stage, and as dark as they become in the preceding stages. The antennæ are eleven-jointed, the club being one and onehalf times as long as joint number ten. The whole body is furnished with tufts of short black hairs, which are

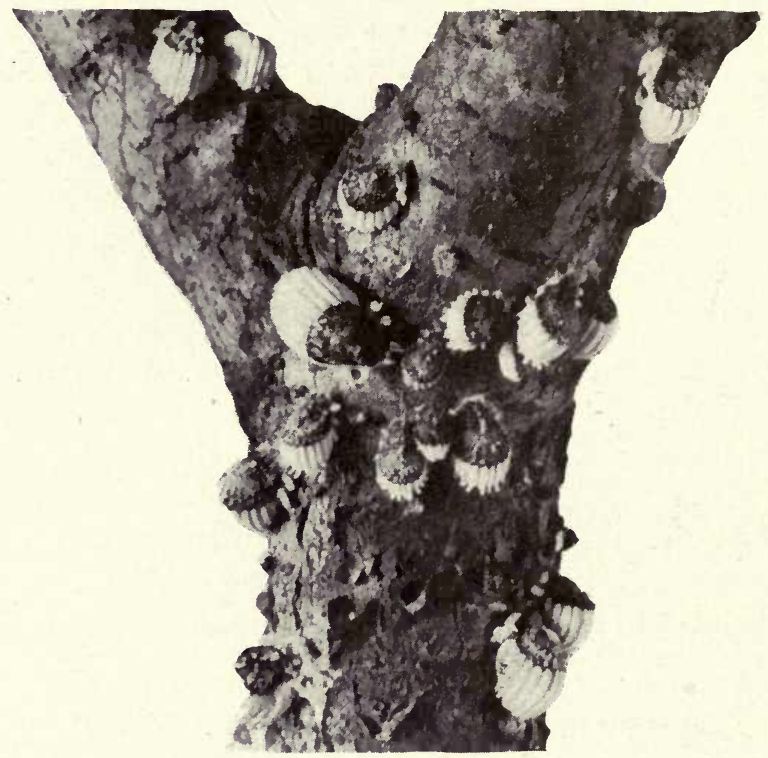

Photo by H. A. Gossard.

Fig. 116. Adult females of the Cottony Cushion Scale (Icerya purchasi Maskell) on myrtle branch, slightly enlarged.

gathered into a parallel row around the edge of the body. The secretory pores are very numerous, occurring in enormous numbers beneath the sides of the body and scattered more sparsely over the back. The inner row of tufts on the back is broken at its anal point by a depres. sion, in which is situated a very large pore from which 
the insect occasionally ejects a globule of semi-liquid honey-dew. This depression is surrounded by an irregular ring of hairs which are yellowish in color instead of black. The glassy filaments described in the last stage are now very long and radiate from the body in almost every direction. They break off very easily, yet they often reach a length double that of the insect and her egg-sac together.

Just as the body of the female begins to swell from the eggs forming inside, the beginning of the egg-sac is made. The insect lies flat on the bark. The edges of the body turn slightly upward, and the waxy material of which the sac is composed begins to issue from numberless pores on the under side of the body, but more especially along the sides below. As the secretion advances the body is raised, the head end still being attached, until the insect is apparently standing on its head, nearly at right angles to the surface to which it is attached. The egg-laying commences as soon as the thin layer of secretion has begun on the inner side of the abdomen and it continues during the formation of the sac. Around the edge of the abdomen there soon appears a narrow ring of white felt-like wax, which is divided into a number of flutings. These flutings grow in length and a mass of eggs and wax under them increases, forcing the female upwards until the sac is completed. When complete it is from two to two and one-half times the length of the female's body. It is of a snow-white color. The outside is covered with fifteen of these longitudinal ridgings or flutings of about equal size, except that the middle one is smaller than the others. The upper part of the sac is firm in texture, but the lower is looser and thinner and from the inner side the young make their escape after 
hatching. The size of the sac and length of time required for its growth depend, leaving the weather and the health of the food plant out of consideration, upon the number of eggs which the female deposits. The excretion of the egg-sac continues as long as oviposition lasts.

It probably requires from 60 to 90 days to complete the egg-sac from the time of its beginning. The length of time depends largely upon the health of the tree on which the insect is located and also upon the number of insects infesting it. Development is much more rapid upon vigorous than upon sickly trees.

The adult male is a winged insect with dark red body, grayish wings, and of very slender, fragile structure. The antennæ are dark colored and have two whorls of light hairs extending from each joint except the first. When the insect is at rest the wings lie flat upon the back. It is readily found in situations where the male larvæ have pupated, under boards, beneath cracks and in the general litter of the grove.

Remedies. It was against the cottony cushion scale that fumigation was first practiced. But neither fumigation nor spraying, although the insect was held in check to some extent, availed much against its inroads. The entire citrus industry of California was threatened, and it was not until the Australian lady-bug was introduced that its ravages were checked. By this predaceous enemy, Novius cardinalis, the cottony cushion scale was brought under absolute control. In Florida the same method of control was likewise entirely successful. Hence, when the cottony cushion scale gains a foothold, its enemy, the Australian lady-bug, should be introduced at once. While waiting temporarily for the arrival of the lady-bugs, resin wash or kerosene emulsion may be used. 
The Mealy Bug. (Dactylopius citri Risso). This insect, with other closely allied species, is very common in Florida. The adult female is from about 0.14 to 0.16 of an inch $(3.5 \mathrm{~mm}$ to $4 \mathrm{~mm})$ in length, 0.08 of an inch in width, and very flat. The color is dull brownish yellow,

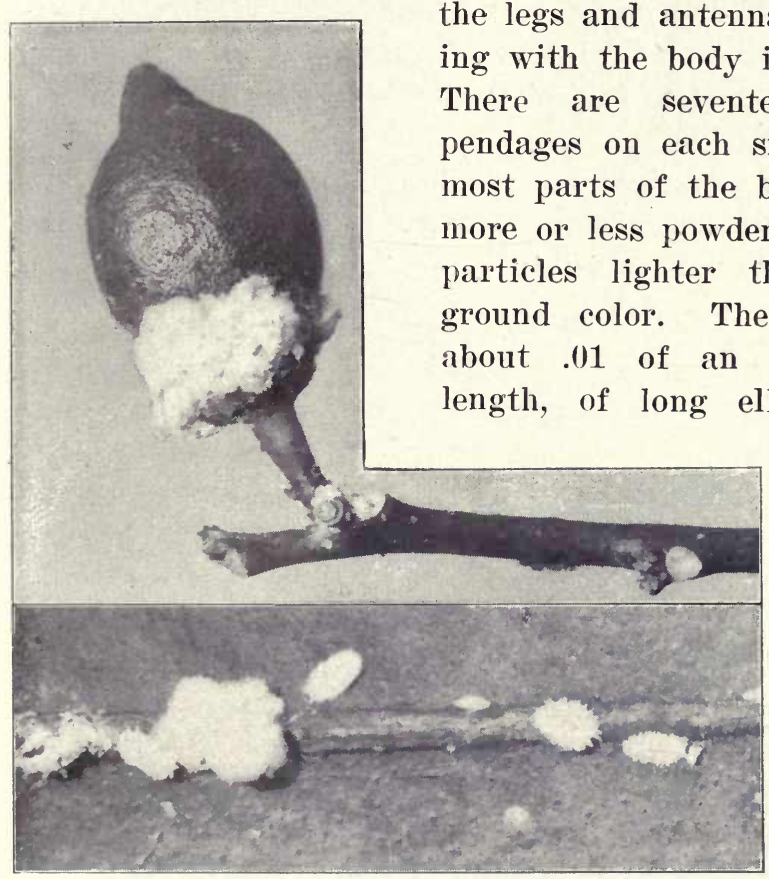

Fig. 117. Mealy bug (Dactylopius citri Risso) clustered at base of young lemon fruit above, on under side of pomelo leaf below. About natural size.

form, and light yellow color.

The eggs are' laid in a large cottony mass at the posterior extremity of the abdomen, and require considerable time to hatch. After hatching, the larvæ exhibit a marked tendency to settle along the midribs and veins 
on the under side of the leaves or upon the younger twigs, especially in the forks. Ants are very industrious agents in scattering them. The honey-dew excreted by the mealy bugs forms the attraction for the ants which care for them in a way that has been compared to the attention man gives to his domestic animals. Free use of carbon di-sulphide or scalding water in the nests of the ants often furnishes the best means of controlling the mealy bug.

It feeds upon house plants, orange, coffee, tobacco, croton, Ipomea, Learii, Habrothamnus, Pæonia, Solanum jasmoides and probably a number of others.

Treatment. Use a powerful force pump and penetrating insecticide, such as kerosene emulsion, upon mature insects. Thoroughness and frequency of application will govern the degree of success achieved in fighting this insect. Repeated applications of potash whale-oil soap, one pound in two or three gallons of water, made while the insects are young will give most successful results. Limbs that are badly infested should have the insecticide painted upon them with a brush or they may sometimes be pruned out altogether.

\section{SUCKING INSECTS OTHER THAN SCALES.}

The White Fly. (Aleyrodes citri Riley and Howard). The egg is very minute, about $1-125$ of an inch $(0.2 \mathrm{~mm})$ in length, being attached to the leaf by a slender stem. or footstalk; about four times as long as thick, widest just beyond the middle towards the free end; color pale yellow, when first laid tinged with greenish, becoming darker as the embryo develops and some specimens becoming of a dark steel gray or blue. Surface smooth and shiny, often with clinging particles of white wax. Red 
eyes of embryo conspicuous through the shell as it approaches maturity.

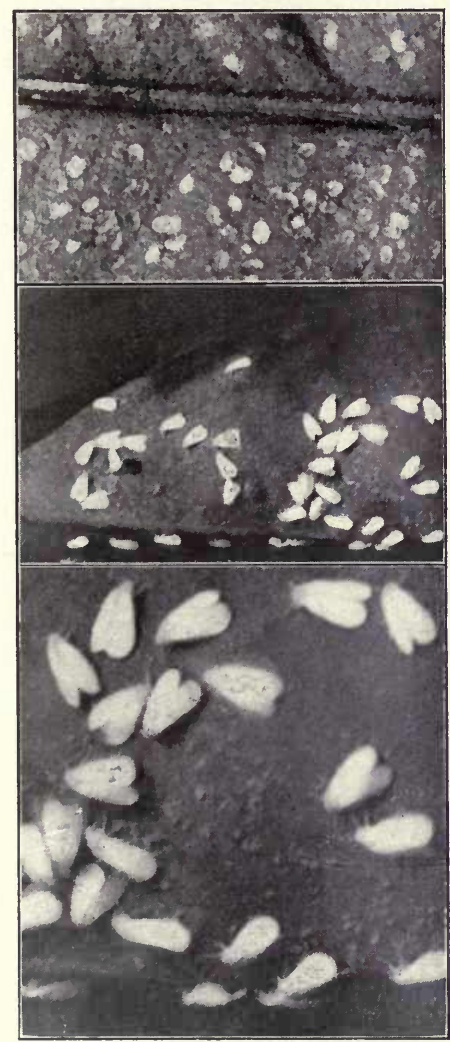

P'ioto by Dorsey.

Egg-laying begins with in eighteen to thirty hours after the adults issue when the weather is warm (sixty-five to seventy-five degrees), but with damp, cool weather several days may elapse before they are deposited. Egg deposition occurs upon the under surface of the leaves, preferably upon new ones especially those of water sprouts, but old leaves may also be well covered with them; they are usual. ly scattered over the sur. face of the leaf without much order of arrangement, but sometimes are laid in the arc of a circle. From four to ten eggs may be observed in such an arc and are so placed by the female, using her beak as a pivot around which the body is swung during the oviposition. putation a leaf from young orange, five inches long and two and one-half inches wide in the middle, collected at Myers, Fig. 118. White fly (Aleyrod above, mature flies in the middle (slightly enlarged), mature flies and eggs below (much enlarged).

\footnotetext{
By mathematical com-
} 
June 22, 1901, had upon it upwards of 20,000 eggs. While so many eggs upon such a space is beyond the average, it is by no means rare, and I have sometimes seen the number exceeded.

Hatching occurs in from three to twenty days, according to the weather.

The larva passes through four moults before reaching the pupa stage. When first hatched the insect is about $1-80$ of an inch in length $(0.3 \mathrm{~mm})$, of a pale greenish yellow color, with two darker yellow spots on the back of the abdomen. There are four conspicuously long bristles at the posterior part of the body and six long ones on the anterior end with minute ones along the sides, each arising from a tubercle. Antennae, three or four jointed. Four eyes, dark reddish. Legs short, six in number. Mouth parts consist of a long sucking tube. On the dorsal side of the last abdominal segment is a subovate, brown colored opening, the vasiform orifice. Appearance in second and third stage not markedly different from the first, except in size and minute microscopical characters. In the fourth stage the length has increased to about 6-100 of an inch $(1.5 \mathrm{~mm})$, the width to $4-100$ of an inch (1 $\mathrm{mm}$ ), and the conspicuous bristles have vanished; a pair of persistent, minute bristles is found on the anterior border, one on each side, and another pair, also minute, is disposed one on each side of the anal cleft. The insect is very flat and close pressed to the leaf; the dorsum or back is crossed by twelve transverse ridges, indicating the segments. Arising from the prothoracic region on each side, extending obliquely outward and forward to the margin is a distinct ridge or fold, the breathing fold. The outline of the developing wings of the embryo can be distinctly seen from the first. 
The young larvæ are motile and crawl about over the leaves and twigs for several hours like young scales before they fasten themselves to the leaves. The larvæ are attached to the under sides of the leaves and are in. conspicuous, because of their transparency and greenish tinge. If the leaf be so doubled in the hand that air is admitted beneath the insect, it at once becomes readily seen and is translucent, whitish green, spotted with orange.

The pupa, to an ordinary observer, is quite similar to the fourth larval stage, but more plump and of thicker body; broadly oval. Measurements about as in fourth stage, slightly narrower. A broad, deep orange or coralred spot on the back near the anterior end of abdomen; eyes purplish; vasiform opening and ring brown; transverse ridges on abdomen shorter and less distinct than in last larval stage.

The adult female is slightly over 1-20 of an inch (1.4 $\mathrm{mm}$ ) in length, the wing expanse being about twice the length of the body $(2.8 \mathrm{~mm})$. The color is light orange, with the rostrum, or beak, tipped with black. The wings are colorless when newly hatched, but within two or three hours become covered with a fine white wax, hence, the name, "mealy-wing," sometimes given to the insect. The body also becomes covered with more or less of wax, but its ground color is not wholly obscured. The tarsi are two-jointed. The eyes, reddish-brown in color, are each divided into two parts by a curved ridge projecting from the cheek, the upper divisions being the smaller. The ovipositor is short and retractile.

The male resembles the female, but is smaller, with the head and abdomen having heavier tufts of adhering wax. The abdomen is more slender and has at its termination a pair of claspers slightly curved upwards. 
Remedies: White fly is difficult to control. Little can be done when the insects are flying about, and all remedial work must be undertaken during the larval and pupal stages. During these stages the insects are at rest on the under sides of the leaves. Fumigation or spraying at this time is effective. The best time for fumigating is from the middle of December to the end of February. Spraying may be done during the same period or in the summer. When the insects are pupating use solutions (6), (8) or (9).

Strong effort should be made to introduce such beneficial fungi as the Red Aschersonia and the Brown fungus. This may be successfully done in a number of ways. See page 550 .

The complete defoliation or destruction of all infected trees and plants during the periods recommended for fumigating will insure the destruction of the insects. Sometimes this is feasible. The principal host plants are all species of citrus, Chinaberry tree, Umbrella China tree, Cape Jessamine and occasionally cherry laurel, Magnolia fuscata and Japan honeysuckle.

Orange Rust Mite and Lemon Silver Mite. (Phytoptus oleivorus Ashmead.) This mite is quite minute, being $0.14 \mathrm{~mm}$. in length. In outline its body is rather wedge-shaped, widest near the head and tapering gradually to the posterior end, which is provided with a pair of appendages. The abdomen is divided into about thirty segments. The legs are four in number, placed close together on the anterior portion.

The young insects are bright yellow in color, becoming darker as they grow older. The eggs are yellow in color, spherical and transparent, and are deposited by the adult singly or in clusters on the leaves. 
Rust mites occur in great numbers on the leaves and fruit, as many as 4,568 having been found by the late H. G. Hubbard on a square inch of leaf surface in winter. During warm weather, when not too dry, these insects multiply rapidly.

They attack both the leaves and the fruit. When the leaves are attacked they lose their glossy color and become covered with brownish spots, but it is upon the fruit that its effects are most noticeable. The mites feed upon the essential oil of the rind and through the punctures which they make the air comes in contact with the oil, bringing about a change in color. On the lemon, the coloration is somewhat silvery, hence the name applied to the insect by Mr. Marlatt. Fruit when attacked does not develop normally, but remains undersized. The insects prefer and seek the shade, hence, the under side of the fruit not exposed to the sun becomes "rusty," while the upper portion in the strong light is not affected.

Because of its attacks, the cost of handling the citrus crop is increased materially, as two classes of fruit have to be made. As a matter of fact the russet fruit is sweeter than the bright, but usually brings somewhat less money, the markets generally preferring a smooth, bright fruit.

Remedies. Spray with formula (11), (12), or (13) or dust with sulphur and lime in equal parts every two weeks. A more adhesive solution, formula (13), may be used, if so desired, and this will destroy the scales as well. If this solution is used, the intervals of application may be lengthened out to about a month with fairly good results.

The Six-Spotted Mite. (Tetranychus sex-maculatus Riley). The length of full grown specimens is $0.3 \mathrm{~mm}$, or about .012 of an inch. This is slightly smaller than 
most members of its family. It is of oval shape, being widest just back of the eyes. General color pale greenish yellow, the abdomen in mature specimens being marked with six or less small dusky spots, arranged in two lateral rows of three in each row on the back. Most of the younger mites are without these spots or have but part of them present. Some of the mature specimens have fewer than six spots and these are often quite indistinct. Eyes, two on each side, the anterior one of each pair being blood-red, and the pigment so disposed as to give the ap. pearance of two red eyes on each side; the posterior eyes are colorous and transparent. A lateral constriction just back of the eyes divides the body in two more or less distinct regions. The terminal joint of the legs is longest. The thumb of the palpus is quite stout and bears on its tip three fingers, of which the middle one is the largest. The young mites have but three pairs of feet. The eggs, which are globular in shape and either colorless or of a pale greenish yellow, are losely attached to the delicate web which may be found chiefly along the under sides of the leaves. With warm, dry weather the life cycle from egg to adult is not more than ten days.

The insects are carried from tree to tree upon the feathers of birds, by becoming attached to the feet of lady bugs, upon fallen leaves driven before the wind, etc. They can travel upon a leaf surface about two inches in one minute or ten feet in an hour, and therefore they quickly spread from any point where they have become newly established.

A yellowing of the leaves, showing as streaks and spots along the midrib on the upper surface of the leaves and as blotches of yellowish rusty brown on the lower sides, indicates the insect's presence. The excrements 
show as minute black spots and the cast skins, where aggregated together, constitute whitish silvery patches. After a few weeks the leaves curl, shrivel and fall, more than one-half of the leaves often coming down and from one-third to two-thirds of the immature fruit. In 1899 one grove located in Citra, Fla., reported a crop of only about ten thousand boxes from the heaviest bloom the grove had ever put forth, whereas it had yielded twentyfour thousand boxes the preceding year, the whole shrinkage of product being attributed to the six-spotted mite.

The rainy season of June and July causes the mites to practically disappear and they remain in such small numbers during the latter part of the year that they are rarely noticed at all. Vigorous trees, especially those grown on high hammock land or low, moist soil, are not apt to be injured, and where irrigation or artificial watering is practiced damage is slight. Drenching the trees with water from a hose, where the water supply is abundant, as in the case of irrigated groves, meets every demand.

Treatment: Formulas (14), (11), (12) or (13).

Purple Mite or Red spider. (Tetranychus mytilaspidis). The Red Spider appears to be identical with the insect known throughout Florida as the Purple Mite. This insect is quite small, yet distinctly visible to the naked eye. During the summer months they frequently appear in large numbers and cause great damage by causing the fruit to drop and injuring the leaves so that they do not properly perform their functions. The leaves become spotted and lose their natural glossy green color.

The females are considerably larger than the males. Both are covered with a number of stiff hairs, which act as a protection. The color of these insects is somewhat 
purplish or reddish-purple in the old ones, while the younger ones are lighter, the newly-hatched ones being almost colorless or straw-colored.

The eggs are bright red in color and are deposited mostly on the under side of the leaves in proximity to the midrib. They are attached to the leaf by a number of silken threads attached to a stalk fastened to the egg at right angles on the upper surface. Eggs hatch rather irregularly, but generally take between one and two weeks. As soon as the young are out of the shell, they commence to such the juices of the plant and continue feeding throughout their whole existence.

Remedies. The insect disappears in Florida with the coming of the rainy season, but much damage is wrought in all citrus districts during dry weather. Spray with formulas (14) and (11) alternately every two or three weeks until damage ceases. 


\section{CHAP'TER XLII.}

\section{FORMULAS FOR SPRAYING MIXTURES.}

BORDEAUX MIXTURE, FORMULA (1).

For Fungi.

Copper sulphate.$\ldots \ldots \ldots \ldots \ldots \ldots \ldots \ldots 6$ pounds.

Unslacked lime ................. 4 pounds.

Water ................... 50 gallons.

Place the six pounds of copper sulphate in a coarse sack and suspend it in a barrel containing twenty-five gallons of water. Hang it from a stick laid across the barrel, so that it is just covered by the water. In this way, the copper sulphate will dissolve much more readily than if it be simply thrown into the barrel. Slack the lime in a wooden bucket by adding water, a little at a time, and reduce the whole to a thin paste. Then place the paste in a second barrel in twenty-five gallons of water. Allow sufficient time to cool, then agitate thoroughly before attempting to mix the two solutions. In pouring the copper sulphate and lime solutions together into the barrel of the spray pump, dip out a bucketful from each and pour them together in a united stream, at the same time thoroughly agitating the mixture in the pump barrel. This method will secure a mixture of the finest quality.

If a large amount of spraying is to be done, stock solutions of copper sulphate should be prepared. In a barrel holding fifty gallons of water, suspend a sack containing 100 pounds of copper sulphate. After the sul- 
phate has dissolved, fill up the barrel to the fifty gallon mark. When thoroughly stirred, each gallon will contain two pounds of copper sulphate.

Carefully slack 100 pounds of good, fresh lime, place it in a second barrel and add water to make fifty gallons. This solution will contain two pounds of lime to each gallon, when thoroughly agitated.

In making up the spraying mixture from these stock solutions, stir well, then dip out three gallons of the copper sulphate solution and dilute to twenty-five gallons with water in one barrel and place two gallons of the lime solution in a second barrel and dilute to twentyfive gallons. Then pour these together in the barrel of the spray pump as already directed.

If sufficient lime is not put into the mixture, there is danger of injuring the foliage. To obviate this, the mixture should be tested before using and if deficient in lime, more should be added. One of three tests may be used. Dip out a small quantity in a shallow dish, hold it up between the eye and the light and blow the breath gently into it. If a thin pellicle forms on the surface, there is sufficient lime present, but if this pellicle is not seen, lime must be added until it becomes visible. Second, dip a clean steel blade into the solution and hold it there for a minute or more. If a thin film of copper forms on the blade, more lime must be added. Third, prepare a solution of ferrocyanide of potash by dissolving an ounce of the substance in four or five ounces of water. Dip out a portion of the Bordeaux mixture into a shallow, white porcelain dish and allow a drop or two of the ferrocyanide of potash solution to fall into it. If a brownish red coloration is noted, lime must be added until no color is seen. 
Strain all solutions into the spray pump, to prevent clogging and use only wooden vessels in preparing the mixture.

AMMONIACAL SOLUTION OF COPPER CARBONATE, FORMULA (2). For Fungi.

Copper carbonate

Strong ammonia (26 per cent.) .........

5 ounces.

Water

3 pints.

Reduce the copper carbonate to a thin paste with water; about a pint and a half is sufficient. Then very slowly add the ammonia. Then add forty-five to fifty gallons of water.

If so desired, the stock solution of copper carbonate made as directed above, may be kept in a tightly corked glass bottle or stone jug and diluted in the proportion given in the formula when desired for use.

lime, CRUde CARbolic ACID AND SAlt, FORMula (3). For Foot Rot.

Unslacked lime ................ 1 peck.

Crude carbolic acid ............... 4 ounces.

Salt .................... 3 pounds.

Water ................... 2 gallons.

Slack the lime in two gallons of water, then add the crude carbolic acid and stir in the salt. If too thick, add a little more water.

CRUde CARbolic ACID solution, FORMula (4). For Foot Rot.

Mix together crude carbolic acid and water in equal parts. 
SULPHUROUS ACID SOLUTION, FORMULA (5).

For Foot Rot.

Mix together sulphurous acid and water in the proportion of three of the former to seventeen of the latter.

$$
\text { RESIN WASH, FORMULA (6). }
$$

For winter use against White Fly and Scale Insects.

Resin

Caustic Soda (98 per cent.) . . . . . . .

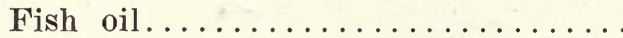

Water, to make.
30 pounds.

8 pounds.

4 1-2 pints. 100 gallons.

Place the resin (well broken up), caustic soda and fish oil in a large iron kettle. Pour over them twenty gallons of water and cook well over a good fire for not less than three hours. Then add hot water, a little at a time, and stir thoroughly until there is at least fifty gallons of the hot solution. Place this in a spray pump and add cold water to make up 100 gallons, or keep the mixture of fifty gallons as a stock solution and dilute with an equal amount of water as desired for use. Cold water should not be added during the cooking process, but a sufficient quantity of hot water should be provided for that purpose.

\section{RESIN WASH, FORMULA (7).}

For White Fly and Scale Insects in summer.

Resin

Caustic Soda (98 per cent.) ..........

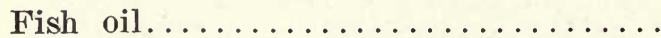

Water, to make.
20 pounds.

5 pounds.

3 pints.

150 gallons.

Prepare as directed for formula (6). 
KEROSENE EMULSION, FORMULA (8).

For Scale Insects and White Fly.

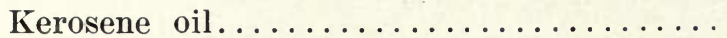

2 gallons.

Soft whale oil soap.............. 1 quart.

or chipped hard soap............ 1-2 pound.

Water .................... 1 gallon.

Dissolve the soap by boiling in the gallon of water and while still boiling hot, pour out into another vessel, removed from the fire. Then add the kerosene and churn steadily for fifteen or twenty minutes or until a good, stable emulsion is formed. The best implement for doing the necessary churning is a force pump, the liquid being pumped back into itself until the emulsion is formed. Make good the amount of water lost in boiling by adding sufficient warm water to bring the solution up to 41 -4 gallons.

For use during winter months, dilute each gallon with ten of water, and for use in summer months, dilute at the rate of one gallon of the mixture to fifteen of water. Never use kerosene emulsion on trees while shedded.

GOOD'S CAUSTIC POTASH WHALE OIL SOAP,

No. 3 , FORMula $(9)$.

For Scale Insects.

Soap.................. 12 to 15 pounds.

Water.................. 50 gallons.

This soap was recommended by Prof. H. A. Gossard in Bulletin No. 51, Florida Experiment Station, for use against citrus scales of different kinds. It is now commonly used throughout Florida and has given good satisfaction. 
KAHLE'S Distillate SOLUTiON, FORMULA (10).

For Scale Insects.

Untreated Distillate, 28 degrees....... 5 gallons.

Whale-oil soap................ 11-2 pounds.

Boiling water................ 5 gallons.

Dissolve the soap in the water. Place the distillate in the barrel of the spray pump and pour the soapy water in on top. Pump the mixture out of the barrel and back into it until a uniform creamy substance is secured. Pumping must be continued until a complete emulsion is formed and all oil globules have disappeared from its surface. This makes the stock solution.

For use on dormant trees dilute one gallon of stock with from twelve to fourteen gallons of water. 'On growing trees it may be used somewhat stronger-one gallon of stock solution to about eleven of water.

SODA-SULPHUR SOLUTION, FORMULA (11).

For Red Spider, Six-Spotted and Rust Mites.

Sulphur ................. 20 pounds.

Caustic soda (98 per cent.) .......... 10 pounds.

Water ..................... 20 gallons.

To make the stock solution, mix the sulphur to a medium thick paste with cold water in a barrel. Then add the caustic soda so that it may boil the sulphur after the same manner as lime boils when slacking. Have at hand twenty gallons of water and as the boiling process progresses, add it to prevent burning. 
For use, take one-half gallon of the stock solution and dilute with forty gallons of water, being careful to strain it well.

SODA-SULPHUR SOLUTION, FORMULA (12).

For Purple Mite, Red Spider and Rust Mites.

Sulphur.................... 30 pounds.

Caustic șoda (98 per cent.) ........... 20 pounds.

Water .................... 3 gallons.

To make the stock solution, place the sulphur in a half-barrel and reduce it to a thick paste with the three gallons of water. Then add the caustic soda and mix it well with the sulphur paste. As the mixture becomes warm, gradually add water to prevent burning. Stir thoroughly, adding water until twenty gallons of solution are obtained. Drain off into a $\mathrm{keg}$ and use as desired.

For use, take one or two quarts of this stock solution to fifty gallons for rust mite and double this strength for six-spotted mite.

$$
\text { SULPHUR-LIME SOLUTION, FORMULA (13). }
$$

Sulphur

6 1-4 pounds.

Lime

1 peck.

Water

10 gallons.

Place the three substances together and boil for thirty minutes. Place in a keg and use as a stock solution.

For use, dilute two gallons of stock solution with forty-eight gallons of water. 
POTASH, WHALE OIL SOAP AND SODA-SULPHUR SOLUTION, FORMULA (14).

For Scale, Mites and Red Spider.

Good's Potash Whale Oil Soap, No. 312 to 15 pounds. Soda-Sulphur Solution (Formula 11) 1 to 2 quarts. Water .................. 50 gallons.

CRIDDLE MIXTURe, FORMULA (15).

For Grasshoppers.

Paris Green.................... 1 part.

Salt $\ldots \ldots \ldots \ldots \ldots \ldots \ldots \ldots \ldots \ldots \ldots \ldots \ldots \ldots \ldots \ldots \ldots \ldots \ldots$ parts.

Horse manure (by measure).......... 40 parts. Water-sufficient to make it soft without being sloppy. Scatter through the grove. 



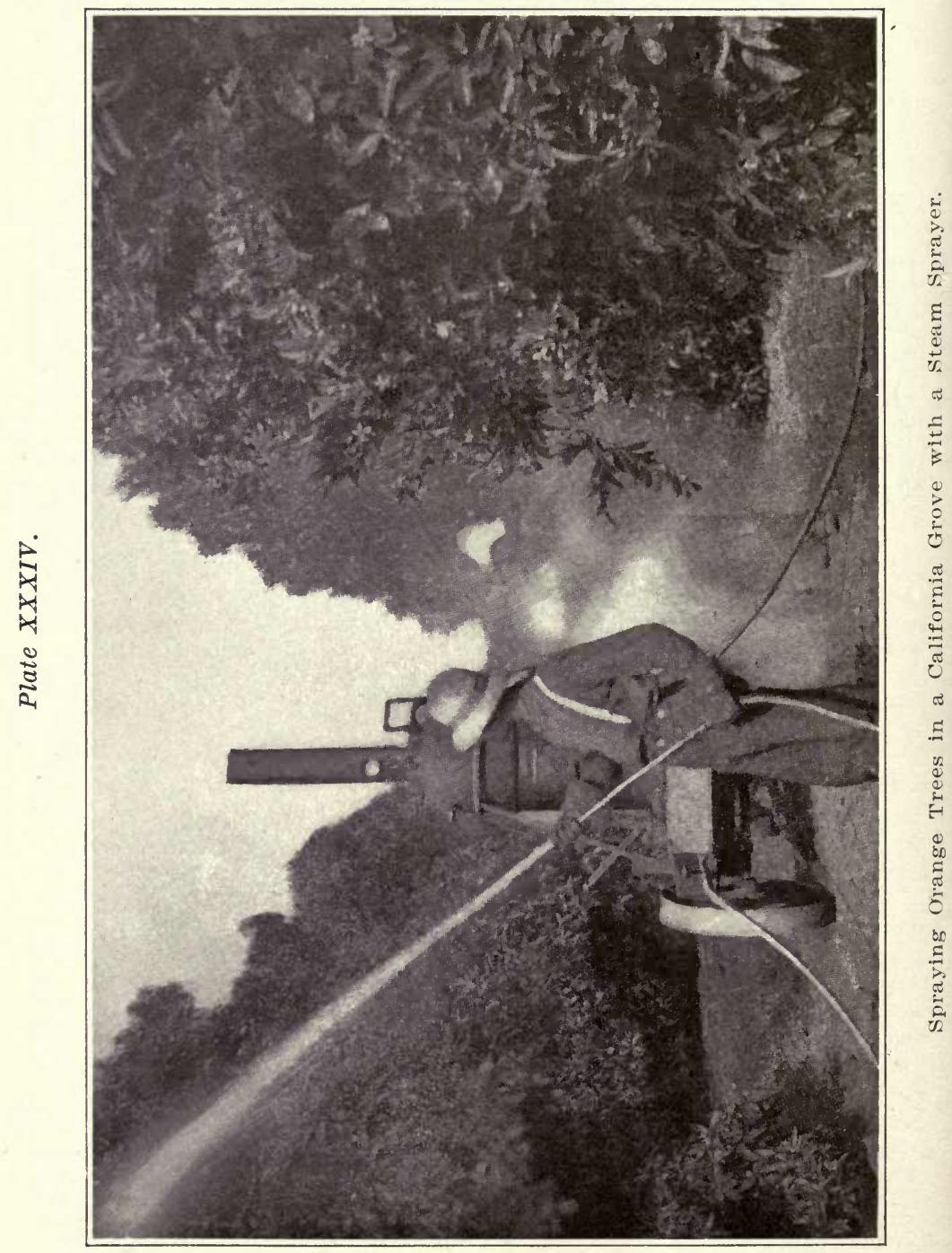




\section{CHAP'TER XIIII.}

\section{SPRAYING AND FUMIGATING.}

In controlling the most injurious citrus insects by direct means, resort must be made either to fumigation or spraying. Under certain conditions each method has its advantages. In Florida more attention has been given to spraying than to fumigating, while in California fumigating has received more attention relatively.

The equipment for fumigating, consisting of tents, wagons, and hoisting apparatus and the cost of operating is much more expensive than the equipment for spraying; for this reason the former method of control is not likely to come into favor with owners of small groves. On the other hand, it may be said that fumigating is more efficient against most insects, as one fumigation will prove as satisfactory as two or three sprayings. As pointed out by Prof. Gossard, the cost of one fumigation and three sprayings is about equal after leaving out of consideration the cost of the tents and the wear and tear on the apparatus. Wherever the expense of fumigating seems justifiable it should be borne, as the results are likely to prove much more satisfactory.

The choice of methods must in some degree be governed by the shape and density of the tops of the trees or the shape of the tree tops must be made to conform to the method of control. It is impracticable to thoroughly spray trees with dense, thick heads, they must be pruned out. The heads of the trees must be formed like a hollow cone with a leaf zone covering the framework of branches. Trees with low, flat heads such as are found by the Ba. 
ronio system of lemon pruning, are well adapted to spraying. All dead wood must be pruned from the interior of the tree before spraying is commenced.

Trees with dense, thick heads, as already noted, are much more easily fumigated than sprayed. The mass of branches prevents the spray from penetrating thoroughly and efficient work cannot be done except by fumigating.

\section{SPRAYING.}

In spraying trees for scale and allied insects, it will be found that, to secure the best results, the work must be thoroughly done. A liberal application should be given. Ten to fifteen gallons will be required for trees from fifteen to twenty feet high, while those from twenty five to thirty-five will require about half a barrel.

For spraying large areas, a gasoline or steam engine (see Plate 34), a strong pump carrying three or four leads of hose and a tank holding about three hundred gallons will prove most satisfactory. For smaller areas, hand pumps may be used and of these there are a number of good ones on the market. The Gould, Deming, Stahl. Friend and Field pumps may be mentioned here as giving good satisfaction.

To hold most insects in check, two or three winter sprayings and one or two summer sprayings will be necessary. As a general rule the armored scales must be sprayed during the immature stages, as they are not easily destroyed when their hard covering is fully developed. White-fly must be attacked during the larval and pupa stages, while the mites must be sprayed whenever active. Resin wash and similar mixtures should not be applied to trees when the fruit is only partially grown. Serious 
loss has been occasioned in some instances in Florida by spraying in May.

It may be stated that fumigation is not effective against the purple mite, the rust mite and similar insects. They must be sprayed, though against the rust mite in Florida, flowers of sulphur applied with a powder gun has proved effective. The sulphur must be applied in the morning when the trees are damp with dew. To keep the fruit bright, by destroying the rust mite, sprays must be applied once about every three weeks during the summer and fall months.

\section{FUMIGATING.}

For fumigating citrus trees hydrocyanic-acid gas generated by treating potassium cyanide with diluted sulphuric acid is used. The gas is liberated under a tent which covers the tree.

Many different kinds of tents are in common use. Among these may be mentioned the sheet hoop and bell tents (Plate 35). The style of tent used is governed in a large measure by the size of the trees, but the sheet tent is probably the most useful of all. For small trees, up to ten or twelve feet, the hoop tent is very serviceable.

Tents and Treatment. The following is from the pen of Prof. C. W. Woodworth, in regard to the materials for making tents and the treatment which must be given to render them gas-tight.

"Common duck is now uniformly employed for making the tent, most of them being made of the 8-ounce canvas, such as is used for light sails. The cloth is lapped and double-sewed in the same manner as for tents or sails. The edge is usually simply hemmed, but some bind it with rope. Whenever permanent rings for handling are at. 
tached, the tent is reinforced, but this is a matter in which there is much diversity. The details of the construction will depend somewhat on the size and kind of tent, and will be referred to again, below.

After the tent is made, it is treated in some manner to make it gas-tight, so as to confine the gas better. Three methods are used for this purpose, all of which seem to give good satisfaction.

The first method is to thoroughly treat the tent with boiled linseed oil. It is applied freely with a brush, and the whole cloth becomes saturated with it. The tent must be kept spread out till quite dry, for the oil has a great tendency to heat if not exposed freely to the air, and the cloth chars and becomes rotten. If properly done, the tent remains strong and tight, and is not too stiff.

The second method consists in the use of sizing and paint. The sizing is applied in the same manner as the oil, and penetrates the fiber of the cloth in the same way. As soon as this coat is dry it is followed by another of rather thin flexible paint, sometimes on both sides; the result being a perfectly tight tent with a very smooth surface and fully as flexible as the oiled tent. The sizing protects the fiber of the cloth, so there is no danger of heating.

The third method is the saturation of the cloth by a decoction of the chopped-up leaves of the common pricklypear cactus (Opuntia engelmani). This decoction is made by filling a barrel two-thirds full of the chopped stems, adding cold water till the barrel is nearly full; then letting it soak twenty-four hours, when it is drawn off and strained, and is ready for use. This decoction is seldom used by itself, but other substances are added according to the whim of the person treating the tents. Very generally a pigment like yellow ochre or Venetian red, is added 
to give more body to the mixture; sometimes glue is added also. There is some tendency in tents treated with the cactus decoction, to become moldy when not in use, to prevent which some prepare a tannin solution to add to the mixture. The decoction may be applied to the tents with a brush, but a better way is to soak them during the night in a trough containing the mixture. In the morning they can be raised by means of ropes and pulleys and allowed to drain for some time and then spread out to dry. Tents treated with this mixture are scarcely at all stiffened and seem to be satisfactorily tight."

In treating cloth so as to render it gas-tight, Prof. H. A. Gossard used and recommends the following:

"Five pounds white lead, fifteen pounds of laundry soap, chipped, ten pounds of lampblack, two gallons of boiled linseed oil, six gallons of water. Heat to boiling two vessels of water, having three gallons in each. In one dissolve the soap and keep the other hot. Thoroughly pulverize the lampblack by stirring and mixing well with onehalf gallon of vinegar. Now add the lampblack to the linseed oil, stir, and pour into the soap solution. Add the white lead, mix the whole thoroughly, using all the water, and apply to cloth with brush, keeping the paint hot enough to just show steaming while being used. If the first coating is not sufficient, reverse the tent and give an application to the opposite side."

The manipulation of tents is a matter requiring considerable skill, and as a rule it is best to secure skilled labor in first undertaking the work. Excellent directions are given by Prof. Woodworth in Bulletin 122, California Experiment Station. The following on the form and handling of sheet tents is taken from that publication: 
"Sheet tents are made either in a regular or in an oval hexagon, and perfectly flat. A pair of rings is often attached on each side, near what is intended as the front edge; it is convenient to attach these rings by iron links, so that they can be rattled and found in the dark by shaking the tent.

The movement of the tent is accomplished by the use of two poles. These are usually simple poles with a small rod projecting from the upper end, over which the ring of the tent is slipped, a rope is also fastened at the upper end. The length of the pole is slightly greater than the height of the trees it is desired to cover. Sometimes the pole has the same shape as the lifter used for the box tents, but the pulleys and guy-ropes are not needed, except for the largest trees.

********* The men approach the tent to be moved, poles in hand, and finding the rings insert the small rods at the end of the poles and take a hitch with the rope over the ring to prevent the latter from slipping off. They then proceed to the other end of their poles, which they have placed even with the trunk on opposite sides of the tree to which the tent is to go. While taking this station they have not let go of the rope, but have held it tight enough not to loosen the tent ring. The next step in the process is to place one foot on the end of the pole, to prevent it from slipping, and to pull on the rope. This will lift up the edge of the tent * * * * * As the men continue to pull on the rope the end attached to the tent moves through the arc indicated by the line of arrows. As soon as the pole becomes nearly enough upright, as not to slip when the foot is removed from the end the man backs off, away from the tree, and thus gets a more direct pull on the tent which by this time has begun 
to require some considerable effort. This becomes necessary also in order that the pull from each side may stretch out the front edge of the tent so that it may clear the top of the tree.

The tent is now spread out over two trees and reaches the ground on either side. As the men at the ropes continue to back away the tent is slipped from one tree to the next and the poles fall to the ground. In this last stage in the process care must be taken that both poles reach the ground at about the same time. If this is not done the tent will shift to the side of the pole which first reaches the ground, and if that side is pulled very much too fast the tent may not reach the ground on the opposite side, and sheet tents are rather harder to adjust than other kinds. This same difficulty, in regard to the front and back ends of the tent, often occurs when using a tent barely large enough for the tree. If the tent is pulled too slowly the poles will slip when the tent is not quite over, and the front will not reach the ground; and on the other hand, if it is pulled too rapidly, the tent will go too far, and the back end be free from the ground. The oval tent was made to overcome this difficulty, for with it care only need be taken to slide the tent far enough.

When using a large tent for a very small tree the tent is pulled up so as to have sufficient slack canvas to go over the tree, and this is pulled over by hand. When being removed, the cloth is pulled back in the same manner as it was put on and dragged along the ground to the next tree.

In the case of very large trees, which require the lifter style of pole, the process is as follows: The poles are set up and the guy-ropes attached as described for the box tent, only that two poles are used. The other ropes are 
now attached to the tent at the near edge and the latter pulled to the top of the pole. The rope is then made fast, the guy-ropes pulled, and the tent slid in the same manner as with smaller tents. Sometimes the pole is not set at such an angle but nearer the tent, when it will be necessary, after sliding the tent part of the way, to again tie the guy-rope and lift the bottom of the pole over; it will then be opposite the trunk, and the tent will be lifted high enough when it is given the final shift.

When there is fear of breaking the branches in removing a tent, the practice is to "skin it off," using a pole of the lifter pattern, and carry the rope around to the far side and attach it to the edge of the tent there. The tent by this method slides over itself and saves the tree to that extent; it is pulled over on to the next tree as in the preceding methods. Since much of the tent by this method falls to the ground, it is harder on the tree while it is being tented. By this process the tent is reversed each time it is changed."

Chemicals and Amounts. Only chemicals of high quality should be used, and to this matter particular attention must be given. There is much variation in dosage as given by different fumigators. In part, this may be due to climatic and other conditions, but the wide difference may be attributed, in a large measure, to a lack of thorough investigation of the subject. Potassium cyanide, sulphuric acid and water in the proportion of 2 to 3 to 6 will give excellent results.

Most of the fumigation of citrus trees has been for scale insects. Sufficient work on white fly has been done to justify the conclusion that it requires the same dosage as for scales. 
One of the most accurate fumigation tables is given by Mr. W. J. Allen, of New South Wales. The following table has been selected from this:

\begin{tabular}{|c|c|c|c|c|}
\hline $\begin{array}{c}\text { DIAMETER OF } \\
\text { TREE }\end{array}$ & HEIGHT OF TREE & $\begin{array}{l}\text { CYANIDE C. P. } \\
\text { (98 per cent) }\end{array}$ & $\begin{array}{l}\text { SULPHURIC } \\
\text { ACID } \\
\text { (66 per cent.) }\end{array}$ & WATER \\
\hline Feet & Feet & Ounces & Ounces & Ounces \\
\hline $\begin{array}{r}4 \\
5 \\
6 \\
9 \\
10 \\
12 \\
14 \\
15 \\
17 \\
18 \\
20 \\
23 \\
23\end{array}$ & $\begin{array}{r}4 \\
5 \\
8 \\
8 \\
12 \\
15 \\
16 \\
20 \\
22 \\
24 \\
24 \\
23 \\
26\end{array}$ & $\begin{array}{l}1^{1 / 3} 1 / 2 \\
1^{1 / 8} \\
4 \\
7^{1 / 4} \\
10^{1 / 2} \\
15^{1 / 2} \\
21^{1 / 4} \\
26 \\
32 \\
41 \\
46\end{array}$ & $\begin{array}{l}y^{1 / 3} 1 / 2 \\
1^{1 / 2} \\
21 / 8 \\
4 \\
71 / 4 \\
10^{1 / 2} \\
15^{1 /} \\
211 / 4 \\
26 \\
32 \\
41 \\
46\end{array}$ & $\begin{array}{c}11 / 4 \\
11 / 2 \\
21 / 2 \\
6 \\
12 \\
21 \\
30 \\
45 \\
63 \\
78 \\
96 \\
123 \\
148\end{array}$ \\
\hline
\end{tabular}

After the tent is in place over the tree, a few shovelfuls of earth should be thrown on the lower rim of the tent, resting on the ground to make it completely gas-tight.

The tent is then ready for charging. The best generator is an earthenware vessel. This is placed outside, close to the tent. The requisite amount of water is placed in the vessel and the acid is added. Into this the cyanide of potassium, previously weighed out in a small sack, is dropped. The generator is then held at arms-length and placed beneath the tent, which is then snugly closed and left for 40 or 45 minutes. Both the cyanide of potassium and the gas are extremely poisonous and must be handled with great care.

Usually the fumigation is done at night. If carried on during the day the tent should be painted black.

The most complete work on the subject of fumigation is one entitled Fumigation Methods, by Prof. W. G. Johnson. 


\section{CHAPTER XLIV.}

\section{FUNGOUS AND INSECT FRIENDS.}

Fortunately, all fungi and insects are not enemies. While many of them are arrayed against the grower, and, at times, interfere seriously with the cultivation of his fruit trees and other plants, on the other hand a considerable number, a by-no-means-insignificant force, wage war against the insects which destroy his crops. The two forces, one working in harmony with the cultivator, the other against him, frequently balance each other, and the injury to the trees and fruit is slight; sometimes his friends overcome the injurious insects and so greatly reduce their numbers that the crop matures without injury; at other times his enemies, under favorable conditions, increase more rapidly than his friends and when such is the case the fruit crop suffers severely unless the grower himself intervenes.

Where fungi and insects can be relied upon to hold the enemies of citrus trees in check, the grower possesses a very considerable advantage over the cultivator who is not so fortunately situated. The latter must resort to spraying or fumigating to protect his fruit and trees from injury, and the added expense is quite an item. If fungous and insect friends can be relied upon to do their part and do it efficiently, the control of insect enemies should be left to them. Many growers have been able to do this, others have not. As a result the growers of citrus fruits have separated along these lines and we now have advocates of spraving, advocates of non-spraying and those 
who mix the two practices. The last-mentioned class get all the bad effects of the other two practices and none of the good. They do enough spraying to destroy or drive away their friends, too little to destroy their foes, and consequently they leave themselves to the tender mercies of the latter. It should be distinctly understood that there is no intermediate ground. The citrus-fruit grower must either spray and do it thoroughly and systematically, just as he would cultivate, fertilize or irrigate, or if he decides to depend upon certain fungi and insects to control the insect foes which attack his trees and fruit, he must leave the field entirely to them and do everything in his power to foster and assist them. There must be no mixing of practices.

Which plan is the best to adopt no one but the grower can determine, and then only after having obtained a thorough knowledge of his own conditions.

To successfully control insects, by natural agents, certain conditions are necessary. The insects to be controlled, must be gregarious and sufficiently numerous in the beginning at least, to enable the controlling agent to become thoroughly established. Thereafter the host insect must always remain in sufficient quantities to supply sufficient food for the existence of the friendly insect or fungus as the case may be. Lacking this, the grower must see to it that a sufficient number of the injurious insects are kept to insure the perpetuation and multiplication, to a considerable extent, of their fungous and insect enemies. In short the latter must be bred and kept for use in case of outbreaks. Then when injurious insects are present in alarming numbers in a section, the controlling agents, fungous or insect, may be introduced and established. 
Fungous Friends. Fungi can be successfully used, to check the ravages of insects, only in those regions having a moist climate and a season sufficiently long to permit of their development. In Florida, Louisiana and the Islands, fungi may be depended upon, to a certain extent and in many cases to a very considerable extent, to control injurious insects, but they would fail utterly in the arid or semi-arid climate of Arizona and Southern California. These regions must depend upon predaceous and parasitic insects as controlling agents. Whether these same agents can be as successfully used in the more humid regions has not been entirely proven, though in one instance at least they have. In some cases a combination of fungous and insect control has been satisfactorily established.

In Florida the control of the more injurious citrus insects, the scales and their relatives, by means of their fungous enemies has received more attention than in any other portion of the world. None of these fungi, so far as known, are introduced species, though some of them may be.

The principal fungous enemies of citrus insects in Florida are the Red Fungus, Sphorostible coccophila Tul., well known through the work of Prof. P. H. Rolfs, as an enemy of the San-Jose Scale (on peaches), the Gray Fungus, Ophionectria coccicola E. and E., and the Black Fungus, probably belonging to the Pyrenomycetes.

Preying on the White Fly, Aleyrodes citri, are two fungi, first brought prominently to notice by Dr. H. J. Webber. These are the Red Aschersonia, Aschersonia aleyrodis Webber, and the Brown Fungus.

The Red Fungus, Sphorostilbe coccophila Tul.- 
When attacked by this disease, the body of the scale becomes filled with a mass of fungal threads (mycelium) and shortly after the time of attack, the insect is dead. By the time the fruit stage of the fungus is reached, the body of the insect has been destroyed; the scale covering alone remains.
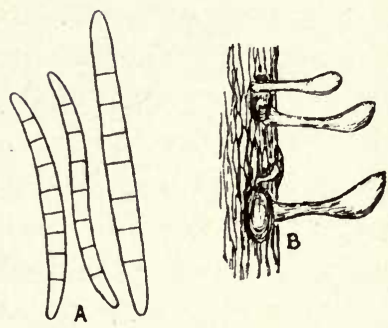

Fig. 119. Red Fungus of Scale Insects (Sphaerostilbe coccophila Tul.) A, Spores (greauy enlarged). B, Spore-bearing bodies growing out of scales (enlarged).

Following this period of growth in the body of the insect, one or more orange-colored, knob-like bodies are produced. Sometimes these actually break through the scale, at other times they emerge from the sides. One of these, enlarged, is shown in Fig. 119. These knob-shaped bodies contain the spores which are microscopical in size. By means of them the disease spreads to other insects. the spores light upon or near other scales. A delicate mycelial tube is produced which penetrates the body of the scale and its death is brought about as before. The spores, greatly enlarged, are shown in Fig. 119.

This fungus is quite effective in holding scale insects in check. It is also found occasionally on the pupæ of White Fly.

The Gray Fungus, Opheonectria coccicola E. and E. So far as observation goes, this is probably the most widely distributed fungous enemy of the citrus scale insects found in Florida. In the early stages, the disease attacks the scale much as the Red Fungus does. A mycelium is produced which grows and develops in the body of the insect. 
Two kinds of spores are produced. The first of these, not heretofore reported as being produced by this fungus, are borne in rather conical knobs, Fig. $120 \mathrm{~A}$. These knobs

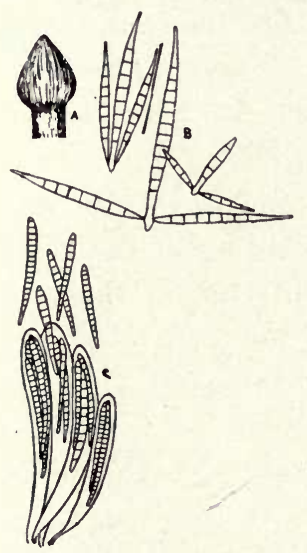

Fig. 120. Spores and spore cases of gray-headed fungus (Ophionectria coccicola E. \& E.) A, Conidiophore in which the spores are clustered in a head. B, Conidia or spores. C, Asci, or spore cases and spores.

conidiophore. If placed under the microscope and a drop of water is added, they move like animate objects.

The other kind of spores, (sporidice) are twelve to fifteen celled, club-shaped and produced, eight together, in a spore case (Fig. $120 \mathrm{C}$ ). In this stage the fungus assumes a gray dirty buff color. These spores are specially provided to carry the fungus through periods unsuitable to its growth.

Both kinds of spores (conidia and sporidia) are in. strumental in disseminating the disease. It serves as a very efficient check in many cases against the Long and Purple scales. are composed of spores (conidia) borne upon a very short stalk, called the conidiophore. When clustered together over the dead scales these conidiophores give a pebbled appearance to the part. They are grey in color. The spores (conidia) Fig. $120 \mathrm{~B}$ are divided into three parts, trident-shaped, the central one being the largest. Each side projection has from five to eight cells, while well-developed central ones have about fifteen. After having dried for a time, these trident-shaped conidia spread apart on the application of moisture and thus are set free from the

\section{(1)}

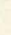


The Black Fungus. Frequently black incrustations covering the dead bodies of scale insects may be seen on citrus trees. This black substance is a fungous growth. evidently a pyrenomycete, but thus far no spores have been found in it in Florida. It evidently does a great deal toward holding scale insects in check in Florida, and Prof. Earle has also found it in Porto Rico.

The Red Aschersomia. (Aschersonia aleyrodis Webber). This is an extremely important enemy of the White Fly, Aleyrodis citri. It attacks the insect in the pupa stage. An elevated ruby or pinkish pustule is formed upon the pupa. This is surrounded by a little yellowish or whitish band. As the fungus matures the color becomes deep red. In this red portion, the spores (sporules) of the fungus are produced. These are borne in pits. They are narrow, pointed and frequently curved. Usually they consist of but a single cell.

The mycelium of the fungus grows and develops in the body of the pupæ, the spore formation taking place after the insect is dead as in other cases.

The fungus, when once established, spreads quite rapidly through a white-fly-infected grove. Unfortunately, it is not so readily spread, artificially, as the Grey Fungus of scale insects.

The Brown Fungus. This fungus was first brought to notice by Dr. H. J. Webber, of the United States De. partment of Agriculture. It is probably the most effective fungous enemy of the White Fly.

The fungus forms hard, brown pustules on the pupæ of the insects. They are attacked when at rest on the leaves. The fungus having once gained a foothold, spreads 
by means of minute threads which grow out from the sides of the pustule. Frequently it forms a thin, solid tissue over the under side of a citrus leaf as it grows from pupa to pupa.

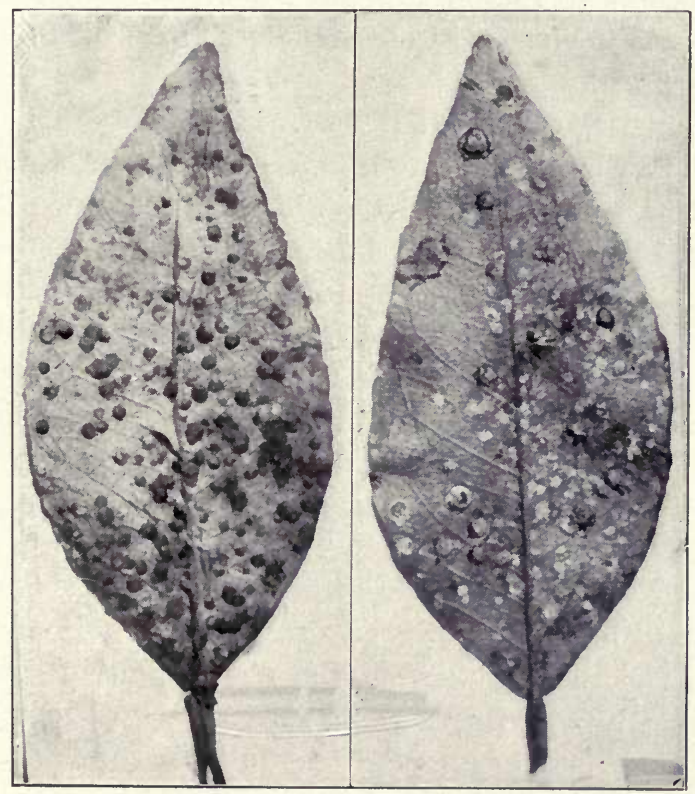

Fig. 122. Fungous enemies of White Fly on the pupae on orange leaves, Brown Fungus on the left, Red Aschersonia on the right

Thus far, the spores of this fungus have not been described, and in fact are not known positively to exist. There is reason to believe, however, that spores are borne in July and August in Southern Florida.

The fungus is disseminated by portions of the mycelium blowing from one leaf or tree to another, and probably by means of spores. 
METHODS OF DISSEMINATING THE SPORES OF BENEFICIAL FUNGI.

The Red and Grey Fungi may be cultivated artificially in the laboratory and afterwards may be placed on the scales, in the grove. A plan which has succeeded in some cases is to take a twig on which the fungus is present, and tie it closely in contact with the scales on an affected branch.

During the year 1907, Mr. H. S. Fawcett, of the Florida Experiment Station, succeeded in producing cultures of both the Red Aschersonia and the Brown Fungus, on artificial media, in the laboratory. In the same year Dr. E. W. Berger, of the same institution, successfully demonstrated that the Aschersonia disease of the white fly could be distributed satisfactorily both by spraying the pupæ with water containing spores of the fungus and by pinning leaves, bearing pupæ covered by the fungus in a fruiting stage, in contact with the insects on the under side of infected leaves. The most satisfactory results were obtaintd during the rainy season, using about one dozen leaves to a good-sized tree. This plan will doubtless rapidly supersede the older plan of spreading the fungus by planting a small tree, on which it is present on the pupæ, so close to the tree in which it is desired to introduce it, that the branches will interlap and allow the fungus to spread naturally.

The success which has rewarded the efforts of these two workers marks another step in the successful control of insect foes by means of fungi parasitic upon them.

Insect Friends. The greatest triumph of modern economic entomology was the control of the cottony cushion scale (Icherya purchasi) by the imported Australian ladybug, Novius cardinalis. The cottony cushion scale secured a strong foothold in California, and threatened the destruction of the whole citrus industry. 
Spraying and fumigating were attempted with indifferent success, when the happy suggestion was made by Mr. Alexander Craw, to send some one to Australia, to find and introduce the natural enemies of the pest. This was accomplished through the co-operation of the United States Department of Agriculture and Mr. Frank McCoppin, of San Francisco, United States Commissioner to the Melbourne (Australia) Exposition. Mr. Albert Koebele was selected to do the work. The task was successfully accomplished. He found the natural enemy, Novius cardinalis. It was sent to California, thrived in its new home and speedily destroyed the dreaded Icherya purchasi.

When the cottony cushion scale became established in Florida, Prof. H. A. Gossard, of the Florida Experiment Station, was instrumental in introducing the ladybug from California, and the ravages of the insect were again checked.

Following this signal triumph, the attention of entomologists has been directed to this means of insect control. The mealybug has been checked in California

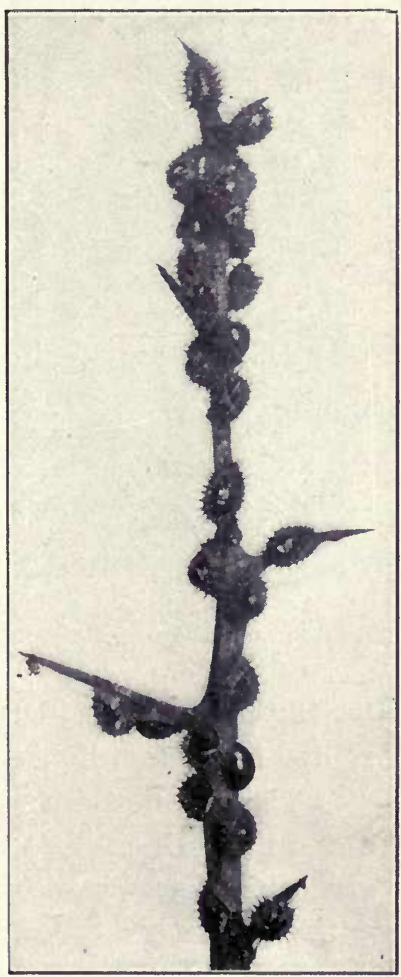

Fig. 123. Ladybug pupae on orange twig. One mature insect may be seen near the bottom. by a ladybug, Cryptolaemus montrouzieri, which preys upon it. Another, Rhizobius ventralis has proved effective as an enemy of the Black scale, Lecanium. 
In Florida the two-spotted ladybug is an effective enemy of scale insects. The ladybugs are very common

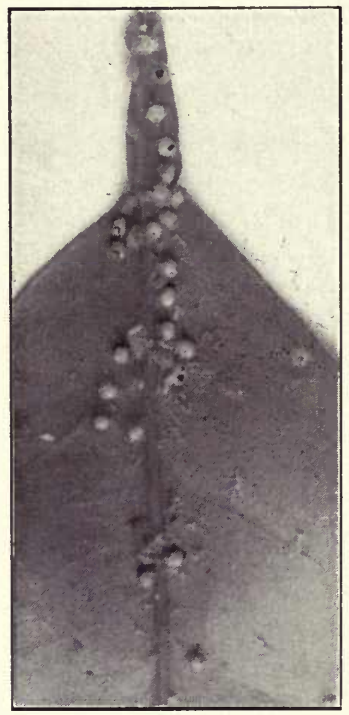

Fig. 124. Parasitized plant lice on an orange tree. throughout the State. The pupæ are shown in Fig. 123. One mature insect is shown on the right of the twig near its base. Both the larva and the mature insects feed upon scale insects.

The Hemispherical scale in Florida is usually held in check by internal parasites of the order Hymenoptera. Insects of the same class usually destroy the green lice or plant lice (Aphis) which frequently infest the new growth on citrus trees. The appearance of the parasitized plant lice is well shown in Fig. 124. The bodies of the aphids are congested, swollen and globular. The minute openings, from which the parasites emerge after having matured inside the bodies of the aphids, are represented by round, black dots on the swollen bodies.

There is no limit to the advances which may be made along these lines. We have probably but entered upon an era which may see our methods of combating insects entirely changed. 
PART IV

LITERATURE 



\section{CHAPTER XLV.}

\section{AMERICAN CITRUS LITERATURE.}

Literature on the culture of citrus fruits in America is brief and scattered. In this country no monumental work, such as Ferrari's Hesperides, Volckamer's Hesperides Norimbergensium, Gallesio's Traite du Citrus, or Risso \& Poiteau's Histoire et Culture des Orangers, has been produced. The following list comprises nearly all that has been published, except that which may be found in the Reports of the Florida State Horticultural Society and of the California State Board of Horticulture. Many of the books and papers listed are out of print and are no longer available. Most of the publications of the Experiment Stations, both of California and Florida, can still be obtained.

Adee, Alvery A. The Orange and the Lemon in Fruit Culture in Foreign Countries. Reports of the Consuls of the United States on fruit culture in their several districts in answer to a circular letter from the Department of State. Washington: Government Printing Office. 1890. Part 1, pp. 399-585. Special Consular Report U. S. Dept. of State.

Bailey's Cyclopedia of American Horticulture. New York: The Macmillan Company; Copyrt. 1900-02. Numerous articles by different writers; see citrus, orange, lemon, lime, pomelo, citron and kumquat.

Davis, George W. A Treatise on the Culture of the Orange and other Citrus Fruits. Jacksonville: Ashmead Bros. Copyrt. 1881-1882. Pp. iv. and 86. 
Downing, A. J. The Orange Family in Fruits and Fruit Trees of America. New York: John Wiley \& G. Putnam. Ninth Ed. 1849 ; pp 542-546.

Garey, Thos. A. Orange Culture in California. San

Francisco: Pacific Rural Press. Copyrt. 1882-1883.

Pp. 210. App. on Grape Culture by L. J. Rose. Pp. 210-227.

Goff, E. S. Citrus Fruits in Lessons in Commercial Fruit Growing. Madison: University Cooperative Association. Copyrt. 1902. 1902. Sec. 4; pp. 101105.

Gossard, H. A. Some Common Florida Scales. Jacksonville: The H. \& W. B. Drew Co., 1900. Illustr.; pp. 106-128. Bulletin No. 51, Florida Agri. Exp. Station.

The Cottony Cushion Scale. DeLand: E. O. Painter \& Co. 1901. Illustr.; pp. 310-356. Bulletin No. 56, Florida Agri. Exp. Station.

White Fly. Deland: E. O. Painter \& Co. 1903. Illustr.; pp. 595-666. Bulletin No. 67, Florida Agri. Exp. Station.

Hart, E. H. Citrus Fruits. In the American Fruit Culturist, by J. J. Thomas. Twentieth Ed., by William

H. S. Wood. New York: Wm. Wood \& Co. Copyrt. 1897. 1897. Part 3; Chap. 25; pp. 558-588.

Harcourt, H. "Culture of Citrus Fruits" in Florida. Fruits and How to Raise Them. Revised and Enlarged Edition. Louisville: J. P. Morton \& Co. Copyrt. 1886. 1886. Chap. I-XVII; pp. 9-116.

Henderson, Peter. Citrus in Henderson's Handbook of Plants and General Horticulture. New edition. New York: Peter Henderson \& Co. Copyrt. 1889. 1890. Page 88. 
Hubbard, H. G. Insects Affecting the Orange. Report on Insects Affecting the Culture of the Orange and Other Plants of the Citrus Family, with Practical Suggestions for their Control or Extermination, made under direction of the Entomologist. Washington: Govt. Printing Office. 1885. Illustr. Pp. 227. Division of Entomology, U. S. Dept. of Agri. Hume, H. Harold. Some Citrus Troubles. Jacksonville: H. \& W. B. Drew Co. 1900. Illustr. pp. 145-180. Bulletin No. 53, Florida Agri. Exp. Station.

Pomelos. Jacksonville: H. \& W. B. Drew Co. 1901. Illustr. pp. 381-421. Bulletin No. 58, Florida Agri. Exp. Station.

Diagrams for Packing Citrus Fruits, with brief directions. DeLand: E. O. Painter \& Co. 1902. Illustr. folio. Bulletin No. 63, Florida Agri. Exp. Station.

Kumquats. DeLand: E. O. Painter \& Co. 1902. Illustr. pp. 551-516.' Bulletin No. 65, Florida Agri. Exp. Station.

The Mandarin Orange Group. DeLand: E. O. Painter \& Co. 1903. Illustr. pp. 567-594. Bulletin No. 66, Florida Agri. Exp. Station.

Cultivation of Citrus Groves. Jacksonville: Industrial Record Printing Co. 1904. Illstr. Bulletin No. 69. Florida Agri. Exp. Station.

Klee, W. G. Citrus Fruits-Orange, Iemon, Lime, etc., in the Report on the Condition of Tropical and Semi-Tropical Fruits in the United States in 1887. 1887. pp. 111-124. Bulletin No. 1, Division of Pomology, U. S. Dept. of Agriculture.

The same. Reprint. 1891. 
Lelong, B. M. Culture of the Citrus in California. Sacramento: A. J. Johnson, Supt. State Printing. 1902. Illustr. pp. 267.

Marlatt, C. L. The Scale Insect and Mite Enemies of Citrus Trees, in Yearbook of U. S. Dept. of Agriculture. 1900. Washington: Govt. Printing Office. 1901. Illustr. pp. 247-290.

Manville, A. H. Practical Orange Culture, Including the Culture of the Orange, Lemon, Lime and other Citrus Fruits, as Grown in Florida. Jacksonville: Ashmead Bros. 1883. pp. VI. 116.

Mills, J. W. Citrus Fruit Culture. Sacramento: A. J. Johnson, Supt. State Printing. 1902. 1902. Illustr. pp. 46. Bulletin No. 138, University of California, College of Agriculture, Agri. Exp. Station.

Moore, T. W. Treatise and Handbook on Orange Culture in Florida. Jacksonville: Florida Sun \& Press. Copyrt. 1877. 1877. pp. VI-67.

The same. Second edition. New York: E. R. Pelton \& Co. Jacksonville: Ashmead Bros. Copyrt. 1881. 1881. pp. IX-170.

The same. Third edition. Revised and enlarged, embracing Florida, Louisiana and California. New York: E. R. Pelton \& Co. Jacksonville: Ashmead Bros. Copyrt. 1881. 1883. pp. IX-170.

Reasoner, P. W. Orange, Pomelo, Lemon. etc., in the Report on the Condition of Tropical and Semi-Tropical Fruits in the United States in 1887. Washington: Govt. Printing Office. 1887. pp. 57-87. BuJletin No. 1, Division of Pomology, U. S. Dept. of Agriculture.

The same. Reprint. 1891. 
Spalding, W. A. The Orange: Its Culture in California, with a brief discussion on the Lemon, Lime and Other Citrus Fruits. Riverside: Press \& Horticulturist Steam Print. Copyrt. 1884. 1885. Illustr. pp. VIII-97.

Stubbs, W. C. \& Morgan, H. A. The Orange and Other Citrus Fruits from Seed to Market, with Insects Beneficial and Injurious, with Remedies for the Latter. Baton Rouge; Truth Book and Job Office. 1893. Illustr. pp. 110. Special Bulletin of the Louisiana Exp. Station.

Swingle, W. T. \& Webber, H. J. The Principal Diseases of Citrus Fruits in Florida. Washington: Govt, Printing Office. 1896. Illustr. pp. VIII-32. Bulletin No. 8, Division of Pomology and Pathology, U. S. Dept. of Agriculture.

Van Deman, H. E. Report on the Relative Merits of Various Stocks for the Orange, with Notes on Maldi-goma and the Mutual Influence of Stock and Scion. Washington: Govt. Printing Office. 1891. pp. 21. Bulletin No. 4, Division of Pomology, U. S. Dept. of Agriculture.

Webber, H. J. Methods of Propagating the Orange and Other Citrus Fruits in Yearbook of U. S. Dept. of Agriculture, 1896. Washington: Govt. Printing Office. 1897. Illustr. pp. 471-488.

Fertilization of the Soil as Affecting the Orange in Health and Disease, in Yearbook of the U. S. Department of Agriculture, 1894. Washington: Govt. Printing Office. 1895. Illustr. pp. 193-202.

The same. Reprint. 
Sooty Mold of the Orange and Its Treatment. Washington: Govt. Printing Office. 1897. Illustr. pp. IV-30. Bulletin No. 13, Division Physiology and Pathology, U. S. Dept. of Agriculture.

White, W. N. Citrus-The Orange Family, in Gardening for the South. New York: C. M. Saxton \& Co. Copyrt. 1856. 1856. pp. 327-330.

Orange, Lemon, etc., in Gardening for the South, second edition, by J. Van Buren \& Jas. Camak. New York: Orange Judd \& Co. Copyrt. 1868. 1868. pp. 382-384.

Whitner, J. N. Kumquat-Otaheite Orange, Orange in Gardening in Florida, a Treatise on the vegetables and Tropical Fruits of Florida. Jacksonville: C. W. DaCosta. Copyrt. 1884. 1885. pp. 210-216.

Wickson, E. J. The Orange, Lemon, Lime, etc., in The California Fruits and How to Grow Them. Third edition. San Francisco: Pacific Rural Press. Copyrt. 1889. 1900. Chap. XXX-XXXI., pp. 331380 .

Woodworth, C. W. Orange and Lemon Rot. Sacramento: A. J. Johnson, Supt. State Printing, 1902. Illustr. pp. 12. Bulletin No. 139, University of California, College of Agriculture, Agri. Exp. Station.

The Red Spider of Citrus Trees. Berkeley: The University Press. 1902. Illustr. pp. 19. Bulletin No. 145, University of California, College of Agriculture, Agri. Exp. Station. 


\section{PART V}

APPENDIX 



\section{CHAPTER XLVI.}

\section{VARIETY LISTS.}

Every grower has his own preferences and his own ideals. Hence the following lists may not meet with the approval of every one. No mention is made of the regions to which they are adapted, as this has been touched upon in the chapters on varieties.

\section{SWEET ORANGES.}

Very Early.-Boone, Early Oblong.

Early.-Enterprise, Centennial, Nonpareil, Parson Brown.

Medium.-Bahia, Pineapple, Ruby, St. Michaels (Blood), Homosassa, Indian River, Jaffa, Magnum Bonum Maltese Blood, Old Vini.

Late.-DuRoi, Maltese Oval, Paper Rind.

Very Late.-Bessie, Hart, Joppa, Valencia.

\section{MANDARIN ORANGES.}

Early.-Satsuma.

Medium.-China, Dancy.

Late.-Oneco.

Very Late.-King.

POMELOS.

Medium Early.-Aurantium, Triumph.

Medium and Late.-Duncan, Marsh, Pernambuco, Standard, Royal. 
KUMQUATS.

Nagami and Marumi.

\section{CITRONS.}

Lemon.

LEMONS.

Eureka, Genoa, Lisbon, Villafranca.

LIMES.

Mexican, Tahiti. 


\section{INDEX.}

PAGE

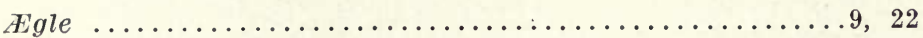

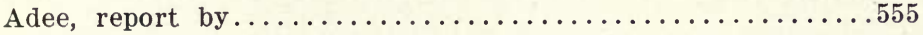

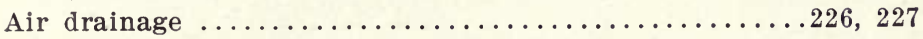

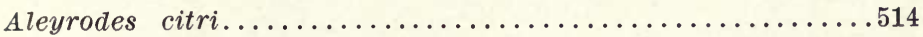

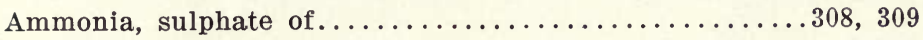

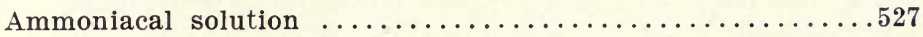

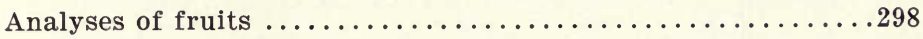

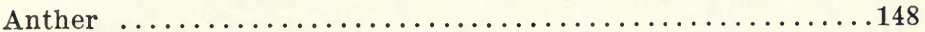

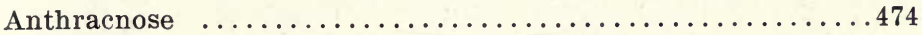

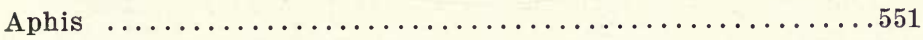

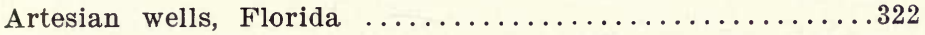

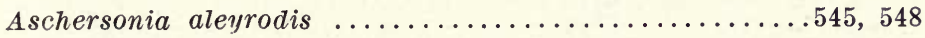

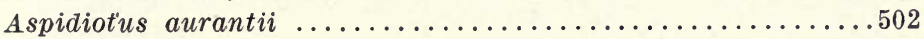

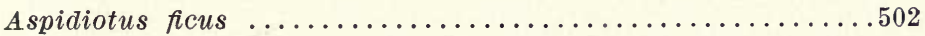

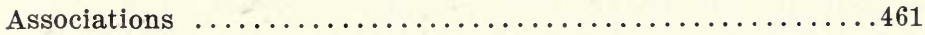

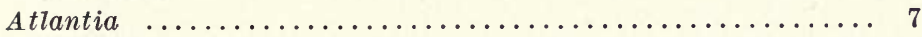

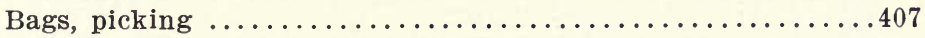

Bailey, L. H., reference to work by ............... 555

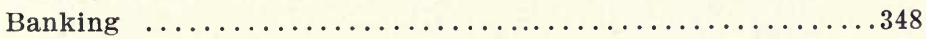

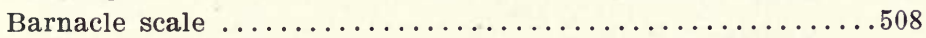

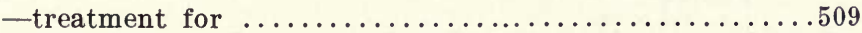

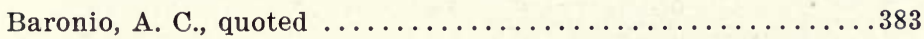

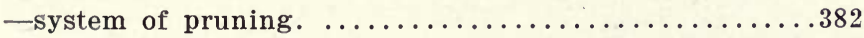

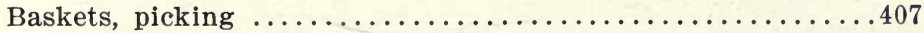

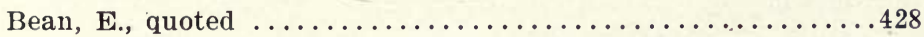

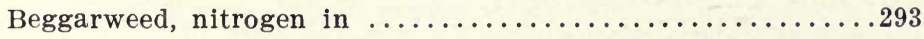

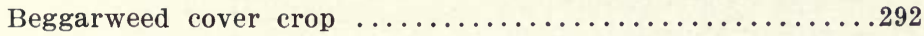

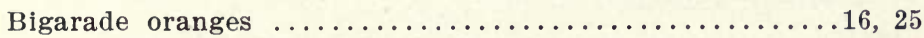

Bigarade orange, introduction of $\ldots \ldots \ldots \ldots \ldots \ldots \ldots \ldots$

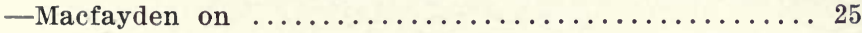

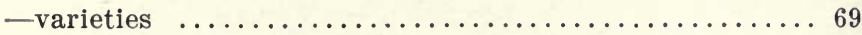

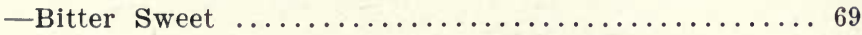

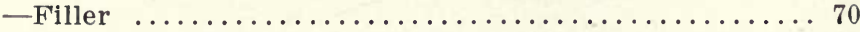

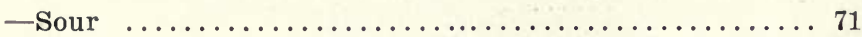

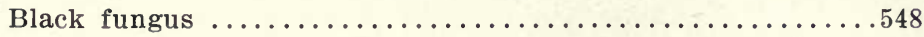


PAGE
PAE

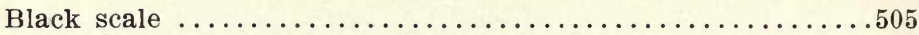

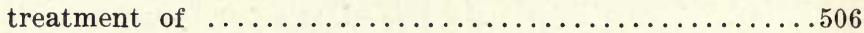

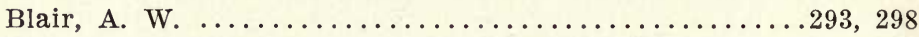

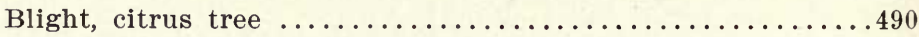

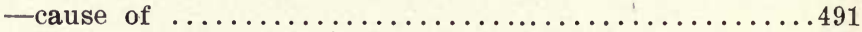

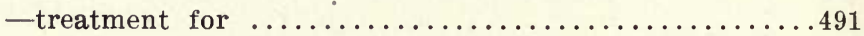

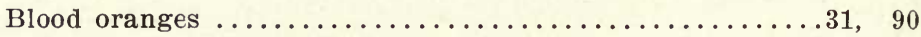

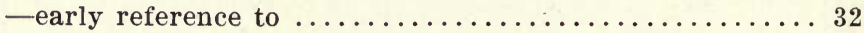

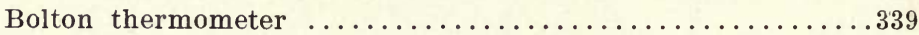

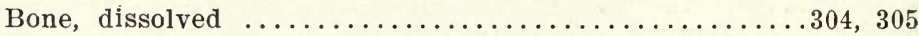

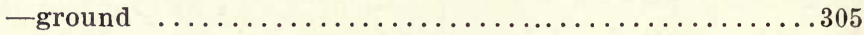

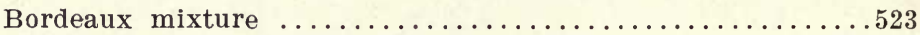

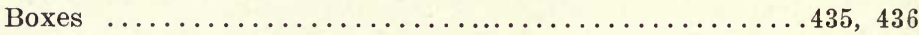

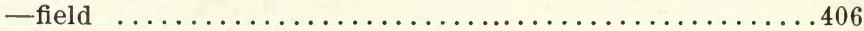

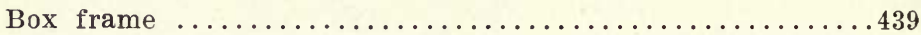

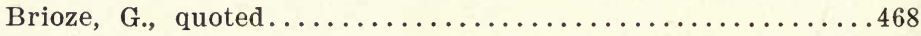

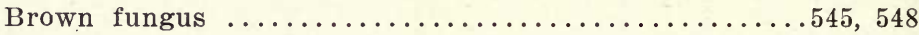

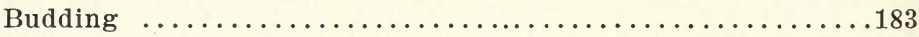

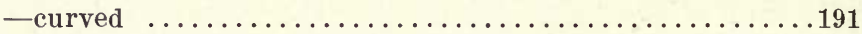

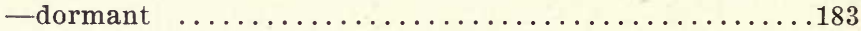

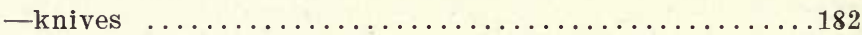

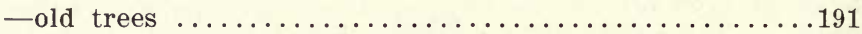

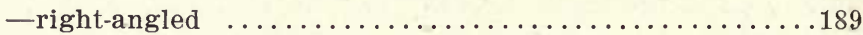

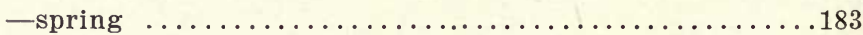

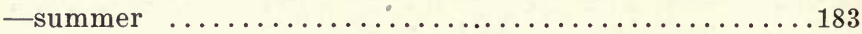

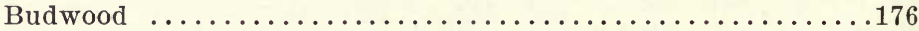

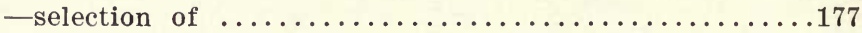

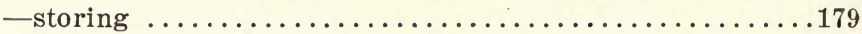

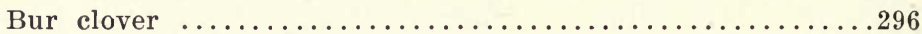

California citrus production $\ldots \ldots \ldots \ldots \ldots \ldots \ldots \ldots \ldots \ldots$

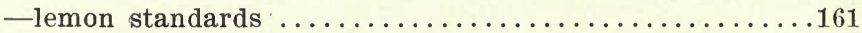

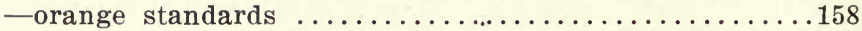

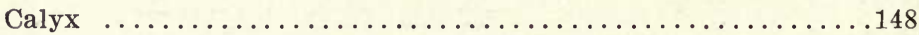

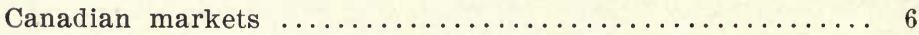

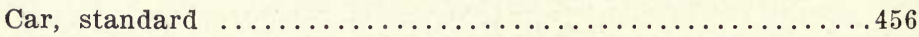

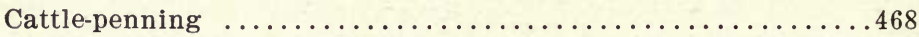

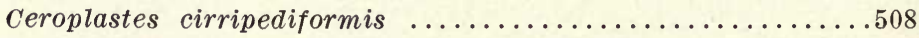

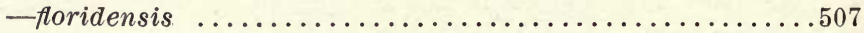

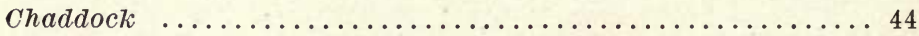

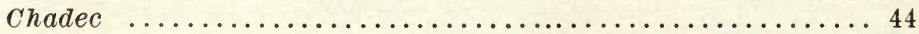


PAGE

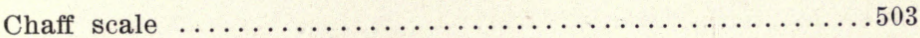

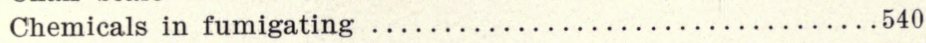

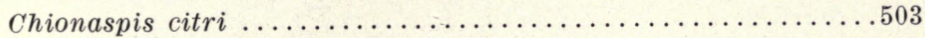

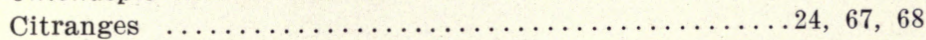

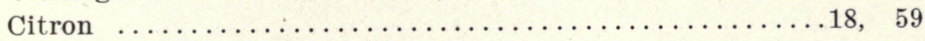

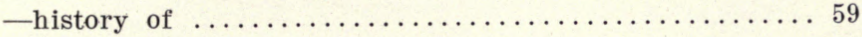

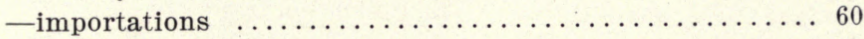

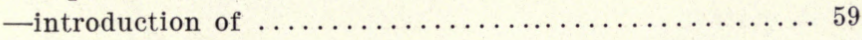

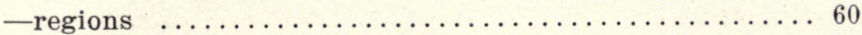

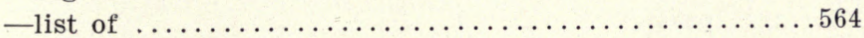

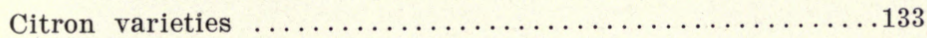

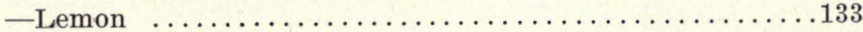

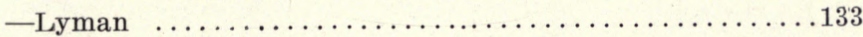

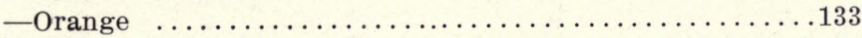

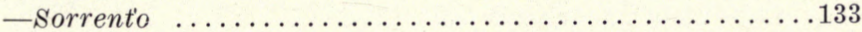

Citrus Aurantium ............................ 16

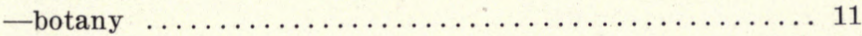

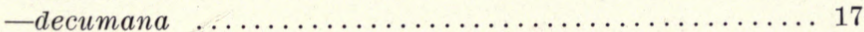

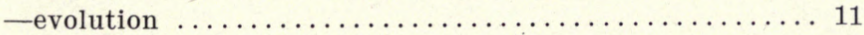

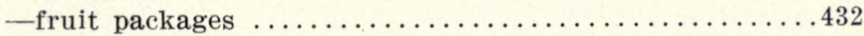

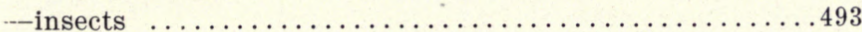

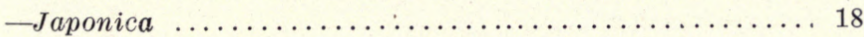

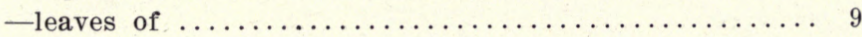

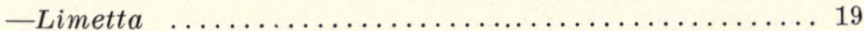

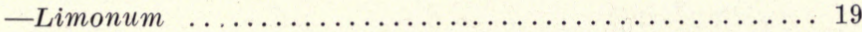

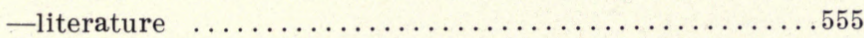

-Medica ........................... 18

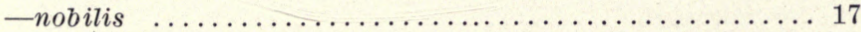

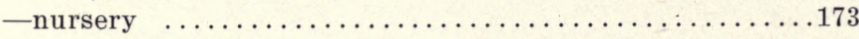

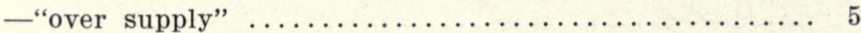

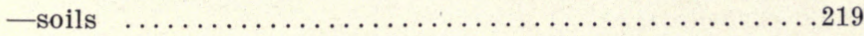

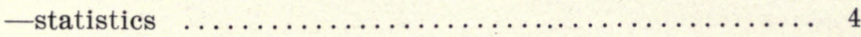

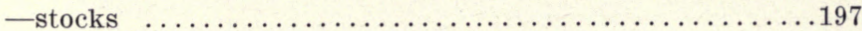

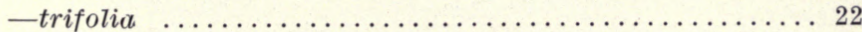

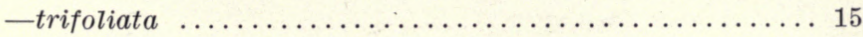

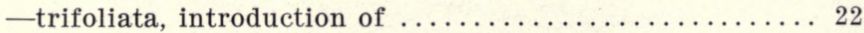

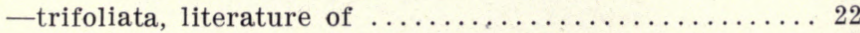

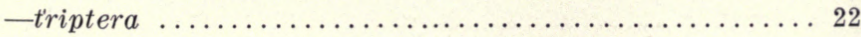

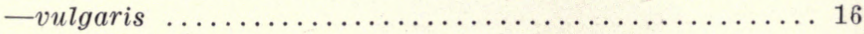


Citrus trifoliata varieties

- Colman

-Morton

-Rusk

-Rustic

- Savage

Cladosporium

Clean culture

Clearing land

Clearings, partial

Cleft-grafting

Clippers, orange

Close planting

Coal fires

-California experience

Collet'otrichum gleosporioides

Commission merchants

Comquot

Corolla

Cotton-seed meal

Cottony-cushion scale

- remedies for

Cover crops 285

-benefits of 285

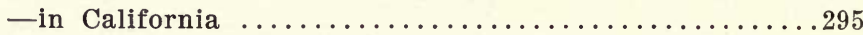

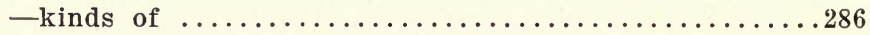

Crab-grass

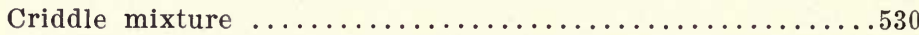

Crosses

Crown-grafting

Crude carbolic acid

Crude petroleum

Cryptolaemus montrouzieri

Cultivation and dormancy

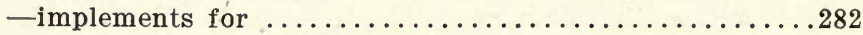

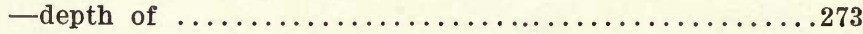

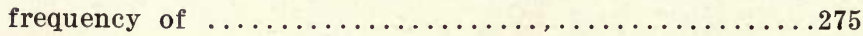


Cumquot

Curing

-lemons

一oranges

—pomelos

Cuttings

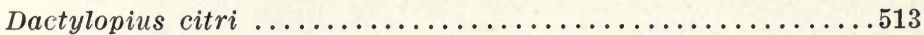

Davis, Geo. W., book by ......................... 555

Die-back ................282, 287, 308, 344, 377, 486

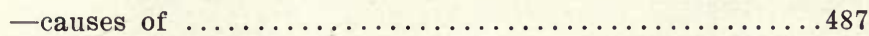

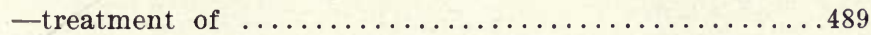

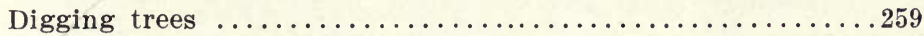

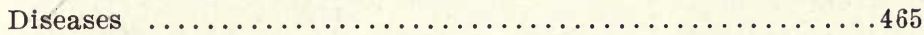

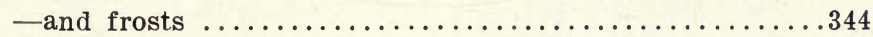

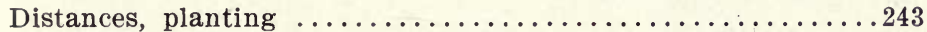

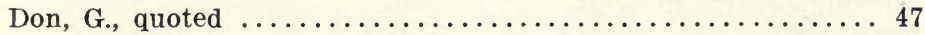

Dormancy ......................... 317, 345

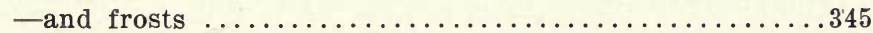

Downing, A. J., quoted..................... 55

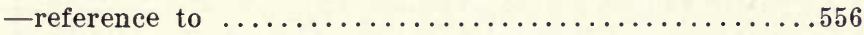

Chas., quoted ........................ 48

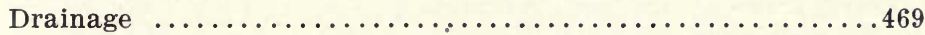

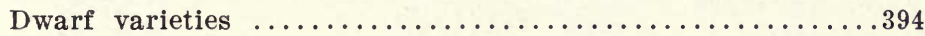

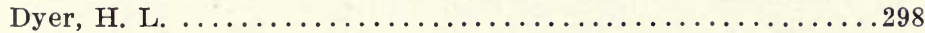

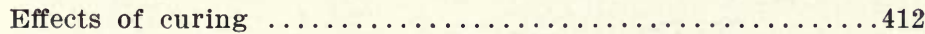

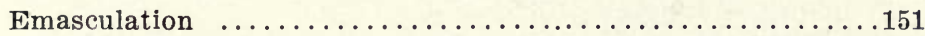

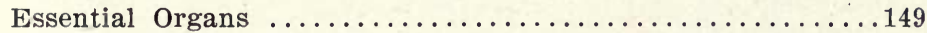

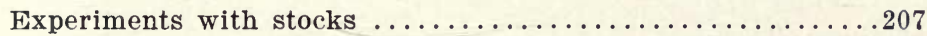

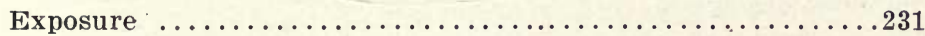

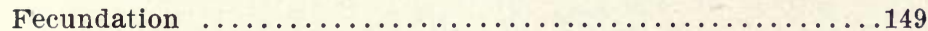

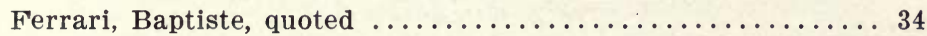

Feronia ......................... 8

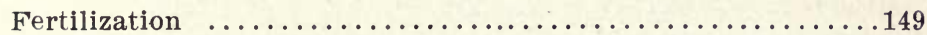

Fertilizer formulas .................................

Fertilizers, amounts of ........................... 315

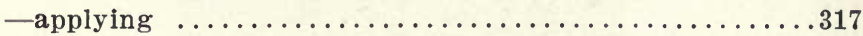

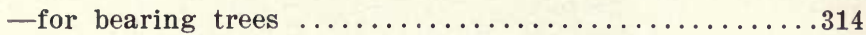

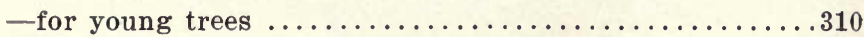

Fertilizing, relation to dormancy ...................

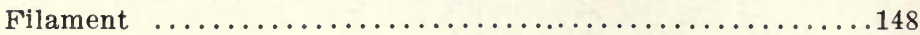


PAGE

Filer Bigarade orange $\ldots \ldots \ldots \ldots \ldots \ldots \ldots \ldots \ldots \ldots \ldots \ldots \ldots \ldots \ldots$

Field boxes ........................... 406

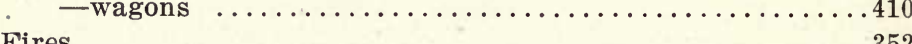

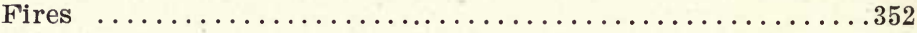

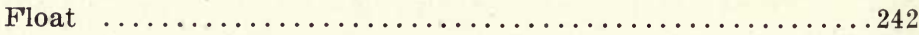

Florida, citrus production $\ldots \ldots \ldots \ldots \ldots \ldots \ldots \ldots \ldots \ldots \ldots$

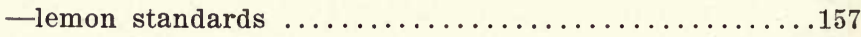

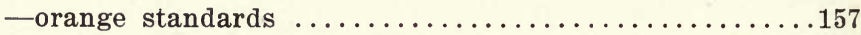

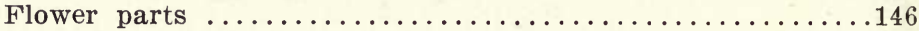

Fly-speck fungus ....................... 481

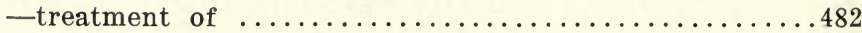

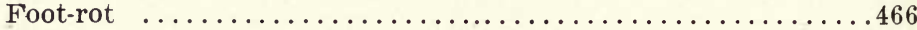

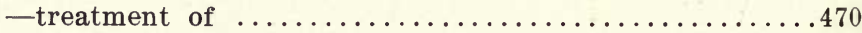

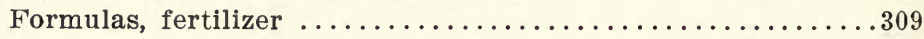

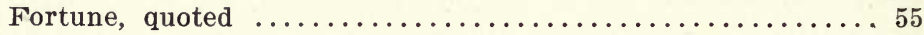

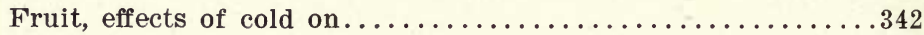

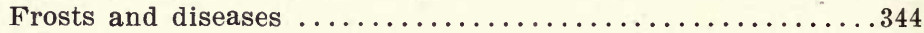

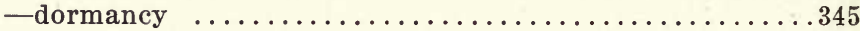

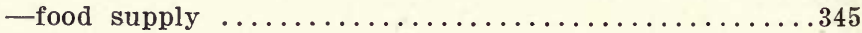

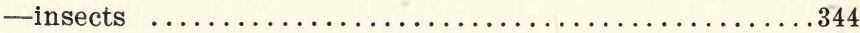

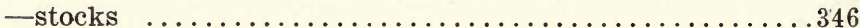

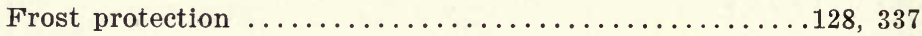

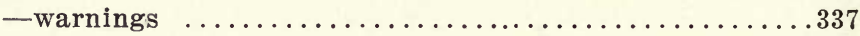

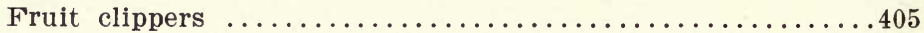

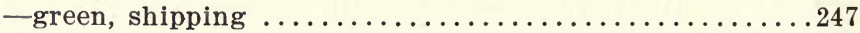

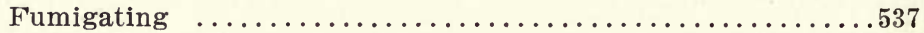

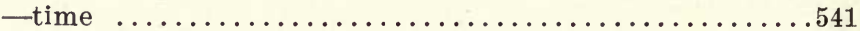

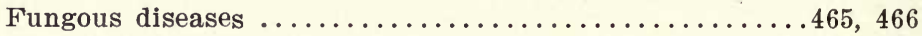

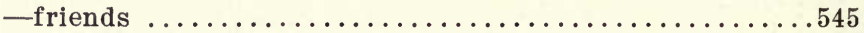

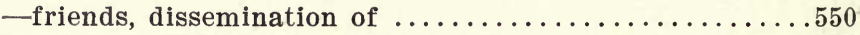

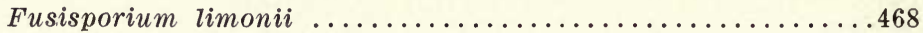

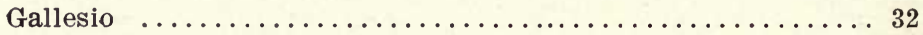

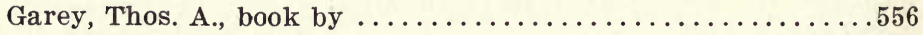

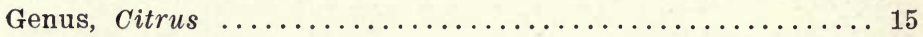

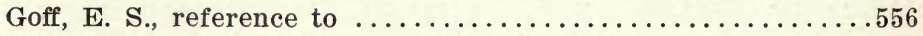

Gossard, H. A., quoted ..................479, 537

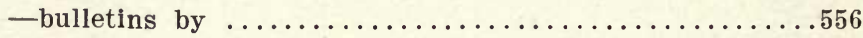

Grades

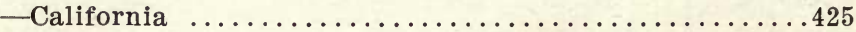

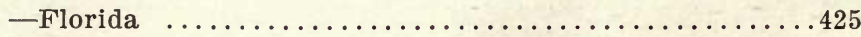

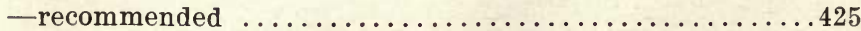


Grading

-time

Grafting

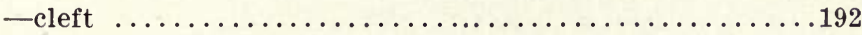

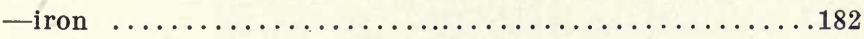

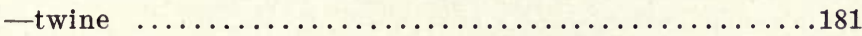

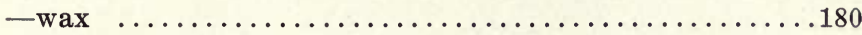

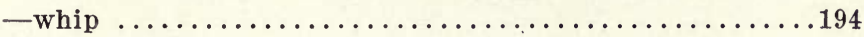

Grapefruit, see pomelo.

Grapefruit, origin of name $\ldots \ldots \ldots \ldots \ldots \ldots \ldots \ldots \ldots \ldots 4$

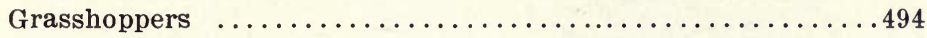

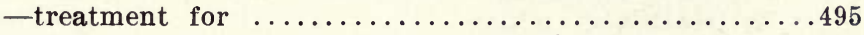

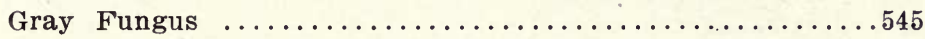

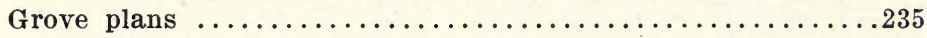

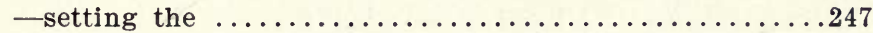

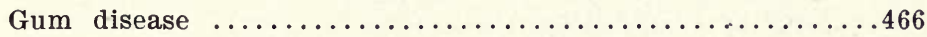

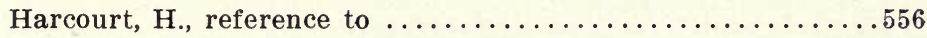

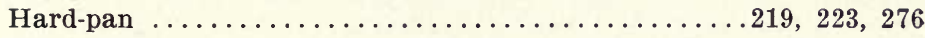

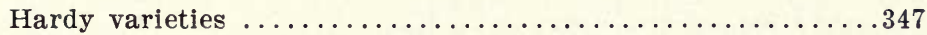

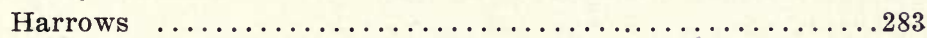

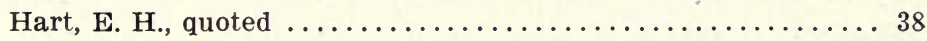

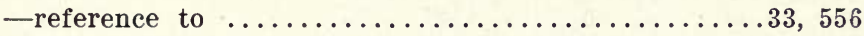

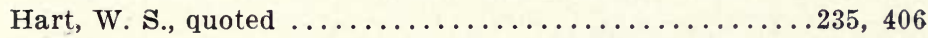

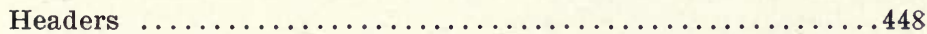

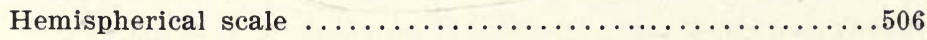

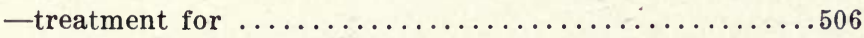

Henderson, Peter, reference to $\ldots \ldots \ldots \ldots \ldots \ldots \ldots \ldots \ldots \ldots 6$

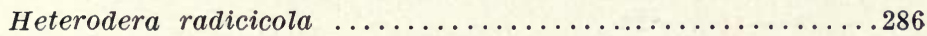

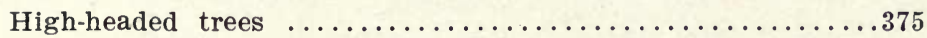

Hubbard, E. S. ....................... 97

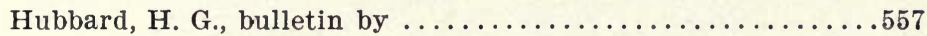

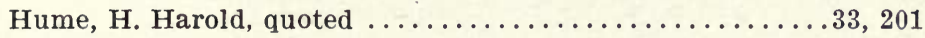

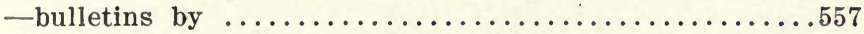

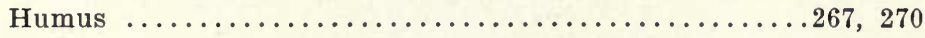

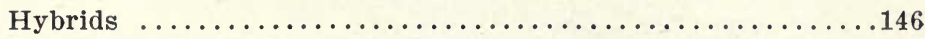

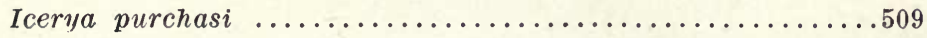

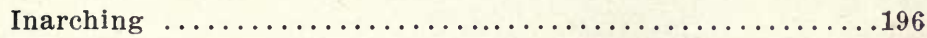

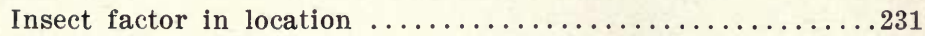

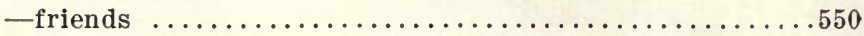


Insects and frost $\ldots \ldots \ldots \ldots \ldots \ldots \ldots \ldots \ldots \ldots \ldots \ldots \ldots$

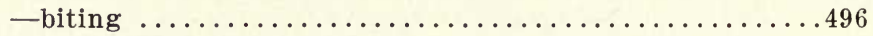

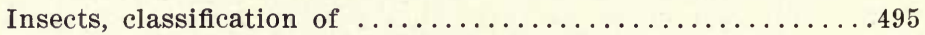

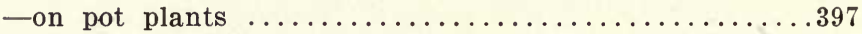

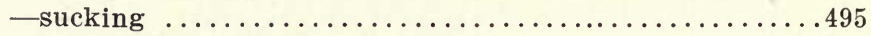

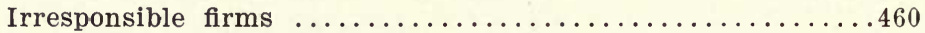

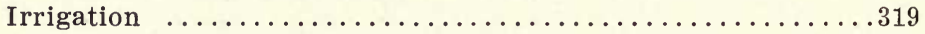

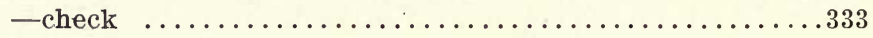

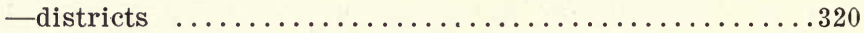

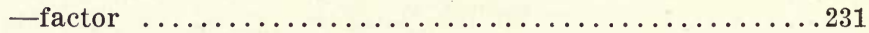

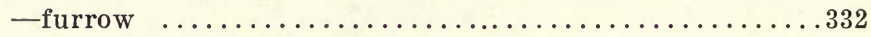

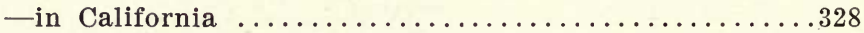

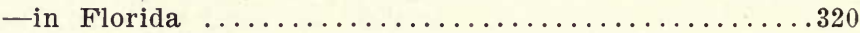

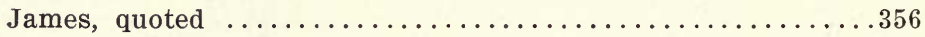

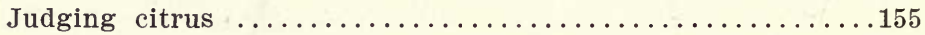

Juice sacks in classification................... 14

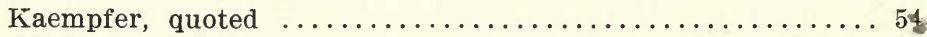

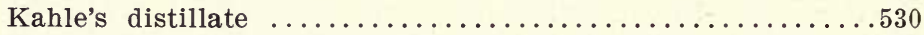

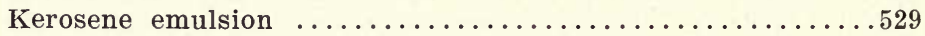

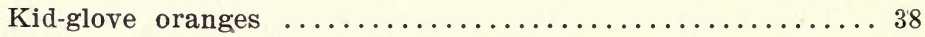

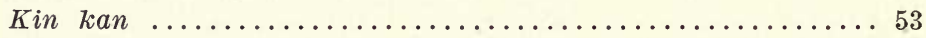

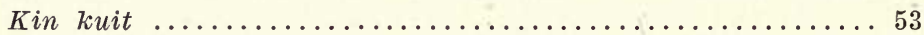

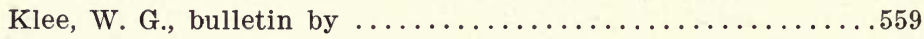

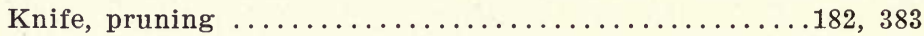

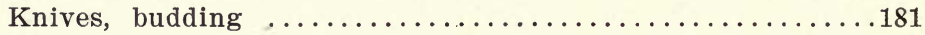

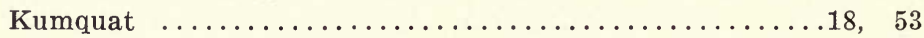

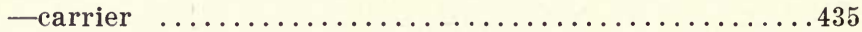

-introduction of $\ldots \ldots \ldots \ldots \ldots \ldots \ldots \ldots \ldots \ldots \ldots \ldots \ldots \ldots \ldots$

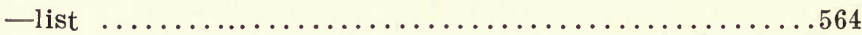

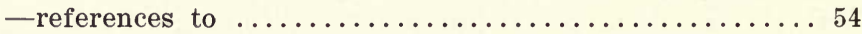

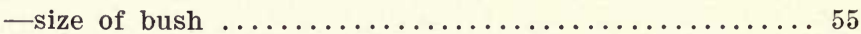

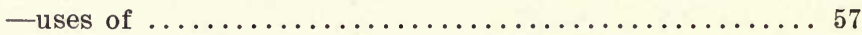

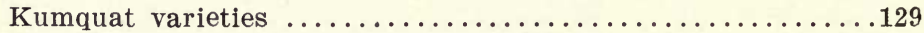

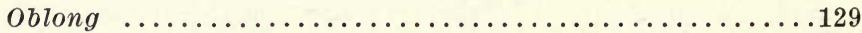

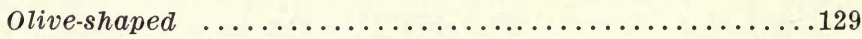

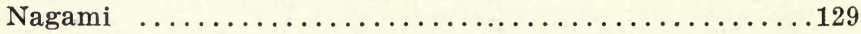

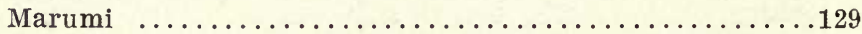

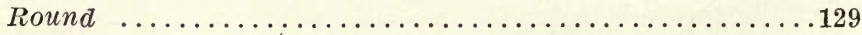

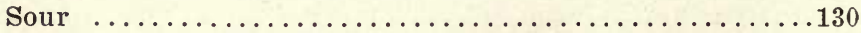




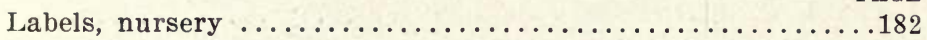

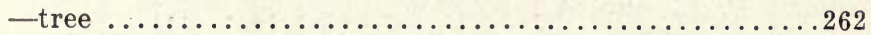

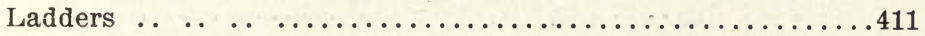

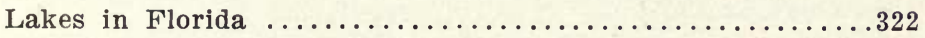

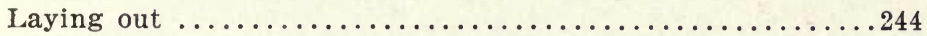

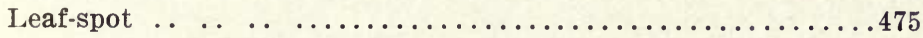

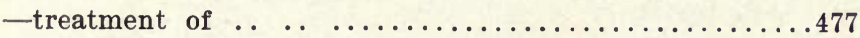

Leaves, effects of cold on ..........................

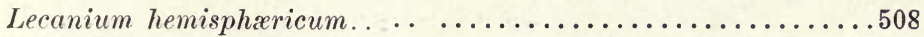

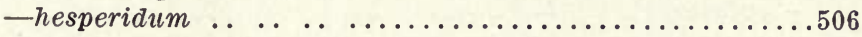

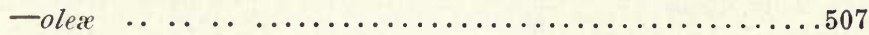

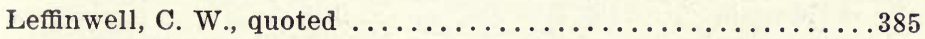

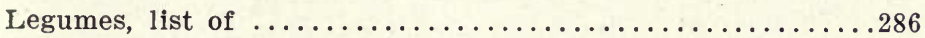

Lemon ... ............................. 19

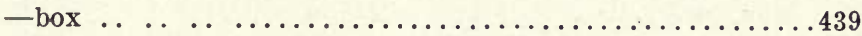

-importations ... .. $\ldots \ldots \ldots \ldots \ldots \ldots \ldots \ldots \ldots \ldots 61$

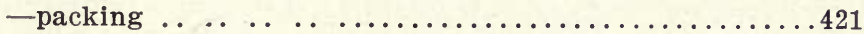

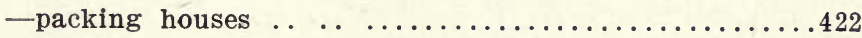

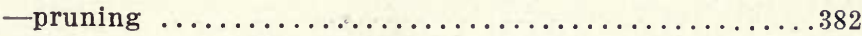

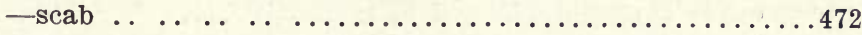

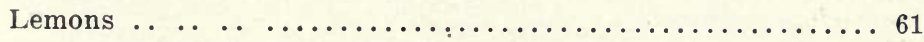

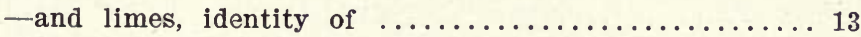

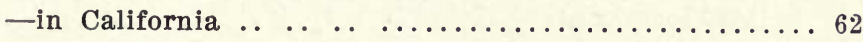

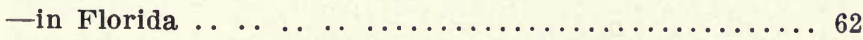

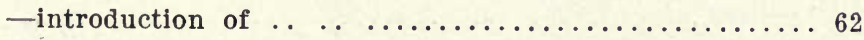

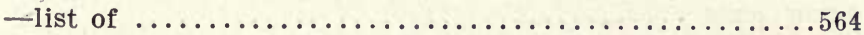

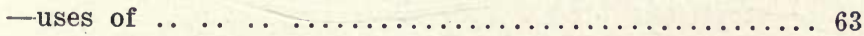

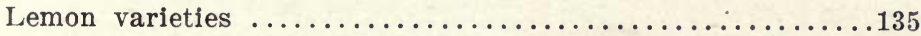

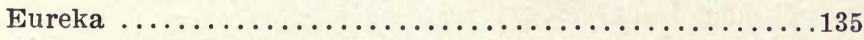

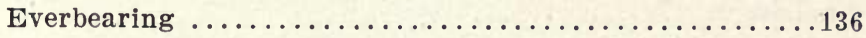

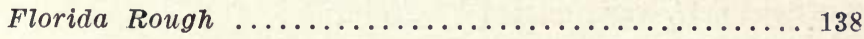

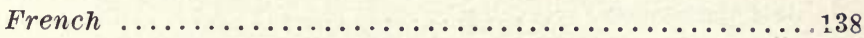

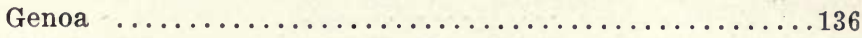

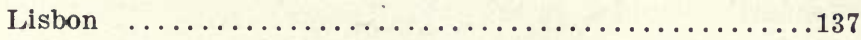

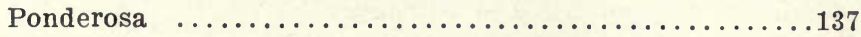

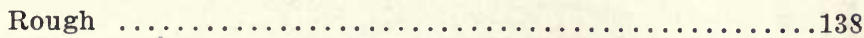

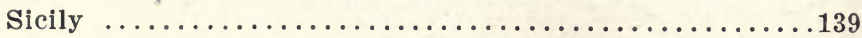

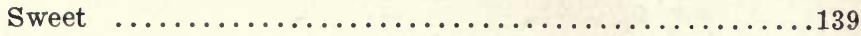

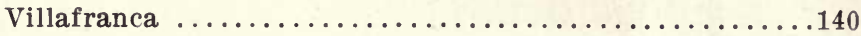


Leonard, G. W., quoted

Leptothyrium Pomi

Leveling

一on leaves

-treatment for

- carrier

-Mexican

-Rangpur

-stock

Lime varieties

Mexican

Rangpur

Rungpore

Rungpur

Tahiti

Lime, crude carbolic acid and salt

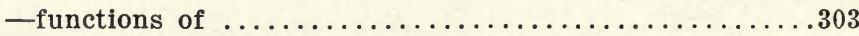

\section{Limes}

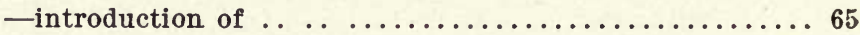

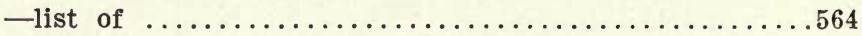

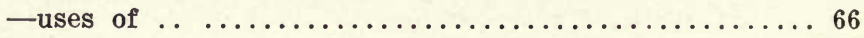

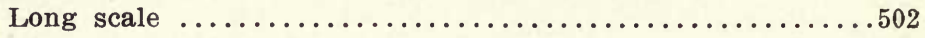

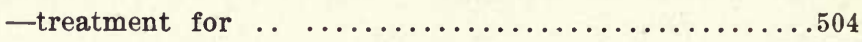

Lopping

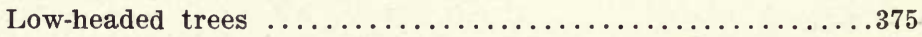

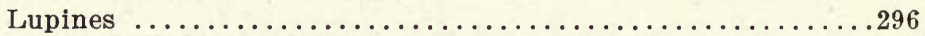

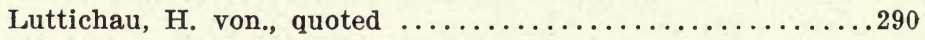

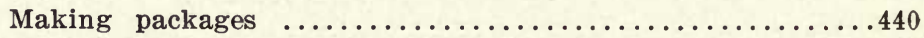

Mal-di-goma .. ....................... 463,468

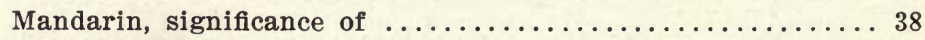

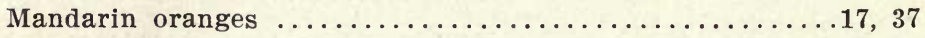

-Bonavia on .. ..................... 40

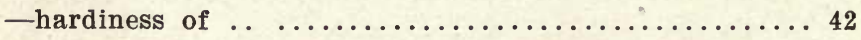

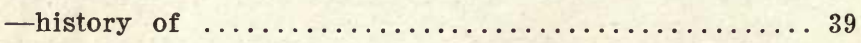

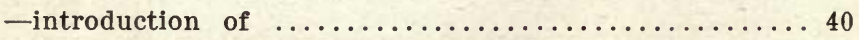


Mandarin oranges-Continued.

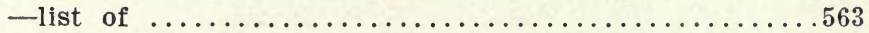

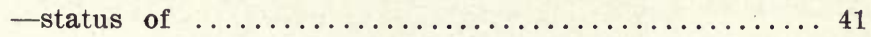

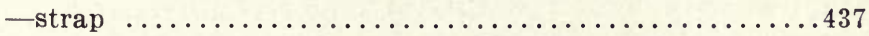

Mandarin orange-varieties.

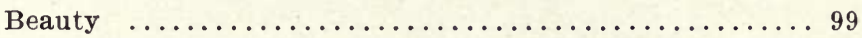

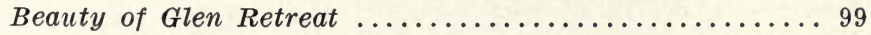

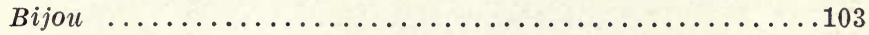

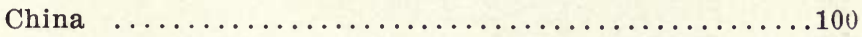

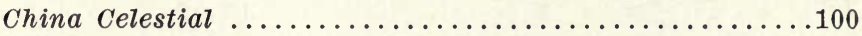

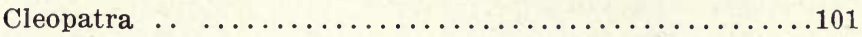

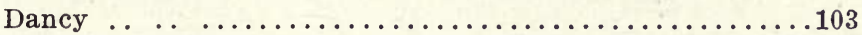

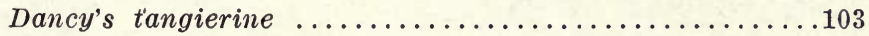

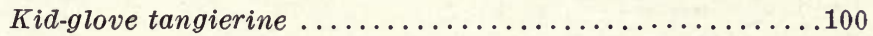

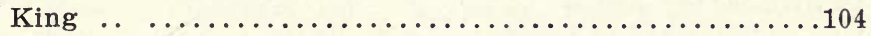

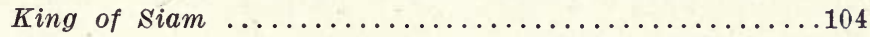

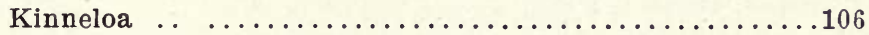

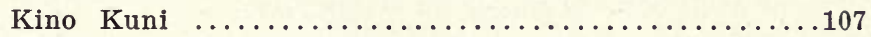

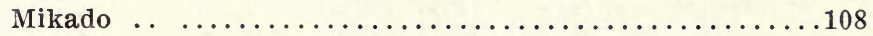

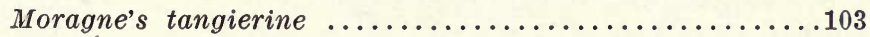

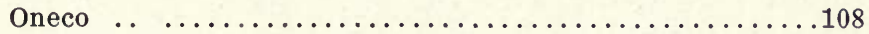

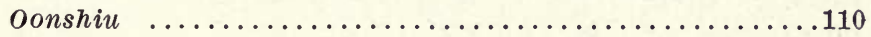

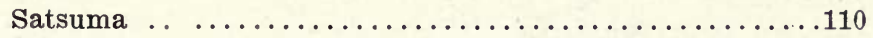

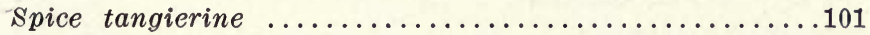

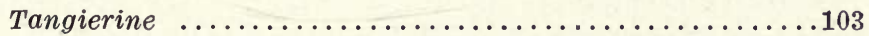

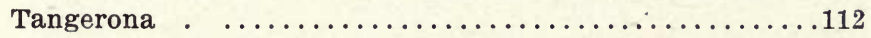

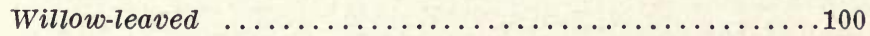

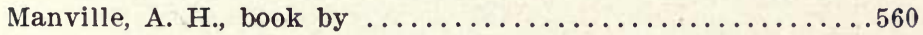

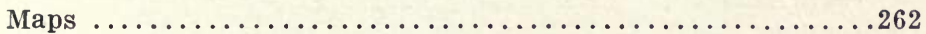

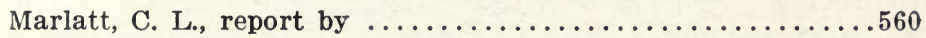

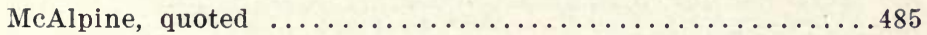

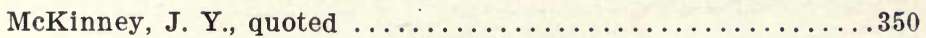

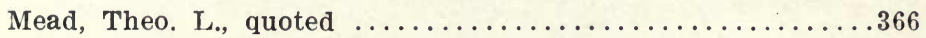

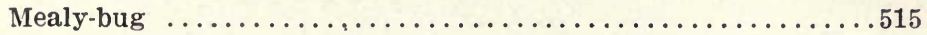

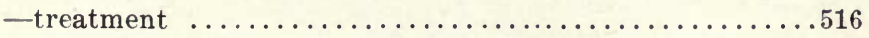

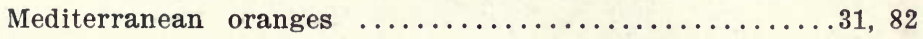

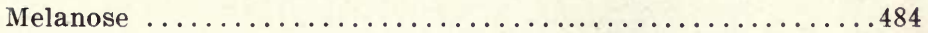

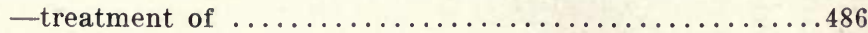

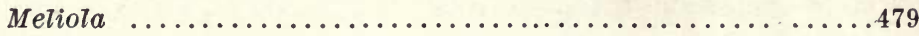




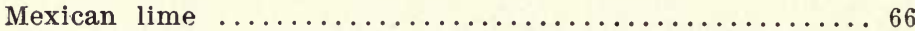

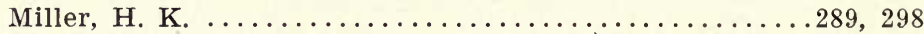

Mills, J. W., quoted ...............216, 218, 260, 276

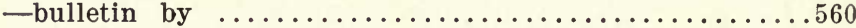

Moore, T. W., reference to ................... 48

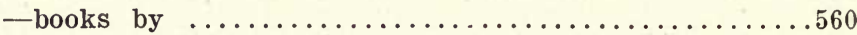

Morgan, H. A., bulletin by .......................

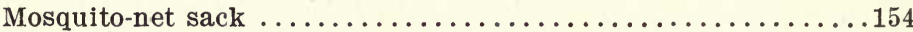

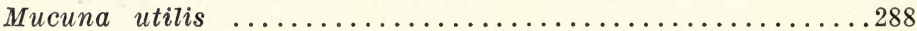

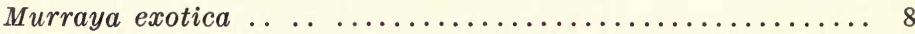

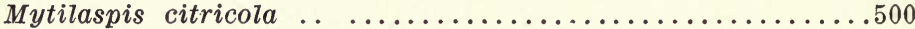

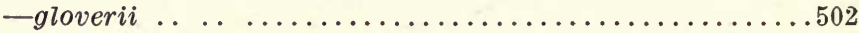

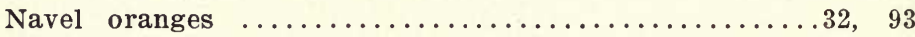

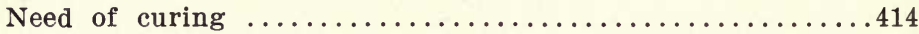

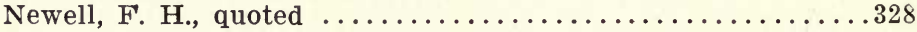

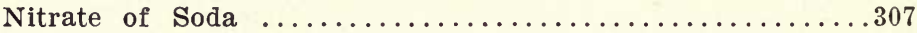

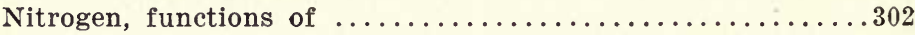

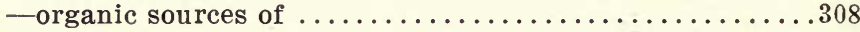

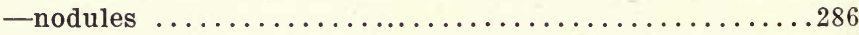

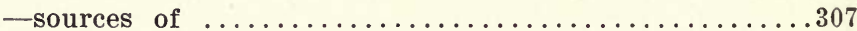

Novius cardinatis . ......................... 553

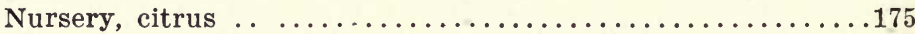

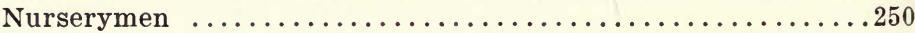

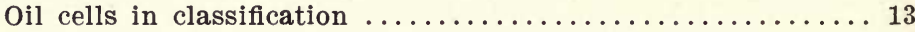

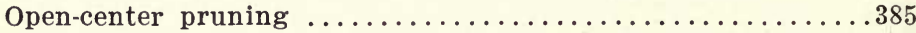

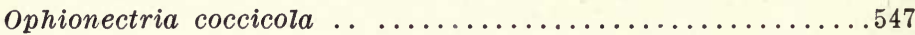

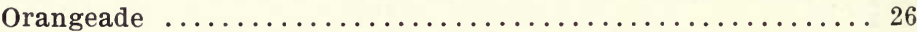

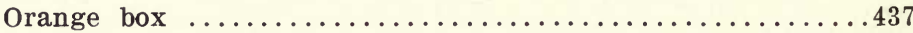

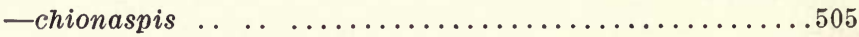

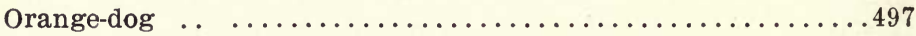

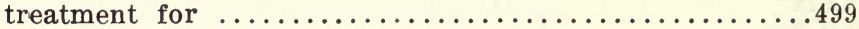

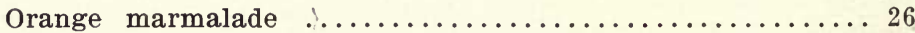

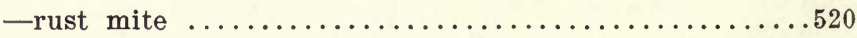

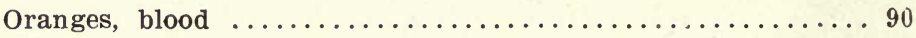

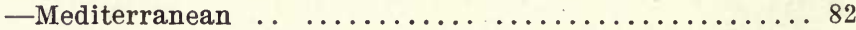

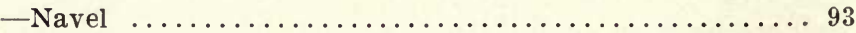

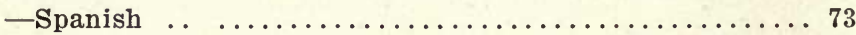

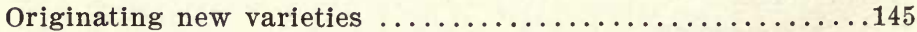

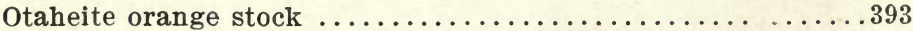


PAGE

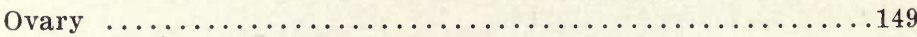

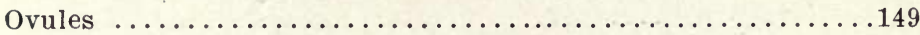

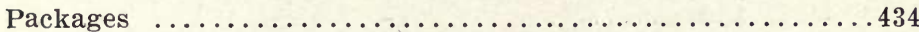

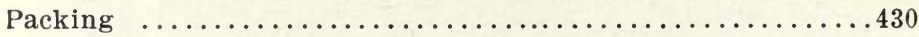

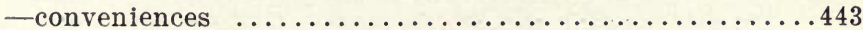

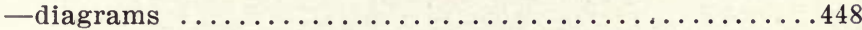

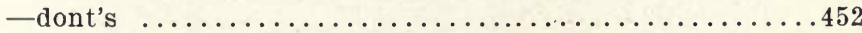

-early experiences in .................... 430

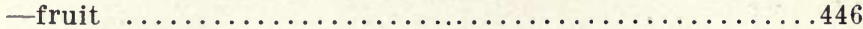

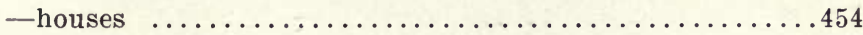

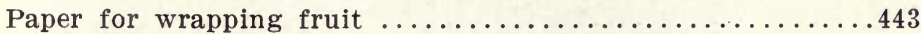

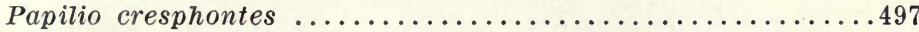

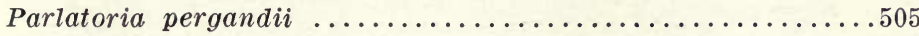

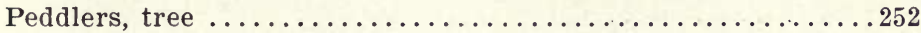

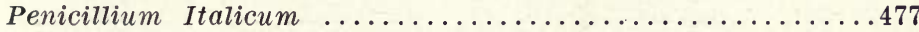

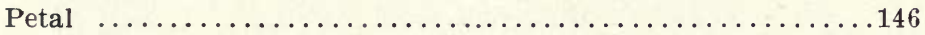

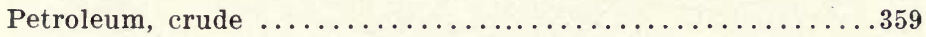

-pots, Froude's ........................ 359

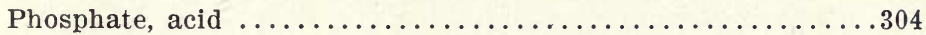

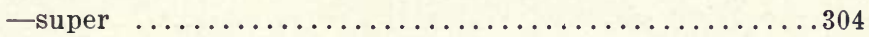

Phosphoric acid, functions of ....................

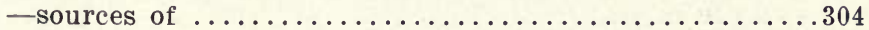

Physiological diseases ..................467, 488

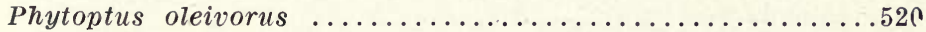

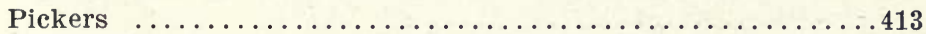

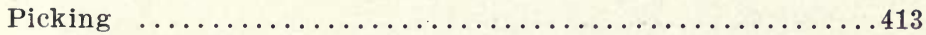

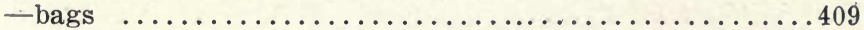

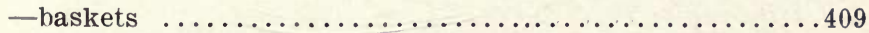

-fruit, time ........................ 405

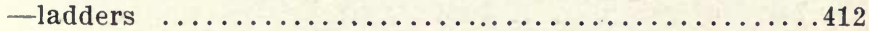

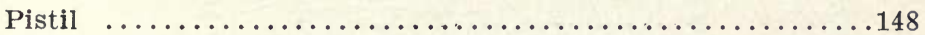

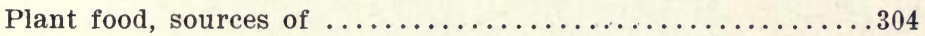

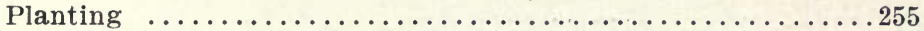

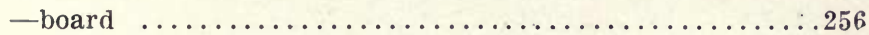

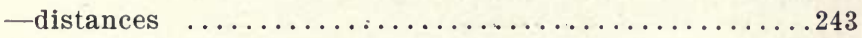

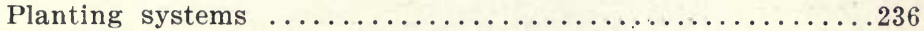

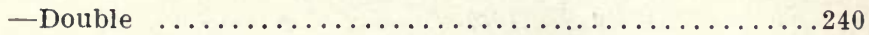

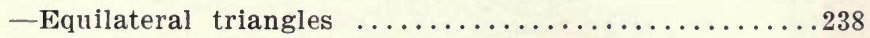

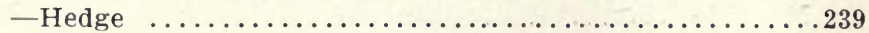


Planting systems-Continued.

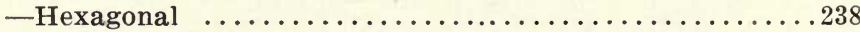

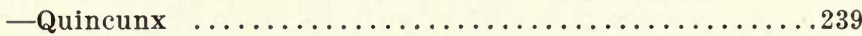

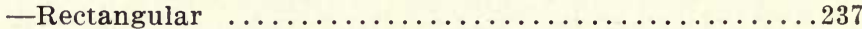

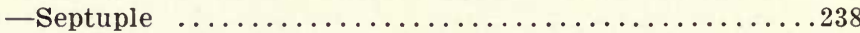

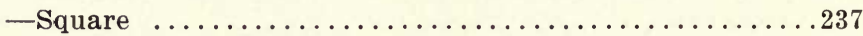

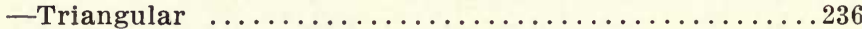

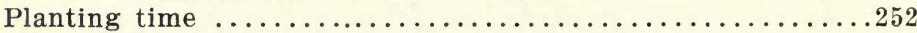

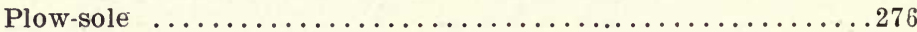

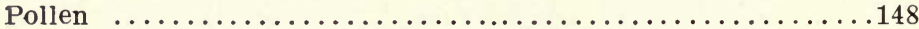

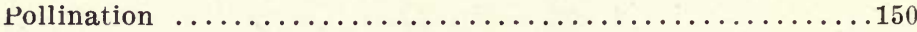

-instruments for .................... 151

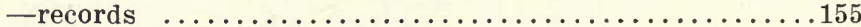

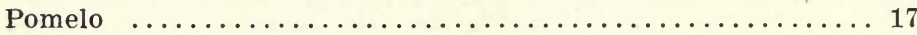

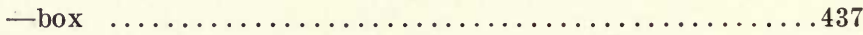

-early references to ..................... 43

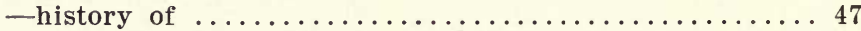

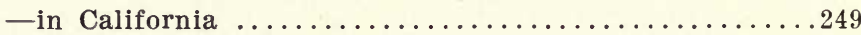

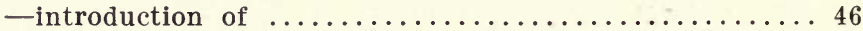

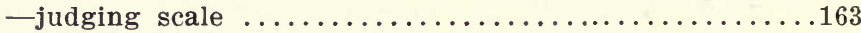

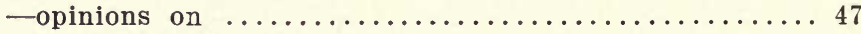

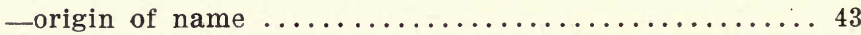

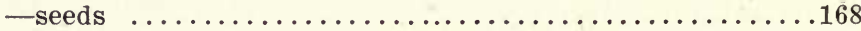

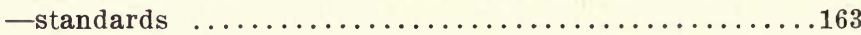

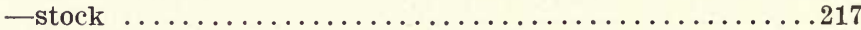

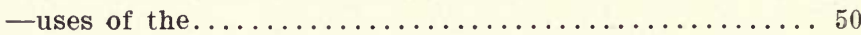

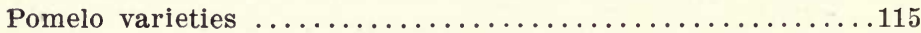

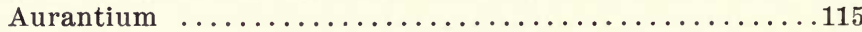

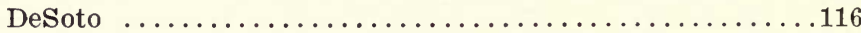

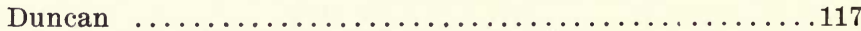

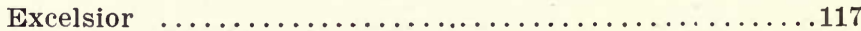

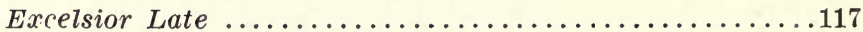

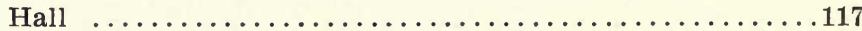

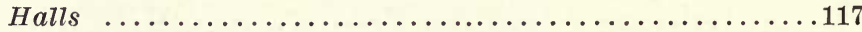

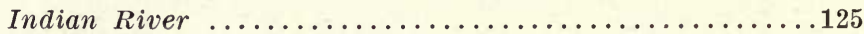

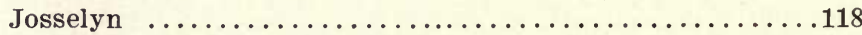

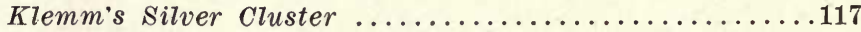

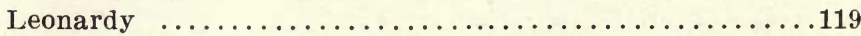

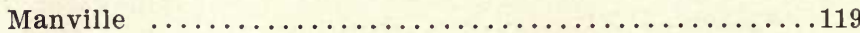




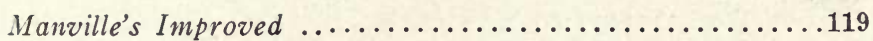

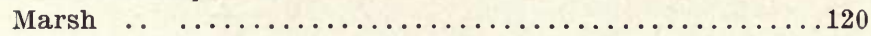

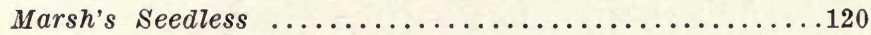

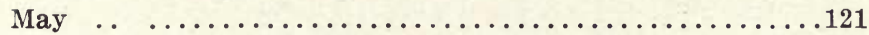

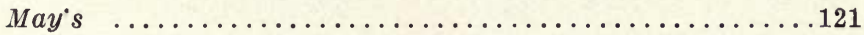

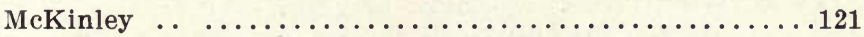

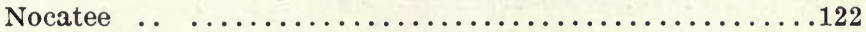

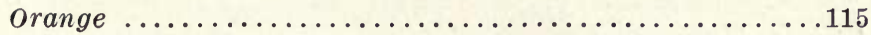

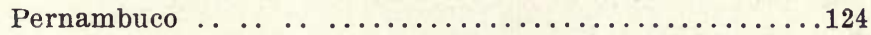

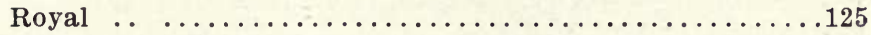

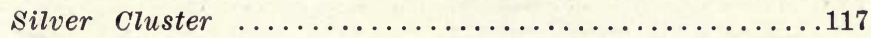

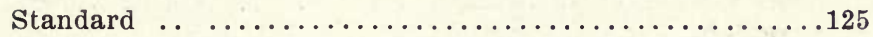

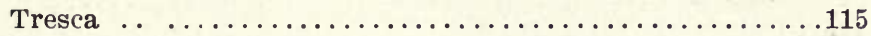

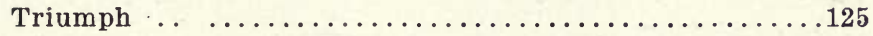

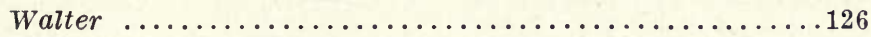

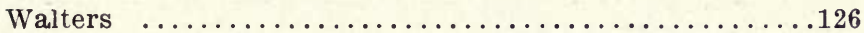

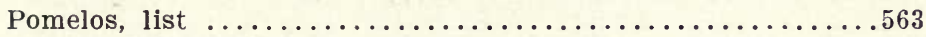

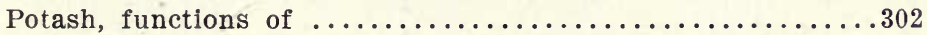

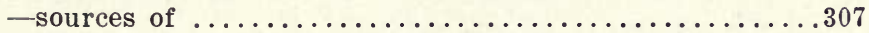

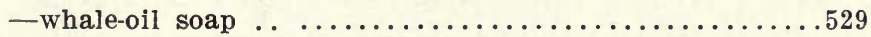

-whale-oil soap and soda-sulphur solution .........532

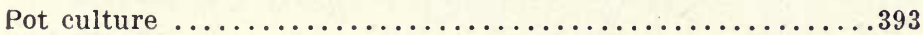

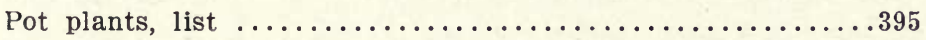

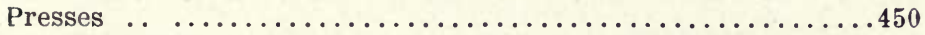

Private trade ................................ 459

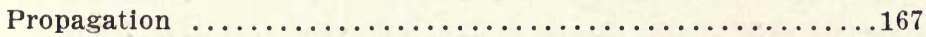

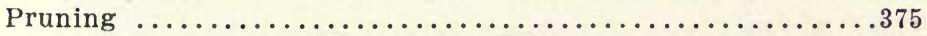

-for die-back ..................................

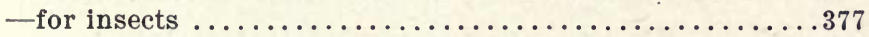

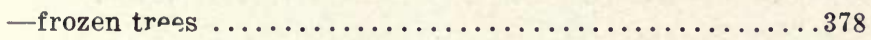

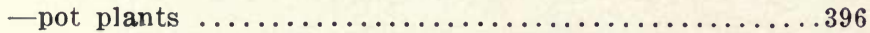

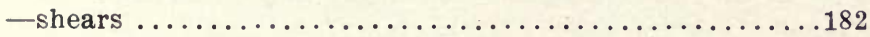

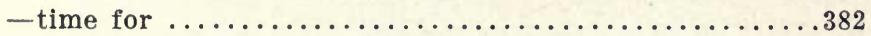

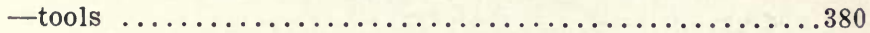

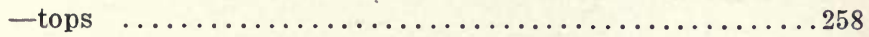

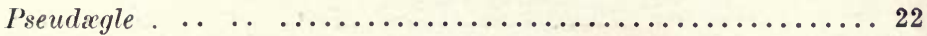

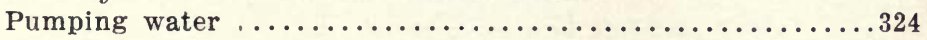

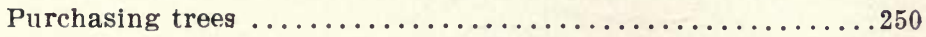




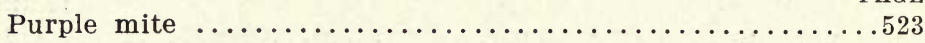

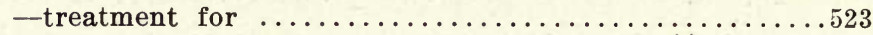

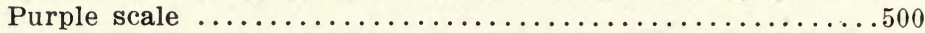

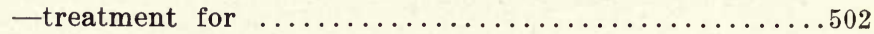

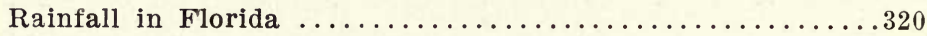

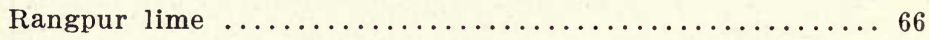

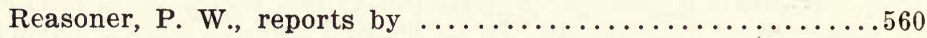

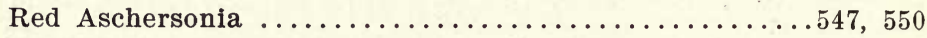

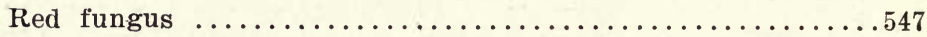

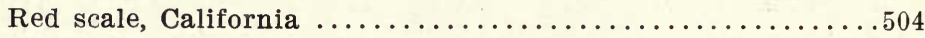

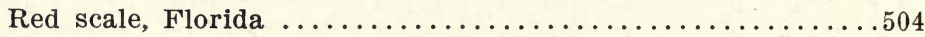

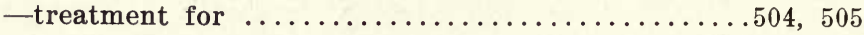

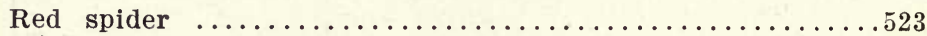

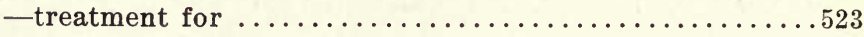

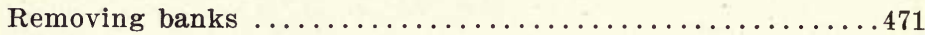

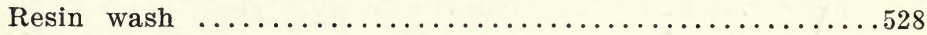

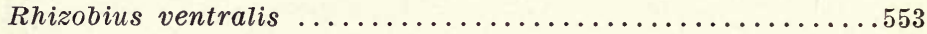

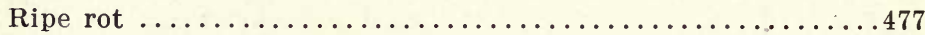

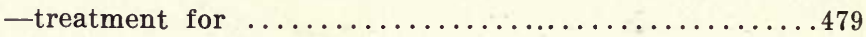

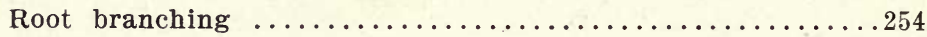

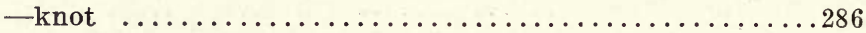

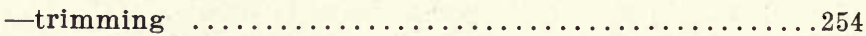

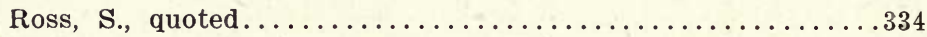

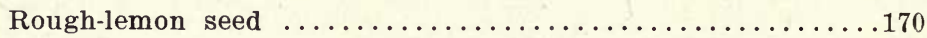

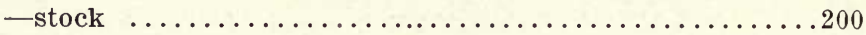

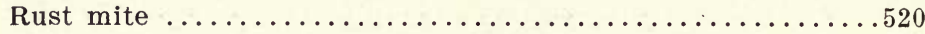

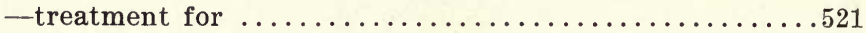

Rutacew family ....................... 14

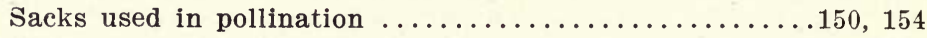

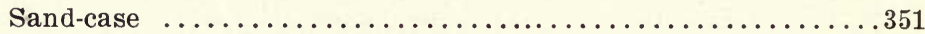

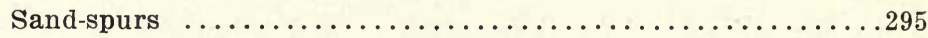

Sampson, F. G., quoted ........................ 403

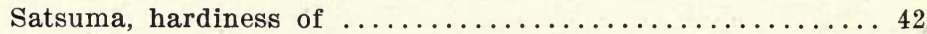

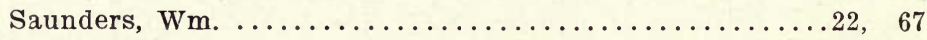

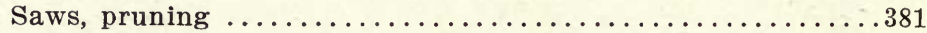

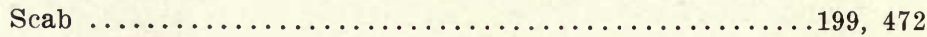

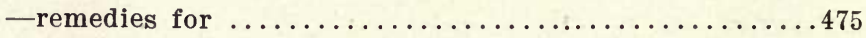

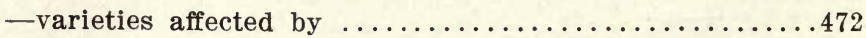




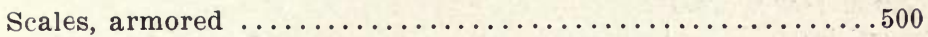

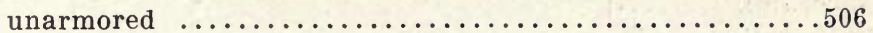

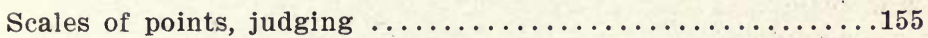

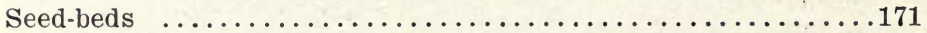

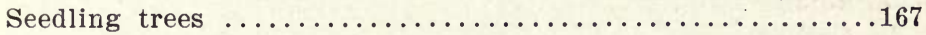

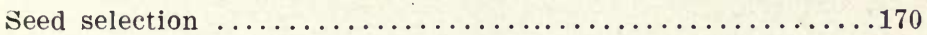

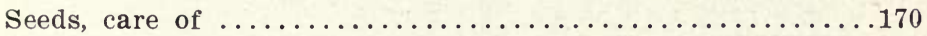

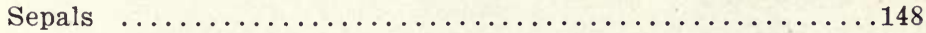

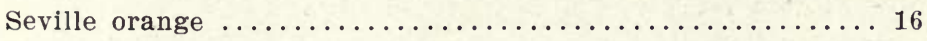

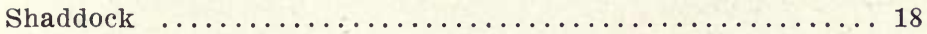

-distinct from pomelo ................... 52

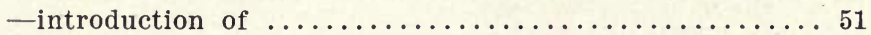

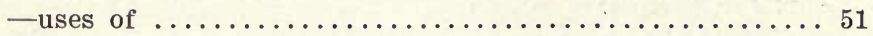

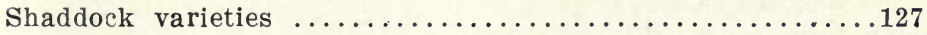

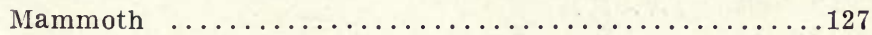

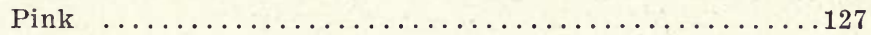

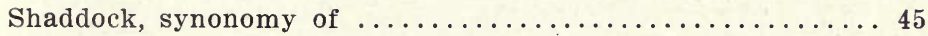

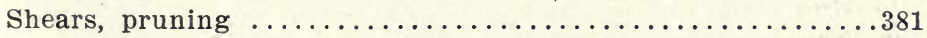

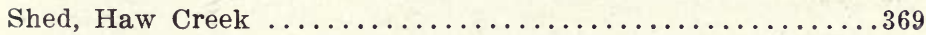

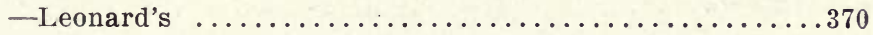

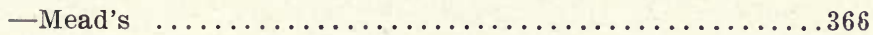

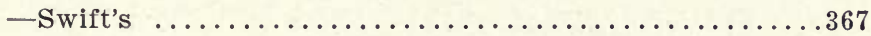

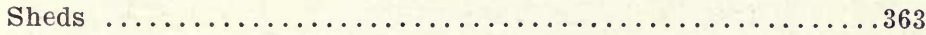

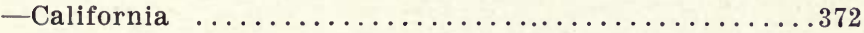

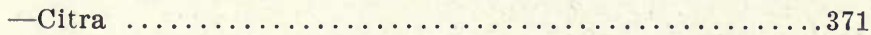

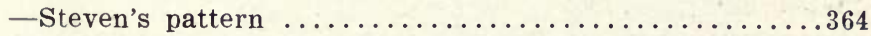

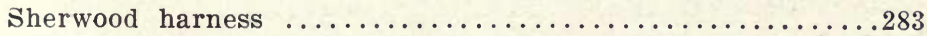

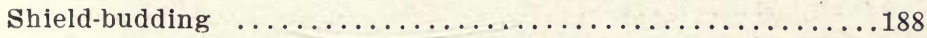

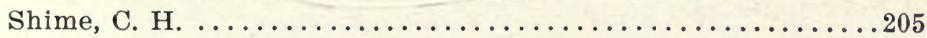

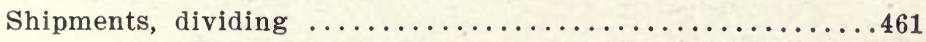

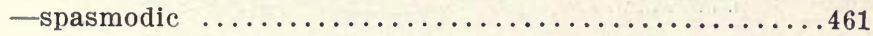

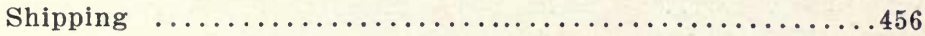

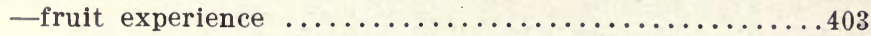

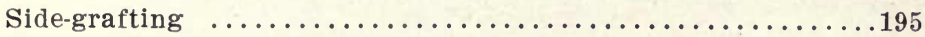

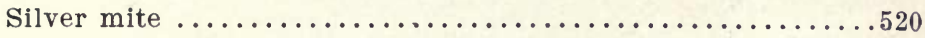

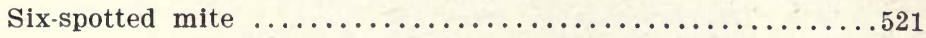

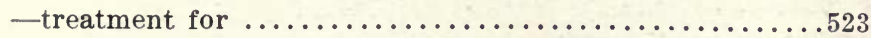

Sizers

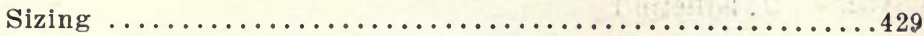




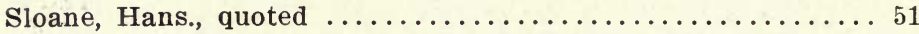

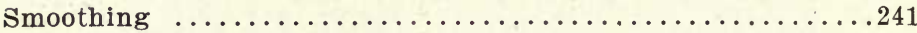

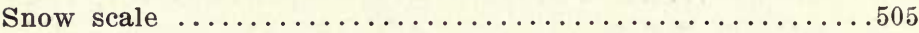

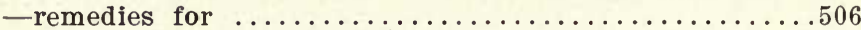

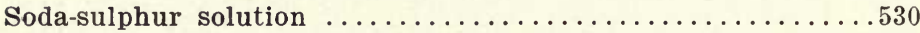

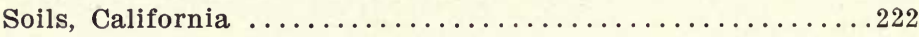

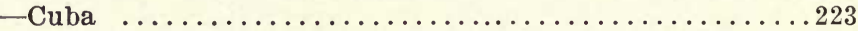

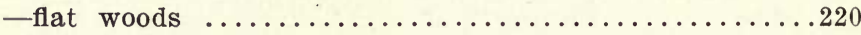

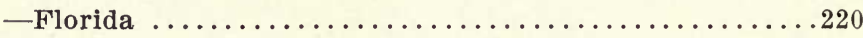

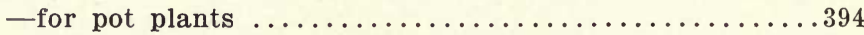

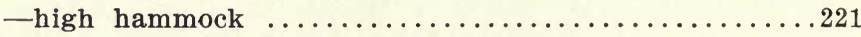

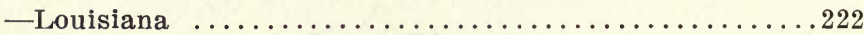

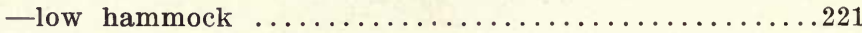

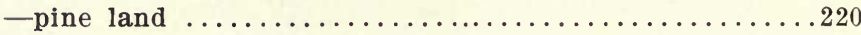

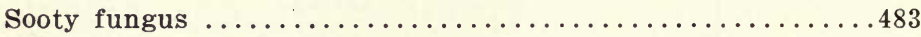

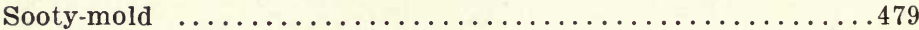

- effects, of, on trees ........................ 481

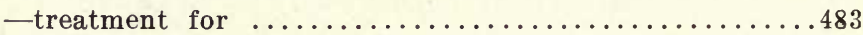

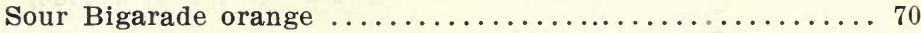

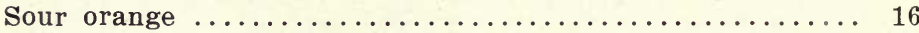

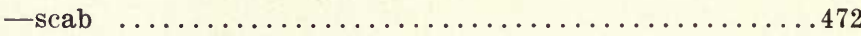

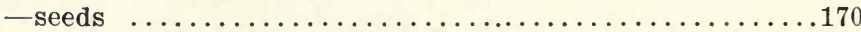

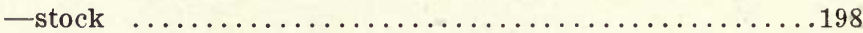

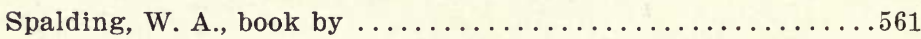

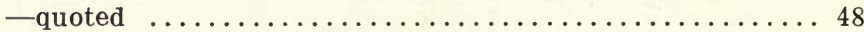

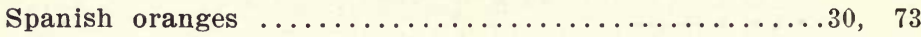

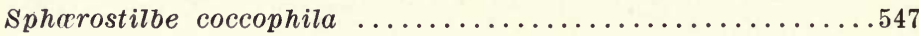

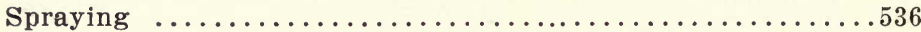

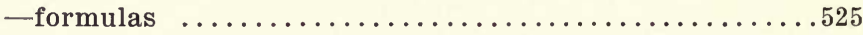

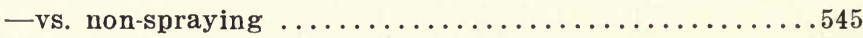

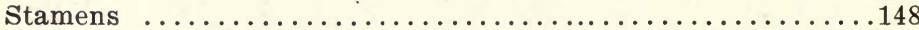

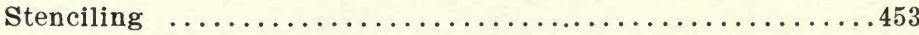

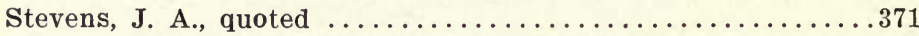

Stocks and frosts ..............................

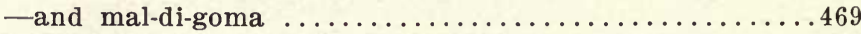

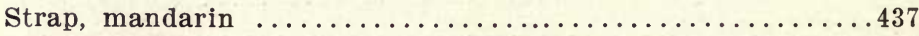

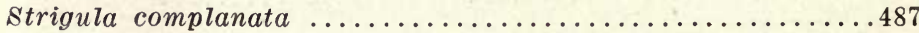

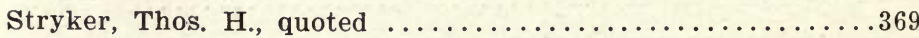

Stubbs. W. C., bulletin by ....................... 561 


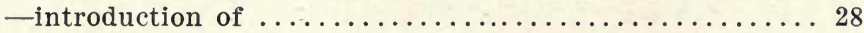

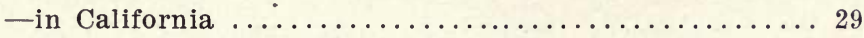

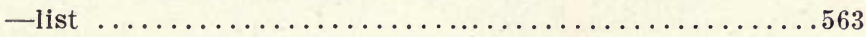

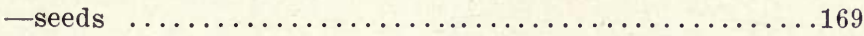

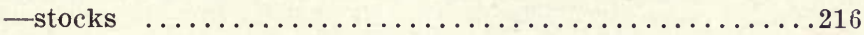

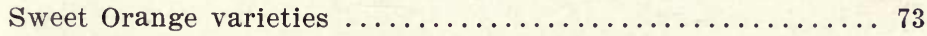

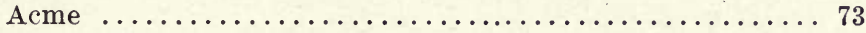

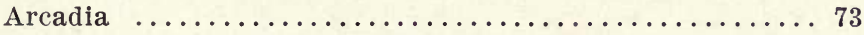

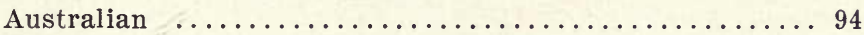

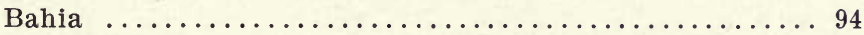

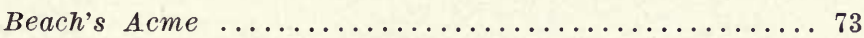

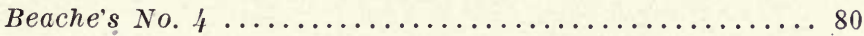

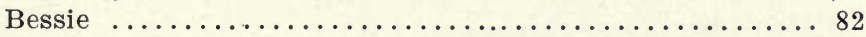

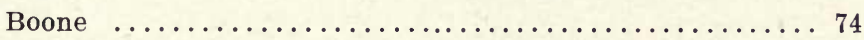

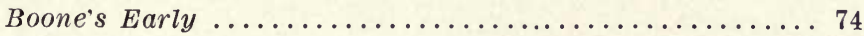

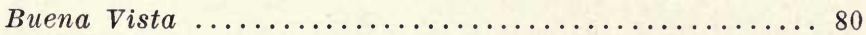

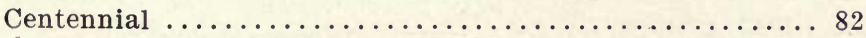

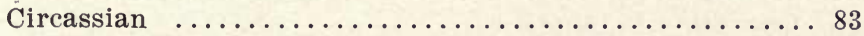

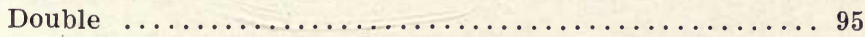

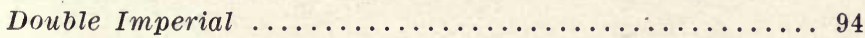

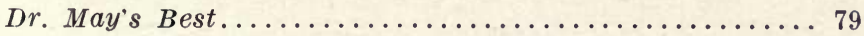

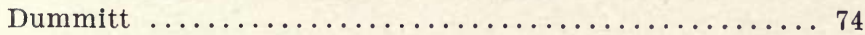

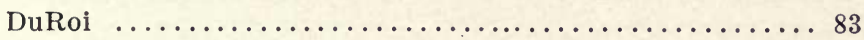

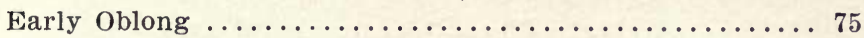

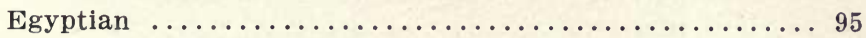

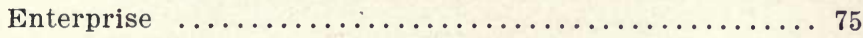

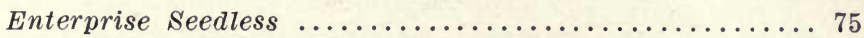

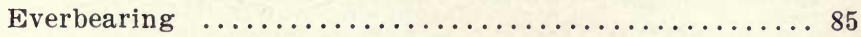

Exquisite ............................. 84 
Sweet orange varieties-Continued.

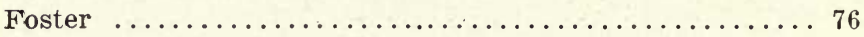

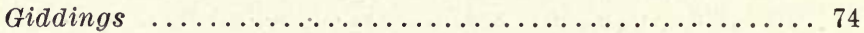

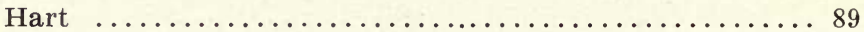

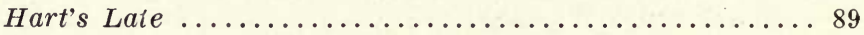

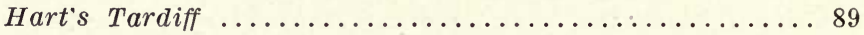

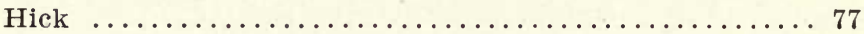

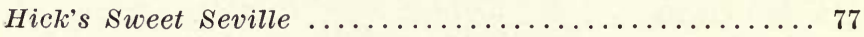

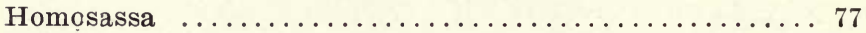

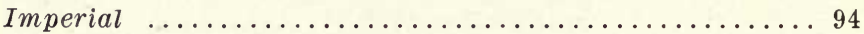

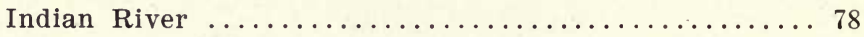

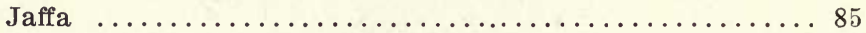

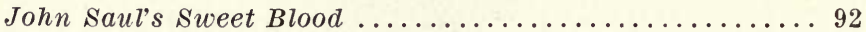

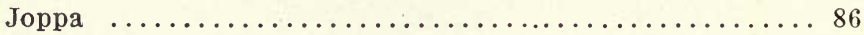

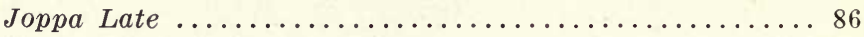

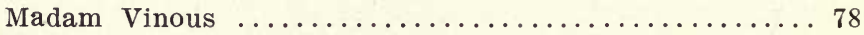

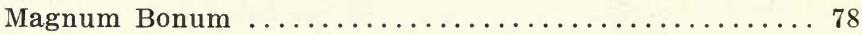

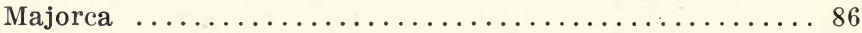

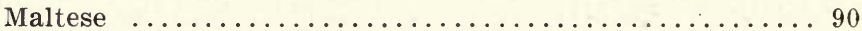

Maltese Oval ......................... 87

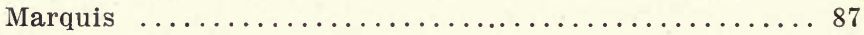

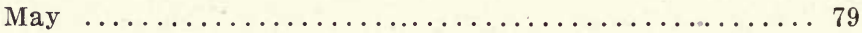

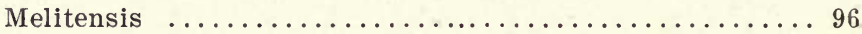

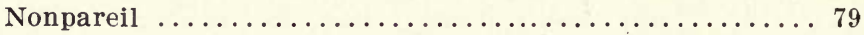

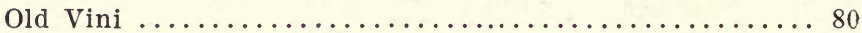

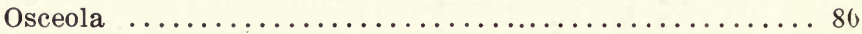

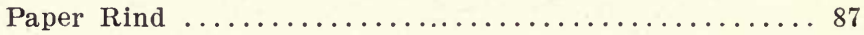

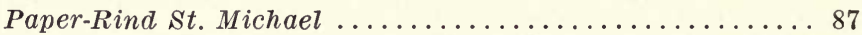

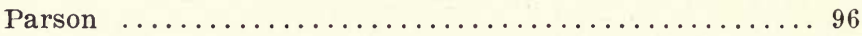

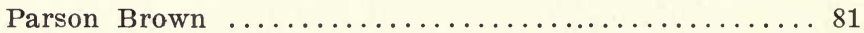

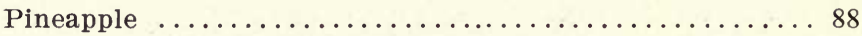

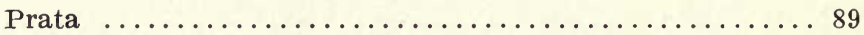

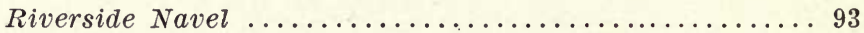

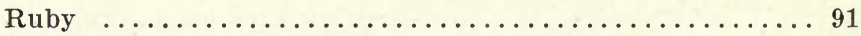

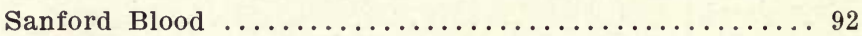

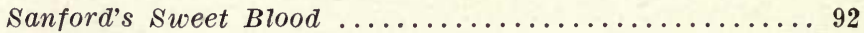

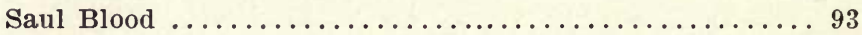

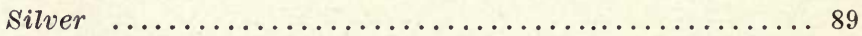

St. Michael (Blood) $\ldots \ldots \ldots \ldots \ldots \ldots \ldots \ldots \ldots \ldots \ldots \ldots \ldots$ 
Sweet orange varieties-Continued.

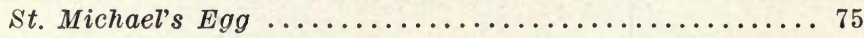

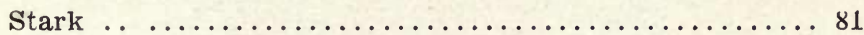

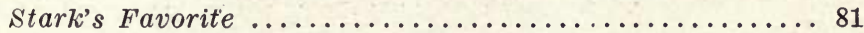

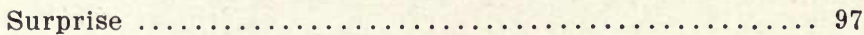

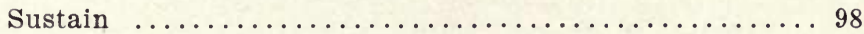

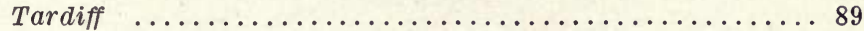

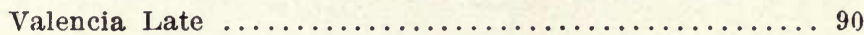

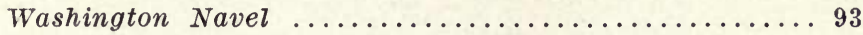

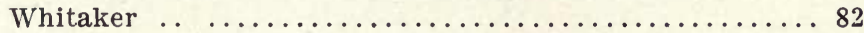

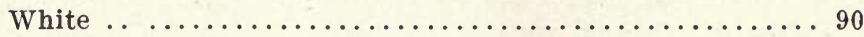

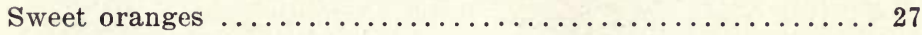

- California introduction .................. 29

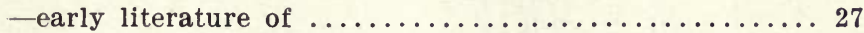

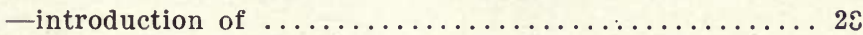

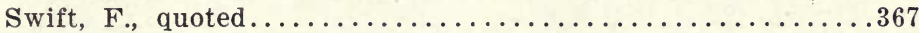

Swingle, W. T., bulletin by ..........................

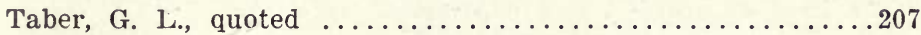

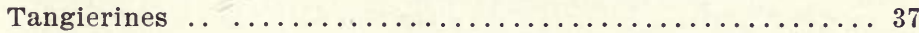

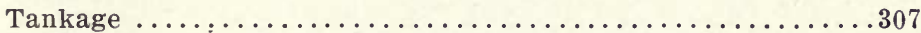

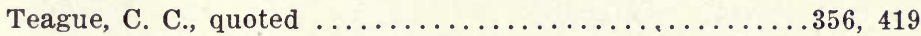

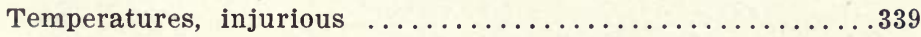

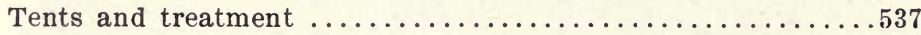

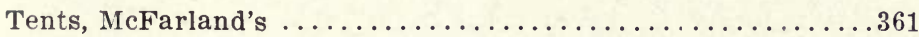

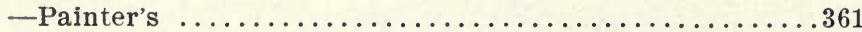

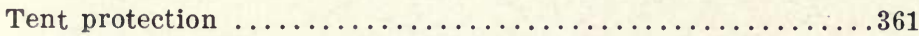

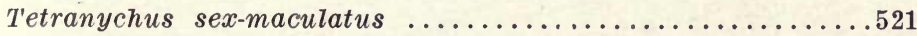

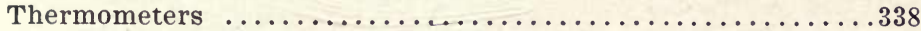

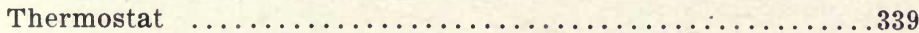

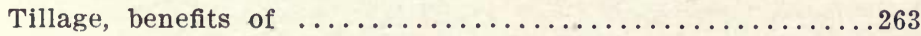

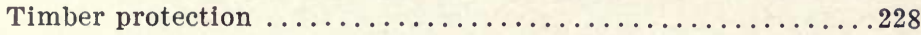

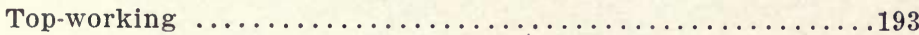

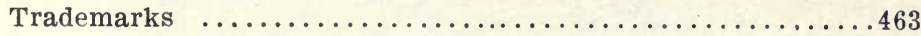

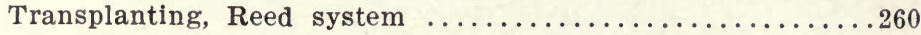

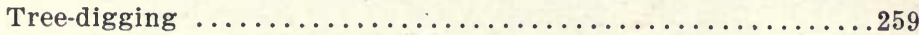

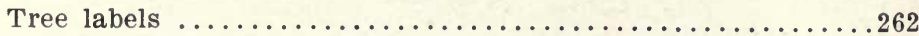

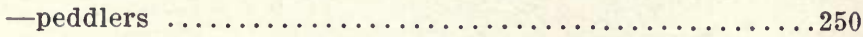

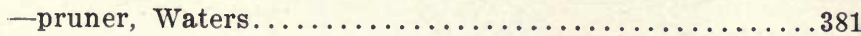

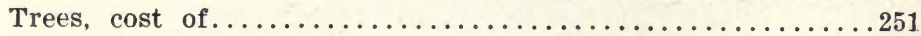


Trees, Cost of-Continued.

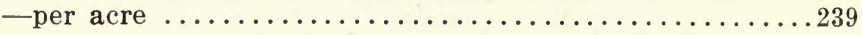

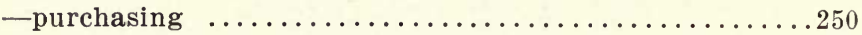

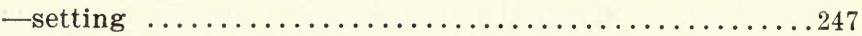

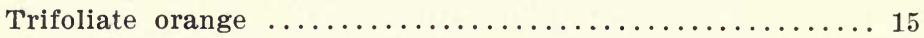

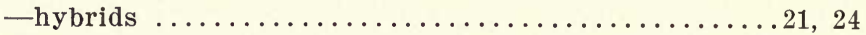

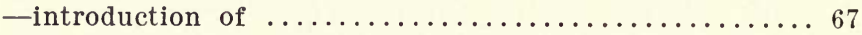

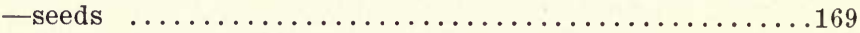

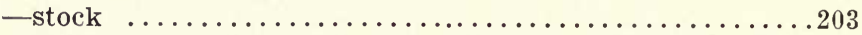

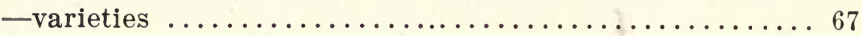

Triphrasia aurantiola $\ldots \ldots \ldots \ldots \ldots \ldots \ldots \ldots \ldots \ldots \ldots \ldots$

Trunk, effects of cold on ...........................

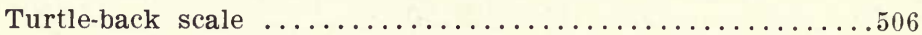

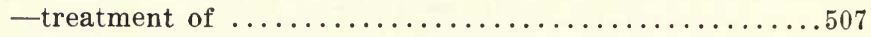

Twigs, effect of cold on ..........................

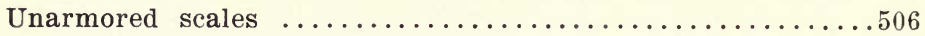

Van Deman, H. E., bulletin by .......................

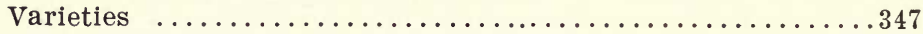

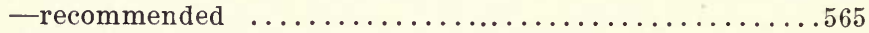

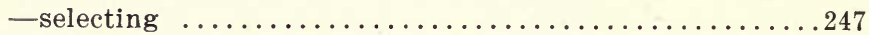

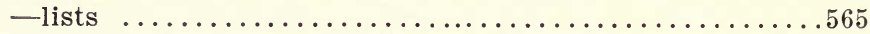

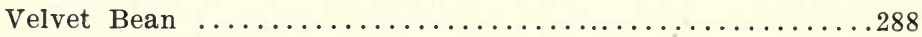

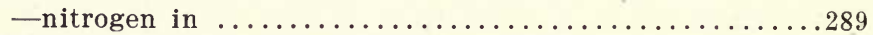

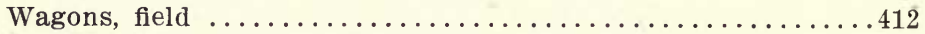

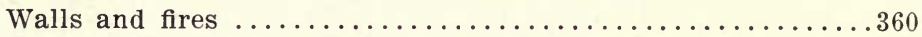

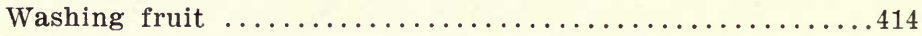

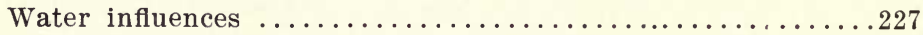

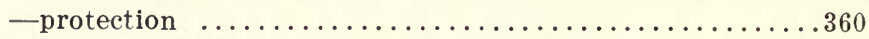

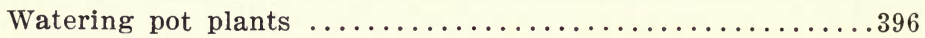

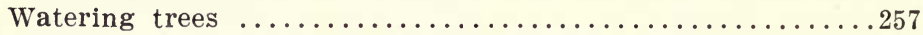

Watson, A., quoted ......................... 47

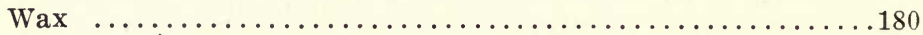

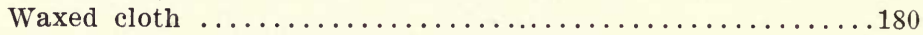

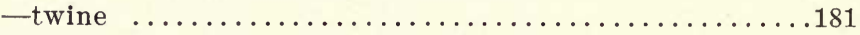

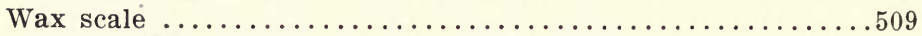

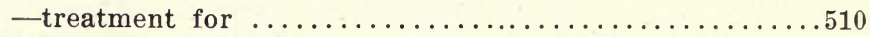

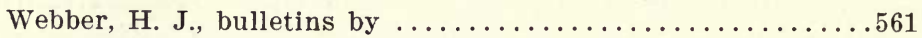

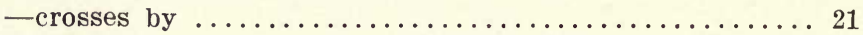

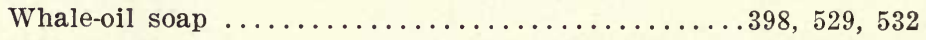

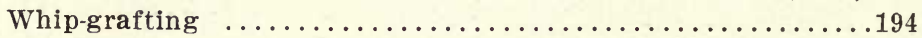




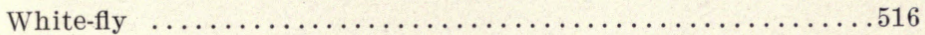

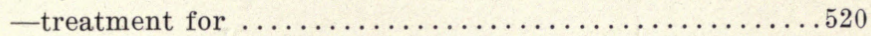

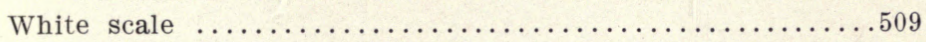

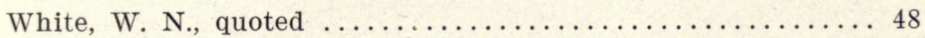

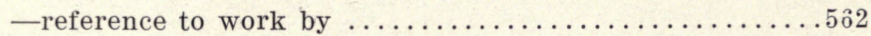

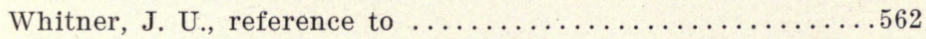

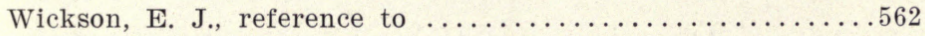

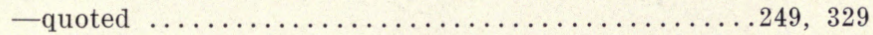

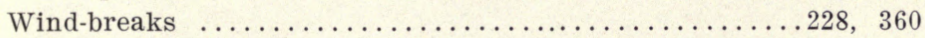

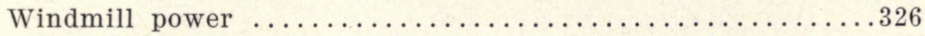

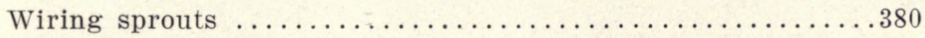

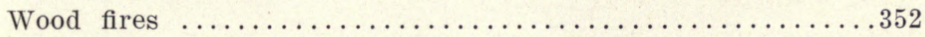

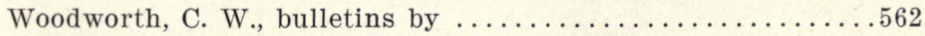

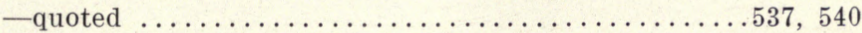

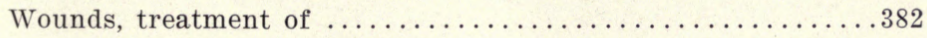








THIS BOOK IS DUE ON THE LAST DATE STAMPED BELOW

\section{AN INITIAL FINE OF 25 CENTS} WILL BE ASSESSED FOR FAILURE TO RETURN THIS BOOK ON THE DATE DUE. THE PENALTY WILL INCREASE TO 50 CENTS ON THE FOURTH DAY AND TO $\$ 1.00$ ON THE SEVENTH DAY OVERDUE.

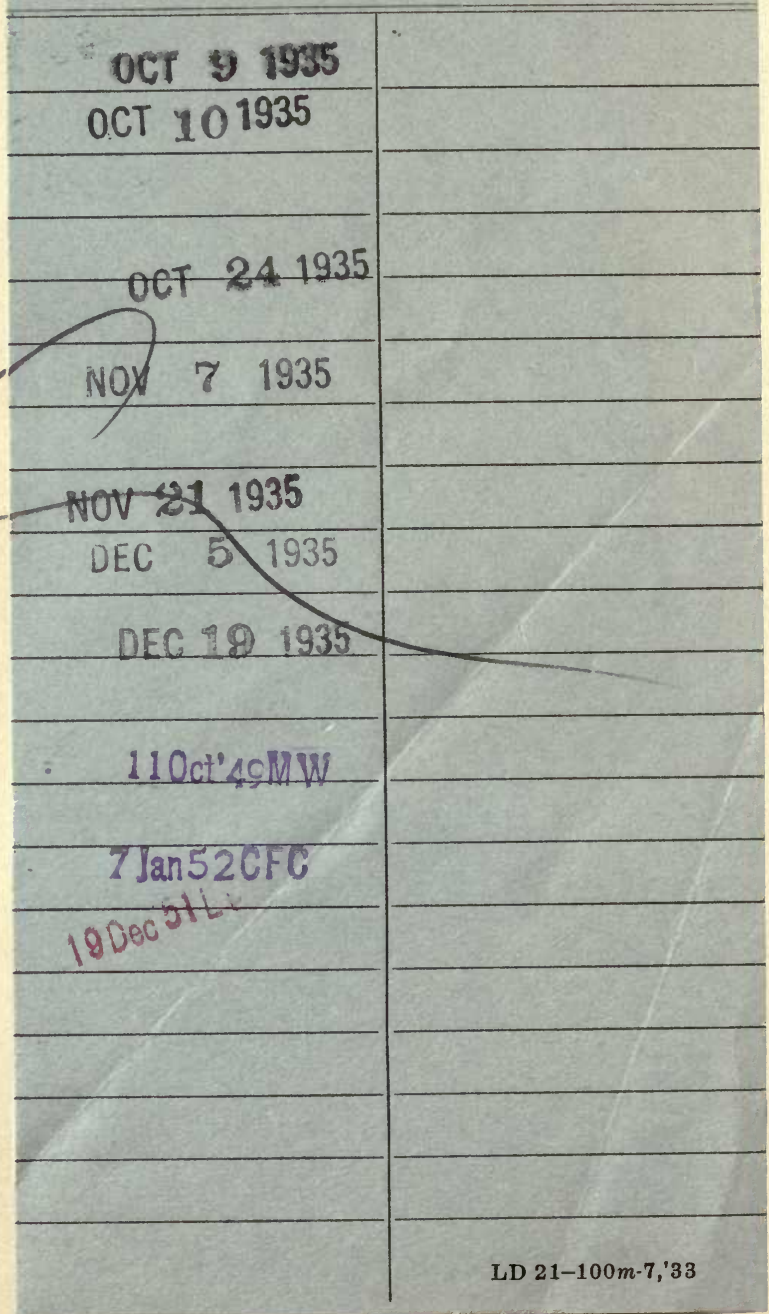




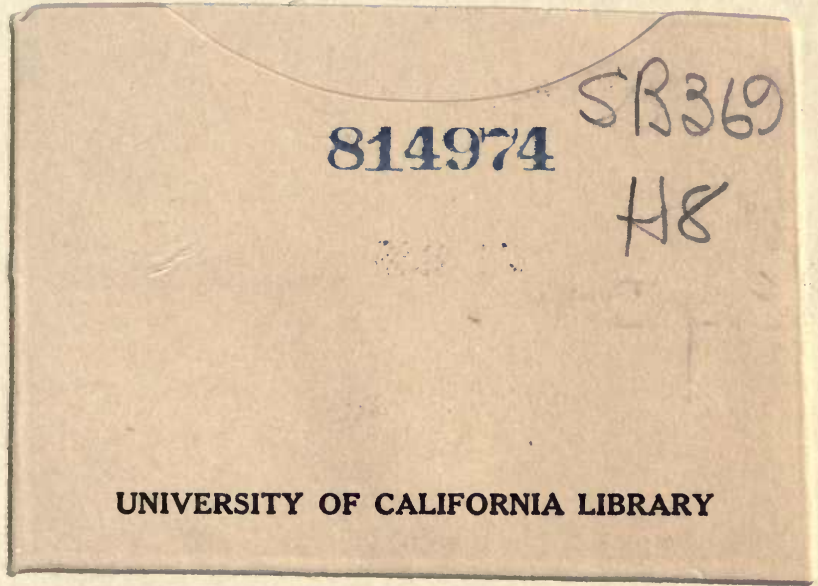


